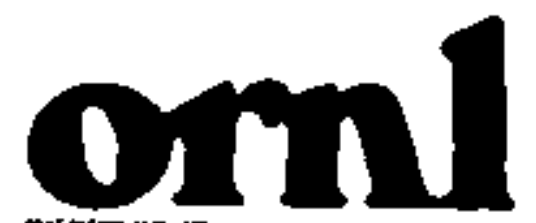

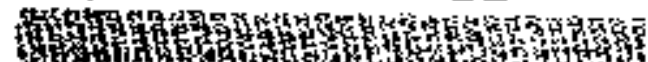

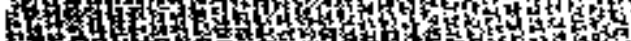

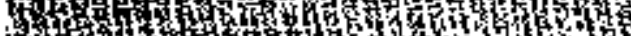

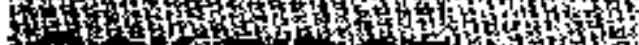
A $5 \div$.

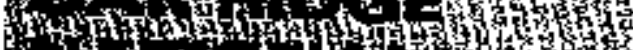
A 9xis (1)

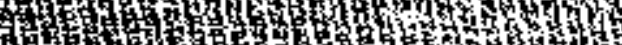
(1)

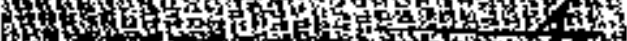
thy of 接

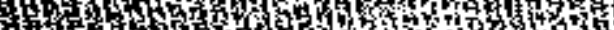
305 a d

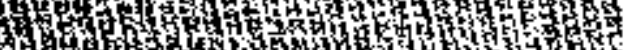
S⿴囗十

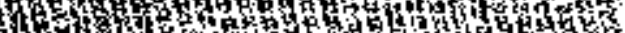

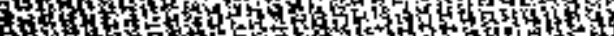

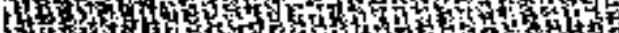

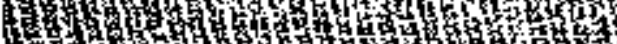

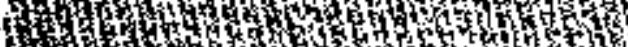
II

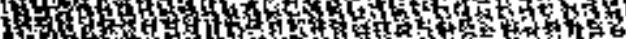

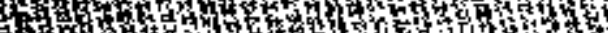
卉 特

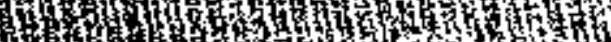

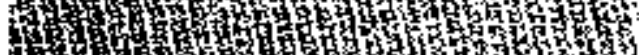

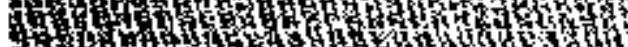

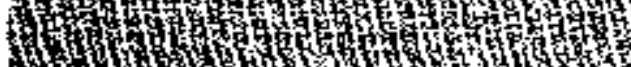

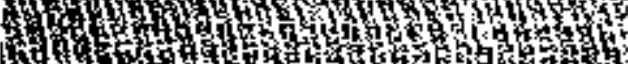

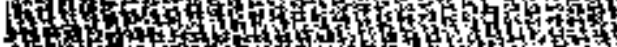
A

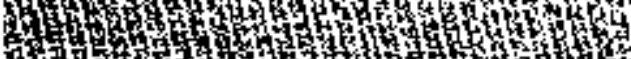

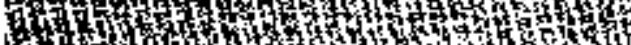

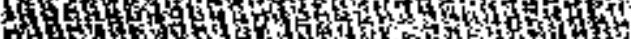

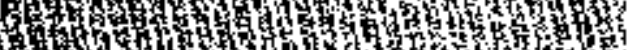

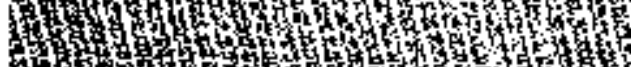
辛

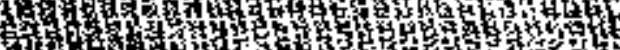
10.

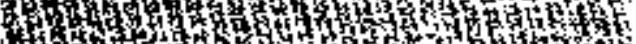

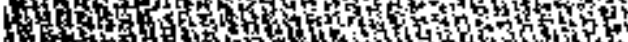

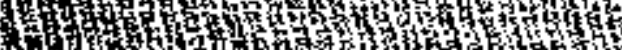

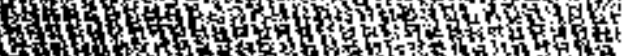
-

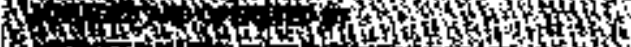
(2)

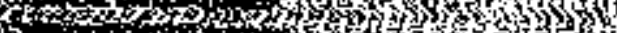

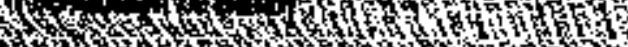
g. 年

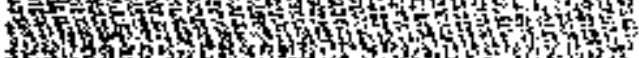

$$
\text { RECEIVED }
$$

\section{IFMIF \\ International Fusion Materials Irradiation Facility Conceptual Design Activity Cost Report}

\author{
Compiled by M.J. Rennich \\ Oak Ridge National Laboratory
}

Date published: December 1996

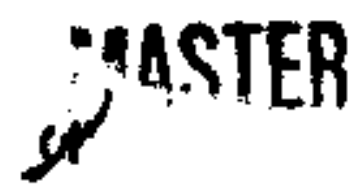

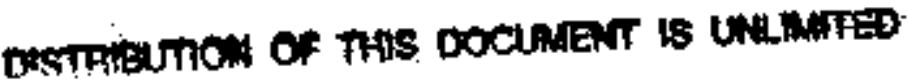


This report has bevi reproduced drecthy from the beat aveluable copy.

Avenable to DOE and DOE contrectors from the Othes of Scientific and Teanni-

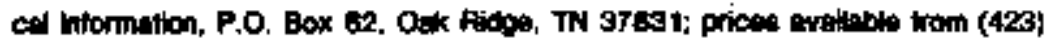
\$70-A401, FTS \$20-6401.

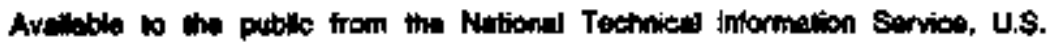
Dupertment of Commaros, 5285 Port Royd Rod, Sprindient, VA 22161.

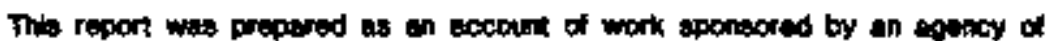
the Untied States Govimment. Nither the United Steten Gortitmenl nor any epanoy theneot, nor any of their enploysec, maked any warranty, oxprass or

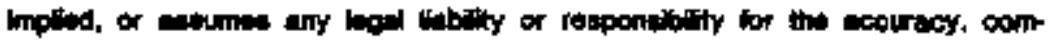

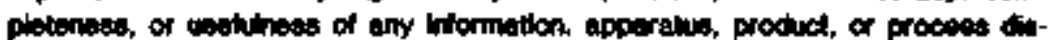

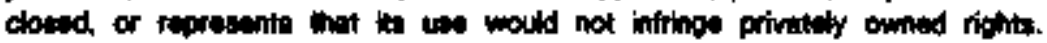

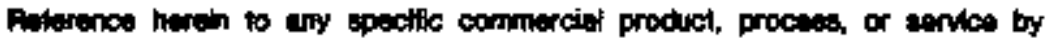

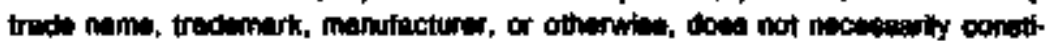
tute or inply the encoraseriem, recommendation, of favaring toy the Unitod Statem

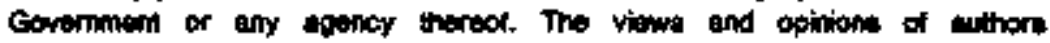

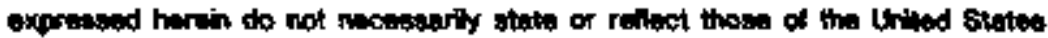
Goveminem or any agency thereot. 


\section{DISCLAIMER}

Portions of this document may be illegible electronic image products. Images are produced from the best available original document. 


\title{
IFMIF \\ International Fusion Materials Irradiation Facility \\ Conceptual Design Activity \\ Cost Report
}

\section{IFMIF CDA Team}

\author{
Report compiled by
}

\author{
M.J. Rennich
}

Oak Ridge National Laboratory

Oak Ridge, Tennessee, U.S.A.

An activity of:

The International Energy Agency (IEA)

Implementing Agreement for a Programme of Research and Development on Fusion Materials

Prepared by OAK RIDGE NATIONAL LABORATORY

Oak Ridge. Tennessee 37831, nanoged by

LOCKHEED MARTIN ENERGY RESEARCH CORP.

for the U.S. DEPARTMENT OF ENERGY

under contract DE-AC05-960R 22464

December 1996 


\section{Preface}

The IFMIF cost report documents the estimate for the International Fusion Materials Irtadiation Facility described in the Conceptual Design Activity Final Report. It was jointly prepared by the design team and has substantial input from the participating institutes and industry representatives from the collaborating countries. The costing data was not changed or edited during the compilation of this docutnent without the concurrence of the originating party.

The results of the IFMIF CDA are documented in a set of two reports:

"TFMIF- International Fusion Materials Iradiation Facility, Conceptual Design Activity, Final Report", IFMIF-CDA Team edited by M. Martone, ENEA Frascat Report, RT/ERG/FUS/96/11 (December, 1996)

"IFMIF- Intemational Fusion Materials Irtadiation Facility, Conceptual Design Activity, Cost Report", IFMIF-CDA Team compiled by M. J. Renuich, ORNLM-5502 (December, 1996)

A complete list of the project documentation is included in the final report. 


\section{Table of Contents}

Acronyms and Definitions

1.0 Introduction

1.1 Cost Summaries

1.2 Integration of an Intemational Cost Estimate

2.0 Costing Methodology

2.1 Scope

2.2 Organization

2.3 Costing Strueture

2.4 Costing Techniques

2.5 Allowance for Indeterminates

2.6 Industrial Participation

2.7 Personnel Costs

2.8 Siting Considerations

2.9 Items Not Included in Cost Estimate

2.10 Cost Estimate Verifrcation

2.11 Shortcomings in Cost Estimate

3.0 Cost Estimate Format

3.1 Worksheets

3.2 Explanation of Cost Categories

3.3 Explanation of Cost Rows

4.0 Cost Estimate Definitions

4.1 Project Management (WBS 1.0)

4.2 Facility Design and Constnction (WBS 2.0-6.0)

4.3 Starnp and Commissioning (WBS 7.0)

4.4 Operating Costs

5.0 Cost Estimate Analysis

5.1 Distribution of Costs by WBS

5.2 Distribution of Costs by Type

5.3 Allowance for Indeterminates

5.4 Industrial Participation

5.5 Expendinure Location

5.6 Managentent Distributions

References

Appendices

A Summary Cost Estimate

B Work Breakdown Structure (WBS)

C. Annual IFMIF Operating Costs

D Cost Estimating Worksheets 


\section{Acronyms and Definitions}

- AFI: Allowance for Indeterminates

- CDA: Conceptual Design Activity

- Conventional Facilities: The balance of plant elements grouped under WBS 2.5

- Ecu: European Currency Units

- EDI: Engineering Design and Inspection

- FMIT: Fusion Materials Iradiation Test

- ITER: International Thermonuclear Experimental Reactor

- ICF: IFMIF Currency Factor; the unit of accounting used uniquely in this estimate.

- Off-site: Activities and charges occurring away from the IFMIF facility.

- On-site: Activities and charges occuning at the IFMIF facility.

- Operating Costs: The cost of operating the facility after the completion of the construction project. These costs do not show in the TPC.

- TEC: Total Estimated Cost: A summary estimate which includes the cost of design, fabrication, testing, installation and all ptoject management costs from project approval to the beginning of facility startup and comrnissioning.

- Technical Facilities: The major process facilities of IFMIF; Test, Target, Accelerator and Central I\&C.

- TPC: Fotai Project Cost: A summary estimate which includes the TEC as well as development and, startup and commissioning costs. The CDA costs are not included

- WBS: Work Breakdown Structure; complete listing in Appendix 5-A 


\subsection{Introduction}

This report documents the cost estimate for the International Fusion Materials Iradiation Facility (IFMIF) at the completion of the Conceptual Design Activity (CDA). The estimate corresponds to the design documented in the Final FMIF CDA Report [1].

In order to effectively involve all the collaborating parties in the development of the estimate, a preparatory meeting was held at Oak Ridge National Laboratory in March 1996 to jointly establish guidelines to insure that the estimate was uniformly prepared while still permitting each country to use customary costing techniques. These guidelines are described in Section 4.

A prelininary cost estimate [2] was issued in July, 1996 based on the results of the Second Design Integration Meeting, May 20-27,1996 at JAERI, Tokai, Japan. This document served as the basis for the final costing and review efforts culminating in a final review during the Third IFMIF Design Integration Meeting, October 14-25, 1996, ENEA, Frascati, Italy.

The present estimate is a baseline cost estimate which does not apply to a specific site. A revised cost estimate will be prepared foljowing the assignment of both the site and all the facility responsibilities.

\subsection{Cost Summaries}

\subsubsection{Construction Cost Estimate Summary}

The following costs summarize the important budgetary numbers in the estimate. A more detailed summary of the cost estimate is provided in Appendix A which also includes various charts which compare and analyze the cost data. Information about the currency units and how the elements are defined and costed is included in the description below.

WBS

1.0 Project Management

2.0 Test Facilities

3.0 Target Facjlities

4.0 Accelerator Facilities

5.0 Conventiona] Facilities-EU/US [JP]

6.0 Central Control and Cornmon Instr.

Total Estimated Construction Cost (TEC):

7.0 Start-up and Commissioning Engineering Validation Phase

Total Project Cost (TPC):
TEC Estimate

$$
\begin{aligned}
& 52,000 \mathrm{kICF} \\
& 107,000 \\
& 115,000 \\
& 409,000 \\
& 90,000[195,000] \\
& 24,000
\end{aligned}
$$

797,000

$$
63,000(\text { avg. })^{*}
$$

49,000

910,000

* Differences in electric power costs result in a range of start-up and commissioning estimates between 54,000 and $79,000 \mathrm{kICF}$

The TEC includes a total Allowance for Indeterminates of $168,000 \mathrm{kICF}$ or $27 \%$ of the TEC; the base TEC is therefore $629,000 \mathrm{kICF}$.

\subsubsection{Operating Cost Estimate}

The estimated cost of operating the IFMIF facility in a normal year including electric power. utilities, maintenance and miscellaneous costs associated with operating the facility will be between 56,000 and 78,000 kICF. The electric power and personnel costs dominate the total number and only the differences in electric power result in the range of site costs. 


\subsection{Integration of an International Cost Estimate}

The IFMIF cost estimate was prepared jointly by the collaborating countries for a generic site within a project defined schedule. Consequentiy, the costs do not apply to a specific site or country. However, the goal of providing a comprehensive base estimate on which a specific estimate could be prepared was accomplished. In particular, the division of the work packages and the costing assumptions have been carefully documented aiong with the costs, enabling each participant to analyze costs based on local considerations.

In order to evaluate the differences between countries a few elements were costed by more than one country, notably the accelerator, conventional facilities and operating costs. Based on these cost comparisons it appears that the cost of manufactured items including contulex one-of-a-kind machinery is driven by international competition among industrial firms. Therefore, the cost of procured items such as power supplies, accelerator and target components and test cell equipment can be estimated by different courtries within a similar range of uncertainty. On the other band, the cost of conventional conseruction and operation is more difficult to generalize since each country must satisfy national requirements for building codes and standards, safety and environinental considerations and niles for construction of facilities on govemment sites. As a result of this difference, a separate Japanese cost estimate for the conventional facilities is appended to the base estimate which is more representative of the cost of these facilities in the US or EU. The operating and start-up and commissioning estimates also include a range of etectric power costs to account for differences in siting. 


\subsection{Casting Methodology}

\subsection{Scope}

Costs bave been developed for the IFMIF project over its entire cycle beginning with the Engineering Validation Phase (EVP) scheduled for 1997, through factlity construction, startup and plant commissioning. The anticipated cost of normal annual operations has also been estimated.

\section{Organization}

\subsubsection{Work Breakdown Structure (WBS)}

All project costs, except operation and decommissioning estimates, are organized in accordance with the IFMnF WBS attached in Appendix B. The WBS listing was completed to the most detailed leveI possible to insure that the estimate is both comprehensive and does not include overlap between Facilities. Costing was performed at the WBS level determined appropriate by the estimating group, usually levels four or five, and summarized at level three.

\subsubsection{Project Schedule}

The preliminary IFMIF master schedule developed for the CDA as shown in Figure 2-1 was used as the time basis for the estimate. Recognizing the effect of iegulatory/licensing requirements on program cost, the master schedule was configured to contain suitable time to obtain approval for IFMIF.

A key provision included in the schedule assumes approval to begin the bidding provess for major contracts, particularly the accelerator, one year ahead of fioal project approval in CY-2000. This advanced effort will save approximately one year in the overall project timetable.

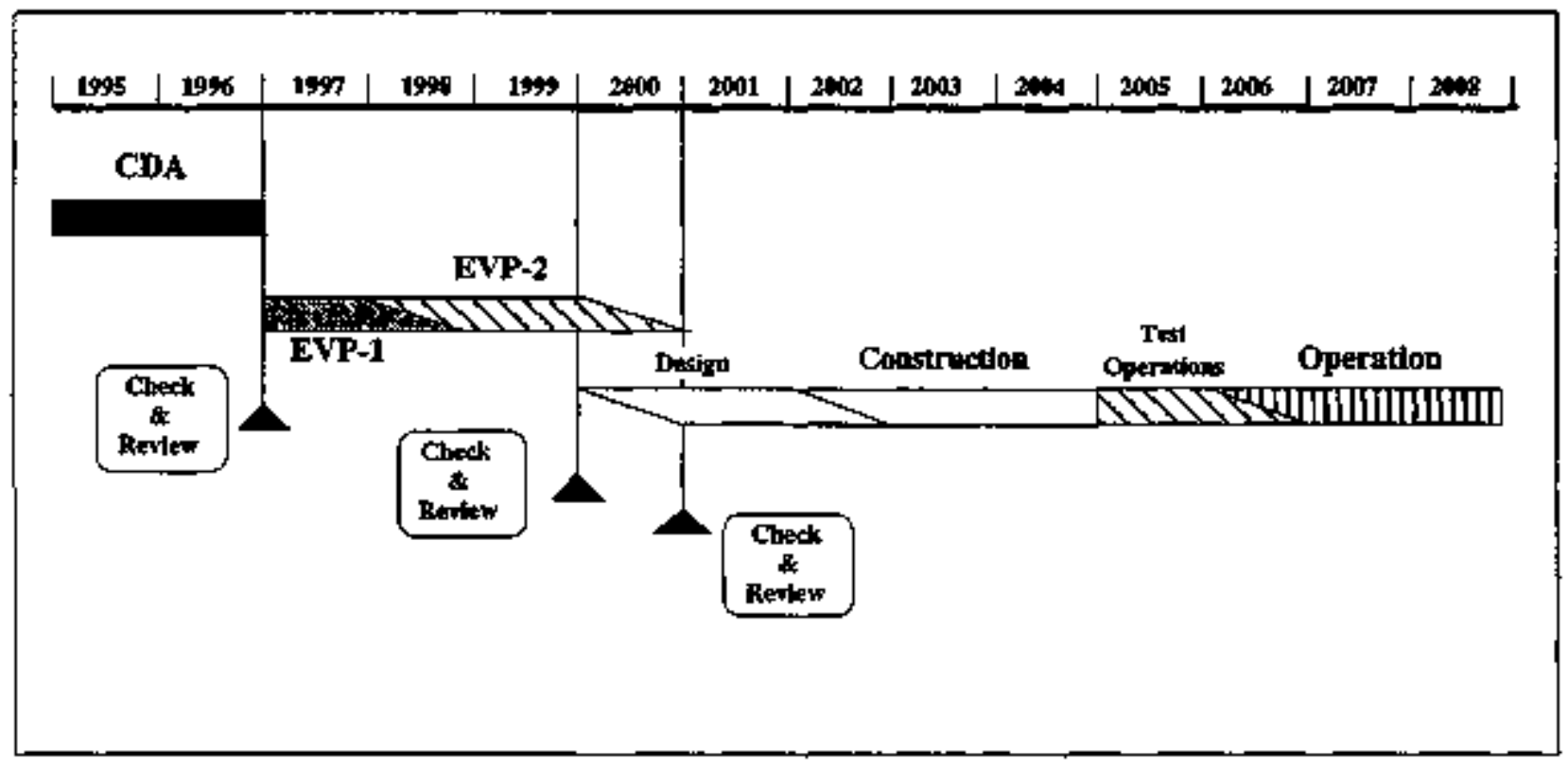

Figure 2-1. Top Level IFMIF Construction Schedule. 


\subsubsection{Coordination}

The cost estimate incorporates information from all parties and provides a summary reference cost for planning and budgeting in all the collaborating countries based on coordinated, common cost input. Thus, while each party developed costs using custonary internal methods, a common-format detailed worksheets were used to report costs. The worksheets are attached as Appendix D .

\subsubsection{Costing Responsibilittes}

The cost estimate has input from all parties as described in Table 2.2-1. In most cases, individual items of the cost estimate were not estimated by more than one party; however, top level cross checking was completed as previously described.

Table 2-1. General costing responsibilities.

\author{
Project Management \\ Test Facilities \\ Target Facilities \\ Accelerator Facilities \\ Conventional Facilities \\ Central Cont. aryd Instru. \\ Startup \& Cormmissioning \\ Operating Costs
}

$\begin{array}{ll}\text { (WBS 1.0) } & \text { AIl parties } \\ \text { (WBS 2.0) } & \text { European Union } \\ \text { (WBS 3.0) } & \text { Japan } \\ \text { (WBS 4.0) } & \text { United States } \\ \text { (WBS 5.0) } & \text { EU/US } \\ \text { (WBS 6.0) } & \text { Japan } \\ \text { (WBS 7.0) } & \text { All parties } \\ & \text { All parties }\end{array}$

\subsection{Costing Structure}

\subsubsection{Accounting}

Each party reported costs in US dollars or the local currency; for example the Europeans used European Currency Units (Ecu's). To provide a uniform cost summary, the estimates from the Facility groups were converted to a unit unique to this estimate called the IFMIF Conversion Factor (ICF). Conversions for the local currencies as of January 1996 are shown in Table 2.3-1.

Table 2-2. Gurrency conversion factors

$$
\begin{aligned}
\text { I ICF } & =1.00 \text { U.S.\$ } & & (\text { Jan 1996) } \\
& =105 \% & & \text { (Jan 1996) } \\
& =0.807 \text { Ear } & & (\operatorname{Jan} 1996)
\end{aligned}
$$

\subsubsection{Intlation}

The cost estimate is reported in January 1996 currency values, inflation is not considered.

\subsection{Costing Techniques}

Estimators, in general, used four basic types of estimating techniques:

Industrial: Detailed quotes or industrial estimates based on exact equipment specifications or requirements. Approximately $75 \%$ of the technical facilities were estimated by industry.

Scaling: The use of known costs for existing equipment and adjusting the costs to account for different sizes, years of constnection etc. to estimate costs for items such as buildings, hot cells, ventilation systems, offices, site preparation and utilities. Roughly $10 \%$ of the estimate was completed using this estimate

Factoring: The use of percentages of known equipment or labor costs to estimate contingency and personnel costs such as project management and construction management which amount to approximately $10 \%$ of the estimate. 
Engineering Judgment: Educted guesses were used for the remaining $5 \%$ of the estimate for which the other estimating techniques were not possible. For example, the cost of maintenanke during the two years of startup and commissioning is impossibje to derive quantitatively at this stage of the project.

\section{Allowance for Indeterminates}

IFMIF is in the earliest stages of design, consequently there are assumed to be many unknowns, thns each Facility group provided an additional cost referred to as the Allowance for Indeterminates (AFI) based on such factors as:

(i) design maturity,

(ii) technological risk,

(iii) historical cost growth in estimates performed at the conceptual design phase.

AFI was applied in the manner customary to the estimating party, at the lowest level possible to prevent subsequent doubling of AFI when summarizing costs across WBS elements. For example, where factoring was used to derive costs, notably Project Management, AFI was not added again since the base numbers included the allowance.

\subsection{Industrial Participation}

The estimate reflects the decision that virtually all design, fabrication and installation functions will be performed by commercial companies operating under the direction of the responsible government sponsored institutes. This approach recognizes that, in general, the IFMIF design is based on conventional or proven technologies which can be easily procured from several vendors. It also provides for the most cost efficient method of building the facility through established design-to-cost and procurement-to-cost techniques. The funding implication of this division of is tracked at all levels of the estimate.

\subsection{Personnel Costs}

Personnel labor costs appear primarily in two places in the cost estimate. First, industrial labor used to manufacture and assemble facility components and construct the facility. And Second, technical staff required to startup and operate the facility. Of necessity, each has been treated differently.

\subsubsection{Manufacurring and Assembiy Labor}

In keeping with the division of the estimate into separate facilities which are fully estimated inaccordance with the procedures customary for the responsible party, the industrial labor rates are specific to the individual countries involved. This allowed each party to evaluate total fabrication costs within the framework customary to that country and avoided the confusion resulting from imposing an international standard for specific types of labors.

\subsubsection{Startup and Operating Personnel}

Since a site has not been designated, all the parties contributed to the startup and operating cost estimates. Specifically, each party provided annual rates for a designated list of personnel from which average rates were computed as shown in Table 2-3. The unit cost for characteristic types of personnel (i.e. technicians, managers, engineers and maintentance shop labor) includes all burdens and overheads. The US figures are based on rates at Oak Ridge National Laboratory and those used by Northrop Grumman in similar estimates. The EU rates were provided by Frascati and FZK, and the Japanese rate by JAERI. Since the labor rates for all the countries are comparable within the accuracy of the overall estimate a single average rate structure was used for Project Management, Operations and Startup \& Commissioning. 
Table 2.3. Average Annual Personnel Costs (Jan 96 kICF)

\begin{tabular}{|c|c|c|c|c|c|}
\hline & \multicolumn{5}{|c|}{ Rate (kICF/yr) } \\
\hline & US & Japan & Inaly & Ger. & Average \\
\hline \multicolumn{6}{|l|}{ Administration } \\
\hline Plant Manager & 195 & 234 & 198 & 152 & 195 \\
\hline Office Support & 50 & 144 & 91 & 88 & 93 \\
\hline \multicolumn{6}{|l|}{ Englneers } \\
\hline Engineers & 173 & 165 & 154 & 152 & 161 \\
\hline Technicians & 150 & 145 & 154 & 121 & 143 \\
\hline \multicolumn{6}{|l|}{ Operations } \\
\hline Shift Superintendent & 149 & 187 & 154 & 152 & 161 \\
\hline Central Control Operators & 94 & I44 & 154 & 121 & 128 \\
\hline Ptant Operators & 94 & 119 & 91 & 121 & 106 \\
\hline Plant Protection & 94 & 119 & 91 & 121 & 106 \\
\hline Safety Officer & 164 & 144 & 154 & 152 & 153 \\
\hline HP Techunicians & 156 & 119 & 154 & 121 & 137 \\
\hline \multicolumn{6}{|l|}{ Mrintenance } \\
\hline Maintenarke Manager & $11 \mathrm{~F}$ & 178 & 154 & 152 & 149 \\
\hline Shop Labor & 92 & 119 & 91 & $8 B$ & 98 \\
\hline \multicolumn{6}{|l|}{ Experimental Operations } \\
\hline Hot Cell Operators & 94 & 119 & 91 & 88 & 98 \\
\hline Data Acquisition & 113 & 144 & 154 & 88 & 124 \\
\hline
\end{tabular}

\subsection{Siting Considerations}

The cost estimate structure segragates work performed "on-site" in the host country from work which could be done "off-site" in other countries or locations. This arrangement, shown in Figure 2-2 represents an extreme case in which the maximum ansount which could be spent "off-site" is established. In a more realistic scentario, the host country would center wodk at the designated site out of convenience, thus the artount of "on-site" expense will probably be higher than that shown in this cost study. 


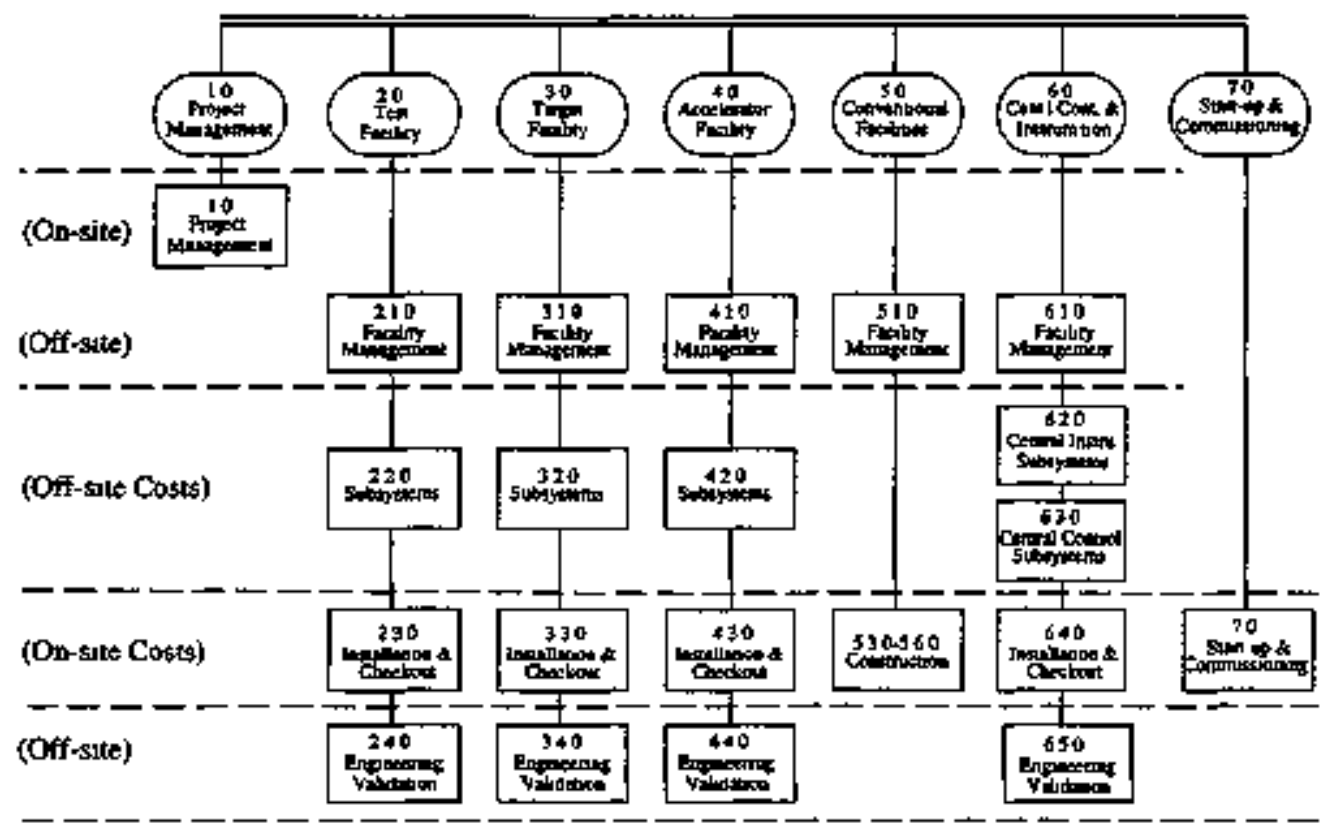

Figure 2-2. Cost Estimate Structure showing separation of off-site and on-site costs.

\subsubsection{Site Spectitic Costing}

Different sites may have significant variations in construction and operating costs. The cost drivers depend on elements which cannot be easily nomalized, such as licensing, labor, electricity and utilities, and to a lesser extent the cost of contaminated waste disposal. The segregation of on and off sitte costs will ultimately allow for a reasonable determination of a more accurate site specific cost estimate. This division will also enable the design team to more easily develop future cost estimates following official site selection.

\subsubsection{Site Support Assumptions}

The cost estimate is based on locating IFMIF within an existing nucleat research facility. This assumption presumes that certain basic support functions are avaifable through the central infrastructure of the parent facility and are therefore not included in the IFMIF construction or operations costs as separate items. The costs for these services are assumed to be included in the "overhead" burden applied to the operating personnel costs $(\sim 48 \%)$. These include:

- Fire protection,

- Security management (but not on-site guards),

- Procurement,

- Accounting and budgeting,

- Computing and nerworks,

- Shipping and receiving control.

- Plant engireering.

- Waste management,

- Waste processing facilities, and

- Governmental interface.

The cost of procuring additional services frotn the parent facility (e.g., design engineering, computer repair) are costed under "Miscellaneous" in the operating budget 


\subsection{Items Not Inchuded in Cost Estimate}

Items not included in the,estimate are:

- The cost of land is not included because the host is assumed to provide the land.

- The costs of various services to the boundary of the site and associated land, such as roads, water, electricity, sewers, are not incladed because the host is assumed to provide such services. Such services on the site are included in the estimate in WBS 5.

- The direct costs associated with the regulatory process, i.e., preparing the required reports in the native language, reviewing the reports and obtaining the necessary approvals, are not included.

- The costs for disposing of IFMIF operational wastes (except high level radioactive material) once they leave the site are not included in the operations cost

- Costs associated with decommissioning and disassembly of the IFMIF after it has completed its operational life are not considered.

\subsection{Cost Estimate Verification}

\subsubsection{Referencing to Eristing Facility Costs}

The most reliable sources of information for verifying the IFMIF cost estimate are the actual costs incursed in the constroction of similar facilities. The ITER cost estimate bas many of this type of cost factors for major elements such as buildings, waste management, site preparation etc. In addition, FZK has recently completed a hot cell facility similar to that proposed in IFMIF thus providing a reliable cost comparison for this portion of this portion of the facility.

\subsubsection{Referencing to FMIT Cost Estimate}

A facility similar to IFMIF, the Fasion Materials Irradiation Test (FMTT), was partially completed before being terminated in 1984. The cost estimate and actual costs of that facility are only slightly relevant to IFMIF because significant physical and operating differences added to the 12 year time lapse make cost comparisons very difficuft and tenuous, consequently, a cost comparison was not completed.

\subsection{Shortconings of the Cost Estimate}

The final cost estimate has three weaknesses of which the most important is that it is based on a conceptual design with all the unknowns inherent to that level of understanding. This problem has been compensated with the use of added Allowance For Indeterminates (AFI) based on historical data. A second weakness, the limited amount of cross-checking between facility groups, results from the minimum amount of funding available to accomptish the CDA activities. Independent, top-level reviews by other groups served as a modest substitute for complete, duplicate estimates. Finally, a full analysis of labor rates has not been completed. This reflects the directive to have each country estimate using domestic rates; however, it also opens the possibility of significantly different ovethead and burden assumptions at the detailed level of the estimate. Given the nature of these shortcomings, the CDA estimate is considered to be a good basis for planning and preparation of the constroction project 


\subsection{Cost Estimate Format and Results}

The overall IFMIF cost estimate is documented in two forms; first costs are accumulated in a spreadsheet format as summarized in Appendix A "Summary Cost Format". Second, the individual costs for each row of the estimate are documented in detailed worksheets as provided in Appendix D and described in Section 3.1 below. Figure 3-1 shows the standard spreadsheet format used to categorize costs. Note that the sheet follows the requirements to segment off-site and on-site costs; industry and institutional costs; allowance for indeterminates (AFI); management and engineering validation.

\subsection{Worksheets}

Standard form worksheets where prepared by the responsible parities at levels 3,4 and 5 as appropriate. The worksheets are linked to the summary cost sheet to enable direct tsacking of costs by a single tabular row in the same fornat as the spreadsheet. The rest of the worksheet provides information to capture lower level costs and the details of the content and approach, employed to reach the final figures. The standard worksheet format is as follows:

\section{A. Summary Cost Estimate:}

A single costing row in the format of the overall spreadsheet appears at the top of the worksheet. The WBS level of the entry is identified at the top of the sfieet and the cunrency units are identified under the row.

\section{B. Description:}

A written description of the items included in the element being costed is provided. This includes as much quantitative information such as sizes, quantities and materials as practical. Special considerations and procedures may also be identified.

\section{Detgiled WBS Listing:}

A continuation of the WBS at levels below the subject row is provided. The additional detail has been added to the overall IFMIF WBS.

\section{Costing Rational:}

An explanation of how all costs were derived (scating, factoring, bottoms-up or engineering judgment) and the origin of the basic cost numbers used (e.g. industrial quote, previous construction, reference book, catalogue). The Allowance For Indeterminates (See Section 4.3.2 below) factor used may also be explained.

\section{E. Detailed Costing:} included.

As muxh of the detailed costing data as requited to explain the costs to an independent reviewer is

\subsection{Explanation of Costs}

The top level costs of the IFMIF Cost Estimate are tabaliated in the Introduction and defined in Figure 3-1 and as follows:

- The Total Estimated Cost (TEC) includes the cost of design, fabrication, testing, installation and all project management costs from project approval to the beginning of facility startap and commissioning.

- The Total Project Cost (TPC) includes the TEC as well as development and, startup and commissioning costs. The CDA costs ane not included

- The lower level cost categories are explained in \$ection 4.0 below 


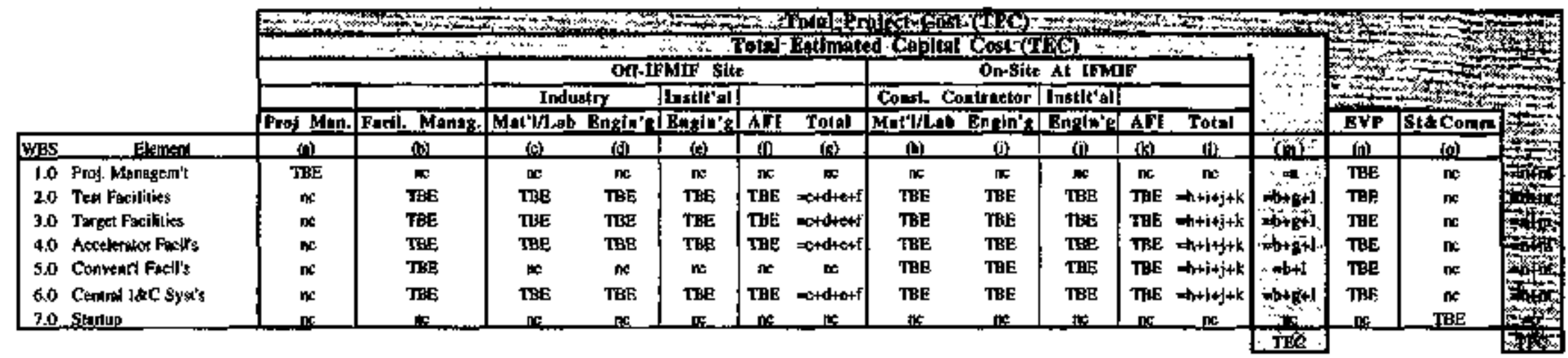

\section{Abrevinutans}

ac No Cosi in lis tknem

TBE To Eo Egtimakid by Fecility Growps

AF1 Allowance for Indoleminnteg

Figure 3-1. Detail structure of IFMIF cost estimate spreadsheet. 


\subsection{Cost Estimate Derunitions}

format.

This section describes major elements of the cost estimate as tabulated in the WBS and summary

\subsection{Project Management and Administration (WBS 1.0)}

This element includes all project management costs for the managennent, administration and control of the overall project (column "a" in Figure 3-1). The management of the Facility design, testing and installation activities are inciuded in the Facility costs. The management team will begin to form in 1998 and disbard following Commissioning. The peak employment years will be between Project Approval at the beginning of the year 2000 and the completion of the major construction elements at the end of the year 2004. Note, project management is considered an "on-site" cost since it is assumed that it will be performed in the host country.

This element includes the following items:

- Project Management and Administration: includes costs for activities such as overall administration, cost control and scheculing, and documentation. Also included are administrative support, meetings, and publications.

- Systems Engineering: costs for engineering beginning after the IFMF is approved as an official project required to ensure the facility functions are properly coordinated including interfaces, RAM and safety.

- Environmental, Safety and Health (ES\&H): includes cost of personael responsible for establishing and maintaining procedures in accordance with the regulations of the country responsible for the Facility.

- Quality Assurance (QA): includes cost of personnel responsible for establishing and maintaining a quality assurance program for the overall project.

- Constnuction Management; coordination of constuction activities for all Facilities, development of construction specifications, oversight of contracts. It is assumed that the construction management activities will be performed by a commercial contractor.

The history of lange projects shows that all Management and Administration costs, including WBS 1.0 and related costs in each Facility WBS X.1.0, should be between 10 and $15 \%$ depending on the complexity of the project. For IFMIF the reduced technical complexity is somewhat off-set by the difficulties of coordination of an international facility. Consequently, the total factor is assumed to be approximately $12.0 \%$ of the TEC. Thus, since the indjvidual facilities estimates included a factor of $5.5 \%$ of the tocal the remaining $6.5 \%$ was assigned to WBS 1.0 . The specific management costs for each Facility are detailed in the appropriate worksheets.

\subsection{Facility Design and Construction (WBS 2 through 6)}

Each of the four WBS elements describing the Technical Facilities of IFMIF include subelements for program management, sabsystems, installation and checkout and subsystem development. The scope and content of each of these subelements is described below. Because the WBS structure for the Technical Facilities is uniform at level 2; all the elements at that level are discussed together.

\subsubsection{Facility Management (WBS X.1)}

All the management activities required to directly support and complete each Facility are included in this element (column " $b$ " in Figure 3-1). The facility management staff is also expected to coordinate all activities with the overall project management staff (WBS 1.0). The subelements are the same as WBS 1.0 and have the same description as applies to the individual facility. 
- Project Management and Administration; basic management costs such as administration, cost control and scheduling, and documentation. Under each of these categories factors such as administrative support, meetings, and publishing are included.

- Systems Engineering: costs for Engineering after the IFMIF is approved as an official project will be estimated based upon anticipated activities needed to support the procurement of elements of the Facility. Engineening will include the following elements:

- preparation of major system specifications,

- preparation of preliminary design documentation,

- vendor and contractor oversight,

- verification testing oversight,

- installation planning and coordination,

- installation oversight,

- startup oversight.

- Environmental, Health and Safety Documentation: support for personsel responsible for establishing and maintaining procedures in accordance with the regulations of the country responsible for the Facility.

- Quality Assurance: support for personnel responsible for establishing and maintaining the quality assurance program for the individual facility. Also inchuded will be activities to coordinate the QA. program will the project office.

\subsubsection{Technical Facility Design, Fabrication, Installation and Testing (WBS X.2)}

This eiement includes the cose for work begun following project approval and performed off-site.

It includes the following items:

Columu "c" [Industry Mat'VLab.]:

- material,

- equipment fabrication.

- fabrication labor.

- factory assembly labor,

- factory verification testing,

- shipment to the IFMIF site.

- special majntenance systems

Column " $d$ " [Industry Engin'g]:

- vendor provided design engineering,

- vendor provided inspection engunering,

Column " $\mathrm{e}$ " [Institutional Engin'g]:

- Manpower (engineering. labor and technical) provided by the responsible institute presented in currency units rather than hours.

Columa "f" Allowance for Indeterminates [AFI]:

An Allowance for Indeterminates (AFI)is added to account for:

(i) design maturity.

(ii) technological risk,

(iii) historical cost growth in estimates perforned at the conceptuat design phase.

Column "g" [Total]:

The total of columns $c, d, e$ and $f$ should give all costs associated with the off-site fabrication, testing and design of the technical facilities. 


\subsubsection{Installation and Checkout (WBS X.3)}

This element includes all work to install and perform verification testing of the individual technical facilities at the IFMIF site. All costs following the acceptance of facilities for operation are included in WBS 7.0.

The Equipment Installation and checkout cost estimate includes the following elements:

\section{Column "h" [Construction Contractor Mar'lLab]:}

- construction contractor provided installation labor,

- construction contractor provided supervision,

- verification testing labor and support.

\section{Column " $\mathrm{j}$ " [Construction Contractor Engin'g]:}

- construction contractor provided installation engineering,

- on-site support by fabricating industry labor and technicians.

Column " $\mathrm{j}$ " [Institutional Engin' $\mathrm{g}]$ :

- On-site support of responsible institute personnel.

Column " $k$ " [AFT]; See explanation of column " $\mathrm{f}$ ".

\subsubsection{Enginering Validation (WBS X.4)}

This element includes the casts for the Engineering Validation Phase of the project, starting in calendar year 1997. The costs ase explained in the IFMIF Engineering Validation Phase plan [3].

\section{All EVP costs are reported in Column " $\mathrm{n}$ "}

\subsubsection{Facility Construction (WBS 5.0)}

FFMIF construction was estimated differently than the technical facilities because all work is perforned on-site. Since IFMIF uses construction technigues similar to those proposed for ITER, costs are generally based on factors developed for the ITER cost estimate.

\section{Column "h" [Construction Contractor Mat'LLab]:}

- eonstruction contractor provided installation labor,

- construction contractor provided supervision.

- verification testing labor and support.

- material,

- purchased equipment.

Column " $\mathrm{i}$ " [Construction Contractor Engin'g]:

- construction contractor provided installation engineering,

- construction contractor design engineering.

Columa " $\mathrm{j}$ " [Institutional Engin' $\mathrm{g}$ ]:

- On-site support of responsible institute personel.

Colums "k" [AFI]: See explanation of column " $\mathrm{f}$ ". 


\subsection{Startup and Commissioning (WBS 7.0)}

This element inciudes the costs for start-up and commissioning of the IFMIF facility. This includes operations and material costs from the startup of the accelerator through the commissioning of the plant.

\subsubsection{Indeterminates:}

This WBS element provides a best estimate of the cost of starting IFMIF regardless of site location. The actual startup and commissioning costs will depend on many imponderable factors including the type of organization responsible for the consertaction phase, the exient or sharing of vendor responsibilities, and the necessary level of interaction with regulatory bodies.

\subsubsection{Personnel Rates:}

Operating personnel will be hired during the Startup and Commissioning phase of the project to assist with operations and training. The personel costs as shown in Table 2.3 include al] overbeads and burdens.

\subsubsection{Electrical Power:}

Electric power costs include the power required for the operating equipment and power consumption during varjous levels of non-operation. This is accounted for in assumptions for a reasonable two-year startup plan. Power costs were developed for Europe, US and Japan, and reported for IFMIF as an average and as a tange.

\section{3,4 Maintenance:}

A percentage factor of the TEC cost was used to cover capital improvements, spare parts and maintenance costs.

\subsubsection{Waste Disposal:}

The volume and cost of waste disposal was reviewed at the Second Design Integration meeting with a resulting average cost based on engineering judgement.

\subsection{Operating Costs}

An estimate of the normal facility annual operating costs is included in Appendix $\mathbf{C}$ The same basic factors of electric power, personnel, maintenance, waste disposal and utilities are included. 


\subsection{Cost Estimate Analysis}

The overall IFMIF cost estimate has been analyzed through a series of charts which provide a relative comparison of many factors which are common to all facilities of this type.

\subsection{Distribution of Costs by WBS}

Char 5-1 shows a percentage distribution of the TPC by WBS level two elements. Note that the accelerator accounts for approximately balf of the total project cost, a common "rule of thimb" for acceierator based facilities. Also note that the relatively low cost of central control and instrumentation. assumes a configuration in which each technical facility provides a stand-alone control capability which is included in the individual facility cost estimates.

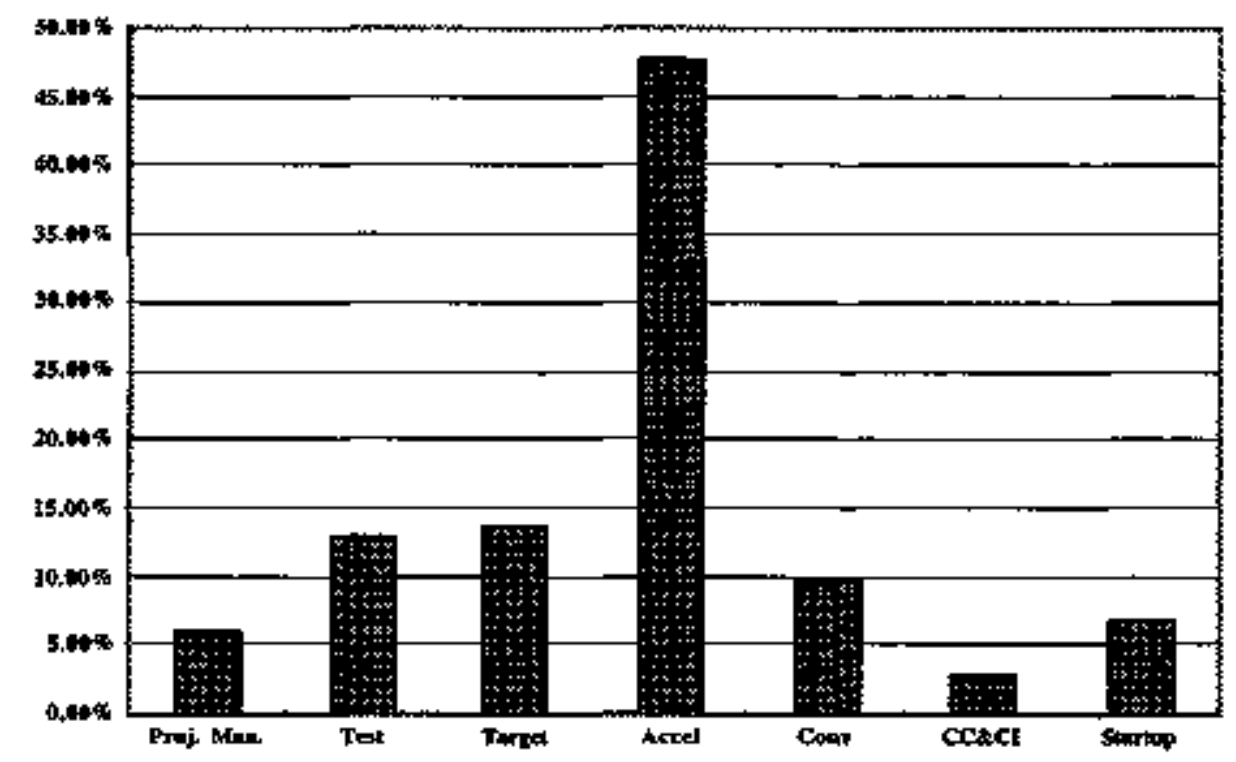

Figure 5-1. Distribution of TPC by WBS level 2 elements. 


\subsection{Distribution of Costs by Type}

Chart 5-2 shows a percentage distribution of the TPC by major types of costs which is close to that expected for a large construction project. The engineering numbers appear low, however, the IFMIF WBS includes a substantial amount of engineering in project management, EVP and Startup and Commissioning. Thus the actual total engineering cost will be closer to the expected value of 30 to $35 \%$.

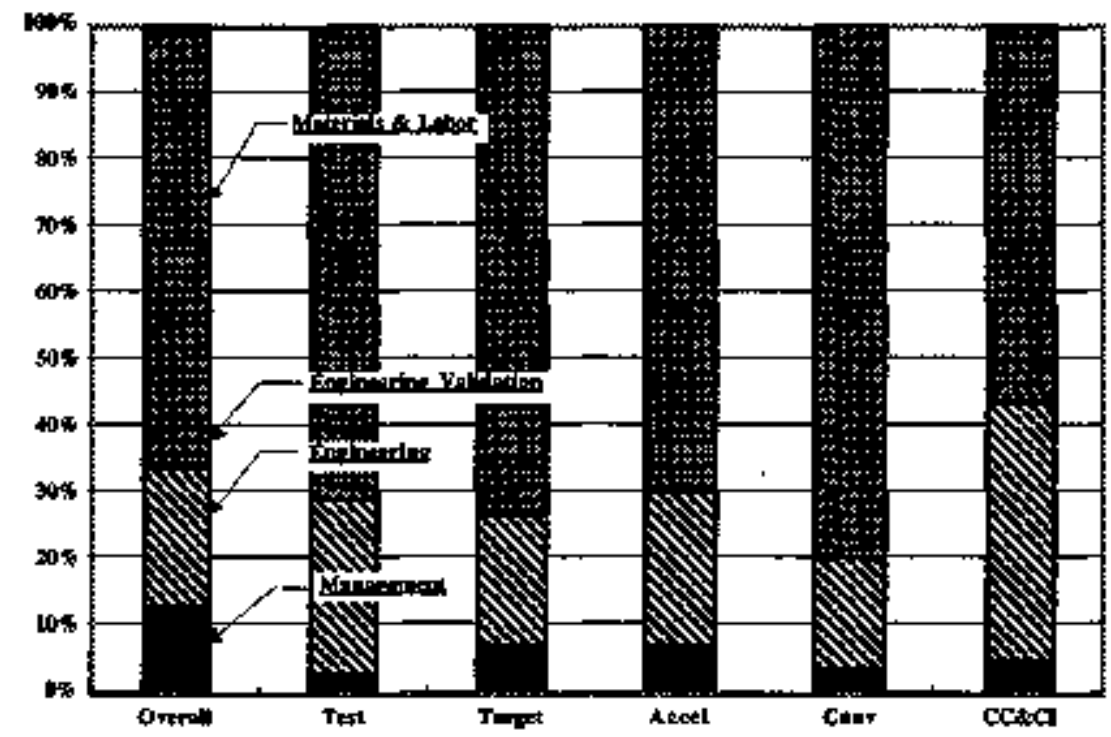

Figure 5-2. Diștribution of basic cost types

\subsection{Allowance for Indeterminates}

Figure 5+3 shows the distribution of AFI for the total system and each major WBS element. The overall value of $27 \%$ seems reasonable since the IFMIF configuration is well established from the FMIT project. Note that the majoity of the AFI is determined by the relatively complex accelerator faculty which has an AFI factor of $35 \%$.

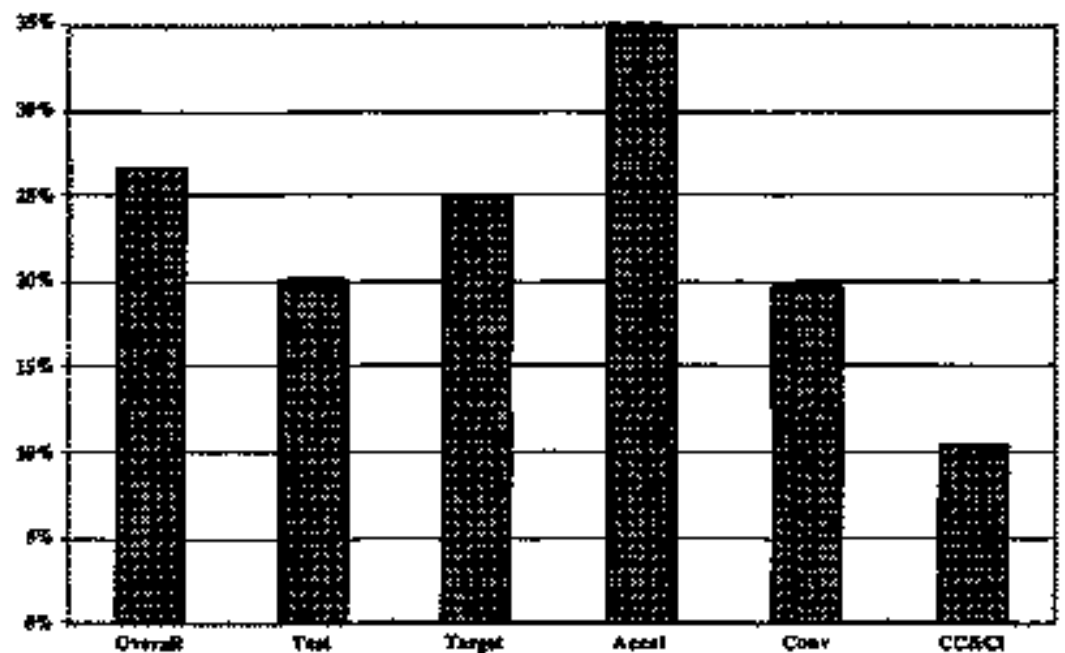

Figure 5-3. Distribution of TEC Allowance for Indeterminates 


\subsection{Indestrial Participation}

The estimate shows that up to $85 \%$ of the FMIF cost conld be contracted to commercial vendors as shown in Figure 5-4. This value includes Project Managenent; if only the individual facilities are considered, the factor would be mone than $90 \%$.

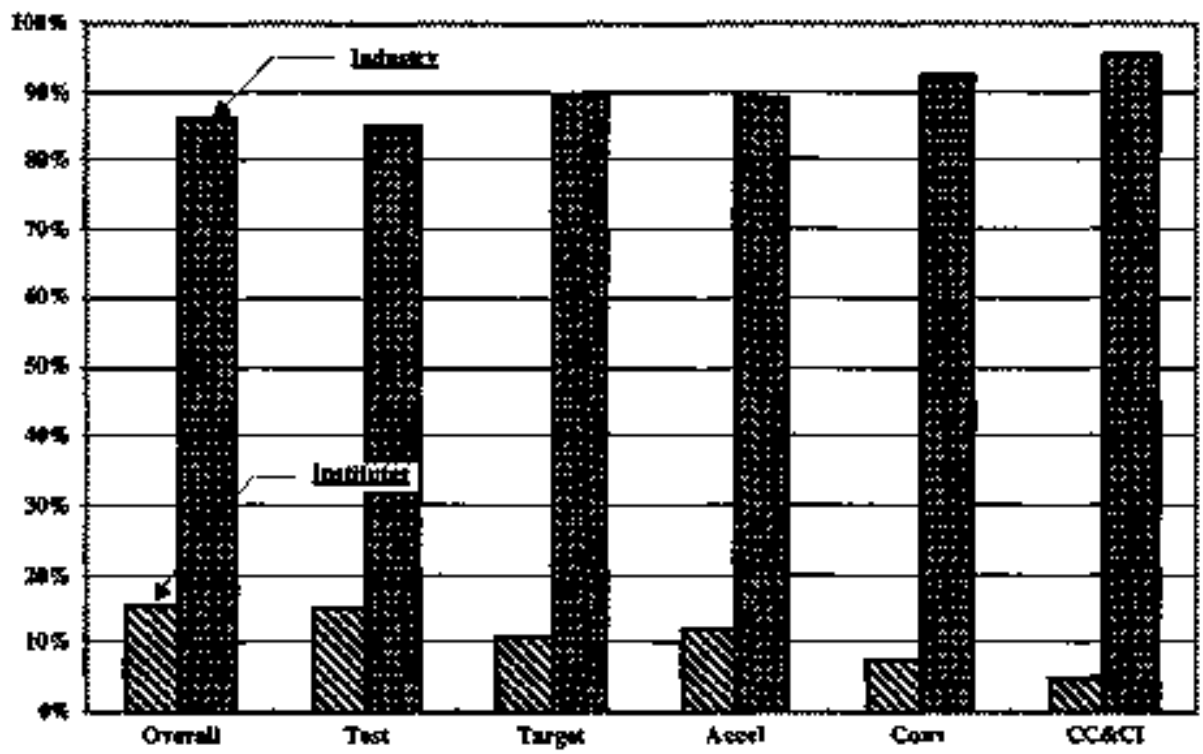

Figure 5-4 Inđọstrial-Laboratory diștribution

\subsection{Expenditure Location}

The estimate shows that up to $70 \%$ of the IFMIF cost cotild ideally be spent "off-site" as shown in Figure 5-5. A more realistic value will probably be lower when a specific site has been selected and additional construction and managenent functions are located at the IFMIF site.

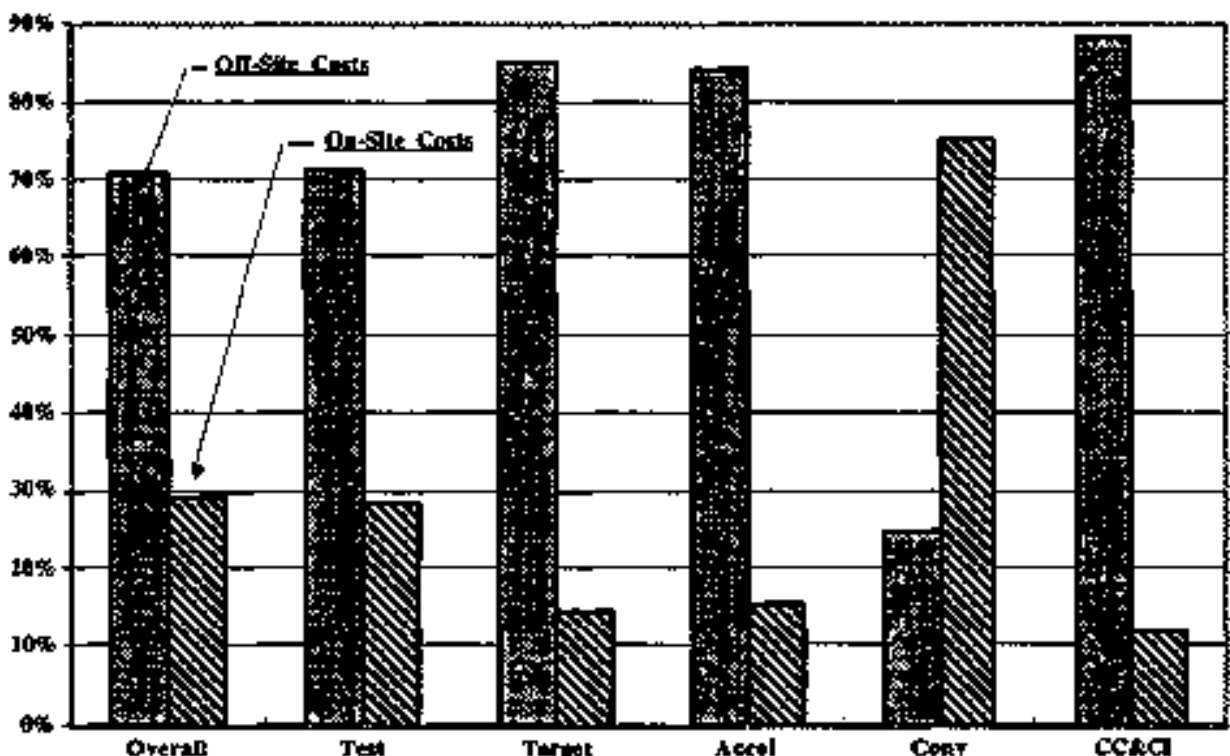

Figure 5-5. "On-site"."off-site" distribution 


\subsection{Management Distrfbutions}

Figure 5-6 shows the percentage of TPC costs for the management of both the overall project and each facility. The "Overall" figure is a combination of both the WBS 1.0 Project Management total and the sum of all the Facility management costs. It is based on historical values for large projects while the facilities management costs were estimated individually by each responsible party. The Target and Accelerator systems are considered the most complex and thus have relatively high management costs. Conventional facilities are to be managed by the Construction Manager which is costed in WBS 1.0 once construction begins thus the value is relatively low.

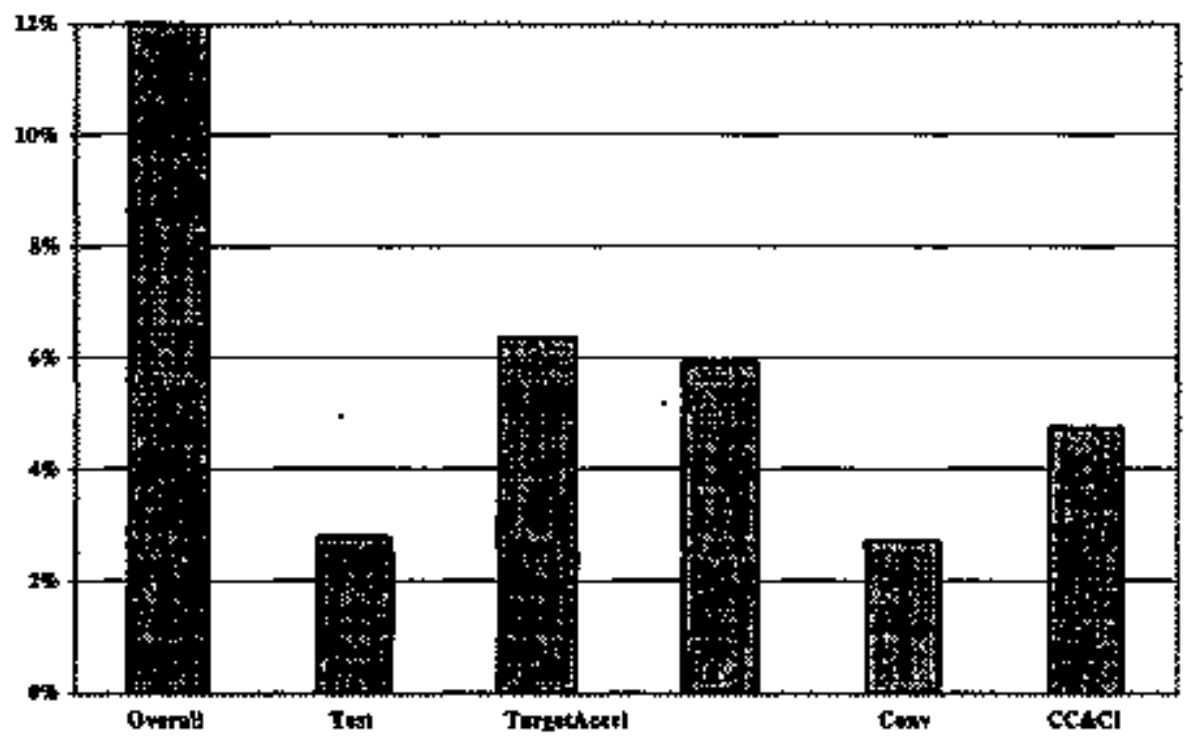

Figure 5-6. Management cost distribation

\section{References:}

1. IFMIF Conceptnal Design Activity Final Report, IFMIF CDA Team, Edited by M. Martone, ENEA, Frascat Italy, No. RT/ERG/FUS/96/11, December, 1996

2. IFMIF Conceptual Design Activity Preliminary Cost Report Compiled by M. J. Rennich, Oak Ridge National Laboratory, ORNLM-5230, July 1995, [Limited Distribution].

3. Proposed Tasks for International Fusion Materials Irradiation Facility - Engineering Validation Phase, IFMIF-CDA Team, JAERI-memo 08-173, August 1996 


\author{
Appendix 5-A \\ Summary Of Preliminary \\ IFMIF Construction and Startup
} Cost Estimate 
Dectwiber IJ4, Find IFMIF Sunmary Cosi Esalmate

\begin{tabular}{|c|c|c|c|c|c|c|c|c|c|c|c|c|c|c|c|c|c|}
\hline & & 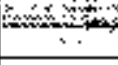 & 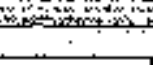 & 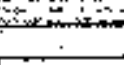 & : & Thibion & Disingut & cintis co & a) (1) & & $\therefore \div \div=$ & $\because$ & $\because \cdots$, & $\therefore$ & 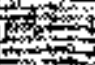 & 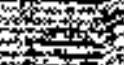 & -1 \\
\hline Curretie & 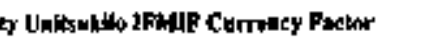 & & & & & TITFWIF & & & & $0.0-5$ & Sth AE JPi & & & & & & \\
\hline & & Oensing & opsite & Indue & & IEMA' & & oft-ik & $C_{0=0} L_{4} C_{0}$ & alration & lothingen & & Omplac & & & & \\
\hline WhB & Elenenl & Prill Man. & Ploil Mant: & Mat'ULA & Enyln's & 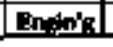 & AFI & Tolel & 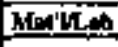 & Entring & En:ln's & AFI & T닌. & 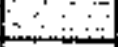 & EYP & 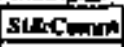 & \\
\hline & Prodect Todnls & 52,000 & $38,34 t$ & 251605 & 3,62 & 17,401 & 122.54 & 525.232 & 114,139. & 21, & 11,77 & $3,2,103$ & 181, & Thits. & $\$ 9,323$ & 63,004 & \\
\hline 1. & 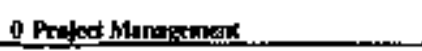 & $5,0,00$ & o & 0 & 0 & $\bullet$ & $\bullet$ & 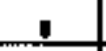 & 0 & : & 0 & 0 & $\mathbf{0}$ & sive & 200 & 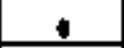 & \\
\hline $2 \div$ & 0 Tost ractille: & 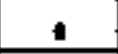 & 3,000 & $\mathbf{4 , 7 3}$ & 10,697 & 4,5Gt & 11,296 & 73,275 & 13,695 & 4,55 & 5,465 & 6,197 & 34,367 & 106,62 & IAG0 & 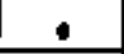 & 211 \\
\hline 1 & 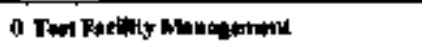 & 0 & 5,040 & - & 0 & $\bullet$ & $\bullet$ & B & $\mathbf{0}$ & $\mathbf{0}$ & 0 & $\mathbf{0}$ & $\bullet$ & $\because \frac{\sin 20}{30}$ & $\bullet$ & 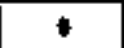 & \\
\hline 2 & 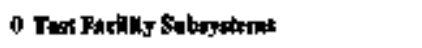 & 0 & $\mathbf{0}$ & 46,710 & $10,6 \%$ & 4,562 & 11,106 & $7 t, 173$ & 10,6 & $4,55 *$ & $s, \infty$ & $6,19 n$ & 21,369 & $2 \sin 2$ & $\bullet$ & $\bullet$ & \\
\hline & $\begin{array}{l}1 \text { Vendeal Tess Assemblles for Tess Cell I } \\
2 \text { Test Cọl I }\end{array}$ & & & $\begin{array}{l}3,465 \\
0,198\end{array}$ & $\begin{array}{r}61 \\
0\end{array}$ & $\begin{array}{c}2,008 \\
928\end{array}$ & $\begin{array}{l}1,045 \\
825\end{array}$ & $\begin{array}{l}1,179 \\
1,951\end{array}$ & $\operatorname{los}$ & 0 & 390 & $\begin{array}{l}59 \\
53\end{array}$ & $\begin{array}{l}594 \\
353\end{array}$ & s.mi: & & & \\
\hline & 3 Tesi Cen Techenlony Rooin 1 & & & 342 & 0 & 127 & 94 & 563 & 155 & 18 & 231 & $\$ 1$ & 485 & 1048 & & & \\
\hline & 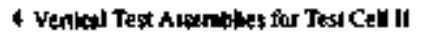 & & & 3.465 & 66 & $20+1$ & 665 & A,ADON & 305 & $\mathbf{0}$ & D9 & 29 & 173 & 4,573 & & & \\
\hline & S Text Call II & & & 3,198 & 0 & $\mathbf{9}$ & 658 & 3,949 & 22 & 0 & 7 & 46 & 275 & $-4,224$ & & & \\
\hline & 6 Tast Cell Testrofoery Ration II & & & $\mathbf{M 2}_{2}$ & 0 & 13 & 71 & 426 & 159 & 2 & 94 & 42 & 253 & 699 & & & \\
\hline & 7 Teat Facility Connoof roost & & & 812 & $\Delta$ & 109 & 195 & $1,1 \times 0$ & 4 & a & 291 & 59 & 354 & $1 \leq 0 \mathrm{~A}$ & & & \\
\hline & 8 Artets Cell & & & 5,110 & 0 & 375 & 1,217 & 7,301 & 60 & 0 & 900 & 320 & 1.919 & 920 & & & \\
\hline & 4 Servine Cell & & & 1,546 & 0 & $\theta$ & 309 & I, Bss & 2,349 & 0 & 629 & 6035 & 3,809 & S,604 & & & \\
\hline & 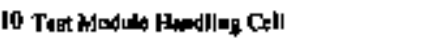 & & & 1,457 & 0 & व & 29] & $1.74:$ & $\mathbf{s s}$ & 0 & 346 & $2 \pi$ & 1,421 & 3,100 & & & \\
\hline & It PE Hol C:Al & & & 3,288 & $\mathbf{9}$ & 0 & $6 \times 8$ & 3,946 & 3352 & 0 & 599 & 758 & 4.729 & $\therefore 655$ & & & \\
\hline & 12 Shineded Otow Box taboratory & & & s,mo & 0 & 0 & 1,704 & 10,764 & 0 & 0 & 311 & $a$ & 373 & $\therefore$ & & & \\
\hline & I3 Trthum Leboratory & & & 10,867 & 9,970 & 15 & 3,471 & 25.023 & 2713 & 4,570 & 1,560 & 3.228 & $\$ .556$ & 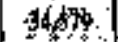 & & & \\
\hline & If Mambertaced 5ystams & & & v & 0 & 0 & 0 & 0 & 1,0no & 0 & $99 !$ & $\$ 12$ & 3,013 & 3070 & & & \\
\hline 3 & 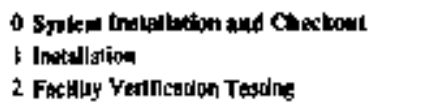 & $\bullet$ & 0 & 0 & 0 & - & - & - & 3.060 & - & - & - & 3,000 & 3ipon & 0 & $\mathbf{0}$ & \\
\hline 4 & 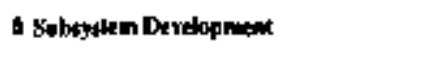 & 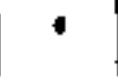 & 0 & $\mathbf{0}$ & 0 & $\bullet$ & D & $\bullet$ & $\mathbf{0}$ & $\bullet$ & - & $\bullet$ & $\mathbf{0}$ & $\begin{array}{c}0 \\
\therefore\end{array}$ & 10,450 & n & \\
\hline
\end{tabular}




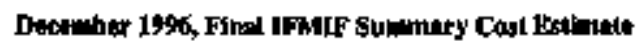

\begin{tabular}{|c|c|c|c|c|c|c|c|c|c|c|c|c|c|c|c|c|c|c|}
\hline \multirow{3}{*}{\multicolumn{3}{|c|}{ 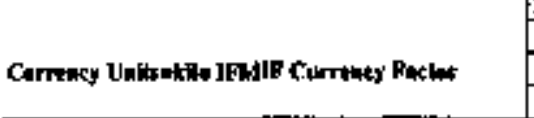 }} & \multicolumn{16}{|c|}{ 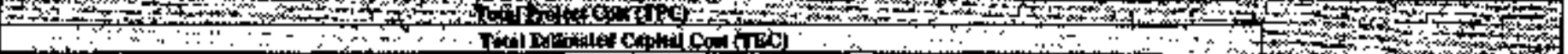 } \\
\hline & & & \multicolumn{7}{|c|}{ 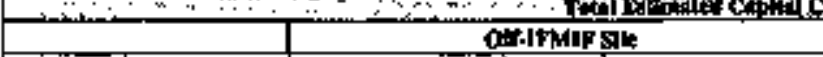 } & \multicolumn{5}{|c|}{ Oarsik At DMMIF } & \multirow{3}{*}{ 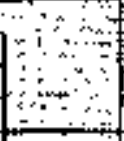 } & \multirow{2}{*}{\multicolumn{3}{|c|}{ 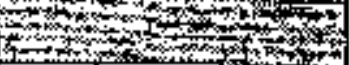 }} \\
\hline & & & \multirow{2}{*}{\begin{tabular}{|c|} 
Oenvile \\
Prol Man \\
\end{tabular}} & \multirow{2}{*}{ OAfrsun } & \multicolumn{2}{|c|}{ Ledessing } & \multirow{2}{*}{ 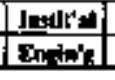 } & \multicolumn{2}{|r|}{ OIfoilt } & \multicolumn{2}{|c|}{ Conlel. Cemprader } & \multirow{2}{*}{ Ensiltal } & \multirow{2}{*}{\multicolumn{2}{|c|}{ AF Thal }} & & & & \\
\hline $\mathbf{W}$ & BS & Dantant & & & Mr'vto & Bnn's & & 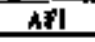 & Told & Mar'tilab & Ene & & & & & EVP & Stecomn & 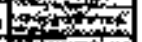 \\
\hline \multirow[t]{20}{*}{3} & $\|$ & 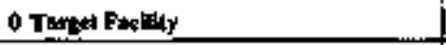 & - & 7,574 & 53,64 & 12,92, & $2,79 s$ & 21,69 & 91,001 & 11,914 & $d, m$ & $\$$ & 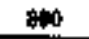 & 16,01 & $-1,5,176$ & 200 & - & $\$ 10$ \\
\hline & 1 & 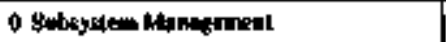 & - & 7,374 & $\bullet$ & 0 & 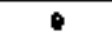 & 0 & 4 & 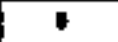 & o & $\bullet$ & $\bullet$ & $\bullet$ & $\because 934$ & \multirow{20}{*}{$\begin{array}{l}8,850 \\
25 ; 894\end{array}$} & \multirow{19}{*}{. } & this: \\
\hline & & 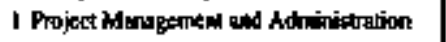 & & 2,143 & & & & & 0 & 0 & 0 & 0 & $a$ & 0 & $\because 2143$ & & & 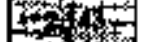 \\
\hline & & 2 Sysiema Enghnering & & $2,3 n$ & & & & & $\theta$ & 0 & o & 0 & 0 & 0 & - & & & \\
\hline & & 3 ESAH Documetintion & & 400 & & & & & 0 & 0 & 0 & a & 0 & 0 & $\therefore 400 \div$ & & & \\
\hline & & 4 Goolvey Assurance & & $1, \mathbf{t 2} 0$ & & & & & 0 & 0 & o & 0 & $\mathbf{0}$ & $a$ & $1,0,30^{-}$ & & & 5 \\
\hline & & 5 Ouler Coste & & 674 & & & & & $\theta$ & 0 & 0 & 0 & 0 & (2) & 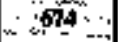 & & & \\
\hline & \multirow{8}{*}{2} & 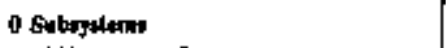 & & & 59,60 & 11,821 & $2 \pi 3$ & 21,545 & 69,7:8 & $4,7 s$ & $\bullet$ & $\bullet$ & 29 & 5,014 & 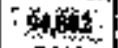 & & & \\
\hline & & 1 Littinen Treet Systen & & & 3,609 & 603 & 640 & 2,445 & 1,936 & 5,54 & 0 & o & 20 & 60,3 & $\therefore 7,939$ & & & \\
\hline & & 2 Whitum Cooling System & & & $|6,1| 3$ & 3,462 & 929 & 3.956 & 24,460 & 2,296 & o & 0 & IIS & $2, \$ 11$ & $\because \frac{1}{20}$ & & & \\
\hline & & 3 Lithlum Rurntex|an \& Moninoring Syotem & & & 7,234 & 2,154 & 1,051 & 3,792 & 14,271 & 866 & 0 & o & 43 & 909 & $\because 510$ & & & $=-\infty$ \\
\hline & & 4 Lithion Kacowety Syutent & & & 10 & 2 & 1 & 7 & $\mathbf{2 0}$ & 0 & 0 & 0 & 0 & 0 & 20. & & & \\
\hline & & 5 Controt $S_{7 y+m}$ & & & 6,394 & $9+5$ & 18 & $m$ & 7,904 & 1,039 & 0 & 0 & 32 & 1,091 & 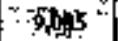 & & & \\
\hline & & 6 Venkilation Syotem & & & 6,291 & 629 & 13 & 1,519 & 8,452 & 0 & 0 & 0 & 0 & 0 & Bust. & & & $\tan 2$ \\
\hline & & 7 Mainknnace Sylums & & & 14,059 & 4,098 & s] & 9,099 & 27,296 & 0 & 0 & 0 & 0 & t & 3.245 & & & \\
\hline & \multirow{4}{*}{3} & 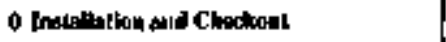 & & & $\bullet$ & 1,106 & 21 & us & 3,113 & 5,139 & 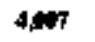 & 84 & 561 & 11,787 & $\therefore \sin$ & & & 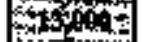 \\
\hline & & I Installaion & & & 0 & 553 & 11 & 36 & 的 & 6,367 & $2, \pm 01$ & 56 & 156 & 9.580 & $\bar{j}, 2 \mathrm{ai}$ & & & 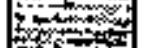 \\
\hline & & 2 Verdirembia TeMlang & & & 0 & 191 & 4 & 9 & 194 & 291 & $29 \mathrm{k}$ & 6 & 29 & 613 & "Bíl & & & \\
\hline & & 3 Fert Detationd & & & (1) & 372 & 3 & 19 & 398 & $5 \mathbf{k} \mathbf{1}$ & 915 & it & 76 & 1,590 & $\therefore, 989$ & & & \\
\hline & 40 & a Subtydum Developmam & & & - & 0 & - & 0 & $\bullet$ & $\bullet$ & $\bullet$ & a & $\mathbf{0}$ & $\mathbf{a}$ & $\because \div$ & & & \\
\hline 4 & - 1 & 0 decelorecer Fasully & - & 24,130 & 169,344 & 58,053 & 9,272 & 8) 8148 & 324,126 & 38,271 & s,45ts & 3,044 & $\mathbf{1 6 , 5 2 0}$ & 61,513 & 40,961 & & 0 & \\
\hline & 10 & 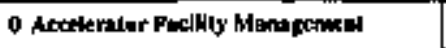 & & $\overline{24,300}$ & & & & & & & & & & 0 & 24 isto & & & 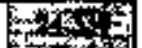 \\
\hline & 2 & 0 Sabystem & & & 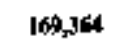 & $\$ 9,053$ & 9,222 & 81,481 & 321,126 & - & $\bullet$ & ⿶ & $\mathbf{0}$ & - & $\mathbf{3} \mathbf{1}, \mathbf{1 2 4}$ & & & 位 \\
\hline & & I Axte-1. Eqpip. Prel Deslon & & & & 11.621 & 2,905 & sinte & 99,610 & & & & & a & $19,610^{\circ}$ & & & \\
\hline & & 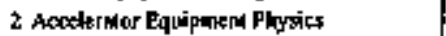 & & & & 4,944 & 2,119 & 2,472 & 9,535 & & & & & o & 1,535 & & & \\
\hline & & 3 Acaletrotm al (Cassox) & & & B5,496 & 28,465 & 3.542 & 4,182 & 158,769 & & & & & 0 & 1ss, \{tom & & & intis \\
\hline & & 4 Accalorayor b2 (Pallux) & & & $7 \$, 050$ & 6,162 & 0 & 29,366 & $\$ 13,978$ & & & & & 0 & 113,978 & & & $10 \times 2$ \\
\hline & & 5 Btsm CABbration Dmmps: & & & $\$ .133$ & 994 & 112 & 2,291 & B,830 & & & & & 0 & $8,830=$ & & & 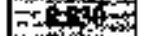 \\
\hline & & 6 Acceknkor byanen Couldror & & & 683 & $4,58]$ & 142 & 1,892 & 7,298 & & & & & 0 & 7,298 & & & 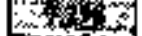 \\
\hline & & I Accelenter Sipport SyEtems & & & & 2,266 & 0 & $\operatorname{sot}$ & 3 mex & & & & & 0 & $3,0 \pm 6$ & & & \\
\hline & & 8 Maintenence Systems & & & & & 0 & 0 & 0 & & & & & 0 & 0 & & & \\
\hline & 3 & 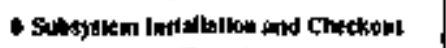 & & & 0 & - & 0 & - & 0 & 39,271 & 5,0 & $3 / 040$ & 16,544 & 1,513 & 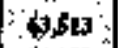 & & $\bullet$ & 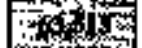 \\
\hline & & I Actolerator *I (Coescor) & & & & & 0 & a & 0 & 20,715 & 3,076 & $1,4 \% 9$ & 8,909 & 34,159 & 34,159 & & $\mathbf{0}$ & 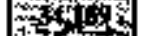 \\
\hline & & 2 Acsclarlor 12 (Pollax) & & & & & o & $\mathfrak{v}$ & 0) & 17,556 & 2,642 & $1, \mathbf{S 4 5}$ & 7,611 & 29.334 & 20,354 & & ) & 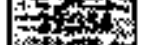 \\
\hline & 4 & O Sulssion Dewelopmerix & & & & & & & & & & & & & $\because 0$ & 15,484 & & \\
\hline
\end{tabular}


December 1996, Pnod IDMTE Summiry Cwa Estimate

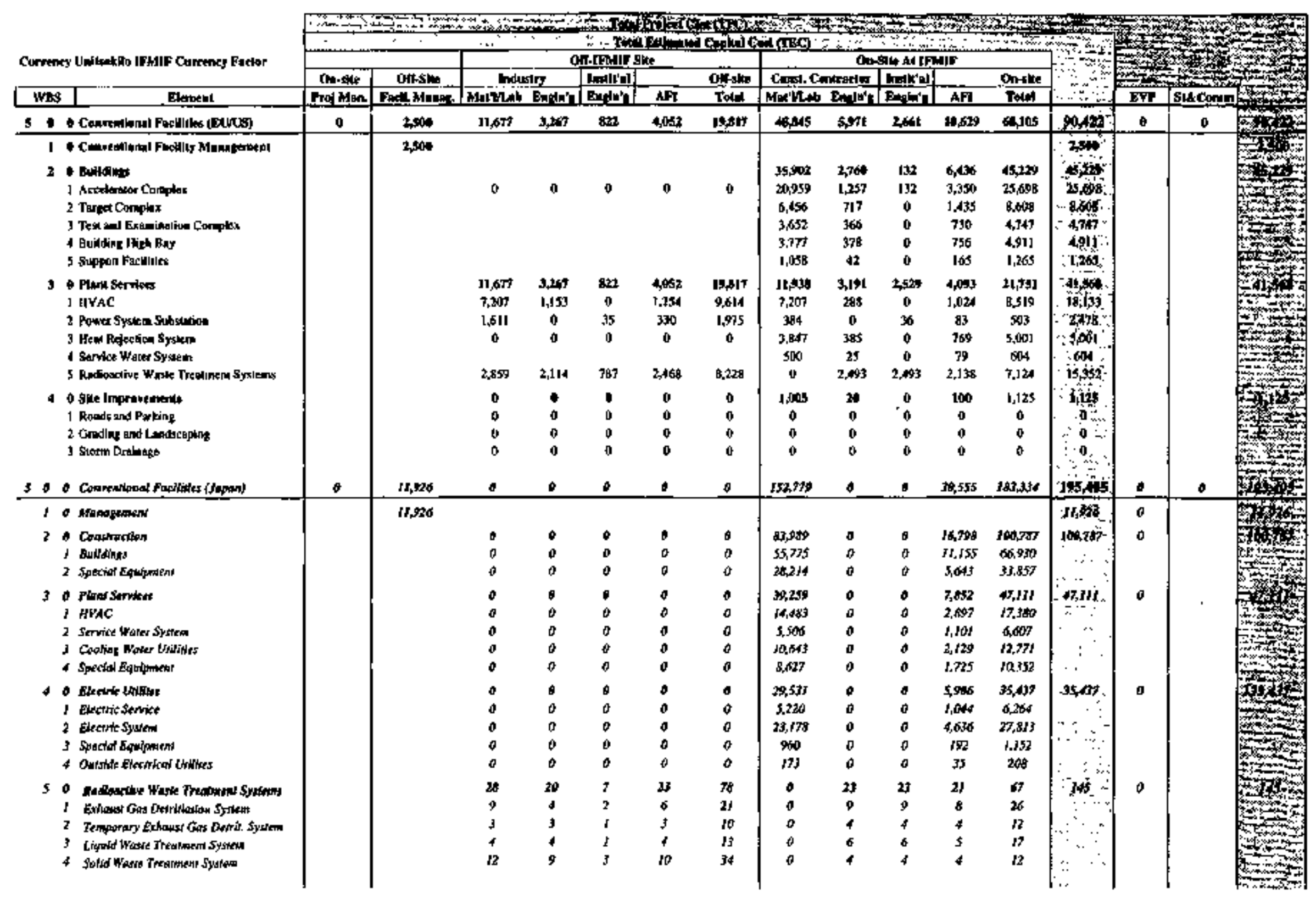




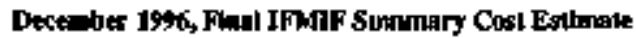

\begin{tabular}{|c|c|c|c|c|c|c|c|c|c|c|c|c|c|c|c|c|c|c|}
\hline & & & - & $\therefore ?$ & (1) & $\frac{1+2}{\cdots+1}$ & 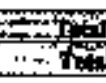 & Prist & 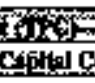 & काEQ & . & 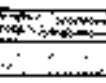 & 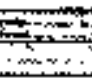 & 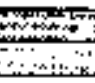 & 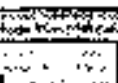 & $+\infty$ & 200 & \\
\hline & rency & 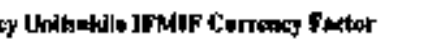 & & & & & II.IFAIIP 5 & & & & On-5 & SlleAI Wa & & & & & & \\
\hline & & & Onsint & Ontshe & hat & & hotil'y & & Ontur & Const. $C_{0}$ & Inter & hothal & & On-fing & & & & \\
\hline & Es & 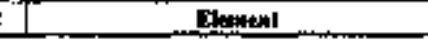 & Proj Min. & Fuchl, Alowars: & MnFulu & Bnilin: & Dinthis. & A노 & Toul & Mitillat & 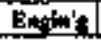 & 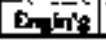 & $A \mathrm{I}$ & Toltat & & EVP & siktchom & ] \\
\hline 6 & 0 & - Condmal Conh and Conamen Inalr. & 0 & 1,143 & 10,196 & 7,726 & $\bullet$ & 2,01 & 20,12 & 1,473 & 1,284 & 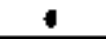 & 57 & 2014 & $+23,963:$ & 1,43 & $\mathbf{0}$ & 32 \\
\hline & 1 & 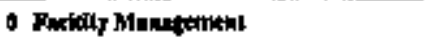 & & 1,1443 & & & & & & & & & & & $1,1+3$ & $\bullet$ & 0 & \\
\hline & 20 & 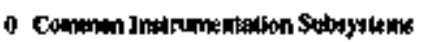 & & & 5,348 & 94 & $\bullet$ & 60 & 6,960 & 713 & 500 & - & 57 & 1,368 & 74as: & 1,439 & 0 & 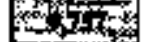 \\
\hline & & I Beam Imanumahuabion & & & 576 & 0 & 0 & 263 & $1,1 \pm 9$ & $\mathbf{0}$ & | & 0 & 31 & $22 z$ & .364 & 1.143 & & $=\frac{1}{2}$ \\
\hline & & 2 Radtaticu Moniteriag & & & 2,616 & $\theta$ & $\mathbf{0}$ & 52 & $2, \pi+7$ & 140 & 422 & 0 & 6 & 368 & 1झ心 & & & 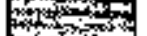 \\
\hline & & 3 V|deo Woatroring & & & 744 & 229 & t5 & 10 & 1,981 & 200 & 0 & 0 & 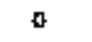 & 200 & $0,2,2 k i$ & 286 & & + \\
\hline & & 1 Axress Control & & & 275 & $2 \mathbf{2 0}$ & 0 & 62 & 365 & 133 & 0 & $\theta$ & 0 & 193 & 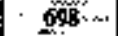 & & & \\
\hline & & 5 Aneountalator & & & 2]4 & 298 & 0 & 56 & 499 & 80 & t) & $\theta$ & $\theta$ & 80 & $\cdot 599 \therefore$ & & & \\
\hline & & 6 Infotmation Display Sigtiont & & & 530 & 220 & 0 & 87 & 846 & 160 & 0 & D & 0 & 160 & $27,00 \%$ & & & \\
\hline & & 7 Safty and Emergeacy Equlpuents & & & 93 & 0 & 0 & 0 & 93 & 0 & 5 & 0 & 0 & 5 & $\therefore 88$. & & & \\
\hline & 3 & 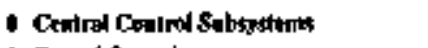 & & & 4,840 & 6,514 & 0 & 1,462 & 12824 & $\mathbf{7 6}$ & 0 & 0 & $\theta$ & 760 & j9, sed & t & - & \\
\hline & & I Centra Conorol & & & 846 & 1,829 & 0 & 399 & 3,034 & 69 & $\mathbf{0}$ & 0 & 0 & 61 & $\because 3,100$ & & & \\
\hline & & 2 LAN & & & 情 & 229 & $\mathbf{0}$ & 83 & 79 & 160 & 0 & 0 & $\mathbf{0}$ & 160 & . & & & \\
\hline & & I huentack lotele & & & $\$ 10$ & 914 & 0 & 178 & 1,502 & 200 & 0 & 0 & 0 & 200 & $\therefore 1,002$. & & & $-x_{\infty \rightarrow \infty}$ \\
\hline & & 4 Central Dtsplay Panel & & & 3.587 & 114 & 0 & 176 & 1,878 & 133 & 0 & 0 & 0 & 133 & : 忽oil & & & \\
\hline & & 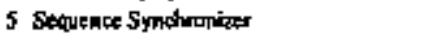 & & & 1,187 & 229 & 0 & [s] & 1,568 & 133 & 0 & 0 & 0 & 133 & $\therefore 1, \times \in Z$ & & & \\
\hline & & 6 Duaniny Subsation & & & 331 & 914 & 0 & 130 & 1,116 & 6) & 0 & 0 & $\mathbf{0}$ & 67 & $\because 1,482$. & & & 10 \\
\hline & & 7 Opesalian and Counfiguration Control & & & 0 & 2,286 & 0 & 343 & 2.629 & 0 & 0 & 0 & $\mathbf{0}$ & 0 &. .20829 & & & \\
\hline & 4 & - symen Insidhisen und Chrskont & & & 0 & $2 \times 8$ & $\bullet$ & - & 238 & - & 486 & $\mathbf{0}$ & • & 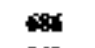 & Y:4 & $\mathbf{0}$ & $\bullet$ & 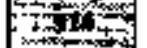 \\
\hline & & I Instullation and Teil & & & 0 & 114 & 0 & 0 & 114 & 0 & 343 & 0 & 0 & 343 & $\because 45$ & & & \\
\hline & & 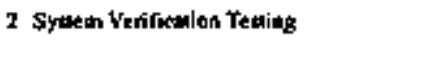 & & & - & Ila & o & n & 114 & 0 & 343 & 0 & 0 & 343 & $\therefore 457$ & & & 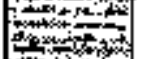 \\
\hline 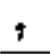 & 0 & - Oparalloml Startup and Comentisa. & - & o & 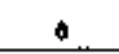 & 0 & 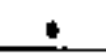 & $\bullet$ & $\bullet$ & $\bullet$ & 0 & 0 & $\bullet$ & o & $\therefore \ddot{~}$ & $\mathbf{0}$ & 60,434 & \\
\hline & $\overrightarrow{\mathbf{I}}$ & 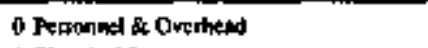 & & & & & & & & 0 & 0 & 32,918 & 3,292 & 36,210 & $\therefore:$ & & 36,210 & \\
\hline & 2 & o Eleethed Power & & & & & & & & 22,509 & 0 & & 2,251 & 24,760 & & & 24,760 & \\
\hline & 3 & 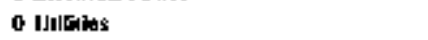 & & & & & & & & 57 & 0 & $\mathbf{0}$ & $5 B$ & 636 & $\ddot{\because}$. & & 636 & \\
\hline & 4 & O) Msiaterence & & & & & & & & 1,000 & 0 & 0 & 1 tin & 1.10ikg & $\therefore:$ & & $1,10 \mathrm{k}$ & \\
\hline & 5 & 0 Wente Dtspods & & & & & & & & 298 & 0 & 0 & 30 & 328 & $\therefore$ & & $32 B$ & \\
\hline
\end{tabular}




\section{APPENDIX 5-B}

Complete Listing of The IFMIF

Work Breakdown Structure 
1. 2. Lexel

1. 0. Project Manszement

1. Project Management and Administration

2. Systems Engineering

3. Eavirontmental, Safety \& Health Documertation

4. Quality Assurance

2. 0. Test Faclities
1. Test Facility Management
2. Test Facility Subsystems
3. Test Facifity System Installation and Checkout
4. Test Facility Subsystem Development

3. 0. Target Facility
1. Target Factity Management
2. Subsystem
3. System Installation and Checkout
A. Subsystern Development

4. 0. Accelerator Faciltty
1. Accelerator Facility Management
2. Subsystems
3. Subsystem Installation and Cbeckout
4. Subsystem Development

5. 0. Conventional Facilities
1. Conventional Facility Management
2. Butldings
3. Plant Services
4. Slte Improvernents

6. 0. Commor Instrumentation and Central Control Systems
1. System Monagement
2. Common Instrumentation Sulasystems
3. Central Control Subsystems
4. System Installation and Cbeckout

7. 0 . Operatlonal Startup and Commissioning
1. Personuel \& Overbead
2. Electrical Power
3. Utilities
4. Maintenance
5. Faste Disposal 


\section{IFMIF Work Breakdown Structure}

\section{2. 3. 4. 5. 6. 7. Lever}

1. 0. 0. 0. D. 0. 0. Projext Manis.

1. 0. 0. 0. 0. 0. Project Manng, and Adminlstratle 1. 0. 0. 0. 0. Administration 2. 0. a, 0. 0. Cout Control 3. 0. a. a o. Schetale 4. 0. 0. 0. Developmeat Oversigth 5. 0. 0. 0. 0. Constrution Mamog. 6. a 0. 0. 2. Doc.

2. 0. 0. 0. 0. a. Systure Engtonering

1. 0 0. 0. 0. Desijen foregration

2. 0. 0. 0. 0. Systems Anelysít

3. 0. 0. 0. O. Requirenencs/specs

4. 0. 0. 0. 0. RAM Amalyzis

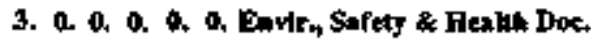

4. 0. 0. 9. 0. Q. Quality Aswrace

2. 0. 0. 0. 0. 0. Te Test Fochliles

1. 0. a. 0. 0. 0. Text Faclliky Maneq.

1. 0. 0. 0. O.Projec Mans and Adrinisarition

I. 0. 0. OAdinfrisartion

2. 0. 0. 0.Con Coutrol

3. 0. 0. aschodale

4. 0. 0.0 .0 ac.

2 a. 0. a OSysums Enginesing

1. D. O O.Design Intertaien

2. D. 0. OSystems Antyatis

3. 12. O O.Requireacentspecs

4. 6. O. ORAM Ardýt

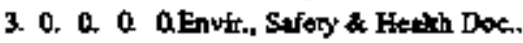

I. a 0 OEnvir., Sufety \& Health Doc.

2. a a D.Luenotes

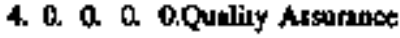

5. 0. 0. Q. O.Oner Cosis

2. 0. a. a a. a.Test Faellity Subcyetems

j. 0. 0. a a Verical Tea Assemblies

l. 0. 0. O.VTAL-WnK

2. 0. O. OVTAL-He

3. 0. O. O.VAZNAK

4. O. O. OVTAZ-He

1. a. OVTA2-He Conoepal 1

2 a O.VTA2-He Consept 2

5. 0. a D.VTT-Syater

6. 0. 0. Oshield Phas

2 0. 0. 0. O. Tent Cell 1

1. D. 0. D.Tex Cell Cover

2. 0. 0. QTes Cell Liner

3. a 0 . O.tent shield

4. 0. O. OSed Plate

5. 0. O. OCamera System

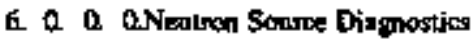

7. a i d Tes Cell Dismostics

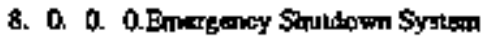

3. 0. D. 0. a.Test Call Techology Reom 1

1. D. a 0.Awently and Tesing

2. D. a. 0.Cosling Syriem

3. 0. O. Q vactura Powjing Syrtem

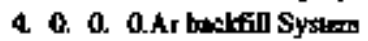

5. 0. 0. O.Diapnodies and Controls

6. a. 0. O. Subsystem Power

4. A. O. a. 0.That Cell 2

l. o. 0. 0.Tesl Cell Cover

2 a. 0. O.Tesi Ced Liner

3. 0. 0. 0. Heat shield

4. 0. 0. Oseal Pale

5. a. a 0.Comer Syster

6. a. 0. 0.Neduron Scurce Diagnostics

7. 0. a Q Terr Cell Diagnopties

B. 0. 0. Q.Energency Shatdown System

5. 0. 0. a. Q.Tex Cell Tectrology Room 2

1. a a OAlsenbly and Testing

2. 0. Q. 0.Coding Sysum

3. 0. Q. Q. Yacown Pumping Syskem

4. D. Q. O.Ar backifil Syation

5. O. O. O.Dinposties and Contrals

6. 0. A. a.Sobxysten Powier

6. 0. 0. a.Test Faciliny Candrol Rocra

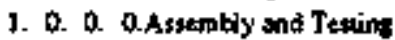

2. 0.0 . 0.Date Acq - VTA 1 - Nak

3. 0. 0. 0.Dall Aeq - VTA-I - He

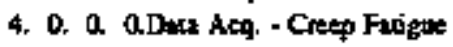

5. A. 0. D.Dati Acg - Tritim Releass

6. 0. 0. 0.Dun Acg - VTI

7. 0. 0. 0.Supenisory Compoter

8. 0. 0. 0.Subsyatem Power

7. 0. 0. 0. O.Acorst Cell

L. 0. 0. Q.Assembly and Tegling

2. 0. 0. 0.Cet Sinaure

3. 0. 0. O.Universid Rabol

4. 0. 0. O.Munipalawe System

5. 0. O OMaistansnce Support Equipmept

6. 0. 0 o.Infrestuncture

c. o. 0. 0. a.Servioe Cell

1. 0. 0. a.Asstmbly mb́ Testing

2. 0. a. acell Strocture

3. D. Q O.Trmsfer Systert

4. 0. A. A.Manípulator Systems

5. D. a. Alidze Crape

6. 0. a. O.Afintantrace Suppor Equip

$\gamma_{1}$ a. 0. O.Infirastueture

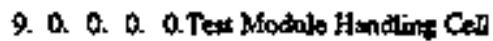

i. 0. 0. OAasenty and Tealings

2. 0. 0. 0.6ell Stroaure

3. 0. 0. OAkripulatur Systrms

4. 0. 0. O.Bridse Crane

5. 0. 0. 0.Msintenance Support Equip

6. 0. 0. O.Inffastructnire 
10. 0. 0. O. OPE $\mathrm{Hox} C=1$

1. 0. 0. OAsumbly mod Teating

2. b. 0. acell Stucture

3. 0. Q. OMenipulatox Syruens

4. 0. 1. 0.Bridge Crine

5. 0. 0. 0.Irksaurucure

6. 0. 0. A.Examination Equipment

1t. 0. 0. 0 a Shieidad Glowe Box Laboratory

1. D. O O.Assembly and Teating

2. 0. 0. OStncture and Suppor Syatens

3. 0. 0. O.Exminution Epripmen

12. 0. 0. 0. 0.Tristom Laboratiry

1. 0. Q. OAssembly and Texting

2. 0. 0. E.Cumpontints

2. 0. 6. O.Tribm Retention

13. 0. D. L OMainteance Syatem

3. 0. 0. 0, 0. G. Tex Facility Systeru InsinglL and Creckow

1. 0. 0. O. O.Inelli.

2. 0. 0. 0. D.Fuility Verification Tenting

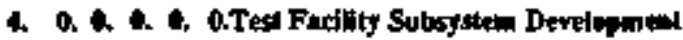

1. a. 0. 0. 0. Project Murag. und Administmition

1. 0. D. 0. Administration

2. 0. 0. 0. Cost Conira

3. 0. 0. 0. Sutedule

4. 0. A. D. Doc.

2. 0. 0. 0. 0. Systems Enginfering

1. 0. 0. O. Dexign Intripation

2. O. 0. 0. Syketns Antysis

3. a D. O. Reqmirementesipes

4. O. 0. O. RAM Anlysts

3. G. a. a. Q Envir, Sefety \& Hankh Doc.

4. 0. 0. 0. 0. Quatiny Assurance

3. 0. 0. 0. 0. 0. 1. Twget Fatility

1. 0. 0. 0. A. G.Target Fudinty Manag.

1. 0. O. D 0.Project Manse-and Administordon

1. 0. 0. OAdninistration

2. 0. a. acosi Courol

3. 0. a 0.Schedule

4. 0. 0 a.doc.

2 0. 0. 0. OSyluent Enginecrivg

1. 1. Q. D.Desion Inegration

2. O. OSystoms Analysis

3. 0. C. ORequifeneatspess

4. O. D. O.RAM Analyats

3. 0. 0. Q O.Envir., Sufty a Henlth Doc.

1. a. O. OEnir., Sofezy \& Heatth Dor.

2 0. 0 0.1ecenses

4. 0. 0. 0 0.Qualiyy Astannes

5. 0. 0. 0. 0.0ther Costs

2. 0. 0. 0. 0. asthsycten

1. 0. 0. 0. 0.Lithium Target Systan

1. 0. 0. 0.Asembly and Testing

f. 0. OAssanbly

2. 0. 0.Tesuing
2. 0. A.Compononits

1. Q 0.Tmpat Astanbly

1. O.L.i Inke Phing

2 A.Fow Srraighteaer

3. a.Norale

4. O.Repluseable Backwall

5. Q.Domnstratm Diffuser

6. ODownswean Baffier

7. OMechanical Connectors:

8. 0.Li System Tarter Atsembly Incerface

9. 0.Mensoring Sysum

2. a 0.Beam-Turget Inzeifuce

I. O.Beam-Taries Sichface Strocture

2. 0.Evacustion \$ystem

3. 0.Emergency Shardoura System

3. 0. D.Turget-Test Cell Interface

1. 0.Trge-Test Cell Inverface Sructure

2 0. 0. a O-Libium Coclies Syan

1. 0. 0. O.Aturbly und Testing

1. a. O.Atembly

2. 0. O.Tesine

2. 0. a 0.Componetis

1. 2. O.Main Linhim laop

l. OEM Pamp

2. Q.Valves

3. O.Flow Meters

4. O.Puing

5. Q.Quench Tank

6. O.Dump Tunk

7. OSurge Tonk

8. O.True Heating

9. O.Insalation

10. O.Atgon Vacurrm System

11. OInsummentsoion and Corinol

12. O.Lithiurs Metel

13. D.Rediation Shietding:

2 Q D.Primary Hent Remowal System

1. A.Primary Heat Exchanger(Li to Organic)

2. O.Fping

3. A.Pिisय

4. avalues

5. O.Flow Meters

6. O.Organic Durnp Tank

7. OUnitrumentation and Comprot

8. aradition Shielding

9. O.Organic Oil

10. D.Orgmic Hetrer

3. 1. D.Secondary Heat Removal Systmin

t. Q.Secoppdary Hest Exchunager (Organic to Water)

2. Os

3. A.Pump

4. O. Valver

5. D.Fon Meters

6. O.ristrimenumion and Comarol 4. O. O.Tertiary Head Exchanger(Whaler

3. 0. 0. 0. a.purifiesion and impurily Manirating Systam

1. 0. o. D.Assembly and Testing 
I. 0. A.Assembly

2. 0. 0.Testing

2. 0. 0. acomponents

1. 1. OSintím Purificotion System

1. O.Cold Trap

2. 0.Hox Trat III

3. a.Hox Trop 12

4. 0.EM Funep

5. a.cold Trap Cooler

6. 0.Ping

7. 0.Vilves

R. 0.Trace Hetring

9. Ofnolation

10. O. Inammemetion tord Control

11. ORadiation Shielding

12. D.Fow Metert

13. 0.Exonomizar

2. 0. 0.jmponity Monikoring Sysuem

1. O.On-Line Mevers

2 0.Off-Line Monilors

3. A.Fom Aletars

4. 0.Pìing

5. 0.Vilves

5. OMain Heater

7. 0.Exonomizer

8. 0.Trace Heating

\%. Alnsularion

10. O.Inanumentation and Conirol

1t. ARadistion Shielding

12. 0.EM Pump

4. 0. 0. 0. OLithima Recowery Sysiem

1. 0. 0. 0.Leaked lithiom Recowery Sysurm

2. 0. 0. aleaked Lithium Deaccion Systan

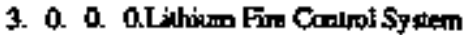

5. 0. 0. a 0.Twper Facilty Costrol Syaten

1. 0. a. 0.Nonmul Oprention Controd Systera

2. 0. 0. A. Emeryency Control Sysuen

6 0. 0. 0. 0.Maintenance Systems

1. 0. 0. A.Mitinatentane Proctudus Development

2. 0. a. O.Special Pappose Tooling

3. 0. 0. O.Remoxe Handling Equipanert

1. a O.For Tirget Assembly

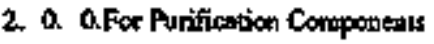

4. 0. 0. O.Mostop Facilities and Tesing

3. 0. 0. 0. 0. 1.Systen Install. and Chection

l. o. 0. D. O.Install.

1. 0. 6. QLinium Twages System

2. 0. 0. OLithinm Coching Systan

3. 0. a a.Lithim Recowary System

4. 0. a 0.Target Fucllicy Conkrol Sysuan

5. 0. a. 0.Target Fanility Ventilation Syrem

6. 0. 0. 0.Turget Faciliny Power System

7. 0. 0. QOher Stppon Facilinies

8. 0. 0. OMtulanance Systems

2 0. 0. 0. 0.Verifienion Testing

3. 0. 0. Q. D.sump

4. 0. 0. 0. a. asubsystat Develeppen1
4. 0. 0. 0. 0. 0. Accelerator Facility

1. 4. 0. 0. 0Ascederator Facllity Mane.

I. 0. 0. O. Qprojea Masag. and Adminisurtion

2 0. 0. 0. D.Systems Engineering

3. 0. 0. 0. 0.Entr. Safery \& Hedtet Dos.

4. 0. 0. 0. O.Qusality Assumate

2. 2. a. 1. 0. asutsyetions

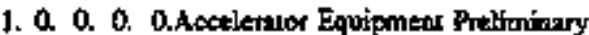
Design (otjector thrs HEBT)

2 0. 0. 0. 0.Accelerios Exyipant Thysics (injetet turs HEBT)

3. 0. 0. Q. D.Acceleralor "I (Cosior)

1. 0. O. O.mjectior Syblem

1. Q. OFinal Desifin lebor

2. a. OProcuretment support/Selles Survellatice

3. 0. a.Purahned Material

1. Q.Scurce and RF power ropply

2 O.LEBT

3. APower supptins

4. M.Operntional Controls \& Sofware

5. A. Vacnom Bquipoent \& Services

6. O.Thernal Conlobl Equip \& Services

7. 0.Strueture and Shicidiag

4. 0. O.Fabrication Labes

5. D. OSugtaining Enginearing

2. a. a ORadio Frequancy Quadrupale \$ystem

L. 0. 0.Cold Moded Derign \& Test

2. 0. O.Final Designt labor

3. a. O.Procurement suppontseller Surveillande

4. 0. O. Ponchused Morenal

1. O.Copper

2. 0. Vwevitu Syatem Equipment \& Servixes

3. O.Drive Loops

4. 0.Electro-kming

5. OStiscellaneova Hardwate

5. 0. O.Fabricention Lubs

6. 0. O.Sugtaining Engineering

3. 0. O O.Dnit Thbe Linuc Sysuen

J. 0. O.Cald Model Design \& Test

2. Q. OFina Design Taks "I-8

3. Q. Q.Tank 1

L. O.Procurament tropport/Seller Surveillowes

2 apurchased Material

1.Drit Tubes

2Dift mbe magnets

3. Vucuum syaten eqpipment \& Services 4.OFHC Copper for Link thell

5. Enctwalls with magnets

6.Tumk suppor sysuem

T,Tunets

8.RF drive kapss

9.Port conplest

10.Drif mbe support girdet

11.Focusing guadrupole packnge

32. Miscellaneous haydware 
3. O.Fatriction laber

4. 0. O.Tenk is

1. O.Procurement apportSeller Sorvilllmet

2 OPurchnsed Meneris

1.Drifi Tobes

2.Difit mbe maprels

3. Vuatom system equipiment Services

4.OfHC Copper for amk ghell

S.Endwalls whi wagneli

6.Tapk soppont nytum.

7.Tmers

8.RF drive loops

g.Perat cosuplers

10.Drift vibe sippon tiutien

11 Focusing quadropole porkage

12 Misceltaneo0s handware

3. A.Fabrication Labor

5. a. Q.Trik is

i. DPpocirement sofponsselder Sarvefllatect

2 0.Purchased Malerial

1.Drifi Tubs

2Dift nube mignets

3. Yacxinn sytem equipment \& Services 4,OFHC Copper for tank whel

5. Endwolls winh magnets

6. Tunk wpport system:

7.Tunets

8.RF dive loops

9.Post coupters:

10. Doith unte suppost gircier

1]. Focasing quadrapole package

12. Miscellaneous burdwire

3. OFabrientar Lesbor

6. 0. 0.Tunk is

J. 0.Prosiremerid supportiseller Sarveitlance

2 O.Parchased Maxerial

1.Difi Tubes

2.Difi rube magnets

3. Vacoum tyatem equipment \& Servict 4,0FHC Copper for tank shet

5.Endwolls wilh magness

G. Tank support sysiem

T. Tuners

BRF dive loopt

9.Post torplets

10.Drift tube suppon ginder

Il.Focuming quatsopois pactuge

12.Mitsellanewes hadware

3. O.Fubrieation Labor

7. O. O.Tank ws

1. O.Procuremen supponiseller

$$
\text { Sarvoillarice }
$$

2. O.Purchased Makeria

I.Drifi Tubes

2Dift tube magnets

3 Vhemun system equipment \& Services 4.OFHC Copper for tank shell

5.Endwalls with ragnets
6.Tork stport tystesh

7.Tuneas

QRF dive bopt

9.Post couplets

I0.Drift nube stppon gindsr

11Focusing qandrupole package

12. Miscellinesous hardware

3. O.Fubricarion Lebor

8. 0. A. Tank W6

l. O.Procurement Irport Seller Surveillmet

2. O.Puschased Mateoial

1.Drift Tubes

2Drift ube magnets

3. Vactum syoxem equiptinent \& Services 4.OFHC Copper for cank shell

5. Endwalls wilh magyess

6. Trak support tystem

7.Tuners

SRF drive locits

9.Pot coupler

Jo.Drift tulbe 9opolt girder

1i.Focusing quadngole package

12. Mtocellonesus hardwate

3. O.Fabrication Labor

9. A. QTank 17

1. QProcurement suppoct/Seller Surveillance

2. 0.Putebuted Material

I.Drift Tubs

2Drift tube magnets

3. Vasum syeten equiprnert to Services 4,OFHC Copper for tank shell

S.Endwalls wilh angents

6.Tard supporl aystem

T.Tuners

8.RF drive locp

9.Posl conpkeri:

10.Dnfit wbe supporn girder

11. Focosimg guadnupole package

12. Miscellonechs haniware

3. O.Fubrictrion Lubor

10. 0. O.Tank ts

i. OProcurement tuppon/Seller

Surveillatice

2. O.Purchned Malerial

1.Drift Tubeq

2.Drill mbe magntes

3.Vacoun system equipunent \& Services 4.OFHC Co proer for lank ohell

5.Endwalls widh magrets

6.Tank suppon system

T.Turers

8.RF drive locps

9.Pont complers

10.Difl ube stppon girder

11Focusing quadrupole parkagte

12.Mikcelluneous hardwire

3. O.Fabrication Laboe

4. 0. a. 0.HEBT System 
1. 1. OFuna Detign labar

2. Q. Q.Procturenem supporiseller Surveillence

3. 1) Q.Purehosed Matorial

1. O.Bnom Tube, Finges, Bellowt, etc

2. ORFCrities

3. O.Suppont/Alignment Structure

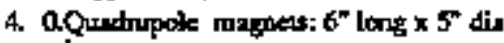
bore

5. Q.Quadrupole magots: $16^{\circ}$ kng a $5^{-}$dio bone

6 0.Quadnupole magnets: $24^{\circ}$ kng $\times 5^{\prime \prime}$ dis bore

7. 0.Ostupale magnets: $16^{+1} \mathrm{long} x 35^{*}$ din bore

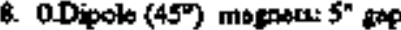

9. 0.Dipole $\left(10^{\circ}\right)$ maptiels: $5^{n}$ gap

10. O.Energy Spreed Monitors

11. OPhnes Spread Motion

12. 0.Video Profile Monivor

13. AMtiantriplines

4. 0. O.Fobrication Labot

5. 0. O. ORF Drive loop

i. 0. O.Final Desien labor

b. 0. 0. OAccelerator \& HEBT Themal Control Enjirtetering

1. 0. O.Full Design labor

20 . Rabrication suppont

7. a. 0. QRF Power Sytom

1. Q ARF control

2. O.RF Pre-drive (firti high gain stage. saltid s|laic)

3. a ORF Final Ampliber inchudine driver : Afprox. $13 \mathrm{MW}$ )

4. a ORF Trmport

1. ORP sition w RFO

2. ORF station to DTL ond Koroentm Compactor

3. O.RF station to Energy Dispersion Crivites

4, QCireulaters (19 Y Y-janction)

5. A.Filtens $\left(19^{+}\right)$

6. D.Low Power Conpkers

7. DRF Durnmy lats

8. D.Air pressprizarion and distribution

5. 0. O.Cavily Resonance Control

6. a OS rilchgerar

7. 0 . A.Cooling

8. Q. ARF ution Monivering and Conunol

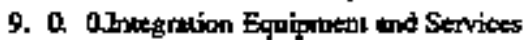

4. 0. 0. 0 0.Acceleruor \#2 (Podna)

1. 0. 2. 0.Derigo Updates

I. A O.Injeceor nystem

2. 0. $O . R F Q$ systrm

3. 0. RDTL Sysken

2. 0. 0. Dlpjector Syptem

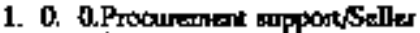
Survtillance

2. 0. 0.Purchesed Marterial

t. O.Souree and RF power strply

2 D.LEBT

3. D.Power supplies

4. O.Dperstional Controls at Sotware

5. O.Vacuum Eqquipmeax \& Services
6. 0.Thermal Coactol Equip \& Services

7. 0.Structure agd Shielding

3. 0. O.Fabdewion Labor

3. O. Q. G.Radio Feegrency Quadmpole Sysem

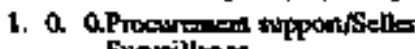
Sucveillace

2. 0. O.Puxchised Malerial

1. OCopper

2. 0.Vecuum System Equipmenr \& Services

3. 0.Drive Loops

4. 0.Eectro-foming

5. O.Mircellancoss Hardwate

3. 0. O.Fabriention Labor

4. 0. 0. ODilt Tnbe Linte Syare

1. 0. 0.Tmk w

1. A. Procuremes supporiseller Surveillance

2. O.Purelbated Manonis?

1.Drift Tubes

2.Drift tube misquets

3. Vocuum systen equipmant \& Services 4. OFHC Copper for itnk they

S.Endwalls with magnets

6.Tank support system

7.Tuness

8.RF drive loops

9. Poos corpters

10.Drift ube suppont gides

If. Focosing quadrupoit pockage

12.Mtiscellaneows handware

3. OFabricotion Lebor

2. 0. D. Tank *2

t. O.Procuremenx supportseller

Surveillanot

2. A.Puchared Malerial

1.Dríl Tukes

2Drifl tube magpels

3. Vecuum sysken equipmonl to Services 4.OFHC Copter for tork and

S. Endwalis with magrets

6.Tunk urpport sytien

7.Tuners

8.RF Arive bops

9.Poot couplers

10.Dhift mbe gapport giriter

1].Focusing quadrupole packate

12 Miscellaneons hapiware

3. O.Fabrigation laber

3. 0. QTank $\pi$

1. O.Progurement suppousteller Surveillimese

2. O.Purchered Meterisl

I.Drifi Tuber

2Dift wbe magnets

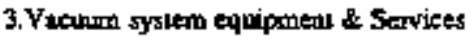
LOFAC Copper for tink shell

S.Endiwalls wirh magness

6.Tank suppont systert

7.Tuners

SRF drive loops 
9.Port couplest

10.Drifi mbe support girder

11.Fobrsing guadmpole packase

J2Mirincellaneopus Madware

3. O.Fabrication Labor

4. 4. OTmik

1. O.Procurement sipport/Sellite Sorveilitonce

2 0.Purchased Materil

I.Dria Tobes

2Drifi mbe magriess

3. Vuctures system equipmant \& Services

4.OFHC Coppos for tank shell

5.Fndwalls with magetels

6.Tank soppor syexem

7.Tuners

8.RF drive locps

S.Post conolers

10.Drift trbe snpport girder

11Fowusing quadrupole packige

12.Miscellaneows bardware

3. A.Fabrication Labar

5. Q. O.Tunk *5

2. OProcutedital tupportiseller Surveinlances

2 0.Purchuted Maletial

1.Dritl Tobes

2Daifl lobe magnets

3. Vacoum xytiem equipantert \& Servites 4OFHC Coppor for tani shat

5.Endwals with magnets

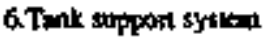

7.Tuners

8.RF drive locps

9. Aot couplers

10.Drift nibe tupport ginter

t1.Focosing qoadrupote puckage

12 Miscellineons burdware

3. O.Fabricaion Labor

6. 0. O.Tark

1. O.Procurtation supportiserles Surverllance

2 0.Purchinsed Mututitl

1.Drift Tubes

2.Drift whe magrels

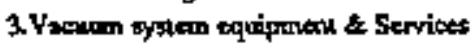
4.OFAC Copper for lank thed

5.End wath with magrest

is Tank stppon systom

7.Tunetr

8.RF drive booss

S.Port conpters?

10. Dinf tmbe suppon ginder

11.Focalging quadimosile packinge

12. Mfecelloneous herdware

3. O.Fabpication Labor

7. O. O.Tuak 17

1. O.Procumbermesuppor/Stelle

Survelitunce

2. 0.1uanchased Matraial

1.Drif Tube
2.Drifl ube magnets

3. Vactom system eqquipmear \& Services 4.OFHC Copper fot unk thed

5.Endwalts with magnes:

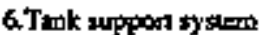

7.Tnness

\&RF driv locjos

9.Poxt coupien

10. Duifil tube support eirsted

11. Focusing quadnupak pactorpe

12 Mixcellaneons hardware

3. A.Fabrication Isber

B. D. atonk $=8$

1. O-Procurement supportSeller Surveillme

2. O.Purchused Makerial

1.Drift Tubes

2Drifi tube magoratp

3. Vuctaum syatem eqquipmat \& Stavices 4,OFHC Copper for tank shell 5.Endwrits with magents

6.Tank woppon syswern

7.Tumers

8.RF drive locpe

9.Post couplets

10.Doift tube support girder

11. Focosing quedrupate pectroge

12. Miscellanocus herdwate

3. OFabrication Labor

5. 0. o. D.HEAT System

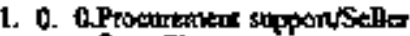
Simpeiliance

2. 0. O.Pwhosed Margrial

I. O.Bean Iobe, Fanges, Bedbows, ets

2. ORFComitirs

3. ASurpont/Aligmment Sinucture

4. O.0uednupole mugnets: $6^{\prime \prime}$ long $\times 5^{m}$ dit bore

5. QQuadnupoic magets: 16 long $\times 5$ dia bort

6. 0.Quadrupale menots: $24^{\prime \prime}$ long x $5^{\text {th }}$ dis bore

7. aOcnipole magress: $16^{n}$ long $x$ 3.5" da bort

8. 0.Dipode (45) monets: $5^{n}$ geP

9. O.Dipole (100) maqnets: 5T enp

10. O. Energy Spread Mopitors:

11. O.Phase Sperad Morilors

12 a Video Prothe Monttor

13. A.Mticosiriplines

3. 0. 0.Fabrication Labor

6. 0. a 0.RF Power Syout

1. Q. BRF contrit

2. A. A.RF Pre-trivet (firs htgh gain torge solid stare)

3. Q. Q.RF Final Amplifier (incliuting driver : Approx. $1.3 \mathrm{~kW}$ )

4. 0. Gekf Transon

1. DRE samion to Reto

2. O.RF station to DFL atd Manentim Compactor

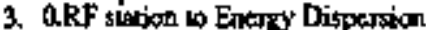
Crvilies

4. O. Cinculators (19n Y-junction) 
5. Q.Filters (IG")

6. O.Low Powar Courplats

7. ORF Dunmy Lands

8. A.Air proseswizntion and diatibution

5. 0. ACivity Rotorines Control

6. 0. O.Swilchiges

7. D. acoolin:

8. a arF slation Mapitoning and Conurol

9. a Ofoutgation Equipmen and Soavipes

5. 0. 0. 0. OBleam Culibration Dumps

I. 0. D QMovesble Beam Dump

1. A OFinal Dosizn

2. 0. 0.Procurement supponsellis Sorvellanice

3. A. O.Pwshased Material

4. A Ofabriantion Lobor

2. Q. Q D.Fuxed Beam Dump

1. O. O.Fmal Design

2. 0. O.Procnersent supportsellet Surveillonce

3. 0 O.Porehated Marecial

4. O. O.Fabricauion Lebor

6. 0. 0. O. OAcolerator Syrzenn Condrol

1. 0. D. O.Fmal Desígn labor

2. 0. 6. O.Procurment topporiseller Sorveilitance

3. 0. O. O.Ponchased Material

1. 12 acentral Compaters

2. D. DAan Transmission Nerwork

3. A. OLoxil Coniri

4. Q. D.Ducubate Comparers

5. D. O.Logeing and Faciliry Fall Analysis Compalers

7. 0. 0. Q. Q.Accekeralor Sutpoin Systom:

3. a. a. a. asuboystem butall and Checkoul

1. 0. 0. a OAccelerwor of (Custor) insisll and Checklor:

1. 0. O. Q.injector syatem

2. O. a D.RFQ sysiem

3. 0. D. QDTL Tankifi] systept

4. a. Q. Q.DTL Twks $\$ 2-\$ 8$ system

5. 0. O 0.4TEBT syatems ("Aber", "Baker", and Churbie"

6. C. 0. ORF power system

7. 0. B Beam Dump

1. 0. OMoredtele Berm Domp

2. 0. afixed Beam Duanp

8. Q a 0.Full Rower Accophance Test (125 mA)

9. 0. O O.Acoelerwor Conurol Syrtem

2 0. 0. 0. O.Acorttrake "2 (Pollon) Install and Checkoul

It at 0. O.frjector system

2. 0. 0. ORFQ system

3. 0. 0. 0.DTL Twkil system

4. A a O.DTL Tanks \#2-4\$ systen

5. 0. 0. O.HEBT systens ("Abel", "Baker", and "Chartie")

6. a. 0. ORF pother bystem

7. 0 0. 0.Full Power Aesexsune Texting (250 ind)

8. a. a. OAccelenator Conlrol Syatem
4. 0. 0. 0. 0. aszbsysten Deviopineat

1. 0. 0. Q. ORF Syatem Development and Teat

2. 0. 1) O. OInjector Systan Development and Test

3. a. 0. 0. a.Design Optimization

5. 0. 0. 4. 0, 0. A. Conventlonal focllities

1. a. a. a. A. Con reational Fucility Mama

1. 0. 0. 0. 0. Project Maris and Admiristration

I. D. 0. 0. Adminituraion

2 a. a. a. Coot Conurol

3. a. 0. O. Scitedule

4. 0 , 0.0 . Dor.

2. 0. B 0. 0. Systems Enginesing

1. 0. 0. 0. Design Integtaion

2. a. 0. 0. Requittumenlstspess

3. 0. O. D. RAM Anniyris

3. 0. 0. at anvir. Safery Heald Dac

4. a. D. 0. O. Quality Angurnoe

3. 0. 0. 0. 0. a.butintas

1. 0. O. 0. O-Acosiertise Complex

1. D. Q OAcoderotor Hat

2. 0. Q. O.Beam Tuning Boirding

3. a. O. ORF Power Bay

4. 0. O. OAcékerator Attembly Mainlenance Bay

2. 0. 0. A. OTarget Complen

1. A. 0. 0.jithinm Processing Cells

2. 0. A O.Prosessing Cell liners

3. 0. 0. 0. 0.Ter and Examfnation Cornplex

1. a. 0. 0.Tent Cells

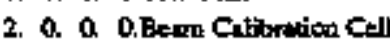

3. 0. 0. O.Test Coll Testhalogy Rooms

4. 0. 0. 0.Acoess Cell

5. a. 0 . o.shielding Doors

6. 0. 0. O.VTA \& Targe Service Cell

7, 0. 0. OShielding Doors

8. 0. 0. OModule Hatriting CaD

9. 6. a DShirding Dock

10. 0. 0. D.Conural Rown Dast Acquisioion Rocm

11. 0. 0. O.PIE Laboratory ATs

12. 0. 0. 0.Trisim PIE Lubankry ATt.

13. 0. O. afiot Cell Utity Call

14. 0. a 0.Corriders

15. 0. 0. 0.Coll Limen

4. 0. 0. a O.tuilding High Buy

l. 0. D. O.thgh Bay Burlding

2. 0. 0. DEriage Crane (30 tonne)

3. 0. O. ator Shcip

4. 0. 1) atiacontemineted Shop

5. 0. O. OManiqulator Repari Room

6. 0. 0. 0Shiping Bay

7. 0. Q ORad Waste Processing Bay

8. 0. O. aRad Waste Shipping Bay

9. 0. A. OHalih Thysics \$otion

10. 0. Q. O.Conriton

5. 0. 0. a 0.Support Fatilixy Euildings

I. D. of O.Plant Senvice Halls

2. 0. O. 0.Otfixe Complex 
3. 0. 4. 6. 4. 0.Pont Serview

1. 0. 0. 0. QHetime Veallation and Alr Cond"ionin; Sytem (HVAC)

1. 0. D QNDoler HVAC

2. 0. a OIndutinl HVAC

2. 0. 0. 0. 0.Power System Sabstation

1. D. O. OMvin trustionmer whorestert \& switcher

2. D. Q OCirooil bretkers (20kV), noxilinity power transfonter

3. 0. D. OKenerating Sea and UPS

3. 0. At A. 0.tinel Rejection Systom

d. a. 0. 0. D.Service Wuer System

5. 0. 0. D. asolid and Liquid kad Wate Prosessing Finnity

4. *. 6. 0. Gske Inproteiments

1 0. 0. 0 akoudy and Parking

1. 0. Q ORoodwry

2. o. O. ariking

3. 0. 0. a.tishing

2. 0. 0. 0. Q.Gradint and Lendsosping

1. 0. 0. 0.0.ening and Gradiag

2. 0. a a.Landsching

3. O. 0 aFmaing

3. 0. 0. 0. DSrom Drafnase

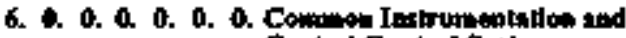
Ceritral Costrol Sptems

1. 6. 0. 0. 0. 0. Syst. Minte.

1. 0. 0. 0. 0. Project Manay- und Adtgixisation

1. O. A. B. Adtrimisuration

2 D. D. D. Cost Control

3. 0. 0. D. Sehedule

4. 0. 0. D. Doc.

2. 0. 0. 0. 0. Systems Entinaring

I. A. 0. 0. Devign Integration

2. D. D. D. Systems Aralysit

3. 0. 0. D. Requireroents/Specs

4. O. O. O. RAM Ansilysi

3. 0. 0. D. 0. Fnvit., Sitery \& Hetlth Doc.

4. 0. 0. 0. 0. Qualiry Agtaranes

2. 9. 9, 0. 4. 9. Coindan Instrumentotion Subspoteins

I. D. 0 0. 0. Berin Instrumentition

1. 0. 0. 0. Oa-Target Profile Moritor

1. 0. 0 . OpticaliR Viewing

2. 0. 0. Neuton Imaging

1. 0. 0

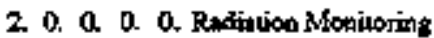

1. 0. 0. 0. Ratiation Morilos

1. 0. 0. Hend \& Fook Monritor

2. 0. 0. GM Sunny Meter

3. 0. 0. Dasse Meter (ganuma o beta ray)

4. 0. 0. Neurot RFIM Counter

5. 0. 0. Sorface Tritiom Survey Meter

6. 0. 0. Ponsble Trioiom Survey Meket

7. 0. 0. Packet Dowenater

B. a. 0. Liquid Scincithuion Couner

9. a. 0. Peescnnel Gias Dosimeter
10. O. O. Suck Gos Moritor

11. A. O. Stect Dust Mopitor

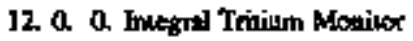

13. 0. 0. Room Gas Monitor

14. Q. t. Neurnoo Atea Moniver

15. 0. Q. Ganma-Tay Afea Mondror

16. 0. 0. Ooldoor Monitoring Foul

17. 0. 0. Leak Devester for Organic Loop

12. 0. 0. Indication Pane:

19. 0. Q Air Squpling Syoem

20. 0. 0. Documents

2 a. 0. Device Consroller

1. 0. 0. CPU (DVE-AT486, 486, 32MB)

2 a. a ADC (MVNE-512, 16ch)

3. 0. 0. Dau Inpal (DVE-S28, 49ch)

4. 1. O. Dan Oripat (DVE-529, 16h)

5. a. 0. Chosis

6. 0. O. Sofware (Windows-NT)

3. 0. 0. a. 0 . Video Moritoring

1. 0. a. 0. JTV Comere (Low Radiuion Arta)

1. a. a. CCD Carrera

20.0 Zoom Lens

3. 0. 0. Cumera Cats, Pun Head

4. 0. A. Pon Head Controllor

5. 0. O. Power Supply

6. a. 0. Modmanor

7, 0. 0. UFS

2. a. a. a $\pi \mathrm{V}$ Cmena (High Radiation Area)

3. 1. 0. Q Display

1. a. 0. Demodtrtior

2 0. 0. Videdamp

3. 0. O. Video Maninor

4. A. a CPY Uni

5. a. 0. Touch Sentor

6. 0. 0. LAN Box. LAN Trarslner

7. a. 0. Powa \$ngidy

4. 0. 0. O. Device Coalroller

t. 0. O. Gubidt

2. 0. 0. Video Swikher

1. 0. a Caracter/Symbot Generator

2 a. 0. Video consoller

2 0. A Camars Contral Teminal

4. D. 0. 0. a decess Control

J. 2. a. Door L'mit Swineh

1. 0. 0. Unth Swixch

2. Q. O. Doer Lock

2. 0. 0. 0. Keybenk

1. 0. O. Key Swizch Pent

2 D. Q. Interlock Unit

3. 1. 1. CPU 名 Memory

4. 0. D. LOU Unil

5. Q. 0. Prosesmming Tool

6. 0. 0. Power Source

7. 0. 0. UTS

B. 0. 0. Cable, Connector, Temint Block. Mics

3. 0. 0. 0. Wamint Lidat

1. 0. 0. Wamin Ligh

5. 0. 0. 0. Emerzency Srop Switch 
I. 0. 0. Soribat Bax

5. 0. 0. 0. 0. Aanouncislor

1. 0. 0. O. Speaker

1. 0. 0. Sptakts

2 0. 0. A. Device Cantrolle

1. a. O. Cobtick

2. 0. 0. Amplifier

3. 0. 0. Auto-papias Syrtar

3. 0. 0. Control Uní

4. 0. 0. USS

6. 0. 0. 0. 0. Infemation Display Stations

J. 0. 0. 0. CATV Network

1. 0. D. Distribuler

2. 0. 0. TV Processios

3. 0. O. BS Toner

4. 0. 0. Modositor

5. 0. O. Miret

6. 0. 0. Nerwork

2. 0. a. a. Costroller

1. 0. 0. Ampliter

2. 0. 0. Control Syenta

3. D. 0. Modulator

3. 0. 0. a. Display Teminals

J. 0. D. Demodalator

2. 0. a. Videa Monikor

3. 0. 0. 0. 0. Sifty and Emergency Equipanents

1. 0. 0. 0. Oxycen Deficit

1. 0. 0. Oxysen Sertsor

2. 0. A. Indicitor/Conlrollex

3. a. 0. Recorder

2. a. Eusape Magk for Oxygen Deficit

3. 0. 0. Oxygen Retenc

2 2. 0. 0. Fine-proot

1. 0. 0. Fure-proof Prolective Clothirs

3. 0. Q. O. Redio Active Ga Leak

1. 0. 0. Self-sonutined Brtwhing Appurtus

1. O. Mask with Bombe

2. A. Slonge Case

3. 0. a. 0. a. a. Central Contrat Sengrestems

1. 0. 0. 0. 0. Coniral Control

1. 0. 0. 0. Compurer Syatam

I. a. 0. Main Computer (Dan Server)

1. 0. Compolter (VRA10 Basic Ser, 1281MB)

2. 0. CPU Erhamcenent (120)

3. 0. 128kM Memory

4. O. FDDI Adapter

5. 0. Peripheral Equipruem

6. a. Software Manuals

2. a. D. Snppart Compungrs

1. D. Compures (VJI 10 Btitic Sel)

2. 0. L2SMB Heracry

3. 0. CD-ROM Driver

4. 0. Petipktent Equiprumt

5. 0. Sotware Munerls

3. 0. 0. Compoter Racks, Fomiture

1. 0. Cobinet

2. 0. Rack Mannt, Fille: Pare

3. 0. VR Class Serwer Mount Kit
2. 0. 0. 0. Dan Storage

1. a. 0. Intemal S. E. SCSI DAT 2-160B

2. a. D. Disir Arry 168GB

3. 0. 0. Maeneto-opticd Dixe 130B

3. 0. 0. 0. Uninuerupuble Power Surpaty

1. 0. 0. L.8kVA UPS 200V

2 a a IJPS Consote

4. 0. 0. 0. Dperales Interfuce

I. 0, 0, X-Window Terrints (ZI" ${ }^{n} C R T, 32 \mathrm{BB}$ )

2. 0. 0. Confole

3. 0. 0. Tounch Sensorr, Rolary Encoder, Slider

2. 0. 0 0. 0. LAN

1. 0. 0. 0. Nework (Ethemer)

1. o. o. Hut for Torminals

2. 0. FDDI Swilch

3. 0. D. PC for Network Otonervation

4. O. D. UTS

2. 0. 0. O. Subsution Interfince

1. 0. B. HUA for Canlral Contrat

2. 0. 0. Substation HUB

3. 0. a. 0. Netwotk Primter

1. 0. 0. Color Ptinter

2. 0. O. Monochroase Psinter

3. it 0. 0. O. Inertock 1oyic

b. 0. 0. O. Hartwized Logic

i. 0. O. Cubide

2. 0. O. Amiliary Relay Uait

3. 0. 0. Power Source

4. 0. O. UTS

5. 0. O. Cabies, Coonectors, Terminal Elocks, MCB, ew

2 0. 0. 0. Logic \& Stens Display

I. O. 0. Logic Display Paned

2. 0. 0. Amiliary Relay Umi

3. 0. O. Power Sowree

4. 0. 0. Cables, Counecuors, Teminal Elocks, $\mathrm{MCB}$, ete

3. 0. 0. 0. Interface for Compuler Control

1. 0. 0. CPU \& Mamory

2. 0. 0. I Unit

3. 0. 0. Programing Tool

4. D. 0. ITS

5. D. O. Cakles, Connection, Temingl Blacks, MCB. 다

4. 0. 0. D. 0. Censil Display Pane]

l. 0. 0. 0. Subzysuma Statos (150\%)

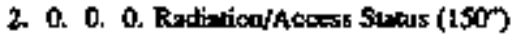

5. 0. 0. 0. 0. Sequence Syachronizes

1. O. O. 0. Timing Dati Gureritor

1. 0. 0. CPU \& Mationy

2 0. D. Clock Pulse Genernior

3. 0. A Timing Generator

4. O. 0. EONOE (Electro-Opueal Conventer)

5. 0. A. Gock Pulac Distributer

6. O. O. VME Chatsi*

7. 0. 0. Cukick

7. 0 . 0 trs

8. 0. 0. Cubles, Connector. Termingl Bkeks, MCB, ete

9. 0. 0. Soltware Developant Tod, Lieface

2. 0.0 .0 . Inserfate for Compurer Conurol 
1. 0. 0. Cempaniention Controllet

2. a. Q Software Dovelopment Tool, Licence

6. 0. 0. 0. 0. Durnmy Subation

I. 0. 0. 0. Compurer Syrem

1. 0. O. Work Stution

2. a. 0. Conpote Deak

2. 0. 0. 0. Opentior Inverfece

1. 0. O. Dipalay Ponei \& Swilch Bowrd

2. 0. O. Auxitiory Relsy Unix

3. 0. 0. Power Souree

4. 0. O. Csbles, Comseckos, Tarminel Blocks, $\mathrm{MCB}, \mathrm{etC}$

3. 0. 0. 0. Imeriace for Computer Cowot

1. D. O. CPU \& Menory

2. 0. 0. IN Jail

3. 0. 0. Progtamming Tool

4. 0. 0. Dunnmy VME Syatem

5. (1. 0. Cukicle

6. 0. O. Cables, Consecuots, Teminat Blocks, $\mathrm{MCE}$, tc

7. 0. 0. 0. 0. Operition and Configatarion Control

l. 0. 0. O. Operation and Configuraion Contral Sofiurate

4. 0. 0. 0. 0. 0. System Install. and Checkout

1. 0. 0. 0. Q. Install and Teat

2. a d. d. 0. \$ystem Verificarion Tearing

3. 0. 0. 0. 0. Opentiond Mairichance

l. 0. 0. 0. Compurer Sysurn

1. O. D. Mais Compoles

1. 1. Hurdware

2. 2. Software

2. 0. D. Support Compurer

J. I. Hardware

2. 2. Software

2. 0. 0. 0. Centnl Control Subsynem

3. 0. 0. O. Daka Opanaions

4. 0. 0. 0. O. Syatem Update

t. 0. 0. 0. 0. *. Operattonal Stariup and Commissionip:

1. a. 0. 0. 0. Persennel \& Owerhead

1. a. o. 0. a. Regular Staf

2. 0. 0. 0. 0. Suroup Suff

2. 6. 0. 0. 0. 0. Electrical Pwer

1. 0. 0. 0. 0. Acoelerator \#I

2. 0. 0. 0. 0. Acotiersor औ2

3. 0. 0. 0. O. Balanet of Phant

3. 0. 0. 0. 6. O. Utiptites

1. 0. 0. 0. 0. Inert Ges

2. A a. D. O. Deionized Watr

3. 0. 0. 0. a. Sewer/wnter

4. 0. 0. 0. 0. 0. Motnteaguese

5. 0. 0. 0. 0. 0. Waste Dosposal

1. a. a. a. 0. Contunimeted

2. 0. 0. 2. 0. thnecnlamisaced 


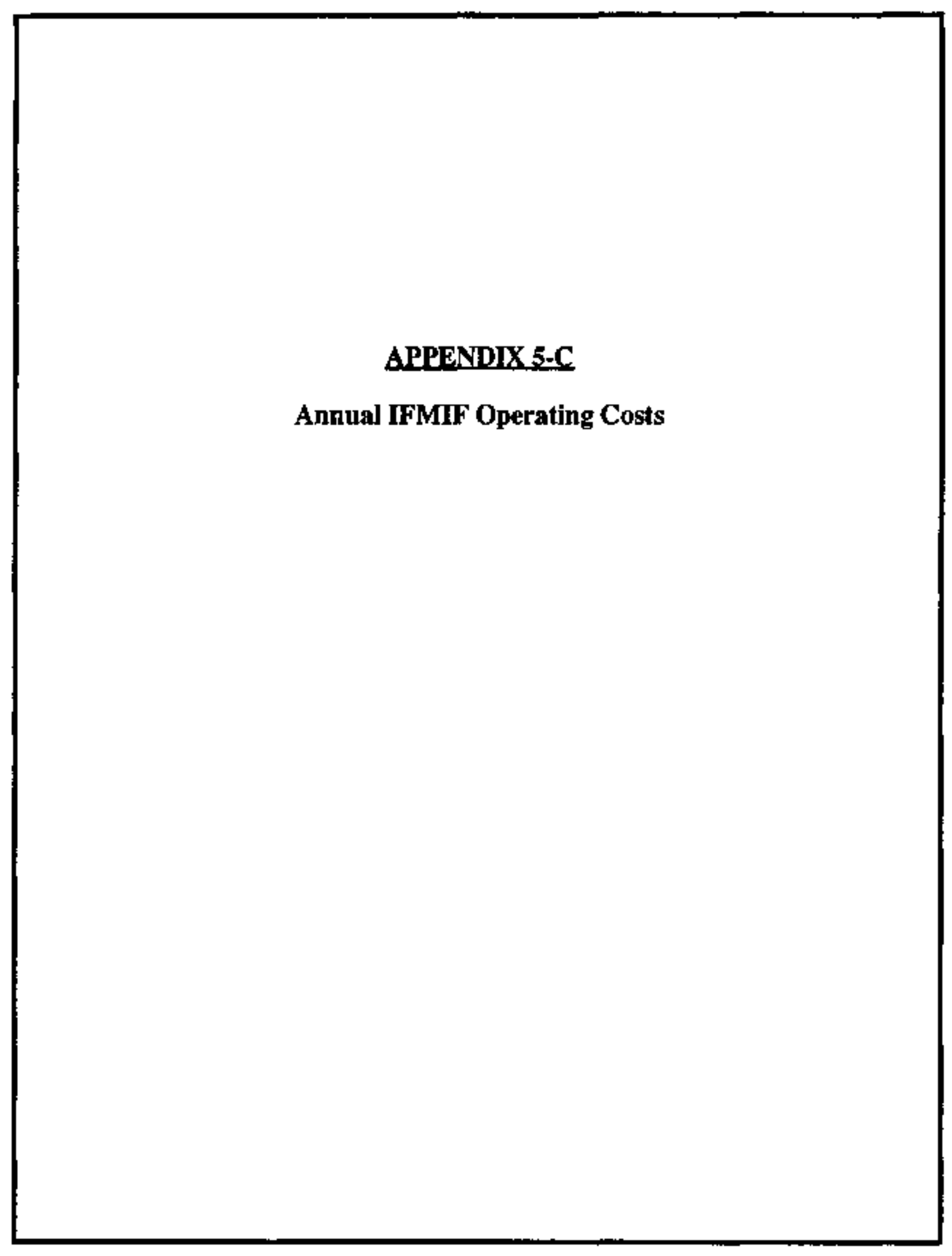




\section{Operations}

A. Annual Estimated Cost:

Average: $\quad 67000$ kilo ICF $\quad$ Year

Minimum: $\quad 56,000$ kilo ICF/Year

Maximum: 78,000 kilo ICF/Year

\section{B. Descriptiog:}

The cost of operating IFMIF for a normal year has been computed based on the cost of six major elements:

Personnel, Electric Power.

Utilities (other than power),

Maintenance,

Waste Disposal, and

Miscellaneous.

Personnel and electric power dominate the total cost. Electric power is also a major variable among the parties thus using the differences in this cost a range of total operating costs was developed. The United States would be the least expensive, Japan the most and Europe approximately the average.

C._Detailed WBS E.jisting:

See Worksheets

D. Costing Rational:

See Worksheets

E. Detailed Costing:

Estimate AFI Total Maximum Minimum

\begin{tabular}{|c|c|c|c|c|c|c|}
\hline $\begin{array}{l}1 \text { Personnel } \\
2 \text { Electric Power } \\
3 \text { Utilities } \\
4 \text { Maintenance } \\
5 \text { Waste Disposal } \\
6 \text { Miscellaneous }\end{array}$ & $\begin{array}{l}\$ 22,999 \mathrm{~K} 10 \% \\
\$ 31,556 \mathrm{~K} 0 \% \\
\$ 689 \mathrm{~K} 25 \% \\
\$ 8,000 \mathrm{~K} 0 \% \\
\$ \quad 483 \mathrm{~K} 25 \% \\
\$ 1,000 \mathrm{~K} 0 \%\end{array}$ & $\begin{array}{l}\$ \\
\$ \\
\$ \\
\$ \\
\$\end{array}$ & $\begin{array}{r}2,300 \mathrm{~K} \$ \\
-\$ \\
172 \mathrm{~K} \$ \\
-\$ \\
121 \mathrm{~K} \$ \\
-\$\end{array}$ & $\begin{array}{r}25,299 \mathrm{~K} \$ \\
31,556 \mathrm{~K} \$ \\
862 \mathrm{~K} \$ \\
8,000 \mathrm{~K} \$ \\
603 \mathrm{~K} \$ \\
1,000 \mathrm{~K} \$ \\
\end{array}$ & $\begin{array}{r}25,299 \mathrm{~K} \$ \\
42,053 \mathrm{~K} \$ \\
862 \mathrm{~K} \$ \\
8,000 \mathrm{~K} \$ \\
603 \mathrm{~K} \$ \\
1,000 \mathrm{~K} \$ \\
\end{array}$ & $\begin{array}{r}25,299 \mathrm{~K} \\
20,299 \mathrm{~K} \\
862 \mathrm{~K} \\
8,000 \mathrm{~K} \\
603 \mathrm{~K} \\
1,000 \mathrm{~K}\end{array}$ \\
\hline
\end{tabular}




\section{WORKSHEET \\ Operating Persomnel}

\section{A. Estimate of Annual Personnel Operating Expense:}

\section{5,299 kilo ICF/year}

\section{B. Description:}

This element includes the technical, managerial and operating staff on-site to operate the IFMIF Facility during daring a single full-power year following plant commissioning.

\section{Detailed Listing:}

See listing in Table 1 below.

\section{Costing Rational:}

The personnel costs were determined in a two step process; first, the unit cost for each type of personnel (i.e. technicians, managers, engineers and shop labor) including all bordens and overhead in each of the prospective countries was determined. The summary of the rates is included in attached Table OPS.1. The US figures are based on rates at Oak Ridge National Laboratory and those used by Northrop Grumrnan in similar estimates The EU rates were provided by Frascati and FZK, and the Japanese rate by JAERI. Since the rates for all the countries are comparable within the accuracy of the overall estimate a single average rate was agreed on.

In the second step of the estimating process, the number of personnel required to operate the facilities during startup of both the total IFMIF facility and the individual technical facilities was estimated by the appropriate groups. In addition, the core of the operations staff expected to be hired during the startup and commissioning period was determined. This group will include key supervisory and technical leaders who will ultimately train the operators. An annual summary for the two years (calendar years 2005 and 2006) of the startup is attached as Table 1.

The Allowance For Indeterminates is established at $10 \%$ to account for potential staff increases due to unforseen operating difficulties.

A detailed explanation of the subelenents in this WBS is as follows:

- Administration: The plant management team will be composed of a small staff sizce it is assumed that many adminstrative functions will be supported by the parent facility.

- Operations: The operations staff bas been determined by each Facility group in accordance with the requirements of similar facilities. The rational for the number of personnel in the accelerator group is provided in attached memo MEM-96-017.

- Maintenance: This staff has been determined by consensous of the IFMIF CDA Team. 
Operations

- Experimental Operations

This staff will be start being assembled in the final year of the starup pbase.

ESTIMATE TYPE: BOTTOMS UP; each element and unit cost was determined indivjulually based on a detailed analysis of the requirements of IFME.

E. Detailed Costing:

Tabile 1. Operating Personnel Costs

\begin{tabular}{|c|c|c|c|c|c|c|c|}
\hline & \multicolumn{5}{|c|}{ Sthift } & \multirow{2}{*}{$\begin{array}{c}\text { Rate } \\
\text { kICF/yr }\end{array}$} & \multirow{2}{*}{$\begin{array}{c}\text { Cost } \\
\mathrm{kJCF} / \mathrm{yr}\end{array}$} \\
\hline & 1 & 2 & 3 & 4 & Total & & \\
\hline Administrafion & 4 & $T$ & $\mathbf{T}$ & $\bar{l}$ & 7 & & \\
\hline $\begin{array}{l}\text { Plant Manager } \\
\text { Pla }\end{array}$ & 1 & 0 & 0 & 0 & 1 & 195 & 19 \\
\hline Office Support & 2 & $\mathbf{1}$ & 1 & 1 & 5 & 93 & \\
\hline Visitor Control & \pm & 0 & 0 & 0 & 1 & 93 & \\
\hline Plant Operations & 13 & 7 & 7 & 7 & 34 & & 4,28 \\
\hline Shift Superintendent & 1 & $\mathbf{1}$ & 1 & 1 & 4 & 161 & \\
\hline Plant Operators & 4 & 1 & 1 & 1 & 7 & 106 & \\
\hline Plant Protection & 3 & 2 & 2 & 2 & 9 & 106 & \\
\hline Safety Officer & I & 0 & 0 & 0 & $\mathbf{1}$ & 153 & \\
\hline HP Technicians & 4 & 3 & 3 & 3 & 13 & 137 & $1,7 \varepsilon$ \\
\hline Test Operations . & 4 & 3 & 3 & 3 & 13 & & 1,9 \\
\hline Experiment Control & 2 & 1 & 1 & 1 & 5 & 161 & or \\
\hline Operations Labor & 2 & 2 & 2 & 2 & 8 & 149 & 1,19 \\
\hline Target Operations & 2 & 1 & $\mathbf{1}$ & 1 & $\mathbf{5}$ & & 80 \\
\hline Supervision & 2 & 1 & 1 & 1 & 5 & 161 & 80 \\
\hline Accelerator Operations & 26 & 22 & 22 & 22 & 92 & & 11,42 \\
\hline Supervision & 5 & 5 & 5 & 5 & 20 & 161 & 3,21 \\
\hline Operations Labor & 10 & 9 & 9 & 9 & 37 & 106 & 3,93 \\
\hline Eng \& Tech Support & 5 & 4 & 4 & 4 & 17 & 149 & 2,52 \\
\hline Accellerator Shop Labor & 6 & 4 & 4 & 4 & 18 & 98 & 1,75 \\
\hline Maintenance & 6 & 4 & 4 & 4 & 18 & & 1,96 \\
\hline Maintenance Manager & 1 & 1 & 1 & 1 & 4 & 149 & \\
\hline Shop Labor & 5 & 3 & 3 & 3 & 14 & 98 & 1,36 \\
\hline Central Control & 5 & 3 & 3 & 3 & 14 & & 1,77 \\
\hline Central Control Operators & 3 & 2 & 2 & 2 & 9 & 128 & 1,15 \\
\hline Data Acquisition & 2 & 1 & 1 & 1 & 5 & 124 & \\
\hline Operations Stafif & 60 & 41 & 41 & 41 & 183 & & 22,999 \\
\hline $\begin{array}{l}\text { Contingency } \\
\text { TOTAL }\end{array}$ & & & & & & {$[10 \%]$} & $\begin{array}{r}2,300 \\
25,299\end{array}$ \\
\hline
\end{tabular}

Note: Personnel costs inciude all overhead and burdens 


\section{WORKSHEET \\ Operations-Electric Power}

\section{A. Annual Estimated Cost:}

Average: $\quad 32,000$ kilo ICF/Year

Maximitim: 42,000

Minimum: 20,000

\section{B. Description:} accelerators.

Electric power will be the primary solurce of power for the facility; notably the

\section{Detailed Listing of Reopirements:}

See Section E for listing.

D. Costing Rational;

Because the cost of electricity varies substantially between potential site countries both an average cost and site specific costs are computed. The estimated power costs computed for a $40 \mathrm{MW}$ facility are shown in Table 7.2.1:

Table 1. Average power costs for potential site countries

\begin{tabular}{|lcc|}
\hline Costs (40 MW cap'ty) & Capacity & Use Rate \\
\hline Italy & kICF/yr & ICF/kWhr \\
Germany & & 0.131 \\
Japan & 5,146 & 0.0934 \\
United States & & 0.12 \\
\hline Average & 1,286 & 0.066 \\
\hline
\end{tabular}

Note that it has been assumed that the power service provider will install the source transformers and power lines with the resulting capacity charge. At some potential sites an existing power system may reduce or eliminate this cost.

The US power rate is based on a national average computed by the "Energy Information Administration"

Table 2 shows the power requirements estimated for IFMIIF a standard full-power operating year. The Allowance For Indetenninates is established at $0 \%$ since operating problems will result in reduced power usage.

ESTIMATE TYPE: BOTTOMS UP; each element and unit cost was determined individually based on an analysis of the requirements of IFMIF operations. 
E. Detfiled Costing:

Tabte 2. Annual Power Costs

Based on 8766 hours/year

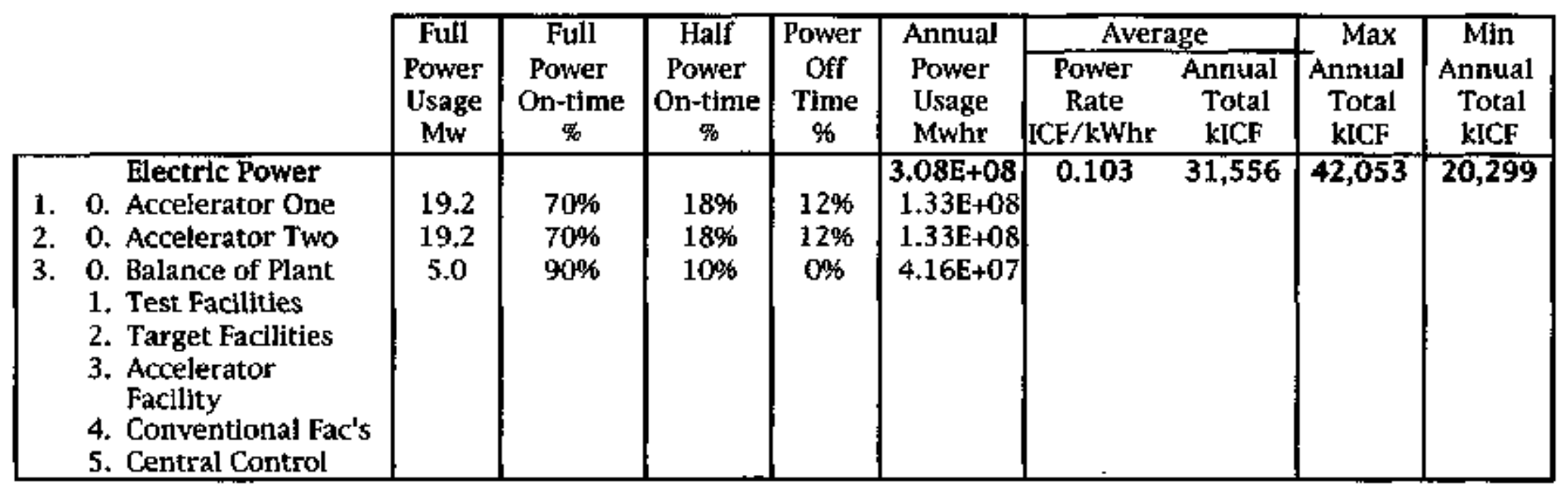




\title{
WORKSHEET \\ Operations -Utilities
}

\section{A. Annual Operating Estimated Cost:}

\author{
603 kilo ICF/Year
}

\section{B._Description:}

Conventional Utilities will be purchased from cormercial vendors and public utilities to support IFMIF operations. These include, sanitary water, sewer, natural gas for heating and inent gases.

The inert gases are assumed to be provided in over-the-road tank trucks or in bottles delivered by a commercial vendor. The gases will be transferred to on-site storage facilities. The quality of the gases requited are important in the cost determination; for this estimate the gases are assumed to be pure at the $10^{-4}$ level.

It is assumed that there will be a water djonization unit on-site at IFMIF, thus all provided water is potable quality. The water and sewer charges vary by a factor of about eight between the three potential sites; however, an average number is applied because the impact on the total cost is relatively small.

\section{Detailed WBS Listing:}

See detatled listing in Table

\section{Costing Rational:}

The estimated costs for each utility service in the three potential site countries are shown in Table:

Table 1 shows the utility recuirements estimated for IFMIF during the startup and commissioning process. The estimated usages were provided by each Facility group. Note that the sewer charge assumes that all water is cycled to the sewer system.

The Allowance For Indeterminates is established at $25 \%$ to account for probable but unpredictable difficulties which will result in extended operating times and increased stility usage.

ESTMMTE TYPE: BOTTOMS UP (Estimate) each utility requirement is estimated; unit costs were determined individually. 
Operations

E. Detailed Costing:

Table 1 Antral Waste Disposal Costs

\begin{tabular}{c|ccc|}
\cline { 2 - 4 } & \multicolumn{3}{c|}{ Annual } \\
\cline { 2 - 4 } & Usage & Rate & Total \\
& $\mathrm{m}^{\wedge} 3$ & ICF/m $/ \mathrm{m}^{\wedge} 3$ & $\mathrm{krCF}$ \\
\hline Waste Disposal & & & $\mathbf{6 0 3}$ \\
Contingency & & {$[25 \%]$} & 121 \\
& & & $\mathbf{4 8 3}$ \\
1. Uncontaminated & 1500 & 75 & 113 \\
2. Contaminated & 50 & 7400 & 370 \\
\hline
\end{tabular}




\section{WORKSHEET \\ Operations -Maintenance}

\section{A. Annmal Espinated Cost:}

\subsection{0 kilo ICE $Y$ ear}

\section{B. Description:}

Maintenance operations include both labor and material. The labor cost is included in the personnel costs, consequently, this section includes only material. Based on historical precedence the total cost of maintenance is approximately $3 \%$ of the TEC. Assaming this divides two-thirds as labor and one-third as material the cost will be approximately $1 \%$ of the TEC or roughly $8000 \mathrm{~K}$. Note that since this number is based on the TEC and includes AFI additional AFI is not added.

\section{Derailed WBS Listing:}

Not Applicable

R. Cosing Rational;

See Section B. above

\section{E. Detailed Costing:}

None 


\section{WORKSHEET \\ Operations. Waste Disposal}

\section{A. Annual Operating Estimnte:}

862 kilo ICF/Yr

\section{B. Description:}

Waste Disposal Services will be purchased from comunercial vendors or public services to suppoit IFMIF operations. Uncontaminated waste will be handled and removed via conventionai transpon. Low level contaminated waste will be handled in accordance with local requirements. High level waste is not included in this estimate; the volume will be relatively small and it is considered the responsibility of the Host country.

Note; it is exteremly difficult to estimate both the type and quantity of waste generated by ifmif. It is also difficult to obtain costs for.disposal at most facilities. As a result approximate numbers based on engineering judgement are used in this preliminary estimate.

\section{Detailed Component Listing:}

See Table below.

\section{Costing Rational:}

The estimated costs for waste disposal costs in the US were estimated from known costs at ORNL. Costs at other sites in Japan and Europe were guessed.

Table 1 shows the disposal requirements estimated for IFMIF during the startup and commissioning process. The estimated rates were estimated by consensus of the IFMIF design integration group based on engineering judgment.

The Allowance For Indeterminates is established at $25 \%$ to account for probable but unpredictable difficulties which will result in extended operations and additional waste. 


\section{E_Detailed Costing:}

Table 1 Annual Estimated Cost of Utilities

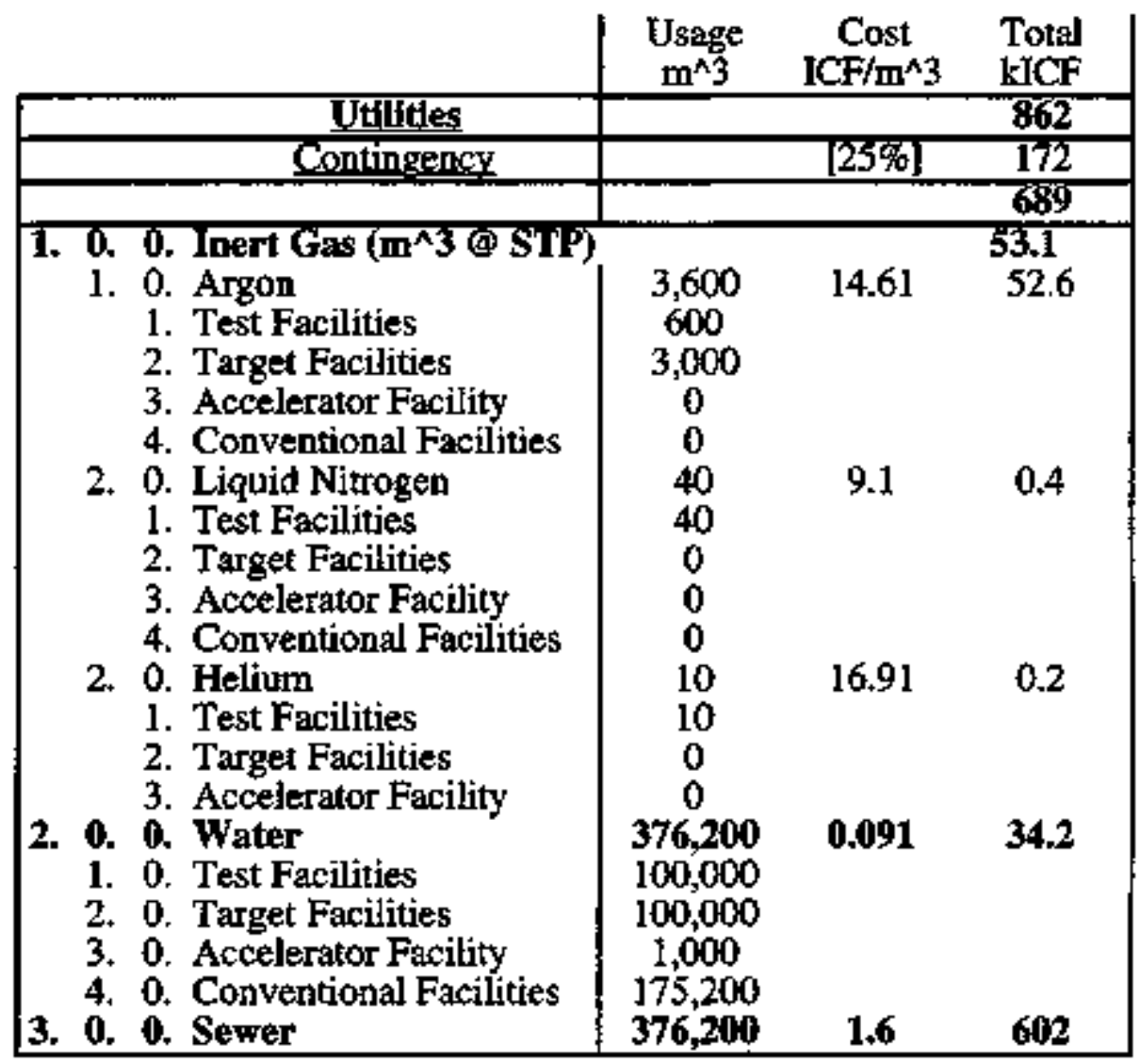




\section{APPENDIX 5.D}

\section{Preliminary IFMIF}

Cost Estimating

Worksheets 


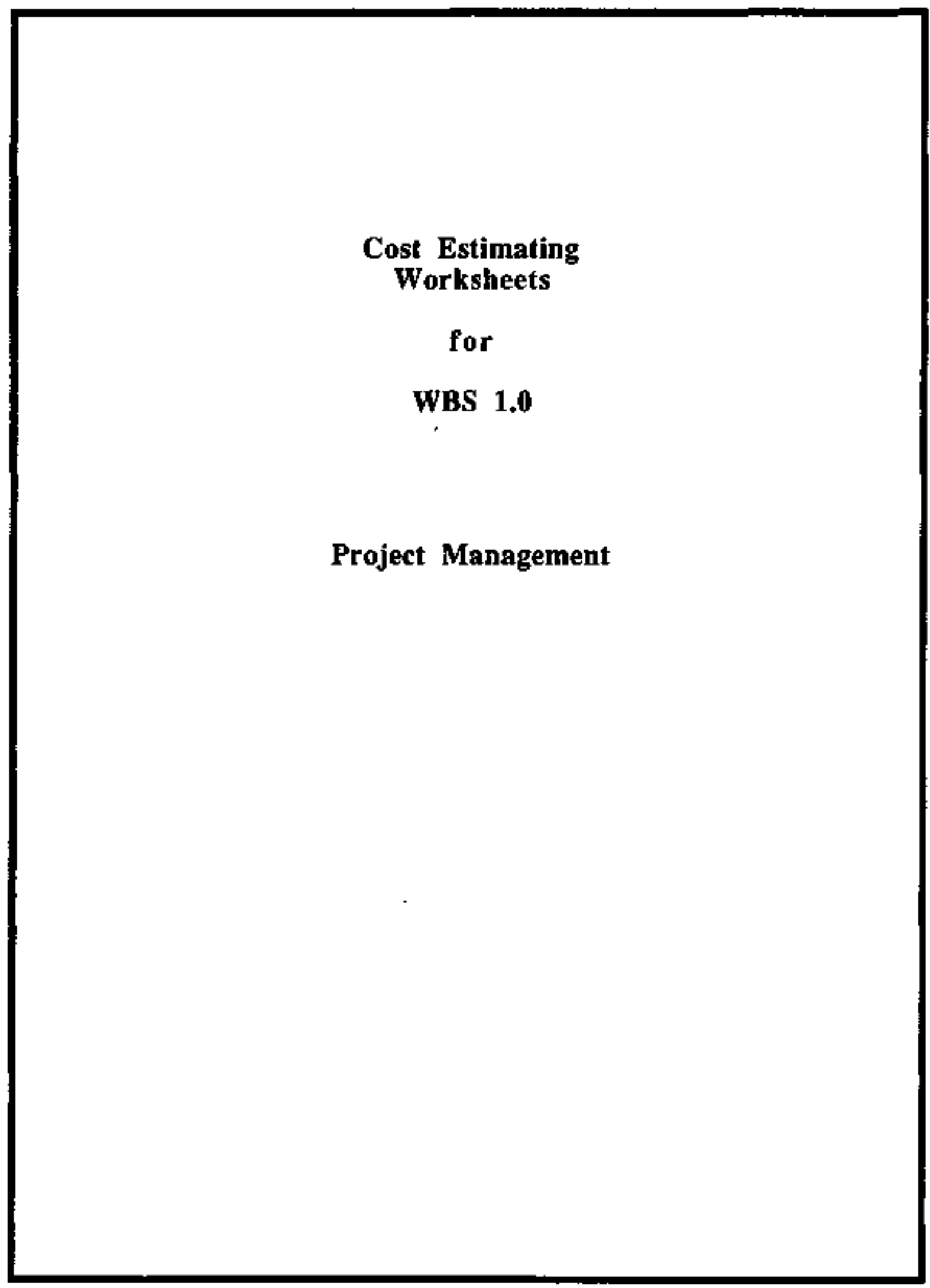




\section{WORKSHEET \\ WBS 1.0 Project Management}

\section{A. Summary Cost Estimate:}

\begin{tabular}{|c|c|cc|}
\hline \multicolumn{4}{|c|}{ On-Site At IFMIF } \\
\hline $\begin{array}{c}\text { Const. } \\
\text { Contractor }\end{array}$ & Instital & & \\
\hline Eng/Man & Eng/Man & AFI & Total \\
\hline 0 & 0 & 0 & $54,800 \mathrm{~K}$ \\
\hline
\end{tabular}

Currency Units: kilo ICF

\section{B. Description:}

This element includes all project management costs for the management, administration and control of the overall project. The management of the Facility design, testing and installation activities are included in the Facility costs. The management team will begin to form in 1998 and disband following Commissioning. The peak employment years will be between Project Approval at the beginning of the year 2000 and the completion of the major construction elements at the end of the year 2004. The elements included in this section are as follows:

- Project Management and Administration: includes costs for basic management activities such as administration, cost control and scheduling, and documentation. Also included are administrative suppont, meetings, and publications. The personnel in this category are assumed to be provided by the parent institute

- Systems Engineering: costs for Systems Engineering after the IFMIF is approved as an official project include enginetring activities required to ensure the facility functions properly. This will include management of interfaces, coordination of RAM and oversight of Facility engineering. It is assumed that the supporting institues will provide Systems Engineering personnel.

- Environmentaj, Safety and Health (ES\&H): includes cost of personnel responsible for establishing and maintaining procedures in accordance with the regulations of the country responsible for the Facility. It is assumed that the supporting institues will provide ES\&H personnel.

- Qualiny Assurance (QA): includes cost of personnel responsible for establishing and maintaining quality assurance procedures in accordance with the regulations of the country responsible for the Facility. It is assumed that the supporting institues will provide QA persomel.

- Construction Management; cootdination of construction activities for all Facilities, development of construction specifications, oversight of contracts. It is assumed that the construction management activities will be peformed by a commercial contractor.

Note project management is considered an "on-sice" charge since it is assumed that it will be performed in the host country. 
The Allowance For Indeterminates (AFI) is established at $0 \%$ since the basis of the number are Facilty estimates which already include AFI factors.

\title{
C. Detoiled WBS Listing:
}

\author{
1. 0. 0. Project Management \\ 1. 0. Project Management and Administration \\ 1. Administration \\ 2. Cost Control \\ 3. Schedule \\ 4. Development Oversight \\ 5. Documentation \\ 2. 0 . Systems Engineering \\ 1. Design Integration \\ 2. Systems Analysis \\ 3. Requirements/Specs \\ 4. RAM Analysis \\ 3. 0. Environmental, Safety \& Health Documentation \\ 4. 0. Quality Assurance \\ 5. 0. Construction Management
}

\section{Costing Rationale:}

Project management costs for the overall project are provided in Table 1.0.1. Although the table details personnel counts and distributions the total WBS $1.0 \mathrm{cost}$ is based on a percentage of the Total Estimated Cost (TEC) extrapolated from the historical data given in Table 1.0.2.

The history of large projects shows that all Management and Administration costs, including WBS 1.0 and related costs in each Facility WBS X.1.0, should be between 10 and $15 \%$ depending on the complexity of the project. For IFMIF the reduced technical complexity is somewhat off-set by the difficulties of coordination of an international facility. Consequently, the total factor is assumed to be approximately $12.0 \%$ of the TEC. Thus, the total cost of WBS 1.0 is assumed to be approximately $6.5 \%$ of the TEC with the remaining $5.5 \%$ accruing in the management of the individual Facilities. The specific management costs for each Facility are detailed in the appropriate worksheets.

Construction Management (WBS 1.5) has historically been in the range of 3-4 \% of the TEC. For IFMIF a value of $3.0 \%$ is used since the Technical Facilities (i.e. Test, Target, Accelerator and Central I\&C) will be installed under the guidance of the Facility groups and the Conventional Facilities are not as complex as the projects used in the historical comparison list.

The personnel estimates are provided in Table 1.0 .1 to cross-check the costs as a test of reasonability. The average personnel loading will peak over a five year period at counts approximately $15 \%$ bigher than the average shown. 


\section{E. Detailed Costing:}

The average labor cost used in the personnel analysis assumes:

\begin{tabular}{lcc} 
Type & Rate & Team Mix \\
\hline Engineers & $165 \mathrm{kICF} / \mathrm{yr}$ & 3 \\
Managers & $195 \mathrm{kICF} / \mathrm{yr}$ & 1 \\
Support & $50 \mathrm{kICF} / \mathrm{hr}$ & 1 \\
\hline Average & $148 \mathrm{kICF} / \mathrm{yr}$ &
\end{tabular}

Table 1.0.1

WBS 1.0 Project Management

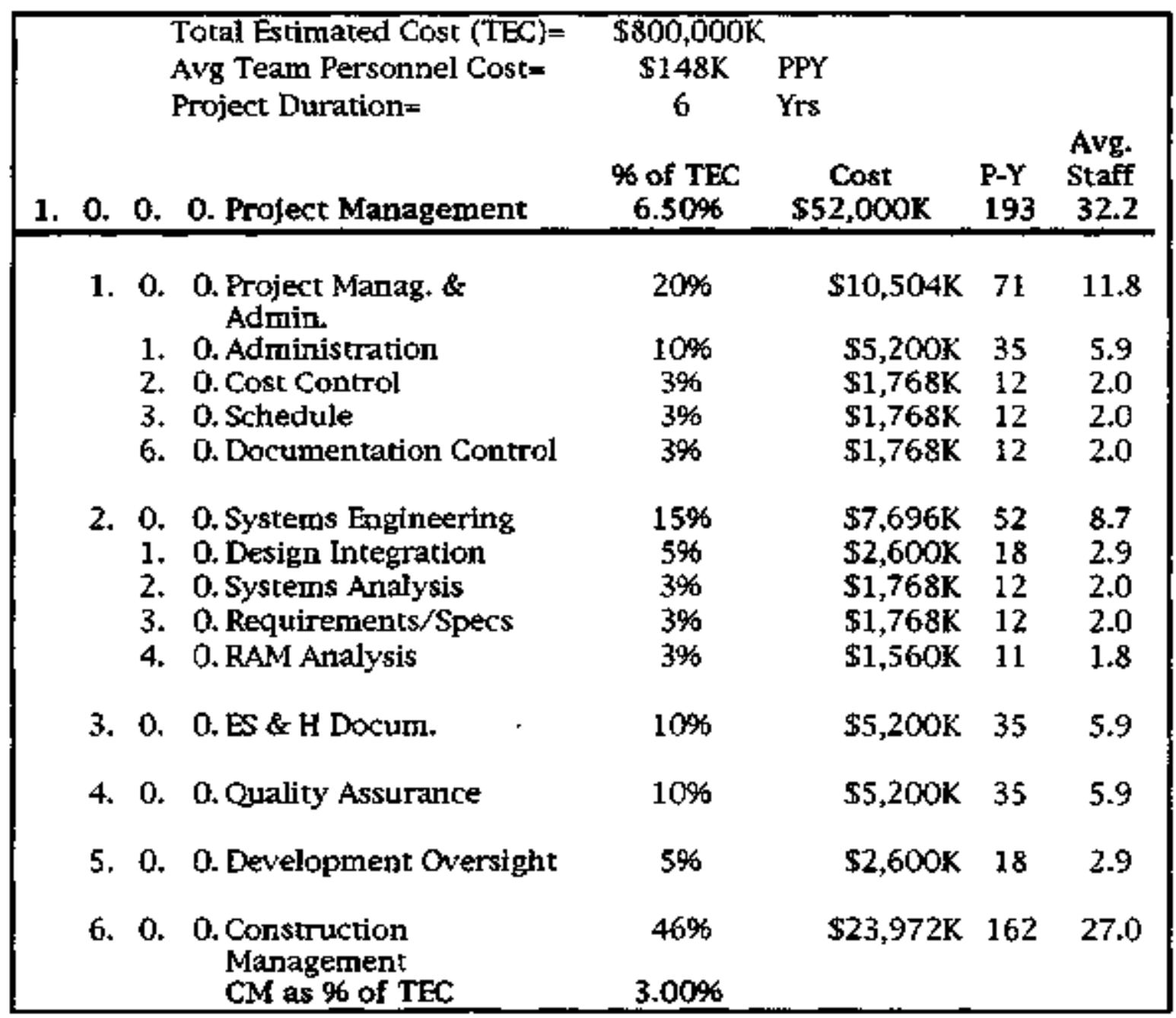


Táble 1.0.2. Historical Dats for Large US Constructlon Projects

Completed Profects

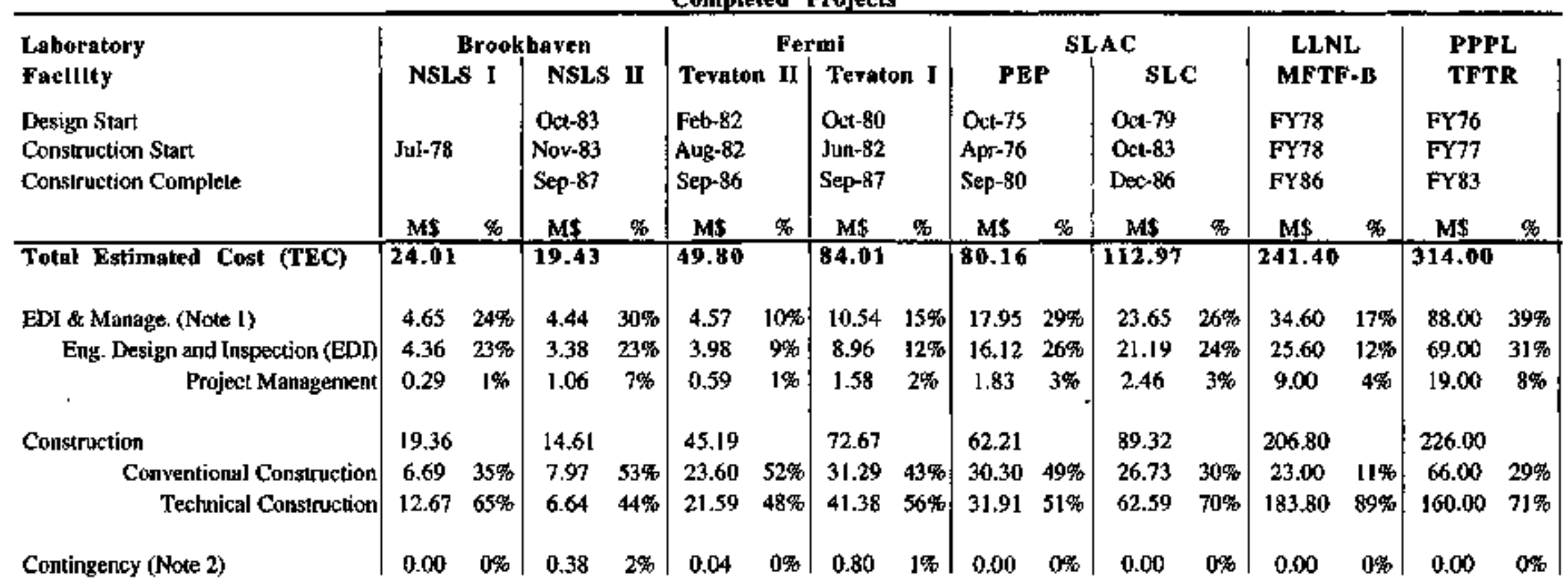

Foolnotes regarding percentage information

1. EDJ as percentage of Construction (ab)

2. Contingency as precent of Construction + EDI+Other

3. Other Project Costs as precent of TEC

4. R\&D as percent of Tech. Component Construction

5. Startup as percent of TEC

6. Future Annual Req'd Operating Cost as precent of TPC: 
WBS 1.0 .0

Table 1.0.2. Historlcal Date for Large US Construction Projects

Projects Uniler Construction

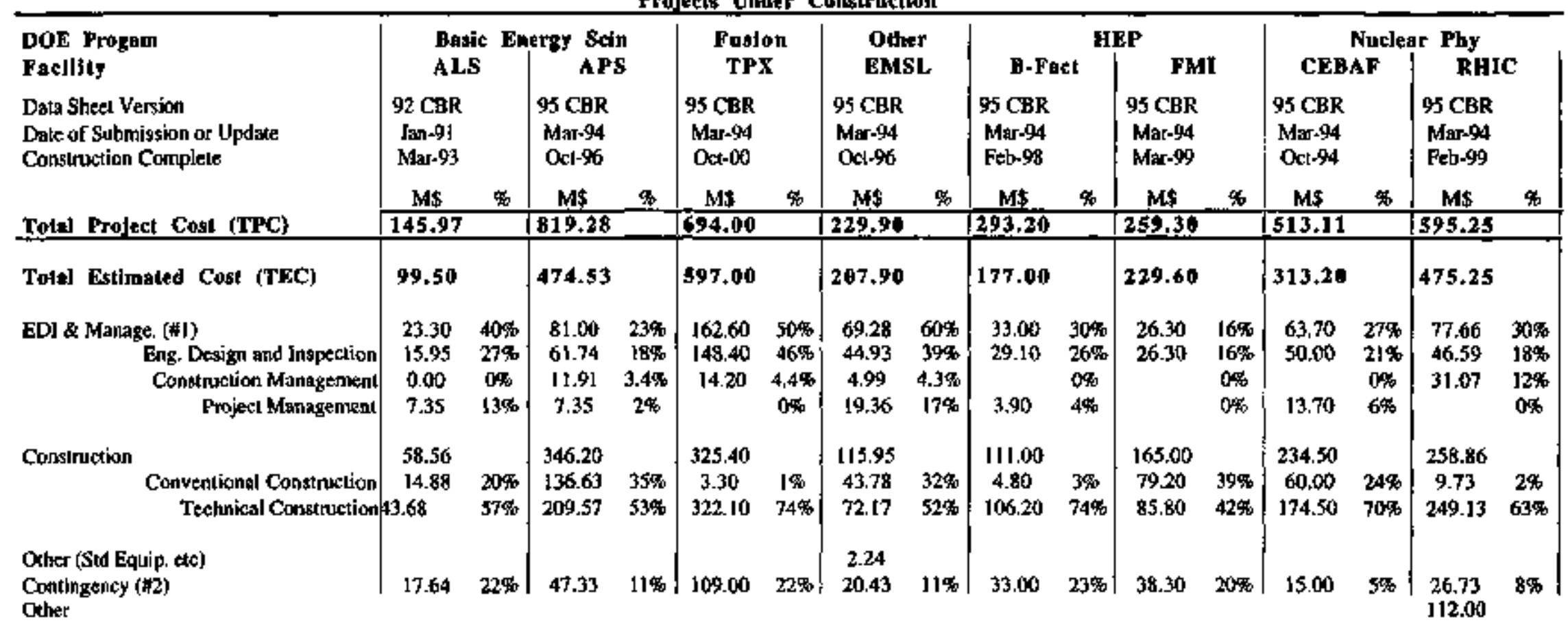




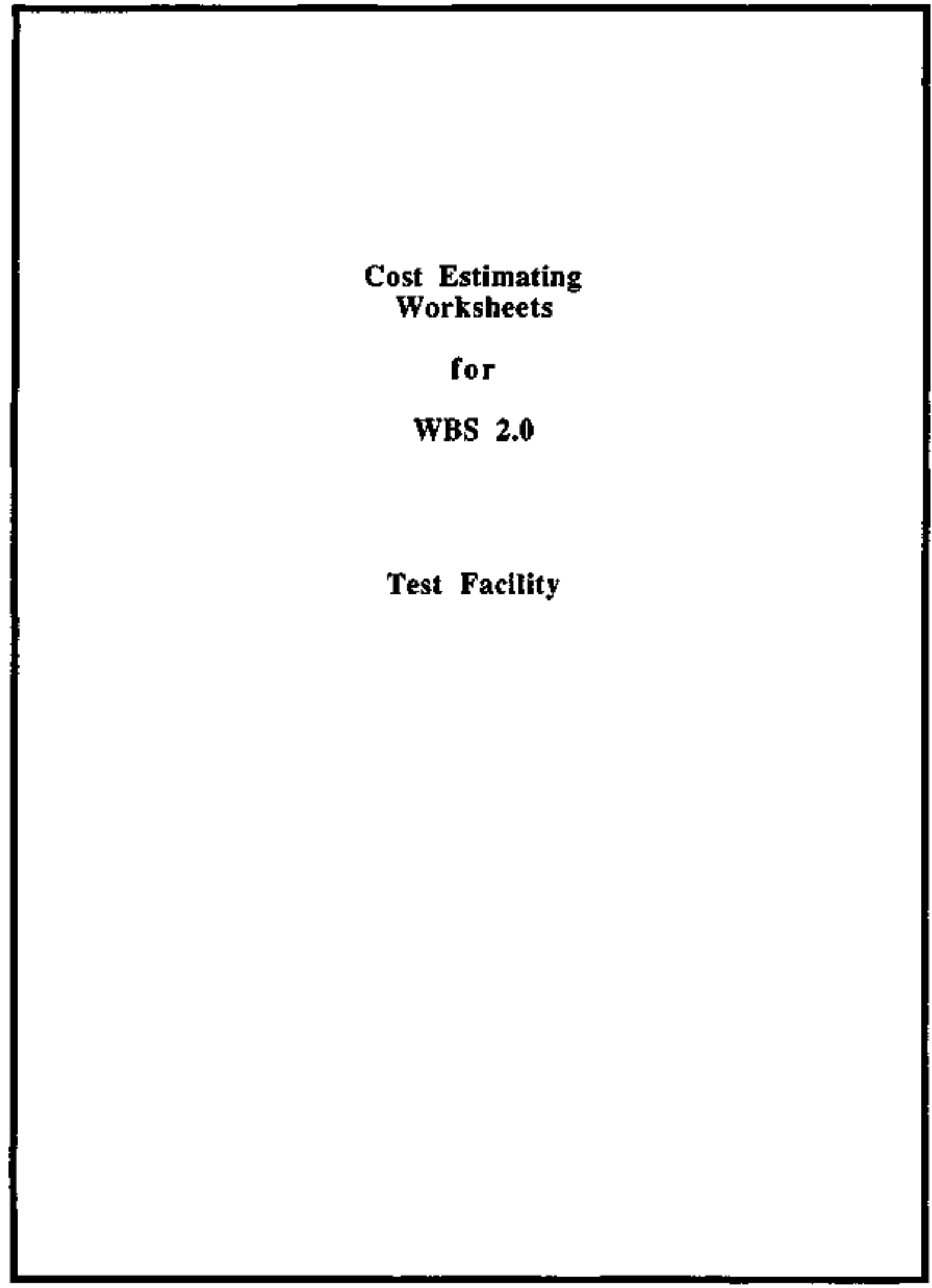


WORKSHEET

WBS 2.1.0 Test Facility Management

\section{A. Summary Cost Estimate:}

\begin{tabular}{|c|c|c|c|c|c|}
\hline \multicolumn{3}{|c|}{ Off-IFMIIF Site } & \multicolumn{3}{|c|}{ On-Site At IFMIF } \\
\hline Industry & Instit' & & $\begin{array}{c}\text { Const. } \\
\text { Contractor }\end{array}$ & Instit'a! & \\
\hline $\begin{array}{c}\text { Mat'l// Engin } \\
\text { Lab }\end{array}$ & Engin & AFI Total & $\begin{array}{l}\text { Mat'l/ Engin } \\
\text { Lab }\end{array}$ & Engin & Total \\
\hline & & 3000 & $0 \quad 0$ & 0 & 0 \\
\hline
\end{tabular}

\section{Currency Units: kilo ICF}

\section{B. Description:}

All the management activities required to directly support and complete the Test Facility are included in this element. These include:

- Project Management and Administration: basic management costs such as administration, cost control and scheduling, and documentation. Under each of these categories factors such as administrative support, meetings, and publishing are included.

- Systems Engineering: costs for Systems Engineering after the IFMIF is approved as an official project will be estimated based upon anticipated activities needed to support the proctrement of each item in the Test Facility including:

- Preparation of Specifications

- Preparation of Preliminary Design

- Fabrication Oversight

- Verification Testing Oversight

- Installation Planning and Coordination

- Installation Oversight

- Startup Oversight

- Environmental, Health and Safety Documentation: support for personnel responsible for establishing and maintaining procedures in accordance with the regulations of the country responsible for the Test Facility.

- Quality Assurance: support for personnel responsible for establishing and maintaining quality assurance procedures in accordance with the regulations of the country responsible for the Facility. 
WBS 2.1

\section{Detailed WBS Listing:}

1. 0. 0. 0. 0. Test Facillty Management

1. 0.0 . 0. Project Management and Administration

1. 0. 0. Administration

2. 0. 0. Cost Control

3. 0 . 0 . Schedule

4. 0. 0. Documentation

2. 0. 0. 0. Systems Engineering

1. 0. 0 . Design Integration

2. 0. 0. Systems Analysis

3. 0. 0. Requirements/Specs

4. 0. 0. RAM Analysis

3. 0. 0. 0. Environmental, Safety \& Health

Documentation

4. 0. 0. 0. Quality Assurance

D. Costing Rationale:

The cost of management is based on a factor of approximately $3 \%$ of the Test Facilty TEC.

E. Detailed Costing:

Not Applicable 
WORKSHEET

WBS 2.2.1.1 NaK Thermally Controlled High-Fhux Vertical Test Assembly (VTA-1 for Test Cell I)

\section{A. Sumomary Cost Estimate:}

\begin{tabular}{|c|c|c|c|c|c|}
\hline \multicolumn{3}{|c|}{ Off-liFMif Ste } & \multicolumn{3}{|c|}{ OF-Site At IFIIF } \\
\hline Induștry & Instit'al & & Const. Contractor & Instit'al & \\
\hline Mat'/4ab Engin's & Engin'g & AFT Total & Max'/ab Enging & Engin'g & AFI Total \\
\hline$2 2 8 \longdiv { 5 5 }$ & 621 & 1851109 & & & \\
\hline
\end{tabular}

Units: U. \$. Dollars (\$1,000)

\section{B. Description:}

VTA-1, which includes the 0.5-L high-flux module, is shown in Fig below. One of the primary design considerations of the VTA-1 is to provide the experimenter with a thermally controlled and wellcharacterized environment. Because of the thermal considerations in the high flux region, the VTA-1 should be designed with a reliable thermal control system. To accomplish this the high-fnux module has been divided into three chanbers, each of which is themally controlled by a liguid metal (NaK) loop. Each chamber is thermally controlled by a separate $\mathrm{NaK}$ thermal control system located on top of VTA 1 . Each $\mathrm{NaK}$ thermal control system consists of a $5-\mathrm{L}$ sump tank, a $2.5-\mathrm{kW}$ cooler a $5-\mathrm{kW}$ heater and a $100-\mathrm{kg} / \mathrm{min}$. induction pump. The thermal control supply and remen lines between the thermal control system and module are contained within a through passage that is provided in the Shielding Body. The thermal control line passage is stepped to reduce radiation streaming to the Test Cell Access Room. A vacuum is maintained in this through passage to prevent oxidation of the thermal control lines at elevated temperatures $\left(1000^{\circ} \mathrm{C}\right.$ and $800^{\circ} \mathrm{C}$ ).

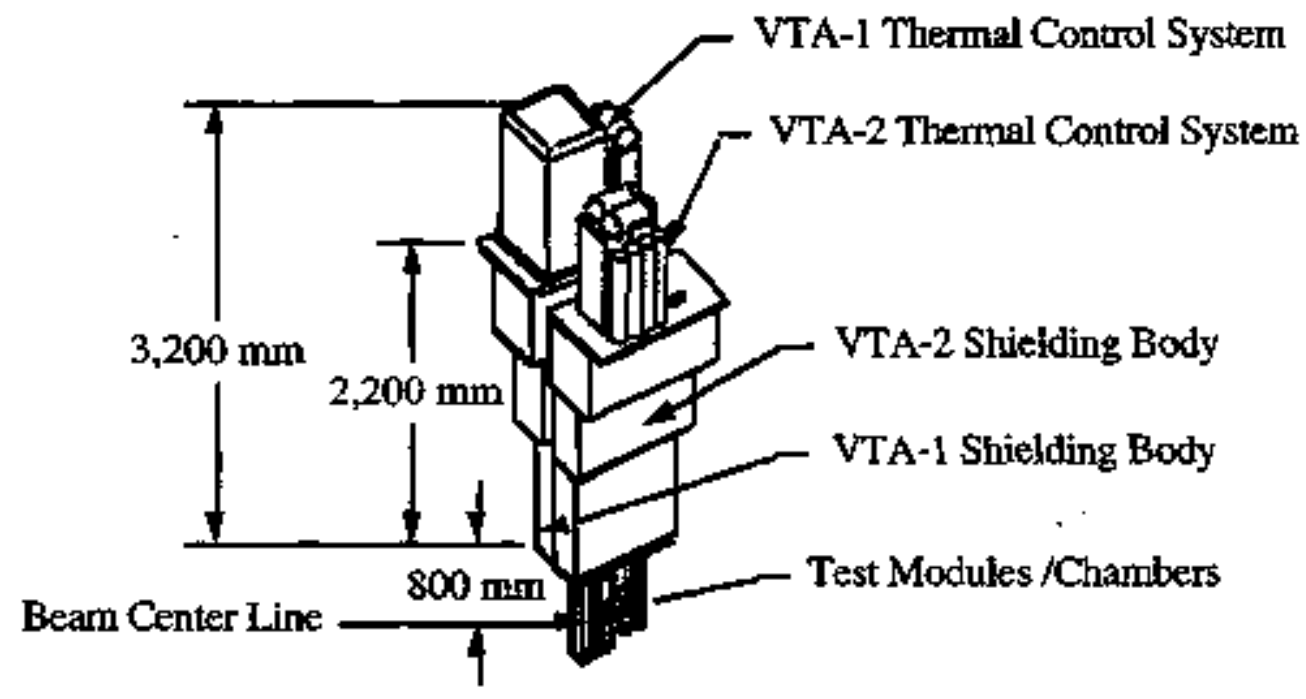

Figure of NaK Thermally Controlled Vertical Test Assemblies VTA-1 and VTA-2 


\section{Detailed WBS Listing}

There are no other WBS Listings in this section of the WBS. The NaK Thermally Controlled High-Flux Vertical Test Assembly (VTA-1), WBS 2.2.1.1, is the lowest WBS level listed.

\section{Costing Rationale:}

Fabrication methods, requirements, and procedures were evaluated for the fabrication and assembly of each major component of the VTA-1. The methods, requirements, and procedures for assembly of the VTA-1 were also so evaluated. From these evaluations, fabrication man-hour estimates were made based on the amount of welding, machining, metal preparation, and general labor required for fabrication and assembly of these major components and the VTA-1 assembly. The fabrication cost is based on a $\$ 67.00$ bourly rate.

Engineering deliverables (such as drawings, specifications, and calculations) required for the design of these components and the assembly of the VTA-1 were also evaluated. An engineering man-hour estimate was made based on these deliverables. The estimated engineting cost is based on a $\$ 98.50$ houtly rate.

\section{E. Detajled Casting:}

Engineering estimate for design of VTA-] Assembly:

a. two (2) E size drawings

300 hr. $\quad \$ 29,550$

Labor estimate for assembly of VTA-I (VTA-1 Body, thermal control Lines, sump pumps, heat exchangers, etc.):

$300 \mathrm{hr} . \$ 20,100$

\section{High Flux VTA-1 Shielding Body TOTAL $\$ 136,070$}

The Shielding Body of the High Fiux VTA-1 consists of a stepped, stainless steel liner that is filled with barytes concrete. The liner is equipped with three steps that interface with the TCRC and SP to eliminate iradiation streaming. A through passage is incorporated into each Shielding Body to accornmodate the $\mathrm{NaK}$ themal control lines and instrumentation cabling. This through passage is vacuum tight.

Engineering estimate for design of High Flux VTA-1 Body:
a. six (6) E size drawings
$600 \mathrm{hr}$.
b. heat transfer calculations
$200 \mathrm{hr}$.
$\$ 59,100$
$\$ 19,700$

Labor estimate for fabrication of High Flux VTA-1 Body:
a metal prep $34 \mathrm{PC}$ of stainless
$240 \mathrm{hr}$.
$\$ 16,080$
b. welding $35 \mathrm{MX} 12.7 \mathrm{~mm}$
$210 \mathrm{hr}$.
$\$ 14,070$
c. machining for $\mathrm{O}$-RING seals o top and
passages, and mounting interfaces
d. Installation of barytes concrete
$200 \mathrm{hr}$
$160 \mathrm{hr}$.
$\$ 13,400$

Materials estimate for fabrication of High Flux VTA Body

(1700 LB stainless \$ \$1.50/LB. and $4500 \mathrm{LB}$ barytes

concrete $\$$ \$0.10/LB.)

$\$ 3,000$

High Flux VTA-1 Piping:

TOTAL

$\$ 49,935$ 
Six thermal control line assemblies each $25.4 \mathrm{~mm}$ Dia, $2.5 \mathrm{M}$ long with eight 90 degree joints, constnucted from $1 \%$ zirconitum and $99 \%$ niobium alloy.

Engineering estimate for design of VTA-1 High Flux thermal control lines:
a two (2) E size drawings
$200 \mathrm{hr}$.
b. heat transfer calculations
$200 \mathrm{hr}$.
$\$ \quad 9,850$

Labor estimate for fabrication of High Flux thermal control lines:
a metal prep $18 \mathrm{PC}$ of pipe
b. welding $48-90$ degree joints
$100 \mathrm{hr}$.
$400 \mathrm{hr}$.
$\$ 5,360$
$\$ 26,800$

Materials estimate for fabrication of High Flux VTA-1 Piping (15M of $25.4 \mathrm{~mm}$ ID. tube and 48-90 degree joints)

$\$ 3,000$

High Fin VTA-1 Thermal Control System

TOTAL

$\$ 687,850$

Engineering estimate for design of VTA-1 High Flux thermal control system:
a. three (3) $\mathrm{E}$ size drawings
b. heat transferthydraulic calculations
$300 \mathrm{hr}$.
$300 \mathrm{hr}$.
$\$ 29,550$
$\$ 29,550$

Engineering estimate for developmentdesign of VTA-1 High Flux thermal control system:
a. Develop Induction/Conduction pumps
b. Develop NaK Coolers
$1500 \mathrm{hr}$.
$1500 \mathrm{hr}$.
$\$ 146,250$
$\$ 146,250$
c. Develop NaK Heaters
$1500 \mathrm{hr}$.
$\$ 146,250$

Procurement estimate for VTA-1 High Flux thermal control system:
a. Three $100 \mathrm{Kg} / \mathrm{Min}$. induction pumps
$\$ 60,000$
b. Three $5 \mathrm{~kW}$ coolers
c. Three $2.5 \mathrm{~kW}$ Heaters
d. Three SL sump Tanks
$\$ 60,000$
$\$ 60,000$
$\$ 10,000$ 
WBS 2.2.1.2

WORKSHEET

WBS 2.2.1.2 Helium gas controlled High Flux Vertical Test Assembly for high temperatures (VTA1Helium for Test Cell I)

A. Summary Cost estimate:

\begin{tabular}{|c|c|c|c|c|c|c|c|}
\hline \multicolumn{4}{|c|}{ Off-IFMIF Site } & \multicolumn{4}{|c|}{ On-site at IFMIF } \\
\hline Industry & Instit'al & & & Industry & Instit'al & & \\
\hline Mat'l/Lab Engin's & Engin's & AFI & Tatal & Mat'//Lab Engin' ${ }^{\prime} \mathrm{g}$ & Engin's & $A F I$ & Total \\
\hline $\begin{array}{ll}1,207 & 290 \\
\end{array}$ & 60 & 311 & 1,868 & & 120 & 24 & 144 \\
\hline
\end{tabular}

Units: 1,000 ICF $(1 \mathrm{ICF}=1.52 \mathrm{DM})$

\section{B. Description:}

This high temperature device (VTA1-Helium) includes the $0.5 \mathrm{~L}$ high thux test module. One of the primary design considerations of the VTA-1-Helium is to provide a test module for specimen temperatures up to $1000 \infty \mathrm{C}$. In addition this device offer

- operational flexibility; various different specimen temperatures can be adjusted in one single test module'

- proper specimen temperature control with thermocouples and with integrated ohmic heaters in the specimen encapsulation,

- reduced risk of overall VTA failure

- fast access to VTA and test module (decay heat controlled)

- upgrading capabilities.

Helium gas as coolant has good compatibility with structural materials in particular and for safety considerations with the Li-target. The VTAJ-helium is controlled by a helium gas coolant loop. All coolant wbes and electrical connectors are stepped within the shiejding body in order to reduce radjation streaming to the Test cell Access Room.

\section{Detailed WBS Listing:}

\subsubsection{High flux VTA (VTA-1-Helium):}

\subsection{Rigs for encapsulated specímens}

2.2.1.2.2 Test Module

2.2.1.2.3 VTA stielding body

2.2.1.2.4 Helium coolant loop

\section{Costing Rationale:}

Engineering efforts, fabrication methods, requirements, and procedures were evaluated for the feasibility, fabrication and assembly of each major component of the VTA-1-Hetiem. From these evaluations, fabrication man-bour estimates were made by the German industry (2.2.1.2.1 - 2.2.1.2.3), and the FZK and Industry (2.2.1.2.4) based on the amount of welding, machining metal preparation and general labor requined for fabrication and assembly. Engineering deliverables (such as drawings, FE-calculations, specifications) reguired for the design were also evaluated. An engineering man-our estimate was made based on these deliverables. The underiying engineering cost is based on DM 120,-or ICF $=75.4$ hourly rate. 


\section{E. Detajled Costing:}

\subsection{Rigs for encapsulated specimens:}

Construction: (3 sizes A, B, C) incl. drawings and listings of items,

Clarification of Fabrication

Laboratory costs

see Attachment (PET comp., p.16)

TOTAl.

\author{
$110,000,-$ DM $62,500 \mathrm{ICF}$ \\ $35.000,-$ DM $\quad 23,000$ ICF \\ 85.500 ICF
}

Fabrication: see Attachment (PET company, p.15)

Specimen encapsulations with integrated Ohrmic heaters, Themoelernents, distance holders and rigs (32x)

Rig fabrication (32x)

179.200 , DM 117,900 ICF

11.200, DM 7,400 ICF

Assembly incl. welds

224.000 , DM $\quad 50,200 \mathrm{ICF}$

Plug system to VTA body: (64x)

64.000, DM $\quad 42,100$ ICF

$28.800,-D M \quad 19,000 \mathrm{ICF}$

Gas and electric power central plug system (metal sealed, 32x)

Fitting material

224.000,- DM

147.400 ICF

8.000,- DM 3,300 ICF

TOTAI.

389,300 ICF

\subsection{Test Module}

Construction (see attachment, p.15):

Static's, FE-calculations

Development, optimization, sealing tests

TOTAL

Fabrication (see attachment p. 15):

He-Vessel to grate insets for rigs

Complete electron beam welding with grares

Seal plates and flanges

Upper part above grate insets

Interface flange

Metal seals, screws, fittings

TOTAL
$120.000,-\mathrm{DM}$

13.000,- DM

55.000,- DM

$120.000,-\mathrm{DM}$

$56.000,-\mathrm{DM}$

45.000;- DM

182.000 ,- DM

25.000,- DM

8.000.- DM

436.000,- DM
79,000 ICF

$8,600 \mathrm{ICF}$

36,200 ICF

123,800 ICF

79,000 ICF

36,800 ICF

29,600 ICF

119,700 ICF

16,400 ICF

5,300 ICF

286,800 ICF 


\subsection{VTA shielding body:}

Construction (see attachment p. 15,16):

Fabrication (see attachment):

Interface to test module

Stee] rips incl. Vessel

$90.000,-\mathrm{DM}=$

59,200 ICF

He-coolant ducts, fittings, connectors, etc.

175,000,-DM

115,100 ICF

$370.000,-D M$

243,400 ICF

$28.000,-D M$

$18,400 \mathrm{ICF}$

He-pipes

21,000,- DM

$13,800 \mathrm{ICF}$

Flanges and concrete

18.000,- DM

$11,800 \mathrm{ICF}$

TOTAL

$643.000,-D M$

423,000 ICF

\subsection{Helium gas coolant loop:}

Accorting to INTERATOM (SIEMENS Company) design layout for FZK High Energy Dual Beam

Facility):

Construction and System specification:

$20 \%$ of Fabrication costs

33.000,- DM

$21,700 \mathrm{ICF}$

Fabrication: Roat pump incl. motor WKP $8000\left(<8000 \mathrm{~m}^{3}\right.$ from Balters

$30 \mathrm{~kW}$ electric power

$72.070,-D M$

Rack carrying parnp, heat exchanger, valves, instrumentation and fittings (without pump and heat exchanger)

Compact heat exchanger

$$
25.000,-\mathrm{DM}
$$

2.500,-

Complete toop control rack

$43.000,-$

Tubes for helium gas inlet and outlet to VTA-1+Helium:

21.000,-

TOTAL

$163.570,+$ DM

107.600 ICF 


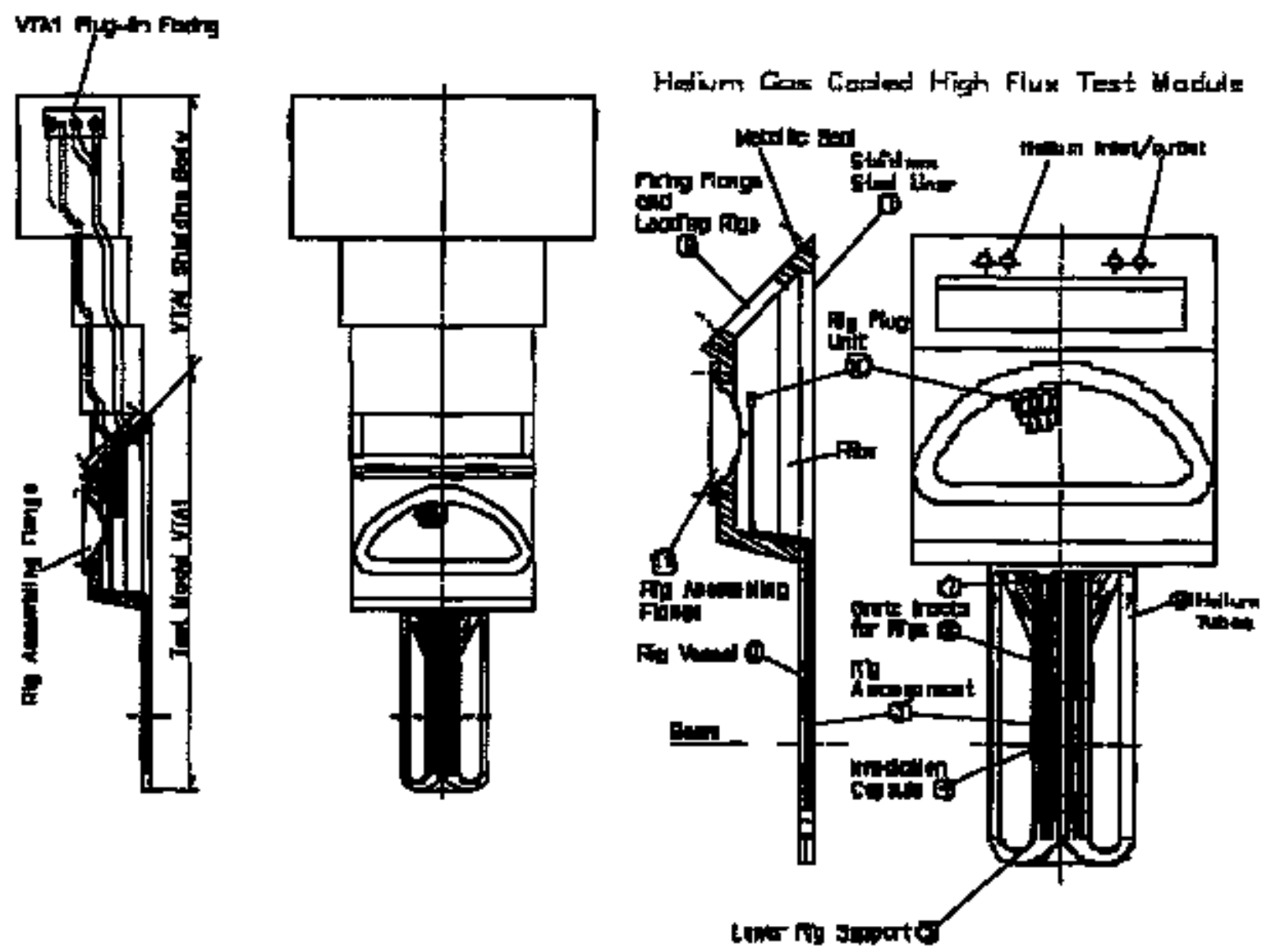

Fig. 2.2.1.2: Elevation and front view of the Helium cooled high flux Test Assembly VTAl-He 
WORKSHET

WaS 2.2.13 Helium gas controlled Medium flux Vertical Test Assembly for In stu Creep-Fatigue Tests (VTA 2-He Creep-Fatigue for Test Cell n)

A. Summary Cost estimate

\begin{tabular}{|c|c|c|c|c|c|c|c|}
\hline \multicolumn{4}{|c|}{ Off-IFMIF Site } & \multicolumn{4}{|c|}{ On-site at IFMEF } \\
\hline Industry & Instit'al & & & Industry & Instit al & & \\
\hline Mat'1/Lab Engin's & Engin'g & AFI & Total & Mat'1/Lab Engin's & Engin's & $\mathrm{AFI}$ & Total \\
\hline $695 \quad 104$ & 25 & 165 & 989 & & 120 & 24 & 144 \\
\hline
\end{tabular}

Units: 1,000 ICF ( 1 ICF = 1.52 DM)

\section{B. Description:}

Inert gas cooked (usually helium) medium fux Vertical Test Assembly for instrimented in-situ creep fatigue tests. The complete assembly consists of

- the test module with a miniaturized universal testing machine for individual creep fanigue tests on 3 pushpull fatigue specimens

- the VTA 2 \$hielding body wish integrated pipes and instrumentation

- the helium gas coolant loop

A suitable specimen design has been already developed which ensures high flexibility with respect to choice of coolant, dynamic temperature variations; mechanical loading conditions and beam-on or beam-off scenarios.
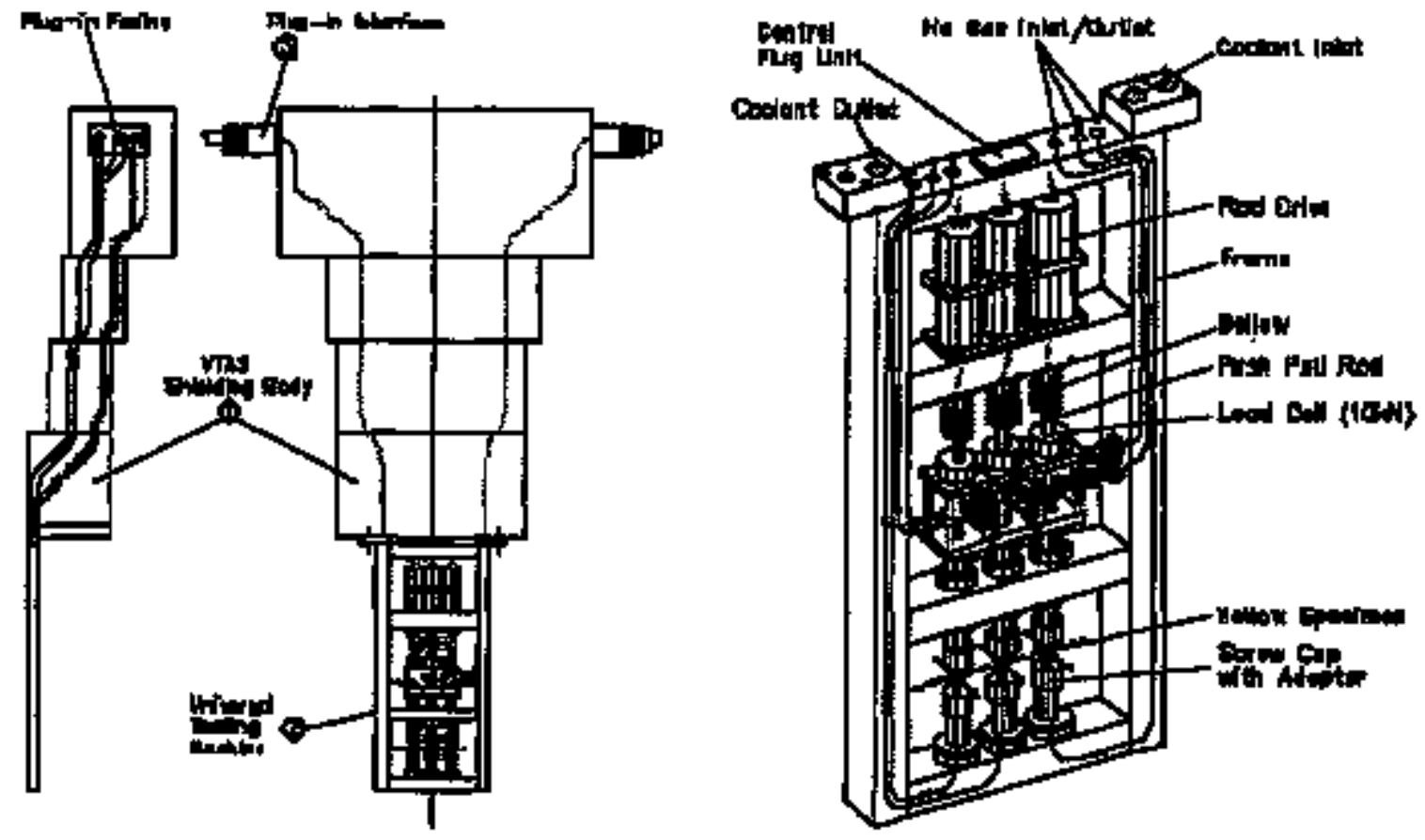

Fig. 2.2.1.3: Elevation view of the VTA 2-He and bitd's view of test module for in situ creep-fatigue tests. 
C. Detailed WBS Listing:

2.2.1.3. High flux VTA (VTA-1-Heliurn):

2.2.1.3.1 Test module with universal testing device and specimens

2.2.1.3.2 VTA shielding body

2.2.1.3.3 Helium coolant joog

D. Costing Rationale:

Engineering efforts, fabrication methods, requirements, and procedures were evaluated for the feasibility, fabrication and assembly of each major cornponent of the VTA-2-Helium. From these evaluations. fabrication man-hour estimates were made by the German industry (2.2.1.3.1 2.2.1.3.2), and the FZK AND Industry (2.2.1.3.3) based on the amount of welding, machining metal preparation and general labor required for fabrication and assembly.

Engineering deliverables (sucb as drawings, FE-calculations, specifications) required.

The estimated engineering cost is based on a $120,-$ DM or 78.90 ICF hourly rate.

E. Detailed Costing:

2.2.1,3,1 Test module with universal testing device:

a) Constnuction (see atlachment):

$$
100.000,-D M
$$

b) Fabrication (see attachment)

Frame with Iow activation anstenitic steel with complete universal testing devices for 3 specimens, He-coolant tubes, bellows, motors, load cell, incl. assembling

$$
\begin{array}{r}
115.000,-\mathrm{DM} \\
85.000,-\mathrm{DM} \\
42.000,-\mathrm{DM} \\
10.000,-\mathrm{DM} \\
10.000,-\mathrm{DM} \\
14.000,-\mathrm{DM} \\
25.000,-\mathrm{DM} \\
301.000,-\mathrm{DM}
\end{array}
$$




\subsection{VTA 2 shield body:}

a) Construction (see attachment):

b) Fabrication (see attachment)

$$
\begin{array}{r}
60.000,-\mathrm{DM} \\
70.000,-\mathrm{DM} \\
420.000,-\mathrm{DM} \\
21.000,-\mathrm{DM} \\
21.000,-\mathrm{DM} \\
14.000,-\mathrm{DM} \\
14.000,-\mathrm{DM} \\
3.000,-\mathrm{DM} \\
563.000--\mathrm{DM}
\end{array}
$$$$
39,000 \text { ICF }
$$

TOTAL

370,000 ICF

\subsection{Helium gas coolant loop:}

Because of compatibility and redundancy the same coolant loop as specified for VTA-1-He is suggested, even if the nuclear heat production in the mid flux region is not as high as in the high flux one. According to INTERATOM (SIEMENS Company) design layout for FZK High Energy Dual Beam Facility):

Construction and \$ystem specification:

$20 \%$ of Fabrication costs

$$
\text { 33.000,- DM }
$$

\section{$25,400 \mathrm{ICF}$}

Fabrication: Root pump incl. motor WKP $8000\left(\$ 8000 \mathrm{~m}^{3} / \mathrm{h}\right.$ from BALZERS
$30 \mathrm{~kW}$ electric power
72.070,- DM

Rack carrying pump, heat exchanger, valves, insuumentation and fittings (without pump and heat exchanger)

Compact heat exchanger

$$
25.000,-\mathrm{DM}
$$$$
\text { 2.500,- DM }
$$

Complete loop control rack

43.000,- DM

2 Molecular sieves incI. Instr.

$30.000,+$ DM

Tubes for helium gas inlet and outlet to VTA-1-Helium:

$21.000,-\mathrm{DM}$

TOTAL

193.570,- DM

$127.000 \mathrm{ICF}$ 
WORKSHEET

WBS 2.2.1.4 Helium gas controlled Medium flux Vertical Test Assembly for Trftium Release tests on Ceramic Breeders (VTA 2-He Breeders for Test Cell I)

A. Summary Cost estimate

\begin{tabular}{|c|c|c|c|c|c|c|c|}
\hline \multicolumn{4}{|c|}{ Off-IFMIF Site } & \multicolumn{4}{|c|}{ On-site at IFMIF } \\
\hline Industry & Instit'a] & & & Industry & Instit'al & & \\
\hline Mat'l/Lb Engin's & Engin's & $\mathbf{A F}$ & Total & Mat'ULab Engin'g & Engin'g & $\mathrm{AFI}$ & Total \\
\hline $640 \quad 163$ & 180 & 197 & $1,180^{\circ}$ & & 150 & 30 & 180 \\
\hline
\end{tabular}

Units: 1,000 ICF ( $1 \mathrm{ICF}=1.52 \mathrm{DM}$ )

\section{B. Description:}

Inert gas cooled (usually helium) medium flux Vertical Test Assembly for instrumented in-situ Tritium release tests on various ceramic breeder materials. The complete assembly consists of

- the test module with at least 4 different subassemblies (chambers)

- the VTA 2 Shielding body with integrated pipes and instrumentation

- the helium gas coolant loop

A suitable specimen design has been already developed which ensures bigh flexibility with respect to choice of coolant, dynamic temperature variations; mechanical loading conditions and beam-on or beamoff scenarios. 

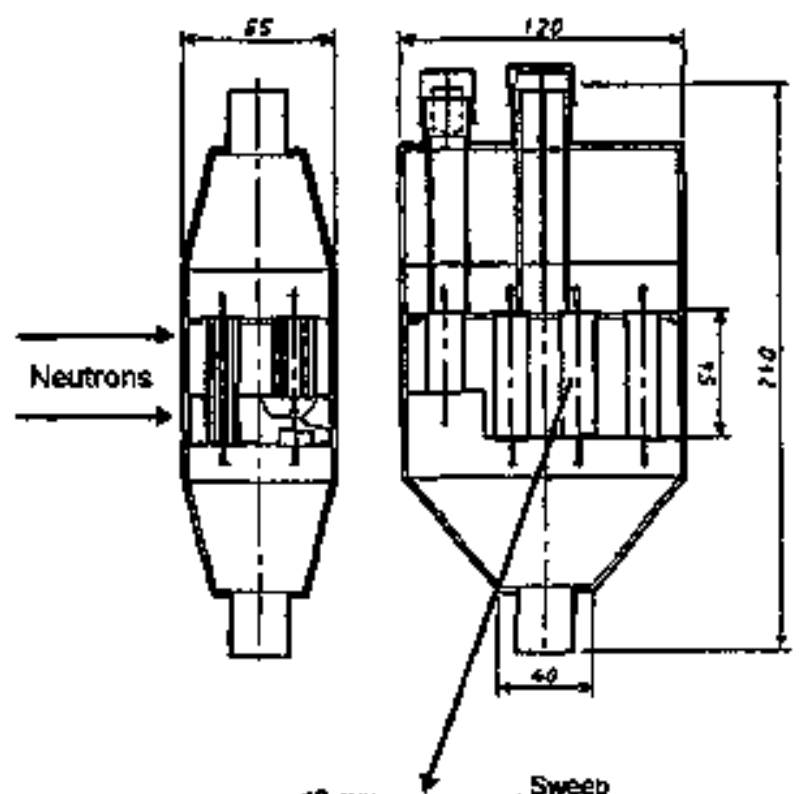

C. Detailed WS Listing:

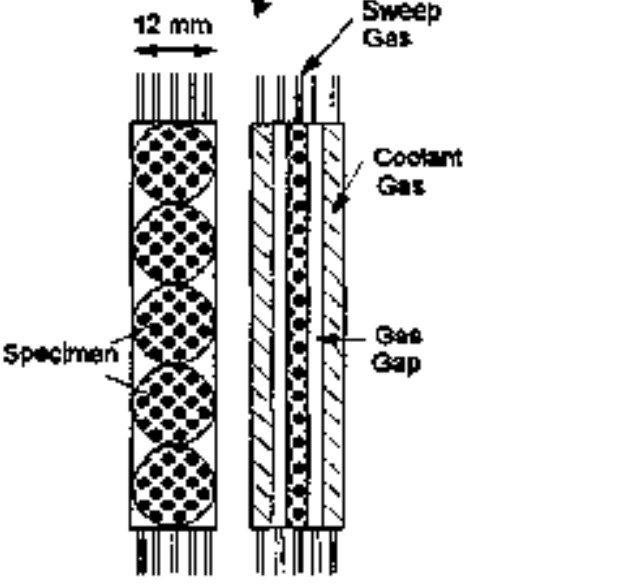

\subsubsection{High flux VTA (VTA-I-Helium);}

2.2.1.4.1 Subassemblies integrated in one test module

2.2.1.4.2 VTA shielding body

2.2.1.4.3 Helium coolant loop

\section{Costint Rationale:}

Engineering effort, fabrication methods, requirements, and procedures were evaluated for the feasibility, fabrication and assembly of each major component of the VTA-2-Helium. From these evaluations,

fabrication man-hour estimates were made by the JAERI (2.2.1.4.1 \& 2.2.1.4.2), and the FZK + Industry (2.2.1.4.3) based on the amount of welding, machining metal preparation and general labor required for fabrication and assembly.

Engineering deliverables (such as drawings, FE-calculations, specifications) required.

The estimated engineering cost is based on a 120 ,- DM or 78.90 ICF hourly rate. 


\section{E. Detailed Cosing:}

2.2.1.3.1 Test module with integrated subassemblies:

A more global cost estimate of the test module is done by JAERI. However, because the involved specimen volurne, the cooling technology and the instrumentation is similar to the Helium cooled High flux test module, the detailed cost estimate of WBS 2.2.1.2.2 is taken:

a) Constriction (see 2.2.1.2.2):

b) Fabrication (see 2.2.1.2.2)

\subsection{VTA 2 shield body:}

a) Construction (see PET quotation p.19):

b) Fabrication (see PET quotation p.20):
TOTAL

TOTAL

$123,800 \mathrm{ICF}$

$286,800 \mathrm{ICF}$

$39,000 \mathrm{ICF}$

$$
\begin{array}{r}
72.000,-\mathrm{DM} \\
370.000,-\mathrm{DM} \\
22.000,-\mathrm{DM} \\
31.000,-\mathrm{DM} \\
21.000,-\mathrm{DM} \\
18.000,-\mathrm{DM} \\
3.000,-\mathrm{DM} \\
537.000,-\mathrm{DM}
\end{array}
$$

$353,000 \mathrm{ICF}$

\subsection{Helium gas coolant loop:}

Because of compatibility and redundancy the same coolant toop as specified for VTA-1-He is suggested, even if the nuclear heat production in the mid flux region is not as high as in the high flux one. There is no cost for coolant requirements in this WBS element, because Tritium release tests and creep fatigue tests are not done at the same time. Therefore, the Helium loop specified in WBS 2.2.1.2.3 will be used. 
WORKSHEET

WBS 2.2.1.5 Vertical Irradiation Tube (10 VIT's) System for Test Cen I

A. Summary Cost Estimate:

\begin{tabular}{|c|c|c|c|c|c|c|c|}
\hline \multicolumn{4}{|c|}{ Off-IFMIF Site } & \multicolumn{4}{|c|}{ On-site at IFMIF } \\
\hline Industry & Instit'al & & & Industry & Instit'al & & \\
\hline Mat'1/Lab Engin'g & Engin's & AFI & Total & Mat'l/Lab Engin's & Engin's & $\mathrm{AFI}$ & Total \\
\hline $666 \quad 49$ & 1,102 & 182 & 1,999 & 105 & & 21 & 126 \\
\hline
\end{tabular}

B. Description:

The VIT system consists of an array of tubes, pneumatic pumps, valves and heat exchangers. The VIT system transports preumatic capsules through an array of tubes from the Loading/Un]oading \$tation to the Iow and very low imadiation areas in the Test Cell. The pneumatic capsules have OD's of 75 mm and $150 \mathrm{~mm}$. These pneumatic capsules remain in the irradiation region until the specimens are irradiated the desired length of time. The pneumatic capsules are then transported back to the Loading/ Unloading Station where they are removed and placed into a shielded container and transported to the PIE Hot Cells or Lead Boxes.

\section{Detailed WBS Listing:}

There are no other WBS Listings in this section of the WBS. The Vertical Tube Iradiation Tube (VIT) system, WBS 2.2.1.5, is the lowest WBS level listed.

\section{Costing Rationale:}

Fabrication methods, requirements, and procedures were evaluated for the fabrication and assembly of each major component of the VIT Plug. From these evaluations, fabrication man-hour estimates were made based on the arnount of welding, machining, metal preparation, and general iabor required for fabrication and assembly of these major components and the VIT Plug. The fabrication cost is based on a $\$ 67.00$ hourly rate.

Engineering deliverables (such as drawings, specifications, and calculations) required for the design of these components and the assembly of the VIT Plug were also evaluated. An engineering man-hour estimate was made based on these deliverables. The estimated engineering cost is based on a $\$ 98.50$ bourly rate.

The IFMIF VIT Transport/Cooling System is very similar to the ANS pneumatic tube transport system. Therefore the cost estimate of the IFMIF VTT TransportCooling System will be based on the cost of the ANS pneumatic tube transport system.

The IFMIF VIT Loading/Unloading Station is very simplar to the ANS pneumatic tube Loading Station. Therefore the cost estimate of the IFMIF VIT Loading/Unloading Station will be based on the actual cost of the HFIR pneumatic tube Loading Station.

\section{E. Detailed Costing:}

Vertical Irradiation Tube (VIT) Plug

TOTAL

$\$ 220,080$

The VIT Ptug consist of 10 VITs mounted into a shielding plug arrangement as illustrated below. The 10 VTTs are positioned inside a stepped stainless steel liner. Barytes concrete is filled between this liner and the 10 VTTs to form the VTT Plug. The barytes concrete provides adequate shielding needed to protect the VTA Access Room from the test cell radiation. The steps in the tiner conform to steps in the TCRC and VTA-2 to eliminate radjation streaming. The VITs are mounted in two rows with each row containing 5 VTTs. The first row of VITs located closest to the beam source are positioned in the low flux region. The second row of VTTs are positioned in the very low flux region. 


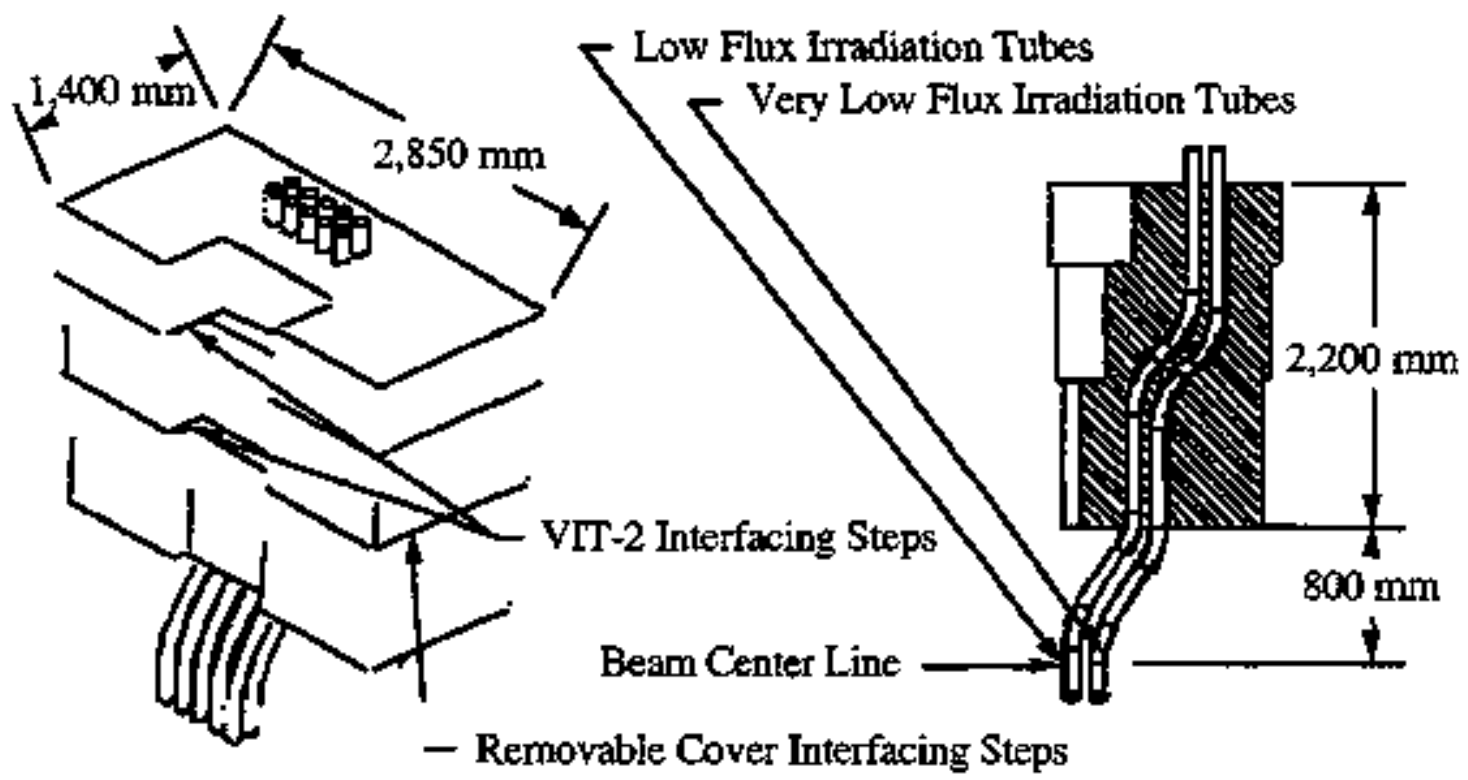

Figure Of The Vertical Irradiation Tube Plug

Engineering estimate for design of VIT p]ug:

a. ten (10) E size drawings

b. heat transfed/hydraulic calculations

$1000 \mathrm{hr} . \quad \$ 98,500$

$300 \mathrm{hr} . \quad \$ 29,550$

Labor estimate for fabrication of the VIT Plug:

a. metal prep $22 \mathrm{PC}$ of stainless plate

b. metal prep 30 PC $(90 \mathrm{M})$ of double wall

$100 \mathrm{hr} . \$ 6,700$

stainless pipe each pipe $3.5 \mathrm{M}$ long with

4 bends exch

c. welding $37 \mathrm{M} \mathrm{X} 12.7 \mathrm{~mm}$

d. machining for Test Cell Seal Plate

e. Installation of barytes concrete

$600 \mathrm{hr} . \quad \$ 40,200$

250 hr. $\$ 16,750$

$40 \mathrm{hr} . \quad \$ 2,680$

$200 \mathrm{hr} . \quad \$ 13,400$

Materials estimale for fabrication of VIT Plug:

(6000 LB stainless \$1.50/LB, and 33,000 LB

barytes concrete (10.10/LB.)

$\$ 12,300$

VIT Transport/Cooling System TOTAL $\quad \$ 557.520$

The VIT Transport/Cooling System is located in the Technology Room and consist of coolant flow pumps, valves, and a heat exchanger. The VIT TransportfCoolisg System uses circulating gas, probably argon, to transport the pneumatic capsules between the Loading/uloading Station and the irradiation areas located in the VITs. The VIT Transport/Cooling System is connected to each of the VITs by $80 \mathrm{~mm}$ or $160 \mathrm{~mm}$ ID tubing running along the wall of the VTA Access Room. The VIT TransportCooling System also provides cooling of the pneumatic capsules during imadiation.

The IFMIF VIT Transport/Cooling System is very similar to the ANS pneumatic tube transport system. Therefore the cost estimate of the IFMIF VIT Transport/Cooling System will be based on the cost estimate of the ANS pneumatic tube transport system. The engineering cost for the ANS pneurnatic tabe transport system was estimated to be $\$ 275,000$ for 5 pneurnatic tubes in 1993 . The Engineering effort for the 10 IFMIF pneumatic tubes will be approximately $50 \%$ more involved, which translates to $\$ 487,000$ in 1996. The Fabrication and Materials cost for the ANS pneumatic tube transport system was estimated to be $\$ 14,000$ for 5 pneumatic tubes in 1993 . This translates to $\$ 33,000$ for 10 pneumatic trbes in 1996. The 
installation cost for the ANS pneumatic tube transport systern was estimated to be 280 man-hours for 5 pneumatic tubes. This translates to $\$ 37,520$ for 10 pheumatic tubes at $\$ 67.0$ hrour.

VIT Loading/Unloading Station TOTAL $\quad \$ 1,144,400$

VIT Loading/Unloading Station is located in the Technology Room and includes its own shielded enclosure. This enclosure contains valves and loading funloading ports that provide access into the VIT System. The VIT Loading/Unloading Station is used to insert the pneumatic capsules into the VTT System. Here the pneumatic capsules are inserted into the VIT System and then transported to the irradiation area by the VTT Transport/Cooling System. The pneumatic capsules are then transported back to the Loading/Unloading Station where they are removed and placed into a shielded container and transported to the PIE Hot Cells or Lead Boxes.

The IFMIF VIT Londing/Unloading Station is very similar to the ANS pneunatic tube Loading/Unloading Station. Therefore the cost estimate of the IFMIF VIT Loading/Unloading Station wili be based on the cost estimate of the ANS pneumatic tube Loading Station. The engineering cost for the ANS pneumatic tube Loading/Unloading Station was estimated to be $\$ 275,000$ for 5 pneumatic tubes in 1993. The Engineering effort for the J0 IFMIF pnenmatic tubes will be approximately 50\% more involved, which translates to $\$ 487,000$ in 1996 . The Fabrication and Materials cost for the ANS pneumatic tube Loading/Unloading Station was estimated to be $\$ 250,000$ for five pneumatic tubes in 1993 . This translates to \$590,000 for 10 pneumatic tubes in 1996. The instailation cost for the ANS pneumatic tube Loading/Unloading Station was estimated to be $\$ 200$ man-hours for 5 pneumatic tubes in 1993 which translates to $\$ 67,400$ for 10 pnenmatic tubes (id $\$ 67,00 /$ hour. 
WORKSHEET

WBS 2.2.1.6

WBS 2.2.1.6 Test Cell Shielding Plug for Test Cell I

A. Summary Cost Estimate:

FOR TEST CELLL I

\begin{tabular}{|c|c|c|c|c|c|}
\hline \multicolumn{3}{|c|}{ Off-IFIMIF Site } & \multicolumn{3}{|c|}{ On-Site Af IFMIF } \\
\hline Industry & Instita: & & Const. Contractor & Gistat'a & \\
\hline Mat'VLab Engin'g & Enging & AFI Tota & Mart/Lab Engin'g & Engin's & AFT Tota \\
\hline 9 & 20 & $\begin{array}{|ll|}6 & 35 \\
\end{array}$ & & & \\
\hline
\end{tabular}

Dnits: 0.\$. Dollars $(\$ 1,000)$

\section{B. Description:}

The Test Cell Shielding Plag (SP) interfaces with both VTAs and the Removable Cover. As illustrated below, the Test Cell SP is equipped with steps that conform to the steps is each VTA and the Removable Cover to prevent rafiation streaming. The Test Cell Shjelding Plug is removed by lifting it straight up. Once the Test Cell SP has been removed, the VTAs can be lifted ont of the Test Cell and into the Test Cell Access Room in any sequence without interfering with the remaining VTA.

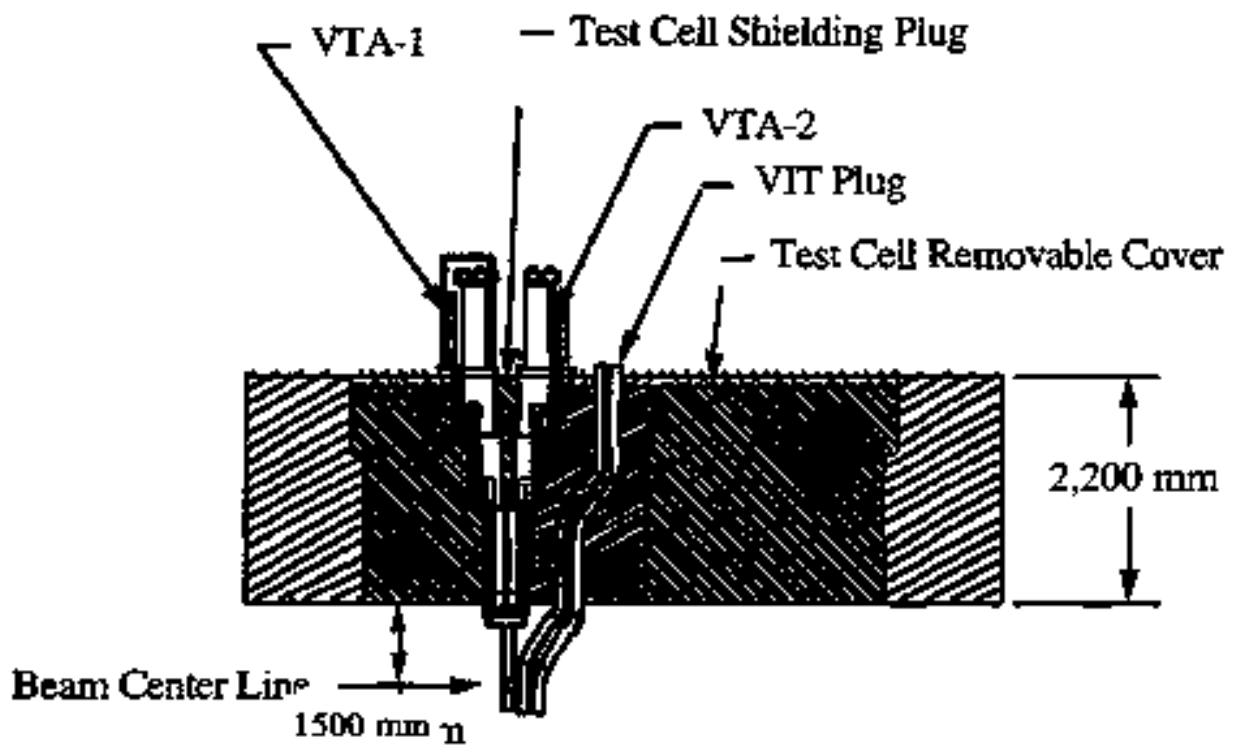

Figure OF Test Cell Shielding Plurg Arrangement

\section{Detailed WBS Listing:}

There are no other WBS Listings in this section of the WBS. The Test Cell SP WBS 2.2.1.4, is the lowest WBS level listed.

\section{Costing Rationale:}

Fabrication methods, requirements, and procedures were evaluated for the fabrication and assembly of each major component of the Test Cell SP. From these evaluations, fabrication man-hour estimates were made based on the anotint of welding, machining, metal preparation, and general labor tequired for fabrication and assembly of these major components and the Test Cell SP. The fabrication cost is based on a $\$ 67.00$ hourily rate. 
Engineering deliverables (such as drawings, specifications, and calculations) required for the design of these components and the assembly of the Test Cell SP were also evaluated. An engineering man-hour estimate was made based on these deliverables. The estimated engineering cost is based on a $\$ 98.50$ hourly rate.

\section{E. Detajled Costing:}

Engineeriag estimate for design of Test Cell SP:

a. two (2) E size drawings

200 hr.

$\$ 19,700$

Labor estimate for fabrication of Test Cell SP

a. metal prep $10 \mathrm{PC}$ of stainless

$40 \mathrm{hr}$.

b. welding $5 \mathrm{M} \times 12.7 \mathrm{~mm}$

c. machining for VTA/Removable Cover Interface

c. Installation of barytes concrete

$35 \mathrm{hr}$.

$30 \mathrm{hr}$.

$20 \mathrm{hr}$.

$\$ 2,680$

$\$ 2,345$

$\$ 2,010$

$\$ 1,340$

Materials estimate for fabrication of $\$ P$ :

250 L. stainless for casing $@ \$ 1.50 / \mathrm{LB}$., 500 LB barytes

concrete $\$ \$ 0.10 / L B$. and $\$ 325$ misc.) 
WORKSHEET

WBS 2.2.2.1

Was 2.2.2.1 Test Cell Removable Cover for Test Cell I

A. Summary Cost Estimate: FOR ONE TEST CELL

\begin{tabular}{|c|c|c|c|c|c|}
\hline \multicolumn{3}{|c|}{ Off-IFMIF Site } & \multicolumn{3}{|c|}{ On-Site At IFMIIF } \\
\hline Industry & Instital & & Const. Contractor & | Instit'al & \\
\hline Mat'l/Lab Engin' & Engin's & AFI Total & Mar'ULab Engin's & Engin'g & AFi Total \\
\hline 1,045 & 184 & $\begin{array}{lll}246 & 1,47\end{array}$ & & & \\
\hline
\end{tabular}

Units: $1,0001 \mathrm{CF}(1 \mathrm{CF}=1.52 \mathrm{DM})$

\section{B. Description:}

The Test Cell Removable Cover (TCRC) is positioned along top of the Test Cell to provide adequate shielding needed to protect the VTA access area from the test cell radiation as shown below. The TCRC thickness of $2.2 \mathrm{M}$ is adequate to protect the equipment in the Test Cell Access Room (i.e., the dose to the equipment is expected to be small enough to allow the use of organic seal, lubricating, and insulating materials). The TCRC interfaces with the Test Cell Liner to provide a vacuum enclosure within the Test Cetl. The TCRC also interfaces with gas cooling ducts that cool the Upper Test Cell Heat Shield (UTCHS). The UTCHS is mounted in the lower portion of the TCRC.. A low-activation stainless steel is used to construct the UTCHS. The UTCHS is approximately $300 \mathrm{~mm}$ thick and is cooled on both sides. The UTCHS is positioned 25 anm below the shielding concrete of the TCRC and $25 \mathrm{~mm}$ above the bottom exterior lining of the TCRC.

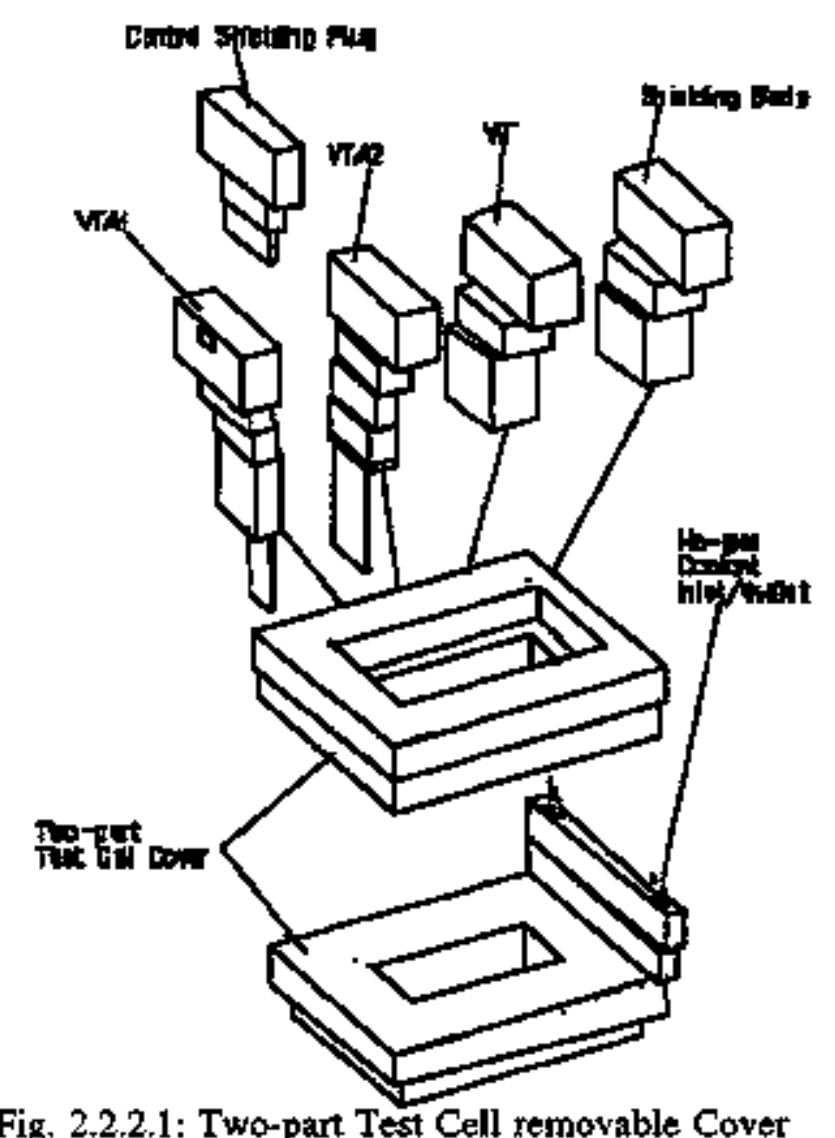

Fig. 2.2.2.1: Two-part Test Cell removable Cover 
The TCRC is removable to gain access to the interior of the Test Cell. Vacunm compatible sealing surfaces are placed along the top of the TCRC adjacent to the VTA's and VTT Plug. These sealing surfaces interface with the Test Cell Seal Plate to provide a vacuum tight seal between the VTA's and VTT Plug. In order to reduce the weight for the lifting system the TCRC is sectioned into two parts,

- the upper TCRC with a weight of approximately $66,68 \mathrm{to}$, and a volume of $16 \mathrm{~m}^{3}$, and

- the lower TCRC with a weight of approximately $57,6 \mathrm{to}$, and volume of $12 \mathrm{~m}^{3}$. Integrated rips and

coolant pipes are foreseen to guarantet stiffuess and ambient temperatures during irradiation.

\section{Detailed WBS Listing:}

\subsubsection{Test Cell Removable Cover (TCRC) \\ 2.2.2.1.1 Upper Test Cell Removable Cover \\ 2.2.2.1.2 Lower Test Cell Removable Cover}

\section{Costing Rationale:}

Fabrication methods, requirements, and procedures were evaluated for the fabrication and assernbly of each major component of the TCRC. From these evaluations, fabrication man-hour estimates were made based on the amount of welding, machining, metal preparation, and general labor required for fabrication and assembly of these major components and the TCRC.

Engineering deliverables (stich as drawings, specifications, and catculations) required for the design of these components and the assembly of the TCRC were also evaluated. An engineering man-hour estimate was made based on these deliverables. The estimated engineering cost is based on a ICU 78.90 hourly rate.

\section{E. Detailed Costing:}

2.2.2.1.1 Upper Test Cell Removable Cover:

Engineering estiuate for design:

a. Construction and FE-calculations

b. Static,

100.000,- DM

$20.000,-D M$

Labor estimate for fabrication of TCRC:

a. metal prep.

b. welding

c. ducts and pipes incl. Welding

d. Fabrication and polishing of seal surfaces, bolts and VTA Interface

e. Leak tests

f. Installation of special concrete TOTAL

325.000,- DM

185.000 - DM

20.000,- DM

$170.000-\mathrm{DM}$

15.000,- DM

95,000,- DM

$810.000,-D M$
$140.000,-\mathrm{DM}$

$20.000,-\mathrm{DM}$

$280.000,-\mathrm{DM}$

$195,000,-\mathrm{DM}$

$80.000-\mathrm{DM}$

c. ducts and pipes incl. Welding

d. Fabrication and polishing of surfaces, bolts and VTA Interface

e. Leak uests

f. Installation of special concrete

125.000,- DM
15.000,- DM

95.000,- DM

$790.000,-\mathrm{DM}$
65,800 ICF

$13,200 \mathrm{ICF}$

213.800 ICF

$121,700 \mathrm{ICF}$

$13,200 \mathrm{ICF}$

111,800 ICF

9,900 ICF

62,500 ICF

$\$ 33,000$ ICF

$92,100 \mathrm{ICF}$

I3,200 ICF

$184,200 \mathrm{ICF}$

128,300 ICF

52,600 ICF

$82,200 \mathrm{ICF}$

9,900 ICF

$62,500 \mathrm{ICF}$

512,000 ICF 
WORKSHEET

WBS 2.2.2.2

WBS 2.2.2.2 Test Cell Liner for Test Cell I

A. Summary Cost Estimate:

FOR ONE TEST CELL

\begin{tabular}{|c|c|c|c|c|c|}
\hline \multicolumn{3}{|c|}{ Off-IFMIF Site } & \multicolumn{3}{|c|}{ On-Site Af IFMIF } \\
\hline Industry & Instital & & Const. Contractor & Tnstita & \\
\hline Marl/Lab Engin'g & Engin' & AFI Total & Mar'VLab Engin'g & Engin's & AFI rotal \\
\hline 891 & 155 & 2091.25 & 59 & & 12 \\
\hline
\end{tabular}

Units: U. S. Dollars $(\$ 1,000)$

\section{B. Description:}

The Test Cell Liner serves as the interior surface of the Test Cell as illustrated in figgure shown below. The Test Cell Liner provides the Test Cell with a vacuum enclosure when sealed by the TCRC. The Test Cell Liner is constructed from $20 \mathrm{~mm}$ thick low-activation steinless steel to sustain the 1 bar external pressure. Active cooling in the form of circulating gas, probably argon, is provided along the external surface of the Test Cell Liner. This will maintain the interior surface of the Test Cell Liner within a safe temperature.

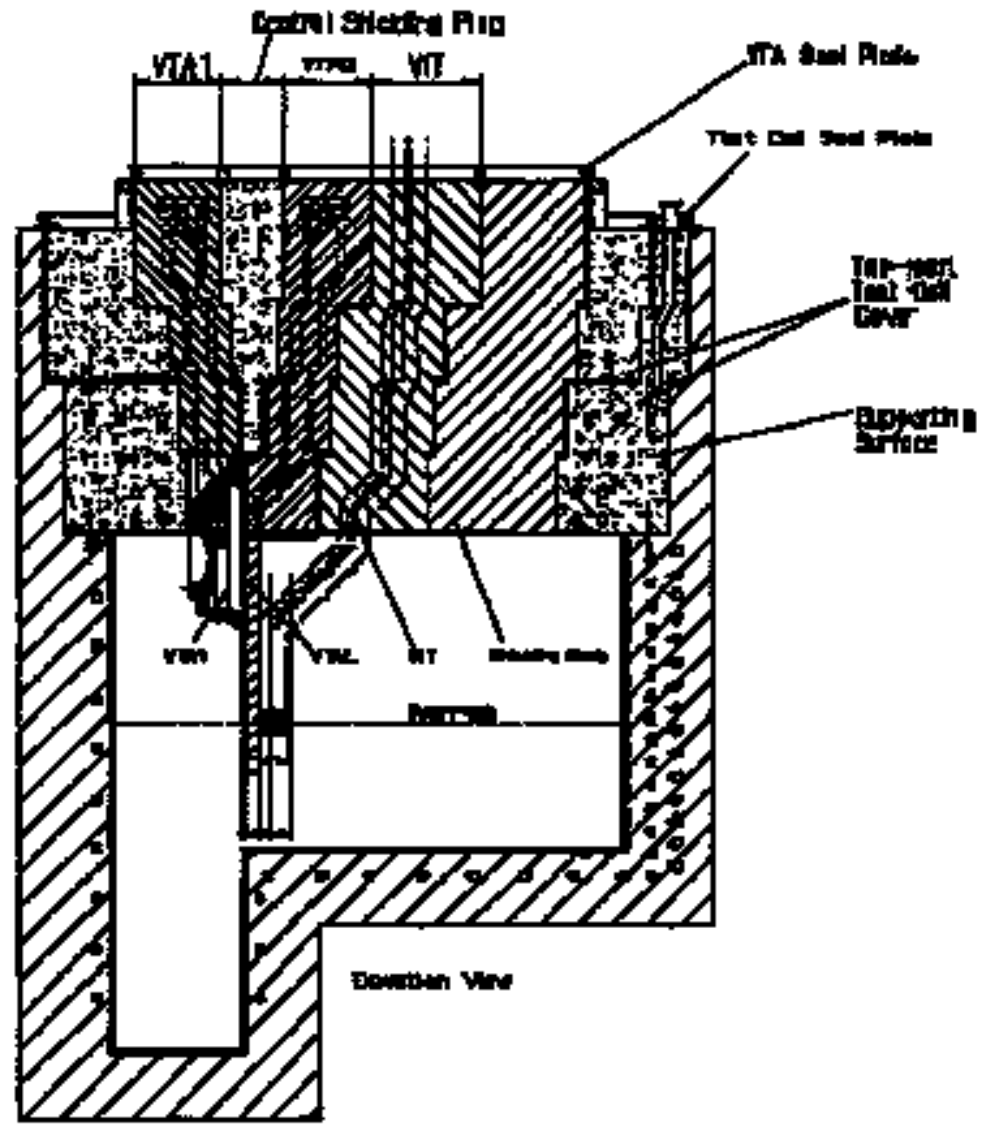

Fig. 2.2.2.2: Figure of Test Cell with Test Cell liner 


\section{Detailed WBS Listing:}

There are no other WBS Listings in this section of the WBS. The Test Cell Liner, WBS 2.2.2.2, is the lowest WBS level listed.

\section{Costing Rationale:}

Fabrication methods, reguirements, and procedures were evaluated for the fabrication and assembly of each major component of the Test Cell Liner. From these evaluations, fabrication man-ftour estimates were made based on the amount of welding, machining, metal preparation, and general labor required for fabrication and assembly of these major components and the Test Cell Liner Enginering deliverables (such as drawings, specifications, and calculations) required for the design of these components and the assembly of the Test Cell Liner were also evaluated. An engineering man-hour estimate was made based on these deliverables. The estimated engineering cost is based on a $\$ 78,90$ hourly rate.

\section{E. Detailed Costing:}

The offer of the PET Company has been used. A second, mich cheaper estimate of ORNL is also available.

Engineering estimate for design of the Test Cell Liner:

a. Construction, hear transfer calculations, drawings

b. Static

$195.000,-\mathrm{DM}$

$40.000,-\mathrm{DM}$
$128,300 \mathrm{ICF}$

$26,300 \mathrm{ICF}$

L.abor estimate for fabrication of the Test Cell Liner (according to PER offer p. 9):
a. metal prep
$910.000, \mathrm{DM}$
$598,700 \mathrm{ICF}$
b. coolant ducts, pipes, rips
c. special fittings for sealing plate, 24 fitting plates
d leak tests of chamber, all flanges and instruments
TOTAL
$310.000,-\mathrm{DM}$
210,500 ICF
35.000,- DM
23,000 ICF
$90.000,-D M$
$59,200 \mathrm{ICF}$
1.355.000,- DM
891,000 ICF

ORNL Engineering estimate for installation of the Test Cell Liner:
a. five (5) E size drawings
b. calculations
$500 \mathrm{be}$.
$100 \mathrm{hr}$.
$\$ 48,750$
$\$ 9,750$

Labor estimate for installation of the Test Cell Liner:

a. position and mounting liner in place

b. welding vacuum lines

500 br. $\quad \$ 33,500$

300 hr. $\quad \$ 20,100$

Materials estimate for installation of Test Cell Liner (misc) 
WORKSHEET

WBS 2.2 .2 .3

WBS 2.2.2.3 Test Cell Heat Shiejd for Test Cell I

A. Summary Cost Estimate: FOR ONE TEST CELL

\begin{tabular}{|c|c|c|c|c|c|}
\hline \multicolumn{3}{|c|}{ Off-IFMIF Site } & \multicolumn{3}{|c|}{ Ot-Site At IFMIF } \\
\hline Industry & Institai & & Const Contractor & Instital & \\
\hline Mar'VLab Engin' $\mathrm{g}$ & Engin'g & AFITotal & Mat'ULab Engin'g & Engin $\mathrm{g}$ & AFr Total \\
\hline 599 & 255 & $17 \sqrt{1025}$ & 79 & & 16 \\
\hline
\end{tabular}

Units: U. S. Dollars (\$1,000)

\section{B. Description:}

The TCHS is placed between the exterior surfaces of the Test Cell Liner and the interior surfaces of the Sbielding Concrete surrounding the Test Cell as shown in figure below. This arrangement reduces the neutronic heat loads in the Test Cell Liner and the Shielding Concrete surrounding the Test Cell. A $25 \mathrm{~mm}$ gap is provided between the TCHS and the Shielding Concrete and Test Cell Liner. With the use of the TCHS, the shielding concrete and the Test Cell Liner can be simply cooled from the edges adjacent to the TCHS using the Test Cell Cooling System. This eliminates the need to use cooling passages embedded in the shielding concrete. A low-activation stainiess steel is used to constract this shielding with a thickness of $500 \mathrm{~mm}$ needed along the surface facing the lithium target and $300 \mathrm{~mm}$ along the other Test Cell walls. The shielding is cooled along its interior edges with circulating gas. With this arrangement, the stainless steel heat shield temperatuse can be maintained to be less than $[\mathrm{TBD}]^{\circ} \mathrm{C}$ higher than the gas coolant at all locations. The peak temperature of the shielding concrete surrounding the Test Cell is expected to be only $[T B D]^{\circ} \mathrm{C}$ higher than the Test Cell gas coolant.

An atterzative coolant system has been proposed by FZK and PET Company based on coolant ducts integrated in concrete. However, for the cost estimate the ORNL proposal is used.

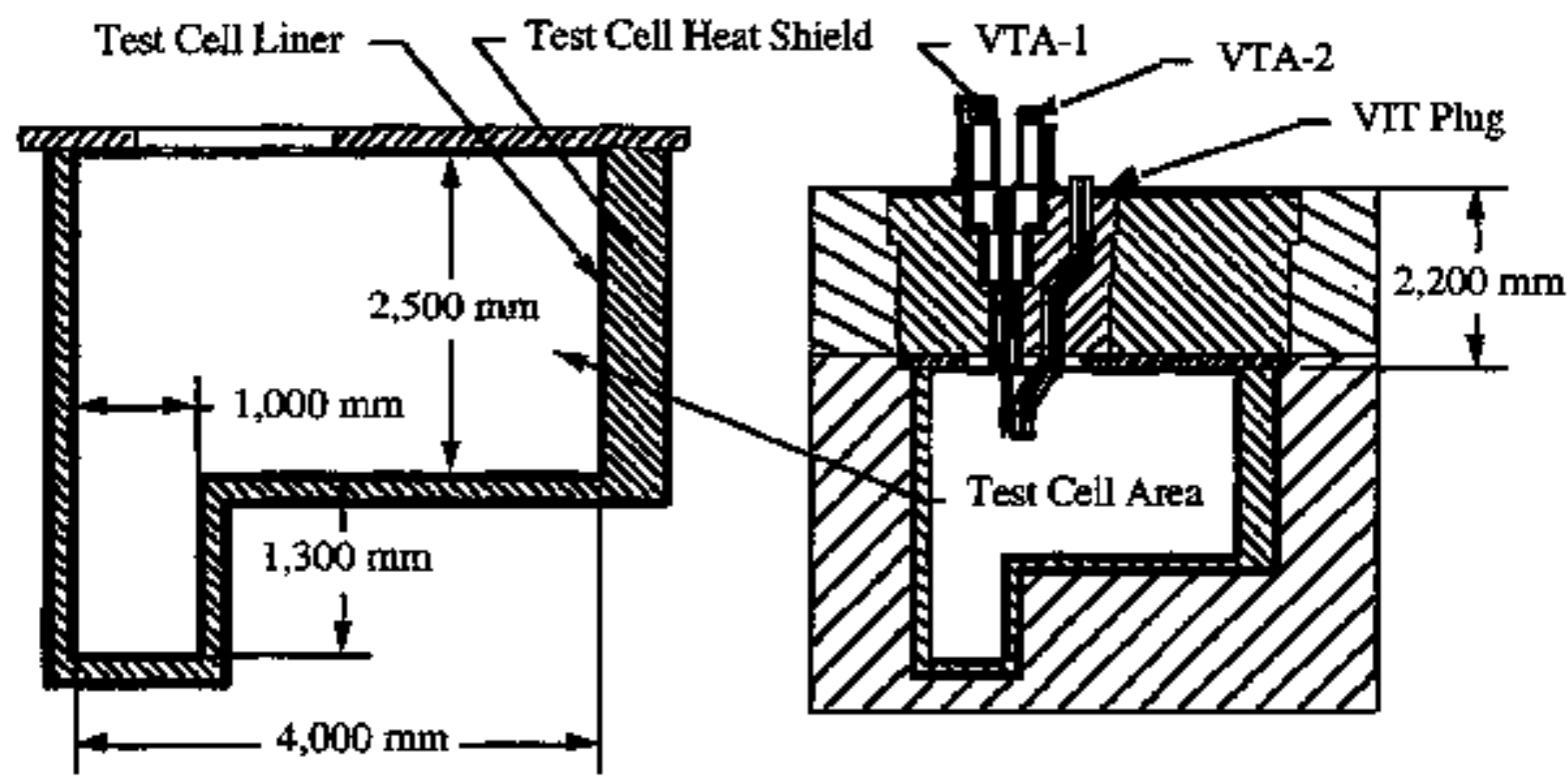

Figure Of Test Cell Liner And Heat Shield 


\section{Detailed WBS Listing:}

There are no other WBS Listings in this section of the WBS. The TCHS WBS 2.2.2.3, is the lowest WBS level listedeđ.

\section{Costing Rationale:}

Fabrication methods, requirements, and procedures were evaluated for the fabrication and assembly of each major component of the TCHS. From these evaluations, fabrication man-hour estimates were made based on the amount of weiding, machining, metal preparation, and general labor required for fabrication and assembly of these major components and the TCHS. The fabrication cost is based on a $\$ 67.00$ hourly rate.

Engineering deliverables (such as drawings, specifications, and calculations) required for the design of these components and the assembly of the TCHS were also evaluated. An engineering man-hour estimate was rade based on these deliverables. The estimated engineering cost is based on a $\$ 98.50$ hourly rate.

\section{E. Detailed Costing:}

Engineering estimate for design of Test Cel] Heat Shie[d:
a. ten (10) E size drawings
b. beat transfer calculations
$1000 \mathrm{hr}$.
$\$ 98,500$
$600 \mathrm{hr}$.
$\$ 58,500$

Labor estimate for fabrication of Test Cell Heat Sirield :
a metal prep $16 \mathrm{PC}$ of stainless steel
b. welding $25 \mathrm{M} \mathrm{X} 12.7 \mathrm{~mm}$
c. fabrication of Heat Shield supports
$1000 \mathrm{hs}$.
$300 \mathrm{hr}$.
$200 \mathrm{hr}$.
$\$ 67,000$
$\$ 20,100$
$\$ 13,400$

Materials estimate for fabrication of Test Cell Heat Shield

a. Heat Shield opposite beam: $3000 \mathrm{~mm}$ X $2500 \mathrm{~mm} \times 500 \mathrm{~mm}$ -

65,000 LB. stainless shielding \$ $\$ 1.75 / \mathrm{LB}$.

b. Heat Stield right of beam: $2500 \mathrm{~mm} \mathrm{X} 4000 \mathrm{~mm}$ X $300 \mathrm{~mm}$ $+1200 \mathrm{~mm} \times 1000 \mathrm{~mm} \times 300 \mathrm{~mm}-60,000 \mathrm{LB}$. stainless shielding

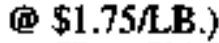

c. Heat Shield left of beam: $2500 \mathrm{~mm} \times 4000 \mathrm{~mm} X 300 \mathrm{~mm}$ $\$ 1200 \mathrm{~mm} \times 1000 \mathrm{~mm} \times 300 \mathrm{~mm}-60,000 \mathrm{LB}$, stainless shielding (ii) $\$ 1.75 / \mathrm{LB}$.)

d. Heat Shield in floor: $3000 \mathrm{~mm} \times 6400 \mathrm{~mm}$ X $300 \mathrm{~mm}$ $100,000 \mathrm{LB}$, stainless shielding (1.95/LB.

Engineering estimate for installation of Test Cell Heat Shield:

a. eight (8) E size drawings

b. calculations $800 \mathrm{hr}$. 200 hr.

Labor estimate for installation of Test Cell Heat Shield :

a position/mounting Heat Shield in place

b. welding cooling lines

$600 \mathrm{hr}$.

$500 \mathrm{br}$.

$\$ 40,200$

$\$ 33,500$

Materials estimate for fabrication of Test Cell Hear Shield (misc.) $\quad \$ \quad 5,000$ 


\section{WBS 2.2.2.4 Test Cell Seal Plate}

A. Summary Cost Estimate:

FOR ONE TEST CELL

\begin{tabular}{|c|c|c|c|c|c|}
\hline \multicolumn{3}{|c|}{ Off-IFMIF Site } & \multicolumn{3}{|c|}{ On-Site At IFMilF } \\
\hline mäustry & Instital & & Const. Contractor & Instital & \\
\hline Mat'VLab Enging & Engin'g & AFI Total & Mac'l/Lab Engin'g & Engin's & AFI Total \\
\hline 309 & 26 & 67402 & & & \\
\hline
\end{tabular}

Units: U. S. Dollars $(\$ 1,000)$

\section{B. Description:}

Two seal systers are presently considered to be necessary:

- The first sealing system is necessary to seal the removable Test cell Cover and consists of a frame with a thickness of 20 to $25 \mathrm{~mm}$, a $O$-ring system (diameter $15 \mathrm{~mm}$ ), size $5.500 \times 4.500 \mathrm{~mm}$ with bellows to adjust different levels and an inner plate

- The second sealing system is necessary for the VTAs and the VIT system. This Test Cell Seal Plate (TCSP) is located on top of the TCRC and interfaces with each VTA and the VIT Plug. The TCSP provides a vacuum seal for the Test Cell by sealing each VTA and the VTF Plug to the Removable Cover. The vacuum sealing surfaces for each VTA and the VIT Plug is located along its top seal plate. The TCSP mates with these seaI plates and another seal plate mounted in the Removable Cover. Fig. 2.2.2.2 shows the seal ing systems.

\section{Detailed WBS Listing:}

\subsubsection{Test Cell Seai Plates: \\ 2.2.2.4.5 Seal frame for the removable Test cell cover \\ 2.2.2.4.6 Seal Plate for the VTAs and the VIT}

\section{Costing Rationale:}

Fabrication methods, requirements, and procedures were evaluated for the fabrication and assembly of each major component of the TCSP. From these evaluations, fabrication man-hour estimates were made based on the amount of welding, machining, metal preparation, and general labor required for fabrication and assembly of these major components and the TCSP.

Engineering deliverables (such as drawings, specifications, and calculations) required for the design of these components and the assembly of the TCSP were also evaluated. An engineering man-hour estimate was made based on these deliverables. The estimated engineering cost is based on a $\$ 78.90$ hourly rate.

Two estimates have been made, one by the ORNL and the second by the German industry (PET): For the cost estimate the offer of PET has been used.

\section{E. Detailed Costing:}

Engineering estimate for design:

2.2.2.4.1 Construction and calculations $\quad 13.000,+\mathrm{DM}$

$$
\begin{array}{rr}
130.000,-D M & 19,700 \mathrm{ICF}
\end{array}
$$

Labor estimate for fabrication of seal plates:

2.2.2.4.1 Seal frame with bellows, $O$-rings and cover interface

Stabilization frame for tifting and adjusting

Leak and manipulation tests

TOTAL

2.2.2.4.I Seal frame with bellows. O-rings and cover interface

$$
\begin{array}{rr}
130.000,-D M & 85.500 \text { ICF } \\
50.000,-D M & 32,900 \mathrm{ICF} \\
20.000,-\mathrm{DM} & 13,200 \mathrm{ICF} \\
200.000,-\mathrm{DM} & 132,000 \mathrm{ICF} \\
130.000,-\mathrm{DM} & 85.500 \mathrm{ICF}
\end{array}
$$


Stabilization frame for lifting and adjusting Leak and manipulation tests

TOTAL
$50.000,-D M \quad 32,900 \mathrm{ICF}$

20.000,-DM 13,200 ICF $200.000,-D M \quad 132,000$ ICF 
WORKSHEET

WBS 2.2.2.5

\section{WBS 2.2.2.5 Test Cell Camera System for Test Cell I}

A. Summary Cost Estimate: FOR ONE TEST CELL

\begin{tabular}{|c|c|c|c|c|c|}
\hline \multicolumn{3}{|c|}{ Ofl-LFMIF site } & \multicolumn{3}{|c|}{ Wn-Site At IFMtF } \\
\hline Industry & Instíta & & Const. Contracter & Instit'aI & \\
\hline Mat'LLab & Engin's & AFI Total & Mat'VLab Engin'g & Engin' $\mathbf{g}$ & AFi Total \\
\hline 162 & 236 & 80478 & 84 & & 17101 \\
\hline
\end{tabular}

Units: U.S. Dollars $(\$ 1,000)$

\section{B. Description:}

The Test Cell Camera \$ystem (TCC\$) provides viewing of the Test Cell interior to aid in the removal and installation of the VTA's and VIT. Viewing takes place only when the beam is not operating and the Test Cell is vented. The TCCS consists of two cameras, two pitch/yaw mechanisms, two carnera booms, two shield plugs, two monitors, and two control paneis that control the zoorn and position of each camera. Each camera is supported by a pitch/yaw mechanism and is equipped with a zoom lens to provide a wide range of viewing. The pitch/yaw mechanism and camera assembly is mounted on the end of the camera boom. The camera boom is equipped with a $2 \mathrm{M}$ telescoping section to control the angle of viewing. The cameras are positioned in the Test Cel] by inserting the booms through vertical ports that are located in opposite corners of the TCRC. Each TCRC port is plugged by the Camera Shield Plug (CSP) during beam operation. These camera shield plugs are equipped with elastomer $Q$-Ring seals that interface with the top of the TCRC to provide a vacuum tight enclosure. Each CSP consists of a stepped, stainless steel liner that is filled with barytes concrete. Each CSP has a cylindrical cross section and is equipped with three steps that conform to steps in the TCRC ports to prevent radiation streaming. The CSP are retnoved and replaced by the camera booms when viewing is required.

\section{Detailed WBS Listing:}

There are no other WBS Listings in this section of the WBS. The TCCS WBS 22.2.6, is the lowest WBS level listed.

\section{Costing Rationale:}

Fabrication methods, requirements, and procedures were evaluated for the fabrication and assembly of each major component of the TCSP. From these evaluations, fabrication man-hour estimates were made based an the amount of welding. machining. metal preparation, and general labor required for fabrication and assembly of these major components and the TCSP. The fabtication cost is based on a $\$ 67.00$ hourly rate.

Engireering deliverables (such as drawings, specifications, and calculations) required for the design of these components and the assembly of the TCSP were also evaluated. An engineering man-hour estimate was made based on these deliverables. The estimated engimeering cost is based on a $\$ 98.50$ hourly rate. 
I. Engineering estimate for design of two CSP:
a. $\operatorname{six}(6) \mathrm{E}$ size drawings
b. stress calculations
$600 \mathrm{hr}$.
$\$ 59,100$
$100 \mathrm{hr}$.
$\$ 9,850$
L. Labor estimate for fabrication of two CSP.
a. metal prep $14 \mathrm{PC}$ of stainless
$140 \mathrm{hr} . \$ 9,380$
b. welding $8 \mathrm{M} \mathrm{X} 12.7 \mathrm{~mm}$
$20 \mathrm{hr} . \$ 1,340$
c. machining for O-Ring seal surfaces and mounting interfaces
d. Installation of barytes concrete
200 hr. $\$ 13.400$
100 hr. \$ $\$ 6,700$

Materiats estimate for fabrication of two CSP:

$(1,500 \mathrm{LB}$ stainiess @ $\$ 1.50 \mathrm{LB}$. and $3,000 \mathrm{LB}$ barytes

concrete $\$ \$ 0.10 /$ LB.)

$\$ 2,550$

F. Engineering estimate for design of two camera booms

a. ten (10) E size drawings

b. Stress calculations

$1000 \mathrm{hr}$.

$\$ 98,500$

$100 \mathrm{br}$

$\$ 9,850$

II. Labor estimate for fabrication of two camera boons:

a. metal prep $16 \mathrm{PC}$ of stainless

b. welding $40 \mathrm{M} \times 12.7 \mathrm{~mm}$

$400 \mathrm{hr}$.

$\$ 26,800$

c. machining for telescoping surfaces and mounting interfaces

$600 \mathrm{hr}$.

$\$ 40,200$

Materials estimate for fabrication of two camera booms:

(1,500 LB stainless (1.50/L.B., screw jacks, and, servo motors)

$\$ 10,000$

III. Engineering estimate for design of two camera control panels
a. six (6) E size drawings
$600 \mathrm{hr}$.
$\$ 59,100$

III. Labror estimate for fabrication of the two camera control panels:

Materials estimate for Procurement of:
a. two cameras:
b. two monitors:
c. two pitch/yaw mechanisms:

$\$ 4,000$

$\$ 1,000$

$\$ 10,000$

IV. Labor estimate for installation of Test Cell Camera System
a. cabling
b. control panels

$1000 \mathrm{hr}$.

$250 \mathrm{hr}$.

$\$ 67,000$

$\$ 16.750$ 
WORKSHEET

WBS 2.2.2.6 Neutron and Gamma Source diagnostics for Test Cell I

A. Summary Cost estimate:

\begin{tabular}{|c|c|c|c|c|c|}
\hline \multicolumn{3}{|c|}{ Off-IFMIF Site } & \multicolumn{3}{|c|}{ On-site at IFMIF } \\
\hline Industry & Instit' al & & Industry & Instit'al & \\
\hline Mat'Luab Engin's & Engin'g & AFI Total & Mat'1/Lab Engin'g & Engin's & AFI Total \\
\hline 99 & & $20 \quad 118,7$ & & & \\
\hline
\end{tabular}

Units: $1,000 \mathrm{ICF}(1,000 \mathrm{ICF}=1.520,-\mathrm{DM})$

B. Description:

During the set-up phase of IFMIF neutron and gamma flux contours downstrearn the Li-Target have to be monitored carefully and compared with the resuits of the transport codes in orter to assess the sensitivity of the codes. This is especially important because the neuron source term in thick $\mathbf{L}$-targets is still a matter with various uncertainties (e.g. production yield of sequential (p, Li) reaction induced additional neutrons. In addition, the heat deposition rate distribution at least in the High Flux VTA has to be determined as a function of different deuteron beam currents both for continuous beam on-target and various beanl-on-beam-off scenarios.

The above procedures includes the availability of suitable neutron and gamma dosimetry as well as the use of a Hight Flux VTA with a special test module. While the VTA body and the coolant system can be identical with those specified for normal operations (see 2.2.1), the test module with already integrated specimens and specimen capsules has to be instrumented with various thermocouples and suitable dosimetry foils.

With respect to uncollided neutrons it is assumed that suitable high flux neutron and gamma moniters for the analysis e.g. of beam foot print and beam density profiles immediately behind the Ljtarget are not part of the Test Facility (Is that true ?). Nevertheless, a beam density probile monitor is surgested, based on the experience of already existing factlities. However, because of the high IFMIF beam density the applicability of conventional monitors is questionable.

\section{Detailed WES Listing:}

There is no other WBS Listings in this section of the WBS.

D. Costing Rationale:

The estimate is base on fully equipped commercial camera systems.

E. Detailed Costing:

2-D-camera systems for X-rays and infrared light (offer from German Industry 1995)

$$
150.000,-\mathrm{DM}
$$




\section{WBS 2.2.2.7 Test Cell Diagnostics for Test Cell I}

A. Summary Cost estimate:

\begin{tabular}{|c|c|c|c|c|c|}
\hline \multicolumn{3}{|c|}{ Off-IFMIF Site } & \multicolumn{3}{c|}{ On-site at IFMIF } \\
\hline Industry & Instit'al & & Industry & Instit'al & \\
\hline Mat'1Lab Engin'g & Engin'g & AFI Total & Mat'VLab Engin'g & Engin'g & AFI Total \\
\hline S3 & nc & $11 \quad 64$ & & & \\
\hline
\end{tabular}

Units: 1,000 ICF $(1,000$ ICF $=1.520,-$ DM)

\section{B. Description:}

At present beam diagnostics has not been specified in detail and also the responsibility (Test Cell, Li-Target or Accelerator Group?) is still not clarified. Nevertheless, a rough description will be given here.

Beam stability, beam profile, beam density and beam time structure are of outstanding importance both for the quality of the irradiation and for safety reasons. While for the imadiation of specimens a fast response is not really needed - to confirm the beam parameters from time to time should be sufficient for the bulk of irradiation experiments - the emergency shutdown system has to be very quick (see WBS 2.2.2.8).

Data collection, conversion and processing are considered to be in the Test Cell Technology Room. Consequently only the sensors has to considered here.

a) Beam diagnostics:

b) Test cell diagnostics: various fast response gamma radiation sensors

-24 thermocouples Type $\mathbf{K}$ (radiation resistant) hornogeneously distributed over the inner Test Cell surface, some liquid metal sensors (e.g. sensors sensitive to short circuit current to monitor liquid metal spill)

some low and high vacuum sensors

\section{Detailed WBS Listing:}

There are no other elements listed in this section. 2.2.2.7 is the lowest WBS level listed.

\section{Costing Rationale:}

Engineering deljverable (such as drawings, FE-calculations, specifications) required. The estimated eagineering cost is based on a $120,+$ DM or $78.90 \mathrm{ICF}$ hourly rate.

E. Detailed Costing (roughly estitmated):

a) 4 Gamma radiation sensors: $\quad 40.000 .-\mathrm{DM} \quad 26,000$ ICF

24 themocouples a 200,- DM including instalłation and testing

$$
24,000,-\mathrm{DM} \quad 16,000 \mathrm{ICF}
$$

4 liguid metal sensors including instalfation and testing

$$
\text { 16.000,- DM }
$$


WORKSHEET

\section{WBS 2.2.2.8 Emergency shutdown system for Test Cell I}

A. Summany Cost estimate:

\begin{tabular}{|c|c|c|c|c|c|}
\hline \multicolumn{3}{|c|}{ Off-IFMIF Site } & \multicolumn{3}{|c|}{ Os-site at IFMMF } \\
\hline Industry & Instit'al & & Industry & Instit'al & \\
\hline Mat'V/Lab Engin'g & Engin'g & AFI Total & Mat'l/Lab Engin's & Engin'g & AFI Total \\
\hline 40 & 72 & $22 \quad 134$ & & 72 & $14 \quad 86$ \\
\hline
\end{tabular}

Units: 1,000 ICF $(1,000$ ICF $=1.520,-\mathrm{DM})$

\section{B. Description:}

At present emergency shuidown systems has not been specified in detail and also the responsibility (Test Cell, Li-Target or Accelerator Group?) is stll not clariffed. Nevertheless, a rough description will be given bere.

Beam stability, beam profile, beam density and beam time structure are of outstanding importance both for the quality of the irradiation and for safety reasons. While for the irradiation of specimens a fast response is not realiy needed - to confirm the beam parameters from time to time should be sufficient for the bulk of irradiation experiments - the emergency shutdown system has to be very quick. The system include

a) Data collection from beam and Test Cell diagnostics

b) Real tirne data conversion and processing

c) Hard wired line to central control system.

C. Detailed WBS Listing:

There are no other elements listed in this section. 2.2.2.7 is the lowest WBS level listed.

D. Costing Rationale:

Engineering deliverable (such as drawings, FE-calculations, specifications) required.

The estimated engineering cost is based on a 120 ,- DM or 78.90 ICF hourly rate.

E. Detailed Costing:

a) Data collection:

Beam diagnostics data (e.g. various gamma irradiation monitors) and Test Cell diagnostics data ( -24 thermocouples at different positions on the Test Cell and Li-Target surfaces, a few liguid metal detectors, a few vacuum sensors) has to be recorded with high frequency of typically $5 \mathrm{~Hz}$.

b) Real time data conversion:

Conversion to industrial standard signals

The requirements very roughly specified in a) and b) can easily be fulfilled with e.g. Hewlett Packard VXIsystem.

$$
60.000,-D M
$$

39,500 ICF

Engineering costs: Detajled system specification, programming and testing.

$$
\text { 1t0.000.- DM }
$$


WORKSHEET

WBS 2.2.3.1 Assembly and Testing with Test Cell Techmology Rocm I

A. Summary Cost estimate:

\begin{tabular}{|c|c|c|c|c|c|}
\hline \multicolumn{3}{|c|}{ Off-IFMIF Site } & \multicolumn{3}{|c|}{ On-site at IFMIF } \\
\hline Industry & Instit'al & & Industry & Instit'al & \\
\hline Mat'l/Lab Engin'g & Engin's & AFI Total & Mat'l/Lab Engin'g & Engin's & AFI Total \\
\hline$n c$ & $n c$ & nc & nc & 77,9 & $16 \quad 93,9$ \\
\hline
\end{tabular}

Units: $1,000 \mathrm{ICF}(1,000 \mathrm{ICF}=1.520,-\mathrm{DM})$

\section{B. Description:}

Atl costs for the assembly and testing of subsystems are already included in the related WBS of the individual systems. However the experience with large accelerator facilities has shown that it is not sufficient to test all subsystems individually. It is necessary to show, that all individual systems can work at the same time and commanicate, if necessary, with each other. Realistic testing includes also, that for the licensing anthorities detailed listings has to be established which includes for any normal and ofnormal condition a save and proper response of the control systern.

The licensing authotity release commissioning only when all system functions works perfectly.

\section{Detailed WBS Listing:}

2.2.3.1: Assembly and testing of Test Cell and VTAs

2.2.3.1.1: Assembly

2.2.3.1.2: Testing

D. Costirig Rationale:

Engineering deliverable (such as specifications, listings, system programming and testing) required. The estimated engineering cost is based on a 120 ,- DM or 78.90 ICF hourly rate.

E. Detailed Costing:

2.2.3.1.1 Assembly:

Al] costs are considered to be inchuded in the individual WBS elements

\subsection{Testing:}

On-site Engineering estimate

$1500 \mathrm{hr}$.

118.400.- DM

$77,900 \mathrm{ICF}$ 
WORKSHEET

WBS 2.2.3.2

WBS 2.2.3.2 Cooling System for Test Cell I

A. Summary Cost Estimate: FOR ONE TEST CELL

\begin{tabular}{|c|c|c|c|c|c|}
\hline \multicolumn{3}{|c|}{ Off-IFMIF Site } & \multicolumn{3}{|c|}{ On-Site At IFMif } \\
\hline andustry & Instita & & Const Contractor & Instita & \\
\hline Mat'VLab Engin'g & Enging & AFI Total & Mat'VLab Engin'g & Engin's & AFI Total \\
\hline 154 & 99 & 253 & 107 & 79 & $35 \quad 221$ \\
\hline
\end{tabular}

Units: U.S. Dollars $(\$ 1,000), 1,000 \$=1,000 \mathrm{ICF}$

\section{B. Description:}

The Test Cell Cooling System is located in the Technology Room and consists of coolant flow pumps, valves, and a heat exchanger. The Test Cell Cooling System uses a circulating gas coolant to cool the Test Cell Heat Shield ats Liner. The Test Cell Liner is cooled along its interior edges and the Test Cell Heat shield is cooled along both of jts edges with this circulating gas coolant. The gas coolant will be maintained at a low pressure and is transported from the Technology Room to the Test Cell in ducts. Heat exchangers are used to remove heat from the gas coolant. Low pressure pumps are used to circulate the gas coolant.

\section{Detailed WBS Listing:}

There are no ather WBS Listings in this section of the WBS. The Test Cell Cooling System WBS 2.2.3.2, is the lowest WBS level listed.

\section{Costing Rationale:}

Fabrication methods, requirements, and procedures were evaluated for the fabrikation and installation of each major comporent of the Test Cell Cooling System. From these evaluations, fabrication and instaliation man-bour estimates were made based on the amount of welding, machining, metal preparation, and general labor reguired for fabrication and installation of these major components. The fabrication cost is based on a $\$ 67$ hourly rate.

Engineering deliverables (such as drawings, specifications, and calculations) required for the design of these components and the assembly of the Test Cell Cooling System were also evaluated. An engineering man-hour estimate was made based on these deliverables. The estimated engineering cost is based on a $\$ 98.50$ hourly rate.

\section{E. Detailed Costing:}

Engineering estimate for design of Test Cell Cooling System:
a. Four (4) E size drawings
$400 \mathrm{hr}$.
$\$ 39,400$
b. Stress calculations
$100 \mathrm{br}$.
\$ 9,850
c. Five Specifications
$500 \mathrm{hr}$
\$ 49,250

Engineering estimate for installation of Test Cel] Cooling System:
a. Ten (10) E size drawings
b. Stress calculations
c. Two Specifications

$\begin{array}{llr}500 \mathrm{hr} & & \$ 49,250 \\ 100 \mathrm{hr} . & \$ 9,850 \\ 200 \mathrm{hr} . & \$ 19,700\end{array}$

Labor estimate for fabrication of Test Cell Cooling System:
a. metal prep for coolant ducts
800 hr. $\$ 53,600$
b. welding $40 \mathrm{M} \mathrm{X} 12.7 \mathrm{~mm}$
$300 \mathrm{hr}$.
$\$ 20,100$ 
Labor estimate for Instatiation of Test Cell Cooling System:
a. Installation for coolant ducts
b. Instaliation for coolant flow pumps (2)
c. Installation for coolant heat exchangers (2)
d. Installation for coolant valves
e. Installation for Shielding material

$800 \mathrm{hr}$.

$200 \mathrm{hr}$.

$200 \mathrm{hr}$.

$200 \mathrm{hr}$.

$200 \mathrm{hr}$.
$\$ 33,600$

$\$ 13,400$

$\$ 13,400$

$\$ 13,400$

$\$ 13,400$

Materials estimate for fabrication of Test Cell Cooling System:
a. Coolant duets
b. Coolant Control Valve (8)
c. Coolant Heat Exchangers (3)
d. Coolant Flow Pumps (3)
e. Shielding material

$\$ 10,000$ 
WORKSHEET

WBS 2.2.3.3 Vacuum Pumping System for Test Cell I

A. Surnmary Cost estimate:

\begin{tabular}{|c|c|c|c|c|c|}
\hline \multicolumn{3}{|c|}{ Off-IFMIF Site } & \multicolumn{3}{|c|}{ On-site at IFMIF } \\
\hline Indostry & Instit'al & & Industry & Instit'al & \\
\hline Mat'1/Lab Engin'g & Engin'g & AFI Total & Mat'l/Lab Engin'g & Engin'g & AFI Total \\
\hline 89,3 & 8,2 & $20 \quad 117,5$ & 18,2 & 6,2 & $5 \quad 29,4$ \\
\hline
\end{tabular}

Units: $1,000 \mathrm{ICF}(1,000 \mathrm{JCF}=1.520 .-\mathrm{DM})$

\section{B. Description:}

In order to meet several safety and reliability requirements, the Test Cell will be evacuated before and during irradiation to a nominal pressure or $10^{\mathrm{L}} \mathrm{Pa}$. For maximum redundancy three vacuum pumps are foreseen (see attachment page 1+3)

\section{Detailed WBS Listing:}

There is no other listings in this section of the WBS. The Test cell vacuum pumping system WBS 2.2.3.3 is the lowest WBS listed.

\section{Costing Rationale:}

Engineering efforts, fabrication methods, requirements, and procedunes were evaluated for the feasibility, fabrication and assembly of each major component of the Test cell vacutan pumping System. From these evaluations, fabrication man-hour estimates were made. Engineering deliverable (such as drawings and system design) required for the design of these components, the assembly and testing are also evaluated.

The estimated enginesing cost is based on a 120 ,- DM or 78.90 ICF hourly rate.

\section{E. Detailed Costing:}

Engineering estimate:

a) design calculations based on detailed outgassing tates, layout of ducts:

$80 \mathrm{br}$

6.300 - DM

4,100 ICF

b) System specification

$80 \mathrm{hr}$

$$
\text { 6.300,- DM }
$$

$4,100 \mathrm{JCF}$

a) On-site system testing and commissioning

$120 \mathrm{hr}$

$$
9.500,-\mathrm{DM}
$$

$6,200 \mathrm{ICF}$

Labor estimate for fabrication and on-site assembly
a) 3 pumps (see attachment):
$36,700 \$$
36,700 ICF

b) Material for tubes, ducts, fittings, gas exhaust, shielding of pimps (low level tritium).

$$
80.000,-\mathrm{DM} \quad 52,600 \mathrm{ICF}
$$

c) On sìte installation/assembly

$350 \mathrm{hr} \quad 27.600 \mathrm{DM}$

$18,200 \mathrm{ICF}$ 
WORKSHEET

WBS 2.2.3.4 Argon Backfill System for Test Cell I

A. Summary Cost estimate:

\begin{tabular}{|c|c|c|c|c|c|}
\hline \multicolumn{3}{|c|}{ Off-IFMp Site } & \multicolumn{3}{|c|}{ On-site at IFMIF } \\
\hline Industry & Instit'al & & Infustry & Instit'al & \\
\hline Mat'lLab Engin's & Engin'g & AFI Total & Mat'1/Lab Ezgin'g & Engin'g & AFI Total \\
\hline 36 & 19 & 1166 & 13 & 6 & 423 \\
\hline
\end{tabular}

Units: 1,000 ICF $(1,000$ ICF $=1.520,-D M)$

\section{B. Description:}

After an irradiation campaign, for maintenance requirements, for the exchange of Test Assemblies, for inspections, and for off-normal conditions it is necessary to flood the evactated Test Cell with inert gas. Due to safety arguments it is foreseen to use Argon gas. The density of Argon is above that of normal air or nitrogen and therefore it does hardly escape into the Access Cell. Also in case of Lithisum spill Argon prevents the floor of the Test Cell from Oxygen or other gaseous molecules. Another advantage of Argon is that due to missing $\mathrm{H}_{2} \mathrm{O}$ molecules final vacuum pressure can be achieved in the shortest possible time. The Ar backfill system is located in the Technology room. From a technical standpoint of view it is very easy to flood the Test Cell within a few seconds with Argon. Therefore e.g. pressurized Argon bottles ( 50 Liter, 200 atm nominal pressure) might be used. The Test Cell can be flooded several times with one singe bottle.

However, to maintain a continuous flow of Argon to the Test Cell in case of accident or in case of a removed Test Cell cover, a bundle of about 6 bottles should be installed in the test Cell control room.

\section{Detailed WBS Listing:}

There is no other listings in this section of the WBS. The Test Argon backfill system WBS 2.2.3.4 is the lowest WBS lisțted.

\section{Costing Rationale:}

The estimated engineering cost is based on a $120,-$ DM or 78.90 ICF hourly rate.

\section{E. Detailed Costing:}

Engineering estimate:

a) Design calculations to estimate the Argon gas escape into the Access Cell in case of removed Test Cell cover, Argon release tests after installation for various conditions
$240 \mathrm{bs}$
$19.000,-D M$
$12,500 \mathrm{ICF}$

b) Design of remote handling and control, test after installation

$120 \mathrm{hr}$

9.500,-- DM

$6,300 \mathrm{ICF}$

a) On-site system testing and commissioning

$120 \mathrm{hr}$

$9.500,-\mathrm{DM}$

$6,200 \mathrm{lCF}$

Labor estimate for fabrication and on-site assembly

a) 6 Argon bottles, 6 remote controlled mixing valves, 12 remote controlled pressure ganges
b) Material for tubes, fittings, bottle holders
54.000.- DM
$35,500 \mathrm{ICF}$
20.000,- DM
13,200 ICF 
WORKSHEET

WBS 2.2.3.5 Diagnostic and Control for Test Cell I

A. Summary Cost estimate:

\begin{tabular}{|c|c|c|c|c|c|}
\hline \multicolumn{2}{|c|}{ Off-IFMF Sire } & \multicolumn{3}{c|}{ On-site at IFMIF } \\
\hline Industry & Instit'al & & Industry & Enstit'al & \\
\hline Mat'l/Lab Engin'g & Engin'g & AFI Total & Mat'1Lab Engin's & Engin' & AFI Total \\
\hline 63 & & 1375 & 31 & 62 & $19 \quad 112$ \\
\hline
\end{tabular}

Units: 1,000 ICF $(1,000$ ICF $=1.520,-D M)$

\section{B. Description:}

Before, during and after irradiation relevant paraneters from the Test CeIl and its supporting devices have to be monitored and controlled.

Therefore three $19^{n}$ Rack Cabinets ( $60 \mathrm{~cm}$ width $200 \mathrm{~cm}$ high) housing all instrumentation and control units are foreseen in the Test Cell Technology Room.

Rack t: $\quad-2$ control units for each of the three vacuum pumps, incl. power supply (6 units)

Rack 2: $\quad 3$ control units for the Test Cell cooling system, incl. power supply

- 1 instrumentation unit for the Test cell cooling system

- 1 control unit for the Argon backfill system

Rack 3: Hardware units: Data collection from beam and Test Cell diagnostics (the sensors are in the Test Cell and therefore part of WBS 2.2.2.8)

The rack includes controllers for all thermocouples, liquid metal leak detectors, vacuim sensors and gamma irradiation monitors (5 slots, width 19").

Firm and Software unit: This is the interface between the hardware/electronics and the central control computer and is able to manage the complete data acquisition and process control of the Test Cell. Is is suggested to use an industrial standardized VXI-systerr.

Such a system includes ease of use and programming, configuration flexibility and not very high costs. (2 slots, width 19").

\section{Detailed WBS Listing:}

There is no other listings in this section of the WBS. The Test Argon backfill system WBS 2.2 .3 .5 is the lowest WBS listed.

\section{Costing Rationale:}

The estimated engineering cost is based on a $120,-$ DM or 78.90 ICF hourly rate.

E. Detaiked Costing:

Enginering estimate:

System design, development and testing:

$1200 \mathrm{hr}$.

$94.700,-\mathrm{DM}$

$62,300 \mathrm{ICF}$

Labor estimate for installation and wining:

$600 \mathrm{hr} . \quad 47,300 .-\mathrm{DM} \quad 31,100 \mathrm{ICF}$

VXI hardware and software, eg. Hewlett Packard VXI Mainframe E149 I A C-size, incl. all controllers and interfaces, HP VEE software 
WBS 2.2.3.6

WORKSHEET

WBS 2,2.3.6 Subsystem Power for Test Cel I

A. Summary Cost estimate:

\begin{tabular}{|c|c|c|c|c|c|}
\hline \multicolumn{2}{|c|}{ Off-IFMIF Site } & \multicolumn{3}{c|}{ On-site at IFMIF } \\
\hline Indusery & Instit'al & & Industry & Instit'al & \\
\hline Mat'lLab Engin'g & Engin'g & AFI Total & Mat'ULab Engin'g & Engin' & AFI Total \\
\hline nc & 1 & 1 & 4 & nc & 1 \\
\hline
\end{tabular}

Units: 1,000 ICF $(1,000$ ICF $=1,520,-D M)$

B. Description;

Electric Power has to installed which is suitable to feed alt devices in the Test Cell Technology Room. Estimated Power:

a) Test Cell cooling system (inert gas pump)

b) Vacuum pumping system (3 turbomolecular pumps a $1.2 \mathrm{KW}$

c) Argon backfill system

d) VIT system

d) Rack 1:

$3 \mathrm{KW}$

e) Rack 2:

$3 \mathrm{KW}$

f) Rack 3:

$1 \mathrm{KW}$

C. Detailed WBS Listing:

There is no other listings in this section of the WBS. The Test Argon backfill system WBS 2.2.3.6 is the lowest WBS listed.

D. Costing Rationate:

The estimated engineering cost is based on a 120, DM or 78.90 ICF hourly rate.

E. Detailed Costing:

Engineering estimate:

Layout of electric power installation

to hr.

800,- DM

500 ICF

Labor estimate for plug inștallation and wiring*

40 hr.

3,200.- DM

2,100 ICF

Material (e.g. plugs, cables):, 
WORKSHEET

WBS 2.2.4.1 NaK Thermally Controlled High-Fhux Vertical Test Assembly (VTA-1 for Test Cell II)

A. Summary Cost Estimate;

\begin{tabular}{|c|c|c|c|c|c|}
\hline \multicolumn{3}{|c|}{ Off-IFMiF Site } & \multicolumn{3}{|c|}{ On-Site At IFMF } \\
\hline Incustry & Instita] & & Const. Contractor & Instit'al & \\
\hline Mat'WLat Engin'g & Engin'g & AFI Total & Mat'Vlab Engin' & Engin's & AFI Tota \\
\hline $248 \quad 35$ & 62 & 631104 & & & \\
\hline
\end{tabular}

Units: U.S. Dollars (\$1,000)

B. Description:

VTA-1-NaK for Test Cell II is identical to the VTA-1-NaK for Test Cell I (WBS 2.2.1.1).

C. Detailed WBS Listing:

There are no other WBS Listings in this section of the WBS. The NaK Thermally Controlled High-Flux Vertical Test Assembly (VTA-1), WBS 2.2.4.1, is the towest WBS level listed.

D. Costing Rationale:

The cost of fabrication is assumed to be the same as for the VTA-1 for Test Cell I. Engineering is estimated to be $10 \%$ as required to follow the fabrication process.

E. Detailed Costing:

See Worksheet for WBS 2.2.1.1 
WORKSHEET

WBS 2.2.4.2 Helium gas controlled High Flux Vertical Test Assembly for high temperatures (VTA1Helium for Test Cell II)

A. Summary Cost estimate:

\begin{tabular}{|c|c|c|c|c|c|c|}
\hline \multicolumn{3}{|c|}{ Off-IFMIF Site } & \multicolumn{4}{|c|}{ On-site at IFMIF } \\
\hline Industry & Instit'al & & Industry & Instit'al & & \\
\hline Mat'1/Lab Engin's & Engin's & Total & Mat'l/Lab Engin'g & Engin's & $\mathrm{AF}$ & Total \\
\hline $1,207 \quad 29$ & 6 & 1,490 & & 12 & 2 & 14 \\
\hline
\end{tabular}

Units: $1,000 \mathrm{ICF}(1 \mathrm{ICF}=1.52 \mathrm{DM}$ )

B. Description:

VTA-1-He for Test Cell II is identical to the VTA-1-He for Test Cell I (WBS 2.2.1.2).

C. Detailed WBS Listing:

There are no other WBS Listings in this section of the WBS. The He Thermally Controlled High-Flux Vertical Test Assembly (VTA-1), WBS 2.2.4.2, is the lowest WBS level listed.

\section{Costing Rationale:}

The cost of fabrication is assumed to be the same as for the VTA-1He for Test Cell I. Engineering is estimated to be $10 \%$ as required to follow the fabrication process.

E. Detailed Costing:

See Worksheet for WBS 2.2.1.2 
WORKSHEET

WBS 2.2.43 Helium gas controlled Medium fux Vertical Test Assembly for in situ Creep-Fatigue Tests (VTA 2-He Creep-Fatigue for Test Cell I)

\section{A. Summary Cost estimate}

\begin{tabular}{|c|c|c|c|c|c|c|c|}
\hline \multicolumn{4}{|c|}{ Off-IFMIE Site } & \multicolumn{4}{|c|}{ On-site at IFMIF } \\
\hline Industry & Instit'al & & & Industry & Instit'al & & \\
\hline Mat'VLab Engin'g & Engif'g & $\mathrm{AFI}$ & Total & Mat'V/Lab Engin'g & Engin'g & AFI & Total \\
\hline $695 \quad 10$ & 3 & 142 & 849 & & 12 & 2 & 14 \\
\hline
\end{tabular}

Units: $1,000 \mathrm{ICF}(1 \mathrm{ICF}=1,52 \mathrm{DM})$

B. Description:

The inert gas cooled (usually helium) medium tux Vertical Test Assembly for instrumented in-situ creep fatigue ; VTA 2 is identical to the the aseembly proposed for Test Cell I (WBS 2.2.1.3)

C. Detailed WBS Listing:

There are no other WBS Listings in this section of the WBS.

D. Costing Rationale:

The cost of fabrication is assumed to be the same as for the VTA-2 for Test Cell L Engineering is estimated to be $10 \%$ as required to follow the fabrication process.

\section{E. Detailed Costing:}

See Worksheet for WBS 2.2.1.3 
WORKSHEET

WBS 2.2.4.4 Helium gas controlled Medium flux Vertical Test Assembiy for Tritium Release tests on Ceramic Breeders (VTA 2-He Breders for Test Cell II)

A. Summary Cost estimate

\begin{tabular}{|c|c|c|c|c|c|c|c|}
\hline \multicolumn{4}{|c|}{ Off-IFMIF Site } & \multicolumn{4}{|c|}{ On-site at IFMIF } \\
\hline Industry & Instit'al & & & Industry & Instit'al & & \\
\hline Mat'1/Lab Engin'g & Engin'g & AFI & Total & Mat'l/Lab Engin'g & Engin'g & AFI & Tocal \\
\hline $640 \quad 16$ & 18 & 135 & 809 & & 15 & 3 & 18 \\
\hline
\end{tabular}

Units: $1,000 \mathrm{JCF}$ ( 1 ICF $=1.52 \mathrm{DM}$ )

\section{B. Description:}

The inert gas cooled (usually belium) medium flux Vertical Test Assembly for instrumented in-situ Tritium release tests on various ceramic breeder materials. (VTA 2) is identical to the the assembly proposed for Test Ceil I (WBS 2.2.1.4)

\section{Detailed WBS Listing:}

There are no other WBS Listings in this section of the WBS.

D. Costing Rationale:

The cost of fabrication is assumed to be the same as for the VTA-2 for Test Cell $I$. Engineering is estimated to be $10 \%$ as required to follow the fabrication process.

\section{E. Detaiked Costing:}

See Worksheet for WBS 2.2.1.4 
WBS 2.2.4.5 Vertical Irradtation Tube (10 VIT's) System for Test Cell II

A. Summary Cost Estimate:

\begin{tabular}{|c|c|c|c|c|c|c|c|}
\hline \multicolumn{4}{|c|}{ Off-IFMIF Site } & \multicolumn{4}{|c|}{ On-site at IFMIF } \\
\hline Industry & Instit'al & & & Industry & Instit'al & & \\
\hline Mat'ULab Engin'g & Engin's & AFI & Total & Mat'1/Lab Engin'g & Engin'g & AFI & Total \\
\hline $666 \quad 5$ & 110 & 78 & 859 & 105 & & 21 & 126 \\
\hline
\end{tabular}

B. Description:

The VIT system proposed for Test Cell II is identical to the the aseembly proposed for Test Cell I (WBS 2.2.1.5)

\section{Detailed WBS Listing:}

There are no other WBS Listings in this section of the WBS.

\section{Costing Rationale:}

The cost of fabrication is assumed to be the same as for the VTI system for Test Cell I. Engineering is estimated to be $10 \%$ as required to follow the fabrication process.

\section{E. Detailed Costing:}

See Worksheet for WBS 2.2.1.5 
WORKSHEET

WBS 2.2.4.6

WBS 2.2.4.6 Test Celi Shlelding Plug for Test Cell II

A. Summary Cost Estimate:

FOR TEST CELL II

\begin{tabular}{|c|c|c|c|c|c|}
\hline \multicolumn{3}{|c|}{ OfY-IFMIF Site } & \multicolumn{3}{|c|}{ On-Site At ifMIF } \\
\hline Endustry & 'Instit'al & & Const. Contractor & Instit'al & \\
\hline Mat'VLab Engin'g & Engin'g & AFC Tota! & Mar'lLab & Engin'g & AFI Total \\
\hline 9 & 2 & 13 & & & \\
\hline
\end{tabular}

Units: U.\$. Dollars ( 31,000$)$

\section{B. Description:}

The Test Cell Shielding Pług (SP) is identical to the the assembly proposed for Test Cel] I (WBS 2.2.1.6)

\section{Detailed WBS Listing:}

There are no other WBS Listings in this section of the WBS.

\section{Costing Rationale:}

The cost of fabrication is assumed to be the same as for the VTA-2 for Test Cell I. Engineering is estimated to be $10 \%$ as required to follow the fabrication process.

\section{E. Detailed Costing:}

See Worksheet for WBS 2.2.1.6 
WORKSHEET

WBS 2.2.6.7

\section{WBS 2.2.6.7 Infrastructure}

A. Summary Cost estimate:

\begin{tabular}{|c|c|c|c|c|c|}
\hline \multicolumn{3}{|c|}{ Off-IFMIF Site } & \multicolumn{3}{|c|}{ On-site at IFMIIF } \\
\hline Industry & Institt ${ }^{t}$ al & & Industry & Instit'al & \\
\hline Mat'1/Lab Engin'g & Engin's & AFI Total & Mat'VLab Engin'g & Engin's: & AFI Total \\
\hline nc & nc & nc & 658 & 99 & $151 \quad 908$ \\
\hline
\end{tabular}

Units: $1,000 \mathrm{ICF}(1,000 \mathrm{ICF}=1.520,-\mathrm{DM})$

\section{B. Description:}

Main infrastnecture installations include

- Electric power which is suitable to feed all devices in the Access Cell

- compressed air, inert gases, cables

- Lightning

- Support structures for Universal Robot System, Ceil Maintenance, Hydraulic Systems

- Storage for 5 VTAs

\section{Detailed WBS Listing:}

There is no other listings in this section of the WBS. The Infrastructure Installation WBS 2.2.9.7 is the lowest WBS listed.

\section{Costing Rarionale:}

Engineering deliverable (such as design, drawings, listings, system programming and extended testing) required. The estimated engineering cost is based on a 120,- DM or 78.90 ICF hourly rate.

\section{E. Detailed Costing:}

Because a more detailed cost estimate is pending (ENEA), the global cost estirnate from the FZK Hot Cell will be used as input.

Attention: the costs in this section are only roughly estimated

Engineering (global estimste $15 \%$ of Mar, fabr, install, and testing):

$$
\text { 150.000.- DM }
$$

Material, fabrication, installation and testing (PET):

$$
1.000 .000 .-\mathrm{DM}
$$


WORKSHEET

WBS 2.7.7 Assembly and Testing of Test Facility Control Room

A. Summary Cost estimate:

\begin{tabular}{|c|c|c|c|c|c|}
\hline \multicolumn{3}{|c|}{ Off-IFMIF Site } & \multicolumn{3}{|c|}{ On-site at IFMIIF } \\
\hline Industry & Instit'al & & Industry & Instit'al & \\
\hline Mat'VLab Engin'g & Engin'g & AFI Total & Mat'lLab Engin'g & Engin ${ }^{2} \mathrm{~s}$ & AFI Total \\
\hline nc & $\pi c$ & $\pi \mathrm{c}$ & nc & 62,3 & 1275 \\
\hline
\end{tabular}

Units: 1,000 ICF (1,000 ICF = 1.520,- DM)

\section{B. Description:}

All costs for the assembly and testing of subsystems are already included in the related WBS of the individual systems. However, it is necessary to show, that all individual systems car work at the same time and communicate, if necessary, with each other. Realistic testing includes also, that the supervising computer can handle all individual experiments as well as the status information from Accelerators, LiTarget and Test Cell. The supervising computer in the Test Cell Control Room can also be used as server for the front end computers of the individual experiments and should therefore be equipped with printers and data storage units.

\section{Detailed WBS Listing:}

There is no other listings in this section of the WBS. The Assembly and testing WBS 2.2.7.1 is the lowest WBS listed.

D. Costing Rationale:

Engineering deliverable (such as system programming and test) required. The estimated enginesing cost is based on a $120,-$ DM or 78.90 ICF hourly rate.

\section{E. Detailed Costing:}

Labor estimate for on-site engineering:

$1200 \mathrm{hr}$. 
WORKSHEET

WBS 2.27.2 Data Acquisition and Process Control for VTA-1-NaK

A. Summary Cost estimate:

\begin{tabular}{|c|c|c|c|c|c|}
\hline \multicolumn{3}{|c|}{ Off-IFMIF Site } & \multicolumn{3}{|c|}{ On-site at FMIIF } \\
\hline Endastry & Instit'al & & Indistry & Enstit'al & \\
\hline Mat'1/Lab En & Engin's & AFI Total & Mat'1/Lab Engin's & Engin't & AFI Total \\
\hline 43 & $\mathrm{BC}$ & 52 & $\mathrm{nc}$ & 36 & 44 \\
\hline
\end{tabular}

Units: 1,000 ICF $(1,000$ ICF $=1.520,-$ DM $)$

B. Description:

The NaK thermally controlled VTA-1-NaK is described in WBS 2.2.1.2.

For a proper control of the VTA-1-NaK with it's 3 individual test modnles one 19 " Cabinet $60 \mathrm{~cm}$ width $x 200 \mathrm{~cm}$ bigh) in the Test Facitity Control Room is sufficient. It includes 7 tnits (width $20 \mathrm{~cm}$ )

a) NaK loop for chamber 1 (Temp. T1):

- Power control unit for heater and cooler incl. flow controller

- Instrumentation unit (display for 6 thermocouples, 2 pressure sensors, 1 flowmeter)

b) $\mathrm{NaK}$ loop for chamber 2 (Temp. T2):

- Power control unit for heater and cooler incl. flow controlles

- Instrumentation unit (display for 6 themocouples, 2 pressure sensors, 1 flowmeter)

b) NaK loop for chamber 3 (Temp. T3):

- Power control unit for heater and cooler inci flow controller

- Instrumentation unit (display for 6 thermocouples, 2 pressure sensors, 1 flowmeter)

c) Data acquisition and process control unit (rack integrated PC)

C. Detailed WBS Listing:

There is no other listings in this section of the WBS. The Assembly and testing WBS 2.2.4.2 is the lowest wBS listed.

D. Costing Rationale;

Engineering deliverable (such as system definition, PC programning and test) required. The estimated engineering cost is based on a $120,-$ DM or 78.90 ICF boutly rate.

\section{E. Detailed Costing:}

Engineering estimate for system design, wiring scheme, installation, programming and test

$700 \mathrm{hr}$.

55.200,- DM

36,300 ICF

Labor estimate for fabrication, racking, cabling:

- 3 Power control units

$12.000 .-$

$7,900 \mathrm{ICF}$

- 3 Instrumentation units

$36.000,-$

23,700 ICF

- PC based data acquisition and control unit

18.000.-

$11,800 \mathrm{ECF}$ 
WORKSHEET

WBS 2.7.3 Data Acquisition and Process Control for VTA-I-Helinm

A. Summary Cost estimate:

\begin{tabular}{|c|c|c|c|c|c|}
\hline \multicolumn{3}{|c|}{ Off-IFMIF Site } & \multicolumn{3}{|c|}{ On-site at IFMIF } \\
\hline Industry & Instit' al & & Industry & Instit'al & \\
\hline Mat'lLab Engin'g & Engin's & AFI Total & Mat'1/Lab Engin'g & Engin's & AEI Total \\
\hline 105,3 & nc & $21 \quad 126$ & nc & 36,3 & $7 \quad 44$ \\
\hline
\end{tabular}

Units: 1,000 ICF $(1,000 \mathrm{ICF}=1.520,-\mathrm{DM})$

B. Description:

The Helium gas cooled VTA-1-helium is described in WBS 2.2.1.2 and WBS 2.2.4.2.

For a proper control of the VTA-1-Helium (wo 19" Cabinet $60 \mathrm{~cm}$ width $\times 200 \mathrm{~cm}$ high) in the Test Facility Control Room are sufficient.

19" Rack Cabinet 1

-Power control unit for heifum gas loop

- PID governors to control helium gas flow

- Instrumentation unit (display for 6 thermocouples, 2 pressure sensors, 1 flowneters)

19 " Rack cabinet 2:

- Display unit for all rig-temperatures (32 thermocouples)

- Display and control unit for 32 Ohmic heaters of the specimen capsules

- Data acquisition and process control unit (rack integrated PC)

C. Detailed WRS Listing:

There is no other listings in this section of the WBS. The Assembly and testing WBS 2.2.7.3 is the lowest WBS listed.

D. Costing Rationale:

Engineering deliverable (strch as system definition, PC programming and test) required. The estimated engineering cost is based on a $120,-\mathrm{DM}$ or $78.90 \mathrm{ICF}$ hourly rate.

\section{E. Detailed Costing:}

Engineering estimate for system design, wiring scheme, installation, programming and test $700 \mathrm{hr}$.

$$
55.200,-\mathrm{DM}
$$

$36,300 \mathrm{ICF}$

Labor estimate for fabrication, racking, cabling:

19" Rack 1 (identical with rack 3 in WBS 2.2.7.4) 105.00,- DM

$69,100 \mathrm{ICF}$

19" Rack 2 (estimated according to experience from FZK Dual Beam Facility)

$$
55.000 \text {,- }
$$


WORKSHEET

WBS 2.7.4 Data Acquisition and Process Control for In-situ Creep-Fatjgue Tests in the Medium Flux Region

A. Summary Cost estimate:

\begin{tabular}{|c|c|c|c|c|c|}
\hline \multicolumn{3}{|c|}{ Off-IFMIF Site } & \multicolumn{3}{|c|}{ On-site at IFMIF } \\
\hline Industry & Instit'al & & Industry & Instit ${ }^{3}$ al & \\
\hline Mat'1Lab_Engin ${ }^{\prime} g$ & Engin's & AFI Total & Mat'1/Lab Engin's & Engin's & AFI Total \\
\hline 262.9 & 31,2 & $59 \quad 353$ & nc & 62,3 & 1275 \\
\hline
\end{tabular}

Units: 1,000 ICF $(1,000$ ICF $=1.520,-$ DM $)$

B. Description:

The Helium gas cooled VTA-2-Helium for in-situ creep fatigue tests is described in WBS

2.2.1.3. It is foreseen to test 3 push-pull fatigue specimens simultaneously, each independent from the other.

For a proper control of the 3 individual creep-fatigue specimens three $19^{\text {n }}$ Cabinets $(60 \mathrm{~cm}$ width $\times 200 \mathrm{~cm}$ high) in the Test Facility Control Room will be sufficient.

The Helium-gas coolant loop is considered to be located in the Access Cell side by side with that one used for the High flux VTA-I-Helium. That is, one fraction of the signais from the Test Cell Control room goes to that Helium gas loop while the others will go directly to the VTA-2-Helium.

19" Rack Cabinet 1:

- 3 power packages, 3 driving units, 3 high level universal testing controd units

- 3 on-board PC processors for closed loop experiments

19" Rack cabinet 2:

- 3 extensiometer control units

- Data acquisition from 3 extensiometers, 3 load cells and 18 thermocouples:

64 channel Scanning $\mathrm{A} / \mathrm{D}$, one thermocouple measuring transducer. one $6^{1 / 2}$ Digital Multimeter

- one Process Computer (PC) with suitable I/O slots and software to control the complete VTA-2-Helium.

19" Rack cabinet 3:

- Power control unit for Helium gas loop

- 4 PID govemors to control helium gas flow inside the hollow specimens

- Instrumentation unit (display for 6 gas temperatures, 6 pressire sensors, 3 flowmeters)

C. Detailed WBS Listing:

There is no other listings in this section of the WBS. The Assembly and testing WBS 2.2.7.4 is the lowest WBS listed.

D. Costing Rationale:

Engineering deliverable (such as system definition, PC programming and test) required. The in* situ creep fatigue experiments in the IFMF medium flux position are with respect to the concept very sinilar to those ones of the FZK High Energy Dual Beam Facility. Therefore the cost estimate of the IFMIF VTA+2-Helizm will be based on the actual cost of the FZK High Energy Dual Beam Facility. 


\section{E. Detailed Costing:}

Engincering estimate for system design, programming and extended tests

800 hr.

94.700,- DM

$62,300 \mathrm{ICF}$

Enginering estimate for drawings, wiring scheme and installation

$400 \mathrm{hr}$.

\$7.400,- DM

$31.200 \mathrm{ICF}$

19" Rack Cabinet 1:

TOTAL:

$$
\text { 122.700,- DM }
$$

80,700 ICF

Because the IFMIF system is very similar to that one of the FZK Dual Facility, the IFMIF cost estimate will be based on the FZK system.

The complete power, driving and control units for one universal testing device was 38.930,- DM (Feb. 1995) which translates to 40.870,- DM.(May 1996). Consequently three units will cost $122.700,-\mathrm{DM}$.

The vendor was ZWICK GmbH \& Co, D-89079 Ulm, Germany

19" Rack Cabinet 2: ,

TOTAL:

$171.000-\mathrm{DM}$

113,100 ICF

Because the IFMIF system is very similar to that one of the FZK Dual Facility, the IFMIF cost estimate will be based on the FZK system.

The complete data acquisition and control units incl. al] software for one universal testing machine was 29.819.- DM (Feb. 1995) which translates to 31.300,- DM.(May 1996). Consequently three units will cost $\quad 93.900,-$ DM. $61,800 \mathrm{ICF}$

One suitable Process Computer incl. software (estimated)

$60.000,-D M$

$39,500 \mathrm{ICF}$

3 extentiometer control units (e.g. Company HOTTINGER) including special cables, all instruments certified 18.000, DM

$11,800 \mathrm{ICF}$

19" Rack Cabinet 3:

TOTAL:

$105,000,-\mathrm{DM}$

$69,100 \mathrm{ICF}$

Because the IFMIF system is very similar to that one of the FZK Dual Facility, the IFMIF cost estimate will be based on the FZK system.

The complete power control unit 70.000,- DM (1985) wtich translates approximately to $105.000,-$

DM (1996). 
WBS 2.2.7.5

WORKSHEET

WBS 2.2.75 Data Acquisition and Process Control for Tritium Release In-situ Tests in the Medium Flax Region

A. Surmariry Cost estimate:

\begin{tabular}{|c|c|c|c|c|c|}
\hline \multicolumn{3}{|c|}{ Off-IFMIF Site } & \multicolumn{3}{|c|}{ On-site at IFMIF } \\
\hline lndustry & Instit' al & & Industry & Instit'al & \\
\hline Mat'1/Lab Engin'g & Engin'g & AFI Total & Mat'1/Lab Engin'g & Engin's & AFI Total \\
\hline 270 & 30 & $60 \quad 360$ & $?$ & $?$ & $?$ \\
\hline
\end{tabular}

Units: $1,000 \mathrm{ICF}(1,000 \mathrm{ICF}=1.520,-\mathrm{DM})$

B. Description:

The system still needs to be described with respect to cost estinate (JAERI)

C. Detailed WBS Listing:

There is no other listings in this section of the WBS. The Assembly and testing WBS 2.2.7.5 is the lowest WBS listed.

D. Costing Rationale:

Engineering deliverable (such as system deffnition, PC programming and test) required.

E. Detailed Costing:

Due to the quite complex experimental set-up it is considered, that 2-3 19:" Rack Cabinets are necessary for the experimental control and data acquisition. Therefore, the overall costs are considered to be similar to that ones of the In-situ creep-fatigue tests.

Rough estimate

$300,000 \mathrm{ICF}$

This number has to be verified by JAERI 
WBS 2.2.5.1 Test Cell Removahle Cover for Test Cell II

A. Summary Cost Estimate:

FOR ONE TEST CELL

\begin{tabular}{|c|c|c|c|c|c|}
\hline \multicolumn{3}{|c|}{ Off-IFMIF Site } & \multicolumn{3}{|c|}{ On-Site At IFM而F } \\
\hline Industry & Instital & & Const. Contractor & Instit'al & \\
\hline Mat'VLab Engin' $g$ & Engin's & AFI Total & Mat'L/Lab Engin'g & Engin'g & AFi Total \\
\hline 1,045 & 18 & 2131,27 & & & \\
\hline
\end{tabular}

Units: 1,000 ICF (1 ICF $=1.52 \mathrm{DM})$

\section{B. Description:}

The Test Cell Removable Cover (TCRC) is identical to the the assembly proposed for Test Cell I (WBS 2.2.2.1)

C. Detailed WBS Listing:

There are no other WBS Listings in this section of the WBS.

\section{Costing Rationalee:}

The cost of fabrication is assumed to be the same as for the TCRC for Test Cell I. Engineering is estimated to be $10 \%$ as required to follow the fabrication process.

\section{E. Detailed Costing:}

See Worksheet for WBS 2.2.2.1 
WORKSHEET

WBS 2.2.5.2

WBS 2.2.5.2 Test Cell Liner for Test Cell II

A. Summary Cost Estimate:

FOR ONE TEST CELL

\begin{tabular}{|c|c|c|c|c|c|}
\hline \multicolumn{3}{|c|}{ Off-IFMIF Site } & \multicolumn{3}{|c|}{ On-Site At IFMIF } \\
\hline Indusery & Instit'al & & Const. Contractor & Instit'ai & \\
\hline Mat'VLab Engin' & Engin'g & AFi Total & Mat'1/Lab Engin' & Engin'g & AfIT Total \\
\hline 891 & 16 & 181,08 & 39 & & 12 \\
\hline
\end{tabular}

Units: U. S. Dollars (\$1,000)

B. Description:

The Test Cell Liner is identical to the the assembly proposed for Test Cell I (WBS 2.2.2.2)

C. Detailed WBS Listing:

There are no other WBS Listings in this section of the WBS.

D. Costing Rationalee:

The cost of fabrication is assumed to be the same as for the Test Cell Liner for Test Cell I. Engineering is estimated to be $10 \%$ as required to follow the fabrication process.

\section{E. Detailed Costing:}

See Worksheet for WBS 2.2.2.2 
A. Summary Cost Estimate:

FOR ONE TEST CELL

\begin{tabular}{|c|c|c|c|c|c|}
\hline \multicolumn{3}{|c|}{ Off-1FMIIF Site } & \multicolumn{3}{|c|}{ On-Site At lFMiliF } \\
\hline Gitutustry & Instit'al & & Const Contractor & Instit'al & \\
\hline Mat'VLab Engin' & Engin'g & AFíotal & Mar'VLáb Engin'g & Engin'g & AFI Tota \\
\hline 599 & 26 & 125749 & 79 & & $16 \quad 95$ \\
\hline
\end{tabular}

Units: U. $\mathbf{S}$. Dollars $(\$ 1,000)$

B. Description:

The Test Cell Heat Shield (TCHS) is identical to the the assembly proposed for Test Cell 1 (WBS 2.2.2.3)

C. Detailed WBS Listing:

There are no other WBS Listings in this section of the WBS.

D. Costing Rationalee:

The cost of fabrication is assumed to be the same as for the TCHS for Test Cell I. Engineering is estimated to be $10 \%$ as required to follow the fabrication process.

E. Detailed Costing:

See Worksheet for WBS 2.2 .2 .3 


\section{A. Summary Cost Estimate:}

FOR ONE TEST CELL

\begin{tabular}{|c|c|c|c|c|c|}
\hline \multicolumn{3}{|c|}{ Off-IFMIF Site } & \multicolumn{3}{|c|}{ On-Site At IFMIlF } \\
\hline Industry & instital & & Const. Contractor & Instit'al & \\
\hline Mat'VLab Engin'g & Engin'g & AFr Total & Mat'V/Lab Engin' & Engin ${ }^{+} g$ & AFI Total \\
\hline 309 & $\overline{3}$ & 62374 & & & \\
\hline
\end{tabular}

Units: U. S. Dollars $(\$ 1,000)$

\section{B. Description:}

The Test Cell seal systems are identical to those proposed for Test Cell I (WBS 2.2.2.4)

\section{Detailed WBS Listing:}

There are no other WBS Listings in this section of the WBS.

\section{Costing Rationatee:}

The cost of fabrication is assumed to be the same as for the Test Cell Seal Systems for Test Cell I. Engineering is estimated to be $10 \%$ as required to follow the fabrication process.

\section{E. Detailed Costing:}

See Worksheet for WBS 2.2.2.4 
WBS 2.2.5.5 Camera System for Test Cell II

\section{A. Summary Cost Estimate:}

FOR ONE TEST CELL

\begin{tabular}{|c|c|c|c|c|c|}
\hline \multicolumn{3}{|c|}{ Off-lFMIIF Site } & \multicolumn{3}{|c|}{ On-Site At IFMIF } \\
\hline Industry & Instit'al & & Const. Contractor & Instit'al & \\
\hline Mat'VLab Engin'g & Engin'g & AF Tota! & Mat'llah Enging & Engin'g & AFir Total \\
\hline 162 & 24 & 37223 & 84 & & TOI \\
\hline
\end{tabular}

Units: U. S. DolIars $(\$ 1,000)$

B. Description:

The Test Cell Camera System (TCCS) is identical to that proposed for Test Cell I (WBS 2.2.2.5)

\section{Detailed WBS Listing:}

There are no other WBS Listings in this section of the WBS.

D. Costing Rationalee:

The cost of fabrication is assumed to be the same as for the TCCS for Test Cell I. Engineering is estimated to be $10 \%$ as required to follow the fabrication process.

\section{E. Detailed Costing:}

Se Worksheet for WBS 2.2.2.5 


\section{WORKSHEET}

WBS 2.2.5.6 Neotron and Gamma Source Diagnostics for Test Cell II

\section{A. Summary Cost estimate:}

\begin{tabular}{|c|c|c|c|c|c|}
\hline \multicolumn{3}{|c|}{ Off-IFMIF Site } & \multicolumn{3}{|c|}{ On-site at IFMIF } \\
\hline Industry & Instit' a] & & Industry & Institt'al & \\
\hline Mat'VLab Engin'g & Engin's & AFI Total & Mat'VLab Engin'z & Engin' & AFI Total \\
\hline 99 & & $\begin{array}{ll}20 & 118,7\end{array}$ & & & \\
\hline
\end{tabular}

Units: 1,000 ICF $(1,000$ ICF $=1.520,-$ DM $)$

\section{B. Description:}

The Neutron and Ganma Source Diagnostics for Test Cell II are identical to those proposed for Test

Cell I (WBS 2.2.2.6)

\section{Detailed WBS Listing:}

There are no other WBS Listings in this section of the WBS.

D. Costing Rationalet:

The cost of fabrication is assumed to be the same as for the Diagnostics for Test Cell I. Engineeting is estimated to be $10 \%$ as required to follow the fabrication process.

E. Detailed Costing:

See Workshet for WBS 2.2 .2 .6 
A. Surmary Cost estimate:

\begin{tabular}{|c|c|c|c|c|c|}
\hline \multicolumn{3}{|c|}{ Off-IFMIF Site } & \multicolumn{3}{|c|}{ On-site at IFMIF } \\
\hline Industry & Instit'al & & Industry & Instit'al & \\
\hline Mat'1/Lab Engin'g & Engin'g & AFI Total & Mat'VLab Engin'g & Engin's & AFI Total \\
\hline 53 & nc & $11 \quad 64$ & & & \\
\hline
\end{tabular}

Units: 1,000 ICF $(1,000$ ICF $=1,520,-$ DM $)$

B. Description:

The Test Cell Diagnostics for Test Cell $\mathrm{I}$ are identical to those proposed for Test Cell I (WBS 2.2.2.7)

c. Detailed WBS Listing:

There are no other WBS Listings in this section of the WBS.

D. Costing Rationalee:

The cost of fabrication is assumed to be the same as for the Diagnostics for Test Cell I. Engineering is estimated to be $10 \%$ as required to follow the fabrication process.

\section{E. Detailed Costing:}

See Worksheet for WBS 2.2.2.7 


\section{WORKSHEET}

\section{WBS 2.2.5.8 Emergency shutdown system for Test Cell II}

A. Summary Cost estimate;

\begin{tabular}{|c|c|c|c|c|c|}
\hline \multicolumn{3}{|c|}{ Off-IFMIF Stte } & \multicolumn{3}{|c|}{ On-site at IFMIF } \\
\hline Industry & Instit'al & & Industry & Instit'al & \\
\hline Mat'1/ab Engin'g & Engin'g & AFI Total & Mat'1/Lab Engin'g & Engin's & AFI Total \\
\hline 40 & 7 & $9 \quad 57$ & & 7 & $2 \quad 9$ \\
\hline
\end{tabular}

Units: 1,000 ICF $(1,000 \mathrm{ICF}=1.520,-\mathrm{DM})$

B. Description:

The eraergency shutdown system for Test Cell II is identical to that proposed for Test Cell I (WBS

2.2.2.8)

\section{Detailed WBS Listing:}

There are no ather WBS Listings in this section of the WBS.

\section{Costing Rationalee:}

The cost of fabrication is assumed to be the same as for the emergency shutdown system for Test Cell I. Engineering is estimated to be $10 \%$ as required to follow the fabrication process.

\section{E. Detailed Costing:}

See Worksheet for WBS 2.2.2.8 
WORIKSHEET

WBS 2.2.6.1 Assembly and Testing with Test Celi Technology Room II

A. Summary Cost estimate:

\begin{tabular}{|c|c|c|c|c|c|}
\hline \multicolumn{3}{|c|}{ Off-IFMIF Sise } & \multicolumn{3}{|c|}{ On-site at IFMIF } \\
\hline Endustry & Inștit'al & & Industry & Instis'al & \\
\hline Mat'l/Lab Engin'g & Engin'g & AFI Total & Mat'l/Lab Engin'g & Engin'g & AFI Total \\
\hline nc & nc & nc & ne & 39 & $8 \quad 47$ \\
\hline
\end{tabular}

Units: 1,000 ICF $(1,000$ ICF $=1.520,-$ DM $)$

\section{B. Description:}

All costs for the assembly and testing of subsystems ane already included in the related WBS of the individual systems. However the experience with large accelerator facilities has shown that it is not sufficient to test all subsystems individually. If is necessary to show, that all individual systems can work at the same time and communicate, if necessary, with each other. Realistic testing includes also, that for the licensing authorities detailed listings has to be established which includes for any normal and ofnormal condition a save and proper response of the control system.

The licensing authority release commissioning only when alt system functions works perfectly.

\section{Detailed WBS Listing:}

\subsubsection{1: Assembly and testing of Test Cell and VTAs}

2.2.6.1.1: Assembly

2.2.6.1.2: Testing

D. Costing Rationalee:

Engineering deliverable (such as specifications, listings, system programming and testing) required. The estimated engineering cost is based on a $120,-\mathrm{DM}$ or $78.90 \mathrm{ICF}$ hourly rate. It is assumed that approximately half the Tech. Cell \#1 engineering effort will be requited to accomplish the assembly and testing of Tech. Cell $\# 2$.

\section{E. Detailed Costing:}

\subsection{Assembly:}

Alt costs are considered to be included in the individual wBS elements

\subsection{Testing:}

On-site Engineering estimate

$750 \mathrm{hr}$.

59200,- DM

38,950 ICF 
WORKSHEET

WBS 2.2.6.2

\section{WBS 2.2.6.2 Cooling System for Test Cell II}

A. Summary Cost Estimate:

FOR ONE TEST CELL

\begin{tabular}{|c|c|c|c|c|c|}
\hline \multicolumn{3}{|c|}{ Off-IFinil Site } & \multicolumn{3}{|c|}{ On-Site At IFIVIF } \\
\hline Intustry & Instit'al & & Const. Contractor & Instit'al & \\
\hline Mat'VLab Engin'g & Enging & AFT Total & Mat'/Lab Engin'g & Engin'g & AFI Total \\
\hline 154 & 10 & $33 \quad 197$ & 107 & 8 & $23 \quad 138$ \\
\hline
\end{tabular}

Units: U. $\$$. Dollars $(\$ 1,000), 1,000 \$=1,000 \mathrm{ICF}$

B. Description:

The Test Ceil Cooling System is identical to that proposed for Test Cell I (WBS 2.2.3.2)

C. Detailed WES Listing:

There are no other WBS Listings in this section of the WBS.

D. Costing Rationalee:

The cost of fabrication is assumed to be the same as for the emergency shutdown system for Test Cell I. Engineering is estimated to be $10 \%$ as required to follow the fabrication process.

E. Detailed Costing:

See Worksheet for WBS 2.2.3.2 


\section{WORKSHEET}

WhS 2.2.6.3 Vacuum Pumping System for Test Cell II

\section{A. Summary Cost estimate:}

\begin{tabular}{|c|c|c|c|c|c|}
\hline \multicolumn{3}{|c|}{ Off-IFMIF Site } & \multicolumn{3}{|c|}{ On-site at IFMLF } \\
\hline Industry & Instit' al & & Industry & Instit'al & \\
\hline Mat'1/Lab Engin'g & Engin's & AFI Total & Mat'l/Lab Engin'g & Engin's & AFI Total \\
\hline 89.3 & 1 & $\begin{array}{ll}18 & 108\end{array}$ & 2 & 1 & $0 \quad 3$ \\
\hline
\end{tabular}

Units: $1,000 \mathrm{ICF}(1,000 \mathrm{ICF}=1.520,-\mathrm{DM})$

B. Description:

The Vacuurn Pumping System for Test Cell Il is identical to that proposed for Test Cell I (WBS 2.2.3.3)

C. Detailed WBS Listing:

There are no other WBS Listings in this section of the WBS.

\section{Costing Rationale:}

The cost of fabrication is assumed to be the same as for the emergency shutdown system for Teșt Cell I. Engineering is estimated to be $10 \%$ as required to follow the fabrication process.

\section{E. Detailed Costing:}

See Worksheet for WBS 2.2.3.3 
WBS 2.2.6.4

WORKSHEET

WBS 2.2.6.4 Argon Backfill System for Test Cell II

A. Summary Cost estimate:

\begin{tabular}{|c|c|c|c|c|c|}
\hline \multicolumn{3}{|c|}{ Off-IFMIF Site } & \multicolumn{3}{|c|}{ On-site at IFMIF } \\
\hline Industry & Instit'al & & Industry & Instit'al & \\
\hline Mat'/Lab Engin'g & Engin'g & AFI Total & Mat'L/Lab Engin'g & Engin's & AFI Total \\
\hline 36 & 2 & 45 & 13 & 1 & 316 \\
\hline
\end{tabular}

Units: $1,000 \mathrm{ICF}(1,000 \mathrm{ICF}=1.520,-\mathrm{DM})$

B. Description:

The Argon Backftl System for Test Cell II is identical to that proposed for Test Cell I (WBS 2.2.3.4)

C. Detailed WBS Listing:

There are no other WBS Listings in this section of the WBS.

D. Costing Rationale:

The cost of fabrication is assumed to be the same as for the emergency shutdown system for Test Cell I. Engineering is estimated to be $10 \%$ as requised to follow the fabrication process.

E. Detailed Costing:

See Worksheet for WBS 2.2.3.4 
WORKSHEET

WBS 2.2.6.5 Diagnostic and Control System for Test Cen II

A. Sumrary Cost estimate:

\begin{tabular}{|c|c|c|c|c|c|}
\hline \multicolumn{3}{|c|}{ Off-IFMIF Site } & \multicolumn{3}{|c|}{ On-site at IFMIF } \\
\hline Industry & Enstir'al & & Industry & Instit'al & \\
\hline Mat'1/Lab Engin's & Engin's & AFI Total & Mat' $1 /$ ab Eagin'g & Engiats & AFI Total \\
\hline 63 & & 1375 & 31 & 6 & 45 \\
\hline
\end{tabular}

Units: $1,000 \mathrm{ICF}(1,000 \mathrm{ICF}=1.520,-\mathrm{DM})$

B. Description:

The Diagnestic and Control System for Test Cell II is identical to that proposed for Test Cell I (WBS 2.2.3.5)

C. Detailed WBS Listing:

There are no other WBS Listings in this section of the WBS.

D. Costing Rationale:

The cost of fabrication is assumed to be the same as for the entrenency shutdown system for Test Cell I. Engineering is estimated to be $10 \%$ as required to follow the fabrication process.

E. Detailed Costing:

See Worksheet for WBS 2.2.3.5 
WORKSHEET

WBS 2.2.6.6

WBS 2.2.6.6 Subsystem Power for Test Cell II

A. Summary Cost estimate:

\begin{tabular}{|c|c|c|c|c|c|}
\hline \multicolumn{3}{|c|}{ Off-IFMIF Site } & \multicolumn{3}{|c|}{ On-site at IFMIF } \\
\hline Industry & Instit'al & & Industry & Instit' al & \\
\hline Mac'1/Lab Engin'g & Engin's & AFI Total & Mat'V/Lab Engin'g & Engin's & AFI Total \\
\hline$n c$ & 0 & 0 & 4 & DC & 1 \\
\hline
\end{tabular}

Units: 1,000 ICF $(1,000 \mathrm{lCF}=1.520,-\mathrm{DM})$

B. Description;

The electric power distribution system for Test Cell II is identical to that proposed for Test Cell I (WBS 2.2.3.6)

\section{Detailed WBS Listing:}

There are no other WBS Listings in this section of the WBS.

D. Costing Rationale:

The cost of fabrication and installation is assumed to be the same as for for Test Cell I. Engincering is estimated to be $10 \%$ as required to follow the fabrication process.

E. Detailed Costing:

See Worksheet for WBS 2.2.3.6 
WORKSHEET

WBS 2.2.7.6 Data Acquivition and Process Control for VTT system

A. Summary Cost estimate:

\begin{tabular}{|c|c|c|c|c|c|}
\hline \multicolumn{3}{|c|}{ Off-IFMIF Site } & \multicolumn{3}{|c|}{ On-site at IFMIF } \\
\hline Industry & Instit'al & & Industry & Instit'al: & \\
\hline Mat'l/Lab Engin'g & Engin'g & AFI Total & Mat'l/Lab Engin't & Engin's & AFI Total \\
\hline 145 & 41 & 37223 & nc & 31.2 & $6 \quad 37$ \\
\hline
\end{tabular}

Units: 1,000 ICF $(1,000 \mathrm{ICF}=1.520,-\mathrm{DM})$

\section{B. Description:}

The VIT control system includes

- Temperature control and control of the instrumented specimen capsules

- The control units for the coolant flow pump (helium gas is recommended). This coolant flow pump is located together with a heat exchanger in the Access Cell (not in the Test Cell Technology Room) side by side with the coolant pumps for the high and medium flux VTAs.

- Control units for the loading/unloading station.

Two 19' Rack cabinets are considered to be sufficient for the complete VTT control

\section{Detailed WBS Listing:}

There is no other listings in this section of the WBS. The Assernbly and testing WBS 2.2.7.6 is the lowest WBS Iisted.

\section{Costing Rationale:}

Engineering deliverable (such as system definition, PC programming and test) required. The estimated engineering cost is based on a $120,-$ DM or 78.90 ICF houriy rate.

\section{E. Detgiled Costing:}

Engineering rough estimate for system design, programaning and tests

400 hr.

$47.400,-\mathrm{DM}$

$31,200 \mathrm{ICF}$

Engineering rough estimate for drawings, wiring scheme and installation

$400 \mathrm{hr}$.

47.400.- DM

$31,200 \mathrm{ICF}$

a) 19" Rack Cabinet 1:

Data acquisition and irradiation experiment control:

No detailed definition of the exact type of experiments will be given during the CDA.Phase. The

VTT system has a high flexibility for a broad parameter range. Therefore, the actual instrumentation can only be roughly estimated. According to the experience with existing facilities the costs for a typical Rack is estimated to 
b) 19" Rack Cabinet 2:

- Power control unit for Helium gas loop.

- PID governors to control imert gas coolant loop and the fraction of coolant for each row of specimens (low and very low flux regions)

- Instrumentation unit (display for gas temperatures, pressure sensors and flowmeters)

- control units for the loading/unloading station.

No detailed definition of the exact type of experiments will be given during the CDA-Phase.

According to the experience with inert gas coolant loops and loading/unloading stations in alteady existing facilities, the costs for a typical Rack is estimated to

$100,000,-D M$

$65,800 \mathrm{ICF}$

Labor estirnate for fabrication, racking, cabling:

- 3 Power control units

12.000.- DM

$7,900 \mathrm{ICF}$

- 3 Instrumentation units

36.000,- DM

23,700 ICF

- PC based data acquisition and control unit

$18.000,-\mathrm{DM}$

11,800 ICF 
WORKSHEST

WBS 2.27.7 Supervising Computer for Test Cell Control Room

A. Summary Cost estimate:

\begin{tabular}{|c|c|c|c|c|c|}
\hline \multicolumn{3}{|c|}{ Off-IFMIF Site } & \multicolumn{3}{|c|}{ On-site at IFMIF } \\
\hline Industry & Instit'al & & Industry & Instit'al & \\
\hline Mat'l/Lab Engin'g & Engin's & AFI Total & Mat'1/Lab Engin'g & Engin'g & AFI Total \\
\hline 46 & nc & $9 \quad 55$ & nc & 62,3 & 1275 \\
\hline
\end{tabular}

Units: 1,000 ICF $($ I,000 ICF = $1.520,-$ DM $)$

B. Description:

A supervising computer is required to coordinate, if necessary, all individual experiments as well as the status information from Accelerators, Li-Target and Test Cell. The supervising computer in the Test Cell Control Room can also be used as server for the front end computers of the individual experiments and should therefore be equipped with printers and data storage units.

C. Detailed WBS Listing:

There is no other listings in this section of the WBS. The Assembly and testing WBS 2.2.7.7 is the lowest WBS listed.

D. Costing Rationale:

Engineering deliverable (such as system programming and test) required. The estimated engineering cost is based on a 120 ,- DM or 78.90 ICF hourly rate.

\section{E. Detailed Costing:}

Estimate for on-site engineering (system integration, programming):

$1200 \mathrm{hr}$.

$94,700,-\mathrm{DM}$

$62,300 \mathrm{ICF}$

Suitable Real Time Multi User Computer (e.g. Workstation with UNLX-System) incl. Terminals, Software, storage and printer units.

Rough Estimate:

70.000,- DM

46,000 ICF 
WORKSHEET

WBS 2.7.8 Subsystem Power

A. Summary Cost estimate:

\begin{tabular}{|c|c|c|c|c|c|}
\hline \multicolumn{3}{|c|}{ Off-IFMIF Site } & \multicolumn{3}{c|}{ On-site at IFMIF } \\
\hline Industry & Instit'al & & Industry & Instit'al & \\
\hline Mat'VLab Engin'g & Engin'g & AFI Total & Mat'VLab Engin'g & Engin''g & AFI Total \\
\hline nc & 1 & 1 & 4 & nc & 1 \\
\hline
\end{tabular}

Units: $1,000 \mathrm{ICF}(1,000 \mathrm{ICF}=1,520,-\mathrm{DM})$

B. Description:

Electric Power has to be installed which is suitable to feed all devices in the Test Cell Control Room. Estitnated Power:
a) WBS 2.2 .4 .2
1 19" Cabinet
$3 \mathrm{KW}$
b) WBS 2.2 .4 .3
2 19" Cabinets
$5 \mathrm{KW}$
c) WBS 2.2 .4 .4
3 19" Cabinets
$7 \mathrm{KW}$
d) WBS 2.2.4.5
3 19" Cabinets
$7 \mathrm{KW}$
e) WBS 2.2 .4 .6
2 19" Cabinets
$5 \mathrm{KW}$
f) WBS 2.2 .4 .7
1 Computer incl. units
$1 \mathrm{KW}$

C. Detailed WBS Listing:

There is no other listings in this section of the WBS. The Test Argon backfill system WBS

2.2.4.8 is the lowest WBS listed.

D. Costing Rationale:

The estimated engineering cost is based on a 120,- DM or 78.90 ICF bourly rate.

E. Detailed Costing:

Engineering estimate:

Layout of electric power installation

$10 \mathrm{hr}$.

800,- DM

500 ICF

Labor estimate for plug installation and wiring:

40 hr.

$3,200-$ DM

2,100 ICF

Material (e.g. plugs, cables):, 


\section{WORKSHEET}

\section{WhS 2.2.8.1 Assembly and Testing of Access Cell}

A. Summary Cost estimate:

\begin{tabular}{|c|c|c|c|c|c|}
\hline \multicolumn{3}{|c|}{ Off-IFMIF Site } & \multicolumn{3}{|c|}{ On+site at IFMIF } \\
\hline Industry & Instit'at & & Industry & Instit'al & \\
\hline Mat'1/Lab Engin'g & Engin's & AFI Total & Mat'l/Lab Engin'g & Engin's & AFI Total \\
\hline nc & ne & nc & nc & 125 & $25 \quad 150$ \\
\hline
\end{tabular}

Units: 1,000 ICF $(1,000$ ICF $=1.520,-$ DM $)$

\section{B. Description:}

The Access Cell is located directly above the Test Cells and has in the present design an inner length of $21,00 \mathrm{~m}$ and a width of $8,00 \mathrm{~m}$. All costs for the assembly and testing of subsystems are already included in the related WBS of the individual systems. However the experience with large accelerator facilities has shown that it is not sufficient to test all subsystems individually. It is necessary to show, that all individual systems can work at the same time and communicate, if necessary, with each other. Realistic testing includes aiso, that the licensing authorities inspects on the basis of detailed listings all relevant maintenance operations nexessary for monnal and off-nomal operations.

While the all devices inside to Access Cell and also the Through Wall Windows are part of the Axcess Cell WBS, the conventional construction including shielding doors and the removable ceiling are considered to be part of the Conventional Facility.

It is thought, that the Access Cell does not need a Cell Liner.

\section{Detailed WBS Listing:}

2.2.8.1 Assembly and testing of Access Cell

2.2.8.1.t Assembly

2.2.8.1.2 Testing

D. Costing Rationale:

Engineering deliverable (such as listings, system programuning and extended testing) required. The estimated engineering cost is based on a $120,-$ DM or 78.90 ICF hourly rate.

\section{E. Detailed Costing:}

\subsection{Assembly:}

All costs (incl engineering ones) are considered to be included in the individual WBS elements.

\subsection{Testing:}

Engineering estimate for IFMIF On-site costs:

- Detailed definition of manipulation sequences for all remote handling operations

- Test on real devices under normal and simujated off-normal conditions

$2400 \mathrm{hr}$.

$189.400,-$ DM 
WBS 2.2 .82

\section{WORKSHEET}

WBS 2.2.8.2 Access Cell Structure

A. Summary Cost estimate:

\begin{tabular}{|c|c|c|c|c|c|}
\hline \multicolumn{3}{|c|}{ Off-IFMIF Site } & \multicolumn{3}{|c|}{ On-site at IFMIF } \\
\hline Industry & Instit'al & & Industry & Instit'al & \\
\hline Mat'1/Lab Engin'g & Engin'g & AFI Total & Mat'1/Lab Engin'g & Engin's & AFl Total \\
\hline nc & & $n c$ & 164 & 13 & $\begin{array}{ll}35 & 212 \\
\end{array}$ \\
\hline
\end{tabular}

Units: 1,000 ICF $(1,000$ ICF $=1.520,-$ DM $)$

\section{B. Description:}

The Access Cell is located directly above the Test Ceil. It houses all remote handling equipment necessary to handle the Vertical Test Assemblies, shield plugs, Test Cell renovable cover. All manipulator systems necessary for any maintenance in the Teșt Cell (including the Li-Target) under normal and off-normal conditions are part of the Access Cel].

In contrast to e.g. the Test Module Handling Cell and the Service cell no steel liner should be necessary in the Access Cell. The conventional constnetion including shielding doors and removable ceiling are part of the Conventional Facility.

\section{Detailed WBS Listing:}

\subsubsection{Access Cell Structure;}

2.2.8.2.1 Cell liner

2.2.8.2.3 Through wall windows

\section{Costing Rationale:}

Engineering efforts, fabrication methods, reguirements, and procedures were evaluated for the feasibility, fabrication and assembly of each major component of the Access Cell. From these evaluations, fabrication man hour estirnates were made by based on the amount of welding, machining metal preparation and general labor required for fabrication and assembly.

Engineering deliverable (stch as drawings, $\mathrm{FE}$-calculations, specifications) requited.

The estimated engineering cost is based on a $120,-$ DM or 78.90 ICF hourly rate.

The cost estimate is done according to the experience from the FZK Hot Cells (see note from $M$. Nagele, Head of FZK Hot Cells).

\section{E. Detailed Costing:}

\subsection{Cell tiner:}

In contrast to e.g. the Test Modnle Handling Cell and the Service Cell no steel liner is considered in the Access Cell. Is that true?

Therefore, this element of the WBS has no costs.

If a steel liner is considened to be necessary, the costs would be considerable fue to the large size of the Access Cell $(20 \mathrm{~m} \times 8 \mathrm{~m}$ ). In this case the costs are estimated assuming a liner 
thickness of $10 \mathrm{~mm}$, an inner surface of $650 \mathrm{~m}^{\mathrm{z}}$

- Materials estimate for On-site fabrication:

(650.000,- DM)

$-1300 \mathrm{~m}^{2}$ proved welds

(220.000,- DM)

-TOTAL

\subsection{Through Wall Windows:}

Such windows are necessary for the Telescopic manipulator systems. They alsa allow a much better visualization of the Access Cell interior as any remote controlled camera system. The globat estimate is based on existing lead windows in the FZK Cyclotron Facility.

Window thickness equivalent to $20 \mathrm{~cm}$ lead.

Window size $100 \mathrm{~cm} \times 100 \mathrm{~cm}$

Material, fabrication and assembling:

5 Through wall windows

Estgineering (layout and drawings):

$250 \mathrm{hr}$

19.500,-

$12,800 \mathrm{JCF}$ 
WORKSHEET

WBS 2.2.8.3 Universal Robot System

A. Summary Cost estimate:

\begin{tabular}{|c|c|c|c|c|c|}
\hline \multicolumn{3}{|c|}{ Off-IFMIF Site } & \multicolumn{3}{|c|}{ On-site at IFMIF } \\
\hline Industry & Instit'al & & Industry & Instit'al & \\
\hline Mat'1/Lab Engin'g & Engin'g & AFI Total & Mat'l/Lab Engin'g & Engin's & AFI Total \\
\hline 3,434 & nc & 4121 & nc & 395 & $79 \quad 474$ \\
\hline
\end{tabular}

Units: 1,000 ICF $(1,000$ ICF $=1.520,-$ DM)

\section{B. Description:}

The Universal Robot System is the main device in the Access Cell for

- coutine Vertical Test Assembly removal and reloading operations both in the Access Cell itself and in the Test Cell,

- removal and exact insertion of shield plugs and Removable test Cell Cover

- any power maintenance operation in the Access Cell and the Test Cells inclioding Maintenance on the $\mathrm{Li}$-target during normal and off-normal operations.

This Universal Robot System should be able

- to handle very heavy loads as lifting device

(tp to 50 tons if the Test Cell Cover has to be removed by this system),

- for precise positioning ( $1 \mathrm{~mm}$ ) of Test Assemblies, Shield plugs and Removable Cover

- to carry various multiple-purpose modular articulated robot systems for any remote handling manipufations. E.g. Modular Robot Systems like "TELEBOT-Walischmiller" allow unlimited rotation of all shafts up to $240 \mathrm{Kg}$.

- to allow remote vision manipulations.

Important features of the Universal Robot System include also positioning of loads in all three dimensions and the ability for virtual reality simulation (e.g. system KISMET-Walischmilier).

Two Universal Robot System are presently under discussion:

- The General handling Robot ROBERTINO (see adached figures)

- A Robot and Lifting Device from PET.

\section{Detailed WBS Listing:}

There is na other listings in this Section of the WBS. The Universal Robot System WBS 2.2.8.3. is the lowest WBS listed.

\section{Costing Rationale:}

Engineering deliverable (such as design improvement, drawings, listings, system programming and extended testing) required. The estimated engineering cost is based on a $120,-\mathrm{DM}$ or $78.90 \mathrm{ICF}$ hourly rate. 


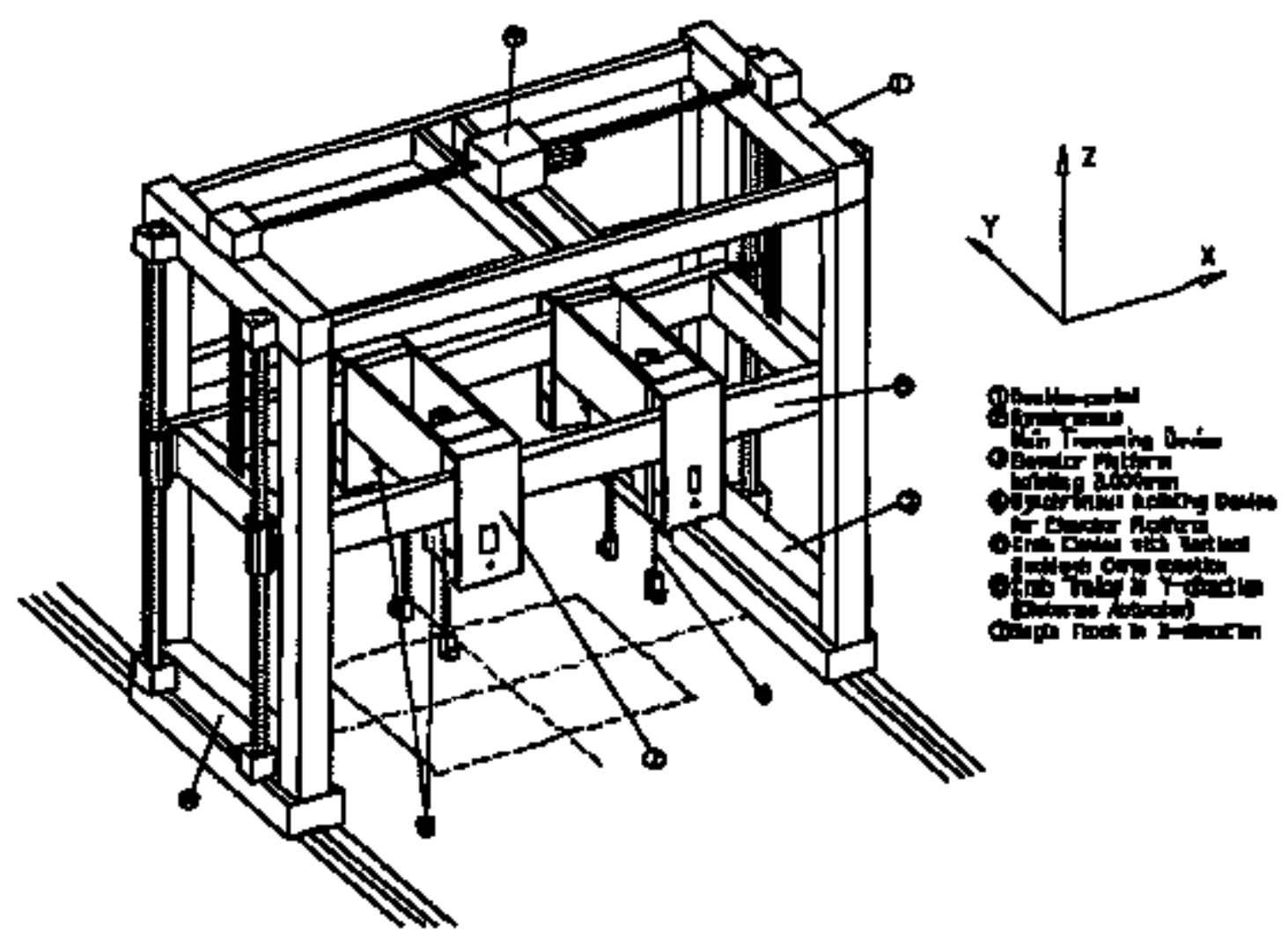

E. Detailed Costing:

Because costs of the ROBERT1O type System are pending (ENEA), the cost estimate of the quotation page 23 from PET (Darmstadt. Germany) is used.

Engineering (global estimate from PET):

$$
600,000,-D M
$$

395,000 ICF

Material, fabrication, installation and testing (PET):

a) Mainframe complete, wingspread $<10 \mathrm{~m}$, lifting $6 \mathrm{~m}$

$$
1.080 .000,-\mathrm{DM}
$$

711,000 ICF

b) Synchro drive for Mainframe (Y-direction):

$$
360.000,-\mathrm{DM}
$$

237,000 ICF

c) Lifting platform , 4-fold precision guide bearings in Z-direction:

d) Synchrodrive at two sides for lifting platform:

$$
540.000,- \text { DM }
$$

355,000 ICF

$780.000,-\mathrm{DM}$

513,000 ICF

e) 4 columnar liftings (Z-direction):

f) 2 drive units for 2 columnar liftings each

$$
110,000,-\mathrm{DM} \quad 72,000 \mathrm{ICF}
$$

$530.000,-\mathrm{DM}$

349,000 ICF

g) 2 drive units for loads in X-direction

$$
\text { 950.000.- DM 625,000,- ICF }
$$

h) $50 \mathrm{~m}$ rails (2 sides) for Universal Robot System

i) Electronics, control units, positioning.

$$
360.000-\mathrm{DM} \quad 237,000 \mathrm{ICF}
$$


WORKSHEET

WBS 2.2.8.4 Manipulator Systems

\begin{tabular}{|c|c|c|c|c|c|}
\hline \multicolumn{3}{|c|}{ Off-IFMIF Site } & \multicolumn{3}{|c|}{ On-site a TFMF } \\
\hline Industry & Institt"al & & Industry & Inștit'al & \\
\hline Mat'ULab Engin'g & Engin'g & AFI Total & Mat'/Lab Engin'g & Engin's & AFI Total \\
\hline 2.140 & nc & $428 \quad 2,568$ & \#C & 165 & $33 \quad 198$ \\
\hline
\end{tabular}

Units: 1,000 ICF $(1,000$ ICF $=1.520,-$ DM)

\section{B. Description:}

The Manipulator Systems are regarded to be necessary for all handling and maintenance purposes which cannot be done by the Universal Robot System. They also assist the Universal Robot System during removal and reloading operations in the Access Cell. The Manipulators should be also able to do maintenance in the Test Cell itself. In the present design

- 5 Power Master/Slave Manipulators are foreseen, integrated in the Access Cell Wall in connection with

Through Wall windows. Telescopic Manipulator based systems with electric indexing for handing loads up to $20 \mathrm{Kg}$ and reach up to $5 \mathrm{~m}$ are necessary

- 2 Mobile Service Robots for special nurpose Activities. They are necessary because due to the inner with of the Access Cell ( $8 \mathrm{~m})$ no: : work can be done by the Master/Slave manipalators.

\section{Detailed WBS Listing:}

\subsubsection{Manipulator Systems}

\subsection{Telescopic Master/Slave Manipulators}

\subsection{Service Robots}

D. Costing Rationale:

Engineering deliverable (such as design improvernent, drawings, listings, system programming and extended testing) required. The estimated engineering cost is based on a 120,- DM or 78.90 ICF hourly rate.

\section{E. Detailed Costing:}

Because a more detailed cost estimate is pending (ENEA), the global cost estimate from the FZK Hot Cell will be used as inpat.

Engineering (global estimate from PET):

2.2 .8 .4 .1

2.2.8.4.2

$$
\begin{aligned}
& 150.000,-\mathrm{DM} \\
& 100.000,-\mathrm{DM}
\end{aligned}
$$

99,000 ICF

$66.000 \mathrm{ICF}$

Material, fabrication, installation and testing (PET):

2.2.8.4.1 5 Complete Telescopic Master/Slave Manipulator Systems

$$
\text { 2.250.000,- DM }
$$

$1,480,000$ ICF

2.2.8.4.2 2 Mobile Service Robots 
WORKSHEET

WBS 2.2.8.5

WBS 23.8.5 Maintenance and Support Equfpment

A. Summary Cost Estimate:

\begin{tabular}{|c|c|c|c|c|c|}
\hline \multicolumn{3}{|c|}{ Off-IFMIF Site } & \multicolumn{3}{|c|}{ On-Site At LFWLF } \\
\hline Industry & Instital & & Const. Contractor & Enstit'ai & \\
\hline Mat'VLab Engin'g & Engin'g & AFI'Total & Mat'TLab Engin'g & Engin's & AFi Total \\
\hline 136 & 375 & 102613 & & 132 & 158 \\
\hline
\end{tabular}

Dnits: U. S. Dollars $(\$ 1, \infty 00)$

\section{B. Description:}

Test Cell Handling Fixtures are used in the removal and instaliation operations of VTA-1, VTA2, and the VIT Plug. Handling tixtures are also used in transporting the VTA's and the VIT Plug to the Service Cell. In addition, fixtures are also used in the Test Module removable and installation operations. These fixtures rook in conjunction with the remote handling equipment and are designed to perform a particular function. A list of these Fixtures, located in the Access Cell, is given below.

\begin{tabular}{|c|c|}
\hline Fixture Name & Fanction \\
\hline VTA-1 Lifting FIxtufe & Used in liting WTA-1 \\
\hline VTA-2 Lifuing Fixture & Used in lifting VTA-2 \\
\hline Vir Pług Lifting Fixtare & Used in lifting ViT Pug \\
\hline VTA-1 Gverting Fixture & Used in inverting VTA-1 \\
\hline VTA-2 Inverting Fixture & Used in invexting VTA-1 \\
\hline VTA-1 Transporting Fixzure & Used in transporting VTA-1 to Service Cell \\
\hline VTA-2 Transporting Fixture & Used in transporting VIA-] to Service Cel \\
\hline VIT Plug Transporting Fixture & Used in transporting VIT to Service Cell \\
\hline VTA-1 Mocule Cover Fixture & $\begin{array}{l}\text { Used to protect VTA-1 Modvile during } \\
\text { transport }\end{array}$ \\
\hline VTA-2 Module Cover Fixture & $\begin{array}{l}\text { Used to protect ViA-2 Modvie diring } \\
\text { transport }\end{array}$ \\
\hline VTA-1 Module Removal Fixture & Used in removing VTA-I Test Module \\
\hline VTA-2 Module Remova Fixture & Used in removing VTA-2Test Module \\
\hline VIA-1 Module Installation Fixture & Used in installing VTA- 1 rest Modtite \\
\hline VTA-2 Module Installation Fixture & Used in installing VTA-2 Test Module \\
\hline
\end{tabular}

\section{Detailed WBS Listing:}

There are no otter WBS Listings in this section of the WBS. The Test Cell SP WBS 2.2.8.5, is the lowest WBS level listed.

\section{Costing Rationale:}

Fabrication methods, requirements, and procedures were evaluated for the fabrication and assembly of each major component of the Test Cell SP. From these evaluations, fabrication man-hour estinates were made based on the amount of weliding. machining. metal preparation, and general labor requjred for fabrication and assembly of these major componerts and the Test Cell SP. The fabrication cost is based on a $\$ 67.00$ hourly rate.

Engineering deliverables (such as drawings, specifications, and calculations) required for the design of these conponents and the assembly of the Test CeIl SP were also evaluated. An engineering man-hour estimate was made based on these deliverables. The estimated engineering cost is based on a $\$ 98.50$ bourly rate. 


\section{E. Detailed Costing:}

1. Engineering estimate for design of VTA-1 Lffting Fixture:

a. three (3) $\mathrm{E}$ size drawings

$300 \mathrm{hr}$.

$\$ 29,550$

1. Labor estimate for fabrication of VTA-1 Lifting Fixtore:

a. metal prep 20 PC of carbon steel

b. welding $10 \mathrm{M} \times 12.7 \mathrm{~mm}$

c. machining for VTA-1 interface

$80 \mathrm{hr}$.

$70 \mathrm{br}$.

s 5,360

$50 \mathrm{hr}$.

$\$ 4,690$

$\$ 3,350$

1. Materials estimgate for fabrication of VTA-1 Lifting Fixture:

250 LB carbon steel (i) $0.60 / \mathrm{hb}$. $\$ 500$ misc.)

$\$ 650$

Total

$\$ 43,600$

2. The cost of the following fixtures will be assumed to be the same as VTA-l Lifling Fixture.

\begin{tabular}{|c|}
\hline ViA-2 Lifting Fixture \\
\hline VIT Flug Lifting Fixture \\
\hline VIA-1 Inverting Fixture \\
\hline VTA-2 Inverting Fixture \\
\hline VTA-1 Iransporting Fixture \\
\hline VTA-2 Iransporting Fixture \\
\hline VIT Plug Transporting Fixture \\
\hline
\end{tabular}

3. Engineering estimate for design of VTA-1 Module Cover Fixture:

a. two (2) E size drawings $200 \mathrm{hr}$.

$\$ 19,700$

3. Labor estimate for fabrication of VTA-1 Module Cover Fixhure:

a. metal prep $10 \mathrm{PC}$ of carbon steel

b. welding $5 \mathrm{M} \mathrm{X} 12.7 \mathrm{~mm}$

$40 \mathrm{hr}$.

c. machining for VTA-1 interface

$35 \mathrm{hr}$.

$30 \mathrm{br}$.

$\begin{array}{ll}\$ & 2,680 \\ \$ & 2,345 \\ \$ \quad 2,010\end{array}$

3. Materials estimate for fabrication of VTA-1 Module Cover Fixture:

$250 \mathrm{LB}$ carbon steel $90.60 / \mathrm{lb}$. $\$ 500 \mathrm{misc}$.)

$\$ 650$

4. The cost of the following fixtures will be assurned to be the same as the VTA-1 Module Cover Fixture:

\begin{tabular}{|c|}
\hline VTA-2 Module Cover Fixture \\
\hline VTA-1 Module Removal Fixture \\
\hline VTA-2 Module Removal Fixture \\
\hline VTA-1 Module Installation Fixture \\
\hline VTA-2 Module Installation Fixture \\
\hline
\end{tabular}


WORKSHEET

WBS $2.2,8.6$

WBS 2.2.8.6 Infrastructure

A. Summary Cost estimate:

\begin{tabular}{|c|c|c|c|c|c|}
\hline \multicolumn{3}{|c|}{ Off-IFMIF Site } & \multicolumn{3}{|c|}{ On-site at IFMIF } \\
\hline Industry & Instit'al & & Industry & Instit'al & \\
\hline Mat'l/Lab Engin'g & Engin'g & AFI Total & Mat'1/Lab Engin'g & Engin's & AFI Total \\
\hline nc & $n c$ & $\pi c$ & 526 & 79 & $121 \quad 726$ \\
\hline
\end{tabular}

Units: $1,000 \mathrm{ICF}(1,000 \mathrm{ICF}=1,520,-\mathrm{DM})$

\section{B. Description:}

Main infrastructure installations include

- Electric power which is suitable to feed all devices in the Access Cell

- compressed air, jnert gases, cables

- Lightming

- Support structures for Universal Robot System, Cell Maintenance, Hydraulic Systems,

C. Detailed WBS Listing:

There is no other listings in this section of the WBS. The Infrastructure Installation WBS 2.2.8.6 is the lowest WBS listed.

\section{Costing Rationale:}

Engineering deliverable (such as design improvement, drawings, listings, system programming and extended testing) required. The estimated engiveering cost is based on a $120,-\mathrm{DM}$ or $78.90 \mathrm{ICF}$ bourly rate.

\section{E. Detailed Costing:}

Because a more detailed cost estimate is pending (ENEA), the global cost estimate from the FZK Hot Cell will be used as input.

Engineering (global estimate from PET): $\quad 120,000,-$ DM $\quad 79,000$ ICF

Material, fabrication, installation and testing (PET) $800,000,-$ DM $\quad 526,000$ ICF 
WORKSHEET

WBS 2.2.9.1 Assembly and Testing of Service Cell

A. Summary Cost estimate:

\begin{tabular}{|c|c|c|c|c|c|}
\hline \multicolumn{3}{|c|}{ Off-IFMIF Site } & \multicolumn{3}{|c|}{ Qn-site at IFMIF } \\
\hline Industry & Enstit' al & & Industry & Instit'al & \\
\hline Mat'1/Lab Engin'g & Engin's & AFI Total & Mat'V/Lab Engis'x & Engin's & AFI Total \\
\hline nc & nc & nc & nc & 125 & $25 \quad 150$ \\
\hline
\end{tabular}

Units: 1,000 ICF $(1,000$ ICF $\approx 1.520,-$ DM $)$

\section{B. Description:}

The large Service Cell will be immediately connected to a Access Cell . All costs for the assembly and testing of subsystems are already included in the related WBS of the individual systens. However the experience with large acceletator facilities has shown that it is not sufficient to test all subsystems individually. It is necessary to stow, that all individual systems can work at the same time and communicate, if necessary, with each other. Realistic testing includes also, that the licensing authorities inspects on the basis of detajled listings all relevant maintenance operations necessary for normal and off-nortnal operations.

While all devices inside to Access Cell and also the Through Wall Windows are part of the Service Cell WBS, the conventional construction including shiejding doors and the removable ceiling are considered to be part of the Conventional Facility. The Service Cell will have a steel liner.

\section{Detailed WBS Listing:}

2.2.9.1 Assembly and testing of Access Cell

2.2.9.1.1 Assembly

2.2.9.1.2 Testing

D. Costing Rationale:

Engineering deliverable (such as listings, system programming and extended testing) required.

The estimated engineering cost is based on a 120 .- DM or 78.90 ICF hourly rate.

\section{E. Detailed Costing:}

2.2.9.1.1 Assembly:

Al costs (incl. engineering ones) are considered to be inciuded in the individual WBS elements.

\subsection{Testing:}

Engineering estimate for IFMIF On-site costs (similar to the Access Cell):

- Detailed deftrition of manipulation sequences for all remote handling operations

- Test on real devices under normal and simulated off-normal conditions

$2400 \mathrm{hr}$.

189.400,- DM

$124,600 \mathrm{ICF}$ 
WBS 2.2.9.2

WORKSFEET

WBS 2.2.9.2 Service Cell Structure

A. Summary Cost estimate:

\begin{tabular}{|c|c|c|c|c|c|}
\hline \multicolumn{2}{|c|}{ Off-IFMIF Site } & . & \multicolumn{3}{|c|}{ On-site at IFMIF } \\
\hline Industry & Enstit'al & & Industry & Instit'al & \\
\hline Mat'1/Lab Engin'y & Engin'g & AFI TotAl & Mat'l/Lab Engin'g & Engin's & AFI Total \\
\hline nc & ac & nc & 573 & 13 & 117 \\
\hline
\end{tabular}

Units: $1,000 \mathrm{ICF}(1,000 \mathrm{ICF}=1.520,-\mathrm{DM})$

\section{B. Description:}

The Service Cell is located directly near the Access Cell. It houses all remote handing equipment necessary to handle the Vertical Test Assemblies, Test Modules, Specimen Rigs and Li-Target components. All manipulator systems necessary for any maintenance in the Service Cell (including the Li-Target) under normal and off-normal conditions are part of the Service Cell.

In contrast to the Access Cell, the remote handling devices inside the Service Cell must be capable to completely strip down and reassemble all devices to be iradiated in the Test Cell. Also unexpected maintenance operations (e.g. welding, cutting) should be possible.

The Service Cell will have a steel liner. The conventional construction including shietding doors and removable ceiling are part of the Conventional Facility.

\section{Detailed WBS Listing:}

\subsubsection{Service Cell Structure:}

\subsection{Cell liner}

2.2.9.2.3 Througb wall windows

\section{Costing Rationale:}

Engireering efforts, fabrication methods, requirements, and procedures were evaluated for the feasibility, fabrication and assembly of each major component of the Access Cell. From these evaluations, fabrication man-hour estimates were made by based on the amount of welding, machining metal preparation and geneal labor required for fabrication and assembly.

Engintering deliverable (such as drawings, FE-calculations, speciffcations) required.

The estimated engineering cost is based on a $120,-$ DM or 78.90 ICF hourly rate.

The cost estimate is done according to the experience from the FZK Hot Cells (see note from M. Natgele, Head of FZK Hot Cells).

\section{E. Detailed Costing:}

\subsection{Cell liner:}

The costs are considerable due to the large size of the Service Cell (13.8m $\times 5.5 \mathrm{~m})$. The costs are estimated assuming a liner thickness of $10 \mathrm{~mm}$, an inner surface of $500 \mathrm{~m}^{2}$ :

- Materials estimate for On-site fabrication:

500.000,- DM

329,000 ICF

$-1000 \mathrm{~m}^{2}$ proved welds

170.000,- DM

L12,000 ICF

-TOTAL

$670.000,-\mathrm{DM}$

$441,000 \mathrm{ICF}$ 


\subsection{Through Wall Windows:}

Such windows are necessary for the Telescopic manipulator systems. They also allow a much better visualization of the Access Cell interior as any remote controlled cannera system. The global estimate is based on existing lead windows in the FZK Cyclotron Facility.

Window thickness equivalent to $20 \mathrm{~cm}$ lead.

Window size $100 \mathrm{~cm} \times 100 \mathrm{~cm}$

Material, fabrication and assembling:

4 Through wall windows

200.000 ,-

132,000 ICF

Engineering (layout and drawings);

$250 \mathrm{hr}$

$19.500 .-$

$12,800 \mathrm{ICF}$ 
WORKSHEET

WBS 2.2.9.3 Component Transfer Systems

A. Summary Cost estimate:

\begin{tabular}{|c|c|c|c|c|c|}
\hline \multicolumn{3}{|c|}{ Off-IFMAF Site } & \multicolumn{3}{|c|}{$\mathrm{O}_{\mathrm{T}-\mathrm{site}}$ at EFMIF } \\
\hline Industry & Instittal & & Industry & Enstit'al & \\
\hline Mat'1Lab Engin'g & Engin'g & AFI Total & Mat'l/Lab Engin't & Engin's & AFI Total \\
\hline nc & ne & rc & 198 & 26 & $45 \quad 269$ \\
\hline
\end{tabular}

Units: $1,000 \mathrm{ICF}(1,000 \mathrm{ICF}=1.520,-\mathrm{DM})$

\section{B. Description:}

In onder to transport hage devices from the Access Cell to the Service Cell, a suitable transport system is necessary. This system is capable to carry heavy (several tons) and long (4.5 meter) devices like complete VTAs. Before VTAs are transported, they have to be turned from a vertical position to a horizontal one. In order to guarantee a safe and quick transport, a rail $(8 \mathrm{~m})$ based chart is saggested. For the transport of the much smaller test modules (length $<1.5 \mathrm{~m}$ ) a transfer chart between the Service Cell and the Test Module Handling Cell is considered to be suffecient.

C. Detaiked WBS Listing:

\subsubsection{Component Transfer Systems}

2.2.9.3.1 Transfer Rail System

2.2.9.3.2 Transfer Chart

D. Costing Rationale:

Engineering deliverable (such as design, drawings, listings, testing) required. The estimated engineering cost is based on a $120,-$ DM or 78.90 ICF hourly rate.

\section{E. Detailed Costing:}

Aftention: the costs in this section ate only roughly estimated

2.2.9.3.1 Transfer Rail System:

Engineering: draft estimate for rails, chart system and remote drive

$300 \mathrm{Hr}$.

Material, fabrication and instaflation: draft estimate:

$$
200,000,-
$$

132,000 ICF

2.2.9.3.2 Transfer Chart:

Engineering: draft estimate for rails, chart system and remote dive

$200 \mathrm{Hr}$.

t5.800 DM

$10,400 \mathrm{ICF}$

Material, fabrication and installation: đraft estimate:

$$
100.000 \text {,- }
$$


WBS 2.2.9.4

WORKSHEET

WBS 2.2.9.4 Manipulator Systems

A. Summary Cost estimate:

\begin{tabular}{|c|c|c|c|c|c|}
\hline \multicolumn{3}{|c|}{ Off-IFMIF Site } & \multicolumn{3}{|c|}{ On-site at IFMIF } \\
\hline Industry & Instit"al & & Industry & Instit'al & \\
\hline Mat'VLab Engin's & Engin's & AFI Tocal & Mac'l/Lab Engin'g & Engin's & AFL Total \\
\hline 1546 & nc & $309 \quad 1855$ & ne & 224 & $45 \quad 269$ \\
\hline
\end{tabular}

Units: $1,000 \mathrm{ICF}(1,000 \mathrm{ICF}=1.520,-\mathrm{DM})$

\section{B. Description:}

The Manipulator Systems are regarded to be necessary for all handling and maintenance perposes. All manjpulator systens necessary for any maintenance in the Service Cell (including the LiTarget) under normal and off-normal conditions are part of the Service Cell. In contrast to the Access Cetl, the remote handling devices inside the Service Cell must be capable to completely strip down and reassemble all devices to be irradiated in the Test Cell. Also unexpected maintenance operations (e.g. welding, cutting) shoutd bo possible. The maripulators are fitted also with cutting and welding tools. In the present design

- 3 Power Master/Slave Manipulators are foreseen, integrated in the Access Cell Wall in connection with

Throngh Wall windows. Telescopic Manipulator based systems with electric indexing for handling loads (?) $20 \mathrm{Kg}$ ) and long reach (?) $5 \mathrm{~m}$ ) are necessary.

- 1 Mobjle Service Robots for special purpose Activities. It is also necessary because due to the inner with of the Service Cell not all work can be done by the Master/Slave manipulators.

- 1 Special purpose Manipulator to turn upside town the NaK cooled VTA-t in order to drain the liquid metal into sump tanks.

C. Detailed WBS Listing:

2.2.9.4 Manipulator Systems

2.2.9.4.1 Telescopic Master/Slave Maripulators

2.2.9.4.2 Service Robot

2.2.9.4.3 Special Purpose Manipulator

D. Costing Rationale:

Enginsering deliverable (such as design. drawings, listings, system prograrnming and extended testing) required. The estimated engineering cost is based on a $120, \cdot$ DM or 78.90 ICF hourly rate.

E. Detailed Costing:

Beciase a more detailed cost estimate is pending (ENEA), the global cost estimate from the FZK Hot Cell will be used as inpurt.

Engineering (global estimates from PET and FZP Hot Celts):

2.2.9.4.1

2.2.9.4.2

2.2.9.4.3
$120.000,-\mathrm{DM}$

$100.090,-\mathrm{DM}$

$120.000,-\mathrm{DM}$
$79,000 \mathrm{ICF}$

66.000 ICF

79,000 ICF

Material, fabrication, installation and testing (PET): 
2.2.9.4.I 3 Complete Telescopic Master/Slave Manipulator Systens

$$
\text { 1.350.000,- DM }
$$

888,000 ICF

2.2.9.4.2

1 Mobile Service Robots

$500.000,-\mathrm{DM}$

329,000 ICF

2.2.9.4.3 1 Special Purpose Robot

$500.000,-\mathrm{DM}$

$329,000 \mathrm{ICF}$ 
WBS 2.2.9.5

WORKSHEET

WBS 2.2.9.5 Bridge Crane

A. Summary Cost estimate:

\begin{tabular}{|c|c|c|c|c|c|}
\hline \multicolumn{3}{|c|}{ Off-IFMIF Site } & \multicolumn{3}{|c|}{ On-site at IFMIF } \\
\hline Inqustry & Instit'al & & Industry & Instit' a1 & \\
\hline Mat'l/Lab Engin'g & Engin'g & AFI Total & Mat'l/Lab Engin'g & Engin's & AFI Total \\
\hline$n c$ & nc & nc & 460 & 6,2 & 559 \\
\hline
\end{tabular}

Units: $1,000 \mathrm{ICF}(1,000 \mathrm{ICF}=1.520,-\mathrm{DM})$

B. Description:

The Bridge Crane in the Service Cell is necessary to lift

- VTAs and in exceptional cases Li-Target components from and onto the transfer rail system between the Service Cell and the Access Cell,

- test modules from and onto the transfer chart between Service cell and Access Cell

Because some VTAs have a weight of up to -11 tons, the bearing capacity should be sufficiently bigh.

For the specified purposes its not necessary to have a bigh precision positioning bridge crane.

C. Detziled WBS Listing:

There is no other listings in this section of WBS. The Bridge Crane WBS 2.2.9.5 is the lowest WBS listed.

D. Costing Rationale:

Engineering deliverabie (such as design, drawings, and testing) required. The estimated engineering cost is based on a $120,+$ DM or 78.90 ICF hourly rate.

E. Detailed Costing:

Because a more detailed cost estimate is pending (ENEA), the global cost estimate from the FZK Hot Cell will be used as input.

Engineering (estimates from FZK Hot Cells):

$120 \mathrm{hr}$.

$9.500,-\mathrm{DM}$

$6,200 \mathrm{ICF}$

Material, fabrication and instalation (estimate from existing Bridge Cranes in FZK Hot Cell)

Complete 15 tons Bridge Crane: $\quad 700000$, DM

$460,000 \mathrm{ICF}$ 
WORKSHAET

WBS 2.2 .9 .6

\section{WBS 2.9.6 Maintenance and Support Devices}

A. Summary Cost estimate:

\begin{tabular}{|c|c|c|c|c|c|}
\hline \multicolumn{3}{|c|}{ Off-FMIF Site } & \multicolumn{3}{|c|}{ On-site at IFMIF } \\
\hline Industry & Instit'al & & Industry & Instit'al & \\
\hline Mat'l/Lab Engin'g & Engin'g & AFI Total & Mat'1/Lab Engin'g & Engin'g & AFl Total \\
\hline ac & ne & nc & 660 & 132 & 158950 \\
\hline
\end{tabular}

Units: 1,000 ICF $(1,000$ ICF $=1,520,-$ DM)

B. Description:

Various Maintenance and Support systems are necessary like card receivers, tables, special purpose tools for check-out and repair operations as well as diagnostic tools (vacuum leakage detectors, electric signal detectors, positioners).

C. Detailed WES Listing:

There is no other listing $s$ in this section of the WBS. The Maintenance and Support Devices WBS 2.2.9.6 is the lowest WBS listed.

D. Costing Rationale:

Engineering deliverable (such as design improvement, drawings, listings, system programming and extended testing) required. The estimated engineering cost is based on a 120,- DM or 78.90 ICF hourly rate.

E. Detailed Costing:

Becarse a more detailed cost estimate is pending (ENEA), the global cost estimate from the FZK Hot Cell will be used as input.

Engineering (global estimate: $20 \%$ of the material, fabrication and inștalation costs):

$$
\text { 200.000,- DM }
$$

132,000 ICF

Material, fabrication and installation (FZK Hot Cell estimate):

$$
\text { 1.000.000,- DM }
$$


WBS 2.2.10.1

\section{WORKSHEET}

WBS 2.2.10.1 Assembly and Testing of Test Module Handling Cell

A. Summary Cost estimate:

\begin{tabular}{|c|c|c|c|c|c|}
\hline \multicolumn{3}{|c|}{ Off-IFMIF Site } & \multicolumn{3}{|c|}{ On-site at IFMIF } \\
\hline Industry & Instit ${ }^{\dagger}$ al & & Industry & Instit'al & \\
\hline Mat'1/Lab Engin'g & Engin'g & AFI Total & Mat'1/Lab Engin's & Engin's & AF Total \\
\hline ne & $n c$ & nc & nc & 78 & 16. \\
\hline
\end{tabular}

Units: $1,000 \mathrm{ICF}(1.000 \mathrm{ICF}=1.520,-\mathrm{DM})$

\section{B. Description:}

The Test Module Handling Cell will be immediately cornected to a Service Cell . All costs for the assembly and testing of subsystems are already included in the related WBS of the individual systems. However the experience with large accelerator facilities has shown that it is not sufficient to test all subsystems individually. It is necessary to show, that all individual systems can work at the same time and communicate, if necessary, with each other. Realistic testing includes also, that the licensing authorities inspects on the basis of detailed listings a]l relevant maintenance operations necessary for normal and off-normal operations.

While all devices inside to Test Module Handling Cell and also the Through Wall Windows are part of the Service Cell WBS, the conventional construction including shielding doors and the removable ceiling are considered to be part of the Conventional Facility. The Service Cell will have a sleel liner.

\section{Detailed WBS Listing:}

\subsubsection{Assernbly and testing of Test Module Handling Celt}

2.2.10.1.1 Assembly

2.2.10.1.2 Testing

D. Costing Rationale:

Engineering deliverable (such as listings, system programming and extended testing) required. The estimated engineering cost is based on a 120, DM or 78.90 ICF hourly rate.

E. Detailed Costing:

\subsection{Assembly:}

All costs (incl. engineering ones) are considered to be included in the individual WBS elements.

\subsection{Testing:}

Engineering estimate for IFMIF On-site costs (similar to the Access Ceil):

- Detailed definition of manipulation sequences for all remote handing operations

- Test on real devices under normal and simulated off-nomal conditions

$1500 \mathrm{hr}$.

118.000,- DM

77,900 ICF 
WBS 2.2 .10 .2

WORKSHEET

WBS 2.2.10.2 Test Module Handing Cell Structure

A. Summary Cost estimate:

\begin{tabular}{|c|c|c|c|c|c|}
\hline \multicolumn{3}{|c|}{ Off-IFMIF Site } & \multicolumn{3}{|c|}{ On-site ar IFMIIF } \\
\hline Industry & Lrstit al & & Industry & Instit'al & \\
\hline Mat'luab Encin'g & Engin'g & AFI Total & Mat'l/Lab Encin's & Engin'] & AFI Total \\
\hline 43 & nc & $9 \quad 52$ & 280 & 12,8 & $59 \quad 352$ \\
\hline
\end{tabular}

Units: 1,000 ICF $(1,000$ ICF $=1.520,-$ DM)

\section{B. Description:}

The Test Module Handling Cell is locafed directly near the Service Cell. The disassembly and reassembly of the test modules will be conducted in this cell. The packages containing the individual specimens will be removed from the test modules, and the packets will be cut open to retrieve the irradiated specimens in this Hot Cell. This cell will also be used for final assembiy of the specimen packets and rigs into the test module prior to irradiation. This Test Module Handling Cell houses all remote handling equipment necessary to handle the test modules, the rigs (in case of helium cooled test modules), the specinen capsules and its instramentation.

Tritium-containing specimens:

a) 1st option: Tritium Laboratory available: For tritium containing or tritium-contaminated materials, only disassembly of the test module will be cartied out in this Hot Cell and retrieval of the specimens by cutting the capsule will be done in the Tritium Laboratory.

b) 2nd option: No Tritium Laboratory on IFMTF site: Retrieval of the specimens by cutting the capsule will be done in this Test Module Handling Cell. If the specimens can be kept duing this procedure at ambient temperatures or slightly above, practically all tritium remains trapped inside the specimens (“frozen”), that is, uncontrolled escape of tritium ipto the environment can be practically excluded. Whether option 1 or 2 has to be used depends on the Tritium release rates allowed on IFMIF site.

This cell is equipped beside other devices with various welding and curting tools. The Test Module Handling Cell will have a steel liner. The conventional constrection including shielding doors and removable ceiling are part of the Conventional Facility.

C. Detailec WBS Listing:

2.2.10.2. Service Cell Structure:

2.2.10.2.1 Cell liner

2.2.10.2.2 Through wall windows

2.2.10.2.3 Tube Mailing system to PIE Hot Cells and Tritiun Laboratory

\section{Costing Rationale:}

Engineering efforts, fabrication methods, requirements, and procedures were evaluated for the feasibility, fabrication and assembly of each major component of the Test Module Handling Cell. From these evaluations, fabrication manthour estimates were made by based on the antunt of weiding, machining metal preparation and general labor required for fabrication and assembly.

Engineering deliverable (such as drawings, specificatjons, testing) required. 
The estimated engineering cost is based on a 120 ,- DM or $78.90 \mathrm{LCF}$ lourty rate.

The cost estimate is done according to the experience from the FZK Hot Cells (see rote from M. Nägele, Head of FZK Hot Cells).

\section{E. Detailed Costing:}

\subsection{Cell liner:}

The size of the Test Module bandling Cell is assumed to be $(5.5 \mathrm{~m} \times 5.5 \mathrm{~m}$ ). The costs are estimated assumiag a liner thickness of $10 \mathrm{~mm}$, an inner surface of $260 \mathrm{~m}^{2}$

- Materials estimate for On-site fabrication:

$$
\begin{array}{r}
260.000--D M \\
88.000 .-D M \\
348.000 \text { - DM }
\end{array}
$$$$
135,000 \mathrm{ICF}
$$$$
-520 \mathrm{~m}^{2} \text { proved weids }
$$

\subsection{Tlirough Wall Windows:}

Such windows are necessary for the Telescopic manipulator systems. They also allow a much better visualization of the test Module Handling Cell interior as any remote controlled camera system. The global estimate is based on existing lead windows in the FZK Cyclotson Facility. Window thicksess equivalent to $20 \mathrm{~cm}$ lead.

Window size $100 \mathrm{~cm} \times 100 \mathrm{~cm}$

Material, fabrication and assembling:

3 Through Wall Windows

Engineering (layout and drawings):

$250 \mathrm{hr}$
150.000.

$99,000 \mathrm{ICF}$

19.500,
$12,800 \mathrm{ICF}$

\subsection{Tube mailing system:}

Presently a tube mailing system to the PIE Hot Celis is not considered to be of primary importance because of the relatively low specimen yield. Therefore, no costs are given for this section of the WBS. Nevertheless a rough estimate will be given:

Engineering (layout and drawings)

$150 \mathrm{hr}$.

(11.800,- DM)

$(7,800 \mathrm{ICF})$

Material, fabrication and assembling (rough estimate)

$$
\text { (150.000,- DM) }
$$


WORKSHEET

WBS 22.10.3 Manipulator Systems

\begin{tabular}{|c|c|c|c|c|c|}
\hline \multicolumn{3}{|l|}{ sum } & \multirow{2}{*}{\multicolumn{3}{|c|}{ On-site at IFMIF }} \\
\hline Off-IF & MIF Site & & & & \\
\hline Endustry & Instit'al & & Industry & Instit"al & \\
\hline Mat'/Lab Engin'g & Engin's & AFI Total & Mat'//Lab Engin'? & Engin's & AFI Total \\
\hline 1,414 & $n c$ & $283 \quad 1,697$ & nc & 145 & 174 \\
\hline
\end{tabular}

Units: $1,000 \mathrm{ICF}(1,000 \mathrm{lCF}=1.520,-\mathrm{DM})$

\section{B. Description:}

The Manipulator Systems are regarded to be mecessary for all handling and maintenance pupposes. A more general short description of this Cell is given in WBS 2.2.7.2. Also unexpected maintenance operations should be possible. The manipulators are fitted among others with cutting and wejding tools. In the present design

- 3 Telescopic Master/Slave Manipulators are foreseen, integrated in the Access Cell Wall in connection with Through Wall windows. Telescopic Manipulator based systems with electric indexing for handling loads $(<20 \mathrm{Kg})$ and long reach $(<5 \mathrm{~m})$ are necessary.

- 4 Modular Robot Systems for disassembly and assembly and check the rigs, specimen packages and test modules. It is foreseen to use multiple purpose modular acticulated robot systems with handling loads of $\angle 240 \mathrm{Kg}$ (E.g. TELBOT-Systems from Walischmilier, Germany).

\section{Detailed WBS Listing:}

\subsubsection{Manipulator Systems}

\subsection{Telescopic Master/Slave Manipulators}

\subsection{Modular Robot Systems}

\section{Costing Rationale:}

Engineering deliverable (such as design, drawings, listings, system programming and extended testing) required.

The estimated engineering cost is based on a $120,-\mathrm{DM}$ or $78.90 \mathrm{ICF}$ hourly mate.

\section{E. Detailed Costing:}

Because a more detailed cost estimate is pending (ENEA), the global cost estimate from the FZK Hot Cell will be used as input.

Engineering (global estimates from FZK Hot Cells):
2.2.10.3.1
$120.000,-\mathrm{DM}$
$79,000 \mathrm{ICF}$
2.2.10.3.2
$100 .(00),-D M$
$66,0001 \mathrm{CF}$

Material, fabrication, installation and testing (global estimate from FZK Hot Cell):

2.2.10.3.1 3 Complete Telescopic Master/Slave Manipulator Systems

2,2.10.3.2 4 Modular Robot Systems

1.350.000.- DM

888,000 ICF

$$
800.000,- \text { DM } 526,000 \text { ICF }
$$


WORKSHEET

WBS 2.2.10.4

\section{WBS 2.2.10.4 Bridge Crane}

A. Summary Cost estimate:

\begin{tabular}{|c|c|c|c|c|c|}
\hline \multicolumn{3}{|c|}{ Off-IFMIIF Site } & \multicolumn{3}{|c|}{ On-site at IFMIF } \\
\hline Industry & Insțtit'al & & Industry & Instit'al & \\
\hline Mat'//Lab Engin'g & Engin'g & AFI Total & Mat'1/Lab Engin's & Engin'? & Total \\
\hline nc & nc & $n c$ & 197 & 6,2 & 244 \\
\hline
\end{tabular}

Units: $1,000 \mathrm{ICF}(1,000 \mathrm{ICF}=1.520,-\mathrm{DM})$

B. Description:

The Bridge Crane in the Test Module Handling Cell is necessary to lift test modules, rigs and other disassembled irradiation devices during maintenance and handling operations. It will be also used to bring complete test modules from and onto the transfer chart between Test Module Handling Cell and Service Cell.

\section{Detailed WBS Listing:}

There is no other listings in this section of WBS. The Bridge Crane WBS 2.2.10.4 is the lowest WBS listed.

D. Costing Rationgle:

Engineering deliverable (such as design, drawings, and testing) required. The estimated engineering cost is based on a $120,-$ DM or 78.90 ICF hourly rate.

\section{E. Detailed Costing:}

Because a more detailed cost estimate is pending (ENEA), the global cost estimate from the FZK Hot Cell will be used as input.

Engineering (estimales from FZK Hot Cells):

$120 \mathrm{hr}$.

$9.500,-\mathrm{DM}$

6,200 ICF

Material, fabrication and instaltation (estimate from existing Bridge Cranes in FZK Hot Cell) Complete 5 tons Bzidge Crane: $\quad 300.000,-$ DM

197,000 ICF 
WORKSHEET

WBS 2.2 .10 .5

WBS 2.2.10.5 Maintenance and Stipport Devices

A. Summary Cost estimate:

\begin{tabular}{|c|c|c|c|c|c|}
\hline \multicolumn{3}{|c|}{ Off-IFMIF Site } & \multicolumn{3}{c|}{ On-site at IFMIF } \\
\hline Industry & Instit'al & & Industry & 'nstit'al & \\
\hline Mat'L/Lab Engin'g & Engin'g & AFI Total & Mat'l/Lab Engin'g & Engin'a & AFI Total \\
\hline ne & nc & nc & 197 & 79 & 55 \\
\hline
\end{tabular}

Units: 1,000 ICF $(1,000$ ICF $=1.520,-$ DM $)$

\section{B. Description:}

Various Maintenance and Support systems are necessary like card receivers, tables, special purpose tools for check-aut and repair operations as well as diagnostic tools (vacuum leakage detectors, electric signal detectors, positioners).

\section{Detailed WBS Listing:}

There is no other listing $s$ in this section of the WBS. The Maintenance and Support Devices WBS 2.2.10.5 is the lowest WBS listed.

\section{Costing Rationale:}

Engineering deliverable (such as design inprovement, drawings, listings, system programming and extended testing) required. The estimated engineering cost is based on a $120,-$ DM or 78.90 ICF hourly rate.

\section{E. Detailed Costing:}

Because a more detailed cost estimate is pending (ENEA), the global cost estimate from the FZK Hot Cell will be used as input.

Engineering (global estimate: $20 \%$ of the material, fabrication and installation costs):

$$
\text { 120.000,- DM }
$$

79,000 ICF

Matertal, fabrication and installation (FZK Hot Cell estimate):

$$
\text { 300.000,- DM }
$$


WORKSHEET

WBS 2.2.10.6 Infrastructure

A. Summary Cost estimate:

\begin{tabular}{|c|c|c|c|c|c|}
\hline \multicolumn{3}{|c|}{ Off-IFMIF Site } & \multicolumn{3}{|c|}{ OF-site at IFMIF } \\
\hline Industry & Instit'al & & Industry & Instit'al & \\
\hline Mat'/Lab Engin'g & Engin'g & AFI Total & Mat'1/Lab Enqin'g & Engin'g & Total \\
\hline nc & $\mathbf{n c}$ & nc & 164,5 & 24,7 & $\begin{array}{ll}38 & 226\end{array}$ \\
\hline
\end{tabular}

Units: $1,000 \mathrm{ICF}(1,000 \mathrm{ICF}=1.520,-\mathrm{DM})$

\section{B. Description:}

Main infrastructure installations include

- Electric power which is suitoble to feed all devices in the Access Cell

- compressed air, inert gases, cables

- Lightring

- Support structures for Robot Systems, Cell Maintenance, Hydraulic Systems

\section{Detailed WBS Listing:}

There is no other listings in this section of the WBS. The Infrastructure Installation WBS 2.2.10.6 is the lowest WBS listed.

\section{Costing Rationale:}

Engineering deliverable (such as design, drawings, listings, system programming and extended testing) required. The estimated engineering cost is based on a $120,-\mathrm{DM}$ or $78.90 \mathrm{ICF}$ hourly rate.

\section{E. Detailed Costing:}

Because a more detailed cost estimate is pending (ENEA), the global cost estimate from the FZK Hot Cell will be tssed as input.

\section{Attention: the costs in this section are only roughly estimated}

Engineering (global estimate $15 \%$ of Mat'l, fabr., install., and testing):

$$
37.500,- \text { DM }
$$

Material, fabrication, installation and testing:

$$
250.000,-\mathrm{DM}
$$


WORKSHEET

WBS 2.2.11.1 Assembly and Testing of PIE Hot Cell

A. Suramary Cost estimate:

\begin{tabular}{|c|c|c|c|c|c|}
\hline \multicolumn{3}{|c|}{ Off-IFMIF Site } & \multicolumn{3}{|c|}{ On-site af IFMIF } \\
\hline Industry & Instit'al & & Industry & Inștit'al & \\
\hline Mat'1/Lab Engin ${ }^{\prime} \mathrm{g}$ & Engin ${ }^{*} \mathrm{~s}$ & AFI Total & Mat'L/Lab Engin'g & Engin's & AFI Total \\
\hline nc & nc & nc & nc & 103 & $21 \quad 124$ \\
\hline
\end{tabular}

Units: 1,000 ICF $(1,000$ ICF $=1.520,-$ DM $)$

\section{B. Description:}

In contrast to a former concept discussed in the first half of the CDA-Phase, a Hot Cell Design is now favored which has only one large Hot Cell instead of varioes independent small ones. That is, all mechanical test devices are within one common Cell. One of the main argaments for one single Hot Cell is a significant coșt reduction with respect to installation and ventilation.

The present design is modular with respect to the size of all remote handling stations and with respect to maintenance procedures.

Beciuse Conventional Hot Cells are operated in a variety of associations all with long term experience, the bulk of all IFMIF Hot Cell assembly and testing procectures is already well known.

\section{Detaìled WBS Lișting:}

2.2.11.1 Assembly and testing of Test Module Handling Cell

2.2.11.1.1 Assembly

2.2.11.1.2 Testing

D. Costing Rationale:

Engineering deliverable (such as listings, system programming and extended testing) required. The estimated engineering cost is based on a $120,-$ DM or $78.90 \mathrm{ICF}$ hourty rate.

E. Detaiked Costing:

No relevant cost uncertainties are expected. Nevertheless, the global cost estimate given below has to evaluated in more detail.

\subsection{Assembly:}

All costs (incl. engineering ones) are considered to be included in the individual WBS elements.

2.2.11.1.2 Testing (including support for commissioning):

Engineering estimate for IFMHF On-site costs:

2000 br.

157.800,- DM

103,000 ICF 
WORKSHEET

WBS 2.2.112 PIE Hot Cell Structure

A. Summary Cost estimate:

\begin{tabular}{|c|c|c|c|c|c|}
\hline \multicolumn{3}{|c|}{ Off-IFMIF Site } & \multicolumn{3}{|c|}{ On-site at IFMIF } \\
\hline Induistry & Institt al & & Industry & Instit'al & \\
\hline Mat'ULab Engin'g & Engin's & AFI Total & Mat'l/Lab Eggin'g & Engin's & AFI Total \\
\hline nc & $\mathrm{nc}$ & $\pi c$ & 1.868 & 164 & $406 \quad 2,438$ \\
\hline
\end{tabular}

Units: 1,000 ICF $(1,000$ ICF $=1.520,-$ DM $)$

B. Description:

The Test Module Handling Cell is an individual, stand alone Hot Cell mainly dedicated to mecharical testing of postimadiated specimens. It consists of the main Hot Cell structure which houses all mechanical testing devices including instrumentation, and an affiliated access cell. If any maintenance or change of a specific test devee is necessary, it will be lifted in the PIE Hot Cell onto a transfer rail system and brought into the Access Cell. In the PIE access cell personal may enter to accomplish maintenance or fitting activities.

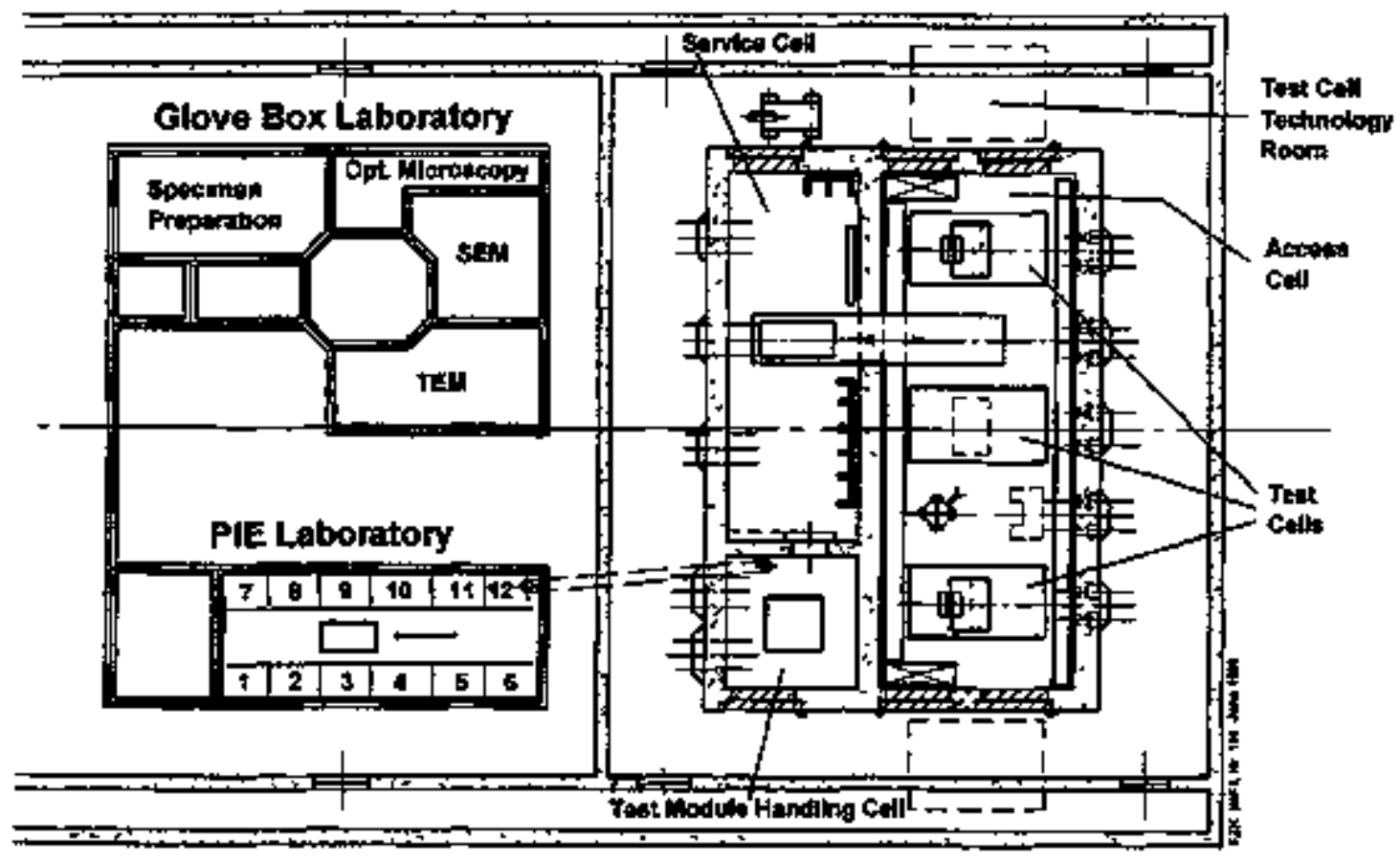

Fig. 2.2.11.2: Plan view of the Test facilities with PIE Laboratory.

C. Detailed WBS Lssting:

2.2.11.2. Service Cell Structure:

2.2.11.2.1 Cell liner

2.2.11.2.2 Lead shielding

2.2.11.2.3 Removable celt ceilung 


\section{Costing Rationale:}

Engineering efforts, fabrication methods, requirements, and procedures were evaluated for therefore the feasibility, fabrication and assembly of each major component of the Test Module Handling Cell. From these evaluations, fabrication man-hour estimates were made by based on the amount of welding. machining metal prepatation and general labor required for fabrication and assembly. Engineering deliverable (such as drawings, specifications, testing) required.

The estimated engineerimg cost is based on a $120 .-\mathrm{DM}$ or 78.90 ICF hourly rate.

The cost estimate is done according to the experience from the FZK Hot Cells (see note from M. Nägele, Head of FZK Hot Cells).

\section{E. Detailed Costing:}

\subsection{Cell liner}

The sizes of the nain PIE Hot Cell and the PIE access cell are assumed to be $-13 \mathrm{~m} x-5.5 \mathrm{~m}$, and $4 \mathrm{~m} \times 5.5 \mathrm{~m}$, respectively. The costs are estimated assuming a liner thickness of $10 \mathrm{~mm}$, and an inner surface of $250 \mathrm{~m}^{2}$

- Matecials estimate for On-site fabrication:

$-500 \mathrm{~m}^{2}$ proved welds

-TOTAL

$$
\begin{array}{r}
250.000,-\mathrm{DM} \\
84.000,-\mathrm{DM} \\
334.000,-\mathrm{DM}
\end{array}
$$

$164,000 \mathrm{ICF}$

$55,000 \mathrm{ICF}$

219,000 ICF

\subsection{Lead shielding:}

This lead shielding is integrated in the steel structure and has in the present design a thickness of $20 \mathrm{~cm}$. Whether it is possible to reduce significantly the wall thickness has to be evaluated on the basis of relevant activation analyses. Frorn the experience with miniaturized specimens it is not unrealistic to assume that a PIE Hot Cel] wall thickness of $10 \mathrm{~cm}$ might be sufficient. The wall thickness reduction would have a big impact on cost reduction.

Material $(20 \mathrm{~cm})$, fabrication and assembling:

$$
2.250 .000, * \mathrm{DM} \quad 1.320,000 \mathrm{ICF}
$$

Engineering (global estimate $10 \%$ of material, fabrication and installation:

$$
\text { 225.000,-DM }
$$

$148,000 \mathrm{ICF}$

\subsection{Removable cell ceiling:}

$30 \mathrm{~cm}$ steel construction is assumed. A ceiling area of $100 \mathrm{~m}^{2}$ implies $30 \mathrm{~m}^{3}$ volume and 250 tons steel à 2000/t DM (completely assembled).

Engineering (global estimate 5\% of material, fabrication and installation):

$$
25.000,-\mathrm{DM}
$$

16,400 ICF

Material, fabrication and assembling (rough estimate)

$$
\text { 500,000,- DM } \quad 329,000 \mathrm{ICF}
$$


WBS 2.2.11.3

WORKSHEET

WBS 2.2.8.3 Manpuiator Systems

A. Summary Cost estimate:

\begin{tabular}{|c|c|c|c|c|c|}
\hline \multicolumn{3}{|c|}{ Off-IFMIF Site } & \multicolumn{3}{|c|}{ On-site at IFMIF } \\
\hline Industry & Inststit'al & & Industry & Instit'al & \\
\hline Mat'1/Lab Engin'g & Engin's & AF Total & Mat'l/Lab Engin'g & Engin's & AFI Total \\
\hline 2214 & nc & $443 \quad 2657$ & nc & 112 & $22 \quad 134$ \\
\hline
\end{tabular}

Units: $1,000 \mathrm{ICF}(1,000 \mathrm{ICF}=1.520 .-\mathrm{DM})$

B. Description:

The Manipulator Systems are necessary for all handling and maintenance purposes. A more general short description of this Cell is given in WBS 2.2.7.2. In the present design

- 15 Working stations (incl. through wall windows) are foreseen which are integrated in the PIE Hot Cell wall.

- 2 Power Master/Slave Manjpulator Systems with various tools are also necessary for general Maincenance and fitting purposes.

C. Detailed WBS Listing:

2.2.11.3 Manipulator Systems

2.2.11.3.1 Working stations

2.2.11.3.2 Power Manipulator Systems

D. Costing Rationale:

Engineering deliverable (such as design, drawings, listings, and extended testing) recuired. The estimated engineering cost is based on a 120 ,- DM or 78.90 ICF hourly tate.

E. Detailed Costing:

Because a more detailed cost estimate is pending (ENEA), the global cost estimate from the FZK Hot Cell will be used as input.

Engineering (global estimates from FZK Hot Cells):

2.2.11.3.1

2.2.11.3.2
120.000.- DM

$50.000,-\mathrm{DM}$
$79,000 \mathrm{ICF}$

$33,000 \mathrm{ICF}$

Material, fabrication, installation and testing (global estimate from FZK Hot Cell):

2.2.11.3.1 each 500.000.- DM

15 Complete Working stations including through wall windows,

2.2.11.3.2

2 Power Manipklator systems, each 1.000.000,-DM

2.000.000,- DM

$1,326,000 \mathrm{ICF}$ 
WORKSHIEET

WBS 2.2.11.4 Bridge Crane

A. Summary Cost estimate:

\begin{tabular}{|c|c|c|c|c|c|}
\hline \multicolumn{3}{|c|}{ Off-IFMIF Site } & \multicolumn{3}{|c|}{ On-site at IFMIF } \\
\hline Industry & Instit'al & & lndustry & Instit' ${ }^{2} \mathrm{al}$ & \\
\hline Mat'1/Lab Engin'g & Engin's & AFI Total & Mat'1/Lab Engin'g & Engin'g & Total \\
\hline nc & $n c$ & $\mathrm{DC}$ & 197 & 6,2 & 244 \\
\hline
\end{tabular}

Units: 1,000 ICF $(1,000$ ICF $=1.520,-$ DM $)$

\section{B. Description:}

The Bridge Crame in the PIE Hot Cell is necessary to lift mechanical testing devices during maintenance and handling operations. It will be also used to move complete test modules from and onto the transfer chart berween the main PIE Hot Cell and the PIE access cell.

\section{Detailed WBS Listing:}

There is no other listings in this section of WBS. The Bridge Crase WBS 2.2.11.4 is the lowest WBS listed.

\section{Costing Rationale:}

Engineering deliverable (such as design, drawings, and testing) required. The estimated engineering cost is based on a $120,-$ DM or $78.90 \mathrm{ICF}$ hourly rate.

E. Detailed Costing:

Because a more detziled cost estimate is pending (ENEA), the global cost estimate from the FZKK Hot Cell will be used as input.

Engineering (estimates from FZK Hot Cells):

$120 \mathrm{hr}$.

$$
9.500,-\mathrm{DM}
$$

6,200 ICF

Material, fabrication and installation (estimate from existing Bridge Cranes in FZK Hot Cell) Complete 5 tons Bridge Crane: 
WORKSHEET

WBS 2.2.11.5

WBS 2.2.11.5 Infrastructure

A. Summary Cost estimate:

\begin{tabular}{|c|c|c|c|c|c|}
\hline \multicolumn{3}{|c|}{ Off-IFMIF Site } & \multicolumn{3}{|c|}{ On-site at IFMIF } \\
\hline Industry & Instit' al & & Industry & Instit'al & \\
\hline Mat'l/Lab Engin's & Engin's & AFI Total & Mat'l/Lab Engin'g & Engin's & AFI Total \\
\hline nc & $\mathrm{nc}$ & nc & 1317 & 132 & $290 \quad 1.739$ \\
\hline
\end{tabular}

Units: 1,000 JCF $(1,000$ ICF $=1.520,-$ DM $)$

B. Description:

Main infrastructure installations include

2.2.11.5.1 - Electric power which is suitable to feed all devices in the PIE Hot Cell - compressed air, jnert gases, cables

- Lightning

2.2.11.5.2 - Support structures for Robot Systems, Cell Maintenance, Hydratalic Systems, locks

- Waste storage containers

- Transfer rail system with cross table

C. Detailed WBS Listing:

\subsubsection{Infrastructure Installation}

2.2.11.5.1 Electric power and gases

2.2.11.5.2 Mechanical Infrastructure

D. Costing Rationale:

Engineering deliverable (such as design, drawings, listings and testing) required. The estimated engineering cost is based on a $120,-\mathrm{DM}$ or $78.90 \mathrm{ICF}$ hourly rate.

\section{E. Detailed Costing:}

The global cost estimate from the FZK Hot Cell will be used as input

2.2.11.5.1: Material, fabrication, installation and testing:

$$
\begin{array}{lrr} 
& 500,000,-\mathrm{DM} & 330,000 \text { ICF } \\
\text { Engineering (10\%): } & 50,000,-\mathrm{DM} & 33,000 \mathrm{ICF}
\end{array}
$$

2.2.11.5.2: Matetial, fabrication, installation and testing:

$$
\begin{array}{rr}
1.500 .000,-\mathrm{DM} & 987,000 \mathrm{ICF} \\
150.000,-\mathrm{DM} & 98,700 \mathrm{ICF}
\end{array}
$$


WORKSHEET

WBS 2.2.11.6 Examination Equipment for PIE Hot Cells

A. Summary Cost estimate:

\begin{tabular}{|c|c|c|c|c|c|}
\hline \multicolumn{3}{|c|}{ Off-IFMIF Site } & \multicolumn{3}{|c|}{ On-site at IFMIF } \\
\hline Industry & Instit' al & & Industry & Instit'al & \\
\hline Mat'l/Lab Engin'g & Engin'g & AFI Total & Mat'VLab Engin'te & Engin's & AFI Total \\
\hline 1,074 & $\mathbf{n c}$ & \begin{tabular}{|ll}
215 & 1,289 \\
\end{tabular} & nc & 42 & $8 \quad 50$ \\
\hline
\end{tabular}

Units: $1,000 \mathrm{ICF}(1,000 \mathrm{ICF}=1.520,-\mathrm{DM})$

\section{B. Description:}

The testing equipment inside the conventional PIE Hot Cell is necessary to do all mechanical investigations on all kinds of irradiated specimens. Also investigations on unirradiated control specimens will be done there. The equipment is defined by the actual requirements to produce relevant data for DEMO oriented materials data bases. Presently the instnumentation includes all mechanical tests foreseen for seven different types of miniaturized specimens mainly irradiated in the high flux region.

\section{Detailed WBS Listing;}

2.2.11.6 Examination equipment inside the conventional PIE Hot Cells:

2.2.11.6.1 Universal testing machines

2.2.11.6.2 Fumaces

2.2.1 1.6.3 Thermal fatigue test devices

2.2.11.6.4 Corrosion test devices

2.2.11.6.5 Fracture toughness test devices

2.2.11.6.6 Fatigue crack growth test device

2.2.11.6.7 Pressurized tube test devices

2.2.1 1.6.8 Optical microscope

2.2.11.6.9 Specitnen preparation tools

\section{Costing Rationale:}

The cost estimate is done according to the experience from the FZK Hot Cells (see note from R. Lindau, FZK). The costs are based on alteady existing devices and were updated according to inflation, if necessary. Because essentially all equipment can be purchased by the industry, the engineering efforts are considered to be negligible compared to the total costs.

At IFMIF on site $4 \mathrm{MJ}$ will be necessary for tests and putting all apparatus into operation

$4 \times 2000 \mathrm{~h} \times 78.90 \mathrm{DM}=63.120 \mathrm{DM} / \mathrm{h}$

41,500 ICF.

E. Detailed Costing:

2.2.11.6.1-9 (see attachment with detailed listings):

TOTAL

$1.633,000,-\mathrm{DM} \quad 1,074,000 \mathrm{ICF}$ 


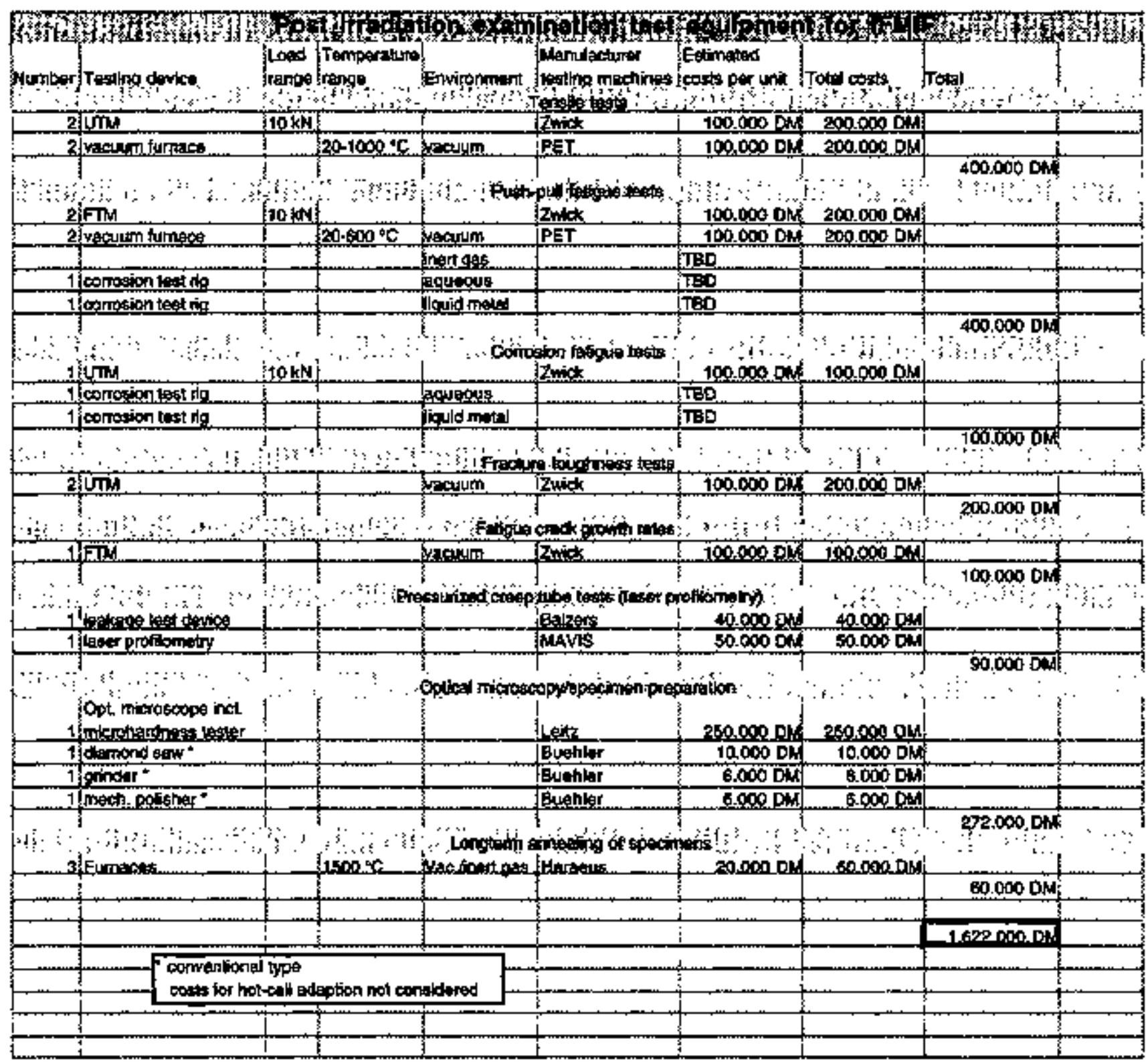


WORKSHEET

WBS 2.2.12.1

WBS 2.2.12.1 Assembly and Testing of Shielded Glove Box Laboratory

A. Summary Cost estimate:

\begin{tabular}{|c|c|c|c|c|c|}
\hline \multicolumn{3}{|c|}{ Off-IFMIF Site } & \multicolumn{3}{|c|}{ On-site at IFMIF } \\
\hline Industry & Instit'al & & Industry & Instit'al & \\
\hline Mat'L/Lab Engin's & Engin's & AFI Total & Mat'L/Lab Engin'g & Engin's & AFI Total \\
\hline$n c$ & IIC & nc & $n c$ & 103 & $21 \quad 124$ \\
\hline
\end{tabular}

Units: 1,000 ICF ( 1,000 ICF $=1.520,-$ DM)

\section{B. Description:}

Similar to the argements for one large PIE Hoc Cell also here one cormon laboratory (only one ventilation system) with separated areas is favored.

Because shielded glove boxes are operated in a variety of associations all with long term experience, the bulk of all necessary assembly and testing procedures is already well known.

\section{Detailed WBS Listing:}

2.2.12.1 Assembly and testing of Shielded Glove Box Laboratory

2.2.12.1.1 Assembly

2.2.12.1.2 Testing

\section{Costing Rationale:}

Engineering deliverable (such as listings, system programming and extended testing) required. The estimated engineering cost is based on a $120,-$ DM or 78.90 ICF bourly rate.

E. Detaikd Costing:

No relevant cost uncertainties are expected Nevertheless, the global cost estimate given below has to evaluated in more detail.

\subsection{Assembly:}

Al] costs (incl. engineering ones) are considered to be included in the individual WBS elements.

2.2.12.1.2 Testing (including support for commissioning):

Engineering estimate for IFMIF On-site costs:

$2000 \mathrm{br}$.

157.800,- DM

103,000 ICF 
WORKSHEET

WBS 2.2.12.2 Structure and Support Systems for Shielded Glove Box Laboratory

A. Summary Cost estimate:

\begin{tabular}{|c|c|c|c|c|c|}
\hline \multicolumn{3}{|c|}{ Off-IFMIF Site } & \multicolumn{3}{|c|}{ On-site at IFMIF } \\
\hline Industry & Instit'al & & Industry & Instit'al & \\
\hline Mat'l/Lab Engin'g & Engin'g & AFI Total & Mat'l/Lab Engin'g & Engin's & AFI Total \\
\hline 7896 & 0 & 15799475 & 0 & nc & $0 \quad 0$ \\
\hline
\end{tabular}

Units: 1,000 ICF $(1,000$ ICF $=1.520, *$ DM $)$

\section{B. Description:}

Shielded glove boxes are useful for PIE of very smal] or low-dose specimens of all kinds of materials, since specimen handling is easy and effective compared with hot cells.

C. Detailed WBS Listing:

2.2.12.2. Structure and Support Systems:

2.2.12.2.1 Lead shielded glove box structure

2.2.12.2.2 Support systems

D. Costing Rationale:

The cost estimate is done according to the experience from the FZK Hot Cells (see note from M. Nägele, Head of FZK Hot Cells). More detailed specifications are pending

E. Detailed Costing:

2.2.12.2.1 Lead shielded glove box:

The overall costs for the steel structure, the lead shields $(10 \mathrm{~cm})$, the glove box devices incl. through wall windows, doors and ceiling is roughly estimated to

$$
10.000 .000,-\mathrm{DM} \quad 6,580,000 \mathrm{ICF}
$$

\subsection{Support systems:}

They inciude the complete infrastnucture installation like electric power, compressed air, inert gases, lighting, waste disposal, small manipulator systerns and universal remote tongs.

$$
\text { 2.000.000,- DM } \quad 1,316,000 \mathrm{ICF}
$$


WORKSHEET

WBS 2.2.12.3 Examination Equipment for Shielded Glove Box Laboratory

A. Sammary Cost estimate:

\begin{tabular}{|c|c|c|c|c|c|c|}
\hline \multicolumn{3}{|c|}{ Off-IFMIF Site } & \multicolumn{4}{|c|}{ On-șite at IFMIF } \\
\hline Industry & Instit'al & & Industry & Instit'al & & \\
\hline Mat' iLab Engin's & Engin's & AFI Total & Mat'l/Lab Engin's & Engin's: & $\mathrm{AFI}$ & Total \\
\hline 1,074 & nc & $215 \quad 1,289$ & $\mathrm{nc}$ & 208 & 42 & 250 \\
\hline
\end{tabular}

Units: 1,000 ICF ( 1,000 ICF $=1.520$,- DM)

\section{B. Description:}

Microstnuctural analyses will be indispensable to describe and understand the irradiation induced defects and their impact on materials properties. Because only very small specimens sizes are necessary for these analyses, shielded glove boxes are sufficient. According to the international standards, this Laboratory will be equipped with 10 bench-top glove boxes, modern scanning and transmission electron microscopes (SEM and TEM). TEM specimen preparation tools, an optical microscope, a microhardness tester, a temporary vacuum storage grid for TFM specimens, and an activation analysis system. The latter is important to confirm experimentally on low and reduced activation materials the predictions from activation inventory codes.

\section{Detailed WBS Listing:}

2.2.12.3. Examination equipment:

2.2.12.3.1 SEM

2.2.12.3.2 TEM

2.2.12.3.3 TEM preparation

2.2.12.3.4 Specimen storage

2.2.12.3.5 Optical microscope

2.2.12.3.6 Microhardness tester

2.2.12.3.7 Activation analysis system

\section{Costing Rationale:}

The cost estimate is done according to the experierice from the FZK Hox Cells (see note from $R$. Lindau, FZK).The costs are based on already existing devices and were updated according to inflation, if necessary. Because essentially all equipment can be purchased by the industry, the engineering efforts are considered to be negligible compared to the total costs.

\section{E. Detailed Costing:}

2.2.9.3.1-7 (see attachment with detailed listings):

TOTAL

Additional on-site manpower ( $2 \mathrm{MJ}$ )will be available for test and putting apparatus into operation:
$2 \times 2000$ h $\times 78.90 \mathrm{DM} / \mathrm{h}=$
3]6,000,-DM
$208,000 \mathrm{ICF}$ 


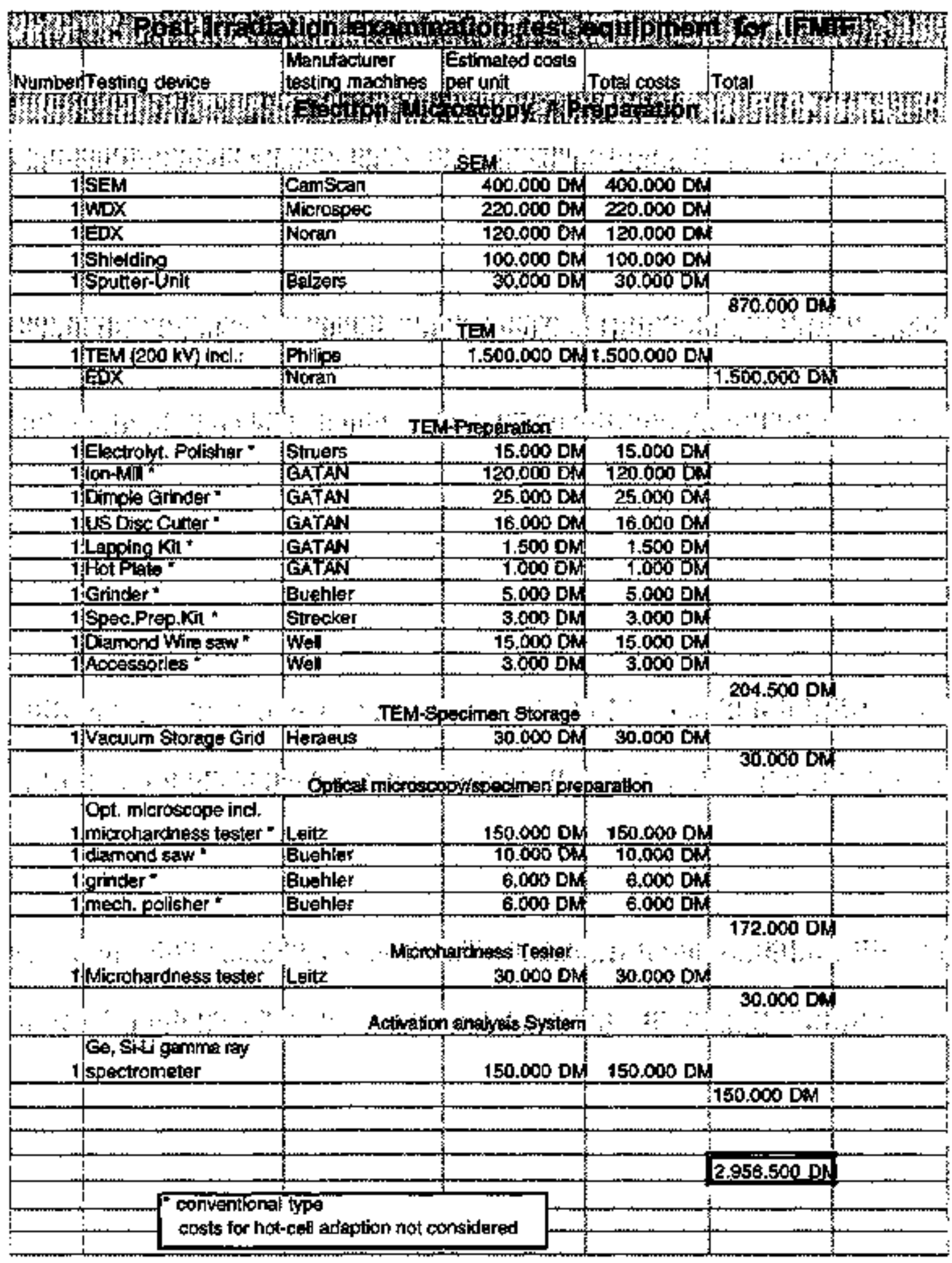


WORKSHEET

WBS 2.2.14 Maintenance Systems

A. Summary Cost estimate:

\begin{tabular}{|c|c|c|c|c|c|}
\hline \multicolumn{2}{|c|}{ Off-IFMIF Site } & \multicolumn{3}{c|}{ Org-site at IFMIF } \\
\hline Industry & Instit'al & & Industry & Instit'al & \\
\hline Mat'l/Lab Engin's & Engin'g & AFI Total & Mat'VLab Engin'g & Engin' g & AFI Total \\
\hline nc & nc & nc & 1,970 & 591 & $512 \quad 3.073$ \\
\hline
\end{tabular}

Units: $1,000 \mathrm{ICF}(1,000 \mathrm{ICF}=1.520,-\mathrm{DM})$

\section{B. Description:}

Beside the maintenance devices already described in the specific WBS elements of the individual cells and rooms, some additional devices are considered to be necessary for unusual events. E.g. for the Access Cell, the Service Cell and the Test Module Handling Cell a supervision robot and special purpose tooling should be available, and for the shipping of huge irradiated or activated devices suitable shielding containers are necessary.

C. Detailed WBS Listing:

\subsubsection{Maintenance Systems}

2.2.14.1 Maintenance Procedute Development

2.2.142 \$pecial Purpose Tooling

2.2.14.3 Remote Handling Equipment

2.2.14.4 Mock-up Facilities and Testing

D. Costing Rationale:

The cost estimate is done according to the long term experience from the FZK Hot Cells and the FZK Cyclotron Facility.

Only a global estimate can be given at present.

\section{E. Global Costing:}


WORKSHEET

WBS 2.2.13.1 Tribum Laboratory Assembly and Testing

\section{A. Summary Cost Estimate:}

\begin{tabular}{|c|c|c|c|c|c|c|}
\hline \multicolumn{4}{|c|}{ Off-IFMif Site } & \multicolumn{3}{|c|}{ On-Site At IFMIF } \\
\hline Industry & Instit & & & $\begin{array}{l}\text { Const. } \\
\text { Contractor }\end{array}$ & Instital & \\
\hline $\begin{array}{l}\text { Mat'l Engin } \\
\text { Lab }\end{array}$ & Engin & AFI & Total & $\begin{array}{l}\text { Mat'V Engin } \\
\text { Lab }\end{array}$ & Engin & Total \\
\hline 906 & 286 & 239 & 1431 & 906 & 286 & 2385 \\
\hline
\end{tabular}

Currency Units: kilo ICF

\section{B. Description:}

This element is the cost for installation and initial testing of the tritium laboratory, that is a part of the Post Irradiation Test facility of the test cell subsystem.

The testing equipment inside the tritium laboratory is necessary for all kinds of mechanical and microstructural investigations on tritium contaminated or tritiumcontaining specimens that generate as the results of the irradiation test. The capsules irradiated in the medium flux region will contain highly activated ceramic breeders like $\mathrm{Li}_{4} \mathrm{SiO}_{4}, \mathrm{Li}_{2} \mathrm{TiO}_{3}$ of other innovative lithium based ceramics. Retrieval of tritium containing specimens from capsules and investigation of mockups with breeder materials requires suitable bot cells. To minimize any cross contamination and to assure effective tritium retention, hot cells for tritium contaminated and containing materials are separated from that of other materials. The fig. shows a bird's eye view of the main subsystems of the Tritium Facility: (i) The airtight tritium bandling hot cells for disassembling. preparation and investigation of high gamma-ray activated specimens, (ii) the airtight tritium glove boxes to analyze small pieces or low activated ceramic breeders, (iii) the temporary storage for tritiated specimens and devices. Detailed layouts have been developed for tritium processing systems with effective detriation and effuent tritium removal subsystems.

These equipment also serves as a tritiated solid waste handling system housing for the radio-active and contaminated wastes generated in the entire IFMIF facility.

\section{Detailed WBS Listing}

\subsubsection{TRITIUM LABORATORY}

\section{Costing Rationale:}

Due to the nature of this subsystem, most of the cost estimated are obtained by scaling and factoring from the experience of the existing facilities.

Instruments and equipment to be installed in the hot cells and gloveboxes are assumed to be purchased from the industry including design, assembly and testing. Industry and institutional engineering costs are estimated for each subsystems. AFIs are estimated to be small, because although some equipment require R\&D before purchase, major part of the system can be assembled with existing technology.

Personnel costs are estimated as follows;

Industry: $10 \%$ manager, $50 \%$ experts and $40 \%$ labor, averaged to be 19Myen/year.

Institutional : 15M yen/year, engineers only. 
WBS 2.2.13

Worksheet

WBS 2.2.13.2 Tritium Hat Cell

A. Summary Cost Estimate:

\begin{tabular}{|c|c|c|c|c|c|c|c|c|}
\hline \multicolumn{4}{|c|}{ Off-IFMII Stite } & \multicolumn{5}{|c|}{ On-Site At IFMiF } \\
\hline Industry & Instit' & & & $\begin{array}{l}\text { Const. } \\
\text { Contra }\end{array}$ & & Instit'al & & \\
\hline $\begin{array}{l}\text { Mat'// Engin } \\
\text { Lab }\end{array}$ & Engin & AFI & Total & $\begin{array}{l}\mathrm{Mar}^{\prime} \mathrm{V} \\
\mathrm{L} \mathbf{a b}\end{array}$ & Engin & Engin & $\mathrm{AFI}$ & Total \\
\hline 52675439 & 286 & 1502 & 12494 & 1143 & 1812 & 1143 & 309 & 3607 \\
\hline
\end{tabular}

Currency Units: kile ICE

\section{B. Description:}

This element covers the fabrication and initial testing of the bot cell of the tritium laboratory, that is part of the post irradiation test facility.

The major fuaction of the element is to process specimens obtained from the medium flux region of the test cell, and to perform various analyses and measurements. Research programs of the IFMIF will include the irradiation of breeding blanket materials and other materials that possibly generate tritium by nuclear reactions. Such samples are handled in the special facility that have a specific leak tightness and capability to hande tritium. This equipment is designed to handle relatively high gamma radiation that should be shielded by hot cells.

Another major function of this system is decontamination and processing of tritiun contaminated solid wastes that will generate in the entire IFMIF facility. Because of the capability of this tritium hot cell to handle highly activated and tritium contaminated materials and mechanically cut and process solid pieces, this equipment can be used for housing solid waste treatment system.

\section{WBS Listing:}

\subsubsection{Tritium Hot Cell}

\section{Costing Rationale:}

Because there is no similar facilities that handles gamma activity and tritium contamination, the cost is estimated from the scaling from existing plutonium or uranium hot cells. Personnel costs are estimated in the method same as in the other tritium systems.. 
WBS 2.2 .13

Worksheet

WBS 2.2.13.3 Tritium Gloveboxes

\section{A. Summary Cost Estimate:}

\begin{tabular}{|c|c|c|c|c|c|c|}
\hline \multicolumn{4}{|c|}{ Off-IFMif Site } & \multicolumn{3}{|c|}{ On-Site At IFMIF } \\
\hline Industry & Instit & & & $\begin{array}{l}\text { Const. } \\
\text { Contractor }\end{array}$ & Tnstit'al & \\
\hline $\begin{array}{l}\text { Mat'//Engin } \\
\text { Lab }\end{array}$ & Engin & AFI & Total & $\begin{array}{l}\text { Mar'l/ Engin } \\
\text { Lab }\end{array}$ & Engin & Total \\
\hline $5600 \quad 3625$ & $1 \overline{43}$ & 1730 & 11098 & 1812 & 131 & 3564 \\
\hline
\end{tabular}

Currency Units: kiloICF

\section{B. Description:}

This element covers the fabrication, installation and initial testing of the gloveboxes of the tritium laboratory, that is a part of the Post Iradiation Test facility of the test cell subsystem. A closed loop atmosphere detritiation that controls these gloveboxes, as well as the tritiun bot cell, is included.

The major function of the element is to perform various analysis and measurement of the irradiated breeding materials, that has less gamma activity and requires more delicate handling than that in the hot cells. Such samples are handled in the special confinement that have a specific leak tightness and capability to handle tritium through gloves. This equipment is designed to handle relatively low ganma radiation, but some local shielding may be considered. Further material testing that require more delicate hands-on operation will be possible with small test specimens prepared in these gloveboxes.

The glovebox atmosphere detritiation system recalculates the inert gas in the gloveboxes and hot cells and remove tritiated species. Oxygen in the atmosphere and bound in the form of moisture is removed by ceramic electrolyte cell. Tritium is removed by gettering with hidriding metal beds. Negative pressure and oxygen concentration is also monitored and controlled. Leak tightuess of the glovebox and hot cell confinement can be continuously monitored by these pressure and oxygen concentration. Excess gas resulted from the maintaining negative pressure is sent to the exhaust detritiation of the conventional facility.

\section{WBS Listing:}

\subsubsection{Tritium glovebox}

\section{Costing Rationale:}

There are similar tritium facilities where large arnount of tritium is handled in Japan, Germany, US and some other countries, and cost data base is available from recently commissioned facilities such as TLK in FzK and TPL in JAERI. Personnel costs are estimated on the basis of WBS 2.2.13.1. 
Cost Estimating

Worksheets

for

WBS 3.0

Target Facility 
WORKSHFET

WBS 3.1.0 Target Fac"itty Management

WBS 3.1.1 Project Managemest and Administration

3. 1. 1.

\section{A. Sumpmary Cost Estingate:}

\begin{tabular}{|c|c|c|c|c|c|c|c|c|c|}
\hline \multicolumn{5}{|c|}{ Off-IFMIF Site } & \multicolumn{5}{|c|}{ On-Site at IFMIF } \\
\hline \multicolumn{2}{|c|}{ Industry } & \multirow{2}{*}{$\begin{array}{l}\text { Instit' } \\
\text { Engin }\end{array}$} & \multirow[b]{2}{*}{ AFI } & \multirow[b]{2}{*}{ Total } & \multicolumn{2}{|c|}{$\begin{array}{l}\text { Const. } \\
\text { Contractor }\end{array}$} & \multirow{2}{*}{$\begin{array}{l}\text { Instit' } \\
\text { Engin }\end{array}$} & \multirow[b]{2}{*}{ AFI } & \multirow[b]{2}{*}{ Total } \\
\hline $\begin{array}{l}\text { Mat'1/ } \\
\text { Lab }\end{array}$ & Engin & & & & $\begin{array}{c}\text { Mat'y } \\
\text { Lab }\end{array}$ & Eng & & & \\
\hline 286,000 & $\begin{array}{c}1,715,0 \\
00\end{array}$ & 40,020 & 102,051 & $2,143,071$ & 0 & 0 & 0 & 0 & 0 \\
\hline
\end{tabular}

\section{Currency Units: ICE}

\section{B. Description:}

In the construction of IFMIF target system, full time project mangement is necessary until its completion.

Following are included in the management:

a) Time schedule management, b) Process management, c) Cost control, d) Regulation with the Accelerator and Test Cell Facitities.

Among the items of Adninisuration, the costs of the adnission of desigu and construction and that of safety licenses are not ibcluded. They are included in Design Integration (WBS 3.1.2.1) and Licenses (WBS 3.1.3.2), respectively.

\section{C.Drtailed WBS Ljsting:}

1. 0. 0. 0. Project Management and Administration

1. 0.0 . Administration

2. 0. 0. Cost Control

3. 0. 0. Schedule

4. 0. 0. Documentation

\section{Costing Rationgle:}

Off-IFMIF Site :

(1) Cost of Industry Material / Labor:

Drawings and lnstruction manual are included

Type of Estirisate: Scaling from the cases of BWR, FBR, etc.

(2) Cost of Induskry Engineering :

Management Engineering : 9-y-year

Type of Estintate : Bottoms-Up

\section{E. Detailed Costini:}

\section{Off-IFMIF Site :}

(t) Industry Material / Labor

(2) Industry Engineering

(3) Institutional Engineering: $2 \%$ of ((1) $+(2)$ )

(4) AFI: $5 \%$ of $((1)+(2)+(3))$

Subtotal

$286,000 \mathrm{ICF}$

$1,715,000 \mathrm{ICF}$

40,020 ICF

102,051 ICF

$2,143,071$ ICF

On-Site at IFMIF : $\quad$ None 
WBS 3.1.2 System Engiaeering

\section{A. Summary Cost Estimate:}

\begin{tabular}{|c|c|c|c|c|c|c|c|c|c|}
\hline \multicolumn{5}{|c|}{ Off-DFMIF S jite } & \multicolumn{5}{|c|}{ On-Site at IFMIF } \\
\hline \multicolumn{2}{|c|}{ Indiestry } & \multirow{2}{*}{$\begin{array}{l}\text { Instit' } \\
\text { Engin }\end{array}$} & \multirow[b]{2}{*}{ AFI } & \multirow[b]{2}{*}{ Total } & \multicolumn{2}{|c|}{$\begin{array}{c}\text { Const } \\
\text { Contractor }\end{array}$} & \multirow{2}{*}{$\begin{array}{l}\text { Instüt" } \\
\text { Engin }\end{array}$} & \multirow[b]{2}{*}{ AFI } & \multirow[b]{2}{*}{ Total } \\
\hline $\begin{array}{l}\text { Mat'V } \\
\text { Lab }\end{array}$ & Engin & & & & $\begin{array}{l}\text { Mat"V } \\
\text { Lab }\end{array}$ & Engin & & & \\
\hline 953,000 & $\begin{array}{c}1,220,0 \\
00\end{array}$ & 43,460 & 110,823 & $2,327,283$ & 0 & 0 & 0 & 0 & 0 \\
\hline
\end{tabular}

\section{Cumency Units:ICF}

\section{B. Description:}

The costs of the Engineering and the computer analysis for the following works are estimated in this category.

a) Settlement of the specifications, b) Systen design, c) Basic design for the components, d) Structaral analysis,

e) Thermal-Fitid analysis, $f$ ) Works of design integration.

The cost of Requirement / Speciftcations is included in the llems of Design Integration.

The cost of RAM Analysis is excluded from the present cost estimations.

C. Detailed WBS Listing:

2. 0. 0. 0. Lithism Target System

t. 0. 0 . Design Integration

2. 0. 0. System Athalysis

3. 0. 0 . Requirement/Specifications

4. 0. 0. RAM Analysis

D. Costimp Rationale:

Off-IFMIF Site :

(1) Cost of Industry Material / Labor :

Running cost of a high performance compute

Type of Escimate : Scaling from the existing plants

(2) Cost of Industry Enginetring :

Manpower provided Design Engineering : $80 \mathrm{~m}$-month

Type of Estimate : Bottoms-Up .

\section{E. Drailed Costing:}

Off-IFMIF Site:

(i) Indusiry Material / Labor

(2) Industry Engineering

(3) Institutional Engineting: $2 \%$ of ((1)+(2))

(4) AFI: $5 \%$ of $((1)+(2)+(3))$

Subtotal

953,000 ICF

$1,220,000 \mathrm{ICF}$

43,460 ICF

110,823 ICF

$2,327,283$ ICF

On-Site at IFMIF : $\quad$ None 
WBS 3.1.3 Environmentel, Sarety Health Doc.

A. Summary Cost Estimate:

\begin{tabular}{|c|c|c|c|c|c|c|c|c|c|}
\hline \multicolumn{5}{|c|}{ Off-IFMIF Sje } & \multicolumn{5}{|c|}{ On-Site at IFMIF } \\
\hline & stry & Instit' & & & $\begin{array}{r}C_{0} \\
\mathrm{Con}\end{array}$ & $\begin{array}{l}\text { st. } \\
\text { ctor }\end{array}$ & Instit" & & \\
\hline $\begin{array}{c}\text { Mat'V } \\
\text { Lab }\end{array}$ & Eaghn & Engín & AFI & Total & $\begin{array}{c}\text { Mat"V } \\
\text { Lab }\end{array}$ & Engin & Engin & AFI & Total \\
\hline 0 & 381,000 & 0 & 19,050 & 400,050 & 0 & Q & 0 & 0 & 0 \\
\hline
\end{tabular}

Cnmency Units:ICE

\section{B. Desscription:}

The Engineering cost is the cost of a full-time superibtendent for the safety management during 2 years installation.

The cost of ticenses which include the jtems of the admission of design and construction, safety licenses, admission of transportation of beavy components, etc. are excluded from the present cost estimations.

\section{Deailet WBS Listing:}

3. 0. 0. 0. Esvironmental, Safety \& Healtb Doc.

1. 0. 0. Environmentat, Safety Health Doc.

2. 0. 0. Licenses

D. Costing Rationale:

Off-FMIIF Site :

(1) Cost of Industry Engineeting:

The full-time superintendent of the Installation works : 2m-year

Type of Estimate : Bottoms-Up

E. Detajitod Costing:

Off-IFMIIF Site :

(1) Industry Material / Labor

(2) Industry Engireering

(3) Institutional Enginetring

(4) AFI ; 5\% of $((1)+(2)+(3))$

Subtatal

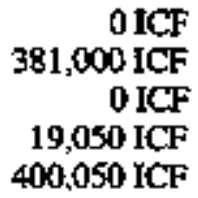

On-Site at IFMIF : $\quad$ None 
WORKSHEET

3. 1. 4.

WBS 3.L.4 Quality, Assurance

\section{A. Summary Cost Estimate:}

\begin{tabular}{|c|c|c|c|c|c|c|c|c|c|}
\hline \multicolumn{5}{|c|}{ Off-IFMIF Site } & \multicolumn{5}{|c|}{ On-Site at IFMIF } \\
\hline & stry & Instit' & & & $\begin{array}{r}\mathrm{Co} \\
\mathrm{Con}\end{array}$ & ctor & Instit' & & \\
\hline $\begin{array}{c}\text { Mat'y } \\
\text { Lab }\end{array}$ & Engin & Engin & AFI & Total & $\begin{array}{c}\text { Mar'V } \\
\text { Lab }\end{array}$ & Engin & Engin & AFI & Total \\
\hline 0 & $\begin{array}{c}1,743,0 \\
00\end{array}$ & 0 & 87,150 & $1,830,150$ & 0 & 0 & 0 & 0 & 0 \\
\hline
\end{tabular}

Cinrency Units: ICF

\section{B. Descriution:}

The item includes the a) Quality assurance (QA), b) Quality control (QC), c) Production control and d) Purchase arrangement

C. Detailed WBS Listing:

4. 0. 0. 0. Quality, Assurance

\section{Costing Rationale:}

Off-IFMWF Site :

(1) Cost of lndustry Engineering :

Mappower provided Engineering for QA, QC, and so on : 10,4-year

Type of Estimate: Botoms-Up

\section{E. Detailed Costing:}

Off-FFMIF Site:

(1) Industry Material / Labor

(2) Industry Engineering

(3) Institutional Engineering

(4) AFI : 5\% of ((1)+(2)+(3)) Subtotal

$\begin{array}{rr}: & \text { O ICF } \\ : & 1,743,000 \mathrm{ICF} \\ \vdots & 0 \mathrm{ICF} \\ : & 87,150 \mathrm{ICF} \\ & 1,830,150 \mathrm{ICF}\end{array}$

On-Site at IFMIF: $\quad$ None 


\section{A. Summary Cost Estimate:}

\begin{tabular}{|c|c|c|c|c|c|c|c|c|c|}
\hline \multicolumn{5}{|c|}{ Of-IFMIF Site } & \multicolumn{5}{|c|}{ On-Site at IFMIIF } \\
\hline & जII & Instil' & & & $\mathrm{Con}$ & ctor & Instit' & & \\
\hline $\begin{array}{c}\text { Mat'V } \\
\text { Lab }\end{array}$ & Erigin & Engin & AFI & Total & $\begin{array}{c}\text { Mat'V } \\
\text { Lab }\end{array}$ & Engin & Engin & AFI & Total \\
\hline 0 & 629,000 & 12580 & 32.079 & 673,659 & 0 & 0 & 0 & 0 & 0 \\
\hline
\end{tabular}

Cumency Units: ICE

\section{B. Descriotion:}

The travel allowance of business trip and the ohther miscellaneous expenses are included in this item.

\section{Detailed WBS Listing:}

5. 0. 0. 0. Other Costs

\section{Costing Rationale:}

Off-IFMIIF Site :

(1) Cost of Industry Engineering :

a. The travel allowance of the business trip for

(a) the previous arrangement in the period of desiga / production, and

(b) the regulations and test operations of the components and the system.

Type of Estimate : Bottoms-Up

b. The other miscellaneous expenses

Type of Estimate: Scaling from the existence plants

\section{E. Detriled_Costing:}

Off-IFMIF Site :

(1) Industry Material / Labor

(2) Industry Engineering

- Contents of Inctustry Engineering

a. The travel allowance of the business trip

b. The other miscellaneous expenses

(3) Institutional Engineeving : $2 \%$ of (2)

(4) AFI : $5 \%$ of $((1)+(2)+(3))$ Subtotal

$$
\begin{array}{r}
\text { 0 ICF } \\
629,000 \text { ICF } \\
\\
(391,000 \text { ICF }) \\
(238,000 \mathrm{ICF}) \\
12,580 \mathrm{ICF} \\
32,079 \mathrm{ICF} \\
673,659 \text { ICF }
\end{array}
$$

Oo-Site at IFMIF: : None 
WORKSHEET

WBS 32.0 Subsystem

WBS 3.2.1 Lithinm Target System

\section{A. Summary Cost Estimater}

\begin{tabular}{|c|c|c|c|c|c|c|c|c|c|c|}
\hline \multirow[b]{3}{*}{ WBS } & \multicolumn{5}{|c|}{ Off-IFMIIF Site } & \multicolumn{5}{|c|}{ On-Site at IFMIF } \\
\hline & \multicolumn{2}{|c|}{ Indestry } & \multirow{2}{*}{$\begin{array}{l}\text { Instit' } \\
\text { Engín }\end{array}$} & \multirow[b]{2}{*}{ AFI } & \multirow[b]{2}{*}{ Total } & \multicolumn{2}{|c|}{$\begin{array}{c}\text { Const. } \\
\text { Contractor }\end{array}$} & \multirow{2}{*}{$\begin{array}{l}\text { Instit' } \\
\text { Engin }\end{array}$} & \multirow[b]{2}{*}{ AFI } & \multirow[b]{2}{*}{ Total } \\
\hline & $\begin{array}{c}\text { Mat'V } \\
\text { Lab }\end{array}$ & Enggin & & & & $\begin{array}{c}\operatorname{Mat}^{7} \mathrm{~V} \\
\mathrm{Lab}\end{array}$ & Engin & & & \\
\hline 3.2.1, & $3,608,000$ & 603,000 & 679,740 & $\begin{array}{r}2,445,3 \\
70\end{array}$ & $7,336,110$ & 574,000 & $\mathbf{0}$ & $\mathbf{0}$ & $\mathbf{2 8 , 7 0 0}$ & 602,700 \\
\hline-.1 .0 .0 & $\mathbf{0}$ & 0 & 0 & 0 & $\mathbf{0}$ & 0 & 0 & 0 & 0 & 0 \\
\hline-.2 .1 .0 & 953,000 & 115,000 & 410,000 & 739,000 & $2,217,000$ & 58,000 & 0 & 0 & 2,900 & 60,900 \\
\hline-2.2 .0 & $2,216,000$ & 422,000 & 269,740 & $\begin{array}{r}1,453,8 \\
70\end{array}$ & $4,361,610$ & $516, \overline{000}$ & 0 & 0 & 25,800 & 541,800 \\
\hline-2.3 .0 & 439,000 & 66,000 & 0 & 252,500 & 757,500 & 0 & 0 & 0 & 0 & 0 \\
\hline
\end{tabular}

Chrrency Units:ICF

\section{B. Descriotion:}

Litrium Target System consists of two sets of target assembties, interfaces with deureron accelerator beamline and with test cell. The costs of Assembly and Testing listed in the WBS(3.2.1.1) are not included in this iterrs but are included in the cost of Installation (WBS (3.3.1))

In the cost of Target Assembly, following conpotents (WBS level-6) are included : 1)Lithiun inlet piping, 2)Flow straightener, 3)Nozzle, 4)Replaceable beckwal, 5)Downstream and 6)Mechanical connectors. The cost of two kind of the downstream structure (diftuser type and baffles type) is inchuded.

In the Beam-Target Interface, the deferential pumping systems are set up for each beam line in the interface region. The total eight turbo molecular puinps (four are the spares for the redundancy) are installed in this system. In the Target-Tesi Cell Interface, the bellows seal structure are set up for following three components -deuteron beam transport lines, and lithium inlet and outtet which penetrate the Test Cell vacuum boundary.

The auclear grade design and materials are applied on this systen.

\section{Detailed WBS Listing:}

l. 0. 0. 0. Lithium Target System

1. 0. O. Assembly and Testing

1. D. Assenbly

2. 0 . Testing

2. 0. 0 . Components

1. D. Target Assembly

2. 0. Beam-Target Interface

3. 0. Target-Test Cell Interface 


\section{Costing Rationale:}

Off-IFMIF Site :

(1) Cost of Industry Material / Labor :

a. Target Assembly (WBS 3.2.1.2.1.0)

(a) two set of target assembly systems which include 1)lithing inlet piping, 2)Flow straightener, 3)Nozzle, 4,Downstream diffeser, 5,Downstream baffles and 6) Mechanical connectors, respectively, and

(b) two replaceable backwalts Type of Estimate : Bottoms-Up

b. Bearn-Tanget Interface (WBS 3.2 .1 .2 .2 .0 )

(a) two deuteron beam transport lines and four gate valyes

(b) four set of the turbo molecular pump systems which respectively inchude one spare for the redundancy (total eight turbo molecular pumps).

Type of Estimate : Bottoms-Up

c. Target-Test Cell Interface (WBS 3.2.1.2.3.0)

(a) four beilows seal stnxctures for the detileron beam transport lines, and lithium iniet and oudtet which penetrare the Test Cell vacuufn boundary.

(b) two argon hoods provided target assembly exchanging Type of Estimate : Boftoms-Up

(2) Cost of Industry Engibeering:

The cost of vendor provided design and inspection engineering for the target assembly system is included.

a. Target Assembly

Type of Estimate : Bottoms-Up

b. Atam-Target Interface

Type of Estinate : Bottoms-Up

c. Target-Test Cell Interface

Type of Estimale : Bottoms-Up

(3) Cost of Institutional Engineering :

The cost of manpower (engineering, labor and technician) provided by the responsible institute is included.

a. Target Assembly

Type of Estimate : Bottoms-Up

b. Beam-Target Interface

Type of Estimate : Bottoms-Up

c. Target-Test Cell Interface

The cost of Off-IFMIF site Institutional Engineering is not included ia this item but is ineiuded in the cost of the Beam-Target Interfact and the lithium Cooling System (WBS (3.2.2)).

\section{On-Site at IFMFF :}

(1) Cost of Construction Contractor Material / Labor :

The cost of construction contractor provided installation labor and supervision, and the cost of verification testing labor and support are inciuded.

a. Target Assembly

Type of Estimate : Bottoms-Up

b. Bearn-Target Interface

Type of Estimate : Bottoms-Up

\section{c. Target-Test Cell lnterface}

The cost of Construction Contractor Material and Labor is not included in this itern but is included in the cost of the Beam-Target Interface and the lithium Cooling System. 
E. Detsiled Costing:

Off-IFMEF Site :

(1) Industry Material / Labor

- Contents of Industry Material / Labor

a. Target Assembly

b. Beam-Target Interface

c. Target-Test Cell Interface

(2) Industry Engineering

- Contents of Industry Engintering

a. Target Assenbły

b. Beam-Target Interface

c. Target-Test Cell Interface

(3) Institutiona Eogineering

- Contents of Institutional Engineering

a. Target Assembly

b. Beam-Target Interface

c. Target-Test Cell Interface

(4) AFI : $50 \%$ of ((1)+(2)+(3))

Subtotal

On-Site at IFMIF :

(1) Construction Contractor Material / Labor

-- Contents of Const. Contractor Matil/Lab

a. Target Assembly

b. Beam-Target Interface

c. Terget-Test Cell Interface

(2) AFI : $5 \%$ of (1)

Subiotal

$: \quad 3,608,000$ ICF

$(953,000$ ICF $)$

(2,216,000 ICF)

$(439,000 \mathrm{ICF})$

$603,000 \mathrm{ICF}$

(115,000 ICF)

(422,000 ICF)

( 66,000 ICF)

: $\quad 679,740 \mathrm{ICF}$

(410,000 ICF)

(269,740 ICF)

(0 ICF)

$2,445,370 \mathrm{JCF}$

$7,336,1101 \mathrm{CF}$

$574,0001 \mathrm{CF}$

$(58,000$ ICF $)$

$(516,000$ ICF $)$

(OICF)

28,700 ICF

$602,700 \mathrm{ICF}$

Total :

Total Estímated Capilal Cost (TEC)

- Contents of TEC

a. Target Assembly

b. Beam-Target Itsterface

c. Triget-Test Cell Interface

$7,938,810 \mathrm{ICF}$

(2,277,900 ICF)

$(4,903,410$ ICF)

(757,500 1CF) 


\section{WBS 3.2.2 I thtom Cooltag System}

\section{A. Simogary Cost Estimate:}

\begin{tabular}{|c|c|c|c|c|c|c|c|c|c|c|}
\hline \multirow[b]{3}{*}{ WBS } & \multicolumn{5}{|c|}{ Off-IFMIF Site } & \multicolumn{5}{|c|}{ On-Site at IFMIF } \\
\hline & \multicolumn{2}{|c|}{ lodestry } & \multirow{2}{*}{\begin{tabular}{|l|} 
Instit' \\
Engin \\
\end{tabular}} & \multirow[b]{2}{*}{ AFI } & \multirow[b]{2}{*}{ Total } & \multicolumn{2}{|c|}{$\begin{array}{l}\text { Const } \\
\text { Contractor }\end{array}$} & \multirow{2}{*}{$\begin{array}{l}\text { Instit' } \\
\text { Engin }\end{array}$} & \multirow[b]{2}{*}{ AF } & \multirow[b]{2}{*}{ Total } \\
\hline & $\begin{array}{c}\text { Mat'V } \\
\text { Lab }\end{array}$ & Engin & & & & $\begin{array}{c}\text { Mat' 'V } \\
\text { Lab }\end{array}$ & Engin & & & \\
\hline 3.2 .2 . & $\begin{array}{r}16,113,00 \\
0\end{array}$ & $\begin{array}{r}3,462,0 \\
0,0\end{array}$ & 929,000 & $\begin{array}{r}3,956,4 \\
0,0\end{array}$ & $24,460,40$ & $\begin{array}{r}2,296,0 \\
00\end{array}$ & 0 & 0 & 114,800 & $\begin{array}{r}2,410,8 \\
0,0\end{array}$ \\
\hline-1.00 & 0 & 0 & 0 & 0 & 0 & 0 & 0 & 0 & $\mathbf{0}$ & 0 \\
\hline-.2 .1 .0 & $9,627,000$ & $\begin{array}{r}2,193,0 \\
00\end{array}$ & 546,000 & $\begin{array}{r}2,959,4 \\
00\end{array}$ & $\begin{array}{r}15,325,40 \\
0\end{array}$ & $\begin{array}{r}1,204,0 \\
00\end{array}$ & 0 & 0 & 60,200 & $\begin{array}{r}1,264,2 \\
00\end{array}$ \\
\hline-.2 .2 .0 & $4,570,000$ & 800,000 & 249,000 & 745,100 & $6,364,100$ & 594,000 & 0 & $\overline{0}$ & 29,700 & 623,700 \\
\hline-2.3 .0 & $1, \$ 16,000$ & 469,000 & 134,000 & 251,900 & $2,770,900$ & 498,000 & 0 & 0 & 24,900 & 522,900 \\
\hline
\end{tabular}

\section{Cumency Units:_CF}

\section{B. Descriotion:}

Lithium Cooling System coosists of a main hithium loop, primary, secondary and tertiary heat removal system.

The Main lithium Loop which circulates the lithium to and from the target assernbly, removes the 10MW heal deposited by the deateron bearn. A single Jithium loop provides flow to either of the target assemblies in the two lest cells. A maximum $10 \%$ flow is provided to the imoperative target for decay heat removal. In the cost of main lithium loop, following components (WBS levet-6) are included : 1)EM pump, 2)Valves, 3)Flow meters, 4)Piping. 5)Quench tank, 6)Dump tank, 7)\$urge tank, 8)Trace beater, 9)Insulation, 10)Argon/vacuum system, 11)Instrumentation and 12) fithium pretial.

The Primary Heat Removal System is the organic oil loop, and transfers the heat from main lithium loop to water loop (secondary heat removal systern). In the cost of this system, I)Printary beat exchanger(lithiun to $O$ il), 2)Piping 3)Pump, 4)Valves, 5)Flow meters, 6)Organic tump tank, 7)Instrumentation, 8)Organic oil and 9)Organic heatter are included.

The Secondary Heat Removal System is the water kop, and transfers the heat to the open-air through the cooling tower (tertiary heat removal system). In the cost of this system, 1)Secondary heat exchanger(Oil to Water). 2)Piping 3)Punp, 4)Valves, 5)Flow meters and 6)Instrumentation are included.

The cost of the Tertiary Heat Removal System is to be estimated in conventional facility and is excluded from this sheet.

The nuclear grade design and materials are applied on the Majs lithium Loop systern and the Primary Heat Removal System.

\section{Detailed WRS Listing:}

2. 0.0 . 0 . Lithiun Cooling System

1. 0. 0. Assembly and Testing

1. 0. Assembly

2. 0. Testing

2. 0. 0 . Components

1. 0. Main lithium loop

2. 0. Primary Heat Removal System

3. 0. Secondary Heat Removal Systen

4. 0. Tertiary Heat Removal System (Water Cooling System) 
D. Costing Rationale:

Off-IFMIF Site :

(1) Cost of Industry Material / Labor :

a. Main lithium loop (WBS 3.2.2.2.1.0)

Following components (WBS level-6) are included :

1)EM pumap, 2) Valves, 3)Flow meters, 4)Piping, 5)Quench tank, 6)Domp tank,

7) Surge tank, 8)Trace heater, 9)Insulation, 10)Argon/vacoutn system.

11)Instrumsentation and 12)lithium metal

Type of Estimate : Bottoms-U $U_{P}$

b. Prímary Heat Removal System(WBS 3.2.2.2.2.0)

Following components (WBS level-6) are incladed :

1)Primaty heat exchanger, 2)Piping, 3)Pump, 4)Valves, 5)Flow meters, 6)Organic

dump tank, 7)Instrumentation. 8)Organic oil and 12)Organic heater

Type of Estimate : Bottoms-Up

c. Secondiny Heat Removal System(WBS 3.2.2.2,3,0)

Following componeuts (WBS level-6) are incluked :

1)Secondary heat exchanger, 2)Piping, 3)Pump, 4)Valves, 5)Flow meters and

6) Hnstrumentation

Type of Estimate : Bottoms-Up

(2) Cost of Industry Engitueering :

The cost of vendor provided design and inspection engitering for esch component is included.

a. Main lithium loop

Type of Estimate : Bottoms-Up

b. Primary Heat Removal System

Type of Estinlate : Bottons-Up

c. Secondary Heat Removal System

Type of Estimate : Bottoms-Up

(3) Cost of Institutional Engineeting :

The cost of manpower (engineering. labor and technician) provided by the rtsponsible institute for important components is included.

a. Main tithium loop

Type of Estimate : Bottonss-Up

b. Primary Heat Removal System

Type of Estimate : Bottons-Up

c. Secondary Heat Removal System

Type of Estimate : Bottomis- Up

On-Site at IFMIF :

(1) Cost of Construction Coutractor Material / Labor :

The cost of construction contractor provided installation labor and supervision,

and the cost of verification testing labot and support are included.

a. Maja lithium loop

Type of Estimate : Bottoms-Up

b. Primary Heat Removal System

Type of Estimate : Bottorns-Up

c. Secondary Heat Removal Sysiem

Type of Estinate : Bottoms-Up 
E. Detailed Costing:

Off-IFMIF Site :

(1) Industry Material / Labor

--. Contents of Industry Materja / Labor

a. Mais lithium loop

b. Primary Heat Removal System

c. Secondary Heat Removal System

(2) Industry Engineering

-.- Contents of Industry Engineering

a. Main lithium loop

b. Primary Heat Removal System

c. Secondary Heat Removal System

(3) Instizutional Engineering

- Conterts of Institutional Engineerang

a. Main lithium loop

b. Ptimary Heat Removal System

c. Secondary Heat Removal System

(4) AFI

-- Contents of AFI

a. Main lithium loop:

$50 \%$ of ((1)*(2)+(3)) for EM pump, 30\% for the else lithium components and $10 \%$ for the ocher

b. Primary Heat Removal System: $30 \%$ of $\{(1)+(2)+(3)\}$ for primary heat exchanger and $10 \%$ for the other

c. Secondary Heat Removal System: $10 \%$ of $((1)+(2)+(3))$

Subtotal

: $\quad 16,113,000$ ICF

$(9,627,000$ ICF)

$(4,570,0001 C \mathrm{CF})$

$(1,916,000$ ICF $)$

: $\quad 3,462,000$ ICF

$(2,193,000 \mathrm{ICF})$

$(800,000$ ICF $)$

$(469,000$ ICF)

$929,000 \mathrm{ICF}$

(546,000 ICF)

(249,000 ICF)

(134,000 ICF)

: $\quad 3,956,400 \mathrm{ICF}$

$(2,959,400 \mathrm{ICF})$

$(745,100$ ICF $)$

$(251,900$ ICF $)$

$24,460,400 \mathrm{ICF}$

On-Site at IFMIF :

(1) Construction Contractor Material / Labor - Contents of Const. Contractor Mativiab

a. Main líthium loop

b. Primary Heat Renoval System

c. Secondary Heat Removal System

(2) AFI : $5 \%$ of (1)

Subtotal

: $\quad 2,296,000$ ICF

$(1,204,000$ ICF $)$

(594,000 ICF)

$(498,000$ ICF $)$

$114,800 \mathrm{ICF}$

$2,410,800$ ICF

Total :

Total Estimated Capital Cost (TEC)

- Contents of TEC

a. Main tithium loop

b. Primary Heat Removal System

c. Secondary Heat Removal Systen

$26,871,200 \mathrm{ICF}$

$(16,589,600 \mathrm{ICF})$

$(6,987,800 \mathrm{ICF})$

$(3,293,800$ ICF $)$ 


\section{WBS 3.2 .3 Purification and Inpurity Mon'toring System}

\section{A. Summary Cost Estimate:}

\begin{tabular}{|c|c|c|c|c|c|c|c|c|c|c|}
\hline \multirow[b]{3}{*}{ WBS } & \multicolumn{5}{|c|}{ Off-IFMF Site } & \multicolumn{5}{|c|}{ On-Site at IFMIF } \\
\hline & \multicolumn{2}{|c|}{ Industry } & \multirow{2}{*}{\begin{tabular}{|c|} 
Instit" \\
Engiin
\end{tabular}} & \multirow[b]{2}{*}{ AFI } & \multirow[b]{2}{*}{ Total } & \multicolumn{2}{|c|}{$\begin{array}{c}\text { Const. } \\
\text { Contractor }\end{array}$} & \multirow{2}{*}{$\begin{array}{l}\text { Instit' } \\
\text { Eng̣in }\end{array}$} & \multirow[b]{2}{*}{ AFI } & \multirow[b]{2}{*}{ Total } \\
\hline & $\begin{array}{c}\text { Mat'V' } \\
\text { Lab }\end{array}$ & Engin & & & & $\begin{array}{l}\text { Mat'y } \\
\text { Lab }\end{array}$ & Engin & & & \\
\hline 3.2 .3 & $7,234,0,0)$ & $\begin{array}{r}2,154,0 \\
00\end{array}$ & $\begin{array}{r}1,051,00 \\
0,0\end{array}$ & $\begin{array}{r}3,791,7 \\
00\end{array}$ & $\begin{array}{r}14,230,70 \\
0\end{array}$ & 866,000 & $\mathbf{0}$ & 9 & 43,300 & 909,300 \\
\hline$-.1,0.0$ & 0 & $\mathbf{0}$ & 0 & 0 & 0 & 0 & 0 & 0 & 0 & 0 \\
\hline-.2 .1 .0 & $5,405,000$ & $\begin{array}{r}1,846,0 \\
00\end{array}$ & 573,000 & $\begin{array}{r}2,648,6 \\
00\end{array}$ & $\begin{array}{r}10,472,60 \\
0\end{array}$ & 625,000 & 0 & 0 & 31,250 & 656,250 \\
\hline-2.20 & $1,829,000$ & 308,000 & 478,000 & $\begin{array}{r}, 143,1 \\
00\end{array}$ & $3,758,100$ & 241,000 & 0 & $\overline{0}$ & 12,050 & 253,050 \\
\hline
\end{tabular}

\section{Cumency Units: ICF}

\section{B. Description:}

The Purification and Impurity Monitoring System consists of two main sections.

One is to purify the impurities (Hydrogen isotopes, Oxygen, Nitrogen, Berilliium-7) by using the Cold Trap and two kind of Hot Traps.

The other is the on-line and off-line monitoring system to detect these impunity levels. The on-line meters inchude the Hydrogen meter, Oxygen meter, Nitrogen meter and lithitus resistivity monitor. However, the study and development are necesssry for the meters except for Hydrogen meter. It is assumed that these costs are same as that of the Hydrogen meter.

For each composents included in the purification and impurity monitoring system, two are set up for the redundancy. The nuclesr grade design and materials are applied on all of the purification and impurity monitoring components.

\section{Detrited WBS Listing:}

3. 0. 0. 0. Lithưn Parification and Impurity Motitoring System

1. 0. 0. Assembly and Testing

1. 0. Assembly

2. 0 . Testing

2. 0. 0. Components

1. 0. Lithium Purification System

2. 0. Impurity Monitoring System 


\section{Costing Rationale:}

\section{Off-IFMIF Site :}

(1) Cost of Incustry Material and Labor :

a. Lithitum Purification System (WBS 3.2.3.2.1.0)

Following components (WBS kvel-6) are included :

1)Coid Trap, 2)Hot Trap f1 (Yutrum Getter), 3) Hot Trap \#2 (Titanium Getter),

4)EM Pump, 5)Cold trap cooker (Argon gas cooling system), 6)Piping, 7) Valves,

8)T Tace heater, 9)Insulation, 10)Irstrumentation, 11)Radiation Shielding (for Cold

Trap), 12)Finow meters and 13)Economizat

Type of Estimate : Bottoms-Up

b. Inpurity Monitoring System(WBS 3.2.3.2.2.0)

Following components (WBS level-6) are included :

1)On-line meters, 2)Off-line monitors, 3)Flow meters, 4)Piping, 5)Economizer and 6)EM pump

The cost of valves of the impurity monitoring system is included in that of the Lithium purification system.

Type of Escimate : Bottons-Up

(2) Cost of Industry Engineering :

The cost of vendor provided design and inspection emgineering for each component is included.

a. Lithium Purification System

Type of Estimate : Bottoms-Up

b. Impurity Monitoring System

Type of Estimate : Bottoms-Up

(3) Cost of Institutional Engineering:

The cost of manpower (engineering, labor and technician) provided by the responsible institute for important components is included.

a. Lithium Purification System

Type of Estimate : Bottoms-Up

b. Impurity Monitoring System

Type of Estimate : Bottoms-Up

\section{On-Site at FMIF :}

(1) Cost of Construction Contractor Material and Labor:

The cost of cossmuction contractor ptovided installation labor and supervision, and the cost of verification testing labor and support are included.

a. Lithiums Purification System

Type of Estimate : Bottoms-Up

b. Impurity Monitoring System

Type of Estimale : Bottoms-Up 
E. Detailed Costing:

Off-IFMIF Site :

(1) Industry Material / Labor

- Contents of Industry Material / Labor

a. Lithium Purification System

b. Impurity Monitoring Systems

(2) Incustry Engineering

- Contents of Industry Engineering

a. Lithium Purification System

b. Impurity Monitaring System

(3) Institutional Engineering

-m- Contents of Institutional Engineering

a. Lithium Purifiestion System

b. Inpantity Monitoriag System

(4) AFI

- Contents of AFI

a. Lithium Purification System:

So\% of $((1)+(2)+(3))$ for Cold / Hot Traps,

$30 \%$ for the else lithium components and

$10 \%$ for the other

b. Impurity Monitoring System:

$50 \%$ of $((1)+(2)+(3))$ for on-line monitors and $30 \%$ for the etse lithium comporents

Subtoifl

\author{
$: \quad 7,234,000$ ICF \\ $(5,405,0001 C F)$ \\ $(1,829,0001 \mathrm{CF})$ \\ : $\quad 2,154,000 \mathrm{ICF}$ \\ $(1,846,000$ ICF $)$ \\ (308,000 ICF) \\ : $\quad 1,051,000 \mathrm{ICF}$ \\ $(573,000 \mathrm{ICF})$ \\ $(478,000 \mathrm{ICF})$ \\ $: \quad 3,791,700$ ICF \\ $(2,648,600 \mathrm{ICF})$ \\ $(1,143,100 \mathrm{ICF})$ \\ $\therefore \quad 14,230,700 \mathrm{ICF}$
}

Op-Site at IFMIF :

(1) Construction Contractor Material / Labor

-. Contents of Const Contractor Math/Lab

a. Lithium Purifictition System

b. Impurity Monitoring Systern

(2) AFI : $5 \%$ of (1)

Subtotal

: $\quad 866,000$ ICF

(625,000 ICF)

(241,000 ICF)

43,300 ICF

$909,300 \mathrm{ICF}$

Total :

Total Estumated Copital Cost (TEC)

- Contents of TEC

a. Lithium Putification System

b. Impurity Monitoring System

$(11,128,850 \mathrm{ICF})$

$(4,011,150 \mathrm{ICF})$ 
WORKSHECT

3. 2.4 .

WBS 3.2.4 Luhium recovery System

\section{A. Summary Cost Estimate:}

\begin{tabular}{|c|c|c|c|c|c|c|c|c|c|}
\hline \multicolumn{5}{|c|}{ Off-IFMIF Sits } & \multicolumn{5}{|c|}{ On-Site at IFMIIF } \\
\hline Ind & & Instit' & & & $\begin{array}{r}\mathrm{Co} \\
\mathrm{Con} 1\end{array}$ & $\begin{array}{l}\text { st. } \\
\text { ator }\end{array}$ & Instit' & & \\
\hline $\begin{array}{c}\text { Mat'lf } \\
\text { Lab }\end{array}$ & Engin & Engin & AFI & Total & $\begin{array}{c}\text { Mat }^{7} l f \\
\text { Lab }\end{array}$ & Engin & Engin & AFI & Total \\
\hline 10000 & 2,000 & 1000 & 6,500 & 19,500 & 0 & 0 & 0 & 0 & 0 \\
\hline
\end{tabular}

Chrincy Units: ICE

\section{B. Descripion:}

Lithium recovery System coosists of three sections - the leaked lithivm recovery system, the leaked lithium detectiog system and lithum tite control system. However, the study and development are necessary for the tecovery systetid and the fire control system. These eosts should be estimated in the next stage.

The cost of only the electric contact type leaked lithium detector is estimated in the present stage. The costs of on-site at IFMIF are not included, but are included in the piping of the main lithium loop (WBS 3.2.2.2.1.4),

\section{C.Detriled WBS Listing:}

4. 0. 0. 0. Lithum recovery Systen

1. 0. 0. Leaked lithium recovery System

2. 0. 0. Leaked lithisura Detection Systern

3. 0. 0. Lithium Fire Control System

\section{Costing Rationali::}

Off-IFMIF Site :

(i) Cost of Industry Material and Labor:

Cost of Industry region includes only the electric contact type leaked lithium dettectors

Type of Estimate : Bottoms-Up

(2) Cost of Industry Engineering :

The cost of vendor provided design and inspection enginesing for each component is inciuded.

Type of Estimate : Bottoms-Up

\section{E. Detriled Coxting:}

Off-IFMIIF Site :

(1) Industry Material / Labor

(2) Industry Engiosering

(3) Institutional Engineering: $50 \%$ of (2)

(4) AFI: $50 \%$ of $((1)+(2)+(3))$

Subtotal

Ou-Site at IFMIF: $\quad$ None 


\section{A. Summary Cost Estimate:}

\begin{tabular}{|c|c|c|c|c|c|c|c|c|c|}
\hline \multicolumn{5}{|c|}{ Off-IFMIF Site } & \multicolumn{5}{|c|}{ On-Site at IFMIF } \\
\hline lnd & stry & Instit' & & & $\begin{array}{r}\mathrm{Cc} \\
\mathrm{Con}\end{array}$ & st. & Instit" & & \\
\hline $\begin{array}{c}\text { Mat'1' } \\
\text { Lab }\end{array}$ & Engin & Engir & $\mathrm{AF}$ & Total & $\begin{array}{c}\text { Mat'l}^{+} / \\
\text {Lab }\end{array}$ & Engin & Engin & AfI & Total \\
\hline $\begin{array}{c}6,334,0 \\
00\end{array}$ & 915,000 & 18,300 & 726,730 & $7,994,030$ & $\begin{array}{c}1,039,0 \\
00\end{array}$ & 0 & 0 & 51,950 & $1,090,950$ \\
\hline
\end{tabular}

Chrrency Units: ICF

\section{B. Drescindion:}

All the funtion of the target facility are controlled by the Target Facility Control System which is linked with the Centrat Control System.

In the cost of the control system, following components are included: a)control systemr, b)ITV inspection system, c)control console of trace heaters

\section{C.Detailed WBS Listing:}

5. 0. 0.0 . Target Facility Control System

i. 0. 0. Nomal Operation Control System

2. 0. 0. Emergency Control System

\section{Costing Rationate:}

Off-IFMIF Site :

(1) Cost of Industry Material and Labor :

Type of Estimate : Bottoms-Up

(2) Cost of Industry Engineering:

The cost of vendor provioed design and inspoction engineering : $2.5 n-y$ and business trip

Type of Estimate : Bottoms-Up

On-Site at IFMIF :

(1) Cost of Construction Contractor Material and Labor :

The cost of construction contractor provided installation labor and supervision, and the cost of verification testing labor and support are included.

Type of Estimate : Bottoms-Up

\section{E Detailed Costing:}

Off-IFMIF Site:
(1) ind tustry Material / Labor
(2) Industry Engineering
(3) Instrtutional Engineering: $2 \%$ of (2)
(4) AFI: $10 \%$ of ((1)+(2)+(3))
Subtotel

$$
\begin{array}{r}
6,334,000 \text { ICF } \\
915,000 \text { ICF } \\
18,300 \text { ICF } \\
726,730 \text { ICF } \\
7994,030 \text { ICF }
\end{array}
$$

On-Site at IFMIF :

(1) Industry Material / Labor

(2) Industry Enginetring

(3) Institutional Engineering

(4) AFI: $5 \%$ of $((1)+(2)+(3))$

Subtotel

$$
\begin{array}{r}
1,039,000 \text { ICF } \\
0 \text { ICF } \\
0 \text { ICF } \\
51,950 \text { ICF } \\
1,090,950 \text { ICF }
\end{array}
$$

Total : 


\section{A. Summary Cost Estimate;}

\begin{tabular}{|c|c|c|c|c|c|c|c|c|c|}
\hline \multicolumn{5}{|c|}{ Off-IFMIF Site } & \multicolumn{5}{|c|}{ On-Site at IFMIF } \\
\hline Ind & stry & Instit' & & & $\begin{array}{r}\mathrm{C} \\
\mathrm{Con}\end{array}$ & st. & Instit $^{+}$ & & \\
\hline $\begin{array}{c}\operatorname{Mat}^{t} 11 \\
\text { Lab }\end{array}$ & Engin & Engin & AFI & Total & $\begin{array}{c}\text { Mat'l } \\
\text { Lab }\end{array}$ & Engin & Engin & AFI & Tatal \\
\hline $\begin{array}{c}6,291,0 \\
00\end{array}$ & 629,100 & 2,582 & $\begin{array}{c}1,519,3 \\
27\end{array}$ & $8,452,009$ & 0 & 0 & 0 & 0 & 0 \\
\hline
\end{tabular}

\section{Curency Units: ICE}

\section{B. Desseriotian:}

Target Facflity Ventilation System consists of two sections.

One is the lithium loop ventilation system which tirculates an Argop gas inside of argon boundaries at each rooms including the lithium components. At the emergency events, this circulation system is stopped and the argon boundaries are enclosed to prevent leakage of lithum mist.

The other is the cooling loop ventilation system. This is an ordinary ventilation system which ventilate a fresh dry-air.

The on-site costs are excluded from the present cost estimanions.

\section{Detailed WBS Listing:}

6. 0. 0. 0. Target Facility Ventilation System

1. 0. 0. Radioactive Gas Evacuation System

1. 0. Tritiom Treatment Facility

2. 0. Other Radioisotope Treatment Facility

2. 0. D. General Ventilation System

\section{Costing Rationale:}

Off-IFMFF Site :

(1) Cost of Industry Material / Labor :

a. Cost of the lithium loop ventilation system (Argon gas circulation system)

Type of Estimate : Bottoms-Up

b. Cost of the Cooling loop ventilation systern (Dry-Air Ventilation system)

Type of Estimate : Bottoms-Up

(2) Cost of Industry Engineering:

The cost of vendor provided design and inspection engineering for each compopent is included.

Type of Estimate : Bottoms-Up

\section{E. Detailes Costins:}

\section{Off-IFMIIF Site :}

(1) Industry Mzterial / Labor

- Contents of Industry Material / Labor

a. Lithium loop ventilation system (Argon gas)

b. Cooling loop ventilation system (Dry-Air)

(2) Industry Engineering

-. Contents of Industry Material / Labor

a. Líthium loop ventilation system

b. Cooling loop ventilation system

(3) Institutional Engintering : $2 \%$ of (2)

- Contents of Industry Marerial / Labor

a. Lithium loop ventilation system,

b. Cooling loop ventilation system

$\begin{array}{lc}: & 6,29 \mathrm{i}, 000 \mathrm{ICF} \\ & (3,748,000 \mathrm{ICF}) \\ & (2,543,000 \mathrm{ICF}) \\ & 629,100 \mathrm{ICF} \\ & (374,800 \mathrm{ICF}) \\ & (254,300 \mathrm{ICF}) \\ & 12,582 \mathrm{ICF} \\ & (7,496 \mathrm{ICF}) \\ & (5,086 \mathrm{ICF})\end{array}$


(4) AFI :

- Contents of Industry Material / Labor

a. Lithitm loop ventilation system:

30 of $((1)+(2)+(3))$

b. Cooling loop ventilation system: $10 \%$ of $((t)+(2)+(3)\}$

Subtotal
: $\quad 1,519,327$ ICF

$(1,239,088 \mathrm{ICF})$

(280,239 FCF)

: $\quad 8,452,009$ ICF

Dn-Site at IFMIF : $\quad$ None 
WBS 3.2.7 Maintenance System

\section{A. Sunfnary Cost Estiparte:}

\begin{tabular}{|c|c|c|c|c|c|c|c|c|c|}
\hline \multicolumn{5}{|c|}{ Off-IFMIF Site } & \multicolumn{5}{|c|}{ On-Site at IFMIF } \\
\hline Indu & & Instit* & & & Con & st. & Instit' & & \\
\hline $\begin{array}{c}\text { Mat'y } \\
\text { Lab }\end{array}$ & Engin & Engin & AFI & Total & $\begin{array}{c}\text { Mat'll } \\
\text { Lab }\end{array}$ & Eagin & Engin & AFI & Total \\
\hline $\begin{array}{c}14,058,00 \\
0\end{array}$ & $\begin{array}{c}4,058,0 \\
00\end{array}$ & $\$ 1,160$ & $\begin{array}{c}9,098,5 \\
80\end{array}$ & $\begin{array}{c}27,255,74 \\
0\end{array}$ & 0 & $\mathbf{0}$ & 0 & 0 & 0 \\
\hline
\end{tabular}

\section{Cumency Units: ICF}

\section{B. Drscription:}

The costs of Remote Handing Equipment for Target Assembly and for Purification Elements (Cold Traps and Yttrium Hot Traps) are estimated. Following components are provided in both remote handling equipment : a)Power Manjpulator, b)Crane, c)YAG laser system, d)Impact wrench e)Welding and Cutting System and f) ITV Monitors.

The costs of Mockup Facilities and Testing are excluded in the present stage.

\section{Detaikd WBS.Listing:}

7. 0. 0. 0. Maintenarice System

1. 0. 0. Maimtebenoe Procedure Development

2. 0. 0 . Special Purpose Tooling

3. 0. 0. Remote Handling Equipment

4. D. o. Mockup Facilities and Testing

\section{Costing Rationals:}

Off-IFMIF Site :

(1) Cost of Industry Matcrial / Labor :

Type of Estimate : Bottorrs-Up

(2) Cost of Industry Engineering :
a) Rasic planning design $24 \mathrm{~m}$-month,
b) Remote Handling Equipment Design $20 \%$ of a),
c) Regulation in Factory 6m-Inonth.
d) Business trip
Type of Estimate : Bottoms-Up

\section{E.Detailed Costing:}

Off-IFMIF Site :

(1) Industry Materia / Labor

(2) Industry Engineering

(3) Institutional Engineering : $2 \%$ of (2)

(4) AFI : $50 \%$ of $\{(1)+(2)+(3))$ Subtotal

$$
\begin{array}{r}
14,058,000 \mathrm{ICF} \\
4,058,000 \mathrm{ICF} \\
81,160 \mathrm{ICF} \\
9,098,580 \mathrm{ICF} \\
27,295,740 \mathrm{ICF}
\end{array}
$$

On-Site at IFMIIF : None 
WORKSHEET

3. 3. 1 .

WBS 3.3.0 System Installation and Checkout

WBS 3.3.1 Installation

\section{A. Summary Cost Estimate:}

\begin{tabular}{|c|c|c|c|c|c|c|c|c|c|}
\hline \multicolumn{5}{|c|}{ Off-IFMIF Site } & \multicolumn{5}{|c|}{ Oa-Site at IFMF } \\
\hline \multicolumn{2}{|c|}{ Industry } & \multirow{2}{*}{$\begin{array}{l}\text { Instit' } \\
\text { Engin }\end{array}$} & \multirow[b]{2}{*}{ AFI } & \multirow[b]{2}{*}{ Total } & \multicolumn{2}{|c|}{$\begin{array}{c}\text { Consi. } \\
\text { Contractor }\end{array}$} & \multirow{2}{*}{$\begin{array}{l}\text { Instit" } \\
\text { Engiin }\end{array}$} & \multirow[b]{2}{*}{ AFI } & \multirow[b]{2}{*}{ Total } \\
\hline $\begin{array}{c}\text { Mat"t } \\
\text { Lab }\end{array}$ & Engin & & & & $\begin{array}{c}\text { Mat'V' } \\
\text { Lab }\end{array}$ & Engin & & & \\
\hline 0 & 553,000 & 11,060 & $\begin{array}{c}56,40 \\
6\end{array}$ & 620,466 & $6,267,000$ & $\begin{array}{c}2,801,0 \\
00\end{array}$ & 56,020 & 456,201 & $9,580,221$ \\
\hline
\end{tabular}

\section{Cuтency Units: ICE}

\section{B. Desigiption:}

The installation and the building construction are simultancously put into practice. The heavy components are previonusly brought into the under floor before the upper floor is closed.

\section{Detailed WBS Listing:}

1. 0. 0. 0. Installation

1. 0.0 . Lithium Target System

2. 0. 0 . Lithium Cooling system

3. 0. 0 . Lithium recovery System

4. 0. 0. Terget Facility Control System

5. 0. 0 . Target Facility Ventilation System

6. 0. 0. Target Facility Power Systern

7. 0. 0. Other Support Pacilities

8. 0. 0. Maintenance System

\section{Costing Rationale:}

\section{Off-IFMIF Site :}

(1) Cost of Industry Engineering :

Labor cost for the installation schedule and artangements for the installation machioe parts : $3 \mathrm{~m}-\mathrm{y}$

Type of Estimate : Bottoms-Lp

On-Site at LFMF:

(1) Cost of Construction Contractor Material / Laber :

Following items are included :

a) Installation Labor

b) Labor cost for the indirect works of the offtee head, installation mangger and technical director,

c) Cost for temporary crane and office.

d) Insurance fee and expenses.

Type of Estimate : Bottons-Up

(2) Cost of Construction Contractor Engineering:

Labor cost for the on-site design engineers.

Type of Estínate : Bottons- Up

\section{E. Detailed Costing:}

Off-IFMIIF Site :

(t) Industry Material / Labor

(2) Industry Engineering

(3) Institutional Engineering: $2 \%$ of (2)

(4) AFI: $10 \%$ of $((1)+(2)+(3))$

Subtotal 
On-Site at IFMIF :

(3) Industry Material / Labor

(2) Industry Enginering

(3) Enstitutional Eugineermig: 20 of (2)

(4) AFI: $5 \%$ of $((1)+(2)+(3)$ )

Subtotal

$\begin{array}{rr}: & 6,267,000 \mathrm{ICF} \\ : & 2,801,000 \mathrm{ICF} \\ : & 56,020 \mathrm{ICF} \\ : & 456,201 \mathrm{ICF} \\ : & 9,580,221 \mathrm{ICF}\end{array}$

Total :

Total Estimated Capital Cost (TEC)

$\quad 10,200,687 \mathrm{ICF}$ 


\section{A Summanz Cost Estimate:}

\begin{tabular}{|c|c|c|c|c|c|c|c|c|c|}
\hline \multicolumn{4}{|c|}{ Off-IFMIF Site } & \multicolumn{5}{c|}{ On-Site at IFMIF } \\
\hline \multicolumn{2}{|c|}{ Industry } & Instit' & & \multicolumn{2}{c|}{$\begin{array}{c}\text { Const. } \\
\text { Contractor }\end{array}$} & Instit' & \\
\hline $\begin{array}{c}\text { Mat'y } \\
\text { Lab }\end{array}$ & Engio & Engin & AFI & Total & $\begin{array}{c}\text { Mat'V } \\
\text { Lab }\end{array}$ & Engin & Engí & AFI & Total \\
\hline 0 & 181,000 & 3,620 & 9,231 & 193,851 & 291,000 & 291,000 & 5,820 & 29,391 & 617,211 \\
\hline
\end{tabular}

\section{Cnorency Units:ICF}

\section{B. Description:}

This iten includes following costs:
a) The planning of the various regulation tests such as the position measurement of piping, components and operation test of each component after the installation is completed (Off-Site).
b) The on-site design and training (On-site Engineering) and On-site Labor (Mat/Lab). Boht labor costs of (2) and (3) were averaged and the same unit cost was applied.

\section{Devailed WRS Listint:}

2. 0. 0. 0 . Verification Testing

\section{Costing Rationate:}

Off-IFMIF Site :

(1) Cost of Industry Engiomering :

Planning for the regulation and testing: 12m-month

Type of Estinate : Bottoms-Up

On-Site at IFMIF :

(1) Cost of Construction Contractor Material / Labor :

Works for the regulation and testing: $20 \mathrm{~mm}-\mathrm{mronth}$

Type of Estimate : Bottoms-Up

(2) Cost of Construction Contractor Engineering :

On-Site design: 20m-month

Type of Estimate : Bottoms-Up

\section{E. Desailed Casting:}

Off-IFMIF Site :

(1) Inidustry Material / Labor

(2) Industry Engineering

(3) Institutional Engineting: 2\% of (2)

(4) AFI: 5 क of $((1)+(2)+(3))$

Subtotal

$\begin{array}{rr}: & 0 \mathrm{ICF} \\ \vdots & 181,000 \mathrm{ICF} \\ \vdots & 3,620 \mathrm{ICF} \\ \vdots & 9,231 \mathrm{ICF} \\ : & 193,851 \mathrm{ICF}\end{array}$

On-Site at IFMIF :

(1) Industry Materisal / Labor

(2) Industry Enginetring

(3) Institutional Engineering: $2 \%$ of (2)

(4) AFI: 5 \% of $((1)+(2)+(3))$

Subtotal

$$
\begin{array}{r}
291,000 \text { ICF } \\
291,000 \text { ICF } \\
5,820 \text { ICF } \\
29,391 \text { ICF } \\
617,211 \text { ICF }
\end{array}
$$

Total : 


\section{A. Summerar Cost. Estimatt:}

\begin{tabular}{|c|c|c|c|c|c|c|c|c|c|}
\hline \multicolumn{5}{|c|}{ Off-FMIIF Site } & \multicolumn{5}{|c|}{ On-Site at IFMIF } \\
\hline & stry & Instir" & & & $\underset{\mathrm{Con}}{\mathrm{C}}$ & & Instit $^{t}$ & & \\
\hline $\begin{array}{c}\text { Mat'l' } \\
\text { Lab }\end{array}$ & Engin & Engin & AFI & Total & $\begin{array}{c}\text { Mat'l } \\
\text { Lab }\end{array}$ & Engin & Engin & AFI & Total \\
\hline 0 & 372,000 & 7,440 & $\begin{array}{c}18,97 \\
2\end{array}$ & 398,412 & 581,000 & 915,000 & 18,300 & 75,715 & $1,590,015$ \\
\hline
\end{tabular}

\section{Cumency Units:ICE}

\section{B. Description:}

This item includes following costs:

a) The planning of the target system test operation (Off-\$ite).

b) The on-site design and training (On-site Engineering) and On-site Labor (MatLab). Both labor costs were averaged and the sane unit cost was appliend.

C. Detailed WBS Listing:

3. 0. 0.0 . Startup

\section{Costing Rationale:}

Off-IFMIF Site :

(1) Cost of Industry Engineering:

The planaing of the target systent test operation: 24m-month Type of Estimate : Bottons-Up

On-Site at IFMIF :

(1) Cost of Construction Contractor Material / Laboo :

On-Site Labor : 40m-month

Type of Estimiate : Bottoms-Ufp

(2) Cost of Construction Contractor Enginering

The on-site design and training : $60 \mathrm{~m}-\mathrm{month}$

Type of Estinate : Bottoms-Up

\section{E. Detailed Costing:}

Off-IFMIF Site :

(t) Industry Material / Labor

(2) Industry Engineering

(3) Institutional Enginetring: $2 \%$ of (2)

(4) API: $\$ \%$ of $((1)+(2)+(3))$

Subtotal

OICF

372,000 ICF

7,440 ICF

18.972 ICF

398.412 ICF

On-Site at IFMIF :

(1) Industry Material / Labor

(2) Industry Engineering

(3) Institutional Engineering: 2\% of (2)

(4) AFI: $5 \%$ of $((1)+(2)+(3))$

Subtotal

581,000 ICF

915,000 ICF

18,300 ICF

$75,715 \mathrm{ICF}$

$1,590,015 \mathrm{ICF}$

Total :

Total Estimated Capital Cost (TEC)

$1,988,427$ ICF 


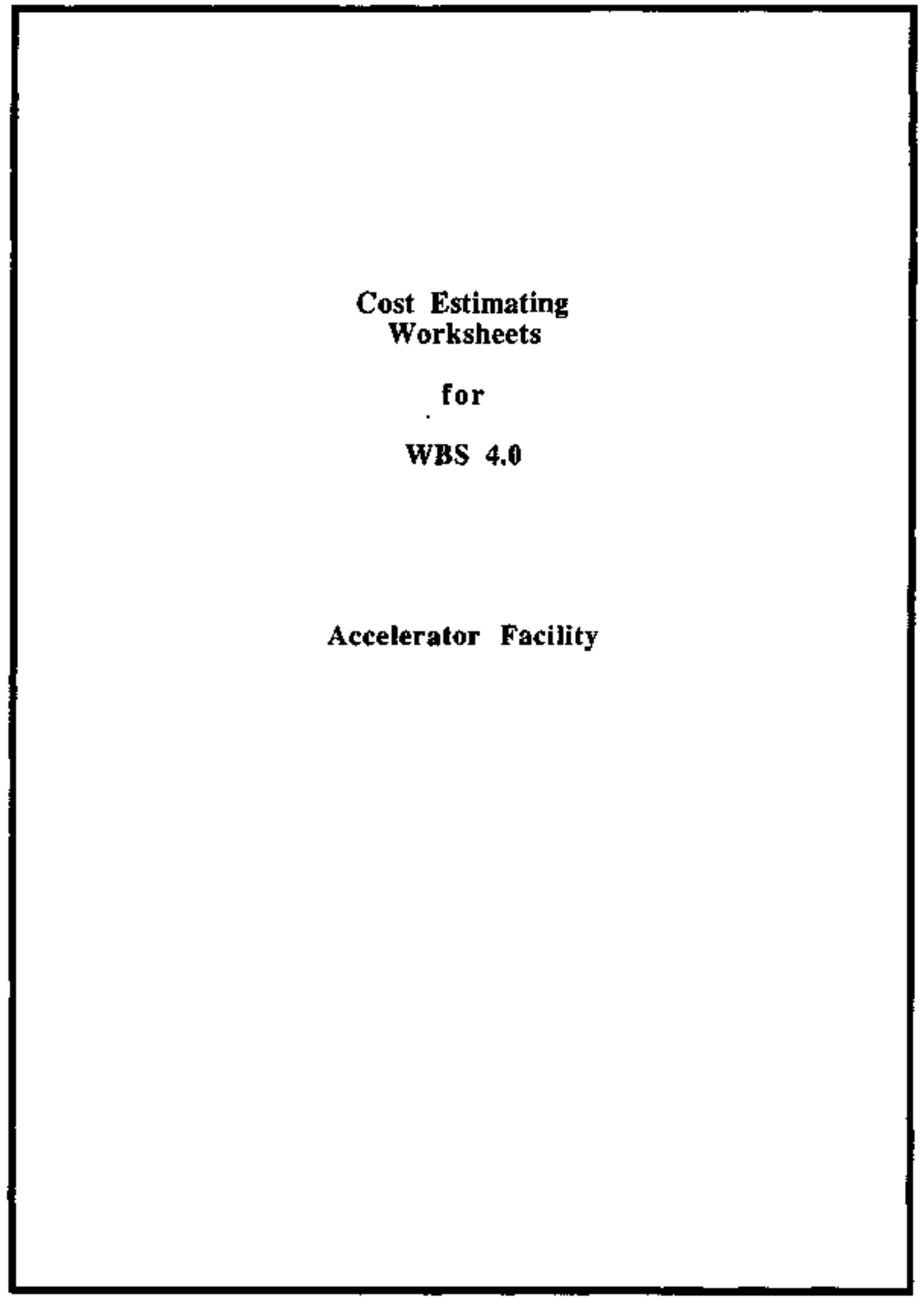




\section{IFMIF Accelerator Equipment Cost Summary:}

\section{Introduction:}

This section contains material that might be useful in the introductory sections before the basis of estimate sheets. This introductory section contains the following:

- An accelerator master schedule derived from the IFMIF program master schedule

- A list of major assumptions

- A Summary Table of Accelerator Costs

- A brief listing of what effort is contained in each part of the cost estimate.

This document is intended to be used in conjunction with the interim CDA report and the design update information generated at the last workshop (held at JAERI, Tokai, Japan). No tunnel or RF hall costs are reported here, only accelerating equipment. The costs for the development program (WBS 4.4), for the period $1997-2000$, are defined by the report at Tokai and are included here for completeness.

\section{Master Schedule:}

The cost estimate for the IFMIF program covers the period after the close of the CDA activities through the point where a facility based on two $125 \mathrm{~mA}$ deuteron accelerators, capable of supplying particles at $40 \mathrm{MeV}$, is commissioned. Preliminary design is scheduled for 2000 , with six years required to complete the design, eventualiy fabricating, installing, and checking out and commissioning the equipment. The top level schedule covering this period is shown below (lower level schedules for each accelerator individually are included at the close of this section):

|


Major Assumptions used in compiling cost estimates _:

- All technology feasibility issues resolved prior to preliminary design

- Costs complied without a separate milestone to commit funds for the second accelerator

- 1996 costs reported, $8 \%$ fee added

- Single shift operation (147 man-hours per man-month)

- Five labor grades considered

Program management:

Pbysics support:

$\$ 150 / \mathrm{hr}$

Engineering (all disciplines): $\quad \$ 100 / \mathrm{hr}$

Technician:

Craft:

$\$ 82 / \mathrm{hr}$

$\$ 25 / \mathrm{hr}$

- $15 \%$ premium pay for work at IFMIF site

- Electric rate for installation and checkout: $\$ 0.10 / \mathrm{kWe}$-hr

- Material costs based on vendor estimates, $10 \%$ reduction in material costs expected at negotiation

\section{Brief Explanation of WBS contents: -}

WBS 4.1 Accelerator Facility Management - employs the following type of organizational structure with varying amounts of personnel in each "box" dependent on the activities of the project.

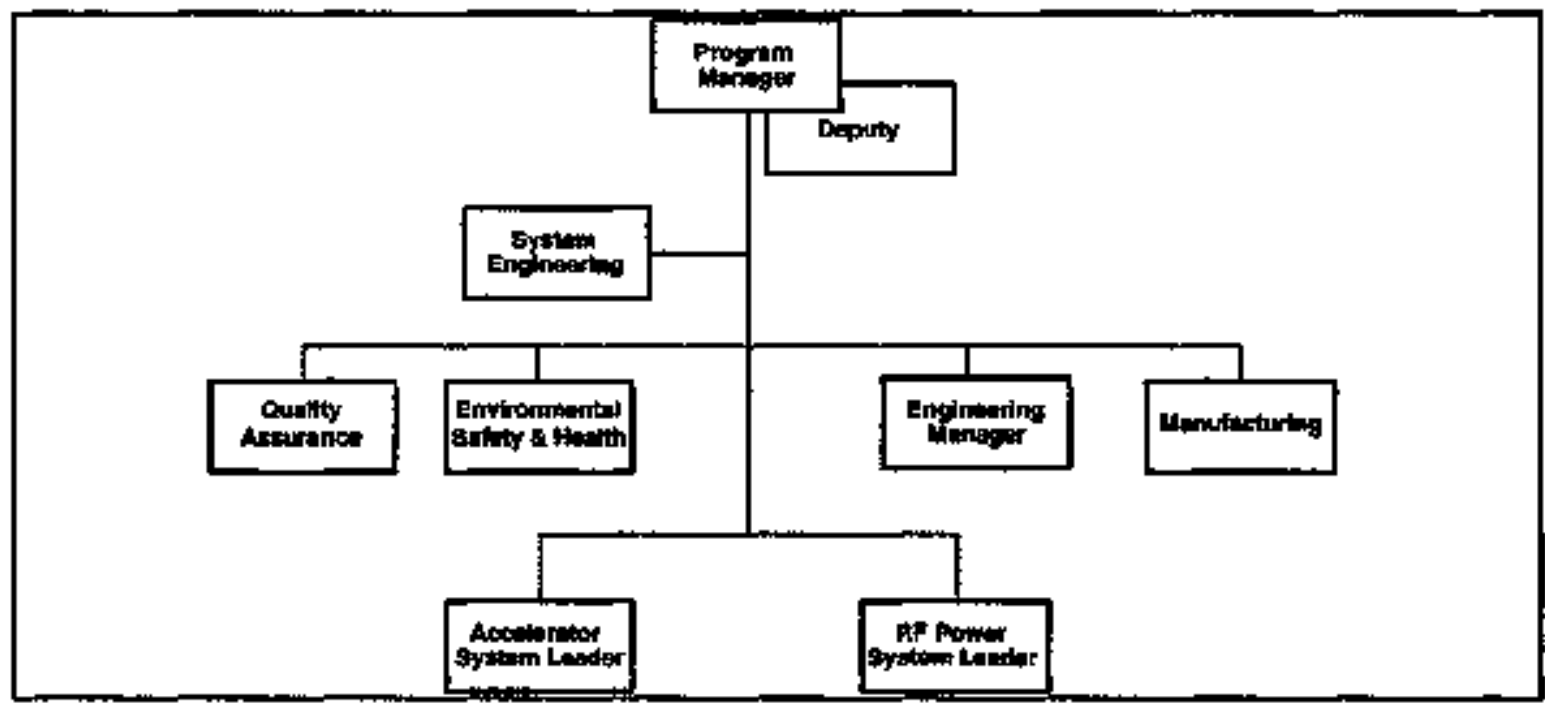

WBS 4.2 Subsystems - This section of the estimate contains all resources necessary to complete the design of the accelerator as well as fabricate and ship it to the IFMIF site. Implicit in the estimate is a plan where most accelerator components are developed, and operationally checked aut, in the US then shipped to the IFMIF site for final assembly. Further, all the nonrecurring costs associated with developing the equipment is book kept against the first accelerator. Examples of these are the final design engineering activities and "cold model" test program for the RFQ and DTL portions of the 
accelerator. The second accelerator estimate contains only the recurring costs associated with producing the second accelerator. Further the material costs are based on a purchase of enough equipment for two accelerators. This allows, in some cases, a better overall unit price because of the larger purchase. The only possible exception is a small allocation in the second accelerator WBS elements to incorporate design upgrades uncovered in completing the first accelerator. Lastly, the first accelerator estimate contains costs attributable to the fixed and moveable diagnostic beam dumps.

WBS 4.3 Subsystem Installation and Checkout - The estimates reflect the staged manner in which the accelerators will be brought on line. Basically for each accelerator, injector operation will be verified first, followed by the RFQ then the first DTL tank. After which, DTL tanks 2 - 8 will be installed and operation verified. Next the beam will be passed through the HEBT, tuned, then to the lithium targets when ready. Starting in parallel with the first accelerator injector effort is an RF test stand which will operate a test tube CW as long as possible to begin building a operational database on the tubes.

The major activity linking the two accelerators is RF power installiation and checkout. The current plan is to maintain an constant rate of RF station installation and checkout. When the work on the first accelerator RF power system is completed, crews will focus on the RF power system for the second accelerator. Accelerator equipment installation will be paced to match this flow.

\section{Summary of Relevant Experience:}

- Beam Experiment Aboard Rocket - BEAR: where Northrop Grumman delivered an Radio Frequency Quadrupole, its power supply, and the external skin for the launch device.

- Ramped Gradient Drift Tube Linac - RGDTL: A program where Northrop Grumman completed the design and eventually fabricated one complete accelerating tank to Los Alamos National Laboratory specification.

- Continuous Wave Deuterium Demonstrator - CWDD: a cryogenic accelerator where Northrop Grumman was the accelerator prime manufacturer responsible for delivering the entire accelerator system.

- Ground Test Accelerator - GrA: a ground based high power accelerator program used as a test bed for space based strategtc defense initiative concepts where Northrop Grumman was selected as the accelerator industrial support contractor.

- Relativistic Heavy Ion Colider - RHIC. a collider program where Northrop Grumman was selected as the manufacturer of the long superconducting main dipole magnets.

- Compact Infra Red Free Electron Laser - CIRFEL: a program where Northrop Grumman has developed a compact FEL for industrial and university use.

- ASR-9 and ARSR-4 commercial radar systems a ground based radar system for airport surveillance for commercial aircraft.

- VHF $14 \mathrm{~kW}$ pulsed radar transmitter experiment airborne radar system built together with MIT and Lincoln labs 


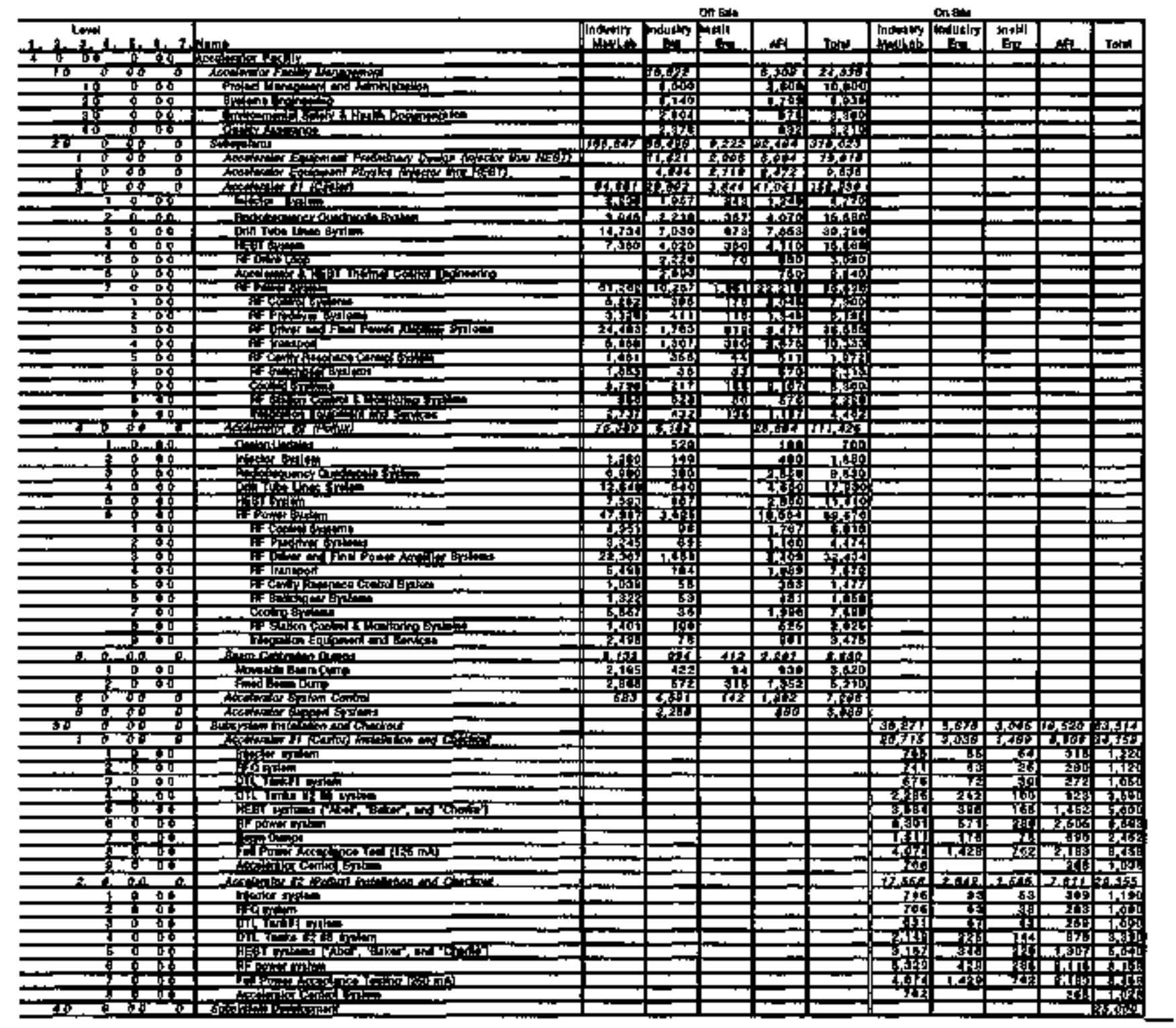

page - 4 


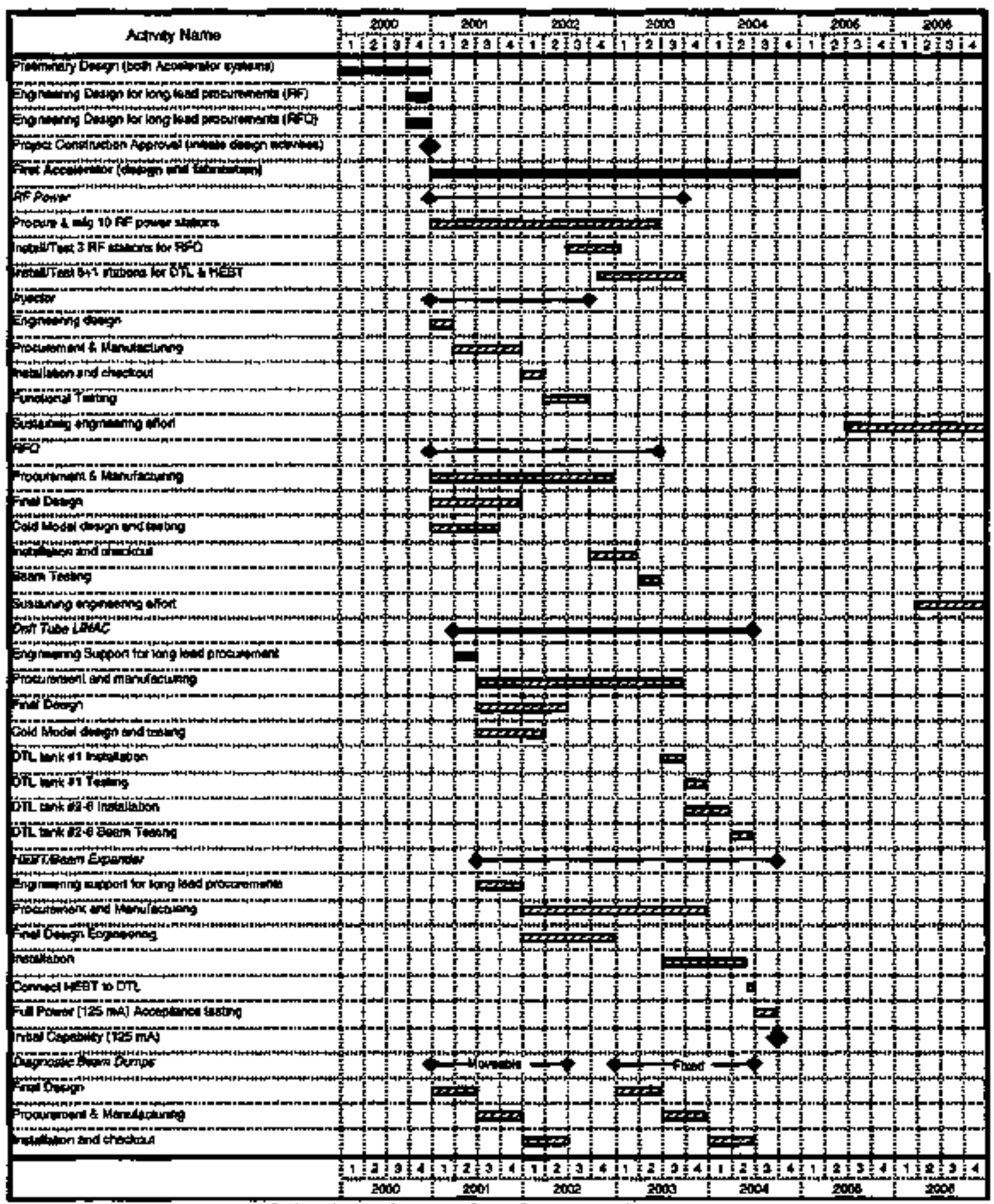

Schedule details for first accelerator 


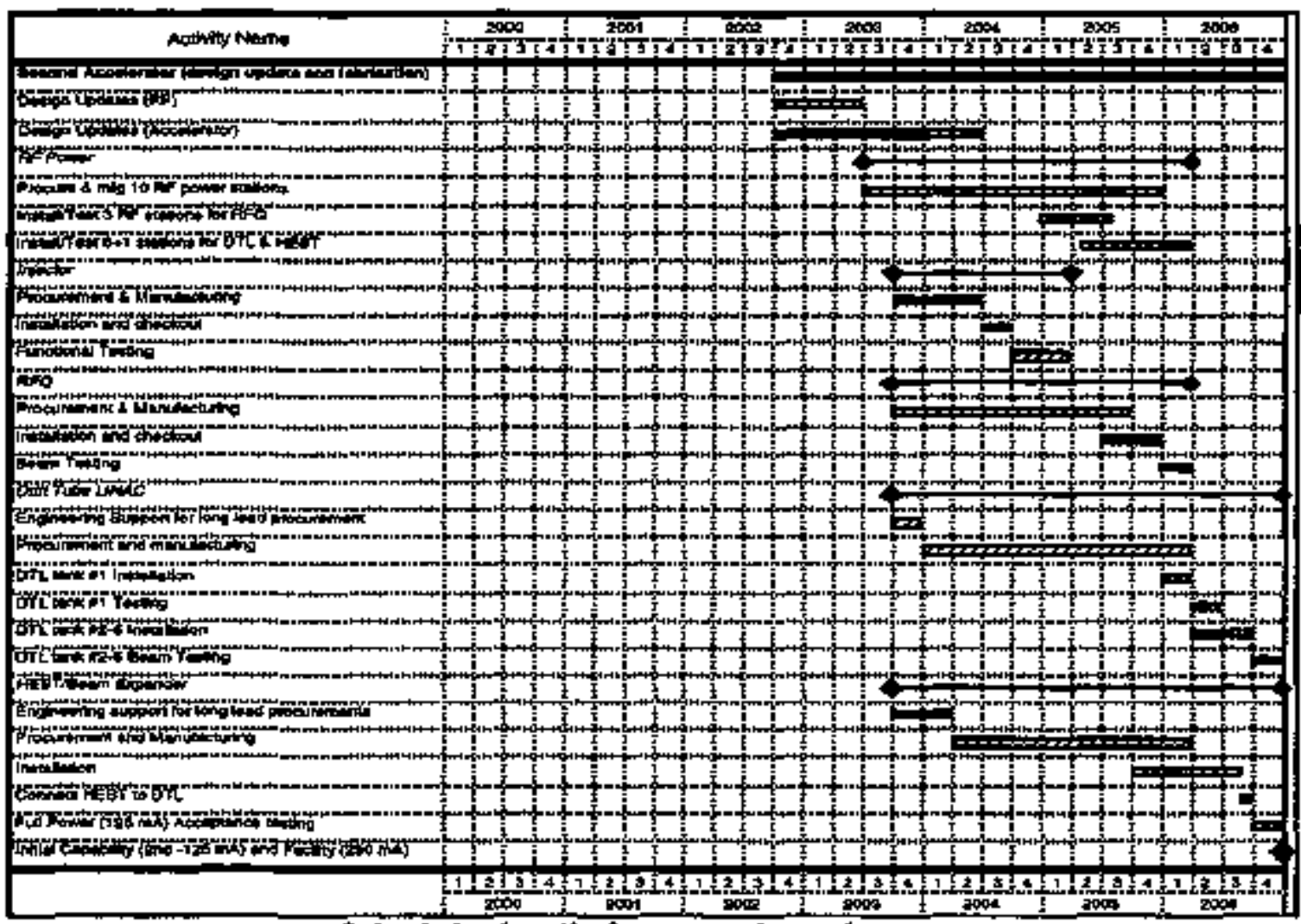

Schedule details for second accelerator 
WORKSHEET

WBS 4.1 Accelerator Facility Management

\section{A. Sumnary Cost Estimate:}

\begin{tabular}{|c|c|c|c|c|c|c|}
\hline \multicolumn{3}{|c|}{ Off-IFMF Site } & \multicolumn{4}{|c|}{ On-Site At IFMiF } \\
\hline Industry & Instit'al & & $\begin{array}{c}\text { Const. } \\
\text { Contractor }\end{array}$ & Instita & & \\
\hline Mat'ULab Engin'g & Engin'g & AFI Total & Mat'Lab Engin'g & Engin'g & AFI & Total \\
\hline 18,022 & -- & $6,308 \quad 24,330$ & - & - & - & -- \\
\hline
\end{tabular}

Units: Kilo ICP

\section{B. Description:}

This WBS element contains estimates of the necessary resources to manage and coordinate the lower level tasks contained in the accelerator facility effort as well coordinate between the accelerator segment activities and the rest of the project. The functional disciplines included in this estimate, and their hierarchical relationship, ate shown in the figure below:

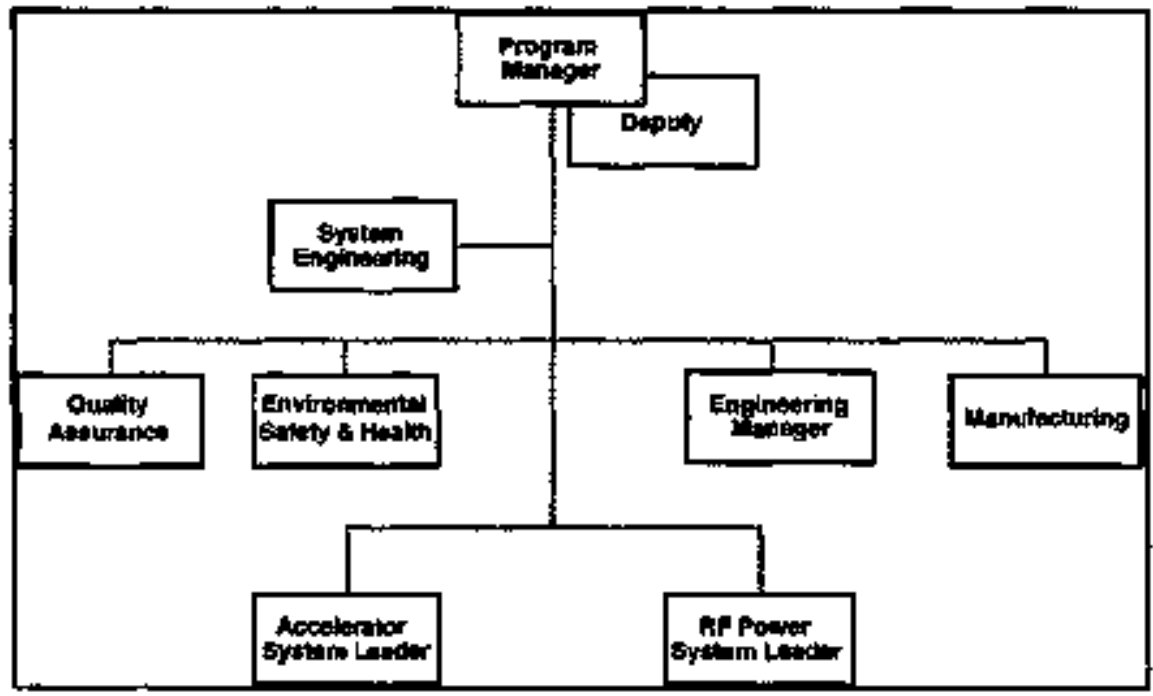

It should be understood that the quantity of individuals in each of these areas is proportional to the amount of activities underway at any one time. Further, for accounting purposes only, the deputy program manager, and the accelerator and RF system leaders are book kept under 4.1.1," Project Management and Administration" and, the Engineering Manager and Manufacturing resources are compiled in WBS 4.1.2," Systems Engineering." 


\section{Detailed WBS Listing: (without AFD)}

4.1.1: Project Management and Administration

Total

4.1.2: Systems Engineering

4.1.3: Environmental Safety \& Health

4.1.4: Quality Assurance

\section{Costing Rationale:}

The size and composition of the team required to perform the management of the accelerator segment, as well as provide coordination within the IFMIIF project, is based upon Northrop Grumman experience producing accelerator components on other programs. Some examples are:

- Beam Experiment Aboard Rocket - BEAR: where Northrop Grumman delivered an Radio Frequency Quadrupole, its power supply, and the external skin for the launch device.

- Continuous Wave Deuterium Demonstrator - CWDD: a cryogenic accelerator where Northrop Grumman was the accelerator prime manufacturer responsible for delivering the entire accelerator system.

- Grotand Test Accelerator - GTA: a ground based high power accelerator program used as a test bed for space based strategic defense initiative concepts where Northrop Grumman was selected as the accelerator industrial support contractor.

- Relativistic Heavy Ion Collider - RHIC a collider program where Northrop Grumman was selected as the manufacturer of the long superconducting majn dipole magnets.

Type of Estimate: Scaling from experience

Allowance for Indeterminates: $35 \%$ based on technical risk

\section{E. Detailed Costing:}

This WBS element details only labor charges. As stated earlier, the number and composition of the staff represented here varies depending on the level of activity and phase of the rest of the accelerator (between the years 2000 and 2006). Instead of expressing the month by month expenditures expected, only the resulting full time equivatent (FTE) number of personnel will be expressed for each 4.I.X level WBS element. Further, the estimate was complied under the following assumptions:

Work hours per month:

Hourly rate (ICF) for program management personnel:

Hourly rate (ICF) for engineering type personnel:

150

Fee:

100

$8 \%$

4.1.1: Project Management and Administration

4.1.2: Systems Engineering

4.00

4.1.3: Environmental Safety \& Health

2.57

4.1.4: Quality Assurance 
WORKSHEET

WBS 4.2 Subsystems

\section{A. Summary Cost Estimate;}

\begin{tabular}{|c|c|c|c|c|c|c|}
\hline \multicolumn{3}{|c|}{ Off-IFMIF Site } & \multicolumn{4}{|c|}{ On-Site At IFMIF } \\
\hline Industry & Instit'a & & $\begin{array}{c}\text { Const. } \\
\text { Contractor }\end{array}$ & Instit'al & & \\
\hline $\begin{array}{c}\text { Mat'1/L Engin } \\
\text { ab }\end{array}$ & $\underset{\mathrm{g}}{\text { Engin' }}$ & Total & Mat'l/1 Engin & Engin't & AFI & Total \\
\hline $169,36459,05$ & 9,222 & $83,487321,126$ & $-\quad-$ & - & - & $\cdots$ \\
\hline
\end{tabular}

Units: Kilo ICF

\section{B. Description:}

This WBS element worksheet contains summary figures of lower level worksheets whose activities span the period of time from the close of the technology development program to the point at which the facility is producing $250 \mathrm{~mA}$ of $\mathrm{CW}$ deuterium at $40 \mathrm{MeV}$. The top level schedule of activities is shown in the figure below:

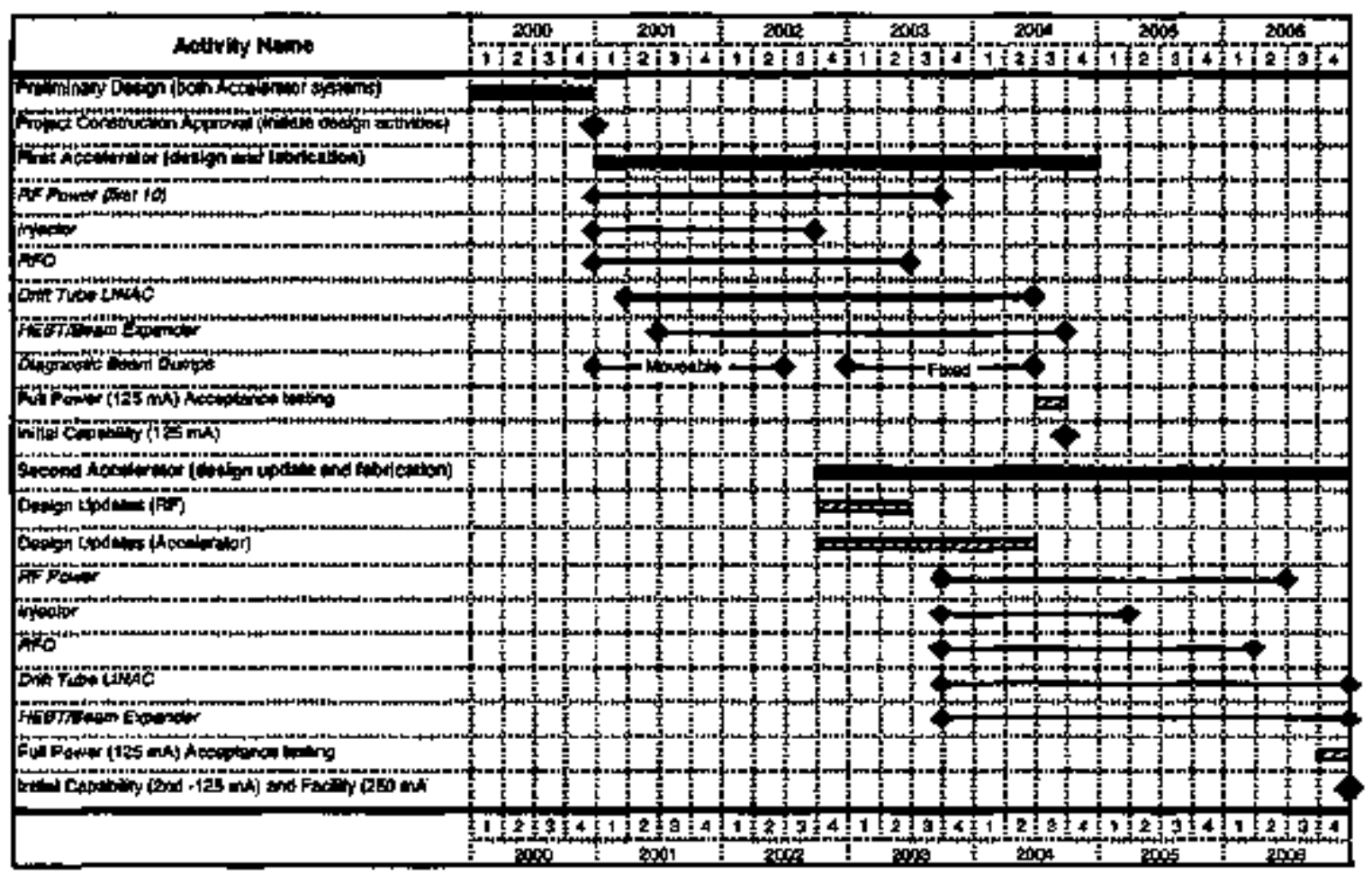


C. Detalled WRS Listing: (without any AEI)

4.2.I: Accelerator Equipment Preliminary Design

4.2.2: Accelerator Equipment Physics Support

4.2.3: Accelerator \#1 (Castor) Equipment

4.2.4: Accelerator \#2 (Pollux) Equipment

Total

4.2.5: Accelerator Beam Calibration Dumps

4.2.6: Accelerator Systems Control

4.2.7: Accelerator Support Systems

7,063

14,526

117,607

84,216

6,539

5,406

2,286

D. Costing Rationale:

See lower level WBS element worksheets

Allowance for Indeterminates: $35 \%$ based on technical risk

Endetailed Costing:

See lower level WBS element worksheets 
WORKSHEET

WBS 4.2.1 Accelerator Equipment Preliminary Design

\section{A. Summary Cost Estimate:}

\begin{tabular}{|c|c|c|c|c|c|c|c|c|}
\hline \multicolumn{4}{|c|}{ Off-IFiNilF Site } & \multicolumn{5}{|c|}{ On-Site At IFMIIF } \\
\hline Industry & Instit'al & & & $\begin{array}{l}\text { Cot } \\
\text { Contt }\end{array}$ & ast & Instit'al & & \\
\hline Mat'lLab Engin'g & Engin'g & AFI & Total & Mat'/Lab & Engin's & Engin'g & AFI & Total \\
\hline 11,621 & 2,905 & 5,084 & 19,610 & -- & -- & - & - & - \\
\hline
\end{tabular}

Units: Kilo ICF

\section{B. Task Description:}

This task will focus on utilizing the design information developed from the engineering validation phases (1997 through 1999) to develop a consistent preliminary design for the entire accelerator system. The subsystems included in this investigation are:
- Injector
- Radio Frequency Quadrupole (RFQ)
- Drift Tube Linac (DTL)
- Radio Frequency (RF) drive loop
- High Energy Bean Transport (HEBT)
- Accelerator \& HEBT Thermal Control
- Accelerator Support
- Data Acquisition and Control
- RF Power
- Beam Calibration Dumps
- Accelerator System Control
- Accelerator Support

The major results will include, but not be limited to, the following:

- completed preliminary engineering performance analysis (mechanical, stress, thermal, vacuum, diagnostics, $R F$, etc.) of all components

- baseline configuration with identification of alternatives/backup technology where appropriate

- deployment of formal design control procedures and development of detailed interface control documents

- optimized subcontracting plan (including identification of all procurement key dates)

- completed procurement specifications (bid packages) for long lead items

- draft drawings and specifications for all components 


\section{Detailed WBS Listing;}

None developed in the definition of this estimate

\section{Costing Rationale:}

Northrop Grumrnan's past experience on simular programs was utilized to develop the composition of the multi-talented engineering team reguired to produce the results described above in the allotted time (one year). Some examples are:

- Beam Experiment Aboard Rocket-BEAR: where Northrop Grumman delivered an Radio Frequency Quadrupole, its power supply, and the external skin for the launch device.

- Continuous Wave Deuterium Demonstrator - CWDD: a cryogenic accelerator where Northrop Grumman was the accelerator prime manufacturer responsible for delivering the entire accelerator system.

- Ground Test Accelerator - GTA: a ground based high power accelerator program used as a test bed for space based strategic defense initiative concepts where Northrop Grumman was selected as the accelerator industrial support contractor.

- Relativistic Heavy Ion Collider - RHIC: a collider program where Northrop Grumman was selected as the manufacturer of the long superconducting main dipole magnets.

Allowance for Indeterminates: $35 \%$ based on technical risk 


\section{E. Defailed Costing:}

For each subsystem listed above, a tean of engineers was estimated which could deliver the desired results. Next, the teams were considered as a whole and areas where sharing of talents would occur were identified and the required number of personnel was decremented to reflect the resource sharing. The resulting number of full time equivalent (FTE) personnel per month, over the one year preliminary design period, is shown in the table below:

(note this estimate contains a summary figure which includes both laboratory and industry engineering)

\begin{tabular}{|lc|}
\hline Skill/Discipline & FTE (per month) \\
\hline Physics Design Liaison & 2.30 \\
Source RF Design & 0.13 \\
RF engineering & 5.30 \\
Mechanical Design & 13.00 \\
Structural Support & 3.00 \\
Stress Analysis & 5.11 \\
Vacuum & 2.25 \\
Thermal/ECS & 6.25 \\
Diagnostics \& Instrumentation & 5.50 \\
Magnet Design & 4.50 \\
Dynamic Analysis & 4.00 \\
Electrical Engineering & 4.00 \\
Data Acquisition Hardware & 5.00 \\
Data Acquisition Software & 5.00 \\
Manufacturing/Produceability & 4.00 \\
System Engineering & 6.90 \\
& TOTAL: \\
\hline
\end{tabular}

All engineering disciplines were estimated at $100 \mathrm{ICF} / \mathrm{hout}$ at 147 man hours per manmonth with an $8 \%$ fee. 
WORKSHEET

WBS 4.2.2 Accelerator Physics Design Support

\section{A. Summary Cost Estimate:}

\begin{tabular}{|c|c|c|c|c|c|c|c|}
\hline \multicolumn{4}{|c|}{ Off-IFMIF"site } & \multicolumn{4}{|c|}{ On-Site At IFMIF } \\
\hline Industry & Instit'al & & & $\begin{array}{c}\text { Const. } \\
\text { Contractor }\end{array}$ & Instit'al & & \\
\hline Mar'1/Lab Engin'g & Enging & AF & Total & Mat'VLab Engin'g & Engin's & AFI & Total \\
\hline $4, \overline{944}$ & 2,119 & 2,472 & 9,535 & $=$ & - & $=$ & - \\
\hline
\end{tabular}

Units: Kilo ICF

\section{B. Task Description:}

During the development of the design, from preliminary to final configurations through fabrication, a constant physics analysis supporting function is required to help resolve design and manufacturing difficulties. Design areas for this support mostly fall in continltally assessing the configuration performance when more and more detail information becomes available. Areas of support during fabrication include resolving difficulties between the selection of existing bardware (at close to specification) or a decision to develop new hardware. During installation, checkout, and commissioning a physics presence is required to help resolve difficulties in startup by interpreting data and suggesting corrective actions.

\section{Detailed WBS Listing:}

None developed in the definition of this estimate

\section{R. Costing Rationale:}

Northrop Grumman's past experience on similar programs was utilized to develop the composition of the physics personnel supported by dedicated engineering talent that would be required to produce the results described above.

Allowance for Indeterminates: $35 \%$ based on technical risk

\section{E. Detailed Costing;}

To estimate this staff function, a review of the underlying accelerator activities was undertaken to understand the potential extent of physics support requirements. The results of this analysis jndicated that a level of effort of $\mathbf{4}$ physicists, with half a man engineering support, woukd be required throughout the program. This estimate includes both industry and laboratory involvement, but no detailed breakout of the tasks were developed.

The hourly rate for engineering support is 100 ICF/hour and the hourly rate for physicists is 120 ICF/hour. For each type of labor, a total of 147 man-hours per manmonth was used. 
WORKSHEET

WBS 4.2.3 Accelerator \#1 (Castor)

A. Summary Cost Estimate:

\begin{tabular}{|c|c|c|c|c|c|c|}
\hline \multicolumn{3}{|c|}{ Off-IFMIF Site } & \multicolumn{4}{|c|}{ On-Site At IFMIF } \\
\hline Industry & $\begin{array}{c}\text { Instit'a } \\
1\end{array}$ & & $\begin{array}{c}\text { Const. } \\
\text { Contractor }\end{array}$ & |'Instit'al & & \\
\hline $\begin{array}{l}\text { Mat'l/ Engin } \\
\text { ab }\end{array}$ & $\begin{array}{c}\text { Engin' } \\
\mathrm{g}\end{array}$ & $\begin{array}{ll}\text { AFI } & \text { Tocal }\end{array}$ & $\begin{array}{cc}\text { Mat'l/L } & \text { Engin } \\
\text { ab } & \text { 'g }\end{array}$ & Engin's & AFI & Total \\
\hline $85,49828,46$ & 3,644 & $41,182158,78$ & $-\quad-$ & - & - & $=$ \\
\hline
\end{tabular}

Units: Kilo ICF

\section{B. Task Description:}

This estimate is a summary level compilation of lower level estimates. As a whole this estimate expresses the total resources required to compiete the final design of the first accelerator, develop and execute all procurements in support of fabrication, eventually reaching the point where the accelerator is installed and checked out ready for commissioning in the facility.

\section{Detailed WBS Listing:}

WRS\#

4.2.3.1: Enjector System

4.2.3.2: Radio Frequency Quadrupole System

4.2.3.3: Drift Tube Linac System

4.2.3.4: High Energy Beam Transport (HEBT) System

4.2.3.5: Radio Frequency Drive Loop System

4.2.3.6: Accelerator \& HEBT Thermal Control System

4.2.3.7: RF Power Supply System
Cost

3,064

15,690

30,290

18,117

3,090

2,840

85,698

158,789

\section{Costing Rationale:}

The estimate is comprised of two major portions labor and material, Northrop Grumman's past experience delivering accelerating components on similar programs was utilized to develop the labor estimates. To understand the material costs, suppliers in the various areas were contacted and subsequently supplied rough order of magnitude prices.

Allowance for Indeterminates: $35 \%$ based on technical risk

\section{E. Detailed Costing:}

See lower WBS worksheets 
WORKSHEET

WBS 4.2.3.1 Injector

\section{A. Summary Cost Estimate:}

\begin{tabular}{|c|c|c|c|c|c|c|c|}
\hline \multicolumn{4}{|c|}{ Off-IFMIF Site } & \multicolumn{4}{|c|}{ On-Site At IFMIF } \\
\hline Industry & $\underset{1}{\text { Instit'a }}$ & & & $\begin{array}{c}\text { Const. } \\
\text { Contractor }\end{array}$ & Instit'al & & \\
\hline $\begin{array}{c}\text { Mat'l/L Engin } \\
\mathrm{ab}\end{array}$ & $\underset{\mathrm{g}}{\text { Engin' }}$ & AFI & Total & $\begin{array}{cc}\text { Mat'1/L } & \text { Engin } \\
\text { ab }\end{array}$ & Engin'g & $\overline{A F I}$ & Total \\
\hline $1,407 \quad 620$ & 243 & 794 & 3,064 & $-\quad--$ & - & - & -- \\
\hline
\end{tabular}

Units: Kilo ICF

\section{B. Task Description:}

The injector portion of the accelerator is fully described in reference 1. This worksheet documents the necessary resources to deliver two full injector assemblies, as well an a additional spare ion source, in support of the first accelerator (nicknamed Castor). This estimate also assumes all technology feasibility issues surrounding the injector system are resolved and a baseline injector architecture has emerged from the prior engineering validation phase. The master schedule for the Castor injector system is shown below;

(1)

This worksheet details the necessary resource for the Engineering Design, Procurement \& Manufacturing, and Sustaining Engineering lines of the schedule. The installation and checkout activities, as well as the functional testing estimates, are contained in WBS 4.3.1.1 Injector.

\section{Detailed_WBS Listing:}

None established

\section{Costing Rationale:}

The estimate is comprised of two major portions labor and material. Northrop Grumman's past experience delivering accelerating components on similar programs was utilized to develop the labor estimates. Some examples of this are the Continuous Wave Deuterium Demonstrator accelerator program where Northrop Grumman was the prime accelerator equipment supplier, and 
our experience in manufacturing and operating our internal research accelerators.

To understand the material costs, suppliers in the various areas were contacted and subsequently provided rough order of inagnitude quotes.

Allowance for Indeterminates: $35 \%$ based on technical risk

\section{E. Detailes Costing:}

The estimate is comprised of two major parts, labor and material. The labor falls into three major categories: industrial engineering, institutional support, and fabrication labor.

Desion Labor.

A review of the necessary tasks to complete the design work and produce the required information to enable the fabrication (drawings, specifications, subcontracting plans, etc.) dictated a mix of engineering talent that equated to $\mathbf{5 . 5}$ full time equivalent (FTE) personnel over the three months allotted for the effort. All of this labor was calculated at the engineering rate of 100 ICF per man hour and 147 man hours per man month. The engineering disciplines included in this estimate are:

- Source RF Design

- Mechanical Design

- Electrical design

- Support Structure Design

- Vacuum Design

- Magnet Design

- Thermal Analysis

- Environmental Control

- Instrumentation/Diagnostics

- Produceability

- System Engineering

\section{Sustaining Labor: -}

Initial estimates of the cycling of personnel between the flist and second accelerator hardware elements, including their respective installation and checkout, showed gaps in activities. These gaps are detrimental to maximizing the information and skill learned during the first accelerator activities. To avoid losing the knowledge base, a stustaining engineering line is included. This will enable a continuous avallability of injector knowledge from beginning to end of the program. The schedule shown above indicates that an 18 month span for this activity in which 2.5 FTE engineers were estimated at 100 ICF per hours and 147 man hours per man month.

Eabrication Labor: 
Northrop Grumman produceability/manufacturing reviewed the requirements and returned a draft subcontracting plan which included differentiation between purchased items and internally fabricated items. For the components that would be internally fabricated estimates of the required labor and material were generated. For the purchased items, vendors were solicited to provide rough order of magnitude costs. The last piece was for the manufacturing department to make an estimate of the assembly tasks. The result of this effort yielded a staff of 2.5 FTE technicians together with 3.7 FTE engineers over the nine months that this task is scheduled to span. The technicians were estimated at 80 ICF per hour, the engineers at 100 ICF per hour, and both considering 147 man hours per man month. An $8 \%$ fee was added to the figures to reflect industrial participation. The engineering skills to be employed during the fabrication task are:

- Liaison Engineering

- Mechanical Design

- Electrical Design

- Quality Control

- Tool Design

Institutional Labor:

Based upon previous programs to develop injector systems an allowance of 1.0 FTE for the entire design, fabrication and installation and checkout process was reported. Like the Industry engineering talent, the Institutional labor will be billed at 100 ICF per hour and 147 man hours per man month

\section{Material:}

The existing level of detai 1 surrounding the device provided enough information to contact vendors concerning rough order of magnitude quotes for the hardware identified below. The total cost for the material portion of this estimate was 418 kilo ICF [ ${ }^{\text {t* }}$ denotes refurbished hardware from the EVP program].

$\begin{array}{lrr}\text { Component } & \text { Cost(KildICE) } \\ \text { Source and RF Power Supply } & 200 \\ \text { Low Energy Beam Transport (LEBT) } & 60 & 85 \\ \text { Magnet Power Supplies } & & 20 \\ \text { Operational Control Equipment and Software } & 40 & 5 \\ \text { Vacuum Equipment and Services } & & -8 \\ \text { Thermal Control Equipment and Services } & 418 & -8\end{array}$

E_References: 
1. ORNL/M-4908, "IFMIF, International Fusion Materials irradiation Facility, Conceptual Design Activity, Interim Report" 


\section{WORKSHEET \\ WBS 4.2.3.2 Radio Frequency Quadrupole (RFQ) System}

\section{A. Summary Cost Estimate:}

\begin{tabular}{|c|c|c|c|c|c|c|c|c|}
\hline \multicolumn{4}{|c|}{ Off-IFMIF Site } & \multicolumn{5}{|c|}{ On-Site At IFIF } \\
\hline Industry & Instit'al & & & $\begin{array}{r}\mathrm{Co} \\
\text { Cont }\end{array}$ & $\begin{array}{l}\text { ist. } \\
\text { actor }\end{array}$ & Instit'al & ' & \\
\hline Mat'/Lab Engia'g & Engin'g & $\mathrm{AFI}$ & Total & Mat'ILak & Enging & Engin'g & $\mathrm{AFI}$ & Total \\
\hline 9,045 & 357 & 4,070 & 15,690 & - & $\cdots$ & $=$ & - & $=$ \\
\hline
\end{tabular}

Units: Kilo ICF

\section{B. Task Description:}

The RFQ portion of the accelerator is folly described in reference 1 . This worksheet documents the necessary resources to deliver one 12 meter long, $8 \mathrm{MeV} \mathrm{RFQ}$, in support of the first accelerator (nicknamed Castor). This estimate also assumes all technology feasibility issues are resolved in respect to the RFQ. The master schedule for the Castor RFQ system is shown below:

(1)

This worksheet details the pecessary resources for the Procurement \& Manufacturing, Final Design, Cold Model Design and Test, and Sustaining Engineering lines of the schedule. The installation and checkout activities, as well as the functional testing estimates, are contained in WBS 4.3.1.2 Radio Frequency Quadrupole.

\section{Detailed WBS Listing:}

None established

\section{Costing Rationale:}

The labor estimate is comprised of two major portions labor and material. Northrop Grumman's past experience delivering accelerating components on similar programs was utilized to develop the Jabor estimates. Some examples are:

- Beam Experiment Aboard Rocket - BEAR: where Northrop Grumman delivered an Radjo Frequency Quadrupole, its power supply, and the external skin for the launch device. 
- Continuous Wave Deuterium Demonstrator - CWDD: a cryogenic accelerator where Northrop Grumman was the accelerator prime manufacturer responsible for delivering the entire accelerator system (including the cryogenic RFQ).

- Ground Test Accelerator - GTA: a ground based high power accelerator program used as a test bed for space based strategic defense initiative concepts where Northrop Grumman was selected as the sccelerator industrial support contractor.

To understand the material costs, suppliers in the various areas were contacted and subsequently provided rough order of magnitude quotes.

Allowance for Indeterminates: $35 \%$ based on technical risk

\title{
E. Detailed Costing:
}

The estimate is comprised of two major parts, labor and material. The labor falls into three major categories: industrial engineering, institutional support, and fabrication labor The schedule for this component is shown above

\section{Design Labor:}

A review of the necessary tasks to complete the design work and produce the required information to enable the fabrication (drawings, specifications, subcontracting plans, etc.) dictated a mix of engineering talent that equated to 6.63 full time equivalent (FTE) personnel over the 12 months allotted for the effort. All of this labor was calculated at the engineering rate of 100 ICF per man hour and 147 man hours per man month, with an $8 \%$ fee. The engineering disciplines included in this estimate are:

\author{
- RF Design \\ - Mechanical Design \\ - Electrical design \\ - Support Structure Design \\ - Vacuum Design \\ - Thermal Analysis \\ - Environmental Control \\ - Instrumentation/Diagnostics \\ - Produceability \\ - System Engineering
}

\section{Cold Model:}

Previous experience demonstrated the need to construct and test a full scale low power aluminum version of the RFQ to verify the electric field distribution, the field stability and to ensure adequate tuning range. Further, some of the details in the RFQ must be empirically developed. Examples of these details are the vane end cuts (which allow the magnetic field to wrap around the vane), the end wall dipole stabilizers size and position, and to properly size the RF drive iris openings. Previous experience dictates that a 2.0 FTE engineers (of which 0.5 FTE is from institutional support) together with 2.0 FTE technicians are required over the 9 months scheduled for this task. In parallel, a 
budget of 212 kilo $\mathrm{ICF}$ is provided to cover the cold model material requirements (aluminum and machining services).

\section{Sustaining Labor:}

Initial estimates of the cycling of personnel between the first and second accelerator hardware elements, including their respective installation and checkout, showed gaps in activities. These gaps are detrimental to maximizing the information and skill transter between accelerator activities. To avoid losing the knowledge base, a sustaining engineering line is included. This enables a continuous availability of injector knowledge from beginning to end of the program. The schedule shown above indicates that an nine month span for this activity in which 2.5 FTE engineers were estimated at 100 ICF per hours and 147 man bours per man month, with an $8 \%$ fee.

\section{Fabrication Labor:}

Northrop Grumman produceability/manufacturing group reviewed the requirements and returned a draft subcontracting plan which included delineation between purchased items and internally fabricated ones. For the components that would be internally fabricated estimates of the reguired labor and material were generated. For the purchased items, vendors were solicited to provide rough order of magnitude costs. The last piece of information from the mantufacturing department provided was an estimate of the assembly tasks. The result of this effort yielded a staff of 13.8 FTE technicians together with 3.68 FTE engineers over the 24 months that this task is scheduled to span. The technicians were estimated at $80 \mathrm{ICF}$ per hour, the engineers at 100 ICF per hour, and both considering 147 man hours per man month with an $8 \%$ fee. The engineering skills to be employed during the fabrication task are:

- Liaison Engineering

- Mechanical Design

- Electrical Design

- Quality Control

- Tool Design

\section{Institutional Labor:}

Based upon previous programs to develop RFQ accelerating systems an allowance of 2.0 FTE for the entire cold modeling and final design efforts was included. Like the Industry engineering talent, the Institutional labor will be billed at 100 ICF per hour and 147 man hours per man month

\section{Material:}

The existing level of detail surrounding the device provided enough information to contact vendors concerning rough order of magnjude quotes for the hardware identified below. The total cost for the material portion of this estiniate was 3000 kilo ICF. 


\begin{tabular}{|lc|}
\hline Component & Cost (Kilo ICF) \\
Oxygen Free High Conductivity (OFHC) Copper & 240 \\
RF drive loops & 580 \\
Electroforming services & 1,170 \\
Miscellaneous hardware \& services & 1010 \\
(Vacuum, Themal, Stress, Structural support, etc.) & \\
& TOTAL: \\
\hline
\end{tabular}

\section{E. References:}

1. ORNL/M-4908, "IFMIF, International Fusion MateriaIs Irradiation Facility, Conceptual Design Activity, Interim Report" 


\section{WORKSHEET \\ WBS 4.2.3.3 Drift Tube Linac (DTL) System}

A. Summary Cost Estimate:

\begin{tabular}{|c|c|c|c|c|c|c|c|}
\hline \multicolumn{4}{|c|}{ Off-IFMHIF Site } & \multicolumn{4}{|c|}{ On-Site At IFlM!F } \\
\hline Industry & Instit'al & & & $\begin{array}{l}\text { Const. } \\
\text { Contractor }\end{array}$ & Instit'al & & \\
\hline Mat'l/Lab Engin'g & Engin'g & $\overline{\mathrm{AFI}}$ & Total & Mat'/Lab Engin'g & Engin'g & AF & Total \\
\hline 14,734 & 673 & $\overline{7,853}$ & 30,290 & $m$ & $=$ & - & - \\
\hline
\end{tabular}

Units: Kilo ICF

\section{B. Task Descijption:}

The technical aspects of the DTL accelerating system of the accelerator is fully described in reference 1. This worksheet uses this information to develop a listing of the necessary resource to deliver eight DTL tanks in support of the first accelerator (nicknamed Castor). This estimate also assumes all technology feasibility issues are resolved in respect to the DTL system prior to preliminary design (in the year 2000). The master schedule for the Castor DTL system is shown below:

|Actvay Name

This worksheet details the necessary resource for the Long Lead Procurement Support, Procurement \& Manufacturing, Final Design, Cold Model Design and Test, and Sustaining Engineering lines of the schedule. The installation and checkout activities, as well as the functional testing estimates, are contained in WBS 4.3.1.3 DTL Tank \#1 and WBS 4.3.1.4 DTL Tanks \#2-\#8. 
C. Detailed WBS Listing (costs expressed with apportioned AEI):

WBS

4.2.3.3.1: Cold Model Design \& Test

4.2.3.3.2: Final Design of DTL system (Tanks \#1-\#8)

4.2.3.3.3: Tank \#1

4.2.3.3.4: Tank \#2

4.2.3.3.5: Tank \#3

4.2.3.3.6: Tank \#4

4.2.3.3.7: Tank \#5

4.2.3.3.8: Tank \#6

4.2.3.3.9: Tank \#7

4.2.3.3.10: Tank \#8

\begin{tabular}{c} 
Cost (kICF) \\
\hline 1,800 \\
6,020 \\
3,348 \\
2,930 \\
2,835 \\
2,740 \\
2,686 \\
2,673 \\
2,633 \\
2,630 \\
\hline 30,290
\end{tabular}

\section{Costing Rationale:}

The estimate is comprised of two major portions labor and material. Northrop Grumman's past experience delivering accelerating components on similar programs was utilized to develop the labor estimates. Some examples of the experience are:

- Ramped Gradient Drift Tube Linac - RGDTL: A program where Northrop Grumman conpleted the design and eventually fabricated one complete accelerating tank to Los Alamos National Laboratory sepcification.

- Continwous Wave Deuterium Demonstrator - CWDD: a cryogenic accelerator where Northrop Grumman was the accelerator prime manufacturer responsible for delivering the entire accelerator system.

- Ground Test Accelerator - GTA: a ground based high power accelerator program used as a test bed for space based strategic defense initiative concepts where Northrop Grumman was selected as the accelerator industrial support contractor.

To understand the material costs, suppliers in the various areas were contacted and subsequently provided rough order of magnitude quotes.

Allowance for Indeterminates: $35 \%$ based on technical risk

\section{E. Detailed Costing:}

The estimate is comprised of two major parts, labor and material. The labor falls into three major categories: industrial engineering, institutional support, and fabrication labor.

\section{Design Labor:}

A review of the necessary tasks to complete the design work and produce the required information to enable the fabrication (drawings, specifications, subcontracting plans, etc.) dictated a mix of engineering talent that equated to 22 full time equivalent (FTE) personmel, of which $1.5 \mathrm{FTE}$ are from institutional engineering, over the 12 months allotted for the effort. The industrial engineering labor was calculated at the engineering rate of 100 ICF per man hour and 147 man hours per man month with an $8 \%$ fee. The engineering disciplines included in this estimate are: 
- RF Design

- Mechanical Design

- Electrical design

- Support Structure Design

- Vacuum Design

- Thermal Analysis

- Environmental Control

- Instrumentation/Diagnostics

- Produceability

- System Engineering

\section{Cold Model:}

Previous experience demonstrated the need to construct and test a full scale low power aluminuma version of a DTL tank to verify the electric field distribution, the field stability provided by the post couplers and to ensure adequate tuning range. The tanks to be modeled include the first where the accelerating gradient is ramped and the second where the gradient is constant. The cold model will be constructed is such a manner as to allow it to be configured to represent either. Previous experience dictates that 2.0 FTE engineers (of which 0.5 FTE is from institutional support) together with 2.0 FTE technicians are required over the 12 months scheduled for this task. In parallel, a budget of 644 kilo ICF is provided to cover the cold model material requirements (aluminum and machining services).

\section{Fabrication Labor:}

Northrop Grumnan produceability/manufactiring reviewed the requirements and returned a draft subcontracting plan which included delineation between purchased items and internally fabricated ones. For the components that would be internally fabricated estimates of the required labor and material were generated. For the purchased items, vendors were solicited to provide rough order of magnitude costs. The last piece of information from the manufacturing department was an estimate of the assembly tasks. The result of this effort yielded a staff of 12.75 FTE technicians over the 36 months that this task is scheduled to span. The technicians were estimated at 80 ICF per hour at 147 man hours per man month with an $8 \%$ fee.

\section{Seller Oversight I,abos:}

The DTL manufacturing plan includes a significant number of procured items that will be produced in large quantity. In support of this a separate team of individuals will be reguired to ensure the subcontracted work is being properly executed. The list of the skill types required is shown below. The schedule shown above indicates that an three years span for this activity in which approximately 4.0 FTE engineers were estimated at 100 ICF per hours and 147 man hours per man month with an $8 \%$ fee.

- Quality Control

- Methads 
- Production Management/Controls

- Tool Design

- Liaison Engineering

Instjtutional Labor:

As discussed previously in this worksheet (Design Labor and Cold Model), the institutional labor estimate was based upon previous programs to develop DTL systems. An allowance of 2.0 FTE for the entire cold modeling and final design efforts was included. Like the Industry engineering talent, the Institutional labor will be billed at 100 ICF per hour and 147 man hours per mant month with an $8 \%$ fee.

\section{Material:}

The existing level of detail surrounding the device provided enough information to contact vendors concerning rough order of magnitude quotes for the hardware identified below. The total cost for the material portion of this estimate was 8,257 kilo ICF.

Purchased material for each tank

\begin{tabular}{|l|}
\hline Drift Tubes \\
\hline Drift tube magnets \\
\hline Vacuum system equipment \& \\
Services \\
\hline Oxygen Free High Conductivity \\
(OFHC) Copper for tank shell \\
\hline Endwalls with magnets \\
\hline Tank support system \\
\hline Rail Tuners \\
\hline Rf drive loops \\
\hline Post couplers \\
\hline Drift tube support girder \\
\hline Inter-tank focusing quadrupole \\
package \\
\hline Miscellaneous hardware \\
\hline
\end{tabular}

Material Breakdown by tank (without AFI)

Tank \#1

Tank \#1

Tank \#1

Tank \#1

Tank \#1

Tank \#1

Tank\#1

Tank \#1
Cost (Kile ICD)

1,390

1,100

1,006

1,000

960

950

930

$\frac{920}{8,257}$ 


\section{E References:}

1. ORNL/M-4908, "IFMIF, International Fusion Materials Irradiation Facility, Conceptual Design Activity, Interim Report" 
WORKSHEET

WBS 4.2.3.4 High Energy Beam Transport (HFBT)

\section{A. Summary Cost Estimate:}

\begin{tabular}{|c|c|c|c|c|c|c|}
\hline \multicolumn{3}{|c|}{ Off-lFMIF Site } & \multicolumn{4}{|c|}{ On-Site At IFMIF } \\
\hline industry & $\begin{array}{c}\text { Instit'a } \\
1\end{array}$ & & $\begin{array}{l}\text { Const. } \\
\text { Contractor }\end{array}$ & Instit'al & & \\
\hline $\begin{array}{c}\text { Mat'l/L Engin } \\
a b\end{array}$ & $\underset{\mathrm{g}}{\text { Engin' }}$ & AFI Total & $\begin{array}{cc}\text { Mat'l/L Engin } \\
\text { ab }\end{array}$ & Engin'g & AFI & Total \\
\hline $9,050 \quad 4,020$ & 350 & $4,697 \quad 18,117$ & $--\quad$ & - & - & - \\
\hline
\end{tabular}

Units: Kilo ICF

\section{B. Task Description:}

The techrical aspects of the HEBT system of the accelerator are fully described in reference 1. This worksheet uses this information to develop a listing of the necessary resources to deliver three transport lines (one to each lithium target and one to the fixed facility beam dump) in support of the first accelerator (nicknamed Castor). This estimate also assumes all technology feasibility issues are resolved in respect to the HEBT system prior to preliminary design (in the year 2000). The master schedule for the Castor HEBT system is shown below:

(1)

This worksheet will detail the necessary resources for the Long Lead Procurement Support, Procurement \& Manufacturing, Final Design, Cold Mode! Design and Test, and Stustaining Engineering lines of the schedule. The installation and checkout activities, as well as the functional testing estimates, are contained in WBS 4.3.1.5 HEBT systems.

C. Detailed WBS Listing:

None developed in support of this costing activity

D. Costinc Rationale: 
Northrop'Grumman's past experience delivering accelerating components on similar programs was utilized to develop the labor estimates. To understand the material costs, information from the past accelerating programs was updated with information collected from suppliers in the various areas who were contacted and subsequently provided rough order of magnitude quotes.

Allowance for Indeterminates: $35 \%$ based on technical risk

\section{E. Detailed Costing:}

The estimate is comprised of two major parts, labor and material. The labor falls into three major categories: industrial engineering, institutional support, and fabrication labor.

\section{Desiun Labor.}

A review of the necessary tasks to complete the design work and produce the required information to enable the fabrication (drawings, specifications, subcontracting plans, etc.) dictated a mix of engineering talent that equated to 12 full time equivalent (FTE) personnel, of which 1.25 FTE are from institutional engineerfng, over the 18 months allotted for the effort. All of this labor was caiculated at the engineering rate of 100 ICF per man hour and 147 man hours, per man month with an $8 \%$ fee. The engineering disciplines included in this estimate are:

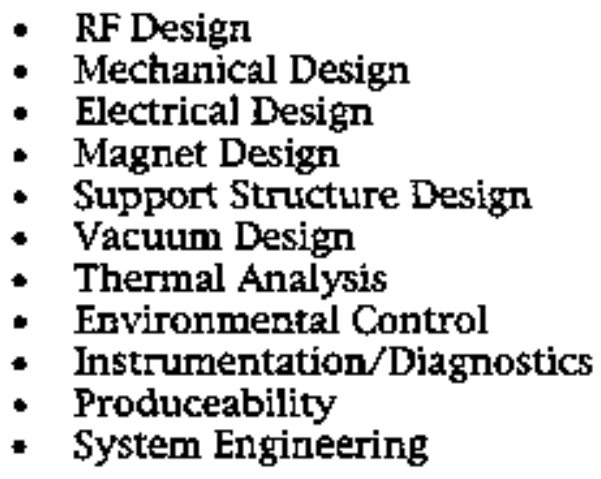

\section{Eabrication Labor}

Northrop Grumman produceability/manufacturing reviewed the requirements and returned a draft subcontracting plan which included delineation between purchased items and internally fabricated ones. For the components that would be internally fabricated estimates of the required labor and material were generated. The later type were the cavities for the momentum compactors and energy dispersion. For the purchased items, vendors were solicited to provide rough order of magnitude costs. The last piece of information from the manufacturing department was an estimate of the assembly tasks. The result of this effot yielded a staff of 5.3 FTE technicians, together with 3.0 engineers, over the 12 months that this task is scheduled to span. The technicians were estimated at 80 ICF per hour, the 
engineers at 100 ICF per man hour, both considering 147 man hours per man month with an $8 \%$ fee. 


\section{Seller oversight Labox .}

The HEBT manufacturing plan includes a significant number of procured items (magnets, diagnostics, power supplies, etc.) that will be produced in large quantity. In support of this a separate team of individuals will be required to ensure the subcontracted work is being properly executed. The list of the skill types recuired is shown below. The schedule shown above indicates that an three years span for this activity in which approximateiy 2.50 FTE engineers were estinated at 100 ICF per hours and 147 man hours per man month with an $8 \%$ fee.

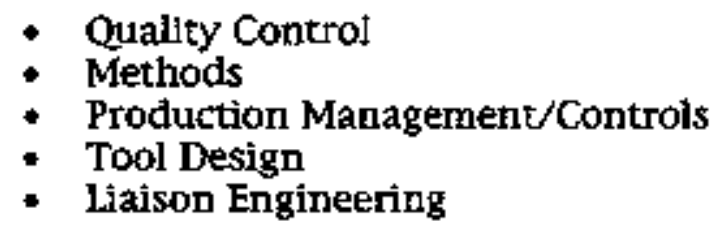

Institutional Labor:

As discussed previously in this worksheet (Design Labor and Cold Model), the institutional labor estimate was based upon previous programs to develop HEBT systems an allowance of 1.25 FTE for the entire final design effort. Like the Industry engineering talent, the Institutional labor will be billed at 100 ICF per hour and 147 man hours per man month

\section{Material:}

The existing level of detail surrounding the device provided enough information to contact vendors concerning rough order of magnitude quotes for the hardware identified below. The total cost for the material portion of this estimate was $8,240 \mathrm{ktlo}$ ICF (without any AFI).

\begin{tabular}{|c|c|}
\hline Purchased Item & Cost (kTCF) \\
\hline Beam Tube, Flanges, Bellows, etc. & 210 \\
\hline RF Cavities & 1,610 \\
\hline Support/Aljgnment Structure & 290 \\
\hline $\begin{array}{l}\text { Ouadrupole magnets: } 6^{\prime \prime} \text { long } \times 5^{\text {"d dia }} \\
\text { bore }\end{array}$ & 250 \\
\hline $\begin{array}{l}\text { Quadrupole magnets: } 16^{\prime \prime} \text { long } \times 5^{\prime \prime} \text { dia } \\
\text { bore }\end{array}$ & 360 \\
\hline $\begin{array}{l}\text { Ouadrupote magnets: } 24^{+1} \text { long } \times 5^{\text {tr }} \text { dia } \\
\text { bore }\end{array}$ & 950 \\
\hline $\begin{array}{l}\text { Octupole magnets: } 16^{\prime \prime} \text { tong } \times 3.5^{n} \text { dia } \\
\text { bore }\end{array}$ & 780 \\
\hline Dipole (45) magnets: $5^{\prime \prime}$ gap & 660 \\
\hline Dipole (10") magnets: $5^{\prime \prime}$ gap & $\overline{340}$ \\
\hline Magnet Power Supplies & 1,670 \\
\hline Energy Spread Monitors & 320 \\
\hline Phase Spread Monitors & 150 \\
\hline
\end{tabular}




\begin{tabular}{|c|c|}
\hline Video Profile Monitor & 80 \\
\hline Microstriplines & 570 \\
\hline TOिTAB & 8.240 \\
\hline
\end{tabular}

E. References:

1. ORNL/M-4908, “IFMIF, IsternationaI Fusion Materials Irradiation Facility, Conceptual Design Activity, Interim Report ${ }^{n}$ 
WORKSHEET

WBS 4.2.3.5 Radio Frequency (RT) Drive Loop

\section{A. Summary Cost Estimate:}

\begin{tabular}{|c|c|c|c|c|c|c|c|c|}
\hline \multicolumn{4}{|c|}{ Off-IFMirit Site } & \multicolumn{5}{|c|}{ On-Site At IFMIIF } \\
\hline Industry & Instit'al & & & $\begin{array}{c}\text { Cor } \\
\text { Cont }\end{array}$ & $\begin{array}{l}\text { st. } \\
\text { actor }\end{array}$ & Instit'al & & \\
\hline Mat/Lab Engin's & Engin'g & AFI & Total & Mat'/Lab & Engin's & Engin'g & AFI & Total \\
\hline 2,220 & 70 & 800 & 3,090 & - & - & -- & - & $-\cdot$ \\
\hline
\end{tabular}

Units: Kilo ICF

\section{B. Task Description:}

This worksheet details a separate effort to develop a production versions of the RF drive loops required throughout the accelerator. The RFQ will require 12 drive loops of $31 / 8$ inch coax type ( $\max$ power $\sim 250 \mathrm{~kW}$ ) capacity, while the DTL and HEBT will require 43 drive loops of the $6 \mathrm{I} / 8$ inch coax type (max power $-500 \mathrm{~kW}$ ). In total, each accelerator in the facility requires a total of 55 drive loops. The technical aspects and configuration of these drive loops is described in reference 1. This worksheet uses this information to develop a listing of the necessary resources to carry out a final design on the two major types. This estimate also assumes all technology feasibility issues are resolved in respect to the drive loops prior to the beginning of preliminary design (in the year 2000).

\section{Detailed WBS Listing:}

None developed in support of this costing activity

\section{Costing Rationale:}

This estimate is comprised of only of labor. Northrop Grumman's past experience developing similar drive loops for both our internal beam line, as well as drive loops for other accelerator programs was utilized to develop the labor estimates.

Allowance for Indeterminates: $35 \%$ based on technical risk

\section{E. Detailed Costing:}

This estimate is comprised completely of labor. Institutional belp is reguired to complete the effort.

\section{Desiga Labor:}

A review of the necessary tasks to complete the design work and produce the required information to enable the fabrication (drawings, specifications, subcontracting plans, etc.) dictated a mix of engineering talent that eguated to approximately 6.0 full time equivalent (FTE) personnel, of which 0.2 FTE are from institutional engineering, 
over the 24 months allotted for the effort. All of this labor was calculated at the engineering rate of 100 ICF per man hour and 147 man hours per man month with an $8 \%$ fee. The engineering disciplines included in this estimate are:

- RF Design

- Mechanical Design

- Electrical Design

- Vacurm Design

- Thermal Analysis

- Produceability

- System Engineering

\section{E. References:}

1. ORNL/M-4908, "IFMIF, International Fusion Materials Irradiation Facility, Conceptual Design Activity, Interim Report" 
WORKSHEET

WBS 4.2.3.6 Accelerator \& BEBT Thermal Control

A. Summary Cost Estimate:

\begin{tabular}{|c|c|c|c|c|c|c|c|c|}
\hline \multicolumn{4}{|c|}{ Off-FMlF Site } & \multicolumn{5}{|c|}{ On-Site At IFMIF } \\
\hline Industry & Instit'al & & & $\begin{array}{c}\mathrm{Co} \\
\mathrm{Cont}\end{array}$ & $\begin{array}{l}\text { ist } \\
\text { actor }\end{array}$ & Instit'al & & \\
\hline Mat'/Lab Eugir'g & Engin'g & AFI & Total & Mat'l/2at & Engin'g & Enging & $\mathrm{AFI}$ & Total \\
\hline 2,090 & - & 750 & 2,840 & -- & -- & - & $\overline{-}$ & - \\
\hline
\end{tabular}

Units: Kilo ICF

\section{B. Task Description:}

This worksheet details a separate effort to provide thermal control of the accelerator and HEBT. While each accelerating component, as well as the HEBT, have embedded thermal analysis efforts, the effort captured here focuses on interfacing between the separate accelerator requirements and the facility. This task is especially useful in minimizing the variety of connections and control loops because it treats the accelerator collectively. After completing the final design, this estimate also provides resource to maintain an engineering presence throughout the fabrication of the accelerator and HEBBT components to maintain continuity in the engineering database. Lastly, since this task does not involve any subsystem or component development no institutional suppot is envisioned.

\section{Detailed WBS Listing:}

None develop̣ed in stupport of this costing activity

\section{Costing Rationale:}

This estimate is comprised of only of labor. Northrop Grumman's past experience developing similar systems for our internal beam line, as well as other accelerator programs, was utilized to develop the labor estimates.

Allowance for Indeterminates: 35\% based on technical risk

\section{E. Detailed Costing:}

Design Labor:

A review of the necessary tasks to complete the design work and produce the required information to enable the fabrication (drawings, specifications, subcontracting plans, etc.) dictated a mix of engineering talent that equated to approximately 3.5 full time equivalent (FTE) personnel over the 24 months that accelerator and HEBT design activities are being executed. All of this labor was calculated at the engineering rate of 100 ICF per man hour and 147 man hours per man month with an $8 \%$ fee. The engineering disciplines included in this estimate are: 
- Mechanical Design

- Thermal/Environmental Control System Analysis

- Produceability

- System Engineering 
WORKSHEET

WBS 4.2.3.7 Radio Frequency (RF) Power System

A. Summary Cost Estimate:

\begin{tabular}{|c|c|c|c|c|c|c|c|c|}
\hline \multicolumn{4}{|c|}{ Off-IFMIF Site } & \multicolumn{5}{|c|}{ On-Site At IFMIF } \\
\hline Industry & Instit'al & & & $\begin{array}{c}\text { Con } \\
\text { Contra }\end{array}$ & $\begin{array}{l}\text { st. } \\
\text { actor }\end{array}$ & Instit'al & & \\
\hline Mar'YLab Engin'g & Engin'g & AFI & Total & Matllab & Engin'g & Engin's & $\mathrm{AFI}$ & Total \\
\hline $5 \overline{1,262}$ & 1,951 & 22,218 & 85,698 & -- & - & & 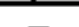 & $\overline{-}$ \\
\hline
\end{tabular}

Units: Kilo ICF

B. Task Description:

This worksheet contains a top level summary of the costs to design, fabricate, functionally test, and ship an RF power system for the first accelerator (Castor) to the IFMIF site. The technical features of this system are described in detail in reference 1. This estimate assumes that during the engineering validation phase (1997-1999) all technology feasibility issues sumounding the RF power system are resolved. Further, the cost estimate assumes the development tube used during the engineering validation phase will be available for use in the IFMIF facility. The nasster schedule of activities is:

(1)

This worksheet differs from the other summary level cost sheets because it contains a separate estimate from the Iower level WBS elements. The cost estimate at this level represents the top level documentation of the RF Station, and includes administration functions such as program management, systems engineering, support engineering, financial controllers, engineering aides for project support, project travel during the desige and construction phase, contracts management, report data and other miscellaneous activities not related to the specific hardware design tasks described in the lower level RF power system WBS element worksheets.

\section{Detailed WRS Listing (costs shown before addition of AFI):} WBS

4.2.3.7: RF Power System

4.2.3.7.1: RF Control

4.2.3.7.2* RF Predriver

4.2.3.7.3: RF Driver and Final Amplifier

4.2.3.7.4: RF Transport

4.2.3.7.5: Cavity Resonance Control System

4.2.3.7.6: Switchgear

4.2.3.7.7; Cooling

\begin{tabular}{c} 
Cost (kICF) \\
\hline 4,703 \\
5,852 \\
3,846 \\
27,078 \\
7,653 \\
1,461 \\
1,743 \\
6,193
\end{tabular}


4.2.3.7.8: RF Station Monitoring and Control

4.2.3.7.9: Integration Equipment and Services

\section{Costing Rationale:}

The estimate is comprised of two major portions labor and material. Northrop Grumman's past experience delivering high power RF systems (through the recently acquired Westinghouse Electronic Systems and Sensors Group) and components on similar programs was utilized to develop the labor estimates. To understand the material costs, suppliers in the various areas were contacted and subsequently provided rough order of magnitude quotes.

Allowance for Indeterninates: $35 \%$ based on technical risk

\section{E. Detailed Costing:}

The estimate, for the managerial work performed at this level of WBS, is based on engineering experience associated with management of large scale desiga and development programs of similar complexity such as the Northrop Grumman production ASR-9 and ARSR-4 radar systems. The management defined here differs from the top level RF system manager defined in WBS 4.J Accelerator Facility Management. The management personnel here will focus on the integration of the many separate efforts with the RF power system, and not on the integration of the RF to accelerator activities.

After review, the labor effort required equates to 2.35 FTE over the project seven year period (2000 through 2006). These personnel will be estimated at the project manager rate of 150 ICF/nour and 147 man hours per man month with an $8 \%$ fee.

\section{E. References:}

1. ORNL/M-4908, "IFMIF, International Fusion Materials Irradiation Facility, Conceptual Design Activity, Interim Report" 
WORKSHEET

WBS 4.2.3.7.1 Radio Frequency (RF) Control Systems

\section{A. Summary Cost Estimate:}

\begin{tabular}{|c|c|c|c|c|c|c|c|c|}
\hline \multicolumn{4}{|c|}{ Off-IFMIF Site } & \multicolumn{5}{|c|}{ On-Site At IFMIF } \\
\hline Industry & Instit'al & & & $\begin{array}{l}\text { Cor } \\
\text { Contr }\end{array}$ & $\begin{array}{l}\text { sit. } \\
\text { actor }\end{array}$ & Instit'al & & \\
\hline Mat'/Lab Engis'g & Engin'g & $\overline{A F I}$ & Total & Mat'lLab & Engin's & Engin'g & $\mathrm{A}$ II & Total \\
\hline 5,282 & 175 & 2,048 & 7,900 & - & 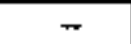 & - & $\overline{-}$ & - \\
\hline
\end{tabular}

Units: Kilo ICF

\section{B. Task Description:}

This estimate documents the resources required to design, fabricate, test, and ship the RF system control components to the IFMIF site for installation and checkout. A detailed description of the specification of this system is contained in reference 1. In summary, this element interfaces with the RF station monitor \& control subsystem, and the cavity resonance control subsystem, and maintains the phasing of the RF delivered by the high power RF amplification chain for proper RFQ, DTL, and HEBT operation. The elements estimated include a $R F$ reference source, a RF reference distribution chain, the cavity field control system, a downconverter, a vector detection-modulation circuitry, a microcontroller and bus interface to the host computer, upconverter interface to the high power RF amplifier, and associated packaging and cooling.

\section{Detailed WBS Listing:}

None developed for this estimate

\section{Costing Rationale:}

The estimate is comprised of two major portions labor and material. Northrop Grumman's past experience delivering high power RF systems (through the recently acquired Former Westinghouse Electronic Systems and Sensors Group) components on similar programs was utilized to develop the labor estimates. To understand the material costs, suppliers in the various areas were contacted and subsequentiy provided rough order of magnitude quotes.

Allowance for Indeterninates: $35 \%$ based on technical risk

\section{E. Detailed Costing:}

\section{Design Labor (Engineering):}

A review of the necessary tasks to complete the design work and produce the required information to ensble the fabrication (drawings, specifications, subcontracting plans, etc.) dictated a mix of engineering talent that equated to 0.75 full time equivalent (FTE) personnel, of which 0.25 FTE are from institutional engineering, over the 45 
months allotted for the effort. All of this labor was calculated at the engineering rate of 100 ICF per man hour and 147 man hours per man month with an $8 \%$ fee. The engineering disciplines included in this estimate are:

- RF Design

- Mechanical Design

- Electrical Design

- Support Structure Design

- Vacuum Design

- Thermal Analysis

- Instrumentation/Diagnostics

- Produceability

- System Engineering

Fabrication Labor

Northrop Grumman produceability/manufacturing reviewed the requirements and drafted a preliminary subcontracting plan which included delineation between purchased items and internally fabricated ones. For the components that would be internally fabricated estimates of the required labor and material were generated. For the purchased items, vendors were solicited to provide rough order of magnitude costs. The last piece of information from the manufacturing department was an estimate of the assembly tasks.

The result of this effort yielded a staff of 7.45 FTE technicians over the 24 months that this task is scheduled to span. The technicians were estimated at 80 ICF per hour at 147 man hours per man month with an $8 \%$ fee.

\section{Instirutional Lahor fEngineeringi:}

Based upon past experience in developing RF control systerns similar to the specifications for the IFMIF ones, an allowance of 0.25 FTE for the entire design effort (preliminary and final) was included. Like the Industry engineering talent, the Institutional labor was estimated at 100 ICF per hour and 147 man hours per man month

\section{Material:}

The existing level of detail surrounding the device provided enough information to contact vendors concerning rough order of magninude quotes on the hardware. The first unit cost for this component is 255 kilo ICF, which, for the 12 sets required by the accelerator, translates to a total cost for the material portion of this estimate of 2,709 kilo ICF.

\section{E. References:}

1. ORNL/M-4908, "IFMIF, International Fusion Materials Irradiation Facility, Conceptual Design Activity, Interim Report" 
WORKSHEET

WBS 4.2.3.7.2 Radio Frequency (RF) Predriver Systems

A. Summary Cost Estimate:

\begin{tabular}{|c|c|c|c|c|c|c|c|c|}
\hline \multicolumn{4}{|c|}{ Off-FMMIF Site } & \multicolumn{5}{|c|}{ On-Site At IFMüF } \\
\hline Industry & Instita & & & $\begin{array}{l}\text { Cor } \\
\text { Contr }\end{array}$ & $\begin{array}{l}\text { ist. } \\
\text { actor }\end{array}$ & Instit'al & & \\
\hline Mat'Uab Engin'g & Engin's & $\mathrm{AFI}$ & Total & MatULab & Engin'g & Engin'g & AFI & Total \\
\hline 3,320 & 135 & 1,346 & 5,192 & - & -- & - & - & - \\
\hline
\end{tabular}

Units: Kilo ICF

B. Task Descriotion:

This estimate documents the resources required to design, fabricate, test, and ship the RF system predriver components to the IFMIF site for installation and checkout. A detailed description and specification of this system is contained in reference 1 . In summary, the RF Predriver is a high gain, $175 \mathrm{MHz}$ solid state amplifuer responsible for boosting the low level RF signal source up to the $3.0 \mathrm{~kW}$ needed by the driver stage of the $\mathrm{RF}$ amplifier chain. The Predriver is composed of two three stage amplifiers which when combined provide over $50 \mathrm{~dB}$ of gain. The Predriver output is isolated from the tetrode driver RF input, and incorporates fail-soft architecture for improved avaslability.

\section{Detailed WBS Listing:}

None developed for this estimate

\section{Costing Rationale:}

The labor estimate is comprised of two major portions labor and material. Northrop Grumman's past experience delivening high power RF systems (through the recently acquired Former Westinghouse Electronic Systems and Sensors Group) components on similar programs was utilized to develop the labor estimates. Predominately, the costs were developed from the Northrop Grumman production VHF $14 \mathrm{~kW}$ pulsed communications transmitter, with a 1.5 complexity factor to adapt the circuitry and packaging for CW operation at $3.0 \mathrm{~kW}$.

Allowance for Indeterminates: $35 \%$ based on technical risk

\section{E. Detailed Costing:}

\section{Design Labor (Engineering):}

A review of the necessary tasks to complete the design work and produce the required information to enable the fabrication (drawings, specifications, subcontracting plans, etc.) dictated a mix of engineering talent that equated to approximately 1.0 full time equivalent (FTE) personnel, of which 0.25 FTE support is from institutional engineering, over the 24 months allotted for the effort. All of this labor was calculated at 
the engireering rate of 100 ICF per man bour and 147 man hours per man month with an $8 \%$ fee. The engineering disciplines involved in this estimate are:

- RF Design

- Mechanical Design

- Electrical Design

- Support Structure Design

- Vacuum Design

- Thermal Analysis

- Instrumentation/Diagnostics

- Produceability

- System Engineering

\section{Eabrication Labor:}

Northrop Gnumman produceability/manufacturing reviewed the requirements and drafted a preliminary subcontracting plan which included delineation between purchased items and internally fabricated ones. For the components that would be internally fabricated estimates of the required labor and material were generated. For the purchased items, vendors were solicited to provide rough order of magnitude costs. The last piece of information from the manufacturing department was an estimate of the assembly tasks.

The result of this effort yielded a staff of approximately 3.75 FTE technicians over the $\mathbf{2 4}$ months that this task is scheduled to span. The technicians were estimated at 80 ICF per hour at 147 man hours per man month with an $8 \%$ fee.

\section{Institutional Labor (Engineeringl:}

Based upon past experience in developing RF control systems similar to the specifications for the IFMIF ones, an allowance of 0.25 FTE for the entire design effort (preliminary and final) was included. Like the Industry engineering talent, the Institutional labor was estimated at J00 ICF per hour and 147 man hours per man month

\section{Material:}

The existing level of detail surrounding the device provided enough information to contact vendors concerning rough order of magnitude guotes on the hardware. The firsi unit cost for this component is $212 \mathrm{kjlo}$ ICF, which for the 12 sets required by the accelerator translates to a total cost for the material portion of this estimate of 2,196 kilo ICF.

\section{F. References:}

1. ORNLMM-4908, "IFMIF, International Fusion Materials Irradiation Facility, Conceptual Design Activity, Interim Report" 
WORKSHEET

WBS 4.2.3.7.3 Radio Frequency (RF) Driver \& Final Power Amplifier Systems

A. Surnmary Cost Estimate:

\begin{tabular}{|c|c|c|c|c|c|c|c|}
\hline \multicolumn{4}{|c|}{ Off-IFMIF Site } & \multicolumn{4}{|c|}{ On-Site At lFinfF } \\
\hline Industry & Instital & & & $\begin{array}{l}\text { Const. } \\
\text { Contractor }\end{array}$ & Instrtal & & \\
\hline Mat'/Lab Engin'g & Engin'g & $\mathrm{AFI}$ & Total & Mat'MLab Engin'g & Engin's & AF & Total \\
\hline $24,483 \quad 1,783$ & 812 & 9,477 & 36,555 & - & - & - & - \\
\hline
\end{tabular}

Units: Kilo ICF

B. Task Description:

This estimate documents the resources required to design, fabricate, test, and ship the RF system driver and final power amplifser components to the IFMIF site for installation and checkout. A detailed description and specification of this system is contained in reference 1 . In sammary, the $\mathrm{RF}$ final amplifier provides over $13 \mathrm{~dB}$ of gain to bring the RF drive up to $1.0 \mathrm{MW}$ of CW power as needed by either the RFQ, DTL, or HEBT configarations. Similar in architecture to the RF driver, the final anplifier is composed of a $1000 \mathrm{~kW}$ output tube (Eimac $4 \mathrm{CM} 2500 \mathrm{KG}$ tetrode or equivalent) and cavity assembly, along with its power conditioning, monitor, control, protection, and cooling interface components. The tetrode output is directly coupled to a matched cavity which directs the output RF to the appropriate RF transport chain..

\section{Detailed WBS Listing:}

None developed for this estimate

\section{Costing Rationale:}

The estimate is comprised of two major portions labor and material. Northrop Grumman's past experience delivering high power RF systems (through the recently acquired Former Westinghouse Electronic Systems and Sensors Group) components on similar programs was utilized to develop the labor estimates.

Allowance for Indeterminates: $35 \%$ based on technical risk

\section{E. Detailed Costing:}

\section{Design Labor (En ineering):}

A review of the necessary tasks to complete the design work and produce the required information to enable the fabrication (drawings, specifications, subcontracting plans, etc.) dictated a mix of engineering talent that equated to approximately 1.0 full time equivalent (FTE) personnel, of which 0.25 FTE support is from institutional engineering, over the 24 months allotted for the effort. All of this labor was calculated at 
the engineering rate of 100 ICF per man hour and 147 man hours per man month with an $8 \%$ fee. The engineering disciplines involved in this estimate are:

- RF Design

- Mechanical Design

- Electrical Design

- Support Structure Design

- Vacuum Design

- Thermal Analysis

- Instrumentation/Diagnostics

- Produceability

- System Engineering

\section{Eabrication Labor:}

This component will be procured as a unit. As a result there are no Northrop Grumman fabrication labor associated with the manufacture of this component.

\section{Institurtional Labor (Engjuecting):}

Based upon past experience in developing RF control systems similar to the specifications for the IFMIF ones, an allowance of 0.25 FTE for the entire design effort (preliminary and final) was included. Like the Industry engineering talent, the Instinutional labor was estimated at 100 ICF per hour and 147 man hours per man month.

\section{Material:}

The existing level of detail surrounding the device provided enough information to contact vendors concerning rough order of magnitude quotes on the hardware. The unit cost for this component is 2310 kilo ICF, which for the 12 sets required by the accelerator translates to a total cost for the material portion of this estimate of 24,483 kilo ICF.

\section{E. References:}

1. ORNL/M-4908, "IFMIF, International Fusion Materials Iradiation Facility, Conceptual Design Activity, Interim Report" 
WORKSHEET

WBS 4.2.3.7.4 RF Transport Systems

A. Summary Cost Estimate:

\begin{tabular}{|c|c|c|c|c|c|c|c|c|}
\hline \multicolumn{4}{|c|}{ Off-IFMLF Site } & \multicolumn{5}{|c|}{ On-Site At iFMIF } \\
\hline Industry & Instital & & & $\begin{array}{l}\text { Cor } \\
\text { Contr }\end{array}$ & $\begin{array}{l}\text { ist. } \\
\text { actor }\end{array}$ & Instital & & \\
\hline Mat'/Lab Engin'g & Engin'g & AFI & Total & Mat'/Lab & Engin's & Engin'g & AFI & Total \\
\hline $5,968 \quad 1,305$ & 380 & 2,678 & 10,333 & - & - & -- & - & - \\
\hline
\end{tabular}

Units: Kilo ICF

\section{B. Task Description:}

This WBS element contains the necessary allocations to cover the design, procurement, and checkout of the various RF transport elements prior to shipment to the IFMIF facility for installation and checkout. The full technical details of the configuration is contained in reference 1 . Most of the elements of the RF transport system (with the exception of the circulator) are catalog items. The circulator, at the IFMIF operating frequency and power level, will need modest development during the engineering validation phase of the program. A base assumption for this estimate is that all technical feasibility issues are resolved prior to any work covered by the allocations here.

\section{Detailed WBS Listing:}

4.2.3.7.4.1

4.2.3.7.4.1.1

4.2.3.7.4.1.2

4.2 .3 .7 .4 .1 .3

4.2.3.7.4.1.4

4.2.3.7.4.2

4.2.3.7.4.2.1

4.2.3.7.4.2.2

4.2.3.7.4.2.3

4.2.3.7.4.2.4

4.2.3.7.4.3

4.2.3.7.4.3.1

4.2.3.7.4.3.2

4.2.3.7.4.3.3

4.2 .37 .4 .3 .4

4.2.3.7.4.4

4.2.3.7.4.5

4.2.3.7.4.6

4.2.3.7.4.7

4.2 .3 .7 .4 .8
RF Station To RFQ

Coax COUPLERS (1- 19" \& 2 - 14" Per Station) Splitters

Windows

RF Station To DTL

Coax COUPLERS (1-19" \& $2-14^{*}$ Per Station)

Splitters

Windows

RF Station To HEBT

Coax

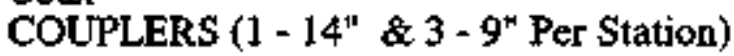

Splitters

Windows

Circulators (19" Y-Junction)

Filters $\left(19^{*}\right)$

Low Power Couplers

RF Dumuny Loads

Air Pressurization \& Distribution 


\section{Costing Rationale:}

The estimate is comprised of mostly of procured material, but some small amount of technician labor is included to cover basic functional checkout of the equipment at the RF vendor prior to shipment to the IFMIF site. Northrop Grumman's past experience delivering high power RF systems (through the recently acquired Fonner Westinghouse Electronic Systems and Sensors Group) components on similar programs was utilized to develop the labor estimates. Predominately, the RF iransport elements are procured items, and the estimates were based on commercial catalog data and vendor quotes per the defined configuration and layout of the transport chain. Engineering effort for the design and specification of the RF transport configuration and for component specifications is also included.

Allowance for Indeterminates: $35 \%$ based on technical risk

\section{E. Detailed Costing:}

Design Labor Engineeringl:

A review of the necessary tasks to complete the design work and produce the required information to enable the fabrication (drawings, specifications, subcontracting plans, etc.) dictated a mix of engineering talent that equated to approximately 4.25 full time equivalent (FTE) personnel, of which 2.0 FTE support is from institutional engineering, over the $\mathbf{2 4}$ months allotted for the effort. All of this labor was calculated at the engineering rate of 100 ICF per man hour and 147 man hours per man month with an $8 \%$ fee. The engineering disciplines involved in this estimate are:

- RF Transport Design

- Mechanical Design

- Thermal Anałysis

- Instrumentation/Diagnostics

- Produceability

- System Engineering

Fabrication Labor:

Northrop Grumman produceability/manufacturing reviewed the subsystem requirements and drafted a preliminary subcontracting plan which included delineation between purchased items and internally fabricated ones. For the components that would be internally fabricated estimates of the required labor and material were generated. For the purchased items, vendors were solicited to provide rough order of magnitude costs. The last piece of information from the manufacturing department was an estimate of the assembly tasks.

The result of this effort yielded a staff of approximately $2.0 \mathrm{FTE}$ technicians over the 24 months that this task is scheduled to span. The technicians were estimated at 80 ICF per hour at 147 man hours per man month with an $8 \%$ fee.

Institutional Labor (Engineering): 
Based upon past experience in developing RF transport systems similar to the specifications for the IFMIF oses, an allowance of 2.0 FTE for the entire design effort (preliminary and final) was included. Like the Industry engineering talent, the Institutional labor was estimated at 100 ICF per hour and 147 man hours per man month

\section{Material:}

The existing level of detail surrounding the device provided enough information to contact vendors concerning rough order of magnitude guotes on the hardware. The list of components included is fully described in reference 1, but a short summary list of the major types of components is included below. The total cost for the hardware list is 5,504 kỉo ICF.

- Coax transport line $(19,14,9$, and 3 inch size $)$

- Directional couplers (various sizes)

- Harmonic filters (various sizes)

- Muiti-port hybrid splitters (various sizes and number of ports)

- Circulator and loads

- RF Windows

\section{E. References:}

1. ORNL/M-4908, "FFMIF, International Fusion Materials Irradiation Facility, Conceptual Design Activity, Interim Report" 
WORKSHEET

WBS 4.2.3.7.5 Cavity Resonance Control Systems

A. Summary Cost Estimate:

\begin{tabular}{|c|c|c|c|c|c|c|c|c|}
\hline \multicolumn{4}{|c|}{ Off-IFMIF Site } & \multicolumn{5}{|c|}{ On-Śite At IFMIIF } \\
\hline Industry & Instit'al & & & Cont & actor & Instit'al & & \\
\hline Mat'VLab Engin'g & Engin's & AFI & Total & Mat'VLab & Engin'g & Engin'g & AFI & Total \\
\hline $1,061 \quad 356$ & 44 & 511 & 1,972 & -- & -- & -- & -- & $=$ \\
\hline
\end{tabular}

Units: Kilo ICF

\section{B. Task Description:}

This estimate documents the resources required to design, fabricate, test, and ship the RF system cavity resonance control system components to the IFMIF site for installation and checkout. A detailed description and specification of this system is contained in reference 1 . In summary, this subsystem is required to minimize distortion of the beam within the accelerator cavities, the system will sample the beam via a 6-port hybrid, and via a microcontroller, control the flow of cooling liquid to maintain the correct cavity temperature that will in tum tone the cavity to the desired frequency.

\section{Destailed WBS Listing:}

None developed for this estimate

\section{Costing Rationale:}

The estimate is comprised of two major portions labor and material. Northrop Grumman's past experience delivering high power RF systems (through the recently acquired Former Westinghouse Electronic Systems and Sensors Group) components on similar programs was utilized to develop the labor estimates. Predominately, the costs were developed from engineering estimates based on use of reflectometer applications for radar measurements and mechanical/thermal experience with proportional flow control loops, liquid cooling equipment, and flow monitor detection of similar complexity on various Northrop Grumman production radar systerns..

Allowance for Indeterminates: $35 \%$ based on technical risk

\section{E. Detailed Costing:}

\section{Design Labor (Engineering):}

A review of the necessary tasks to complete the design work and produce the required information to enable the fabrication (drawings, specifications, subcontracting plans, etc.) dictated a mix of engineering talent that equated to approximately 1.0 full time equivalent (FTE) personnel, of which $0.10 \mathrm{FIE}$ support is from institutional engineering, over the 24 months allotted for the effort. All of this labor was calculated at 
the engineening rate of $100 \mathrm{ICF}$ per man hour and 147 man hours per man month with an $8 \%$ fee. The engineering disciplines involved in this estimate are:

- Mechanical Desiga

- Thermal Analysis

- Instrumentation/Diagnostics

- Produceability

- System Engineering

\section{Fabrication Labor:}

Northrop Grumman produceability/manufacturing reviewed the subsystem requirements and drafted a preliminary subcontracting plan which included delineation between purchased iterns and internally fabricated ones. For the components that would be internally fabricated estimates of the required labor and material were generated. For the purchased items, vendors were solicited to provide rough order of magnitude costs. The last piece of information from the manufacturing department was an estimate of the assembly tasks.

The result of this effort yielded a staff of approximately 1.25 FTE technicians over the $\mathbf{2 4}$ months that this task is scheduled to span. The technicians were estimated at $80 \mathrm{ICF}$ per hour at 147 man hours per man month with an $8 \%$ fee.

\section{Institutional Labor (Engineering):}

Based upon past experience in developing RF control systems similar to the specifications for the IFMIF ones, an allowance of 0.10 FTE for the entire design effort (preliminary and final) was included. Like the Industry engineering talent, the Institutional labor was estimated at $100 \mathrm{ICF}$ per hour and 147 man hours per man month

\section{Material:}

The existing level of detail surrounding the device provided enough information to contact vendors concerning rough order of magnitude quotes on the hardware. The unit cost for this component is 65 kilo ICF, which, for the 12 sets required by the accelerator, transiates to a total cost for the material portion of this estimate of 672 kilo ICF.

\section{E. References:}

1. ORNL/M-4908, "IFMIF, International Fusion Materials Irradiation Facility, Conceptual Design Activity, Interim Report" 
WORKSHEET

WBS 4.2.3.7.6 Switchgear Systems

\section{A. Summary Cost Estimate:}

\begin{tabular}{|c|c|c|c|c|c|c|c|c|}
\hline \multicolumn{4}{|c|}{ Off-EMMIF Site } & \multicolumn{5}{|c|}{ On-Site At FMIF } \\
\hline Industry & Instit'al & & & $\begin{array}{c}\text { Con } \\
\text { Contra }\end{array}$ & $\begin{array}{l}\text { st. } \\
\text { actor }\end{array}$ & Instital & & \\
\hline Mar'/Lab Engin'g & Engin'g & AFI & Total & Mat'hab & Engin'g & Enginatg & AFI & Total \\
\hline $1,635 \quad 35$ & 53 & 570 & 2,313 & - & - & $=$ & 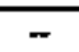 & - \\
\hline
\end{tabular}

Units: Kjlo ICF

B. Task Descciption:

This estimate documents the resources required to design, fabricate, test, and ship the RF system switchgear components to the IFMIF site for installation and checkout. A detailed description and specification of this system is contained in reference 1. In summary, this worksheet includes all low level switchgear, voltage transformers, and AC power distribution necessary for proper RF station operation which is not included in the procured driver and final RF amplifier high voltage power supplies. It is assumed that the initial step-down transformers from the primary power transmission lines are provided as part of the site facility switchyard.

\section{Detailed WBS Listing:}

None developed for this estimate

\section{Costing Rationaie:}

The labor estimate is comprised of two major portions labor and material. Northrop Grumman's past experience delivering high power RF systems (through the recentiy acquired Former Westinghouse Electronic Systems and Sensors Group) components on similar programs was utilized to develop the labor estimates. Predominately, the costs were developed from engineering experience associated with the integration of liquid cooled, high power, remotely controlled RF sources of similar complexity on various Northrop Gnumman production radar systems.

\section{Aliowance for Indeterninates: $35 \%$ based on technical risk}

\section{E. Detailed Costing:}

\section{Design Labor. (Engineeringl:}

A review of the necessary tasks to complete the design work and produce the required information to enable the fabrication (drawings, specifications, subcontracting plans, etc.) dictated a mix of engineering talent that equated to approximately 0.25 full time equivalent (FTE) personnel, of which 0.15 FTE support is from institutional engineering, over the 24 months allotted for the effort All of this labor was calculated at 
the engineering rate of 100 ICF per man hour and 147 man hours per man month with an $8 \%$ fee. The enginetring disciplines involved in this estimate are:

- Mechanical Design

- Thermal Analysis

- Instrumentation/Diagnostics

- Produceability

- System Engineering

\section{Eabrication Labor:}

Northrop Grumman produceability/manufacturing reviewed the subsystem requirements and drafted a preliminary subcontracting plan which included delineation berween purchased items and internally fabricated ones. For the components that would be internally fabricated estimates of the required labor and material were generated. For the purchased items, vendors were solicited to provide rough order of magnitude costs. The last piece of information from the manufacturing department was an estimate of the assembly tasks.

The result of this effort yielded a staff of approximately 0.65 FTE technicjans over the 24 months that this task is scheduled to span. The technicians were estimated at $80 \mathrm{ICF}$ per hour at 147 man hours per man month with an $8 \%$ fee.

\section{Institutional Labor(Engineeringi:}

Based upon past experience in developing RF control systems similar to the specifications for the IFMIF ones, an alfowance of 0.15 FTE for the entire design effort (preliminary and final) was included. Like the Industry engineering talent, the Institutional labor was estimated at 100 ICF per hour and 147 man hours per man month

\section{Material:}

The existing level of detail surrounding the device provided enough information to contact vendors concerning nough order of magnitude quotes on the hardware. The unit cost for this component is 141 kilo ICF, which, for the 12 sets required by the accelerator, translates to a total cost for the material portion of this estimate of 1458 kilo ICF.

\section{E. References:}

1. ORNL/M-4908, "IFMIF, International Fusion Materials Irradiation Facility, Conceptual Design Activity, Interim Report" 
WORKSHEET

WBS 4.2.3.7.7 Cooling Systems

\section{A. Summary Cost.Estimate:}

\begin{tabular}{|c|c|c|c|c|c|c|c|c|}
\hline \multicolumn{4}{|c|}{ Off-IFMIIF Site } & \multicolumn{5}{|c|}{ On-Site At IFMIF } \\
\hline Industry & Instit'al & & & $\begin{array}{r}\text { Con } \\
\text { Contr }\end{array}$ & |st. & Instital & & \\
\hline Mat'WLab Engin'g & Engin'g & $\overline{\mathrm{AFI}}$ & Total & Mat'l/Lab & Engin'g & Engin'g & $\overline{\mathrm{A}} \overline{\mathrm{FI}}$ & Total \\
\hline $5.790 \quad 217$ & 186 & 2,167 & 8,360 & $=$ & 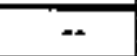 & - & - & - \\
\hline
\end{tabular}

Units: Kilo ICF

\section{B. Task Description:}

This estimate documents the resources required to design, fabricate, test, and ship the RF system cooling components to the IFMH site for installation and checkout. A detailed description and specification of this system is contained in reference 1. In summary, this worksheet includes separate cooling loops in each RF station to provide temperature, flow, and pressure interlocks, and include a distribution pump system and manifold with flow regulators, coolant conditioning and filtering, and a liquid-to-liquid heat excharger to transfer heat to the IFMIIF site cooling system.

\section{Detailed WBS Listing:}

None developed for this estimate

\section{Costing Rationale:}

The estimate is comprised of two major portions labor and material. Nortbrop Grumman's past experience delivering high power RF systems (through the recently acquired Former Westinghouse Electronic Systems and Sensors Group) components on similar programs was utilized to develop the labor estimates. Predominately, the costs were developed from vendor quotes on procured items such as the heat exchanger, plumbing, pumps and manifolds, and is also based on engineering experience associated with liquid cooling of high power radar systems which are similar in complexity.

Allowance for Indeterminates: $35 \%$ based on tecbnical risk

\section{E. Detailed Costing:}

\section{Design Labor (Engineering):}

A review of the necessary tasks to complete the design work and produce the required information to enable the fabrication (drawings, specifications, subcontracting plans, etc.) dictated a mix of engineering talent that equated to approximately 1.1 full time equivalent (FTE) personnel, of which 0.5 FTE support is from institutional engineering, over the 24 months allotted for the effort. All of this labor was calculated at 
the engineering rate of 100 ICF per man hour and 147 man hours per man month with an $8 \%$ fee. The engineering disciplines involved in this estimate are:

- Mecharical Design

- Thermal Analysis

- Instrumentation/Diagnosties

- Produceability

- System Engineering

\section{Fabrication Labor:}

Northrop Grumman produceability/manufacturing reviewed the subsystem requirements and drafted a preliminary subcontracting plan which included delineation between purchased items and internally fabricated ones. For the components that would be intemally fabricated estimates of the required labor and material were generated. For the purchased items, vendors were solicited to provide rough order of magnitude costs. The last piece of information from the manufacturing department was an estimate of the assembly tasks.

The result of this effort yielded a staff of approximately 4.3 FIE technicians over the 24 months that this task is scheduled to span. The technicians were estimated at 80 ICF per hour at 147 man hours per man month with an $8 \%$ fee.

\section{Institutional Lahor (Engineering):}

Based upon past experience in developing RF control systems similar to the specifications for the IFMIF ones, an allowance of 0.5 FTE for the entire design effort (preliminary and final) was included. Like the Industry engineering talent, the Institutional labor was estimated at 100 ICF per hour and 147 man hours per man month

\section{Material:}

The existing level of detail surtounding the device provided enough information to contact vendors concerning rough order of magnitude quotes on the hardware. The unit cost for this component is 443 kilo ICF, which, for the 12 sets required by the accelerator, translates to a total cost for the material portion of this estimate of 4,585 kilo ICF.

\section{E. References:}

t. ORNL/M-4908, "IFMIF, International Fusion Materials Irradiation Facility, Conceptsal Design Activity, Interim Report" 
WORKSHEET

WBS 4.2.3.7.8 Radio Frequency (RF) Station Control \& Monitoring Systems

\section{A. Summary Cost Estimate:}

\begin{tabular}{|c|c|c|c|c|c|c|c|c|c|}
\hline \multicolumn{5}{|c|}{ Off-IFMIF Site } & \multicolumn{5}{|c|}{ On-Site At IFMiF } \\
\hline Ind & stry & Instit'al & & & Cont & $\begin{array}{l}\text { st. } \\
\text { actor }\end{array}$ & Instit'a & & \\
\hline MarliLat & Engin's & Engin'g & $\mathbf{A F I}$ & Total & Mar'lLab & Engin's & Engir'g & AFI & Total \\
\hline 966 & 628 & 50 & 576 & 2,220 & -- & -.- & $=$ & - & -- \\
\hline
\end{tabular}

Units: Kilo ICF

\section{B. Task Description:}

This estimate documents the resources required to design, fabricate, test, and ship the RF system station control and monitoring components to the IFMIF site for installation and checkout. A detailed description and specification of this system is contained in reference 1. In sumrnary, this worksheet includes the integrated control and monitoring function to maintain the proper operation of the complete RF station, and also provides remote digital information transfer to the master IFMIF control system via data bus interconnections. A central microprocessor will provide the local control and monitor display and interface within each RF station.

\section{Detailed WBS Listing: \\ 1 None developed for this estimate}

\section{Costing Rationale:}

The estimate is comprised of two major portions lator and material. Northrop Grumman's past experience delivering high power RF systems (through the recently acquired Former Westinghouse Electronic Systems and Sensors Group) components on similar prograns was utilized to develop the labor estimates. Predominately, the costs were developed from the Northrop Grumman production ASR-9 radar remote monitoring subsystem, which is of similar complexity to the RF station environment.

Allowance for Indeterminates: $35 \%$ based on technical risk

\section{E. Detailed Costing:}

\section{Design Labor (Engineering):}

A review of the necessary tasks to complete the design work and produce the required information to enable the fabrication (drawings, specifications, subcontracting plans, etc.) dictated a mix of engineering talent that equated to approximately 1.5 full time equivalent (FTE) personnel, of which 0.1 FTE support is from institutional engineering, over the 24 months allotted for the effort. All of this labor was calculated at 
the engineering rate of 100 ICF per man hour and 147 man hours per man month with an $8 \%$ fee. The engineering disciplines involved in this estimate are:

- Instrumeatation/Diagnostics

- Produceability

- System Engineering

\section{Eabrication Labor:}

Northrop Grumman produceability/manufacturing reviewed the subsystem requirements and drafted a preliminary subcontracting plan which included delineation between purchased items and internally fabricated ones. For the components that would be internally fabricated estimates of the required jabor and material were generated. For the purchased items, vendors were solicited to provide rough order of magnitude costs. The last piece of information from the manufacturing department was an estimate of the assembly tasks.

The result of this effort yielded a staff of approximately 2.0 FTE technicians over the 24 months that this task is scheduled to span. The technicians were estimated at 80 ICF per hour at 147 man hours per man month with an $8 \%$ fee.

\section{Institutionai Labor(Engineering):}

Based upon past experience in developing RF control systems similar to the specifications for the IFMIIF ones, an allowance of 0.1 FTE for the entire design effort (preliminary and final) was included. Like the Industry engineering talent, the Institutional labor was estimated at $100 \mathrm{ICF}$ per hour and 147 man hours per man month

\section{Material:}

The existing level of detail surrounding the device provided enough information to contact vendors concerning rough order of magnitude quotes on the bardware. The unit cost for this component is 35 kilo ICF, which, for the 12 sets required by the accelerator, translates to a total cost for the material portion of this estimate of 356 kilo ICF.

\section{E. References:}

1. ORNL/M-4908, "IFMIF, International Fusion Materials Irradiation Facility, Conceptual Design Activity, Interim Report" 
WORKSHEET

WBS 4.2.3.7.9 Integration Equipment and Services

\section{A. Summary Cost Estimate:}

\begin{tabular}{|c|c|c|c|c|c|c|c|}
\hline \multicolumn{4}{|c|}{ Off-IFMÏF Site } & \multicolumn{4}{|c|}{ On-Site At IFMiF } \\
\hline Industry & Instit'al & & & $\begin{array}{c}\text { Const. } \\
\text { Contractor }\end{array}$ & Instital & & \\
\hline Mat'líab Engin'g & Engin's & $\mathrm{AFI}$ & Total & Mat'lLab Engin'g & Engin's & $\overrightarrow{\mathrm{A}} \hat{\mathrm{F} I}$ & Total \\
\hline 2,737 & 136 & $\overline{1,157}$ & $\overline{4,460}$ & $\overline{--}$ & 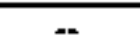 & - & 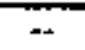 \\
\hline
\end{tabular}

Units: Kilo ICF

\section{B. Task Description:}

This estimate documents the resources required to design, fabricate, test, and utilize the RF system integration equipment prior to any equipment being shipped to the to the IFMIF site. A detailed description and specification of this system is contained in reference 1. In summary, this worksheet includes the equipment needed to install and setup the RF stations and RF transport ejements of the IFMIF system for a test before they are shipped to the site. The items in this task are those which are manufactured and/or used in the testing of the equipment prior to stipment.

\section{Detailed WBS Listing:}

None developed for this estimate

\section{Costing Rationale:}

The estimate is comprised of two major portions labor and material. Northrop Grumman's past experience delivering high power RF systems (through the recently acquired Former Westinghouse Electronic Systems and Sensors Graup) components on similar programs was utilized to develop the labor estimates. Predominately, the costs were developed from the engineering experience obtained from the integration of high power radar transmitters in various Northrop Grumman production systems, and the quote prepared for the 1.0 MW S-band RF source for the Arecibo Observatory in Puerto Rico.

Allowance for Indeterminates: $35 \%$ based on technical risk

\section{E. Detailed Costing:}

\section{Design Labor (Engineeringli:}

A review of the necessary tasks to complete the design work and produce the required information to enable the fabrication (drawings, specifications, subcontracting plans, etc.) dictated a mix of engineering talent that equated to approximately 1.75 full time equivalent (FTE) personnel, of which 0.5 FTE support is from institutional engineering, over the 24 months allotied for the effort. All of this labor was calculated at 
the engineering rate of 100 ICF per man hour and 147 man hours per man month with an $8 \%$ fee.

\section{Eabrication Labor:}

Northrop Grumman produceability/manufacturing reviewed the subsystem requirements and drafted a preliminary subcontracting plan which included delineation between purchased items and internally fabricated ones. For the components that would be intemally fabricated estimates of the required labor and material were generated. For the purchased items, vendors were solicited to provide rough order of magnitude costs. The last piece of information from the manufachuring department was an estimate of the assembly tasks.

The result of this effort yielded a staff of approximately 6.5 FTE technicians, and 3.0 FTE craft labor over the 24 months that this task is scheduled to span. The texhricians were estimated at 80 ICF per hour, while the craft were estimated at $25 \mathrm{ICF}$ per hour, and both at 147 man hours per man month with an $8 \%$ fee.

\section{Instifutional Labor (Engineering):}

Based upon past experience in developing RF control systems similar to the specifications for the IFMIF ones, an allowance of 0.5 FTE for the entire design effort (preliminary and final) was included. Like the Industry engineering talent, the Institutional labor was estimated at 100 ICF per hour and 147 man hours per man month

\section{Material:}

The existing level of detail surrounding the device provided enough information to contact vendors concerning rough order of magnitude quotes on the hardware. The unit cost for this component is 35 kilo ICF, which, for the 12 sets required by the accelerator, translates to a total cost for the maferial portion of this estimate of 357 kilo ICF.

\section{E. References:}

1. ORNL/M-4908, "IFMIF, International Fusion Materials Irradiation Facility, Conceptual Design Activity, Interim Report" 
WORKSHEET

WBS 4,2.4 Accelerator \#2 (Pollux)

\section{A. Summary Cost Estimate:}

\begin{tabular}{|c|c|c|c|c|c|c|}
\hline \multicolumn{3}{|c|}{ Off-IFMIF Site } & \multicolumn{4}{|c|}{ On-Site At FMIF } \\
\hline Industry & Instit'a & & $\begin{array}{c}\text { Const. } \\
\text { Contractor }\end{array}$ & Instit'al & & \\
\hline $\begin{array}{c}\text { Mat'l/L Engin } \\
\text { ab }\end{array}$ & $\underset{g}{\text { Fingin' }}$ & AFI Total & Mat'l/L Engin & Engin'g & AFT & Total \\
\hline $78,050 \quad 6,162$ & - & $29,766113,98$ & $\begin{array}{ll}- & - \\
\end{array}$ & - & - & - \\
\hline
\end{tabular}

Units: Kilo ICF

\section{B. Task Description:}

This estimate is a summary level compilation of lower level estimates. As a whole this estimate expresses the total resources required to update the design with lessons learned from the first accejerator, then to produce a second accelerator. Other than this exception there is no other design work included in this estimate. Further, the labor estimates employed here assume the experience gained in fabricating and fielding the first accelerator is maintained and applied to the benefit of the second accelerator. Lastly, because of the experience gained on the first accelerator, the labor estimates here assume that the second accelerator system can be built entirely by industry without the any laboratory oversight. The top level schedule for the second accelerator is: 


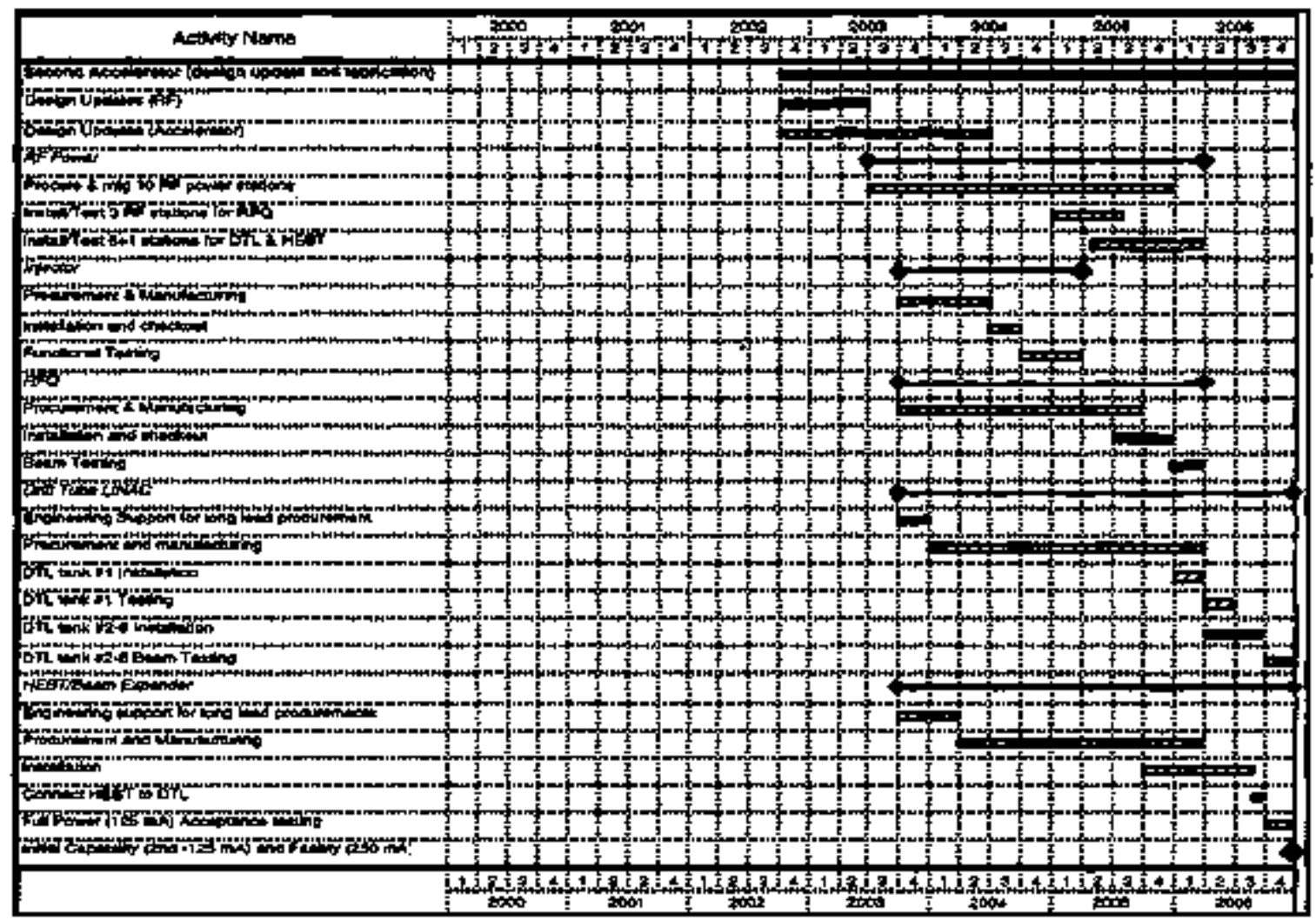

\section{C.Detailed WBS Lusting:}

WBS

4.2.3.1: Design Updates

Cost

4.2.3.2: Injector System

700

4.2.3.3: Radio Frequency Quadrupole System

1,880

4,2.3.4: Drlft Tube Linac System

9,830

4.2.3.5: High Energy Bearn Transport (HEBT) System

4,2.3.6: RF Power Supply System

17,930

13,662

69.980

Total: . . 113,978

\section{Costingetationale;}

The estimate is comprised of two major portions labor and material. Northrop Grumman's past experience delivering accelerating coraponents on similar programs was utilized to develop the labor estimates. To understand the material costs, suppliers in the various areas were contacted and subsequently supplied rough order of magnitude quotes.

Allowance for Indeterminates: $35 \%$ based on technical zisk

\section{E. Detailed Costing:}

See lower WBS worksheets 
WORKSHEET

WBS 4.2.4.1 Design Updates

A. Summary Cost Estimare:

\begin{tabular}{|c|c|c|c|c|c|c|c|}
\hline \multicolumn{4}{|c|}{ Off-IFIMIF Site } & \multicolumn{4}{|c|}{ On-Site At IFMif } \\
\hline Industry & Instit'al & & & $\begin{array}{c}\text { Const. } \\
\text { Contractor }\end{array}$ & Instit'al & & \\
\hline Mat'/Lab Engin'g & Engin'g & AFI & Total & Mar'ULab Engin'g & Engin'g & AFI & Total \\
\hline 320 & $\because$ & 180 & 700 & -- & -- & -- & - \\
\hline
\end{tabular}

Units: Kilo ICF

B. Task Description:

This worksheet documents the necessary manpower to update the design of the second accelerator (Pollux) to reflect experience gained from the fabrication and check out of the first accelerator system (Castor). It is anticipated that this task will contain only industrial engineering labor hours due to the nature of the design updates expected. The schedule for these activities is shown below.

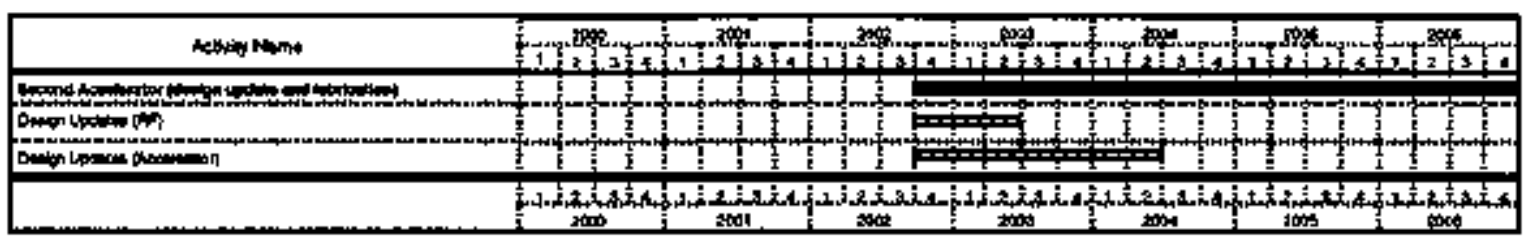

\section{Detailed WBS Listing:}

None used in the preparation of this estimate

\section{Costing Rationale:}

The labor estimate was developed from Northrop Grumman experience on other similar programs.

Allowance for Indeterminates: $35 \%$ based on technical risk

\section{E. Detailed Costing:}

As stated previously, this is a labor only task. A 1.0 full time equivalent (FTE) engineer is assigned to each major subsystem for the activity duration. These personnel were costed at the engineering rate of $100 \mathrm{ICF}$ per hour and 147 man hours per man month with an $8 \%$ fee. 
WORKSHEET

WBS 4.2.4.2 Injector

\section{A. Summary Cost Estimate:}

\begin{tabular}{|c|c|c|c|c|c|c|c|}
\hline \multicolumn{4}{|c|}{ Off-IFMIF Site } & \multicolumn{4}{|c|}{ On-Site At IFMIF } \\
\hline Industry & Instit'al & & & $\begin{array}{l}\text { Const. } \\
\text { Contractor }\end{array}$ & Institial & & \\
\hline Marl/Lab Engin'g & Ëngip'g & AFI & Total & Mat'/Lab Epgin'g & Engin'g & AFI & Total \\
\hline $1,260 \quad 140$ & 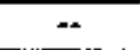 & 480 & 1,880 & - & - & - & $\because$ \\
\hline
\end{tabular}

Units: KiJo ICF

\section{B. Task Description:}

The injector portion of the accelerator is fully described in reference 1 . This worksheet documents the necessary resources to deliver two full injector assemblies, as well an additional spare ion source, in support of the second accelerator (Pollux). This estimate also assumes that the injector design for the first accelerator is maintained with little or no modifications. Any modifications will not require further engineering analysis before commencing with the fabrication and pre-shipment checkout. All design upgrade engineering will be accomplished under WBS 4.2.4.1 Design Upgrade activities. Further, this estimate assumes that the assembly experience gained during the Castor accelerator work will reduce some of the assembly labor necessary for the Pollux injector system. The master schedule govening the activities of this worksheet is shown below:

(1)

\section{Detailed WBS Listing:}

None established

\section{Costing Rationale:}

The estimate is comprised of two major portions labor and material. Northrop Grumman's past experience delivering accelerating components on similar programs was utilized to develop the labor estimates. To understand the material costs, suppliers in the various areas were contacted and subsequently provided rough order of magnitude quotes.

Allowance for Indeterminates: $35 \%$ based on technical risk

\section{E. Detailed Costing:}


The estimate is comprised of two major parts, Labor and material. The labor falls into two major categories: industrial support engineering and fabrication labor.

\section{Industrial Supoort Engineering:}

1.0 full time equivalent (FTE) engineer is provided to support the fabrication effort as well as provide capability to address any difficulties which may arise. This support is scheduled to extend over the nine months required to field the injector system. This labor is estimated at 100 ICF per bours and 147 man hours per man month with an $8 \%$ fee.

\section{Fabrication Labor:}

The draft subcontracting plan developed for the first accelerator was modified to reflect the expected savings in labor and fabrication time for the follow on effort for the second accelerator. The result of this effort yielded a staff of 3.0 FTE technicians together with 2.0 FTE engineers over the nine months that this task is scheduled to span. The technicians were estimated at 80 ICF per hour, the engineers at 100 ICF per hour, and both considering 147 man bours per man month with an $8 \%$ fee. The engineering skills to be employed during the fabrication task are:
- Liaison Engineering
- Mechanical Design
- Electrical Design
- Quality Control

Material:

The existing level of detail surrounding the device provided enough information to contact vendors concerning rough order of magnitude quotes for the hardware identified below. The total cost for the material portion of this estimate was $670 \mathrm{kijo}$ ICF.

Component

Source and RF Power Supply

Low Energy Beam Transport (LEBT)

Magnet Power Supplies

Operational Control Equipment and Software

Vacuum Equipment and Services

Thermal Control Equipment and Services

Structural Support and Shielding Equipment

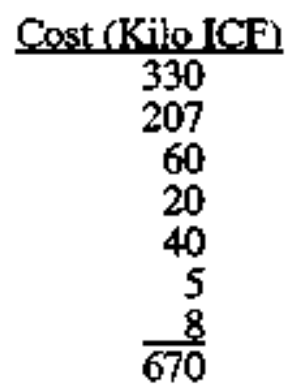

\section{F. References:}

1. ORNL/M-4908, "IFMIF, International Fusion Materials Irradiation Facility, Conceptual Design Activity, Interim Report" 


\section{WORKSHEET \\ WBS 4.2.4.3 Radio Frequency Quadrupole (RFO) System}

\section{A. Summary Cost Estimate:}

\begin{tabular}{|c|c|c|c|c|c|c|c|}
\hline \multicolumn{4}{|c|}{ Off-IFMtF Site } & \multicolumn{4}{|c|}{ On-Site At IFMiF } \\
\hline Industry & Instit'al & & & $\begin{array}{c}\text { Const. } \\
\text { Contractor }\end{array}$ & Instit'al & & \\
\hline Mat'l/Lab Eugin's & Engin's & AFI & Total & Mat'//_ab Engio' & Engin's & AFI & Total \\
\hline 6,900 & - & 2,550 & 9,830 & - & - & - & -- \\
\hline
\end{tabular}

Units: Kilo ICF

\section{B. Task Description:}

The RFQ portion of the accelerator is fully described in reference 1 . This worksheet documents the necessary resource to deliver one 12 meter long, $8 \mathrm{MeV} R F Q$, in support of the second accelerator (Pollux). This estimate also assumes that the experience base developed during the fabrication of the first accelerator RFQ can be transferred to the second accelerator and utilized to reduce the associated manpower required. The master schedule for the Pollux RFQ system is shown below:

(1)

\section{Detailed WBS Listing:}

None established

\section{Costing Rationale:}

The estimate is comprised of two major portions labor and material. Northrop Grumman's past experience delivering accelerating components on similar programs was utilized to develop the fabor estimates. To understand the material costs, suppliers in the various areas were contacted and subsequently provided rough order of magnitude quotes.

Allowance for Indeterminates: $35 \%$ based on technical risk

\section{E. Detailed Costing:}

The estimate is comprised of two major parts, labor and material. The labor falls into two major categories: industrial support engineering and fabrication labor. 
Industrial Support Engineering Labor:

An allowance of 1.0 full time equivalent (FTE) personnel is included to help oversee the procurement activities and address any difficulties that arise. This activity is scbeduled to extend over the full 24 months of the procurement and manufacturing effort shown in the schedule above. The engineer were estimated at 100 ICF per hours and 147 man hours per man month with an $8 \%$ fee.

\section{Eabrication Labor:}

Utilizing the experience gained from the first RFQ fabrication an estimate was developed to express the amount of savings that could be realized. The result of this effort yielded a staff of 6.4 FTE technicians together with 5.0 FTE engineers over the 24 months that this task is scheduled to span. The technicians were estimated at 80 ICF per hour, the engineers at 100 ICF per hour, and both considering 147 man bours per man month with an $8 \%$ fee. The engineering skills to be employed during the fabrication task are:

- Liaison Engineering

- Mechanical Design

- Electrical Design

- Quality Control

\section{Material:}

The existing level of detail surrounding the device provided enough information to contact vendors concerning rough order of magnitude quotes for the hardware identified below. The total cost for the material portion of this estimate was 3000 kilo ICF.

Component

Oxygen Free High Conductivity (OFHC) Copper

$\mathrm{RF}$ drive loops

Cost (KiloICF)

Electroforning services

Miscellaneous hardware $\&$ services

(Vactuun. Themnal, Stress, Structural support, etc.)

TOTAL:

\section{E. References:}

1. ORNL/M-4908, "IFMIF, Intemational Fusion Materials Irradiation Facility, Conceptual Design Activity, Interin Report" 
WORKSHEET

WRS 4.2.4.4 Drift Tube Linac (DTL) System

A. Summary Cost Estimate:

\begin{tabular}{|c|c|c|c|c|c|c|c|c|}
\hline \multicolumn{4}{|c|}{ Off-LFMF Site } & \multicolumn{5}{|c|}{ On-Site At IFMîF } \\
\hline Goustry & Tnstital & & & $\begin{array}{l}\text { Con } \\
\text { Contr }\end{array}$ & $\begin{array}{l}\text { st. } \\
\text { actor }\end{array}$ & Instita & & \\
\hline Mat'/Lab Ëngin'g & Engin'g & AFI & Total & Mat'ULab & Engin'g & Engin'g & AFI & Total \\
\hline $12,640-640$ & 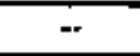 & 4,650 & $1 \overline{7}, 930$ & $=$ & - & - & -- & $=$ \\
\hline
\end{tabular}

Units: Kilo ICF

B. Task Description:

The technical aspects of the DTL accelerating system is fully described in reference 1. This worksheet uses this information, together with the information contained in WBS 4.2.3.3 Drift Tube Linac System (for first accelerator), to develop a listing of the necessary resource to deliver eight DTL tanks in support of the second accelerator (Pollux). This estimate assumes that the experience gained during the first accelerator manufacture will be employed for this accelerator and a resulting savings in fabrication labor will be realized. Further, any engineering modifications driven from the experience will be incorporated in the design under the WBS 4.2.4.1 Design Updates axtivities. The master schedule for the Pollux DTL system is shown below:

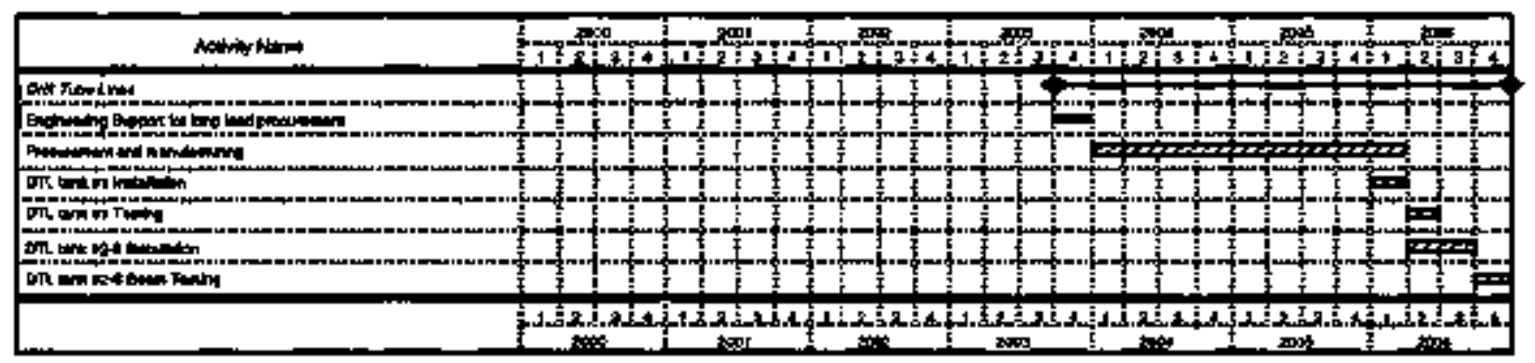

C. Detailed WBS Listing (costs expressed with_apportioned AE):

WBS

4.2.4.4.1: Tank \#1

4.2.4.4.2: Tank \#2

4.2.4.4.3: Tank \#3

4.2.4.4.4: Tank \#4

4.2.4.4.5: Tank \#5

4.2.4.4.6: Tank \#6

4.2.4.4.7: Tank \#7

4.2.4.4.8: Tank \#8

$\begin{array}{cc} & \text { Cost (kICF) } \\ & 2,580 \\ 2,420 \\ 2,250 \\ \\ & 2,190 \\ & 2,150 \\ & 2,130 \\ & 2,090 \\ \text { TOTAL: } & 2,080 \\ & 13,280\end{array}$

page - 66 


\section{D.Costing Rationale:}

The labor estimate is cormprised of two major portions labor and material. Northrop Grumman's past experience delivering accelerating components on similar programs was utilized to develop the labor estimates. To understand the material costs, suppliers in the various areas were contacted and subsequently provided rough order of magnitude quotes.

Allowance for Indeterminates: $35 \%$ based on technical risk

\section{E. Detailed Costing:}

The estimate is comprised of two major parts, labor and material. The labor falls into two major categories: industrial support engineering and fabrication labor.

\section{Industrial Support Engineering:}

The DTL manufacturing plan includes a significant number of procured items that will be produced in large quantity. In support certain engineering skills will be required to ensure the subcontracted work is being properly executed. The list of the skill types required is shown below. The schedule shown above indicates that an three years span for this activity in which approximately 1.0 FTE engineers were estimated at 100 ICF per bours and 147 man hours per man month with an $8 \%$ fee.

- Quality Control

- Methods

- Production Management/Controls

- Liaison Engineering

\section{Eabrication Labor:}

The draft subcontracting plan created for the first accelerator DTL system was reviewed and modified for use on the second accelerator. The embedded fabrication labor was then modified to reflect the experience from producing the first series of DTL accelerating tanks. The result of this effort yielded a staff of 5.0 FTE technicians, together with 2.5 engineers, over the 36 months that this task is scheduled to span. The technicians were estimated at 80 ICF per hour, the engineers at 100 ICF per man hour, and both at 147 man hours per man month with an $8 \%$ fee. 


\section{Material:}

The existing level of detail surrounding the device provided enough information to contact vendors concerning rough order of magnitude quotes for the hardware jdentified below. The total cost for the material portion of this estimate was 8,080 kilo ICF.

Purchased material for each tank

\begin{tabular}{|l|}
\hline Drift Tubes \\
\hline Drift tube magnets \\
\hline Vacuum system equipment \& \\
Services \\
\hline Oxygen Free High Conductivity \\
(OrHC) Copger for tank shell \\
\hline Endwalls with magnets \\
\hline Tank supgort system \\
\hline Rail Tuners \\
\hline RF drive loops \\
\hline Post couplers \\
\hline Orift tube support girder \\
\hline Inter-tank focusing quadrupole \\
package \\
\hline miscellaneous harcware \\
\hline
\end{tabular}

Material Breakdown by tank (without AFI)

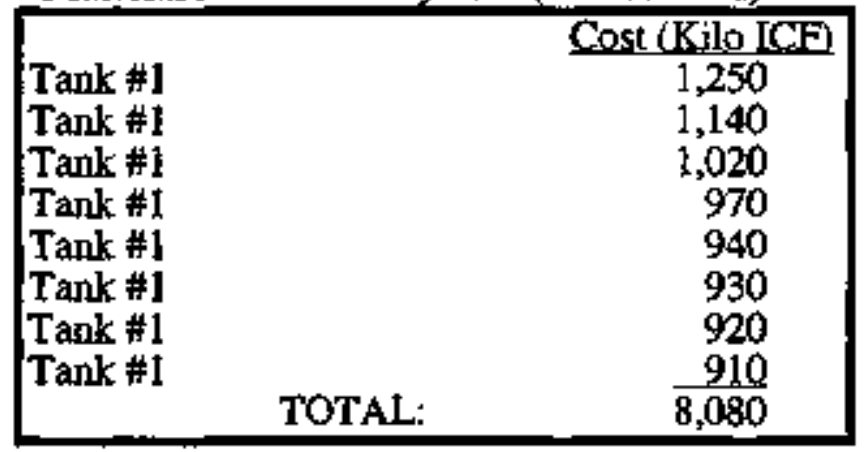

\section{E. References:}

1. ORNL/M-4908, "IFMIF, International Fusion Materials Irradiation Facility, Conceptual Design Activity, Interim Report" 
WORKSHEET

WBS 4.2.4.5 High Energy Beam Transport (HEBT)

A. Summary Cost Estimate:

\begin{tabular}{|c|c|c|c|c|c|c|c|}
\hline \multicolumn{4}{|c|}{ Off-IFMIF Site } & \multicolumn{4}{|c|}{ On-Site At IFMIF } \\
\hline Industry & $\begin{array}{c}\text { Instlt'a } \\
1\end{array}$ & & & $\begin{array}{c}\text { Const. } \\
\text { Contractor }\end{array}$ & Instit'al & & \\
\hline Mat'l/L Engin & Engin' & AFI & Total & $\operatorname{Mat}_{\mathrm{ab}} \mathrm{E}_{\mathrm{b}}$ & Engin't $\mathrm{g}$ & AFI & Total \\
\hline $9,263 \quad 857$ & $\ldots$ & 3,542 & 13,662 & $-{ }_{-}--$ & - & -- & - \\
\hline
\end{tabular}

Units: Kilo ICF

\section{B. Task Description:}

The technical aspects of the HEBT system of the accelerator are fully described in reference 1 . This worksheet uses this information developed in WBS 4.2.3.4 High energy Beam Transport to estimate the necessary resources to deliver three transport lines (one to each lithium target and one to the fixed facility beam dump) in support of the second accelerator (Pollux). This estimate also assumes the experience gained in manufacturing the first HEBT system will be used to produce a savings in fabrication labor for the Pollux HEBT. The master schedule for the Pollux HEBT system is shown below:

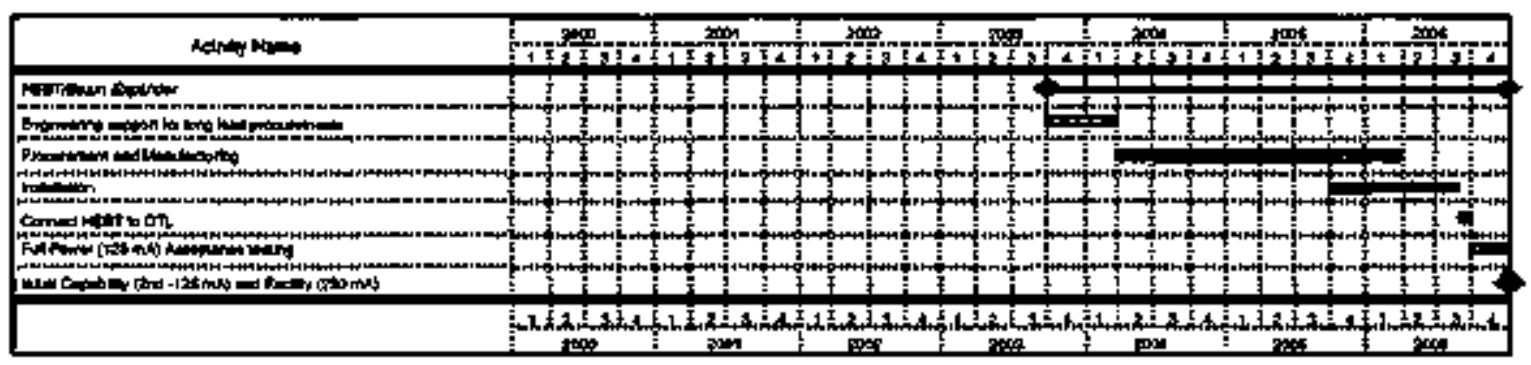

C._Detailed WBS Listing:

None developed in support of this costing activity

\section{Costing Rationale;}

This estimate is comprised of two major portions, labor and material. Northrop Grumman's past experience delivering accelerating components on similar programs was utilized to develop the labor estimates. To understand the material costs, information from the past accelerating programs was updated with information collected from suppliers in the various areas who were contacted and subsequently provided rough order of magnitude quotes.

Allowance for Indeterminates: $35 \%$ based on technical risk 


\section{E. Detailed Costing:}

The estimate is comprised of two major parts, labor and material. The labor falls into two major categories: industrial support engineering and fabrication labor.

\section{Industrial Support Engineering Labor -}

The HEBT manufacturing plan includes a significant number of procured items (magnets, điagnostics, power supplies, etc.) that will be produced in large quantity. In support of this a separate team of individuals will be required to ensure the subcontracted work is being properly executed. The list of the skill types required is shown below. The schedtile shown above indicates that a 27 month span for this activity in which approximately 2.00 FTE engineers were estimated at IOO ICF per hoturs and 147 man hours per man month with an $8 \%$ fee,

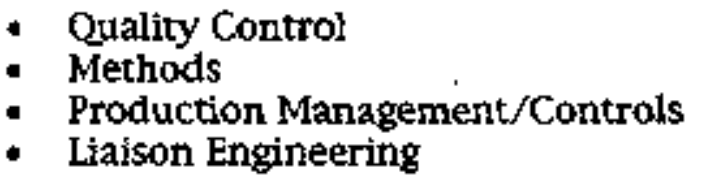

\section{Eabrication Labor}

The draft subcontracting plan prepared for the first HEBT was modifled to reflect the savings in fabrication labor that due to the experience of fabricating the first accelerators HEBT. The result of this effort yielded a staff of 4.0 FTE technicians, with support form 2.0 FTE engineers, over the 12 months that this task is scheduled to span. The technicians were estimated at 80 ICF per hour, with the engineers at 100 ICF per man hour, both considering 147 man hours per man month with an $8 \%$ fee.

\section{Matecial:}

The existing level of detail surrounding the device provided enough information to contact vendors concerning rough order of magnitude quotes for the hardware identified below. The total cost for the material portion of this estimate was 8,420 kilo ICF (without any AFI).

\begin{tabular}{|c|c|}
\hline Purchased Item & Cost (kICF) \\
\hline Beam Tube, Flanges, Bellows, etc. & 210 \\
\hline RF Cavities & 1,610 \\
\hline Support/Alignment Structure & 290 \\
\hline $\begin{array}{l}\text { Quadrupole magnets: } 6 \text { "long } \times 5^{\prime \prime} \text { dia } \\
\text { bore }\end{array}$ & 250 \\
\hline $\begin{array}{l}\text { Ouadrupole magnets: } 16^{\prime \prime} \text { long } \times 5^{\text {r dia }} \\
\text { bore }\end{array}$ & 360 \\
\hline $\begin{array}{l}\text { Quadrupole magnets: } 24^{\prime \prime} \text { long x } 5 \text { " dia } \\
\text { bore }\end{array}$ & 950 \\
\hline $\begin{array}{l}\text { Octupole magnets: } 16^{+1} \text { long x } \overline{3} .5^{\prime \prime} \text { dia } \\
\text { bore }\end{array}$ & 780 \\
\hline Dipole $\left(45^{\circ}\right)$ magnets; 5 " gap & 660 \\
\hline Dipole $\left(10^{\circ}\right)$ magnets: 5 "gap & 340 \\
\hline
\end{tabular}




\begin{tabular}{|c|c|}
\hline Magnet Power Supolies & 1,670 \\
\hline Energy Spread Monitors & 320 \\
\hline Phase Spread Monitors & 150 \\
\hline Video Profile Monitor & 80 \\
\hline Microstrlplines & 570 \\
\hline & 8,420 \\
\hline
\end{tabular}

\section{E. References: -}

1. ORNL/M-4908, "IFMIF, International Fusion Materials Irradiation Facility, Conceptual Design Activity, Interim Report" 


\section{WORKSHEET \\ WBS 4.2.4.6 Radio Frequency (RF) Power System}

A. Summary Cost Estimate:

\begin{tabular}{|c|c|c|c|c|c|c|c|}
\hline \multicolumn{4}{|c|}{ Off-IFMIF Site } & \multicolumn{4}{|c|}{ On-Site At LFMIF } \\
\hline İndustry & Instit'al & & & $\begin{array}{c}\text { Const. } \\
\text { Contractor }\end{array}$ & Instital & & \\
\hline Mat'/Lab Engin'g & Engin'g & $\overline{\mathrm{AF}}$ & Total & Mat/Lab Enģin'g & Engin'g & AF! & Total \\
\hline $47,987 \quad 3,652$ & - & 18,064 & 69,676 & $-\quad-$ & - & - & - \\
\hline
\end{tabular}

Units: Kilo ICF

B. Task Description:

This worksheet contains a top level summary of the costs to design, fabricate, test, and ship out an RF power system for the second accelerator (Pollux). The technical features of this system are described in detail in reference 1 . This estimate assumes that during the engineering validation phase (1997-1999) all technology feasibility issues surrounding the RF power system are resolved. Further, the cost estimate assumes the development tube used during the engineering validation phase will be available for use in the IFMIF facility. The master schedule activities is:

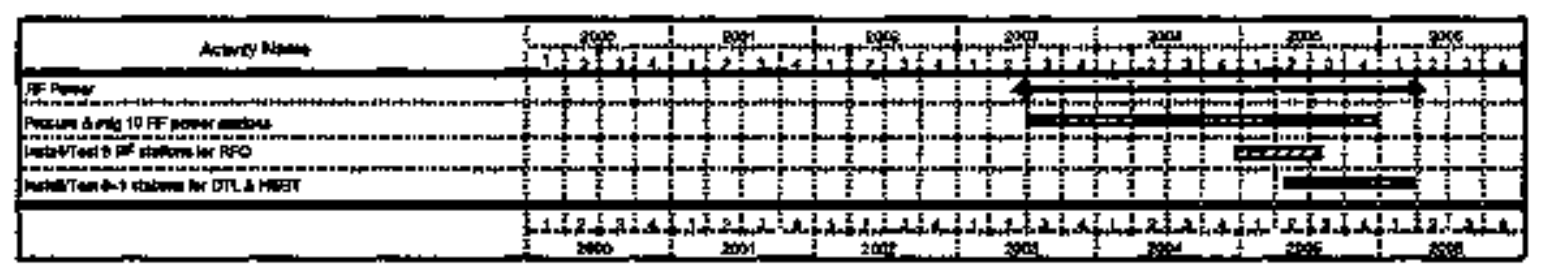

This worksheet differs from the other sumrnary level cost sheets because it has a separate estinate from the lower level WBS elements. The cost estimate at this level represents the top level documentation of the RF Station, and includes administration functions such as program management, systems engineering, support engineering, financial controllers, engineering aides for project support, project travel during the design and construction phase, contracts management, report data and other miscellaneous activities not related to the specific bardware design tasks described in the lower level RF power system WBS element worksheets.

C. Detailed WBS Listing (costs shown before addition of AFI:

WBS

4.2.3.7:

RF Power System

4.2.3.7.1: RF Control

4.2.3.7.2: RF Predriver

4.2.3.7.3: RF Driver and Final Amplifier

4.2.3.7.4:

4.2.3.7.5:

4.2.3.7.6:

4.2.3.7.7:
RF Transport

Cavity Resonance Control System

Switchgear

Cooling
Cost (kIC)

1,294

5,049

3,314

24,025

5,866

1,094

1,375

5,703 


\subsubsection{8: RF Station Monitoring and Control}

4.2.3.7.9: Integration Equipment and Services

\section{Costing Rationate:}

Like the system for the Castor accelerator this estimate is comprised of two major portions labor and material. Northrop Grumunan's past experience delivering high power RF systems (through the recently acquired Former Westinghouse Electronic Systems and Sensors Group) components on similar programs was utilized to develop the labor estimates. To understand the material costs, suppliers in the various areas were contacted and subsequently provided rough order of magnitude quotes.

Allowance for Indeterninates: $35 \%$ based on technical risk

\section{E. Detailed Costing:}

The estimate, for the managetial work performied at this level of WBS, is based on engineering experience associated with management of large scale design and development programs of similar complexity such as the Northrop Grumman production ASR 9 and ARSR-4 radar systems. The management defined here differs from the top level RF system manager defined in WBS 4.1 Accelerator Facility Management. The management personnel here will focus on the integration of the many separate efforts with the RF power system, and not on the management of the RF to accelerator activities.

After review, the labor effort required equates to 1.5 FTE over the project seven year period (2000 through 2006). These personnel will be estimated at the project manager rate of $150 \mathrm{ICF} / \mathrm{hour}$ and 147 man hours per mar month with an $8 \%$ fee.

\section{E. References:}

1. ORNL/M-4908, "IFMIF, International Fusion Materials Irradiation Facility, Conceptual Design Activity, interim Report" 


\section{WORKSHEET}

WBS 4.2-4.6.1 Radio Frequency (RF) Control Systems

A. Summary Cost Estimate:

\begin{tabular}{|c|c|c|c|c|c|c|c|c|}
\hline \multicolumn{4}{|c|}{ Off-IFMIF Site } & \multicolumn{5}{|c|}{ On-Site At IFMIF } \\
\hline Industry & Instit'an & & & $\begin{array}{c}\mathrm{Co} \\
\text { Cont }\end{array}$ & act & Instital & & \\
\hline Mat'ilLab Engin'g & Enging & $\overline{\text { AFI }}$ & Total & Mat $1 / L a b$ & Engin'g & Engin'g & $\mathbf{A F I}$ & Total \\
\hline $4,951 \quad 98$ & $-\infty$ & 1,767 & 6.816 & - & - & - & - & - \\
\hline
\end{tabular}

Units: Kilo ICF

\section{B. Task Description:}

This estimate documents the resources required to design, fabricate, test, and ship the RF system control components to the IFMIF site for installation and checkout. A detailed deseription of the specification of this system is contained in reference 1 . In summary, this element interfaces with the RF station monitor \& control, and the cavity resonance control system, and maintains the phasing of the RF delivered by the high power RF amplification chain for proper RFQ, DTL, and HEBT operation. The elements estimated include a RF reference source, a RF reference distribution chain, the cavity field control system, a downconverter, a vector detection-modulation circuitry, a microcontroller and bus interface to the host computer, upconverter interface to the high power $\mathrm{RF}$ amplifier, and associated packaging and cooling.

\section{Detailed WBS Listing:}

None developed for this estimate

\section{Costing Rationale:}

Like the system for the Castor acceierator this estimate is comprised of two major portions labor and material. Northrop Grumman's past experience delivering high power RF systems (through the recently acquired Former Westinghouse Electronic Systems and Sensors Group) components on similar programs was utilized to develop the labor estimates. To understand the material costs, suppliers in the various areas were contacted and subsequently provided tough order of magnimade quotes.

Allowance for Indeterminates: $35 \%$ based on technical nisk

\section{E. Detaikd Costing:}

\section{Design Labor(Engineering):}

A review of the necessary tasks to maintain the design material to enable the fabrication (drawings, specifications, subcontracting plans, etc.) dictated a mix of engineering talent that equated to 0.25 full time equivalent (FTE) personnel over the 24 months allotted for the effort. All of this labor was calculated at the engineering rate of 
100 ICF per man hour and 147 man hours per man month with an $8 \%$ fee. The engineering disciplines included in this estimate are:

- Mechanical Design

- Electrical Design

\section{Fabrication Labor:}

Northrop Grumman produceability/manufacturing reviewed the requirements and drafted a preliminary subcontracting plan which included delineation between purchased items and internally fabricated ones. For the components that would be internally fabricated estimates of the required labor and material were generated. For the purchased items, vendors were solicited to provide rough order of magnitude costs. The last piece of information from the manufacturing department was an estimate of the assembly tasiks.

The result of this effort yielded a staff of 6.75 FTE technicians over the 24 months that this task is scheduled to span. The technicians were estimated at 80 ICF per hour at 147 man hours per man month with an $8 \%$ fee.

\section{Material:}

The existing level of detail surrounding the device provided enough information to contact vendors concerning rough order of magnitude quotes on the hardware. The first unit cost for this component is 255 kilo ICF, which, for the 12 sets required by the accelerator, translates to a total cost for the material portion of this estimate of 2,469 kilo ICF.

\section{E. References:}

1. ORNLM-4908, "IFMIF, International Fusion Materials Irradiation Facility, Conceptual Design Activity, Interim Report" 
WORKSHEET

WBS 4.2.4.6.2 Radio Frequency (RF) Predriver Systems

A. Summary Cost Estimate:

\begin{tabular}{|c|c|c|c|c|c|c|c|c|}
\hline \multicolumn{4}{|c|}{ Off-IFMIIF Site } & \multicolumn{5}{|c|}{ On-Site At IFMIF } \\
\hline Industry & Instital & & & $\begin{array}{l}\text { Const } \\
\text { Contrac }\end{array}$ & st. & Instit'al & & \\
\hline Mat'/Lab Engin'g & Engin'g & AF & Total & Mat'Zlab E & Engin's & Engin'g & $\mathbf{A F I}$ & Total \\
\hline 3,245 & $\overrightarrow{-}$ & 1,160 & 4,474 & -- & $=$ & -- & - & - \\
\hline
\end{tabular}

Units: Kilo ICF

\section{B. Task Description:}

This estimate documents the resources required to design, fabricate, test, and ship the RF system predriver components to the IFMIF site for installation and checkout. A detailed description and specification of this system is contained in reference 1. In summary, the RF Predriver is a high gain, $175 \mathrm{MHz}$ solid state amplifier responsible for boosting the low level RF signal source up to the $3.0 \mathrm{~kW}$ needed by the driver stage of the RF amplifier chain. The Predriver is compased of two three stage amplifiers which when combined provide over $50 \mathrm{~dB}$ of gain. The Predriver output is isolated from the tetrode driver RF input, and incorporates fail-soft architecture for improved availability.

\section{Detailed WBS Listing:}

None developed for this estimate

\section{Costing Bationale:}

Like the system for the Castor accelerator this estimate is comprised of two major portions labor and material. Northrop Grumman's past experience delivering high power RF systems (through the recently acquired Former Westinghouse Electronic Systems and Sensors Group) components on similar programs was utilized to develop the labor estimates. Predominately, the costs were developed from the Northrop Grumman production VHF $14 \mathrm{~kW}$ pulsed communications transmitter, with a 1.5 complexity factor to adapt the circuitry and packaging for CW operation at $3.0 \mathrm{~kW}$.

Allowance for Indeterminates: $35 \%$ based on technical risk

\section{E. Detailed Costing:}

\section{Design Labor Fogineering:}

A revicw of the necessary tasks to maintain the design material to enable the fabrication (drawings, specifications, subcontracting plans, etc.) dictated a mix of engineering talent that equated to approximately 0.2 full time equivalent (FTE) personne] over the 24 months allotted for the effort. All of this labor was calculated at the 
engineering rate of 100 ICF per man hour and 147 man hours per man month with an $8 \%$ fee. The engineening disciplines involved in this estimate are;

- RF Design

- Mechanical Design

- Electrical Design

\section{Eabrication Labor:}

Northrop Grumman produceability/manufacturing reviewed the requirements and drafted a prefiminary subcontracting plan which included delineation between purchased items and internally fabricated ones. For the components that would be internally fabricated estimates of the required labor and material were generated. For the purchased items, vendors were solicited to provide rough order of magnitude costs. The last piece of information from the manufacturing department was an estimate of the assembly tasks.

The result of this effort yielöed a staff of approximately 3.75 FTE technicians over the 24 months that this task is scheduled to span. The technicians were estimated at 80 ICF per hour at 147 man hours per man month with an $8 \%$ fee.

\section{Material:}

The existing level of detail surrounding the device provided enough information to contact vendors concerning rough order of magnitude quotes on the hardware. The Init cost for this component is 212 kilo ICF, which for the 12 sets required by the accelerator translates to a total cost for the material portion of this estimate of 2,053 kilo ICF.

\section{F. References:}

1. ORNL/M-4908, "IFMIF, International Fusion Materials Irradiation Facility, Conceptual Design Activity, Interim Report" 
WORKSHEET

WBS 4.2.4.6.3 Radio Frequency (RF) Driver \& Final Power Amplifier Systems

A. Summary Cost Estimate:

\begin{tabular}{|c|c|c|c|c|c|c|c|c|}
\hline \multicolumn{4}{|c|}{ Off-IFMIF Site } & \multicolumn{5}{|c|}{ On-Site At IFMIF } \\
\hline Industry & Instit'al & & & $\begin{array}{l}\text { Cor } \\
\text { Cont }\end{array}$ & act. & Instit'al & & \\
\hline Mat'/Lab Engin'g & Engin's & $\mathrm{AFI}$ & Total & Mat'/Uab & Engin'g & Enging & AF & Total \\
\hline $\begin{array}{ll}22,367 & 1,658\end{array}$ & - & 8,409 & $\overline{32,434}$ & - & $\because$ & - & - & - \\
\hline
\end{tabular}

Units: Kilo ICF

\section{B. Task Description:}

This estimate documents the rescurces required to design, fabricate, test, and ship the RF system driver and final amplifier components to the IFMIIF site for installation and checkout. A detailed description and specification of this system is contained in reference 1. In summary, the RF Final Amplifier provides over $13 \mathrm{~dB}$ of gain to bring the RF drive up to $1.0 \mathrm{MW}$ of CW power as needed by either the RFQ. DTL, or HEBT configurations. Similar in architecture to the RF Diver, the firal amplifier is composed of a $1000 \mathrm{~kW}$ output tube (Eimac 4CM2500KG tetrode or equivalent) and cavity assembly, along with its power conditioning, monitor, control, protection, and cooling interface components. The tetrode output is directly coupled to a matched cavity which directs the output RF to the appropriate RF Transport chain..

\section{Detailed WBS Listing:}

None developed for this estimate

\section{Costing Rationale:}

Like the system for the Castor accelerator this estimate is comprised of two major portions labor and material. Northrop Grumman's past experience delivering high power RF systems (through the recently acquired Former Westinghouse Electronic Systems and Sensors Group) components on similar programs was utilized to develop the labor estimates.

Allowance for Indeteminates: $35 \%$ based on technical risk

\section{E. Detailed Costing:}

\section{Design Labor (Engineering):}

A review of the necessary tasks maintain the design material to enable the fabrication (drawings, specifications, subcontracting plans, etc.) dictated a mix of engineering talent that equated to approximately 4.25 full time equivalent (FTE) personnel over the 24 months allotted for the effort. All of this labor was calculated at 
the engineering rate of 100 ICF per man hour and 147 man hours per man month with an $8 \%$ fee. The engineering disciplines involved in this estimate are:

- RF Design

- Mechanical Design

- Electrical Design

- Instrumentation and Diagnostics

- Systems Engineering

Fabrication Labor:

This component will be procured as a unit. As a result there are no Northrop Grumman fabrication labor associated with the manufacture of this component.

Material:

The existing level of detail surrounding the device provided enough information to contact vendors concerning rough order of magnitude quotes on the hardware. The unit cost for this component is $2310 \mathrm{kilo}$ ICF, which for the 12 sets required by the accelerator translates to a total cost for the material portion of this estimate of 22,367 kilo ICF.

\section{F. References:}

1. ORNL/M-4908, "IFMIF, International Fusion Materials Irradiation Facility, Conceptual Design Activity, Interin Report" 


\title{
WORKSHEET \\ WBS 4.2.4.6.4 RF Transport Systems
}

\section{A. Summary Cost Estimate:}

\begin{tabular}{|c|c|c|c|c|c|c|c|c|}
\hline \multicolumn{4}{|c|}{ Off-IFMIF Site } & \multicolumn{5}{|c|}{ On-Site At BFMIF } \\
\hline Industry & Instital & & & $\begin{array}{r}\text { Co } \\
\text { Cont }\end{array}$ & $\begin{array}{l}\text { ist. } \\
\text { actor }\end{array}$ & Instital & & \\
\hline Mat'VLab Enging & Enging & AFI & Total & Mat'lLal & Eng̦in'g & Engin'g & AFI & Total \\
\hline $5,499 \quad \lcm{84}$ & - & 1,989 & 7,672 & - & - & - & - & $*$ \\
\hline
\end{tabular}

Units: Kilo ICF

\section{B. Task Description:}

This WBS element contains the necessary allocations to cover the design, procurement, and checkout of the various RF transport elements prior to shipment to the IFMIF facility for installation and checkout. The full technical details of the configuration is contained in reference 1. Most of the elements of the RF transport system (with the exception of the circulator) are procured iterns. The circulator, at the IFMIF operating frequency and power level, will need modest development diring the engineering validation phase of the program. A base assumption for this estimate is that all technical feasibility issues are resolved prior to any work covered by the allocations here.

\section{Detailed WBS Listing:}

\author{
4.2.4.6.4.1 \\ 4.2.4.6.4.1.1 \\ 4.2.4.6.4.1.2 \\ 4.2.4.6.4.1.3 \\ 4.2.4.6.4.1.4 \\ 4.2.4.6.4.2 \\ 4.2.4.6.4.2.1 \\ 4.2.4.6.4.2.2 \\ 4.2.4.6.4.2.3 \\ 4.2.4.6.4.2.4 \\ 4.2.4.6.4.3 \\ 4.2.4.6.4.3.1 \\ 4.2.4.6.4.3.2 \\ 4.2.4.6.4.3.3 \\ 4.2.4.6.4.3.4 \\ 4.2.4.6.4.4 \\ 4.2.4.6.4.5 \\ 4.2.4.6.4.6 \\ 4.2.4.6.4.7 \\ 4.2.4.6.4.8 \\ RF Station To RFQ \\ Coax \\ COUPLERS (1- 19" 2 - 14" Per Station) \\ Splitters \\ Windows \\ RF Station To DTL \\ Coax \\ COUPLERS (1- 19" \& 2 - 14" Per Station) \\ Splitters \\ Windows \\ RF Station To HEBT \\ Coax \\ COUPLERS $\left(1-14^{*} \& 3-9^{n}\right.$ Per Station) \\ Splitters \\ Windows \\ Circulators (19" Y-Junction) \\ Filters (19") \\ Low Power Couplers \\ RF Dummy Loads \\ Air Pressurization \& Distribution
}




\section{Costing Rationale:}

Like the system for the Castor accelerator this estimate is comprised of mostly of procured material, but some small amount of techrician labor is included to cover basic functional checkout of the equipment at the RF vendor prior to shipment to the IFMIF site. Northrop Grumnan's past experience delivering high power RF systems (through the recently acquired former Westinghouse Electronic Systems and Sensors Group) components on similar programs was utilized to develop the labor estimates. Predominately, the RF transport elements are procured items, and the estimates were baset on commercial catalog data and vendor quotes per the defined configuration and layout of the transport chain. Engineering effort for the design and specification of the RF transport configuration and for component specifications is also included.

Allowance for Indeterninates: $35 \%$ based on technical risk

\section{E. Detailed Costing:}

\section{Design Labor (Engineering):}

A review of the necessary tasks to maintain the design material to enable the fabrication (trawings, specifications, subcontracting plans, etc.) dictated a mix of engineering talent that equated to approximately 0.5 full time equivalent (FTE) personnel over the 24 months allotted for the effort. All of this labor was calculated at the engineering rate of $100 \mathrm{ICF}$ per man hour and 147 man hours per man month. The engineering disciplines involved in this estimate are:

$$
\text { - RFTransport Design }
$$

\section{Eabrication Labor:}

Northrop Grumman produceability/manufacturing reviewed the subsystem requirements and drafted a preliminary subcontracting plan which included delineation between purchased items and internally fabricated ones. For the components that would be internally fabricated estimates of the required labor and material were generated. For the purchased items, vendors were soljcited to provide rough order of magnitude costs. The last piece of information from the manufacturing department was an estimate of the assembly tasks.

The result of this effort yielded a staff of approximately 1.5 FTE technicians over the 24 months that this task is scheduled to span. The technicians were estimated at 80 ICF per hour at 147 man hours per man month.

\section{Material:}

The existing level of detail surounding the device provided enough information to contact vendors concerning rough order of magnitude quotes on the hardware. The list of components included are fully described in reference 1 , but a short summary list of the 
major types of components is included below. The total cost for the hardware list is 5,229 kilo ICF.

- Coax transport jine $(19,14,9$, and 3 inch size)

- Directional couplers (various sizes)

- Harmonic filters (various sizes)

- Multi-port hybrid splitters (various sizes and number of ports)

- Circulator and loads

- RF Windows

\section{E.References:}

1. ORNL/M-4908, "IFMIF, International Fusion Materials Irradiation Facility, Conceptual Design Activity, Interim Report" 
WORKSHEET

WBS 4.2.4.6.5 Cavity Resonance Control Systems

A. Summary Cost Estimate:

\begin{tabular}{|c|c|c|c|c|c|c|c|c|}
\hline \multicolumn{4}{|c|}{ Off-IFIVIF Site } & \multicolumn{5}{|c|}{ On-Site At IFMLF } \\
\hline Industry & Instit'al & & & $\begin{array}{l}\text { Con } \\
\text { Contr }\end{array}$ & st. & Instit'al & & \\
\hline Mat'/Lab Engin'g & Engin'g & AFI & Total & Mat'/Lab & Engin'g & Engin'g & AFI & Total \\
\hline 1039 & - & 383 & 1,477 & - & - & - & - & - \\
\hline
\end{tabular}

Units: Kilo ICF

\section{B. Task Description:}

This estimate documents the resources required to design, fabricate, test, and ship the RF system cavity resonance control components for the second accelerator to the IFMIF site for installation and checkout. A detailed description and specification of this system is contained in reference 1. Like the system for the first accelerator, this subsystem is required to minimize distortion of the beam within the accelerator cavities, the system will include a resonance control system which will sample the beam via a 6port hybrid, and via a microcontroller control the flow of cooling liquid to maintain the correct cavity temperature that will in tum tune the cavity to the desired frequency.

\section{C.Detailed WBS Listing:}

None developed for this estimate

\section{Costing Rationale:}

The estimate is comprised of two major portions labor and material. Northrop Grumman's past experience delivering high power $\mathrm{RF}$ systems (through the recently acquired Former Westinghouse Electronic Systems and Sensors Group) components on similar programs was utilized to develop the labor estimates. Predominately, the costs were developed from on engineering estimates based on use of reflectometer applications for radar measurements and mechanical/thermal experience with proportional flow control loops, liquid cooling equipment, and flow monitor detection of similar complexity on various Northrop Grumman production radar systems.

Allowance for Indeterminates: $35 \%$ based on technical risk

\section{E. Detailed Costing:}

Desien Labor (Engineering):

A review of the necessary tasks to maintain the design material to enable the fabrication of a second set of equipment (drawings, specifications, subcontracting plans, etc.) dictated a mix of engineering talent that equated to approximately 0.15 full time equivalent (FTE) personnel over the 24 months allotted for the effort. All of this labor 
was calculated at the engineering rate of $100 \mathrm{ICF}$ per man hour and 147 man hours per man month with an $8 \%$ fee. The engineering disciplines involved in this estimate are:

- Mechanical Design

\section{Fabrication Labor:}

The draft subcontracting plan, created for the first accelerator, was modified for the second accelerator. This inclucted delineation between purchased items and internally fabricated ones. For the components that would be internally fabricated estimates of the required labor and material were generated. For the purchased items, vendors were soljcited to provide rough order of magnitude costs. The last piece of information from the manufacturing department was an estimate of the assembly tasks.

The result of this effort yielded a staff of approximately 1.3 FTE technicians over the 24 months that this task is scheduled to span. The technicians were estimated at 80 ICF per hour at 147 man hours per man month with an $8 \%$ fee.

\section{Material:}

The existing level of detail surrounding the device provided enough information to contact vendors concerning rough order of magnitude quotes on the hardware. The unit cost for this component is 65 kilo ICF, which, for the 12 sets required by the accelerator, translates to a total cost for the material portion of this estimate of 649 kilo ICF.

\section{F.References:}

1. ORNL/M-4908, "IFMIF, International Fusion Materials Irradiation Facility, Conceptual Design Activity, Interim Report" 
WORKSHEET

WBS 4.2,4.6.6 Switchgear Systems

A. Summacy Cost Estimate:

\begin{tabular}{|c|c|c|c|c|c|c|c|c|}
\hline \multicolumn{4}{|c|}{ Off-IFMilF Site } & \multicolumn{5}{|c|}{ On-Site At IFIMIF } \\
\hline Industry & Instit'a & & & $\begin{array}{l}\text { Con } \\
\text { Contr: }\end{array}$ & act. & Instital & & \\
\hline Mat'lLab Engin'g & Engir'g & $\mathrm{AFI}$ & Total & Mat'VLab & Enging & Engign'g & AFI & Total \\
\hline $1,322 \quad 53$ & -- & 481 & 1,856 & $=$ & $\overline{--}$ & 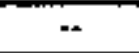 & $=$ & - \\
\hline
\end{tabular}

Units: Kilo ICF

B. Task Description:

This estimate documents the resources required to design, fabricate, test, and ship the RF system switchgear components for the second accelerator to the MFMIF site for installation and checkout. A detailed description and specification of this system is contained in reference 1 . Like the system for the first accelerator, this worksheet includes all low level switchgear, voltage transformers, and AC power distribution necessary for proper RF station operation which is not included in the procured Driver and Final RF amplifier high voltage power supplies. It is assumed that the initial step-down transformers from the primary power transmission lines are provided as part of the site facility switchyard.

\section{Detailed WBS Listing:}

None developed for this estimate

\section{Costing Rationale:}

The estimate is comprised of two major portions labor and material. Northrop Grunman's past experience delivering high power RF systems (through the recently acquired Forner Westinghouse Electronic Systems and Sensors Groupl components on similar programs was atilized to develop the labor estimates. Predominately, the costs were developed from engineering experience associated with the integration of liguid cooled, high power, remotely controlled RF sources of similar complexity on various Northrop Grumman production radar systems.

Allowance for Indeterninates: $35 \%$ based on technical risk

\section{E. Detailed Costing:}

\section{Design Lahor (Engineering:}

A review of the necessary tasks to maintain the design materiat to enable the fabrication of a second set of equipment (drawings, specifications, subcontracting plans, etc.) dictated a mix of engineering talens that equated to approximately 0.15 full time equivalent (FTE) personnel over the $\mathbf{2 4}$ months allotted for the effort. All of this labor 
was calculated at the enginesring rate of $100 \mathrm{ICF}$ per man hour and 147 man hours per man month with an $8 \%$ fee. The engineering discipline involved in this estimate are:

- Mechanical Design

\section{Eabrication Labor:}

Northrop Grumman produceability/manufacturing used the draft subcontracting plan from generated for the first accelerator as gujdance in determining a delineation between purchased items and internally fabricated ones. For the components that would be intemally fabricated estimates of the required labor and material were generated. For the purchased items, vendors were solicited to provide rough order of magnitude costs. The last piece of information from the manufacturing department was an estimate of the assembly casks.

The result of this effort yielded a staff of approximately 0.6 FTE technicjans over the 24 months that this task is scheduled to span. The technicians were estimated at 80 ICF per hour at 147 man hours per man month with an $8 \%$ fee.

\section{Material:}

The existing level of detail surrounding the device provided enough information to contact vendors concerning rough order of magnitude quotes on the hardware. The first unit cost (in respect to the first accelerator) for this component is 141 kilo ICF, which, for the second 12 sets required by the second accelerator, translates to a total cost for the material portion of this estimate of 1125 kilo ICF.

\section{E.References:}

1. ORNL/M-4908, "IFMIF, International Fusion Materials Irradiation Facility, Conceptual Design Activity, Interim Report" 


\section{WORKSHEET}

WBS 4.2.4.6.7 Cooling Systems

\section{A. Summary Cost Estimate:}

\begin{tabular}{|c|c|c|c|c|c|c|c|c|}
\hline \multicolumn{4}{|c|}{ Off-IFML Site } & \multicolumn{5}{|c|}{ On-Site At IFMIF } \\
\hline Indastry & Instital & & & $\begin{array}{r}\text { Co } \\
\text { Cont }\end{array}$ & $\begin{array}{l}\text { st. } \\
\text { actor }\end{array}$ & Instit'al & & \\
\hline Mat'LLab Enging & Engin'g & $\mathrm{AFI}$ & Total & Mat'l/Lal & Engja'g & Engè'tg & AF & Total \\
\hline 5,667 & - & 1996 & $\overline{7,699}$ & 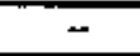 & $\bar{m}$ & - & - & $\overline{-}$ \\
\hline
\end{tabular}

Units: Kilo ICF

\section{B. Task Description:}

This estimate documents the resources required to design, fabricate, test, and ship the RF system cooling components for the second accelerator to the IFMIF site for instaflation and checkout. A detailed description and specification of this system is contained in reference 1 . Like the first accelerator, this worksheet includes separate cooling loops in each RF station to provide temperature, flow, and pressure interlocks, and include a distribution pump system and manifold with flow regulators, coolant conditioning and filtering, and a liquid-to-liquid heat exchanger to transfer heat to the IFMIF site cooling system.

\section{Detailed WBS Lissing:}

None developed for this estimate

\section{Coscing Rationale:}

The estimate is comprised of two major portions labor and material. Northrop Grumman's past experience delivering bigh power RF systems (through the recently acquired Former Westinghouse Electronic Systems and Sensors Group) components on similar programs was utilized to develop the labor estimates. Predorminately, the costs were developed from vendor quotes on procured items such as the heat exchanger, plumbing, pumps and manifolds, and is also based on enginetring experience associated with liquid cooling of high power radar systems which are similar in complexity.

Allowance for Indeterminates: $35 \%$ based on technical risk

\section{E. Detailed Costing:}

\section{Design Labor (Engineering):}

A review of the necessary tasks to maintain the design material to enable the fabrication of a second set of equipment (drawings, specifications, subcontracting plans, etc.) dictated a mix of engineering talent that equated to approximately 0.1 full time equivafent (FTE) personnel over the $\mathbf{2 4}$ months allotted for the effort. All of this labor 
was calculated at the engineering rate of $100 \mathrm{ICF}$ per man hour and 147 man hours per man month with an $8 \%$ fee. The engineering discipline involved in this estimate are:

- Mechanical Design

\section{Fabrication Labor:}

Northrop Grumman produceability/manufacturing reviewed the subsystem requirements and drafted a preliminary subcontracting plan which included delineation between purchased items and internally fabricated ones. For the components that would be internally fabricated estimates of the required labor and material were generated. For the purchased items, vendors were solicited to provide rough order of magnitude costs. The last piexe of information from the manufacturing department was an estimate of the assembly tasks.

The result of this effort yielded a staff of approximately 4.0 FTE technicians over the 24 months that this task is scheduled to span. The technicians were estimated at 80 ICF per hour at 147 man hours per man month with an $8 \%$ fee.

\section{Material:}

The existing level of detail surrounding the device provided enough information to contact vendors concerning rough order of magnitude quotes on the hardware. The first unit cost (for the first accelerator) for this component is $\mathbf{4 4 3}$ kilo ICF, which, for the 12 sets required by the second accelerator, translates to a total cost for the material portion of this estimate of 4,585 kilo ICF.

\section{E. References:}

1. ORNL/M-4908, "IFMIF, International Fusion Materials Inradiation Facility, Conceptual Design Activity, Interim Report" 
WORKSHEET

WBS 4.2,4,6.8 Radio Frequency (RF) Station Control \& Monitoring Systems

\section{A. Summary Cost Estimate;}

\begin{tabular}{|c|c|c|c|c|c|c|c|c|}
\hline \multicolumn{4}{|c|}{ Off-IFMiF Site } & \multicolumn{5}{|c|}{ On-Site Af 1FMIF } \\
\hline Industry & Instit'al & & & $\begin{array}{l}\text { Con } \\
\text { Contra }\end{array}$ & st. & Instit'al & & \\
\hline Mat'Lab Engin'g & Enging & AFI & Tota] & Mat1/Lab & Engin'g & Engin'g & AFI & Total \\
\hline $\begin{array}{ll}, 401 & 100\end{array}$ & -- & 525 & 2,026 & $=$ & - & - & $=$ & - \\
\hline
\end{tabular}

Units: Kilo ICF

\section{B. Task Descriotion:}

This estimate documents the resources required to design, fabricate, test, and ship the RF system station control and monitoring components for the second accelerator to the IFMIF site for installation and checkout. A detailed description and specification of this system is contained in reference 1. Like the equipment for the first accelerator, this worksheet includes the integrated control and monitoring function to maintain the proper operation of the complete RF station, and also provides remote digital information transfer to the master IFMIF control system via data bus interconnections. A central microprocessor will provide the local control and monitor display and interface within each RF station.

\section{Detailed WBS Listing:}

None developed for this estimate

\section{Costing Rationale:}

The estimate is comprised of two major portions labor and material. Northrop Grumman's past experience delivering high power RF systems (through the recently acquired Former Westinghouse Electronic Systems and Sensors Group) components on similar programs was utilized to develop the labor estimates. Predominately, the costs were developed from the Northrop Grumban production ASR-9 radar rernote monitoring subsystem, which is of similar complexity to the RF station environment.

Allowance for Indeterninates: $35 \%$ based on technical risk

\section{E. Detailed.Cosțing:}

Design Labor (Enginesring):

A review of the necessary tasks to maintain the design material to enable the fabrication of a second set of equipment (drawings, specifications, subcontracting plans, etc.) dictated a mix of engineering talent that equated to approximately 0.25 fulf time equivalent (FTE) personnel over the 24 months allotted for the effort. All of this labor 
was calculated at the engineering rate of 100 ICF per man hour and 147 man hours per man morth with an $8 \%$ fee. The engineering discipline involved in this estimate are:

- Instrumentation/Diagnostics

Eabrication Labor:

Northrop Grumman produceability/manufacturing reviewed the draft subcontracting plan created for the first accelerator to delineate between purchased items and internally fabricated ones for the second accelerator. For the components that would be internally fabricated estimates of the required labor and material were generated. For the purchased items, vendors were solicited to provide rough order of magnitude costs. The last piece of information from the manufacturing department was an estinate of the assembly tasks.

The result of this effort yierded a staff of approximately 3.0 FTE technicians over the 24 months that this task is scheduled to span. The technicians were estimated at 80 ICF per hour at 147 man hours per man month with an $8 \%$ fee.

\section{Material:}

The existing level of detail surrounding the device provided enough information to contact vendors concerning rough order of magnitude quotes on the hardware. The first unit cost (in the first accelerator) for this component is 35 kilo ICF, which considering lot savings, for the 12 sets required by the second accelerator, translates to a total cost for the material portion of this estimate of 345 kilo ICF.

\section{F. References:}

1. ORNLMM-4908, "IFMIF, International Fusion Materials Irradiation Faciltty, Conceptual Design Activity, Interim Report" 
WORKSHEET

WBS 4.2.4.6.9 Integration Equipment and Services

\section{A. Sumanary Cost Estimate:}

\begin{tabular}{|c|c|c|c|c|c|c|c|c|}
\hline \multicolumn{4}{|c|}{ Off-IFMïF Site } & \multicolumn{5}{|c|}{ On-Site At IFMIF } \\
\hline Industry & Instital & & & ${ }_{C o n}^{C o}$ & $\begin{array}{l}\text { ist. } \\
\text { actor }\end{array}$ & Instital & & \\
\hline Matt/Lab Engin's & Engin's & AFI & Total & Mat'/Lah & Engin's & Engin'g & AFI & Tots] \\
\hline $2,496 \quad 78$ & - & 901 & 3,475 & - & - & - & - & - \\
\hline
\end{tabular}

Units: Kilo ICF

\section{B. Task Descriotion:}

This estimate documents the resources reguired to design, fabricate, test, and ship the RF system integration equipment for the second accelerator to the IFMIF site for installation and checkout. A detailed description and specification of this system is contained in reference 1 . In summary, this worksheet includes the equipment needed to install and setup the RF Stations and RF Transport elements of the IFMIF system for a test before they are shipped to the site. The jtems in this task are those which are manufactured and/or used in the testing of the equipment prior to shipment.

\section{C._Detailed WRS Listing:}

None developed for this estimate

\section{Costing Rationale:}

The estimate is comprised of two major portions labor and material. Northrop Grumman's past experience delivering high power RF systems (through the recently acquired Former Westinghouse Electronic Systems and Sensors Group) components on similar programs was utilized to develop the labor estimates. Predominately, the costs were developed from the engineering experience obtained from the integration of high power radar transmitters in various Northrop Grumman production systems, and the quote prepared for the 1.0 MW S-band RF source for the Arecibo Observatory in Puerto Rico.

Allowance for Indeterminates: $35 \%$ based on technical risk

\section{E. Detailed Costing:}

\section{Design Labor (Engineering):}

A review of the necessary tasks to complete the design work and produce the required information to enable the fabrication (drawings, specifications, subcontracting plans, etc.) dictated a mix of engineering tatent that equated to approximately 1.75 full time equivalent (FTE) personnel, of which 0.5 FTE support is from institutional exgineering, over the 24 months allotted for the effort. All of this labor was calculated at 
the engineering rate of 100 ICF per man hour and 147 man hours per man month with an $8 \%$ fee.

\section{Eabrication Labor:}

Northrop Grumman produceability/manufacturing reviewed the subcontracting plan for the first accelerator for guidance in determining a delineation between purchased items and internally fabricated ones for the second accelerator system. For the components that would be internally fabricated estimates of the required labor and material were generated. For the purchased items, vendors were solicited to provide rough order of magnitude costs. The last piece of information from the manufacturing department was an estimate of the assernbly tasks.

The result of this effort yielded a staff of approximately 5.5 FTE technicians, and 2.5 FTE craft labor over the 24 months that this task is scheduled to span. The technicians were estimated at $80 \mathrm{ICF}$ per hour, while the craft were estimated at $25 \mathrm{ICF}$ per hour, and both at 147 man hours per man month with an $8 \%$ fee.

\section{Material:}

The existing level of detail surrounding the device provided enough information to contact vendors concerning rough order of magnitude quotes on the hardware. The first unit cost (in the first accelerator) for this component is 35 kilo ICF, which considering a combined purchase, for the 12 sets required by the accelerator, translates to a total cost for the material portion of this estimate of 345 kilo ICF.

\section{E. References:}

1. ORNL/M-4908. "IFMIF, International Fusion Materials Irradiation Facility, Conceptual Design Activity, Interim Report". 
WORKSHEET

WBS 4.25 Beam Calibration Dumps

\section{A. Summary Cost Estimate:}

\begin{tabular}{|c|c|c|c|c|c|c|c|c|}
\hline \multicolumn{4}{|c|}{ Off-lFMifiF Site } & \multicolumn{5}{|c|}{ On-Site At IFMIF } \\
\hline Industry & Instital & & & $\begin{array}{r}\text { Con } \\
\text { Contr }\end{array}$ & $\begin{array}{l}\text { st. } \\
\text { actor }\end{array}$ & Instital & & \\
\hline MatИLab Engin'g & Engin'g & AFI & Total & Max'LLab & Engin'g & Engin'g & $\overline{\mathrm{AFI}}$ & Total \\
\hline $5,133 \quad 994$ & 412 & $\overline{2,291}$ & 8,830 & - & - & -- & - & - \\
\hline
\end{tabular}

Units: Kilo ICF

\section{B. Task Description:}

This estimate is a summary level compilation of lower level estimates. It expresses the resources necessary to complete delivery of both a moveable diagnostic beam dump system (capable of accepting $13 \mathrm{~W} / \mathrm{cm}^{2}$ ), and the facility fixed diagnostic beam dump capabie of accepting $2 \%$ of the full energy $\mathrm{CW}$ deuterium $125 \mathrm{~mA}$ beara. This estimate covers the work between the beginning of preliminary design and the point at which the facility is commission to operate at $40 \mathrm{MeV}$ and $250 \mathrm{~mA}$. The master schedule for these activities is:

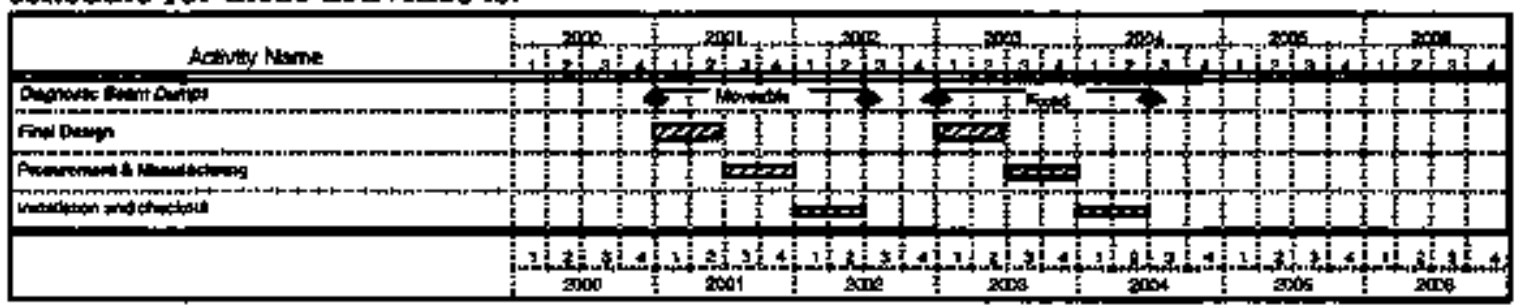

C. Detailed WBS Listing: (with AEl included)

WBS\#

4.2.5.1: Moveable Beam Dump

Cost

4.2.5.2: Fixed Beam Dump

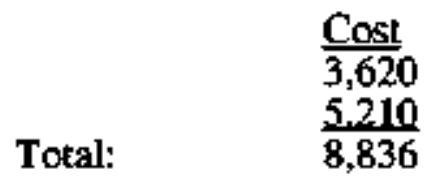

\section{Costing Rationale:}

This estimate is comprised of two major portions: labor and material. Northrop Grumman's past experience delivering accelerating components on similar programs was utilized to develop the labor estimates. To understand the material costs, suppliers in the various areas were contacted and subsequently provided rough order of magnitude quotes.

Allowance for Indeterminates: $35 \%$ based on technical risk

\section{E. Detailed Costing:}

See lower WBS worksheets 


\section{WORKSHEET \\ WBS 4.2.5.1 Moveable Beam Calibration Dump}

\section{A. Summary Cost Estimate:}

\begin{tabular}{|c|c|c|c|c|c|c|c|}
\hline \multicolumn{4}{|c|}{ Off-LFiMLIF Site } & \multicolumn{4}{|c|}{ On-Site At IFMIF } \\
\hline Industry & Instit'al & & & $\begin{array}{l}\text { Const. } \\
\text { Contractor }\end{array}$ & Instit'al & & \\
\hline Mat'LLab Engin'g & Engin'g & $\mathrm{AFl}$ & Total & Mac'l/Lab Enging & Engin's & AFI & Total \\
\hline 2,165 & 94 & 939 & 3,620 & -- & 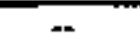 & - & $\Rightarrow$ \\
\hline
\end{tabular}

Units: Kilo ICF

\section{B. Task Description:}

This estimate documents the allocations required to design, fabricate, and test a moveable diagnostic beam dump assembly. After which the assembly will be shipped to the IFMIF site and re-assembled [WBS 4.3.7 Beam Dump Installation and Checkout contains the labor necessary to accomplish the re-assembly]. The assembly can be broken into two major pieces, the diagnostic package and the beam dump. The diagnostic package will include a long drift section where the beam will be interrogated at three stations with video profile monitors, and two stations where microstriplines will be installed to make time of flight measurements. The combination of the two types of measurements enables calculations to determine the beam divergence and emmittance as it exists the accelerator. The dump section consists of two major pieces also, the first being a series of electromagnetic solenoids which blow up the beam from a few millimeters to tens of centimeters. This expanded beam then passes to a slanted ceramic ile beam dump. The tiles radiate the deposited heat to an actively cooled back plate. The maximum design heat deposition is to be less than, or equal to, $13 \mathrm{~kW} / \mathrm{cm}^{2}$.

\section{Detailed WBS Listing:}

None established

\section{Costing Rationale:}

The estimate is comprised of two major portions labor and material. Northrop Grumman's past experience delivering accelerating components on similar programs was utilized to develop the labor estimates. To understand the material costs, suppliers in the various areas wete contacted and subsequently provided rough order of magnitude quotes.

Allowance for Indeterminates: $35 \%$ based on technical risk

\section{E. Detailed_Costing:}


The estimate is comprised of two major parts, labor and material. The labor falls into three major categories: industrial engineering, institutional support, and fabrication labor The schedule for this component is:

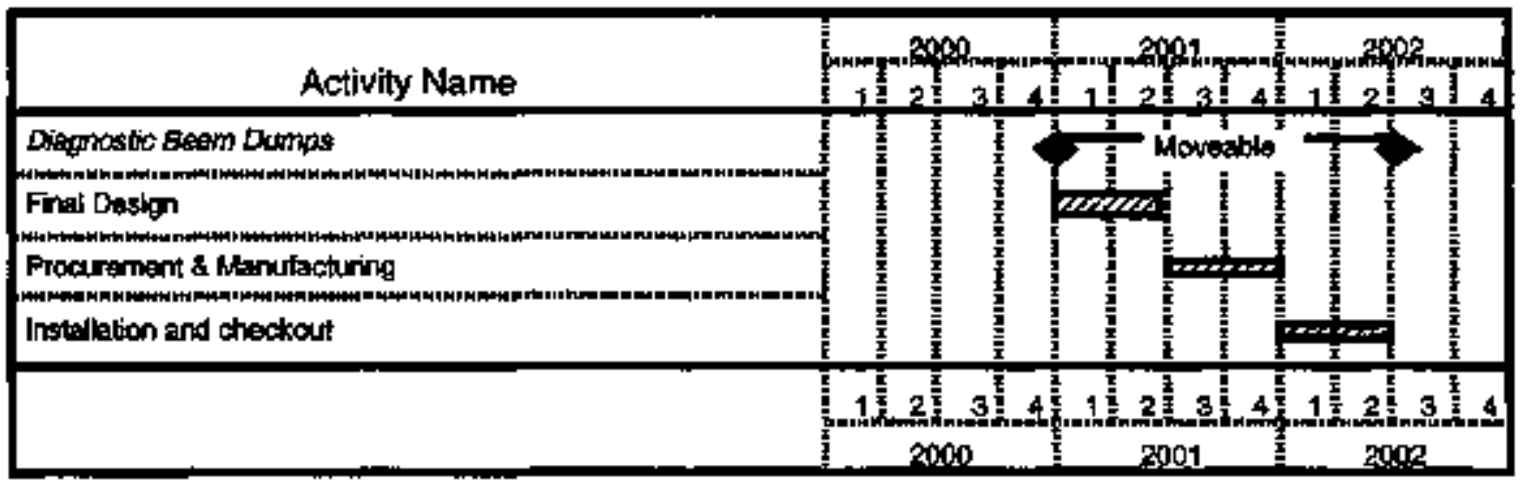

\section{Design Labor:}

A review of the necessary tasks to complete the design work and produce the required information to enable the fabrication (drawings, specifications, subcontracting plans, etc.) dictated a mix of engineering talent that equated to four full time equivalent (FTE) personnel over the six months allotted for the effort. These were all billed at the engineering rate of $100 \mathrm{ICF}$ per man hour and 147 man hours per man month with an $8 \%$ fee.

\section{Eabrication Labor:}

Northrop Grumman produceability/manufacturing reviewed the requirements and returned an estimate of the necessary labor to fabricate the known pieces of this component (listed above). The result of this effort yielded a staff of 7.54 FTE over the six months that this task is scheduled to span. These personnel were estimated at 80 ICF per hour and 147 man hours per man month with an $8 \%$ fee.

\section{institutional Labor:}

Based upon previous programs to develop diagnostic packages an allowance of 0.5 FTE for the entire design and fabrication process was included. Like the industry engineering resource, the Institutional labor will be billed at $100 \mathrm{ICF}$ per hour and 147 man hours per man month

\section{Material:}

The existing level of detail surrounding the device provided enough information to contact vendors concerning rough order of magnitude quotes. The resulting total cost is 2,165 kilo ICF. 
WORKSHEET

WBS 4.2.5.2 Fixed Beam Calfhration Dump

A. Summary Cost Estimate:

\begin{tabular}{|c|c|c|c|c|c|c|c|c|}
\hline \multicolumn{4}{|c|}{ Off-IFMIF Site } & \multicolumn{5}{|c|}{$\overline{O n-S i t e ~ A t ~ I F M I F ~}$} \\
\hline Tndustry & Instit'a] & & & $\begin{array}{r}\text { Co } \\
\text { Cont }\end{array}$ & $\begin{array}{l}\text { sst. } \\
\text { actor }\end{array}$ & Instit'al & & \\
\hline Mat'7Lab Engin' & Engin'g & AFI & Total & Mat1/Lat & Engin'? & Engin'g & AFI & Total \\
\hline 2,968 & 318 & 1,352 & 5,210 & - & -- & - & - & - \\
\hline
\end{tabular}

Units: Kilo ICF

\section{B. Task Description:}

This estimate documents the resources required to design, fabricate, and test a the fixed diagnostic beam dump assembly. After which the components will be disassembled and shipped to the IFMIF site and re-assembled [WBS 4.3.7 Bearn Dump Installation and Checkout contains the labor necessary to accomplish the re-assembly]. The beam dump can be broken into two major pieces, the diagnostic package and the beam dump. The diagnostic package will includes both thermal imaging video cameras as well as visible light spectrum cameras. The combination of the two types of measurements will enable determination of the beam characteristics as it exists the high energy beam transport. The final receptacle for the beam will be a slant faced ceramic tiled beam stop modeled after the FMIT design. The tiles radiate the deposited heat to an actively cooled back plate. This beam stop will be designed to accept $<2 \%$ duty factor of the full energy $125 \mathrm{~mA}$ deuterium beam.

\section{Defailed WBS Listing:}

None established

\section{Costing Rationale:}

The estimate is comprised of two major portions labor and material. Northrop Gromman's past experience delivering accelerating components on similar programs, coupled to the existing material on the FMIT beam stop, was utilized to develop the labor estimates. To understand the material costs, suppliers in the various areas were contacted and subsequently provided rough order of magnitude quotes.

Allowance for Indeterminates: $35 \%$ based on technical risk

\section{E. Detailed Costing:}

The estimate is comprised of two major parts, Iabor and material. The labor falls into three major categories: industrial engineering, institutional support, and fabrication labor The schedule for this component is: 


\begin{tabular}{|l|l|l|}
\hline \multicolumn{1}{|c|}{ Activity Name } \\
\hline Olagnostic Beam Dumps \\
Frnal Design \\
Procurement \& Marjulacturng
\end{tabular}

This worksheet details the resources in the Final Design and Procurement and Manufacturing lines of the schedule. The resource to cover the installation and check out, as well as functional testing are included in WBS 4.3.1.7.2 Fixed Diagnostic Beam Dump.

\section{Design Labor:}

A review of the necessary tasks to complete the design work and produce the required information to enable the fabrication (drawings, specifications, subcontracting plans, etc.) dictated a mix of engineering talent that equated to six full time equivalent (FTE) personnel over the six months allotted for the effort. These were all billed at the engineering rate of $100 \mathrm{ICF}$ per man hour and 147 man hours per man month with an $8 \%$ fee.

\section{Eabrication Labar:}

Northrop Grumman produceability/manufacturing reviewed the requirements and returned an estimate of the necessary labor to fabricate the known pieces of this component (listed above). The result of this effort yielded a staff of 9.50 FTE over the six months that this task is scheduled to span. These personnel were estimated at $80 \mathrm{ICF}$ per hour and 147 man bours per man month with an $8 \%$ fee.

\section{Institutional Labor:}

Based upon previous programs to develop diagnostic packages an allowance of 1.0 FTE for the entire design and fabrication process was included. Like the industry engineering resource, the institutional labor will be billed at 100 ICF per hour and 147 man hours per man month

\section{Material:}

The existing level of detail surrounding the device provided enough information to contact vendors concerning rough order of magnitude quotes for the hardware. The total cost for the material was 2,968 kilo ICF. 
WORKSHEET

WBS 4.2.6 Accejerator System Control

A. Summary Cost Estimate:

\begin{tabular}{|c|c|c|c|c|c|c|c|c|}
\hline \multicolumn{4}{|c|}{ Off-IFMIF Site } & \multicolumn{5}{|c|}{ On-Site At IFMIF } \\
\hline Industry & Instit'al & & & $\begin{array}{c}\text { Con } \\
\text { Contra }\end{array}$ & $\begin{array}{l}\text { St. } \\
\text { actor }\end{array}$ & Instit'al & & \\
\hline Mat'l/Lab Engin'g & Engir'g & AFI & Total & Mat'/Lab & Engin'g & Engin's & AFI & Total \\
\hline $\begin{array}{ll}683 & 4,581\end{array}$ & 142 & $\overline{3,892}$ & $\overline{7,297}$ & $\overline{-}$ & $\overline{--}$ & $\overline{-}$ & 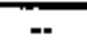 & $\overline{-}$ \\
\hline
\end{tabular}

Units: Kilo ICF

\section{B. Task Description:}

The overall instrumestation and control system configuration for the IFMTF accelerators is conceived as an independent, stand-alone system for each acceierator line, with shared services for safety monitoring/response and local data archiving/evaluation. A graphic of the architecture intended is included at the close of this worksheet. Each beam line control consists of a primary station for operational monitoring and control feedback, supported by three sub-control stations: injector/LEBT, RFQ/DTL, and HEBT. Common to the two systems is the safety interlock logic and status display, and a diagnostic/evaluation station and storage system. This configuration will provide autonomous control in all phases - installation, test, commissioning and preliminary operation. During full facility operation each accelerator station will serve as a control pass-through to the master or central conputer control.

Each of the nine computer stations for instrumentation monitoring and control is costed similarly. Computer hardware and displays, operating and station software, network equiprent and protocol software and station-specific items. such as signal processing crates, safety logic and displays, parameter evaluation and presentation software are estimated from vendor-supplied catalogs of like-type items. EPICS has been assumed to be the operational control and processing software; license supplied at no charge. Labor for software development is assumed to be a mix of laboratory and vendor-supplied personnel. Effort in system design and planning, logic development, sensor calibration and installation procedures are incorporated in the first accelerator, scaled with the estimated number of channels to be processed. Duplicated software development and calibration tasks for the second accelerator are assumed to 'learn' from the first, and thus a $50 \%$ gain in those efforts has been included.

Spares requirements are predicated on the probability of failure and the criticality of the component. Specific note is made of the diagnostic station computer hardware which is intentionally configured as a reserve for any substation. 


\section{Detailed WBS and Cost Listing (without AF included):}

\section{Subsystem}

Castor Accelerator Control Station

Poilux Accelerator Control Station

- Castor InjectorlLEeT Substation

Pollux Injector/LEBT Substation

Castor RFQDTL Substation

Pollux RFQDDTL Substation

Castor HEBT Substation

Pollux HEBT Substation

Castor/Follux Evaluation/Backup

Substation

Total: Castor Accelerator

Total: Pollux Accelerator

$\begin{array}{ccc}\begin{array}{c}\text { Purchased } \\ \text { Material } \\ 88.3\end{array} & \begin{array}{c}\text { Industrol } \\ \text { Engincering } \\ 1,105.8\end{array} & \begin{array}{c}\text { Instltutional } \\ \text { Enginetring }\end{array} \\ 88.3 & 552.9 & 34.2 \\ 49.4 & 221.4 & 17.1 \\ 49.4 & 110.7 & 6.8 \\ 106.1 & 885.6 & 3.4 \\ 106.1 & 442.8 & 27.4 \\ 87.2 & 664.2 & 13.7 \\ 87.2 & 332.1 & 20.5 \\ 20.5 & 265.4 & 8.2 \\ 351.5 & 3,142.3 & 97.2 \\ 331.0 & 1,438.5 & 44.5\end{array}$

D. Costing Rationale:

The estimate is comprised of two major portions labor and material. Northrop Grumman's past experience delivering control systems on other complex physics problems was used to extrapolate the labor estimates. Examples of these programs are:

- Continuous Wave Deuterium Demonstrator - CWDD: a cryogenic accelerator where Northrop Grumman was the accelerator prime manufacturer responsible for delivering the entire accelerator system.

- Ground Test Accelerator - GTA: a ground based bigt power accelerator program used as a test bet for space based strategic defense initiative concepts where Northrop Grumman was selected as the accelerator industrial support contractor.

- Relativistic Heavy Ion Collider - RHIC: a collider program where Northrop Grumman was selected as the manufacturer of the long superconducting main dipole magnets.

- Compact Infra Red Free Electron Laser - CIRFEL: a program where Northrop Grumman has developed a compact FEL for industrial and university use.

To understand the material costs, suppliers in the various areas were contacted and subsequently provided rough order of magninde quotes.

Allowance for Indeterrainates: $35 \%$ based on technical tisk 


\section{Proposed Architecture:}

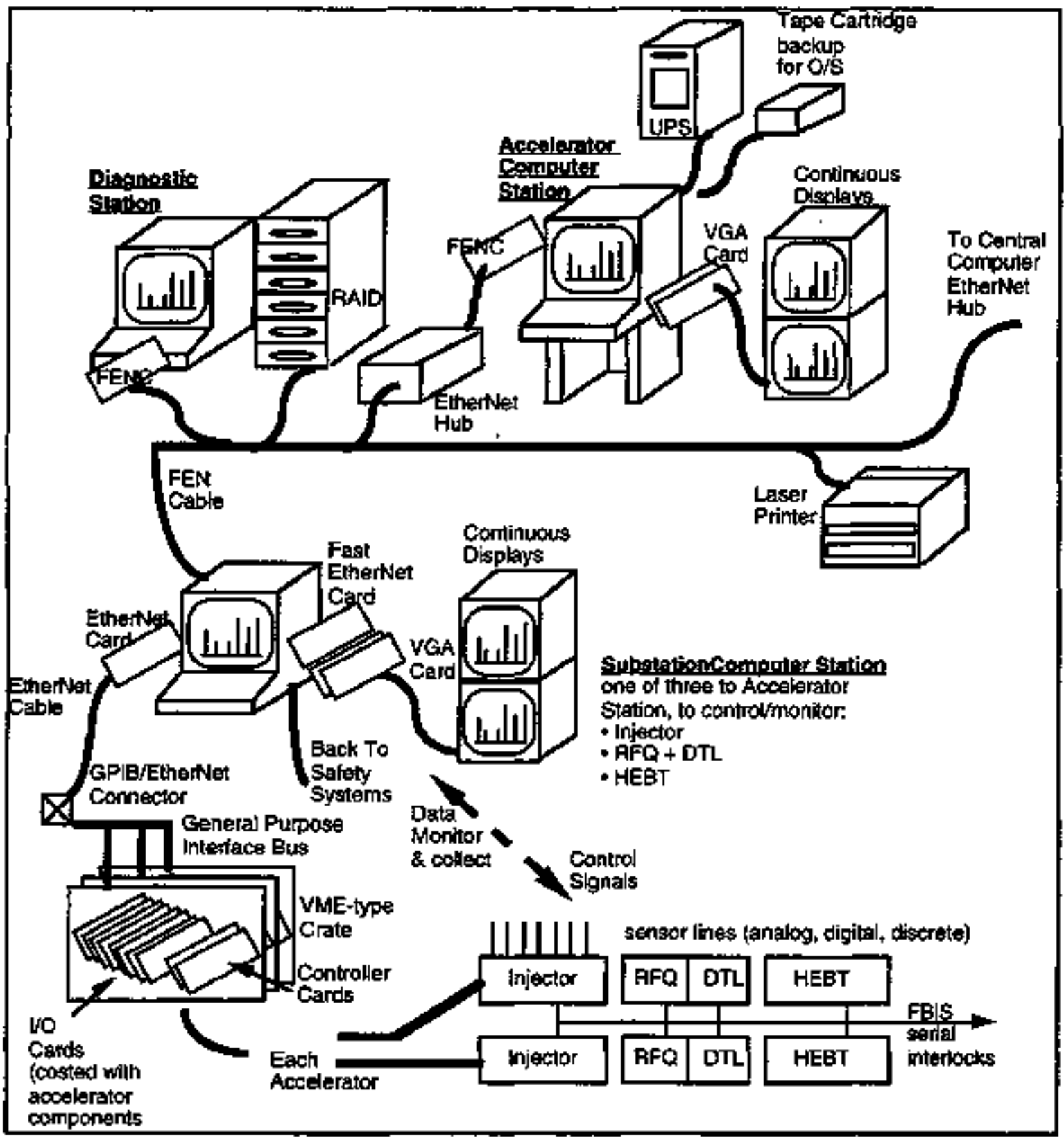


WORKSHEET

WBS 4.2.7 Accelerator Support Systems

A. Summary Cost Estimate:

\begin{tabular}{|c|c|c|c|c|c|c|c|c|}
\hline \multicolumn{4}{|c|}{ Off-IFMIF Site } & \multicolumn{5}{|c|}{ On-Site At IFMLIF" } \\
\hline Industry & Instit'al & & & $\begin{array}{l}\text { Con } \\
\text { Contr }\end{array}$ & st. & Instit'al & & \\
\hline Mat'Lab Engin'g & Engíg & AFI & Total & Mat'V/Lab & Engin's & Engin'g & AFI & Total \\
\hline 2,286 & -- & 800 & 3,086 & $\overline{--}$ & -- & - & -- & $-\pi$ \\
\hline
\end{tabular}

Units: Kilo ICF

\section{B. Task Description:}

This task is focused on providing the necessary labor provide support covering the host of equipment racks that connect the accelerating equipment (power supplies, cobtrol cards, diagnostics, and instrumentation) to the appropriate system components. This effort is tracked independent of the individual accelerating components because the correct architecture will span all accelerating components. The exception to this, is the hartiware necessary to house the connections. The estimate of these resources is contained in the miscellaneous hardware section of the accelerating component estimates (WBS 4.2.3.X.X and 4.2.4.X.X).

\section{Detailed WBS Listing:}

None used in the preparation of this estimate

\section{Costing Rationale:}

The labor estimate was developed from Northrop Grumman experience on other similar programs.

Allowance for Indeterminates: $35 \%$ based on technical risk

\section{E. Detailed Costing:}

Considering the type and quantity of accelerating components in this design a level load of two electrical engineers over the entire span of the program starting at the close of preliminary design is required. These are costed at the standard engineering rate of 100 ICF per man hour, 147 man-hours per man month, and an $8 \%$ fee. 
WORKSHEET

WBS 4.3.1 Accelerator \#1 (Castor) Installation and Checkout

\section{A. Summary Cost Estimate:}

\begin{tabular}{|c|c|c|c|c|c|c|}
\hline \multicolumn{3}{|c|}{ Off-IFMIF Site } & \multicolumn{4}{|c|}{ On-Site At IFMIF } \\
\hline Endustry & Instit'al & & $\begin{array}{c}\text { Const. } \\
\text { Contractor }\end{array}$ & Instit'al & & \\
\hline Mat'VLab Engin'g & Engin'g & Afrl Total & Mat'VLab Engin'g & Engin'g & AFII & Total \\
\hline- & - & - & $20,715 \quad 3,036$ & 1,499 & 8,909 & 34,159 \\
\hline
\end{tabular}

Units: Kilo ICF

\section{B. Description:}

This account contains a summary estimate for the installation and checkout of the first accelerator equipment at the IFMIF site. A baseline assumption for this estimate is that the individual accelerating components are functionally checkout at the equipment vendor before shipment to the IFMIF site.

\section{Detailed WBS Listing:}

This element is comprised of the following lower level estinates which are detailed on separate worksheets:

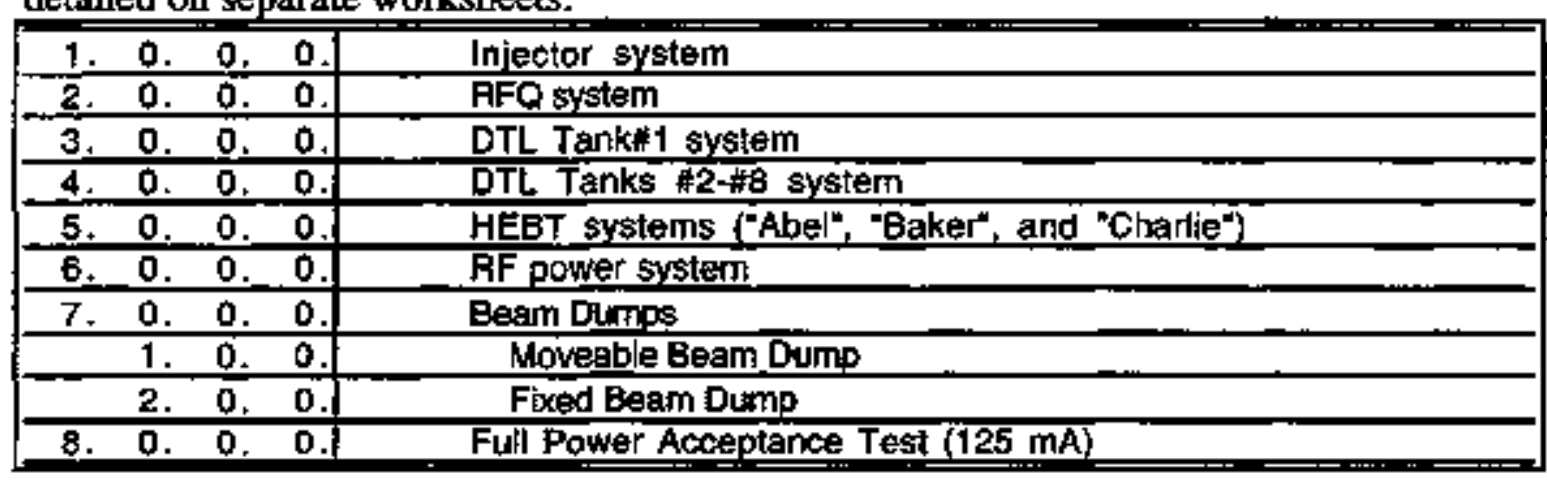

D. Costing Rationale:

See lower leve] detail sheets

Type of Estimate: Bottons up

Allowance for Indeterminates: $35 \%$

\section{E. Detailed Costing:}

See lower level detail sheets 
WORKSHEET

WBS 4.3.1.1 Injector System

A. Surnmary Cost Estimate:

\begin{tabular}{|c|c|cc|cc|c|cc|}
\hline \multicolumn{3}{|c|}{ Off-1FMIF Site } & \multicolumn{5}{c|}{ On-Site At IFMIF } \\
\hline Industry & Instit'al & & $\begin{array}{c}\text { Const. } \\
\text { Contractor }\end{array}$ & Instit'al & & \\
\hline Mat'L/Lab Engin'g & Engin'g & AFI & Total & Mat'1/Lab Engin'g & Engin'g & AFI & Total \\
\hline- & - & - & - & 765 & 85 & 54 & 316 & 1,220 \\
\hline
\end{tabular}

Units: Kilo ICF

\section{B. Descriotion:}

This WBS element contains estimates of the necessary resources to begin unpacking the injector equipment (including the RF power supply) at the site, and finish with its complete installation, assembly and checkout. This task assumes the accelerator tunnel construction is completed and the room is ready for equipment installation.

The installation sequence begins with two parallel efforts, one focused on instailing the ion source, the other focused on installing the necessary drive power for the source. Both activities are working toward a point where the source operation (with H24, at modest pulsed current $\sim 50 \mathrm{~mA}$ ) can be verified. A major portion of this effort is spent on integrating the ion source/RF subsystems with the accelerator control system. After stable beam is extracted from the source, the low energy beam transport will be installed and beam will be transmitted through it. The operational characteristics of the injector will then be investigated and system performance optimized. The transmitted beam will range from low duty factor modest current (tens of $\mathrm{mA}$ ) to $\mathrm{CW}$ with full current.

Preliminary estimates of the $\mathrm{AC}$ power requirements for the source are $0.058 \mathrm{MWe}$ (including magnet power supplies). Based on recent Northrop Grumunan experience on the Contraband Detector System program (a very similar source), this operational level should be reached wjthin the first month. Once established, till the end of the testing, the injector should be operated as much as possible to build an operability/availability database.

\section{Detailed WBS Listing:}

No lower level WBS elements

\section{Costing Rationale:}

The size and composition of the team required to install and commission the injector system is based upon Northrop Grumman experience in commissioning similar in systems.

Type of Estimate: Factored from experience

Allowance for Indeterminates: $35 \%$ based on technical risk 


\section{E. Detailed Costing:}

The estimate contains two major portions: Iabor and electricity. The labor estimates are from experience on similar programs. This experience dictated a certain type of team would be needed to perform the activities. The team is led by an engineer reporting to project management, with the balance of the team comprised of skilled technicians and craft laborers (riggers, fitters, electricians, plumbers, etc.). The injector installation and checkout is scheduled to extend over three quarters ( 9 months) and will include the following full time equivalent number of personnel working on the effort from each area:

\begin{tabular}{|c|c|c|c|}
\hline Skill byp: & Quarter 1 & Quater 2 & Quarter 3 \\
\hline Engineers & 1 & 1 & 1 \\
\hline Techincians & 5 & 5 & 5 \\
\hline Craft labor & 5 & 3 & 3 \\
\hline
\end{tabular}

The respective rates for these categories of labor are:

$\begin{array}{ll}\text { engineering } & 100 \mathrm{ICF} / \text { man-hour } \\ \text { technician } & 80 \mathrm{ICF} / \mathrm{man}-\mathrm{hour} \\ \text { craft } & 25 \mathrm{ICF} / \mathrm{man}-\mathrm{howr}\end{array}$

The costs were compiled using a $15 \%$ premium to cover short term placement of individuals to the IFMIF site. Further, the costs were complied using 147 man-hours/ man-month with an $8 \%$ fee added.

Preliminary estimates of the AC power requirements for the source are 0.058 MWe (including magnet power supplies). Experience indicates this operational level should be reached within the first month. From there on, till the end of the testing, the injector should be operated as much as possible to build an availability database. Over a quarter this turns out to be:

$40 \mathrm{hrs} /$ week X 12weeks/quarter X0.058 MWe= $27.84 \mathrm{MWehr} /$ quatter

The electric rate used in cost calculations was $0.1 \mathrm{ICF} / \mathrm{kWehr}$. 
WORKSHEET

WBS 4.3.1.2 RFQ System

\section{A. Summary Cost Estimate:}

\begin{tabular}{|c|c|c|c|c|c|c|}
\hline \multicolumn{3}{|c|}{ Offi-ll-MIF Site } & \multicolumn{4}{|c|}{ On-Site At IFMIF } \\
\hline Industry & Instital & & $\begin{array}{c}\text { Const. } \\
\text { Contractor }\end{array}$ & Instit'al & & \\
\hline Mat'/Lab Engin'g & Engin'g & AFI Total & Mat'LLab Engin's & Engin'g & AFI & Total \\
\hline- & -- & $=\quad-$ & $74 !$ & 26 & 290 & 1,120 \\
\hline
\end{tabular}

Units: Kilo ICF

\section{B. Description:}

This WBS element contains estimates of the necessary resources to begin with unpacking the RFQ equipment at the site, eventually ending with its complete installation, assembly and checkout. This task assumes that the injector testing is complete and its operation has been characterized. Further the accelerator tunnel construction is completed and the room is ready for equipment installation.

The first step in the RFQ installation process is the remove all the shipping bracing from the accelerating cavity. This is followed by an alignment check prior to physical installation of the $\mathrm{RFQ}$ on its mounts in the tunnel. Next, the connection to the LEBT is completed and accelerator alignment is once again checked. Once the RFQ is in place, all the exterior cooling, vacuum, instrumentation, and RF feed hook-up will be connected. In parallel with the RFQ installation work a separate team of personnel will focus on the installation of the three RF power stations that will supply power to the RFQ. The RF activity will interface with the accelerator at the RF window on the RFQ structure. [Note: the estimate covering the RF activities is included in WBS 4.3.1.6 "RF Power Systems", but a discussion of the activities is included for clarity.]

After installation of the RFQ and power stations are complete, the RFQ requires conditioning before bean can be transmitted. Conditioning is accomplished by first pulsing the $\mathrm{RF}$ power system into the cavity at increasing levels of power until the cavity is capable of accepting full power. After which the cavity will be subjected to CW power operation, still with no transmitted beam, until it reaches a vacuum equilibrium. The conditioning process will take approximately two weeks to reach CW operation and to sufficiently prepare the structure for beam.

Next, the injector will be run with $\mathrm{H} 2+$ at low duty factor/low current as in the initial injector tests. Transmission through the RFQ will be checked against predicted values and corrective action taken. After which beam duty factor and current will be increased until the maximum power limit of the portable beam diagnostic dump is reached. After a stable transmitted beam is achieved, the cavity will be adjusted to achieve peak effjciency. 


\section{Detailed WBS Listing:}

No lower level wBS elements

\section{Costing Rationale:}

The size and composition of the team required to install and commission the RFQ system is based upon Northrop Grumman experience in commissioning similar systems. Some of these programs are:

- Beam Experiment Aboard Racket - BEAR: where Northrop Grumman delivered an Radio Freqkency Quadrupole, its power supply, and the external skin for the launch device.

- Continuous Wave Deuterium Demonstrator - CWDD; a cryogenic accelerator whete Northrop Grumman was the accelerator prime manufacturer responsible for delivering the entire accelerator system.

- Ground Test Accelerator - GTA: a ground based high power accelerator program used as a test bed for space based strategic defense initiative concepts where Northrop Grumman was selected as the accelerator industrial support contractor.

Type of Estimate: Factored from experience

Allowance for Indeterminates: $35 \%$ based on technical risk

\section{E. Detailed Costing:}

The estimate contains two major portions: labor and electricity. The labor calculation was developed using experience from similar programs which indicated that a certain type of team would be needed to perform the activities. The team is comprised of an engineer leading a team of skilled technicians and craft laborers (riggers, fitters, electricians, plumbers, etc.). The RFQ installation and checkout is scheduled to extend over four quarters (12 months) and will include the following full time equivalent number of personnel working on the effort from each area:

\begin{tabular}{|c|c|c|c|c|}
\hline Sill towe & Quarter 1 & Quarter 1 & Quarter 1 & Quarter 1 \\
\hline Engineers & 1 & 0.75 & 0.5 & 0.25 \\
\hline Techndalans & 3 & 3 & 3 & 3 \\
\hline Crafi labor & 5 & 3 & 2 & 1 \\
\hline
\end{tabular}

The respective rates for these categories of labor are: engineering technician $100 \mathrm{ICF} / \mathrm{man}$-irour craft $80 \mathrm{ICF} / \mathrm{man}-\mathrm{hour}$ $25 \mathrm{ICF} / \mathrm{man}$-bour

The costs were compiled using a $15 \%$ premium to cover short term placement of individuals to the IFMIF site. Further, the costs were complied using 147 man-hours/ man-Inonth with an $8 \%$ fee added.

Preliminary estimates of the AC power requirements for the RFQ consist of two parts: cavity conditioning and beam operation. The conditioning period starts with low power pulsed operation and continues by lengthening both pulse duration and increasing 
power levels until CW full power operation is achieved. A conservative estimate of the time required to get the cavity conditioned is 2 weeks. For budgeting, $75 \%$ max power is considered over this period. This equates to:

\section{$5.772 \mathrm{MWe} X 0.75=4.329 \mathrm{MWe}$ over $80 \mathrm{hrs}$ or $346.32 \mathrm{MWehr}$}

For beam testing, the RFQ will be operated at $20 \%$ duty factor $(-31 \mathrm{~mA}$ peak current), for $50 \%$ of the period (1 week in operation, 1 week in adjustment, etc.). The additional power, over and above the injector is:

40hrs/week X 6 weeks ops/quarter X 5.772MWe $=1385 \mathrm{MWehr} / q u a r t e r$

The electric rate used is cost calculations was $0.1 \mathrm{ICF} / \mathrm{kWehr}$. 


\section{WORKSHEET \\ WBS 4,3.1.3 DTL Tank \#1. System}

\section{A. Summary Cost Estimate:}

\begin{tabular}{|c|c|c|c|c|c|c|}
\hline \multicolumn{3}{|c|}{ Off-IFMIIF Site } & \multicolumn{4}{|c|}{ On-Site At IFML } \\
\hline Industry & Instit'al & & $\begin{array}{c}\text { Const. } \\
\text { Contractor }\end{array}$ & Instit'al & & \\
\hline Mat'l/Lab Engin'g & Engin's & AFI Total & Mat'MLab Engir's & $\operatorname{Engin}^{1} \mathbf{g}$ & AFI & Total \\
\hline- & - & - & 676 & 30 & 272 & 1,050 \\
\hline
\end{tabular}

Units: Kilo ICF

\section{B. Description:}

This WBS element contains estimates of the necessary resources to begin unpacking the first Drift Tube Linac (DTL) equipment at the site, and finish with its complete installation, assembly and checkout. This task assumes that the injector and RFQ testing is complete and operation through these components has been characterized. Further, the accelerator tunnel construction is completed and the room is ready for equipment installation.

The first step in the DTL tank installation process is to unpack and re-align the accelerating cavity. Unlike the injector and RFQ, the DTL will be shipped with an elaborate internal brace to minimize the amount of site alignment required. After which, the physical installation of the DTL on its mounts in the tunnel can begin. Optical alignment checks will be employed to ensure proper connection between the DTL and the $\mathrm{RFQ}$. Having accomplished this, all the exteriot cooling, vacuum, instrumentation, and RF feed hook-ups will be connected. In parallel with the DTL installation work a separate team of persontnel will focus on the installation of the RF power station that will supply power to the DTL tank. The RF activity will interface with the accelerator at the RF window on the DTL structure. [Note: the estimate covering the RF activities is included in WBS 4.3.1.6 "RF Power Systems" element, but a discussion of the activities is included for clarity.]

After installation of the DTL and its power station are complete, the DTL will enter a conditioning phase similar to the RFQ. Conditioning is accomplished by first pulsing the RF power system into the cavity, at increasing levels of power, until the cavity is capable of accepting full power. After which the cavity will be subjected to $\mathrm{CW}$ power operation, still with no transmitted bearn, and aliowed to reach vacuum equilibrium. The conditioning process will take approximately two weeks in total. The cavity is now ready for beam.

Similar to the beam line components before it, the DTL will begin by transmitting a low current pulsed beam, eventually ramping up to the current limit of the moveable beam dump $(-50 \mathrm{~kW})$. After a stable transmitted beam is achieved, the cavity will be adjusted to achieve peak efficiency. 


\section{Detailed WBS Listing:}

No lower level WBS elements

\section{Costing Rationale:}

The size and composition of the team required to install and commission the first DTL tank system is based upon Northrop Gnumman experience in commissioning siniliar systems. Some examples are:

- Beam Experiment Aboard Rocket - BEAR: where Northrop Grumman delivered an Radio Frequency Quadrupole, its power supply, and the external skin for the launch device.

- Ramped Gradient Drift Twbe Linac - RGDTL: A program wbere Northrop Grumman completed the design and eventually fabricated one complete accelerating tank to Los Alamos National Laboratory sepcification.

- Continuous Wave Deuterium Demonstrator - CWDD: a cryogenic accelerator where Northrop Grumman was the accelerator prime manufacturer responsibie for delivering the entire accelerator system.

- Ground Test Accelerator - GTA: a ground based high power accelerator program used as a test bed for space based strategic defense initiative concepts where Northrop Grumman was selected as the accelerator industrial support contractor.

Type of Estimate: Factored from experience

Allowance for Indeterminates: $35 \%$ based on technical risk

\section{E. Detailed Costing:}

The estimate contains two major portions: labor and electricity. The labor calculation was developed using experience from similar programs which indicates that a certain type of team would be needed to perform these activities. The team is led by engineers reporting to program management, and comprised of skilled technicians and craft laborers (riggers, fitters, electricians, plumbers, etc.). The DTL tank \#1 installation and checkout is scheduled to extend over one quarter ( 3 months) and will include the following full time equivalent number of personnel working on the effort from each area:

\begin{tabular}{|c|c|}
\hline Skill bres & Quater 1 \\
\hline Engineers & 2.1 \\
\hline Techniölans & 10 \\
\hline Cratt labor & 15 \\
\hline
\end{tabular}

The respective rates for these categories of latwor are:

engineering

technician

craft
100 ICF/man-hour

80 ICF/man-hour

$25 \mathrm{ICF} / \mathrm{man}$-hour 
The costs were compiled using a $15 \%$ premium to cover short term placement of individuals to the IFMIF site. Further, the costs were complied using 147 man-hours/ man-month with an $8 \%$ fee added.

Preliminary estimates of the AC power requirements for the DTL consist of two parts: cavity conditioning and beam operation. The conditioning period starts with low power pulsed operation and continues by lengthening both pulse duration and increasing power levels until CW full power operation is achieved. A conservative estimate of the time required to get the cavity conditioned is 2 weeks. For budgeting, 75\% max power is considered over this period. This equates to:

\section{$2.25 \mathrm{MWe} X 0.75=1.688 \mathrm{MWe}$ over 80 hrs or $135.04 \mathrm{MWehr}$}

Next an estimate of the beam-on testing is required. Unlike the Injector and RFQ, the full current/energy beam discharged from this cavity cannot be handled by the beam. demp. The limit for the moveable dump has been set at the $C W$ power output of the RFQ with $\mathrm{H} 2+(-50 \mathrm{~kW})$. For the increased energy, the DTL tank must be operated at low duty factor $(-25 \%)$ duty factor to accelerate enough curreat, yet still maintain the power deposited on the beam dump. The additional power required per quarter for the DTL (assuming 1 week operation followed by 1 week adjustments) is:

40hrs/week X 6 weeks ops/quarter X [2.25 MWe X 25\%] 135.0 MWehr/quarter

The electric rate used in cost calculations was $0.1 \mathrm{ICF} / \mathrm{kWehr}$. 
WORKSHEET

WBS 4,3.1.4 DTL Tanks \$2 - \#8 System

A. Summary Cost Estimate:

\begin{tabular}{|c|c|c|c|c|c|c|}
\hline \multicolumn{3}{|c|}{ Off-IFiMIF Site } & \multicolumn{4}{|c|}{ On-Site At IFMIIF } \\
\hline Industry & Instita & & $\begin{array}{l}\text { Const. } \\
\text { Contractor }\end{array}$ & Instital & & \\
\hline Mar'/Lab Engin'g & Engin'g & AFI Total & Mat'lLab Engin'g & Engin'g & $\overline{\text { AFI }}$ & Total \\
\hline$\overline{-}$ & $\bar{m}$ & $-\quad \quad-$ & $2295 \quad 242$ & 190 & 923 & 3,360 \\
\hline
\end{tabular}

Ưnits: Kilo ICF

B. Description:

This WBS element contains estimates of the necessary resources to begin with unpacking the second through eighth Drift Tube Linac (DTL) tanks from their shipping frames at the site, and ending with their complete installation, assembly, and checkout. This task assumes that the injector, RFQ, and first DTL tank installation and testing is complete and beam operation through these components has been characterized and optimized. Further, this estimate assumes accelerator tunnel construction is fully completed and the room is ready for accelerator equipment installation.

The first step in the DTL tank installation and checkout process is to unpack and re-align the accelerating cavities. Unlike the injector and $\mathrm{RFQ}$, the DTL tanks will be shipped with elaborate intenal bracing to minimize the amount of site alignment required. After which, the physical installation of the DTL tanks on their mounts in the tunnel can begin. Optical alignment checks will be employed to ensure proper connection between the DTL tanks and the previously installed beam line components. Having accomplished structural installation, all the exterior cooling, vacuum, instrumentation, and RF feed hookups will be connected. In parallel with the DTL installation work a separate team of personnel will focus on the installation of the RF power stations for these accelerating cavities. The RF activity will interface with the accelerator at the RF window on the DTL tanks. [Note: the estimate covering the RF activities is not included in this WBS element, but rather detailed in WBS 4.3.6 RF Power Systern.]

After complete hook-up of the DTL tanks cavity conditioning activities can commence. Conditioning is accomplished by slowly ramping the RF power transmitted to the cavity from low duty factor/ow power until the cavity can accept full power in a $C W$ mode. Having reached $C W$ power levels, still with no transminted beam, the cavity is allowed to reach equilibrium. The whoie conditioning process will take approximately two weeks to reach $C W$ operation. Once the cavity has been conditioned it is ready for beam transmission.

Similar to the beam line components before it, DTL tanks $2-8$ will begin by transmitting low current pulsed beam, eventually moving up to the current limit of the moveable beam dump. After a stable transmitted bean is achieved, each cavity will be adjusted to achieve peak efficiency. Unlike the components before it, tanks 2-8 will be tested as a unit. 


\section{C.Detailed WBS Listing:}

No lower level WBS elements

\section{Costing Rationale:}

The size and composition of the team required to install and commission the DTL tanks 2-8 accelerating system is based upon Northrop Grumman experience in commissioning similar systems. Some examples are:

- Ramped Gradient Drift Tube Linac - RGDTL: A program where Northrop Grumman completed the design and eventually fabricated one complete accelerating tank to Los Alamos National Laboratory sepcification.

- Continuous Wove Deuterium Demonstrator - CWDD: a cryogenic accelerator where Northrop Grumman was the accelerator prime manufacturer responsible for delivering the entire accelerator system.

- Ground Test Accelerator - GTA: a ground based high power accelerator program used as a test bed for space based strategic defense initiative concepts where Northrop Grumman was selected as the accelerator industrial support contractor.

Type of Estimate: Factored from experience

Allowance for Indeterminates: $35 \%$ based on technical risk

\section{E. Detailed Costing:}

The estimate contains two major portions: labor and electricity. The labor calculation was developed using experience from similar programs which indicates that a certain type of team would be needed to perform these activities. The team is led by engineers reporting to program management, and comprised of skilled technicians and craft laborers (riggers, fitters, electricians, plumbers, etc.). The DTL tank 2-8 system installation and checkout is scheduled to extend over two quarters ( 6 months) and will include the following full time equivalent number of personnel working on the effort from each area:

\begin{tabular}{|c|c|c|}
\hline Skill type & Quarter 1 & Quarter 2 \\
\hline Engineers & 3.5 & 3.5 \\
\hline Technicians & 10 & 16 \\
\hline Crafl labor & 30 & 30 \\
\hline
\end{tabular}

The respective rates for these categories of labor are:

$\begin{array}{ll}\text { engineering } & 100 \mathrm{ICF} / \text { man-hour } \\ \text { technician } & 80 \mathrm{ICF} / \text { man-hour } \\ \text { craft } & 25 \mathrm{ICF} / \text { man-hour }\end{array}$

The costs were compiled using a $15 \%$ premium to cover shost term placement of individuals to the IFMIF site. Further, the costs were complied using 147 man-hours/ man-month with an $8 \%$ fee added. 
Preliminary estimates of the AC power requirements for the DTL tank 2-8 system consist of two parts: cavity conditioning and beam operation. The conditioning period starts with low power pulsed operation and continues by lengthening both pulse duration and increasing power levels until CW full power operation is achieved. A conservative estimate of the time required to get the cavity conditioned is 2 weeks. For bukgeting. $75 \%$ max power is considered over this period. This equates to:

10.554 MWe X $0.75=7.916 \mathrm{MWe}$ over $80 \mathrm{hrs}$ or $633.24 \mathrm{MWehr}$

Next an estimate of the beam-on testing is reguired. Unilike the Injector and RFQ system the full currentenergy beam discharged from this cavity cannot be handled by the beam dump. The limit for the moveable dump has been set at the CW power output of the RFQ with H2+ ( $-50 \mathrm{~kW})$. For the increased energy out of tank \#8, the accelerator must be operated at less than $10 \%$ ( $-12.5 \mathrm{~mA}$ peak current) duty factor to maintain the power deposited on the beam dump. The additional power required per quarter for the DTL tank system (assuming 1 week operation followed by 1 week of adjustments) is:

40has/week X 12 weeks ops X $[10.554 \mathrm{MWe} X 10 \%]=506.6 \mathrm{MWehr}$

The electric rate used in cost calculations was 0.1 ICF/ $/$ Wehr. 
WORKSHEET

WBS 4.3.1.5 High Energy Beam Trausport (HEBT) Systems

A. Summary Cost Estrimate:

\begin{tabular}{|c|c|c|c|c|c|c|}
\hline \multicolumn{3}{|c|}{ Off-IFMIIF Site } & \multicolumn{4}{|c|}{ On-Site At IFMiF } \\
\hline Industry & Instit'al & & $\begin{array}{c}\text { Const. } \\
\text { Contractor }\end{array}$ & Instit'al & & \\
\hline Mat'/Lab Engin'g & Engin'g & AFI Total & Mat'Mab Engin'g & Engin'tg & $\mathrm{AF}$ & Towal \\
\hline$---\quad-$ & - & $-\quad-$ & $\begin{array}{ll}3,584 & 398 \\
\end{array}$ & 166 & 1452 & 5,600 \\
\hline
\end{tabular}

Units: Kilo ICF

B. Description:

This WBS element contains estimates of the necessary resources to complete the installation, assembly, and checkout of the three HEBT lines for the first accelerator at the IFMIF site. This task assumes that the accelerator installation and testing is complete and beam operation through these components has been characterized and optimized. Further, this estimate assumes turning room constriction is fully completed and the hall is ready for HEBT equipment installation. Lastly, this estimate assumes the fixed diagnostic dump is installed, checked out, and ready for use.

The installation process begins by assembling the -60 meters of beam tube from the accelexator to the fixed diagnostic beam dump, blanking off the other two branches to the lithium targets. Interspersed in each beam pipe are a approximately 13 RF cavities (for bunching and energy dispersion) which need to be positioned correctly in the turning room to mate up with structural supports as well as the drive lines from the RF power station. Next to be installed are the various vacuum pumps distributed among the transport line. After completion of this activity, the beam tube and RF cavities can be pumped to operational levels, and RF cavity conditioning can commence. Similar to the accelerator cavities the buncher and energy dispersion cavities will be subjected to a series of varying RF power levels from low power pulsed to full power $\mathrm{CW}$ levels. When the cavities can sustain full power RF, they are ready to be used to transport beam to the diagnostic dump.

The next step in the process is the installation of the 25 magnets around the beam pipe, with all the associated connections to control \& monitoring, cooling, and power supplies. Once completed the HEBT is ready for beam.

After testing/optimization is complete on the beam line to the diagnostic dump, efforts will shift toward installing the remaining equipment for the transport sections to the lithium targets. The steps empioyed will be the same as used to install the transport line to the diagnostic dump (first beam tube/cavity/vacuum installation, followed by conditioning, and magnet installation). When completed the HEBT is ready for testing with beam into any of the targets.

\section{C.Detailed WBS Listing:}


No lower level WBS elements

\section{Costing Rationale:}

The size and composition of the team required to install and commission the HEBT system is based upon Northrop Gnuman experience in commissioning similar systems.

Type of Estimate: Scaling from experience

Allowance for Indeteminates: $35 \%$ based on technical risk

\section{E. Detailed Costing:}

The estimate contains two major portions: labor and electricity. The labor calculation was developed using experience from similar programs which indicates that a certain type of team would be needed to perform these activities. The team is led by engineers reporting to program management, and comprised of skilled technicians and craft laborers (riggers, fitters, electricians, plumbers, etc.). The HEBT system installation and checkout is scheduled to extend over four quarters (12 months) and will include the following full time equivalent number of personnel working on the effort from each area:

\begin{tabular}{|c|c|c|c|c|}
\hline Gdil brof & Ouarter 1 & Quartor2 2 & Quarter 3 & Quarter 4 \\
\hline Engineers & 2.75 & 2.75 & 2.75 & 2,75 \\
\hline Technictans & 15 & 15 & 15 & 15 \\
\hline Craft labor & 25 & 25 & 25 & 25 \\
\hline
\end{tabular}

The respective rates for these categories of labor are:

$\begin{array}{ll}\text { engineering } & 100 \mathrm{ICF} / \text { man-hour } \\ \text { technician } & 80 \mathrm{ICF} / \text { man-hour } \\ \text { craft } & 25 \mathrm{ICF} / \mathrm{man}-\mathrm{hour}\end{array}$

The costs were compiled using a $15 \%$ premium to cover shart term placement of individuals to the IFMIF site. Further, the costs were complied using 147 man-hours/ man-month with an $8 \%$ foe added.

Preliminary estimates of the AC power requirements for the HEBT system consist of two parts: cavity conditioning and beam operation. The conditioning period starts with low power pulsed operation and continues by lengthening both pulse duration and increasing power jevels until CW full power operation is achieved. A conservative estimate of the time required to get the cavity conditioned is 2 weeks. This equates to:

$$
1.44 \mathrm{MWe} X 3 \mathrm{beam} \text { lines }=4.32 \mathrm{MWe} \text { over } 80 \mathrm{hrs} \text { of } 345.6 \mathrm{MWehr}
$$

Next an estimate of the betm-on testing is required. This is comprised of 2 weeks operation at $2.5 \%$ daty factor as weil as 1 week at full power. The additional HEBT power required over the needs of the accelerator is:

$$
120 \mathrm{hrs} \mathrm{X}[1.44 \mathrm{MWe}]=172.8 \mathrm{MWehr}
$$

The electric rate used in cost calculations was $0.1 \mathrm{lCF} / \mathrm{kWehr}$. 
WORKSHEET

WBS 43.1.6 RF Systems

A. Summary Cost Estimate:

\begin{tabular}{|c|c|c|c|c|c|c|}
\hline \multicolumn{3}{|c|}{ Off-IFMIF Site } & \multicolumn{4}{|c|}{ On-Site At EMIF } \\
\hline industry & Instit'al & & $\begin{array}{c}\text { Const. } \\
\text { Contractor }\end{array}$ & Instit'al & & \\
\hline Mat'ZLab Engin'g & Engin'g & AFI Total & Mat'ULab Enging & Engin's & AFI & Total \\
\hline- & - & - & $6,301 \quad 571$ & 286 & 2,505 & 9,663 \\
\hline
\end{tabular}

Units: Kilo ICF

B. Description:

This WBS element contains estimates of the necessary resources to complete the installation, assembly, and checkout of the RF power system for the first accelerator and HEBT system at the IFMIF site. This task assumes each RF station has been preassembled and tested by the RF prime subcontractor, then disassembjed and shipped to the IFMIF site. Further, this estimate assumes RF hall is fully completed and is ready for equipment installation.

The instaliation process will be sequenced to provide fully operational power stations to support the accelerating cavity efforts. One exception however will be the power station for the HEBT. This power station is from the development program and will be transferred to the FMFF site and put into operation as soon as possible to continue to build an operational database on the RF equipment as well as provjde an excellent platform for operator training.

The steps in the installation process begin with the unpacking of the equipment. The equipment forming the switchgear, transformer/rectifier and crowibar subsystems will be installed and connected to the electric feeds from the facility substation and tested. Next, the balance of the system equipment (with the exception of the RF transport berween the circulator output and the accelerating cavities will be instaljed and checked out. In parallel with this work, the station control and monjtoring subsystem will be installed and checked out. Having completed this phase of the buildup the station can be commissioned and operated into a dummy load, with a local RF source, to begin to condition the station (typically requiring 72 hours constant operation). Commencing somewhere in the middle of this activity will be another effort to install the $\sim 20$ meters of RF transport line from the accelerating cavity in the tunnels up to the RF power station on the floor above the tunnel. Once the transport connection is made to the power station the entire RF power station can be tested into the accelerating structure. The performance of station will be assessed against established values and any necessary optimization perforned.

This process is repeated for each station. In parallel with the station installation and checkout the global RF source will be instajled. Once operational this source wilf replace the local source used for station commissioning.

\section{Detailed WBS Listing;}


No lower level WBS efements

D. Costing Rationale:

The size and composition of the team required to install and conmission the RF power system is based upon Northrop Grumman experience in commissioning similar systems.

Type of Estimate: Scaling from experience

Allowance for Indeterminates: $35 \%$ based on technical risk

\section{E. Detailed Costing:}

The estimate contains two major portions: labor and electricity. The labor calculation was developed using experience from similar programs which indicates that a certain type of team would be needed to perform these activities. The team is led by engineers reporting to program management, and comprised of skilled technicians and craft laborers (riggers, fitters, electricians, plumbers, etc.). The RF Power system installation and checkout is scheduled to extend over six quarters (18 months) and will include the following full time equivalent number of personnel working on the effort from each area:

\begin{tabular}{|c|c|c|c|c|c|c|}
\hline Sill lypo & Quarter 1 & Quarter 2 & Quarter 3 & Quarter 4 & Quarter 5 & Quarter 6 \\
\hline Erainegs & 3 & 3 & 3 & 3 & 3 & 3 \\
\hline Technicians & 15 & 15 & 15 & 15 & 15 & 15 \\
\hline Craft labor & 20 & 20 & 20 & 20 & 20 & 20 \\
\hline
\end{tabular}

The respective rates for these categories of labor are:

$\begin{array}{ll}\text { engineering } & 100 \text { ICF/man-hour } \\ \text { technician } & 80 \mathrm{ICF} / m a n-h o u r \\ \text { craft } & 25 \text { ICF/man-hour }\end{array}$

The costs were compiled using a $15 \%$ premium to cover short term placement of individuals to the IFMIF site. Further, the costs were complied using 147 man-hours/ man-month with an $8 \%$ fee added.

Preliminary estimates of the $\mathrm{AC}$ power requirements for the $\mathrm{RF}$ power system consist of three parts: , test bed operation, new station conditioning, and beam operationThe estimates of the power required for beam operation are tracked against each accelerating component WBS (4.3.1.1 "Injector Systems" through 4.3.1.5 "DTL tanks \#2 \#8 System"). Leaving only the conditioning and test bed operational period for inclusion in this estimate. Each power station will require $-1.5 \mathrm{MWe}$ for max. power conditioning, therefore:

\section{$1.5 \mathrm{MWe} \times 12$ stations $\times 72$ hours $=1,296 \mathrm{MWehr}$}

Operating the HEBT power station at representative levels until required for HEBT commissioning equates to 8760 bours of operation into the dummy load or:

$$
8760 \mathrm{hrs} X[1.5 \mathrm{MWe}]=13,140 \mathrm{MWehr}
$$

The electric rate used in calculations was $0.1 \mathrm{lCF} / \mathrm{kWehr}$. 


\section{WORKSHEET \\ WBS 4.3.1.7 Beam Dump Systems}

\section{A. Summary Cost Estimate:}

\begin{tabular}{|c|c|c|c|c|c|c|}
\hline \multicolumn{3}{|c|}{ Off-IFMIF Site } & \multicolumn{4}{|c|}{ On-Site At IFMIF } \\
\hline fndustry & Instit'al & & $\begin{array}{c}\text { Const. } \\
\text { Contractor }\end{array}$ & Instit'al & & \\
\hline Mat'l/Lab Engin's & Engin's & AFI Total & Mat'/ $\bar{L}$ ab Engin'g & Ëngin'g & $\hat{\mathrm{AFI}}$ & Total \\
\hline- & - & - & 1,511 & 75 & 690 & 2,452 \\
\hline
\end{tabular}

Units: Kilo ICF

\section{B. Description:}

This WBS element contains estimates of the necessary resources to complete the installation, assembly, and checkout of the two diagnostic beam dumps (fixed and moveable) at the IFMIF site. This task assumes that both beam dumps have been preassembled and tested, then disassembled and shipped to the IFMIF site.

The moveable dump will be capable of accepting up to $13 \mathrm{~kW} / \mathrm{cm}^{2}$ of deposited power. The fixed dump will be designed to accept $125 \mathrm{~kW}$ ( $2.5 \%$ of full energy beam) of deposited power. Both designs are derivatives of the FMIT design which contains a slanted beam face covered in ceramic tiles backed by a water tube thermal control system. The fixed dump will include provisions for IR video of the target face used in beam diagnostics.

The fixed dump will be installed at a later period in the program. It will require approximately six months in total for each diagnostic dump to accomplish the assembly and installation as well as the connection of the vacuum, cooling, and instrumentation hook-ups.

\section{Detailed WBS Listing: (including apportioned AED}

\subsubsection{1: Moveable Beam Dump \\ 4.3.1.7.2: Fixed Beam Dump}

D. Costing Rationale:

The size and composition of the team required to install and commission the diagnostic dump systems is based upon Northrop Grumman experience in commissioning similar devices.

Type of Estimate: Scaling from experience

Allowance for Indeterminates: $35 \%$ based on technical risk

\section{E. Detailed.Costing:}


The estimate was developed by examining the design requirements, and preliminary configuration of the two dumps, then generating labor estimates to support the installation at the site. The labor calculation was developed using experience fron similar programs which indicates that a certain type of team would be needed to perform these activities. The team is led by engineers reporting to program management, and comprised of skilled technicians and craft laborers (riggers, fitters, electricians, plumbers, etc.). The installation and checkout of each djagnostic dump is scheduled to extend over 2 quarters ( 6 months) and will include the following full time equivalent number of personnel working on the effort from each area:

\section{Moveable Beam Dump:}

\begin{tabular}{|c|c|c|}
\hline SkIll iype & Quarter 1 & Quarter 2 \\
\hline Engineers & 1.5 & 1.5 \\
\hline Tectinickans & 3 & 3 \\
\hline Craft labor & 5 & 5 \\
\hline
\end{tabular}

Fixed Beam Dump:

\begin{tabular}{|c|c|c|}
\hline Sikll lype & Quarter 1 & Quarter 2 \\
\hline Engineers & 5 & 5 \\
\hline Technictans & 8 & 8 \\
\hline Craft labor & 5 & 5 \\
\hline
\end{tabular}

The respective rates for these categories of labor are:

$\begin{array}{ll}\text { engineering } & 100 \mathrm{ICF} / \mathrm{man}-\mathrm{h} \text { our } \\ \text { technician } & 80 \mathrm{ICF} / \text { man-hour } \\ \text { craft } & 25 \mathrm{ICF} / \text { man-hour }\end{array}$

The costs were compiled using a $15 \%$ premium to cover short term placement of individuals to the IFMIF site. Further, the costs were complied using 147 man-hours/ man-month with an $8 \%$ fee added. 
WORKSHEET

WBS 4.3.1.8 Full Power Acceptance Test (125 mA)

A Summary Cost Estimate:

\begin{tabular}{|c|c|c|c|c|c|c|}
\hline \multicolumn{3}{|c|}{ Off-iFMIF Site } & \multicolumn{4}{|c|}{ On-Site At IFMIF } \\
\hline Industry & Instit'al & & $\begin{array}{l}\text { Const. } \\
\text { Contractor }\end{array}$ & Instit'al & & \\
\hline Mat'1Lab Engin'g & Engin'g & AFI Total & Mat'//Aab Engio's & Engìn'g & AFI & Total \\
\hline-- & $-\cdot$ & - & $4,074 \quad 1,429$ & 762 & 2,193 & 8,458 \\
\hline
\end{tabular}

Units: Kilo ICF

B. Description:

This estimate covers the resources necessary to operate the accelerator system, at varying power levels, until stable operation at full power and current is achieved. This estimate details the labor and electricity required to reach full power operation. The schedule for the entire procedure, from initial low current operation, through full current deaterium operation is scheduled to extend over six months. This period of time will allow ample time to address any difficulties encountered during the commissioning process.

\section{Detailed WBS Listing:}

No lower definition exists

D. Costing Rationale:

The size and composition of the team required to install and commission the diagnostic dump systems is based upon Northrop Grumman experience in commissioning similat devices.

Type of Estimate: Scaling from experience

Allowance for Indettrminates: $35 \%$ based on technical risk

\section{E. Detailed Costing:} labor.

The costs for this activity ase broken iato two parts: electrical usage and support

Electricity: [ a rate of $0.1 \mathrm{kICF} / \mathrm{kWehr}$ was used in the cost calculation]

This activity is scheduled to cover 6 months and ramp from full current $2.5 \%$ duty cycle $\mathrm{H} 2+$ operation to $\mathrm{CW}$ deuterium operation. The estimate includes $50 \%$ operations (@2.5\% duty) the first month, full operation for the second through forth month (@2.5\% duty), transitioning to $\mathrm{CW}$ operation for the last two months. All of this will be done on a 5-day, $40 \mathrm{hr}$ work week. This yields: 
1st month: $\quad 19.30 \mathrm{MW} \mathrm{X} 0.025 \times 20 \mathrm{hrs} /$ week X 4 weeks $=39 \mathrm{MWehrs}$ 2nd month: $\quad 19.30 \mathrm{MW} \mathrm{X} 0.025 \times 40 \mathrm{hrs} /$ week X 4 weeks $=77 \mathrm{MWehrs}$ 3rd month: $\quad 19.30 \mathrm{MW} X 0.025 \times 40 \mathrm{hrs} /$ week X 4 weeks $=77$ MWehrs First Quarter Total: 193 MWehrs

4th month: $\quad 19.30 \mathrm{MW} X 0.025 \times 40$ hrs/week X 4 wetks $=77$ MWehrs 5th month: $\quad 19.30 \mathrm{MW} X 40$ hrs/week X 4 weeks = 3088 MWehrs 6th month: $\quad 19.30 \mathrm{MW} \mathrm{X} 40$ hrs/week X 4 weeks $=\quad 3088$ MWehrs Second Quarter Total: 6253 MWehrs

\section{TOTAL FOR EFFORT: $\quad 6446$ MWehrs}

Assuming the baseline electric rate is $0.1 \mathrm{ICF} / \mathrm{kWehr}$ yields a cost for this of: (6446e3 kWehr x 0.1 ICF/kWehr) $/ 1 \mathrm{e} 3 \mathrm{ICF} / \mathrm{kilo} \mathrm{ICF}=645 \mathrm{kilo}$ ICF

\section{Associated Labor:}

Projections of the staff required to support commissioning operations were obtained from Northrop Grumman experience commissioning other beam lines. Some of these projects are:

The size and composition of the team required to support the activities were broken into three major categories: institutional engineering, industrial engineering, and technician. After examining the major tasks required the respective full time equivalent personnel in these categories were calculated to be 8 institutional engineers, 15 industrial engineers, and 45 technicians. 


\section{WORKSHEET}

WBS 4.3.1.9 Accelerator System Control

A. Summary Cost Estimate:

\begin{tabular}{|c|c|c|c|c|c|c|c|}
\hline \multicolumn{4}{|c|}{ Off-IFMIF Site } & \multicolumn{4}{|c|}{ On-Site At IFIVIIF } \\
\hline Industry & linstit'al & & & $\begin{array}{c}\text { Const. } \\
\text { Contractor }\end{array}$ & Instit'al & & \\
\hline Mat'ULab Engja'g & Engin'g & AFI & Total & Mat'LLab Engin's & Engin'g & $\mathrm{AFI}$ & Total \\
\hline 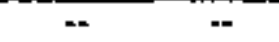 & -- & - & - & 767.7 & 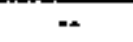 & 268.3 & 1,036 \\
\hline
\end{tabular}

Units: Kilo ICF

B. Task Description:

On-site materials/labor encompasses that effort needed for installation, inegration and testing of computer, data transfer and instrumentation signal processing equipment. Hardware installation for the accelerator station, three substations and a diagnostic station includes: computer processors, displays, data storage and interface equipment; signal query and processing racks; network bus, rotuter and interfaces; instrumentation cabling. trays and other furniture. Software installation includes station operating system, base applications, network protocols, developed control logic (EPICS routines) and sensor calibration databases.

By far the largest expenditure of effort will be signal calibration of the individual sensor outputs and the establisbment of a real-time database for such. Integration and testing of sensor signals for computer monitoring and evaluation, feedback control logic and signal processing, safety interlock parameters and logic will also be a significant onsite effort.

\section{Detailed WBS and Cost Listing (without AFI included):}

Subsystem

Accelerator Control Station

Injector/LEBT Substation

RFOLTL Substation

HEBT Substation

Castor/Pollux Evaluation/Backup

Substation

Total:

Cost (trCF)
28.9
91.6
366.5
274.9
5.9

767.7

\section{Costing Rationale:}

The estimate is comprised of labor only. Northrop Grumman's past experience commissioning control systems on other complex physics programs was used to extrapolate the labor estimates. Examples of these programs are: 
- Continuous Wave Deuterium Demonstrator - CWDD: a cryogenic accelerator where Northrop Grumman was the accelerator prime manufacturer responsible for delivering the entire accelerator system.

- Ground Test Accelerator - GTA: a ground based high power accelerator program used as a test bed for space based strategic defense initiative concepts where Northrop Grumman was selected as the accelerator industrial support contractor.

- Compact Infra Red Free Electron Laser - CIRFEL: a program where Northrop Grumman has developed a compact FEL for industrial and university use.

Allowance for Indeterminates: $35 \%$ based on technical risk 
WORKSEEET

WBS 4.3.2 Accelerator \#2 (Pollux) Instaliation and Checkout

\section{A. Summary Cost Estimate:}

\begin{tabular}{|c|c|c|c|c|c|c|}
\hline \multicolumn{3}{|c|}{ Off-ÏFMIF Site } & \multicolumn{4}{|c|}{ On-Site At IFMIF } \\
\hline Industry & Instit'al & & $\begin{array}{c}\text { Const. } \\
\text { Contractor }\end{array}$ & Instit'al & & \\
\hline Mat'TLab Engín'g & Engin's & AFI Total & Mat'//ab Engin'g & Engin's & AFI & Total \\
\hline- & $\because$ & - & 17,556 & 1,546 & 7,611 & 29,355 \\
\hline
\end{tabular}

Units: Kilo ICF

\section{B. Description:}

This account contains a surnmary estimate for the installation and checkout of the second accelerator equipment at the IFMIF site. As with the first accelerator, a baseline assumption for this estimate is that the individual accelerating components are functionally checkout at the equipment vendor before shipment to the IFMIF site. Further, the labor estimates contained herein reflect savings from the experience with the first accelerator (WBS 4.3.1).

\section{Detailed WBS Listing:}

This element is comprised of the following lower level estimates which are detailed on separate worksheets:

\begin{tabular}{|c|c|}
\hline 2. 0.0 .0 .0 .0$. & Accelerator \#2 (Pollux) Installation and Checkout \\
\hline t. 0.0 .0$. & Injector system \\
\hline 2. 0.0 .0$. & RFO syatem \\
\hline 3. 0.0 .0$. & DTL Tank\#1 system \\
\hline 4.0 .0 .0 .0 & DTI Tanks \#2 \#A system \\
\hline 5. 0.0 .0 .0$. & HEBT. systems ("Abel", "Baker", and "Charlie") \\
\hline 6. 0.0 .0 .0$. & RF power system \\
\hline 7. 0.0 .0 .0$. & Fus Power Acoptance Testing (250 mA) \\
\hline
\end{tabular}

D. Costing Rationale:

See lower leve] detail sheets

Type of Estimate: Bottoms up

Allowance for Indeterminates: $35 \%$

E. Detailed Costing:

See lower level detail sheets 
WORKSHEET

WRS 4.3.2.1 Infector System

\section{A. Summary Cost Estimate:}

\begin{tabular}{|c|c|c|c|c|c|c|}
\hline \multicolumn{3}{|c|}{ Off-IFMLF Site } & \multicolumn{4}{|c|}{ On-Site At İMMIF } \\
\hline Industry & Instital & & $\begin{array}{c}\text { Const. } \\
\text { Contractor }\end{array}$ & Instit'al & & \\
\hline Mat't/Lab Engin'g & Engin's & AFI Total & Mat'//Lab Ëngin'g & Engin's & AFI & Total \\
\hline- & -- & $\cdots$ & 745.5 & 53 & 308.5 & 1,190 \\
\hline
\end{tabular}

Units: Kijlo ICF

\section{B. Description:}

This WBS element contains estimates of the necessary resources to unpack the injector equipment (including its RF power supply) at the site, complete its installation, assembly and checkout, then perform an acceptance test on it to ensure operation within specified parameters. This task assumes the accelerator tunnel construction is completed and the room is ready for equipment installation.

The installation sequence begins with two paraflel efforts, one focused on installing the ion source, the other focused on installing the necessary drive power for the source. Both activities are working toward a point where the source operation (with H2+, at modest pulsed current $-50 \mathrm{~mA}$ ) can be verified. A major portion of this effort is spent on integrating the ion source/RF subsystems with the accelerator control system. After stable beam is extracted from the source, the low energy beam transport will be installed and beam will be transmitted through it. The operational characteristics of the injector will then be investigated and system performance optimized. The transmitted beam will range from low duty factor modest current (tens of $\mathrm{mA}$ ) to $\mathrm{CW}$ with full current.

Preliminary estimates of the AC power requirements for the source are $0.058 \mathrm{MWe}$ (including magnet power supplies). Based on recent Northrop Grumuman experience on the Contraband Detector System progran (a very similar source), this operational level should be reached within the first month. Once established, till the end of the testing, the injector should be operated as much as possible to build an operability/availability database.

\section{Detailed WBS Listing:}

No lower level WBS elements

\section{Costing Rationale;}

The size and composition of the team required to install and commission the injector system is based upon Northrop Grumman experience in commissioning similar systems.

Type of Estimate: Factored from experience

Allowance for Indeterminates: $35 \%$ based on technical risk 


\section{E. Detailed Costing:}

The estimate contains two major portions: labor and electricity. The labor estimates are from experience on similar programs. This experience dictated a certain type of team would be needed to perform the activities. The team is led by an engineer reporting to project management, with the balance of the team comprised of skiled technicians and craft laborers (riggers, fitters, electricians, plumbers, etc.). The injector installation and checkout is scheduled to extend over three quarters ( 9 months) and will include the following full time equivalent number of personnel working on the effort from each area:

\begin{tabular}{|c|c|c|c|}
\hline SkIII hype & Quarter 1 & Quarter 2 & Quarter 3 \\
\hline Engineers & 1 & 1 & 1 \\
\hline Technicians & 4.5 & 4.5 & 4.5 \\
\hline Craft labor & 5 & 3 & 3 \\
\hline
\end{tabular}

The respective rates for these categories of labor are: $\begin{array}{ll}\text { engineering } & 100 \mathrm{ICF} / \text { man-hour } \\ \text { technician } & 80 \mathrm{ICF} / \text { man-hour } \\ \text { craft } & 25 \mathrm{ICF} / \text { man-hour }\end{array}$

The costs were compiled using a $15 \%$ premium to cover short term placement of individuals to the IFMIF site. Further, the costs were complied using 147 man-hours/ man-month with an $8 \%$ fee added.

Preliminary estimates of the AC power requirements for the source are 0.058 MWe (including magnet power supplies). Experience indicates this operational level should be reached within the first month. From there on, till the end of the testing, the injector should be operated as much as possible to build an availability database. Over a quarter this tums out to be:

40hrs/week X 12weeks/quarter X $0.058 \mathrm{MWe}=27.84 \mathrm{MWehr} /$ quarter

The electric rate used in cost calculations was 0.1 ICF/kWehr. 
WORKSHEET

WBS 4.3.2.2 RFQ System

A. Summary Cost Estimate:

\begin{tabular}{|c|c|c|c|c|c|c|}
\hline \multicolumn{3}{|c|}{ Off-IFMIF Site } & \multicolumn{4}{|c|}{ On-Site At IFMLF } \\
\hline Industry & Instital & & $\begin{array}{c}\text { Const. } \\
\text { Contractor }\end{array}$ & Instit'al & & \\
\hline Mat'ULab Engin'g & Engin's & AFI Total & Mat'/Lab Engin's & Engin'g & $\overline{\mathrm{AFI}}$ & Total \\
\hline$-\quad \quad-$ & - & $-\quad-$ & $706 \quad 63$ & 38 & 283 & 1,090 \\
\hline
\end{tabular}

Units: Kilo ICF

\section{B. Description:}

This WBS element contains estimates of the necessary resources to begin with unpacking the RFQ equipment at the site, eventually ending with its complete installation, assembly and checkout. This task assumes that the injector testing is complete and its operation has been characterized. Further the accelerator tunnel construction is completed and the room is ready for equipment installation.

The first step in the RFQ installation process is the remove all the shipping bracing from the accelerating cavity. This is followed by an alignment check prior to physical installation of the RFQ on its mounts in the tunnel. Next the connection to the LEBT is completed and accelerator alignment is once again checked. Once the RFQ is in place, all the exterior cooling, vacuum, instrumentation, and RF feed hook-up will be connected. In parallel with the RFQ installation work a separate team of personnel wili focus on the installation of the three RF power stations that will supply power to the RFQ. The RF activity will interface with the accelerator at the RF window on the RFQ structure. [Note: the estimate covering the RF activities is included in WBS 4.3.1.6 "RF Power Systems", but a discussion of the activities is included for clarity.]

After installation of the RFQ and power stations are complete, the RFQ reguires conditioning before beam can be transmitted. Conditioning is accomplished by first pulsing the RF power system into the cavity at increasing levels of power until the cavity is capable of accepting full power. After which the cavity will be subjected to $C W$ power operation, still with no transmitted beam, until it reaches a vacuum equilibrium. The conditioning process will take approximately two weeks to reach $\mathrm{CW}$ operation and to sufficiently prepare the structure for the beam.

Next, the injector will be rua with $\mathrm{H} 2+$ at low duty factor/low current as in the initial injector tests. Transmission through the RFQ will be checked against predicted values and corrective action taken. After which beam duty factor and current will be increased until the maximum power limit of the portable beam diagnostic dump is reached. After a stable transmitted beam is achieved, the cavity will be adjusted to achieve peak efficiency. 
C.Detailed WBS Listing:

No lower level WBS elements

\section{Costing Rationale:}

The size and composition of the team required to install and commission the RFQ systern is based upon Northrop Grumman experience in commissioning similar systems.

Type of Estimate: Factored from experience

Allowance for Indeterminates: $35 \%$ based on technical risk

\section{E Detailed Costing:}

The estimate contains two major portions: labor and electricity. The labor calculation was developed using experience from similar programs which indicated that a certain type of team would be needed to perform the activities. The tean is comprised of an engineer leading a team of skilled technicians and craft laborers (iiggers, fitters, electricians, plumbers, etc.). The RFQ installation and checkout is scheduled to extend over four quarters (12 months) and will include the following full time equivalent number of personneI working on the effort from each area:

\begin{tabular}{|c|c|c|c|c|}
\hline Skidl tylab & Quarter 1 & Ouarter 1 & Quarter 1 & Quarter 1 \\
\hline Engineers & 1 & 0.75 & 0.5 & 0.25 \\
\hline Technicians & 2.75 & 2.75 & 2.75 & 2.75 \\
\hline Crait labor & 5 & 3 & 2 & 1 \\
\hline
\end{tabular}

The respective rates for these categories of labor are:

$\begin{array}{ll}\text { engineering } & 100 \mathrm{ICF} / \mathrm{mman} \text {-hour } \\ \text { technician } & 80 \mathrm{ICF} / \mathrm{man} \text {-hour } \\ \text { craft } & 25 \mathrm{ICF} / \mathrm{man}-\mathrm{hour}\end{array}$

The costs were compiled using a $15 \%$ premiurn to cover short term placement of individuals to the IFMIF site. Further, the costs were complied using 147 man-hoursi man-month with an $8 \%$ fee added.

Preliminary estimates of the AC power reguirements for the RFQ consist of two parts: cavity conditioning and beam operation. The conditioning period starts with low power pulsed operation and continues by lengthening both pulse duration and increasing power levels until $C W$ full power operation is achieved. A conservative estimate of the time required to get the cavity conditioned is 2 weeks. For budgeting, $75 \% \max$ power is considered over this period. This equates to:

\subsection{MWe X $0.75=4.329 \mathrm{MWe}$ over $80 \mathrm{hrs}$ of $346.32 \mathrm{MWehr}$}

For beam testing, the RFQ will be operated at $20 \%$ duty factor ( $-31 \mathrm{~mA}$ peak current), for $50 \%$ of the period ( $\mathrm{l}$ week in operation, 1 week in adjustment, etc.). The additional power, over and above the injector is:

$40 \mathrm{hrs} /$ week X 6 weeks ops/quarter X 5.772MWe $=1385 \mathrm{MWehu/quarter}$

The electric rate used in cost calculations was $0.1 \mathrm{ICF} / \mathrm{kWehr}$. 
WORKSHEET

WBS 4.3.2.3 DTL Tank \#1 System

A. Sunumary Cost Estimate:

\begin{tabular}{|c|c|c|c|c|c|c|}
\hline \multicolumn{3}{|c|}{ Off-IFMIF Site } & \multicolumn{4}{|c|}{ On-Site At IFMIIF } \\
\hline Industry & Instital & & $\begin{array}{l}\text { Const. } \\
\text { Contractor }\end{array}$ & Instit'al & & \\
\hline Mat'И尚 Engio'g & Engin's & AFI Total & Mat'VLab Engin'g & Engin's & AFI & Total \\
\hline-- & $=$ & - & 631 & 43 & 259 & 1,000 \\
\hline
\end{tabular}

Units: Kilo ICF

B. Description:

This WBS element contains estimates of the necessary resources to begin unpacking the first Drift Tube Linac (DTL) equipment at the site, and finish with its complete installation, assembly and checkout. This task assumes that the injector and RFQ testing is complete and operation through these components has been characterized. Further, the accelerator tunnel construction is completed and the room is ready for equipment installation.

The first step in the DTL tank installation process is to unpack and re-align the accelerating cavity. Unlike the injector and RFQ, the DTL will be shipped with an elaborate internal brace to minimize the amount of site alignment required. After which, the physical instaflation of the DTL on its mounts in the tunnel can begin. Optical alignment checks will be employed to ensure proper connection between the DTL and the RFQ. Having accomplished this, all the exterior cooling, vacuum, instrumentation, and RF feed hook-ups will be connected. In parallel with the DTL installation work a separate team of personnel will focus on the installation of the RF power station that will supply power to the DTL tank. The RF activity will interface with the accelerator at the $\mathrm{RF}$ window on the DTL structure. [Note: the estimate covering the RF activities is included in WBS 4.3.2.6 "RF Power Systems" element, but a discussion of the activities is included for clarity.]

After installation of the DTL and its power station are complete, the DTL will enter a conditioning phase similar to the $R F Q$. Conditioning is accomplished by first pulsing the RF power system into the cavity, at increasing levels of power, until the cavity is capable of accepting full power. After which the cavity will be subjected to $\mathrm{CW}$ power operation, stiil with no transmitted beam, and allowed to reach vacuum equilibrium. The conditioning process will take approximately two weeks in total. The cavity is now ready for bean.

Similar to the beam line components before it, the DTL will begin by transmitting a low current pulsed beam, eventually ramping up to the current limit of the moveable beam dump $(-50 \mathrm{~kW})$. After a stable transmitted beam is achieved, the cavity will be adjusted to achieve peak efficiency. 


\section{C._Detailed WBS Listing:}

No lower level WBS elements

\section{Costing Rationale:}

The size and composition of the team required to install and commission the first DTL tank system is based upon Northrop Grumman experience in commissioning similar systems.

Type of Estimate: Factored from experience

Allowance for Indeterminates: $35 \%$ based on technical risk

\section{E. Detailed Costing:}

The estimate contains two major portions: labor and electricity. The labor calculation was developed using experience from similar programs which indicates that a certain type of team would be needed to perfom these activities. The team is led by engineers reporting to program management, and comprised of skilled technicians and craft laborers (riggers, fitters, electricians, plumbers, etc.). The DTL tank \#1 installation and checkout is scheduled to extend over one quarter ( 3 months) and will include the following full time equivalent number of personnel working on the effort from each areat

\begin{tabular}{|c|c|}
\hline Skill bipe & Qugrkes 1 \\
\hline Enginears & 2.1 \\
\hline Technicians & 9 \\
\hline Craft labor & 13 \\
\hline
\end{tabular}

The respective rates for these categories of labor are:

$\begin{array}{ll}\text { engineering } & 100 \mathrm{ICF} / \mathrm{man}-\mathrm{hour} \\ \text { teclinician } & 80 \mathrm{ICF} / \mathrm{man} \text {-hour } \\ \text { craft } & 25 \mathrm{ICF} / \mathrm{man} \text {-hour }\end{array}$

The costs were compiled using a $15 \%$ premium to cover short tern placement of individuals to the IFMIF site. Further, the costs were complied using 147 man-hours' man-month with an $8 \%$ fee added.

Preliminary estimates of the AC power requirements for the DTL consist of two parts: cavity conditioning and beam operation. The conditioning period starts with low power pulsed operation and continues by lengthening both pulse duration and increasing power levels until CW full power operation is achieved. A conservative estimate of the time required to get the cavity conditioned is 2 weeks. For budgeting, $75 \%$ max power is considered over this period. This equates to:

\section{$2.25 \mathrm{MWe} X 0.75=1.688 \mathrm{MWe}$ over $80 \mathrm{hrs}$ or $135.04 \mathrm{MWehr}$}

Next an estimate of the beam-on testing is required. Unlike the Injector and RFQ, the full current/energy beam discharged from this cavity cannot be handled by the beam dump. The limit for the moveable dump has been set at the CW power output of the RFQ with $\mathrm{H} 2+(-50 \mathrm{~kW})$. For the increased energy, the DTL tank must be operated at low duty factor $(\sim 25 \%)$ duty factor to accelerate enough current, yet still maintain the power 
deposited on the beam dump. The additional power required per quarter for the DTL (assuming 1 week operation followed by 1 week adjustments) is:

40hrs/week X 6 weeks ops/quarter X [2.25 MWe X 25\%] 135.0 MWehr/quarter The electric rate used in cost calculations was $0.1 \mathrm{ICF} / \mathrm{kWehr}$. 
WORKSHEET

WBS 4.3.2.4 DTL Tanks \#2 - \#8 System

A. Summary Cost Estimate:

\begin{tabular}{|c|c|c|c|c|c|c|}
\hline \multicolumn{3}{|c|}{ Off-IFMIF Site } & \multicolumn{4}{|c|}{ On-Site At IFMIF } \\
\hline Endustry & Instit'al & & $\begin{array}{c}\text { Const. } \\
\text { Contractor }\end{array}$ & Instit' & & \\
\hline Mar'/Lab Engin'g & Engin'g & AFI Total & Mat'1/Lab Engin's & Engin'g & AF & Total \\
\hline- & $=$ & - & 2,142 & 144 & 879 & 3,390 \\
\hline
\end{tabular}

Units: Kile ICF

B. Description:

This WBS element contains estimates of the necessary resources to begin with unpacking the second through eighth Drift Tube Linac (DTL) tanks from their shipping frames at the site, and ending with their complete installation, assembly, and checkolit. This task assumes that the injector, RFQ, and first DTL tank installation and testing is complete and beam operation through these components has been characterized and optimized. Further, this estimate assumes accelerator tunnel construction is fully completed and the room is reaty for acceierator equipment installation.

The first step in the DTL tank installation and checkout process is to unpack and re-align the accelerating cavities. Unlike the injector and $R F Q$, the DTL tanks will be shipped with elaborate intemal bracing to minimize the amoune of site alignment required. After which, the physical installation of the DTL tanks on their mounts in the tunnel can begin. Optical alignment checks will be employed to ensure proper connection between the DTL tanks and the previously installed beam line components. Having accomplished structural installation, all the exterior cooling, vacuum, instrumentation, and RF feed hookups will be connected. In parallel with the DTL, installation work a separate team of personnel will focus on the installation of the RF power stations for these accelerating cavities. The RF activity will interface with the accelerator at the RF window on the DTL tanks. [Note: the estimate covering the RF activities is not included in this WBS element, but rather detailed in WBS 4.3.6 RF Power System.]

After complete hook-up of the DTL tanks cavity conditioning activities can commence. Conditioning is accomplished by slowly ramping the RF power transmitted to the cavity from low duty factor/fow power until the cavity can accept full power in a $C W$ mode. Having reached CW power levels, still with no transmitted beam, the cavity is allowed to reach equilibrium. The whole conditioning process will take approximately two weeks to reach $\mathrm{CW}$ operation. Once the cavity has been conditioned it is ready for beam transmission.

Similar to the beam line components before it. DTL tanks 2-8 will begin by transmitting low current pulsed beam, eventually moving up to the current limit of the moveable beam durnp. After a stable transmitted beam is achieved, each cavity will be adjusted to achieve peak efficiency. Unlike the components before it, tanks $2-8$ will be tested as a unit. 


\section{Detailed WBS Listing:}

No lower level WBS elements

\section{Costing Rationale:}

The size and composition of the team required to install and commission the DTL tanks 2-8 accelerating system is based upon Northrop Grumman experience in commissioning similar systems.

Type of Estimate: Factored from experience

Allowance for Indeterminates: $35 \%$ based on technical risk

\section{E. Detaiked Costing:}

The estimate contains two major portions: labor and electricity. The labor caiculation was developed using experience from similar programs which indicates that a certain type of team would be needed to perform these activities. The team is led by engineers reporting to program management, and comprised of skilled technicians and craft laborers (riggers, fitters, electricians, plumbers, etc.). The DTL tank 2-8 system installation and checkout is scheduled to extend over two quarters (6 months) and will include the following full time equivalent number of personnel working on the effort from each area:

\begin{tabular}{|c|c|c|}
\hline Sikill type & Quarter 1 & Quarter 2 \\
\hline Engineers & 3.5 & 3.5 \\
\hline Technicians & 16 & 16 \\
\hline Craft labor & 26 & 26 \\
\hline
\end{tabular}

The respective rates for these categories of labor are:

$\begin{array}{ll}\text { engineering } & 100 \mathrm{ICF} / \mathrm{man}-\mathrm{hour} \\ \text { technician } & 80 \mathrm{ICF} / \mathrm{man}-\mathrm{how} \\ \text { craft } & 25 \mathrm{ICF} / \mathrm{man}-\mathrm{h} \text { ow }\end{array}$

The costs were compiled using a $15 \%$ premium to cover short term placement of individuals to the IFMIF site. Further, the costs were complied using 147 man-hours/ man-month with an $8 \%$ fee added.

Preliminary estimates of the AC power requirements for the DTL tank $2-8$ system consist of two parts: cavity conditioning and beam operation. The conditioning period starts with low power pulsed operation and continues by lengthening both pulse duration and increasing power levels until CW full power operation is achieved. A conservative estimate of the time required to get the cavity conditioned is 2 weeks. For budgeting, $75 \%$ max power is considered over this period. This equates to:

$$
\text { 10.554 MWe X } 0.75=7.916 \mathrm{MWe} \text { over } 80 \text { hrs or } 633.24 \mathrm{MWehr}
$$

Next an estimate of the beam-on testing is required. Unlike the Injector and RFQ system the full currenv/energy beam discharged from this cavity cannot be handled by the beam demp. The limit for the moveable dump has been set at the CW power output of the RFQ with $\mathrm{H} 2+(-50 \mathrm{~kW})$. For the increased energy out of tank $\mathrm{H} 8$, the accelerator must be operated at less than $10 \%(-12.5 \mathrm{~mA}$ peak current) duty factor to maintain the power 
deposited on the beam dump. The additional power required per quarter for the DTL tank system (assuming 1 week operation followed by I week of adjustments) is:

40 hrs/week X 12 weeks ops X [10.554 MWe X 10\%] = 506.6 MWehr The electric rate used in cost calculations was $0.1 \mathrm{ICF} / \mathrm{kW}$ ehr. 


\section{WORKSHEET \\ WBS 4.3.2.5 High Energy Beam Transport (HEBT) Systems}

A. Summary Cost Estimate:

\begin{tabular}{|c|c|c|c|c|c|c|}
\hline \multicolumn{3}{|c|}{ Off-LFMIF Site } & \multicolumn{4}{|c|}{ On-Site At IFMIF } \\
\hline Industry & Instit'a & & $\begin{array}{c}\text { Const. } \\
\text { Contractor }\end{array}$ & Instit'al & & \\
\hline MarVLab Enging & Engin'g & AFI Total & Mar//Lab Enging & Engin'g & AFI & Total \\
\hline-- & - & - & 3,167 & 220 & 1,307 & 5,040 \\
\hline
\end{tabular}

Units: Kilo ICF

\section{B. Description:}

This WBS ejement contains estimates of the necessary resources to complete the installation, assembly, and checkout of the three HEBT lines for the second accelerator. This task assumes that the accelerator installation and testing is complete and beam operation through these components has been characterized and optimized. Further, this estimate assumes turning room construction is fully completed and the hall is ready for HEBT equipment installation. Lastly, this estimate assumes the fixed diagnostic domp is installed, checked out, and ready for use.

The installation process begins by assembling the $\sim 60$ meters of beam tobe from the accelerator to the fixed diagnostic beam dump, blanking off the other two branches to the lithium targets. Interspersed in the beam pipe are a total of $13 \mathrm{RF}$ cavities (for bunching and energy dispersion) which need to be positioned correctly in the triming room to mate up with structural supports as well as the drive lines from the RF power station. Next to be installed are the various vacuum pumps distributed among the transport line. After completion of this activity, the beam tube and RF cavities can be pumped to operational levels, and RF cavity conditioning can commence. Similar to the accelerator cavities the buncher and energy dispersion cavities will be subjected to a series of varying RF power levels from low power pulsed to full power CW levels. When the cavities can sustain full power RF, they are ready to be used to transport beam to the diagnostic dump.

The next step in the process is the installation of the 25 magnets around the beam pipe, with all the associated connections to control \& monitoring, cooling, and power supplies. Once completed the HEBT is ready for beam.

After testing/optimization is complete on the beam line to the diagnostic dump, efforts will shift toward installing the remaining equipment for the transport sections to the lithium targets. The steps employed will be the same as used to install the transport line to the diagnostic dump (first beam tube/cavity/vacuum installation, followed by conditioning, and magnet installation). When completed the HEBT is teady for testing with bean into any of the targets.

\section{Detailed WBS Ljsting:}


No lower levef WBS eiements

\section{Costing Rationale:}

The size and composition of the team required to instail and commission the HEBT system is based upon Northrop Grumman experience in commissioning similar systems.

Type of Estimate: Scaling from experience

Allowance for Indeterminates: $35 \%$ based on technical risk

\section{E. Detailed Costing:}

The estimate contains two major portions: labor and electricity. The labor calculation was developed using experience from similar programs which indicates that a certain type of team would be needed to perform these activities. The team is led by engineers reporting to program management, and comprised of skilled technicians and craft laborers (riggers, fitters, electricians, plumbers, etc.). The HEBT system installation and checkout is scheduled to extend over four quarters (12 months) and will include the following full time equivalent number of personnel working on the effort from each area:

\begin{tabular}{|c|c|c|c|c|}
\hline 3kill type & Quarter 1 & Quarter 2 & Quarter 3 & Quarter 4 \\
\hline Ërgineers & 2.75 & 2.75 & 2.75 & 2.75 \\
\hline Technicians & 14 & 14 & 14 & 14 \\
\hline Craftlabor & 20 & 20 & 20 & 20 \\
\hline
\end{tabular}

The respective rates for these categories of labor are:

$\begin{array}{ll}\text { engineering } & 100 \mathrm{ICF} / \text { man-hour } \\ \text { technician } & 80 \mathrm{ICF} / \mathrm{man}-\mathrm{hour} \\ \text { craft } & 25 \mathrm{ICF} / \text { man-hour }\end{array}$

The costs were compiled using a $15 \%$ premium to cover short term placement of individuals to the IFMIF site. Further, the costs were complied using 147 man-hours man-month with an $8 \%$ fee added.

Preliminary estimates of the AC power requirements for the HEBT system consist of two parts: cavity conditioning and beam operation. The conditioning period starts with low power pulsed operation and continues by lengthening both pulse duration and increasing power levels until CW full power operation is achieved. A conservative estimate of the time required to get the cavity conditioned is 2 wekks. This equates to:

\subsection{MWe X 3 beam lines $=4.32 \mathrm{MWe}$ over $80 \mathrm{hrs}$ or $345.6 \mathrm{MWehr}$}

Next an estimate of the beam-on testing is required. This is comprised of 2 weeks operation at $2.5 \%$ duty factor as well as 1 week at full power. The additional HEBT power required over the needs of the accelerator is:

$$
120 \mathrm{hrs} X[1.44 \mathrm{MWe}]=172.8 \mathrm{MWehr}
$$

The electric rate used in cost calculations was $0.1 \mathrm{ICF} / \mathrm{kWehr}$. 
WORKSHEET

WBS 4,3,2.6 RF Systems

A. Summary Cost Estimate:

\begin{tabular}{|c|c|c|c|c|c|c|}
\hline \multicolumn{3}{|c|}{ Off-IFMIF Site } & \multicolumn{4}{|c|}{ On-Site At IFMIF } \\
\hline Industry & Enstit'al & & $\begin{array}{c}\text { Const. } \\
\text { Contractor }\end{array}$ & Instit'al & & \\
\hline Mar"ZLas Engin's & Engints & AFI Total & MatVLab Engin'g & Engin'tg & AFT & Total \\
\hline- & - & $-\quad-$ & $\begin{array}{ll}5,239 & 429 \\
\end{array}$ & 286 & 2,115 & 8,159 \\
\hline
\end{tabular}

Units: Kilo ICF

B. Description:

This WBS element contains estimates of the necessary resources to complete the installation, assembly, and checkout of the RF power system for the first acceletator and HEBT system at the IFMIF site. This task assumes each RF station has been pre* assembled and tested by the RF prime subcontractor, then disassembled and shipped to the IFMIF site. Further, this estimate assumes RF hall is fully completed and is ready for equipment installation.

The installation process will be sequenced to provide fully operational power stations to support the accelerating cavity efforts.

The steps in the installation process begin with unpacking the equipment. The equipment forming the switchgear, transfomed/rectifier and crowbar subsystems will be installed and connected to the electric feeds from the facility substation and tested. Next, the balance of the system equipment (with the exception of the RF transport between the circulator output and the accelerating cavities will be installed and checked out. In parallel with this work, the station control and monitoring subsystem will be installed and checked out. Having completed this phase of the buildup the station can be commissioned and operated into a dummy load, with a local RF source, to begin to condition the station (typically requiring 72 hours constant operation). Commencing some where in the middle of this activity will be another effort to install the $\sim 20$ meters of $R F$ transport line from the accelerating cavity in the aunnels up to the RF power station on the floor above the tunnel. Once the transport connection is made to the power station the entire RF power station can be tested into the accelerating structure. The performance of station will be assessed against established values and any necessary optimization performed.

This process is repeated for each station. In parallel with the station installation and checkout the global RF source will be installed. Once operational this source will replace the local source used for station commissioning.

\section{Detailed WBS Listing;}

No lower level WBS elements

D. Costing Rationale: 
The size and composition of the team required to install and commission the RF power system is based upon Northrop Grumman experience in commissioning similar systems.

Type of Estimate: Scaling from experience

Allowance for Indeterminates: $35 \%$ based on technical risk

\section{E. Detailed Costing:}

The estimate contains two major portions: labor and electricity. The labor calculation was developed using experience from similar prograns which indicates that a certain type of team would be needed to perform these activities. The team is led by engineers reporting to program mansgement, and comprised of stilled technicians and craft laborers (riggers, futters, electricians, plumbers, etc.). The RF Power system installation and checkout is scheduled to extend over six quarters (18 months) and will include the following full time equivalent number of personnel working on the effort from each area:

\begin{tabular}{|c|c|c|c|c|c|c|}
\hline Skfil iype & Quarter 1 & Quarter 2 & Quarter 3 & Quarter 4 & Quarter 5 & Quarter 6 \\
\hline Engineers & 3 & 3 & 3 & 3 & 3 & 3 \\
\hline Technicians & 15 & 15 & 15 & 15 & 15 & 15 \\
\hline Cralt labor & 20 & 20 & 20 & 20 & 20 & 20 \\
\hline
\end{tabular}

The respective rates for these categories of labor are:

$\begin{array}{ll}\text { engineering } & 100 \mathrm{ICF} / \mathrm{man}-\mathrm{hour} \\ \text { technician } & 80 \mathrm{ICF} / \mathrm{man}-\mathrm{hour} \\ \text { craft } & 25 \mathrm{ICF} / \text { man-hour }\end{array}$

The costs were compiled using a $15 \%$ premium to cover short tem placement of individuals to the IFMIIF site. Further, the costs were complied using 147 man-hours/ man-month with an $8 \%$ fee added.

Preliminary estimates of the AC power requirements for the HEBT system consist of three parts: , test bed operation, new station conditioning, and beam operation. The estimates of the power required for beam operation are tracked against each accelerating component WBS (4.3.1.1 "Injector Systems" through 4.3.1.5 “ DTL tanks \#2-\#8 System"). Leaving only the conditioning and test bed operational period for inclusion in this estimate. Each power station will require $\sim 1.5 \mathrm{MWe}$ for max. power conditioning, therefore:

\section{$1.5 \mathrm{MWe} \times 12$ stations $\times 72$ hours $=1,296 \mathrm{MWehr}$}

Operating the HEBT power station at representative levels until required for HEBT commissioning equates to 8760 hours of operation into the durnmy load or:

$$
8760 \mathrm{hrs} X[1.5 \mathrm{MWe}]=13,140 \mathrm{MWehr}
$$

The electric rate used in cost calculations was $0.1 \mathrm{ICF} / \mathrm{kWehr}$. 
WORKSHEET

WBS 4.3.2.7 Full Power Acceptance Test (125 mA)

\section{A. Summary Cost Estimate:}

\begin{tabular}{|c|c|c|c|c|c|c|}
\hline \multicolumn{3}{|c|}{ Off-IFMIF Site } & \multicolumn{4}{|c|}{ On-Site At IFMIF } \\
\hline Industry & Instit'al & & $\begin{array}{c}\text { Const } \\
\text { Contractor }\end{array}$ & Instit'al & & \\
\hline Mat'1Lab Engin'g & $\overline{\text { Engin'g }}$ & AFI Total & Mat'/Lab Engin'g & Engin'g & AFI & Total \\
\hline$*$ & - & - & 4,074 & 762 & 2,193 & 8,458 \\
\hline
\end{tabular}

Units: Kilo ICF

\section{B. Description:}

This estimate covers the resources necessary to operate the accelerator system, at varying power levels, until stable operation at full power and current is achieved. This estimate details the labor and electricity required to reach full power operation. The schedule for the entire procedure, from initial low current operation, through full current deuterium operation is scheduled to extend over six months. This period of time will allow ample time to address any difficulties encountered during the commissioning process.

\section{Detailed WBS Listing:}

No lower definition exists

\section{Costing Rationale:}

The size and composition of the team required to install and commission the diagnostic dump systems is based upon Northrop Grumman experience in commissioning similar devices.

Type of Estimate: Scaling from experience

Allowance for Indeteminates: $35 \%$ based on technical risk

\section{E. Detailed Costint:} labor.

The costs for this activity are broken into two parts: electrical usage and support

Electricity: [ a rate of $0.1 \mathrm{kJCF} / \mathrm{kWehr}$ was used in the cost ca]culation]

This activity is scheduled to cover 6 months and ramp from full current $2.5 \%$ duty cycle $\mathrm{H} 2+$ operation to $\mathrm{CW}$ deuterium operation. The estimate includes $50 \%$ operations (@2.5\% duty) the first month, full operation for the second through forth month (@2.5\% duty), transitioning to CW operation fot the last two months. All of this will be done on a 5-day, 40 hr work week. This yields: 
1st month: $\quad 19.30 \mathrm{MW} \times 0.025 \times 20 \mathrm{hrs} /$ week X 4 weeks $=39$ MWehrs

2nd month: $\quad 19.30 \mathrm{MW} X 0.025 \times 40$ hrs/week X 4 weeks $=77$ MWehrs

3rd month: $\quad 19.30 \mathrm{MW} X 0.025 \mathrm{X} 40$ hrs/week X 4 weeks $=77 \mathrm{MWehrs}$

First Quarter Total: 193 MWelirs

4th month: $\quad 19.30 \mathrm{MW} X 0.025 \times 40$ hrs $/$ week X 4 weeks $=77$ MWehrs 5th month: $\quad 19.30 \mathrm{MW} \mathrm{X} 40 \mathrm{hrs} /$ week X 4 weeks $=\quad 3088 \mathrm{MWehrs}$ 6th month: $\quad 19.30 \mathrm{MW} X 40$ hrs/week X 4 weeks = $3088 \mathrm{MW}$ ehrs Second Quarter Total: 6253 MWehrs

\section{TOTAL FOR EFFORT: $\quad 6446$ MWehrs}

Assuming the basseline electric rate is 0.1 ICF/ $\mathrm{k}$ Whe yields a cost for this of: (6446e3 kWehr x $0.1 \mathrm{ICF} / \mathrm{kWehr}) / 1 \mathrm{e} 3 \mathrm{ICF} / \mathrm{kjlo} \mathrm{ICF}=645 \mathrm{kjlo} \mathrm{ICF}$

Associated Labor:

Projections of the staff required to support commissioning operations were obtained from Northrop Grumman experience commissioning other beam lines. Some of these projects are:

The size and composition of the team required to support the activities were broken into three major categories: institutional engineering, industrial engineering, and technician. After examining the nujor tasks required the respective full time equivalent personnel in these categories were calculated to be 8 institutional engineers, 15 industrial engineers, and 45 technicians. 
WORKSHEET

WBS 4.3.2.8 Accelerator System Control

A. Summary Cost Estimate:

\begin{tabular}{|c|c|c|c|c|c|c|c|c|}
\hline \multicolumn{4}{|c|}{ Off-IFMIF Site } & \multicolumn{5}{|c|}{ On-Site At IFIVLF } \\
\hline Industry & Instital & & & $\begin{array}{r}\operatorname{con} \\
\operatorname{Con}\end{array}$ & $\begin{array}{l}\text { st. } \\
\text { actor }\end{array}$ & Instita] & & \\
\hline Marl/Lab Engin'g & Engin'g & $\overline{A F I}$ & Total & Mat'/Lab & Engin'g & Engin'g & AFI & Total \\
\hline$-2 \quad-$ & - & 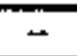 & - & 761.8 & - & - & 266.2 & 1,028 \\
\hline
\end{tabular}

Units: Kilo ICF

B. Task Description:

Like the estimate for the installation of the first set of control equipment, the onsite materials/labor encompasses that effor needed for installation, integration and testing of computer, data transfer and instrumentation signal processing equipment. Hardware instalfation for the accelerator station, three substations and a giagnostic station includes: computer processors, displays, data storage and interface equipment; signal query and processing racks; network bus, router and interfaces; instrumentation cabling, trays and other furniture. Software installation includes station operating system, base applications, network protocols, developed control logic (EPICS routines) and sensor calibration databases.

By far the largest expenditure of effort will be signal calibration of the individual sensor outputs and the establishment of a real-time database for such. Integration and testing of sensor signals for computer monitoring and evaluation, feedback control logic and signal processing, safety interlock parameters and logic will also be a significant on-site effort.

\section{Detailed WBS and Cost Listing (without AEL included):}

Subsystem

Accelerator Control Station

Injector/LEBT Substation

RFODTL Substation

HEBT Substation
Cost (kICF)

28.9

91.6

366.5

274.9

Total: $\quad 761.8$

\section{Costing Rationale:}

The estimate is comprised of two major portions labor and material. Northrop Grumman's past experience delivering control systems on other complex physics programs was used to extrapolate the labor estimates. Examples of these programs are:

- Continuous Wave Deuterium Demonstrator - CWDD: a cryogenic accelerator where Northrop Grumman was the accelerator prime manufacturer responsible for delivering the entire accelerator system. 
- Ground Test Accelerator - GTA: a ground based high power accelerator program used as a test bed for space based strategic defense initiative concepts where Northrop Grumman was seiected as the accelerator industrial support contractor.

- Relativistic Heavy Ion Collider - RHIC: a collider program where Northrop Grumman was selected as the manufacturer of the long superconducting main dipole magnets.

- Compact Infra Red Free Electron Laser - CIRFEL: a program where Northrop Grumman has developed a compact FEL for industrial and university use.

To understand the material costs, suppliers in the various areas were contacted and subsequently provided rough order of magnitude quotes.

Allowance for Indeteminates: $35 \%$ based on technical rișk 


\section{ENGINEERING VALIDATION PHASE Accelerator}

\section{Total - \$25M ICF}

An Engineering Validation Phase is proposed for 1997-1999. A budget of $\sim 25 \mathrm{M}$ ICF is presently allocated for the IFMIF accelerator system, on the basis of a pro-rated $10 \%$ of the project cost. The accelerator system is the largest cost system, but also the highest technology systern. Based on our assessment of the IFMiF task and knowledge of comparable projects, 25M ICF is quite marginal, but a great deal could be accomplished in these three years with this amount.

\section{Task One - RF System Development and Test - 15M ICF}

Development and testing of a $1 \mathrm{MW}$ tetrode-based RF system is identified as the highest impact development item. Existing tetrode operating experience is with pulses of a few seconds to order a minute of CW operation, at frequencies generally lower (easier) than the IFMIF frequency. No test stand capable of $1 \mathrm{MW}$ CW tests to $100-1000$ hours is available in the world, with the possible exception of Russia. Detailed costs to design, construct, and test the first $\mathbf{R F}$ station are available in the extensive costing information developed for the Tokai meeting, so a reliable estimate of $-15 \mathrm{M}$ ICF for this task is in hand. As the EVP proceeds, efforts would be made to economize on this number, including exploration of existing equiprnent and facilities as well as the possibilities in Russia.

The RF amplifier power level baseline of $1 \mathrm{MW}$ and the defined EVP program have important advantages. The $1 \mathrm{MW}$ power level insures that a competitive bid could be obtained from two manufacturers. Accomplishing a full-scale test of the first system would allow the remaining large procurement to be on a fixed-price basis. The involvement of two manufacturers would help insure a tube supply over the facility lifetime.

\section{Task Two - Injector System Development and Tesk - SMUCF}

The injector system has the second highest impact in terms of reaching the required performance and RAM goals for IFMIF. Two technical approaches (the ECR and volume type ion sources) are to be developed to the full test stage. The primary effort will be located at EC facilities with strong support from Japanese and US teams. A budget of $\sim 5 \mathrm{M}$ ICF is presently assigned to this task. It is anticipated that source test stands can be brought to fully operational level at the end of 1998 within this budget. Operational testing to demonstrate an initial goal of 100-hour lifetime would be conducted in 1999; further budget discussion will probably be required to complete these tests.

Task_Three - Design For Acceptable Beam_Loss Minimal Activation And Machine Maintainabilizy-SM ICF

Minimization of beam loss and activation such that remote bandling will not be necessary, is a critical activity that is both more promising and more difficult than for the FMIT design. More promising because of progress in understanding beam dynamics. More difficult due to more stringent radiation reguirements worldwide. The remaining $\sim 5 \mathrm{M}$ ICF is allotted to this area. The tasks involve detailed design of the baseline and superconducting option for the accelerator beam transport from ion source to target. fundamental investigations to gain understanding of the loss mechanisms, coordination 
with neutronics calculations and shielding design, coordination with engineering aspects of the accelerator design, and so on. The allocation for this area is insufficient to fuily prepare for the construction phase; however much can be accomplished. 
Cost Estimating

Worksheets

for

WBS 5.0

Conventional Facilities 
WBS 5. 1. 0 Conventional Fac:lities Management

\section{A. Summary Cost Estimate:}

\begin{tabular}{|c|c|c|c|c|c|}
\hline \multicolumn{3}{|c|}{ Off-LFMIF Site } & \multicolumn{3}{|c|}{ On-Site At IFMUF } \\
\hline Industry & Instit' & & $\begin{array}{l}\text { Const. } \\
\text { Contractor }\end{array}$ & Instit'al & \\
\hline $\begin{array}{c}\text { Mat"V/ Engin } \\
\text { Lab }\end{array}$ & Engin & Afi Tatal & $\begin{array}{l}\text { Mat'l/f Engin } \\
\text { Lab }\end{array}$ & Engin & AFI Total \\
\hline & & $\overline{2500}$ & 0 & $\overline{0}$ & 0 \\
\hline
\end{tabular}

\section{Currency Units: kilo ICF}

\section{B. Description:}

The govemmental management activities required to directly support and complete the Conventional Facilities are included in this element. The larger task of construction management is covered in the overall project management element, WBS 1.0 with an estimate of $24,000 \mathrm{kICF}$. These include:

- Project Management and Administration: basic institutional management costs such as administration, cost control and scheduling, and documentation to initate and oversee the placement of the $\mathrm{CM}$ coniract.

- Systems Engineering: costs for Systems Engineering after the IFMIF is approved as an official project will be estimated based upon anticipated activities needed to support the initjation of the conventional facitities work:

- Preparation of Specifications

- Preparation of Preliminary Design

- Fabrication Oversight

- Verification Testing Oversight

- Installation Planning and Coordination

- Installation Oversight

- Startup Oversight

- Environmental, Health and Safety Documentation: support for personnel responsible for establishing the EH \& $\$$ procedures to be applied during construction.

- Quality Assurance: support for personne! responsible for establishing and maintaining quality assurance procedures in accordance with the regulations of the country responsible for the Facility. 


\section{Detailed WBS Listing:}

1. 0. 0. 0. 0. Conventional Facilities Management

1. 0. 0. 0. Project Management and Administration

1. 0. 0. Administration

2. 0. 0. Cost Control

3. 0.0 . Schedule

4. 0. 0. Documentation

2. 0. 0. 0. Systems Engineering

1. 0. 0. Design Integration

2. 0. 0. Systems Analysis

3. 0. 0. Requirements/Specs

4. 0. 0. RAM Analysis

3. 0. 0. 0. Environmental, Safety \& Health

Documentation

4. 0. 0. 0. Quality Assurance

\section{Costing Rationale:}

The cost of management is based on a factor of approximately $3 \%$ of the Conventional Facilities TEC.

\section{E. Detailed Costing:}

Not Applicable 
WORKSHEET

WBS 5.2.1.1 Accelerator Hall

A. Summary Cost Estimate:

\begin{tabular}{|c|c|c|c|c|c|}
\hline \multicolumn{3}{|c|}{ Off-lrinlasite } & \multicolumn{3}{|c|}{ On-Site at IFMLF } \\
\hline Industry & Instit'al & & Constr Contr & Instical & \\
\hline Mat'WLab Engin'g & Engin'g & AFI Total & Mat'/Lab Engin'g & Engin'g & AFI Total \\
\hline nc nc & nc & ne ne & $5460 \quad 328$ & & $876 \quad 6719$ \\
\hline
\end{tabular}

\section{Cumency Units: kilos}

\section{B.Description:}

The accelerator hall includes the two accelerator tunnels and routing space for the RF power and other services between the accelerators. Clearance is provided on the other side for horizontal removal of accelerator modules. The hall structure is reinforced concrete. The roof is $2.5 \mathrm{~m}$ thick to shield the RF power bay above. The floor is a $1 \mathrm{~m}$ thick slab to provide stability. The walls are $1 \mathrm{~m}$ thick below grade or $2.5 \mathrm{~m}$ thick above grade. The accelerator horizontal spacing of $11 \mathrm{~m}$ and vertical spacing of $5 \mathrm{~m}$ are based on the beam optics design. The internal dimensions of each tunnel are $7.5 \mathrm{~m}$ wide by $58.53 \mathrm{~m}$ long and $6 \mathrm{~m}$ high. The overall structure external dimessions are approximately $22 \mathrm{~m}$ wide by $15 \mathrm{~m}$ high by $60 \mathrm{~m}$ long. A 2.5 con crane is provided in each tunnel.

\section{Detaited WBS Listing:}

\subsubsection{Accelerator Hall}

\section{Costing Rationale:}

The building quantities were estimated from the conceptual design drawings, and costs scaled using the IFER unit cost codes.

- Type of Estimate: Scaling

- Allowance for Indeterminates: $15 \%$ AFI is applied to account for uncertainty in the building requirements.

\section{E. Demiled Costing:}

A spreadsheet showing the cost calculation by the ITER codes is attached. The IIER JCT has developed labor codes and unit hourly costs and commodity codes to support consistent costing of facilities. Associated with each commodity code is a unit labor code and content, unit material content and cost, and unit support content and cost The cumrent values are maintained on a cost data file and are those used for the ITER May 1995 interim cost estimate. The IFMIF spreadsheet is organized by the commodity code. It combines the associated labor code, unit hourly content of the commodity unit, and unit hourly cost as a unit labor cost based on the commodity units. The support cost is assumed to be equal to the labor cost, consistent with the current ITER estimates. 
5,2.1.1 Accelerator Hall Costing Sheel Based on ITER dala for similar facilities

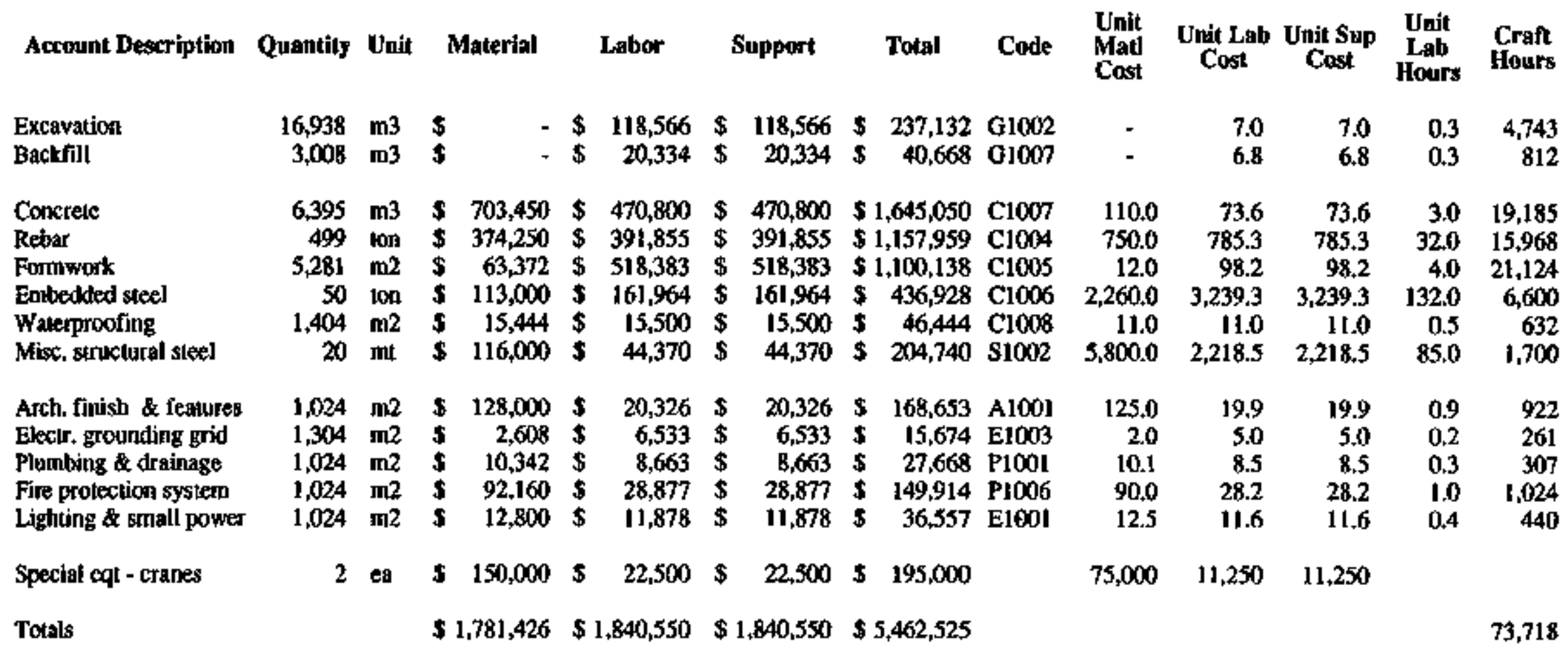




\section{WORKSHEET \\ WBS 5.2.1.2 Beam Turning Building}

\section{A. Summary Cost Estimate:}

\begin{tabular}{|c|c|c|c|c|c|}
\hline \multicolumn{3}{|c|}{ Off-iFMiF Site } & \multicolumn{3}{|c|}{ On-Site at IFMIF } \\
\hline Industry & Instit'al & & Constr Contr & Instit'a & \\
\hline Mat'/Lab Engin' $g$ & Engin's & AFI Total & Mat'ULab Engin'g & Engin' $\mathrm{g}$ & AFI rotel \\
\hline nc & 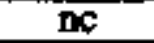 & nc & 7680 & 77 & 12329449 \\
\hline
\end{tabular}

Currency Units: kilof

\section{B. Descrintion:}

The beam tarming buikding internal dimensions are approximately $25 \mathrm{~m}$ wide by 64 $\mathrm{m}$ long and $11 \mathrm{~m}$ high. The building is divided by shielding walls into a steering vault 14.4 $\mathrm{m}$ long, a turning vault $42 \mathrm{~m}$ long, and maintenance area $5 \mathrm{~m}$ long. Clearance and a 10 ton crane are provided to allow replacement of transport elements. Hatches are provided to lift removed components into the hot cell area above. The structure is reinforced concrete, 2.5 $\mathrm{m}$ thick for shielding above grade and $1 \mathrm{~m}$ thick below grade.

\section{DetailedWBS Listing:}

\subsubsection{Beam Turning Building}

\section{Costing Rationale:}

The building quantities were estimated from the concepual design drawings, and costs scaled using the ITER unit cost codes.

- Type of Estimate: Scaling

- Allowance for Indeterminates: $15 \%$ AFI is applied to account for uncertainty in the building requirements.

\section{E. Desailed Costing:}

A spreadsheet showing the cost calculation by the ITER codes is attached. 
5.2.1.2 IEMUE Begm Turning Buildius

Eactors Based on TTER Data for Similar Construction

\begin{tabular}{|c|c|c|c|c|c|c|c|c|c|c|c|c|}
\hline Account Description & Qaant. & Unit & Malerial & Labor & Support & Tolal & Code & $\begin{array}{l}\text { Unit } \\
\text { Matl } \\
\text { Cost }\end{array}$ & $\begin{array}{c}\text { Unit Lab } \\
\text { Cost }\end{array}$ & $\begin{array}{l}\text { Unit Sup } \\
\text { Cost }\end{array}$ & $\begin{array}{c}\text { Unil } \\
\text { Lab } \\
\text { Hours }\end{array}$ & $\begin{array}{l}\text { Craft } \\
\text { Hours }\end{array}$ \\
\hline $\begin{array}{l}\text { Excayation } \\
\text { Backfill }\end{array}$ & $\begin{array}{r}32,339 \\
7,084\end{array}$ & $\begin{array}{l}\mathrm{m} 3 \\
\mathrm{~m} 3\end{array}$ & $\begin{array}{l}- \\
-\end{array}$ & $\begin{array}{r}226,373 \\
47,888\end{array}$ & $\begin{array}{r}226,373 \\
47,888\end{array}$ & $\begin{array}{r}452,746 \\
95,776\end{array}$ & $\begin{array}{l}G 1002 \\
G 1007\end{array}$ & - & $\begin{array}{l}7.0 \\
6.8\end{array}$ & $\begin{array}{l}7.0 \\
6.8\end{array}$ & $\begin{array}{l}0.3 \\
0.3\end{array}$ & $\begin{array}{l}9,055 \\
1,913\end{array}$ \\
\hline $\begin{array}{l}\text { Concrete } \\
\text { Rebar } \\
\text { Formwork } \\
\text { Embedded sleel } \\
\text { Waterproofing } \\
\text { Misc. structural steel }\end{array}$ & $\begin{array}{r}8,497 \\
663 \\
7,460 \\
85 \\
2,000 \\
30\end{array}$ & $\begin{array}{l}\mathrm{m} 3 \\
\mathrm{tod} \\
\mathrm{m} 2 \\
\text { ton } \\
\mathrm{m} 2 \\
\mathrm{mt}\end{array}$ & $\begin{array}{r}934,670 \\
497,250 \\
89,520 \\
192,100 \\
22,000 \\
174,000\end{array}$ & $\begin{array}{r}625,549 \\
520,641 \\
732,274 \\
275,339 \\
22,080 \\
66,555\end{array}$ & $\begin{array}{r}625,549 \\
520,641 \\
732,274 \\
275,339 \\
22,080 \\
66,555\end{array}$ & $\begin{array}{r}2,185,768 \\
1,538,531 \\
1,534,067 \\
742,778 \\
66,160 \\
307,110\end{array}$ & $\begin{array}{l}\text { C10Ot } \\
\text { C1004 } \\
\text { C1005 } \\
\text { C1006 } \\
\text { C100B } \\
\$ 1002\end{array}$ & $\begin{array}{r}110.0 \\
750.0 \\
12,0 \\
2,260.0 \\
11,0 \\
5,800.0\end{array}$ & $\begin{array}{r}73.6 \\
785.3 \\
98.2 \\
3,239.3 \\
11.0 \\
2,218.5\end{array}$ & $\begin{array}{r}73.6 \\
785.3 \\
98.2 \\
3,239.3 \\
11.0 \\
2,218.5\end{array}$ & $\begin{array}{r}3.0 \\
32.0 \\
4.0 \\
132.0 \\
0.5 \\
85.0\end{array}$ & $\begin{array}{r}25,491 \\
21,216 \\
29,840 \\
11,220 \\
900 \\
2,550\end{array}$ \\
\hline $\begin{array}{l}\text { Arch, finish \& features } \\
\text { Electr. grounding grid } \\
\text { Plumbing \& drainage } \\
\text { Fire prolection system } \\
\text { Lighting \& snall power }\end{array}$ & $\begin{array}{l}1,529 \\
1,745 \\
1,529 \\
1,529 \\
1,529\end{array}$ & $\begin{array}{l}m 2 \\
m 2 \\
m 2 \\
m 2 \\
m 2\end{array}$ & $\begin{array}{r}191,125 \\
3,490 \\
15,443 \\
137,610 \\
19,113\end{array}$ & $\begin{array}{r}30,351 \\
8,742 \\
12,935 \\
43,118 \\
17,736\end{array}$ & $\begin{array}{r}30,351 \\
8,742 \\
12,935 \\
43,118 \\
17,736\end{array}$ & $\begin{array}{r}251,826 \\
20,975 \\
41,314 \\
223,846 \\
54,585\end{array}$ & $\begin{array}{l}\text { A1001 } \\
\text { E1003 } \\
\text { P1001 } \\
\text { P1006 } \\
\text { E1001 }\end{array}$ & $\begin{array}{r}125.0 \\
2.0 \\
10.1 \\
90.0 \\
12.5\end{array}$ & $\begin{array}{r}19.9 \\
5.0 \\
8.5 \\
28.2 \\
11.6\end{array}$ & $\begin{array}{r}19.9 \\
5.0 \\
8.5 \\
28.2 \\
11.6\end{array}$ & $\begin{array}{l}0.9 \\
0.2 \\
0.3 \\
1.0 \\
0.4\end{array}$ & $\begin{array}{r}1,376 \\
349 \\
459 \\
1,529 \\
657\end{array}$ \\
\hline Tolal & & & $2,376,320$ & $2,650,581$ & $2,650,581$ & $7,677,482$ & & & & & & 106,555 \\
\hline
\end{tabular}


WORKSHEET

WBS 5.2.1.3 RF Power Bay

A. Surmonary Cost Estimate:

\begin{tabular}{|c|c|c|c|c|c|}
\hline \multicolumn{3}{|c|}{ Off-IFMIF Site } & \multicolumn{3}{|c|}{ On-Site at IFMIF } \\
\hline Indusiry & Institi'al & & Constr Contr & Instital & \\
\hline Mar'Wab Engin'g & Engin'g & AFr rotal & Mat' $/$ Lab Engin's & Engin's & \\
\hline$n c \quad n c$ & $\mathrm{nC}$ & $\mathbf{A C}$ & $4858 \quad 291$ & & 772 \\
\hline
\end{tabular}

Currency Units: kilos

B. Description:

The RF power supplies for the two accelerators are located above the accelerator hall in a steel framed structure with insulated metal siding and roof. The building is approximately $44 \mathrm{~m}$ wide by $51 \mathrm{~m}$ long by $12 \mathrm{~m}$ high. A partial basement, $18 \mathrm{~m}$ wide by $49 \mathrm{~m}$ long by 4 m high, is provided for support systems. A 25 ton crane is provided.

\section{Detailed WBS Listing:}

\subsubsection{RF Power Bay}

\section{Costing Rationale:}

The building size was estimated from the conceptual design, and costs scaled with volume from similar ITER buildings.

- Type of Estimate: Scaling

- Allowance for Indeterminates: $15 \%$ AFI is applied to account for uncertainty in the building requirements.

\section{E. Detailed Costing:}

A task to perform the stmactural design and costing of the ITER conventional steel-framed boildings was recently completed. The average building cost was $\$ 160 / \mathrm{m} 3$ with a range of $\$ 125 / \mathrm{m} 3$ to $\$ 200 / \mathrm{m} 3$. The average cost was used for the RF power bay. 
WORKSHEET

WBS 5.2.1.4 Accelerator Assembly/Maintenance Bay

A. Summary Cost Estimate:

\begin{tabular}{|c|c|c|c|c|c|}
\hline \multicolumn{3}{|c|}{ Off-IFMLIF Site } & \multicolumn{3}{|c|}{ On-Site at FMIF } \\
\hline Intustry & Instit'al & & Constr Contr & Instiv'al & \\
\hline Mat'VLab Engin's & Engur's & AFI Total & Mat'VLab Engin'g & Enging & AFI Total \\
\hline $\mathrm{HC} \quad \mathrm{nC}$ & $\mathbf{I C}$ & nc nc & $2961 \quad 178$ & 0 & 4703609 \\
\hline
\end{tabular}

Cumency Units: kilos

\section{B. Description:}

The accelerator assentibly and maintenance bay is a steel-framed structure located at the injector end of the accelerator hall. It is approximately $43 \mathrm{~m}$ wide by $23 \mathrm{~m}$ long by 12 $m$ high, and includes a basement for access to the tunnels.

\section{Detailed WBS Listing:}

\subsubsection{Accelerator Assembly/Maintenance Bay}

\section{Costing Rationale:} buildings.

The building sizes were estimated and costs scaled with volume from similar IIER

- Type of Estimate: Scaling

- Allowance for Indeteminates: $15 \%$ AFI is applied to account for uncertainty in the building requirements.

\section{E. Detailext Costing:}

A task to perform the structural design and costing of the ITER conventional steclframed buildings was recently completed. The average building cost was $\$ 160 \% \mathrm{~m} 3$ with a range of $\$ 125 / \mathrm{m} 3$ to $\$ 200 / \mathrm{m} 3$. The average cost was used for the accelerator mainterance bay. 
WORKSHEET

WBS 5.2.2 Target Complex

\section{A. Summary Cost Estimate:}

\begin{tabular}{|c|c|c|c|c|c|c|c|c|}
\hline \multicolumn{5}{|c|}{ OtififMif site } & \multicolumn{4}{|c|}{ On-Site Af IFUAF } \\
\hline $\begin{array}{l}\text { Indusiry } \\
\text { Mat'i/Lab }\end{array}$ & Engin'g & $\begin{array}{l}\text { instit'al } \\
\text { Enging }\end{array}$ & $A F I$ & Total & $\begin{array}{c}\text { Const. Contractor } \\
\text { Mat' } / / L a b\end{array}$ & Engin'tg & $A F$ & Total \\
\hline & & & & & 5210,0 & 579,0 & 1157,9 & 6946,9 \\
\hline
\end{tabular}

Units: kECU

\section{B. Description:}

The Target Complex consists of 8 cells designed to host the Lithium loop. the Chemistry Purification Loop, the Impurity Monitoring Loop, the Li-transfer System and all loop components. The cells are located below the Test Cell. The floors and the walls, up to an height of 2 metres, are lined with a stainless steet plate $1 \mathrm{~cm}$ thick. The overall structure external dimensions are approximately $29 \mathrm{~m}$ wide by $30 \mathrm{~m}$ high by $27.5 \mathrm{ml}$ long.

\section{Detailed WBS Listing:}

0. $\quad 0$. Target Complex

1. 0 . Lithium Processing Cells

1. Liners

\section{Costing Rationale:}

The Complex size has been estimated and the cost scaled with volume from the total cost of IFMIF Main Building. This last has been estimated by a bottom-up procedure based on prices quoted in the manuals "Prezzi informativi delle OPERE EDILI in Milano" August 1995 and "Prezzi informativi dell'Edilizia (ediz. 1994)" published by DEI-Tipografia of Genio Civile, updated according to the official inflation rate. The reinforced concrete costs have been worked out using the ENEA PEC Nuclear Installation constuction experience.

Two main sections, on the cost estimate point of view, were singled out; the former is the so called Bunker, that is the part of the building realised mainly below the ground level, and consisting mainly of shielded areas and cells, the latter is the so called Industrial Building including the above ground level construction plus the Radwaste Treatment and Shipping bays (located below ground level).

Type of Estimate: Mixed Bottorn-up + Factoring

Allowance for Indeterminates: $20 \%$ based mainly on the uncertainties on design specifications

E Detailed Costing:

Target Complex Lithiurr Processing Cells Liners

\begin{tabular}{rrrr} 
Mat'/Lab & \multicolumn{1}{c}{ Engin'g } & \multicolumn{1}{c}{$A F /$} & \multicolumn{1}{c}{ Total } \\
\hline 5210,0 & 579,0 & 1157,9 & 6946,9 \\
4630,5 & 521,0 & 1042,0 & 6193,5 \\
579,5 & 58,0 & 115,9 & 753,4
\end{tabular}


WORKSHEET

WBS 5.2.3.0 Test and Examination Complex

\section{A. Summary Cost Estimate:}

\begin{tabular}{|c|c|c|c|c|c|c|c|c|}
\hline \multicolumn{5}{|c|}{ otf-lFMIF site } & \multicolumn{4}{|c|}{ On:Sile At IFMfF } \\
\hline $\begin{array}{l}\text { Industry } \\
\text { Mat'l/Lab }\end{array}$ & Engin't & $\begin{array}{l}\text { instit'al } \\
\text { Engin's }\end{array}$ & AF & Total & $\begin{array}{c}\text { Const. Contractor } \\
\text { Mat'l/Lab }\end{array}$ & Engin'g & $A F \mid$ & Total \\
\hline & & & & & 2946,9 & 294,7 & 589,4 & 3830,9 \\
\hline
\end{tabular}

Units: kECU

\section{B. Description:}

The Test and Examination Complex consists of a ntmber of Cells, Hot Cells and Operative Areas, designed to host the Test Module during irradiation and to transport safely the material samples to the Post Irradiation Examination Laboratory.

\section{Detailed WBS Listing:}

0. 0 . Test and Examination Complex

1. 0 . Test Ceils

2. 0. Bean Calibration Station Cell

3. $0 . \quad$ Test Cell Technology Rooms

4. 0. Access Cell

4. 1. Shielding Doors

5. $0 . \quad$ Service Cell

5. 1. Shielding Doors

6. 0 . Test Module Handling Cell

6. 1. Shielding Door

7. 0 . Control Room

8. 0. Data Acquisition Room

9. 0 . PIE Laboratory Area

10. 0 . Tritium Laboratory Area

11. 0. Hot Cell Utilitiy Area -

12. 0. Corridors

\section{Costing Rationale:}

The Complex size has been estimated and the cost scaled with volume from the total cost of IFMIF Main Building. This last has been estimated by a bottom-up proceduse based on prices quoted in the manual "Prezzi informativi delle OPERE EDILI in Milano" August 1995 and "Prezzi informativi dellEdilizia (ediz. 1994)" published by DEI-Tipografia of Genio Civile, updated according to the official inflation rate. The reinforced concrete costs have been worked out using the ENEA PEC Nuclear Installation construction experience.

Two main sections, on the cost estimate point of vjew, were singled out the former is the so called Bunker, that is the part of the building realised mainly below the ground level, and consisting mainly of shielded areas and cells, the latter is the so called Industrial Building including the above ground level construction plus the Radwaste Treatment and Shipping bays (located below ground level).

Type of Estimate: Mixed Bottom-up + Factoring Allowance for Indeterminates: $20 \%$ based mainly on the uncertainties on design specifications 
E. Detailed Costing:

Test and Examination Complex Test Cells

Bean Calibration Station Cell Test Cel Technology Rooms Accoss Cell

Shielding Doors

VTA \& Target Service Cell

Shielding Doors

Mockde Handing Ceth

Shielding Door

Control Room

Data Acquisition Room

PIE Laboratory Area

Tritium PIE Laboratory Area

Hot Cell Utility Cell

Corridors

Cell tiners

\begin{tabular}{rrrr} 
Ma!"l/Lab Enging & \multicolumn{1}{c}{ AFI } & \multicolumn{1}{c}{ Totel } \\
\hline $\mathbf{2 9 4 6 , 9}$ & $\mathbf{2 9 4 , 7}$ & $\mathbf{5 8 9 , 4}$ & $\mathbf{3 6 3 0 , 9}$ \\
44,1 & 4,4 & 8,8 & $\mathbf{5 7 , 3}$ \\
22,0 & 2,2 & 4,4 & 28,6 \\
117,5 & 11,8 & 23,5 & 152,8 \\
626,7 & 62,7 & 125,3 & 814,7 \\
52,7 & 5,3 & 10,5 & 68,5 \\
325,2 & 32,5 & 65,0 & 422,8 \\
52,7 & 5,3 & 10,5 & 68,5 \\
156,1 & 15,6 & 31,2 & 202,9 \\
31,1 & 3,1 & 6,2 & 40,4 \\
34,7 & 3,5 & 6,9 & 45,1 \\
37,8 & 3,8 & 7,6 & 49,2 \\
170,3 & 17,0 & 34,1 & 221,4 \\
252,4 & 25,2 & 50,5 & 328,1 \\
422,7 & 42,3 & 84,5 & 549,5 \\
135,1 & 13,5 & 27,0 & 175,7 \\
465,6 & 46,6 & 93,1 & 605,3
\end{tabular}


WORKSHEET

WBS 5.2.4 Building High Bay

A. Summary Cost Estimate:

\begin{tabular}{|c|c|c|c|c|c|c|c|c|}
\hline \multicolumn{5}{|c|}{ Off-IFMIF Site } & \multicolumn{4}{|c|}{ On-Site At IFMIF } \\
\hline $\begin{array}{l}\text { Industiry } \\
\text { Mat'i/Lab }\end{array}$ & Engin's & $\begin{array}{l}\text { Instil'al } \\
\text { Engin'g }\end{array}$ & AfJ & Total & $\begin{array}{c}\text { Corst. Contractor } \\
\text { Mat'illabb }\end{array}$ & Enoin'g & $A F \mid$ & Total \\
\hline & & & & & 3047,6 & 304,8 & 609,5 & 3961,9 \\
\hline
\end{tabular}

Units: $\mathrm{kECU}$

B. Description:

The Building High Bay consists of a series of halls designed to host plant general facilities. It is characterised by a Bridge Crane nuning in a High Bay and serving almost all the halls including the Test Complex and Examination Complex.

\section{Detailed WBS Listing:}

0. $\quad$. Building High Bay

1. $0 . \quad$ High Bay

1. 1. Bridge Crane (30 t capacity load)

2. 0. Hot Shop

3. 0. Uncontaminated Shop

4. $\quad 0$. Manipulator Repair Room

5. $0 . \quad$ Shipping Bay

6. 0. Rad Waste Processing Bay

7. 0. Rad Waste Shipping Bay

8. 0. Health Physics Station

9. 0. Corridors

\section{Costing Rationale:}

The Complex size has been estimated and the cost scaled with volume from the total cost of IFMIF Main Building. This last has been estimated by a bottom-up procedure based on prices quoted in the manual "Prezzi informativi delle OPERE EDLI in Milano" August 1995 and "Prezzi informativi dell'Edilizia (ediz. 1994)" published by DEI-Tipografia of Geaio Civile, updated according to the official inflation rate. The reinforced concrete costs have been worked out using the ENEA PEC Nuclear Installation construction experience.

Two main sections, on the cost estimate point of view, were singled out; the former is the so called Bunker, that is the part of the building realised mainly below the ground level, and consisting mainly of shielded areas and cells, the latter is the so called Industrial Building including the above ground level construction plus the Radwaste Treatment and Shipping bays (located below ground level).

Type of Estimate: Mixed Bottom-up + Factoring Allowance for Irdeterminates: $20 \%$ based mainly on the uncertainties on design specifications 


\section{E. Detailed Costing:}

Building High Bay

High Bay

Bridge Crane

Hot Shop

Uncontaminated Shop

Manipulator Repair

Shipping Bay

Rad Waste Processing

Fad Waste Shipping

Health Phisycs Station

Corridors \begin{tabular}{cccc} 
Mat'/Lab Engin's & AF & Totol \\
\hline $3047,6304,8$ & 609,5 & 3961,9
\end{tabular}

$1670,6 \quad 167,1 \quad 334,1$

$364,4 \quad 36,4 \quad 72,9$

2171,7

473.7

$66,7 \quad 6,7 \quad 13,3$

86,7

$48,8 \quad 4,9 \quad 9,8$

63,4

$27,6 \quad 2,8 \quad 5,5$

35,9

$292,6 \quad 29,3 \quad 58,5$

380,4

$215,0 \quad 21,5 \quad 43,0$

279,5

$178,1 \quad 17,8$

35,6

231,5

48,8

4,9

9,8

63,4

$135,1 \quad 13,5 \quad 27,0$

175,7 
WORKSHEET

\section{WBS 5.2.5.0 Support Facility Buildings}

\section{A. Summary Cost Estimate;}

\begin{tabular}{|c|c|c|c|c|c|}
\hline \multicolumn{3}{|c|}{ Off-IFMUF Site } & \multicolumn{3}{|c|}{ On-Site at IFIMIF } \\
\hline Industry & Instat'al & & Constr Contr & Thstat'al & \\
\hline Mat'/Lab Engin's & Engin's & AFI Total & Mat'W/Lb Engin's & Engin's $\mathrm{g}$ & AFI Toal \\
\hline $\mathrm{nc} \quad \mathrm{nc}$ & $\mathrm{HC}$ & nc $n c$ & $1038 \quad 42$ & & $\begin{array}{ll}165 & 1263 \\
\end{array}$ \\
\hline
\end{tabular}

\section{Currency Units: kilos}

\section{B. Description:}

An office area of $4000 \mathrm{~m} 3$ is provided for local administrative services at the IFMIF facility which is located within an existing nuclear research site. It provides space for 80 people, meeting rooms, and a reception area for controtled access to the main building. A local shop area of $2700 \mathrm{~m} 3$ is also provided for conventional plant services, parts storage and ordinary repair and calibration. The process maintenance shops and activities are located in the main building areas they serve. The host site is assumed to provide visitor control, shipping and receiving control, and conventional infrastructure services.

\section{Detailed WBS Listing:}

\section{2 .5 \\ 5.2 .5 .1 \\ 5.2 .5 .2
Support Facility Buildings
Plant Service Halls
Office Complex

\section{Costing Rationale:}

The building sizes were estimated and costs scaled with volume from similar ITER buildings.

- Type of Estimate: Scaling

- Allowance for Indeterminates: $15 \%$ AFI is applied to account for uncertainty in the building requirements.

\section{E. Detailed Costing:}

A task to perform the structural design and costing of the ITER conventional steel-framed buildings was recently completed. The average building cost was $160 \$ / m 3$ with a range of I25 to $200 \$ / \mathrm{m} 3$. The office building, with its special furnishings is assumed to be 180 $\$ / \mathrm{m} 3$, while the simple shop area is taken as $125 \$ / \mathrm{m} 3$. 
WBS 5.3.1.0

\section{WORKSHEET \\ WBS 5.3.1.0 Heating, Ventilation and Air Conditioning (HVAC)}

A. Summary Cost Estimate:

\begin{tabular}{|c|c|c|c|c|c|c|c|c|}
\hline \multicolumn{5}{|c|}{ Off IFMIF Site } & \multicolumn{4}{|c|}{ On-Site At IFMIF } \\
\hline $\begin{array}{l}\text { Industry } \\
\text { Mat'lLab }\end{array}$ & Engin'g & $\begin{array}{l}\text { Instit'al } \\
\text { Engin'g }\end{array}$ & $A F I$ & Total & $\begin{array}{l}\text { Const. } \\
\text { Contractor } \\
\text { Mar } V / L a b\end{array}$ & Engin'g & $A F I$ & Total \\
\hline 7.207 & 1.153 & & $1.25_{4}$ & $9.6 \overline{15}$ & 7.207 & 0.288 & 1.124 & 8.620 \\
\hline
\end{tabular}

Units: M\$

\section{B. Description:}

The Heating and Ventilation Air Conditioning system provides sufficient air throughput to ensure acceptable air quality for continuous access of the operating staff. Air is drawn from the external, filtered, conditioned and distributed to the IFMIF plant operating areas.

HVAC includes an Industrial HVAC and a Nuclear HVAC plus the Active Ventilation System. The Industrial HVAC simply provides air conditioning and distribution to areas where the risk of radiological contamination is excluded. The Nuclear HVAC serves potentially contaminated rooms, as the maintenance bay, the lithium cells, the accelerator hall, the RF power bay and the beam turning areas. These rooms are contínuously monitored for gamma and/or tritium and are kept at a lower pressure than the external, to prevent uncontrolled releases of radioactivity. Air effluents from Nuclear HVAC ane filtered by means of prefilters and HEPA filters and discharged through a stack of adequate characteristics. Effluents are monitored for radioactivity.

Part of the area supplied from the Nuclear HVAC is subtracted from the operating areas and used for the ventilation of some secondary containment enclosures (Service Cell, Access Cell, Test Module Handling Celf). Effluents from these enclosures are collected by a dedicated piping system, (active ventilation) provided of independent exhaust blowers and HEPA filters. The pressure at the pipe headers is negative in the range of $1-2 \mathrm{kPa}$.

\section{Detailed WBS Listing}

1. 0. Heating, Ventilation and Air Conditioning (HVAC)

1. 1. Nuclear HVAC

1. 2. Industrial HVAC

1. 3. Active Ventilation

D. Costing Rationaie:

The cost of the Industrial HVAC was obtained by an analogous estimate done for the Italian TERA Project (a facility for the Oncological Hadronoterapy) scaling up the cost according to the share with respect to the building cost. A value of 48 US $\$ / \mathrm{m}^{3}$ was considered.

The cost for the Nuclear HVAC was worked out using as a reference the unitary cost reported in "ITER Outline Design Cost Estimate" Doc. ITER TAC-4-14, January 1994. A value of 211 US $\$ / m^{3}$ was considered. Costs of the Active Ventilation System (including the exhaust ducts, air filtering and expulsion) were evaluated, on the basis of a cost breakdown, about $0.6 \mathrm{M} \$$ for a $91000 \mathrm{~m}^{3} / \mathrm{h}$ system. These were added to the Industrial and Nuclear HVAC costs.

An equal share between on-site (50\%) and off-site (50\%) for the Material and Labor Cost was assumed, while the share for Engineering Costs was assumed $80 \%$ off-site and $20 \%$ on-site. 
WBS 5.3.1.0

Type of Estimate: Factoring

Allowance for Indeterminates: $15 \%$ based mainly on the uncertainties on design specifications.

\section{E. Detailed Costing:}

1. 0 Heating, Ventilation and Air \begin{tabular}{cclc} 
Mat'Lab & Engin'g & AFI & Total \\
\hline 14.415 & 1.441 & $\mathbf{2 . 3 7 8}$ & $\mathbf{1 8 . 2 3 5}$
\end{tabular}

1. 1. Industrial HVAC

$\begin{array}{llll}4.581 & 0.458 & 0.756 & 5.794\end{array}$

1. 2. Nuclear HVAC

9.354

0.935

1,543

11.832

1. 3. Active Ventilation

0.481

0.048

0.079

0.608 
WORKSHEET

WBS 5.3.2.0 Power System

A. Summary Cost Estimate with 380KY GRID

\begin{tabular}{|c|c|c|c|c|c|}
\hline \multicolumn{3}{|c|}{ Off-IFMIIF Site } & \multicolumn{3}{|c|}{ On-Site At IFMIF } \\
\hline Industry & Instit' & & Const. Contrac & ofnstit & \\
\hline Mat'Lab Eagit & 'g Engin: & Toral & Mat1/Lab Engin & g Engir & $\overline{\mathrm{AFI}}$ \\
\hline 1300 & 28 & $\begin{array}{ll}26 \overline{6} & 1594\end{array}$ & 310 & 29 & 404 \\
\hline
\end{tabular}

Units: kilo ECU.

\section{B. Descrintion:}

The Power System serves to receive electrical power from the $60 \mathrm{MW}$ which includes $9 \mathrm{MW}$ for possible power increase. In order to carry out this mission it consists of the components listed in the following poin $C$ and in the annex

The present valutations are based on the following assumptions:

-The level of the grid voltage is $380 \mathrm{KV} 50 \mathrm{~Hz}$ with a short circuit power of 10GVA and with no feedthrough line. The advantages of this solution are: the problems of reactive power compensation and filtering of the gentrated harmonics are very small, high reliability of the grid,power availability for futtre plant's increases.

- Excluded reactive power compensation and the filtering of the generated harmonics, as included in the terrode HV supply unit.

- The power sizes of the generating set and UPS are arbitrary.

- Voltage levels according to the European Standard ( $380 \mathrm{KV}$ or $132 \mathrm{KV}$ - 20KV-380V).

- Not included autotransformers to adapt the imput voltage of the RF feeders

- Not included civil works.

\section{Detailed WBS Listing:}

5. 3. 2. 0. 0. Power System

1. 0. Substation

1. Main transformer with general breaker and switches

2. Circuit breakers ( $20 \mathrm{KV}$ ), auxiliary power transformer

3. Generating set and UPS

\section{Costing Rationale:}

The costs were drawn by scaling from the projects ITER and IGNITOR, these datas are given by primary European firms. specifications

Allowance for Indeterminates: $20 \%$ based mainly on the uncertainties on design

\section{E. Detailed Costing:}

A detailed list of the equipments used to develop summary costs and a genera! scheme of the power substation are attached 


\section{WORKSHEET \\ WBS 5.3.3.0 Heat Rejection System}

A_Summary Cost Estimate:

\begin{tabular}{|c|c|c|c|c|c|c|c|c|}
\hline \multicolumn{5}{|c|}{ Off-TMIF Site } & \multicolumn{4}{|c|}{ On-Site At IFMIF } \\
\hline $\begin{array}{l}\text { Industry } \\
\text { Mat'Lab }\end{array}$ & Engin's & $\begin{array}{l}\text { Instit'al } \\
\text { Engin'g }\end{array}$ & $A F I$ & Total & $\begin{array}{c}\text { Const. Contractor } \\
\text { Mat } t / L a b\end{array}$ & Engin'g & $A F I$ & Total \\
\hline & & & & & 3104,3 & 310,4 & 620,9 & $\overline{4035,6}$ \\
\hline
\end{tabular}

Units: kECU

\section{B. Description:}

The Heat Rejection System is required to reject process heat. A circulating water system with cooling towers will serve all of the water-cooled equipment where risk of contamination cannot be excluded like accelerator and beam transport elements. Approximately $14000 \mathrm{l} / \mathrm{min}$ of deionized water for each accelerator and $3000 \mathrm{~V}$ min for the beam transport elements are envisaged. The total required heat rejection capacity through water circulation is approximately $10 \mathrm{MW}$. The heat rejection system $(10 \mathrm{MW})$ for the target is accounted for in cost estimate of the Target Complex. Another $20 \mathrm{MW}$ of heat power are rejected through the plant ventilation system (it is not accounted for).

\section{Detailed WBS Listing:}

0. $\quad 0$. Heat Rejection System

\section{Costing Rationale:}

The cost of the Heat Rejection System has been worked out using as a reference the cost reported by an analogous estimate done for the Italian TERA Project (a facility for the Oncological Hadronoterapy). The heat rejected in the TERA by the demineralised water cooling is $0.6 \mathrm{MW}$, so the cost has been scaled up using a correlation with the cost proportional to the power removed with exponent 0.60 . The cost estimate has been also checked against one worked out applying the same correlation in scaling down the cost estimation done for the ITER Project heat rejection system, (reference "ITER Outline Design Cost Estimate" Doc. ITER TAC-4-14, January 1994).

Type of Estimate: Factoring

Allowance for Indeterminates: $20 \%$ based mainly on the uncertainties on design specifications

\section{E. Detailed Costing: na}




\section{WORKSHEET \\ WBS 5.3.3.0 Heat Rejection System}

A. Summary Cost.Estimate:

\begin{tabular}{|c|c|c|c|c|c|c|c|c|}
\hline \multicolumn{5}{|c|}{ Off-IFMIF Site } & \multicolumn{4}{|c|}{ On-Site At IFMIF } \\
\hline $\begin{array}{l}\text { Industry } \\
\text { Mat'/Lab }\end{array}$ & Engin'g & $\begin{array}{l}\text { Instit'al } \\
\text { Engin'g }\end{array}$ & $A F I$ & Total & $\begin{array}{c}\text { Const. Contractor } \\
\text { Mot'llab }\end{array}$ & Engin's & $A F I$ & Total \\
\hline & & & & & 3104,3 & 310,4 & 620,9 & 4035,6 \\
\hline
\end{tabular}

Units: kECU

\section{B. Description:}

The Heat Rejection System is required to reject process heat. A circulating water system with cooling towers will serve all of the water-cooled equipment where risk of contamination cannot be excluded like accelierator and beam transport elements. Approximately 14000 l/min of deionized water for each accelerator and $3000 \mathrm{l} / \mathrm{min}$ for the beam transport elements are envisaged. The total required heat rejection capacity through water circulation is approxinately $10 \mathrm{MW}$. The heat rejection system ( $10 \mathrm{MW}$ ) for the target is accounted for in cost estimate of the Target Complex. Another $20 \mathrm{MW}$ of heat power are rejected through the plant ventilation system (it is not accounted for).

\section{Detailed WBS Listing:}

0. $\quad$ o. Heat Rejection System

\section{Costing Rationale:}

The cost of the Heat Rejection System bas been worked out using as a reference the cost reported by an analogous estimate done for the Italian TERA Project (a facility for the Oncological Hadronoterapy). The heat rejected in the TERA by the demineralised water cooling is $0.6 \mathrm{MW}$, so the cost has been scaled up using a correlation with the cost proportional to the power removed with exponent 0.60 . The cost estimate has been also checked against one worked out applying the same correlation in scaling down the cost estination done for the ITER Project heat rejection system, (reference "ITER Outline Design Cost Estimate" Doc. ITER TAC-4-14, January 1994).

Type of Estimate: Factoring

Allowance for Indeterminates: $20 \%$ based mainly on the uncertainties on design specifications

\section{E. Detailed Costing: na}


WORKSHEET

WBS 5.3.4.0 Service Water System

A. Summary Cost Estimate:

\begin{tabular}{|c|c|c|c|c|c|}
\hline \multicolumn{3}{|c|}{ Off-IFMLrite } & \multicolumn{3}{|c|}{ On-Site at lFMifiF } \\
\hline Industry & Instit'al & & Constr Contr & Instit'al & \\
\hline Mat'VLab Engin'g & Engin'g & AFI Total & Mat'Vlab Engin'g & Engin' & AFl Total \\
\hline nc $\quad$ nC & nc & nc nc & $500 \quad 25$ & 0 & $79 \quad 604$ \\
\hline
\end{tabular}

Currency Units: kijos

B. Description:

The plant service water system provides piping for potable water, fire water, and sanitary sewage between the IFMIF bujldings and the site services.

C. Detailed WBS Listing:

5.3.4.0 Service Water Systems

D. Costing Rationale:

The system costs are scaled from estimates for similar facilities.

- Type of Estimate: Scaling

- Allowance for Indeterminates: $15 \%$ AFI is applied to account for uncertainty in the system requirements.

E. Detailed Costing:

Service water system costs are scaled based on estimated length of pipe and ITER unit costs per length. 
WORKSHEET

WBS 5.3.5.0 Radioactive Waste Treatment Systems

A. Summary Cost Estimate:

\begin{tabular}{|c|c|c|c|c|c|c|}
\hline \multicolumn{4}{|c|}{ Off-IFMIF Site } & \multicolumn{3}{|c|}{ On-Site At IFMIF } \\
\hline Industry & Instit' & & & \begin{tabular}{|l|} 
Const. \\
Contractor
\end{tabular} & Instit'al & \\
\hline $\begin{array}{l}\text { Mat'l/ Engin } \\
\text { Lab }\end{array}$ & Engin & AFI & Total & $\begin{array}{l}\text { Mat'l/ Engin } \\
\text { Lab }\end{array}$ & Engin & Total \\
\hline $2859 \quad 2114$ & 787 & 2468 & 8228 & 2493 & 2493 & 2138 \\
\hline
\end{tabular}

Currency_Units: kiloICF

B. Description:

The Waste Treatment Systems will manage the gaseous, liquid and solid wastes generated from IFMIF components. They consist of Exhaust Gas Detritiation System, Temporary Exhaust Detritiation System, Liquid Waste Treatment System and Solid Waste Treatment System. Exhaust gas that contains tritium is cleaned in the processing systems described here and sent to the Nuclear HVAC for disposal from stack. Solid and Liquid wastes are processed and packaged for shipment to the final processing / disposal facility of the hosting site.

\section{Detailed WDS Listing}

5.3.5.1 Exhaust Gas Detritiation System

5.3.5.2 Temporary Exhatust Gas Detritiation System

5.3.5.3 Liquid Waste Treatment System

5.3.5.4 Solid Waste Treatment System

\section{Costing Rationale:}

Most of the cost estimated are obtained by scaling and factoring from the experience of the existing facilities that handles irradiaked and/or contaminated materials. Equipments to be installed in the system are assumed to be purchased from the industry including design, assembiy and testing. Industry and institutional engineering costs are estimated for the total of the each subsystems. AFIs are estimated to be $30 \%$, because of the uncertainty of the detailed requirements and source terms, while major part of the system can be assembled with existing technology. Personnel costs are estimated as follows:

Industry: $10 \%$ manager, $50 \%$ experts and $40 \%$ labor, averaged to be $19 \mathrm{Myen} / \mathrm{year}$. Institutional : $15 \mathrm{M}$ yen/year. 
WBS 5.3.5.1 Exhaust Detritiation System

\section{A. Summary Cost Estimate:}

\begin{tabular}{|c|c|c|c|c|c|c|}
\hline \multicolumn{4}{|c|}{ Off-IFMIF Site } & \multicolumn{3}{|c|}{ On-Site At IFMIF } \\
\hline Industry & Instit' & & & $\begin{array}{l}\text { Const. } \\
\text { Contractor }\end{array}$ & Instit'al & \\
\hline $\begin{array}{l}\text { Mat'l/ Engin } \\
\text { Lab }\end{array}$ & Engin & AFI & Tota & $\begin{array}{l}\text { Mat'1/ Engin } \\
\text { Lab }\end{array}$ & Engin & AFI Total \\
\hline $899 \quad 453$ & 215 & 671 & 2238 & 950 & 950 & $27 ! 4$ \\
\hline
\end{tabular}

Cumency Units: kilo ICF

\section{B. Description:}

Exhaust Gas Detrtiation System is operated for management of the exhaust gas from vacuum systems, the tritium cell, GB exhaust system and some other process effluent. The exhaust gas from the vacuum system is assumend to consist of about $1 \mathrm{~m} 3 \mathrm{~h}$ of $\mathrm{Ar}$ with $1 \times 105 \mathrm{~Bq} / \mathrm{cc}$ tritium gas and about $19 \mathrm{~m} 3 / \mathrm{h}$ of air with $0-5 \mathrm{~Bq} / \mathrm{cc}$ liquid tritiated water equivalent vapor. The amount of the exhaust gas from other sources such as tritium cell and GB exhausting system is considered to be total of $200 \mathrm{~m} 3 \mathrm{~h}$ with a small amount of tritiated water. Process is based on permeation membrane technology and no materials are consumed by the operation.

\section{WBS Listing:}

\subsubsection{Exhaust Detritiation System}

\section{Costing Rationale:}

Cost estimate on this system is based on the industrial dry air production equipment, and a detritiation system being developed in Japanese facility. 
WBS 5.3.5.2 Temporary Exhaust Detritiation System

A. Summary Cost Estimate:

\begin{tabular}{|c|c|c|c|c|c|c|c|}
\hline \multicolumn{4}{|c|}{ Off-IFMiF Site } & \multicolumn{4}{|c|}{ On-Site At IFMIF } \\
\hline Industry & Instit' & & & $\begin{array}{l}\text { Const. } \\
\text { Contractor }\end{array}$ & Instital & & \\
\hline $\begin{array}{l}\text { Mar't/ Engin } \\
\text { Lab }\end{array}$ & Engin & AFI & Total & $\begin{array}{l}\text { Mat'V/ Engin } \\
\text { Lab }\end{array}$ & Engin & AFI & total \\
\hline 335302 . & 143 & 334 & 1114 & 470 & 470 & 403 & 1343 \\
\hline
\end{tabular}

Clarrency Units: kilo ICE

\section{B. Description:}

Temporary Exhaust Gas Detritiation System is operated for management of the gas, mostly anticipated to be air with low level tritiated water vapor which is exhausted in operation for maintenance. The amount of temporary exhaust gas is considered to be $100 \mathrm{~m} 3 / \mathrm{h}$ with a small amount of tritiated water, fed through the flexible ventilation ducts from various areas of the facility where the maintenance operation with radioactive contamination is anticipated.

\section{WBS Listing:}

\subsubsection{Temporary Exhaust Detritiation System}

D. Costing Rationale:

Cost is estimate from a dry air production unit based on hollow fiber permeation membrane comercially available in Japan. 
WBS 5.3.5.3 Liquid Waste Treatment System

\section{A. Summary Cost Estimate:}

\begin{tabular}{|c|c|c|c|c|c|c|c|}
\hline \multicolumn{4}{|c|}{ Off-IFMIF Site } & \multicolumn{4}{|c|}{ On-Site At IFMA } \\
\hline Industry & Instit' & & & $\begin{array}{l}\text { Const. } \\
\text { Contractor }\end{array}$ & Instit'al & & \\
\hline Mat'd/ Engin & Engin & $\mathrm{AFI}$ & Tota! & $\begin{array}{l}\text { Lat'l/ Engin } \\
\text { Lab }\end{array}$ & Engin & AFI & Total \\
\hline $414 \quad 453$ & 143 & 433 & 1443 & 640 & 640 & 549 & 1829 \\
\hline
\end{tabular}

\section{Currency Uinits: kilo ICF}

\section{B. Description:}

Liquid Waste Treatment System is operated for management of liquid wastes. Liquid wastes are considered to be generated mainly from cooling system of accelerator facility and decontamination facility for the components removed for maintenance purpose. Backwail and target assemble from the target system, and irradiated VTA and sample capsule parts are anticipated to be the major source of the solid waste to be cleaned. The amount of the liquid wastes is considered to be about $10 \mathrm{~m} 3 /$ year of alkaline water with lithium hydroxide and about $5 \mathrm{~m} 3 /$ year of neutral water. A small amount of tritiated water and radioactive metals generated by collosion are considered to be included in the liguid wastes.

Waste water is recycled after the treatment by neutralization, evaporation and ion exchange for purification. Concentrated liquid waste is solidified for disposal. Tritium removal is not attempted.

\section{WBS Listing:}

\subsubsection{Liquid Waste Treament System}

D. Costing Rationale:

Cost is based on a small liquid waste handling equipment recently installed in a irradiation facility in Japan. 
WBS 5.3.5.4 Solid Waste Treatment System

\section{A. Summary Cost Estimate:}

\begin{tabular}{|c|c|c|c|c|c|c|c|}
\hline \multicolumn{4}{|c|}{ Off-IFMIF Site } & \multicolumn{4}{|c|}{ On-Site At IFMIF } \\
\hline Industry & 'nstit' & & & $\begin{array}{l}\text { Const. } \\
\text { Contractor }\end{array}$ & Instit'al & & \\
\hline $\begin{array}{l}\text { Mat'/ Engin } \\
\text { Lab }\end{array}$ & Engin & AFI & Total & $\begin{array}{l}\text { Mat'l/ Engin } \\
\text { Lab }\end{array}$ & Engin & AFi & Total \\
\hline 1211906 & 286 & 1030 & $\overline{3433}$ & 433 & 433 & 372 & 1238 \\
\hline
\end{tabular}

Currency_Units: kilo ICF

\section{B. Description;}

Solid Waste Treatment System is operated for management of solid wastes. The main solid wastes are considered to be irradiated articles of consumption from the target room. About 30kg/year of solid wastes are considered to be generated from the target room in normal operation, and about $200 \mathrm{~kg} / \mathrm{batch}$ of solid wastes are also considered to be generated irregularly at maximum. The amount of other solid wastes such as irradiated specimens and holders, etc., is considered to be about 10 containers/year.

The system is installed in the tritiu bot cell in the Post Irradiation Examination facility that has a capability to handle activated and tritium-contaminated materials.

\section{WBS Listing:}

\subsubsection{Solid Waste Treatment System}

\section{Costing Rationale:}

Cost is based on a small solid waste handling equipment recently installed in a irradiation facility in Japan. 


\section{WORKSHEET}

\section{WBS 5.4.0.0 Site Improvements}

\section{A. Summary Cost Estimate:}

\begin{tabular}{|c|c|c|c|c|c|}
\hline \multicolumn{3}{|c|}{ Off-IFMIF Site } & \multicolumn{3}{|c|}{ On-Site at IFMIF } \\
\hline Industry & Instit'al & & Constr Contr & Instit'al & \\
\hline Mat'M/Lab Engin's & Engin's & AFI Total & Mat'//ab Engin'z & Engin'g & AfI Total \\
\hline nc $\quad$ nc & IC & $\mathrm{nc}$ nc & $1005 \quad 20$ & 0 & $100 \quad 112$ \\
\hline
\end{tabular}

Cumency Units: kilos

\section{B. Descrintion:}

The IFMIF site includes a land area of $10 \mathrm{ha}$, of which $2 \mathrm{ha}$ are developed. The land is provided within an exising nuclear research facility with central infrastructure support. The site improvements cost includes road transportation, land clearing and landscaping, and storm drainage for the area dedicated to IFMIF.

\section{C.Detailed WBS Listing:}

5.4.0 Site Improvements

5.4.1 Roads and Parking

5.4.2 Grading and Landscaping

5.4.3 Stom Drainge

D. Costing Rationale:

The required quantities were estimated using an assumed site layout, and costs were estimated using the ITER cost data base.

- Type of Estinate: Scaling

- Allowance for Indeterminates: $10 \%$ AFI is applied to account for unusual site conditions.

\section{E_Detailed Costing:}

A spreadsheet showing the cost elements and ITER unit costs is attached. 
IFMIF Site Improvements Costing Sheet

Costs Factoring Based on ITER Data for Sinilar Facilities

\begin{tabular}{|c|c|c|c|c|c|c|c|c|c|c|c|c|}
\hline $\begin{array}{l}\text { Account } \\
\text { Description }\end{array}$ & Quant. & Unit & Mat'I & Labor & Support & Total & Code & $\begin{array}{l}\text { Unit } \\
\text { Matl } \\
\text { Cost }\end{array}$ & $\begin{array}{l}\text { Unit } \\
\text { Lab } \\
\text { Cast }\end{array}$ & $\begin{array}{l}\text { Unit } \\
\text { Sup } \\
\text { Cost }\end{array}$ & $\begin{array}{l}\text { Unit } \\
\text { Lab } \\
\text { Hrs }\end{array}$ & $\begin{array}{l}\text { Craft } \\
\text { Hrs }\end{array}$ \\
\hline Roadway & 700 & $\mathbf{m}$ & 105,000 & 122,696 & 122,696 & 350,392 & G1010 & 150 & 175 & 175 & 7 & 4,900 \\
\hline Parking & 2,000 & $\mathrm{~m} 2$ & 8,000 & 6,000 & 6,000 & 20,000 & G1012 & 4 & 3 & 3 & 0 & 240 \\
\hline Lighting & 25 & ea & 6,250 & 6,743 & 6,743 & 19,735 & $\mathrm{E} 1002$ & 250 & 270 & 270 & 10 & 250 \\
\hline Clearing and grading & 100,000 & $\mathrm{~m} 2$ & - & 88,000 & 88,000 & 176,000 & G1001 & - & 1 & 1 & 0 & 4,000 \\
\hline Landscaping & 10,000 & $\mathrm{~m} 2$ & 10,000 & 150,200 & 150,200 & 310,400 & G1006 & 1 & 15 & 15 & 1 & 6,000 \\
\hline Fencing & 1,200 & $\mathbf{m}$ & 38,400 & 30,048 & 30,048 & 98,496 & G1008 & 32 & 25 & 25 & 1 & 1,200 \\
\hline Stonm drainage & 20,000 & $\mathfrak{m} 2$ & 20,000 & 5,000 & 5,000 & 30,000 & G1005 & 1 & $\mathbf{0}$ & 0 & 0 & 200 \\
\hline Total & & & 187,650 & 408,687 & 408,687 & $1,005,023$ & & & & & & 16,790 \\
\hline
\end{tabular}




\section{WORKSHEET}

WBS 5.1.0 Conventional Facilities ; Management (JA)

\section{A. Surmary Cost Estimate:}

\begin{tabular}{|c|c|c|c|c|c|c|c|}
\hline \multicolumn{3}{|c|}{ Off-FMMIF Site } & \multicolumn{5}{|c|}{ On-Site At IFMIF } \\
\hline Industry & 'Instit' & & Const C & tractor & Instit'al & & \\
\hline Mat'i/Lab Engin & Engin & AFT Tota & I Wat'VLab & Engin & Engin & $\mathrm{AFI}$ & Total \\
\hline Inc & nc & nc & $1,043,418$ & $\mathbf{n c}$ & nc & 208,844 & 252,262 \\
\hline
\end{tabular}

Surency Units: kilo Yen

\section{B_Descriotion:}

The total price is consist of management (1.5\%) and tax (5\%).

\section{Costing Rational:}

Type of Estimate: $\quad$ factor

D. Detailed Casting: (Unit : k-yen)

5.2 Buildings

5.3 Utilities

5.4 Electric Utilities

5.5 Radioactive Waste Treatment Systems

Item

Management (1.5\%)

Mat'llab

AFI

$16,052,576 \times 1.5 \%$

$3,212,972 \times 1.5 \%$

Tax

(5\%)

Mat'1/Lab $\quad 16,052,576 \times 5 \%$

AFI

$$
3,212,972 \times 5 \%
$$

Mat'V/ab :

AFI :
$240,789+802,629$

$48,195+160,649$

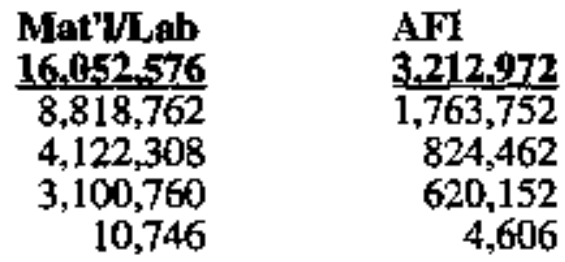

\begin{tabular}{cr} 
Cost & (k-ICF) \\
$\mathbf{2 8 8 , 9 8 4}$ & $\mathbf{2 . 7 5 3}$ \\
\hline $\mathbf{2 4 0 , 7 8 9}$ & $\mathbf{2 , 2 9 4}$ \\
$\mathbf{4 8 , 1 9 5}$ & $\mathbf{4 5 9}$
\end{tabular}

963.278 $\quad 2.174$

$802,629 \quad 7,644$

$160,649 \quad 1,530$

$1,043,418 \quad 9,938$

$208,844 \quad 1,989$

Total $1,252,262 \quad 11,927$ 
WBS 5.2.0(JA)

WORKSHEET

WBS 5.2.0 Conventional Faćlíties ; Buildings (JA)

\section{A. Summary Cost Estimate:}

\begin{tabular}{|c|c|c|c|c|c|c|}
\hline \multicolumn{3}{|c|}{ Off-IFMIF Site } & \multicolumn{4}{|c|}{ On-Site At IFMIF } \\
\hline Industry & Instit' & & Const Contractor & Instital & & \\
\hline $\begin{array}{l}\text { Matl/ Engi } \\
\text { Lab n }\end{array}$ & Engin & AFI Total & $\begin{array}{l}\text { Mat'l/ Engin } \\
\text { Lab }\end{array}$ & Engin & AFI & Total \\
\hline $\mathrm{nc} \quad \mathrm{nc}$ & nc & flac & $8,818,762$ & $\mathrm{nc}$ & $1,763,75$ & $\overline{0,582,514}$ \\
\hline
\end{tabular}

Chimency Units:_kilo Yen

\section{B. Description:}

The conventional facilities buildings for IFMIF consists of accelerator complex, target complex, neutron imaging, building high bay, support facilities and plant gasecus effluent system This cost is not included the expense of a geological survey and hedging and ditching works. The otal orice is not included management $(1.5 \%)$ and tax $(5 \%)$.

\section{Detailed WBS Listing:}

1. 0. 0. 0. Buildings

1. 0. 0. Construction

1. 0. RF Power Bay

2. 0 . Target Cell and ete.

3. 0. Lab, rooms and etc.

4. 0. Administration Building

5. 0. Machine rooms and etc.

6. 0. Caisson/Post

7. 0. Water proof on Mat

8. 0. Water proof at Basement

9. 0. Improvement of Ground

2. 0. 0. Special Equipment

1. 0. Sbiejding Door

2. 0. Crane

3. 0. Shielding Plug

4. 0. Lift

5. 0. Free Access Flower at Control Roopr

6. 0. Epoxy Lining

7. 0. SUS Lining

8. 0. Hatch at ceiling and etc.

\section{Costing Rational:}

Type of Estimate : nearly bottom-up and scaling

Allowance for Indeterminates: $\quad 20 \%$ based on technical risk

E. Detaiked Costing: (Unit : k-yen)

Buildings Item

Special Equipment

Cost $5,856.337$ $2.962,425$
(k-ICF)

55,775

28,214 
WORKSHEET

WBS 5.2.1.1 Construction (JA)

\section{A. Summary Cost Estimatei}

\begin{tabular}{|c|c|c|c|c|c|}
\hline \multicolumn{3}{|c|}{ Off-IFMlF Site } & \multicolumn{3}{|c|}{ On-Site Ax IFMiF } \\
\hline Industry & Insistit' & & Const. Contractor & Instital & \\
\hline $\begin{array}{l}\text { Mat'l/ Engin } \\
\text { Lab }\end{array}$ & Engin & AFI Total & $\begin{array}{l}\text { Mat'lf Engin } \\
\text { Lab }\end{array}$ & Engin & Total \\
\hline nc & DC & $\mathrm{BC}$ & $5,856,337$ & nc & $1,171,2677,056,38$ \\
\hline
\end{tabular}

\section{Currency Units: kilo Yen}

\section{B. Description:}

This cost is not included the expense of a geological survey and hedging and ditching works. Tbe total price is not included manggement (1.5\%) and tax (5\%).

\section{Detalled WBS Listing:}

1. 0. 0. Construction

1. 0. RF Power Bay

2. 0. Target Cell and etc.

3. 0. Lab. rooms and etc.

4. 0. Administration Buvking

5. 0. Machine rooms and etc.

6. 0. CaissoniPoșt

7. 0. Water proof on $\mathrm{Mal}$

8. 0. Water proof at Basement

9. 0. Impravement of Ground

\section{Costing Rational:}

Type of Estimate :

Allowance for Indeterminates :

nearfy bottom-up and scaling

$20 \%$ based on technical risk

E. Detailed Costing: (Unit : k-yen)

1.1 RF Power Bay

1.2 Target Cell, etc.

$1.3 \mathrm{Lab}$. rooms, etc.

1.4 Administration Building

1.5 Machine rooms, etc.

1.6 Caisson/Post

1.7 Water proof on Mat

1.8 Water proof at Basement

1.9 Improvement of Ground
$3,360 \mathrm{~m}^{2} \times 12 \mathrm{mH}$
$13,000 \mathrm{~m}^{2} \times 6 \mathrm{mH}$
$1,365 \mathrm{~m}^{2} \times 5 \mathrm{mH}$
$1,650 \mathrm{~m}^{2} \times 5 \mathrm{mH}$
$900 \mathrm{~m}^{2} \times 6 \mathrm{mH}$
799,108
$3,113,110$
222,870
269,404
153,945
371,800
132,000
102,000
692,100

Cost 
WORKSHEET

WBS 5.2.1.2 Special Equipment (JA)

\section{A. Sommary Cost Estimate:}

\begin{tabular}{|c|c|c|c|c|c|c|}
\hline \multicolumn{3}{|c|}{ Off-IFLUF Site } & \multicolumn{4}{|c|}{ On-Site At IFMIF } \\
\hline Industry & Instit' & & Const. Contractor & Institt'al & & \\
\hline $\begin{array}{l}\text { Mat'l/ Engin } \\
\text { Lab }\end{array}$ & Engin & Total & $\begin{array}{c}\text { Mat'ly Engin } \\
\text { Lab }\end{array}$ & Engin & AFI & Total \\
\hline $\mathbf{n C}$ & nc & nc & $2,962,425$ & Inc & $5 9 \longdiv { 2 , 4 8 }$ & $, 554,91$ \\
\hline
\end{tabular}

Currency Units: Kilo Yen

\section{B. Description:}

This cost is not included the expense of a geological survey and hedging and ditching works. The total price is not inchoded manganent $(1.5 \%)$ and tax $(5 \%)$

\section{Detailed WBS Listing:}

2. 0. 0. Spectal Equipment

1. 0. Shielding Door

2. 0. Crane

3. 0. Shielding Plug

4. 0. Lift

5. 0. Free Access Flower at Control Room

6. 0. Epoxy Lining

7. 0. SUS Lining

8. 0. Stacb

8. 0. Hatch at ceiling and etc.

\section{Costing Rational:}

Type of Estimate : nearly bottom-up and scaling

Allowance for Indeterminates : $20 \%$ based on technical risk

E. Detailed Costing: (Unit : k-yen)

2.1 Shielding Door

$5 \mathrm{~m} \mathrm{~W} \times 8 \mathrm{~m} \mathrm{H} \times 2.5 \mathrm{~m} \mathrm{~T} \times 2$

$\operatorname{lm} W \times 2 \mathrm{~m} \mathrm{H} \times 1 \mathrm{~m} \mathrm{~T}$

2.2 Crane 30/5-ton, 24m-span x 34m L x 25m H 25/5-ton, 40m-span $\times 70 \mathrm{~m} \mathrm{~L} \times 20 \mathrm{mH}$ 10-ton, $24 \mathrm{~m}$-span $\times 41 \mathrm{~m} \mathrm{~L} \times 10 \mathrm{~m} \mathrm{H}$

5-ton, $7.5 \mathrm{~m}$-span $\times 50 \mathrm{~m} \mathrm{~L} \times 10 \mathrm{~m}$ H $\times 2$ $2.5 \mathrm{~m} \times 5.2 \mathrm{~m} \times 1.8 \mathrm{mT} \times 2$

2.3 Shielding Plug $1-\operatorname{ton} \times 2$

2.4 Lift

$$
\text { 1-ton } \times 2
$$

2.5 Free Access Flower at Control Room

2.6 Epoxy Lining

$2.7 \mathrm{SS}$ Lining

2.8 Stach $14,900 \mathrm{~m}^{2}$ $5,000 \mathrm{~m}^{2}$

$175 \mathrm{~m}^{2}$

Cost

190,000

10,000

76,000

132,000

39,000

38,800

90,000

100,000

9,625

132,000

$2,000,000$

$30 \mathrm{mH}$ 
WORKSHEET

WBS 5.3 Conventional Facilities ; Utilities/Ventilation etc. (JA)

\section{A. Summary Cost Estimate:}

\begin{tabular}{|c|c|c|c|c|c|c|c|}
\hline \multicolumn{4}{|c|}{ Off-IFINIF Site } & \multicolumn{4}{|c|}{ On-Site At IFMilF } \\
\hline Industry & Tnstit' & & & Const. Co & tractor & Instit'al & \\
\hline Mat'1Lab Engin & Engin & AFI & Total & Mat'/Lab & Engin & Engin & Total \\
\hline$\overline{\mathrm{nc}} \quad \overline{\mathrm{nc}}$ & ne & $\mathrm{nc}$ & $\overline{\mathrm{n} k}$ & $4,122,308$ & $\mathrm{nc}$ & nc & $824,462 \quad 4,946,770$ \\
\hline
\end{tabular}

\section{Cumrency Units: kilo Yen}

\section{B. Description:}

The utilities for IFMIF consists of ventilation, water cooling system, service water system, cooling water utilities and special equipment. This utility is not included electric utilities. The total price is not included management $(1.5 \%$ ) and tax $(5 \%)$.

\section{Detailed WBS Listing:}

3. 0. 0. 0. Utillties

1. 0. 0 Ventilation

1. 0. Cold Ares

2. a. Type-1 Conurolled Areg

3. 0. Type-2 Controlled Area

2. 0. 0. Service Water System

1. 0. Cold Area

2. o. Type-1 Controlled Area

3. a. Type-2 Controlled Area

3. 0. o. Cooting Water Utilities

1. 0. Conling system for Type- $\imath$ Area

2. a. Cooling system for Type-2 Asea

3. 0. Cooling system for Accelerator \& Target

4. 0.0 . Special Equijpment

1. 0. Filter and etc.

2. 0. Control System

\section{Custing Rational:}

Type of Estimate :

Allowance for Indeterminates : $\quad 20 \%$ based on technical risk

E. Defailed Costing: (Unit : k-yen)

Item

Ventilation

Service Water System

Cooling Water Utilities

Special Equipment
Cost

$1.520 .767 \quad 14.484$

$578.162 \quad 5,506$

$1,117,500 \quad 10,643$

$905.879 \quad 8,627$

Ground Total 4,122,308 $\quad 39,260$ 
WORKSHEET

WBS 5.3.1 Ventilation (JA)

\section{A. Summary Cost Estimate:}

\begin{tabular}{|c|c|c|c|c|c|c|}
\hline \multicolumn{4}{|c|}{ Off-IFMIF Site } & \multicolumn{3}{|c|}{ On-Site At IFMIF } \\
\hline Industry & Instit" & & & Const Contractor & Instital & \\
\hline Mat'VLab Engin & Engia & $\mathrm{AFI}$ & Total & Mat'//Lab Engin & Engin & Total \\
\hline $\mathrm{ac}$ & ac & $\mathrm{nc}$ & $\mathrm{ne}$ & $1,520,767$ & ne & $304,153 \quad 1,824,920$ \\
\hline
\end{tabular}

\section{Currency Units: kilo Yen}

\section{B. Description:}

The total price is not included management $(1.5 \%)$ and tax ( $5 \%)$.

\section{Detalled WBS Listing:}

1. 0. 0. Vertilation

1. 0. Cold Ares

2. 0. Type-1 Controlled Area

3. 0. Type-2 Controlled Area

\section{Costing Rational:}

Type of Estimate :

bottom-up

Allowance for Indeterminates : $\quad 20 \%$ based on technical risk

\section{E. Detailed Costing: (Unit : k-yen)}

1.1.0 Cold Area :

1. AAMB

2. RF Power Bay

3. Staircase Hall

4. Data Acquisition

5. HEBT Assembly

6. Staircase Hall

7. Ventilation Room

8. Aaxiliary Equipment Room

$\underline{11}, 407 \mathrm{~m}^{2}$

$350 \mathrm{~m}^{2}(7 \mathrm{mH}) \times 57.90 \times 1.10 \times 1.00$

$3,283 \mathrm{~m}^{2}(12 \mathrm{mH}) \times 57.90 \times 1.40 \times 1.00$

$105 \mathrm{~m}^{2}(40 \mathrm{mH}) \times 57.90 \times 4.00 \times 1.00$

$232 \mathrm{~m}^{2}(5 \mathrm{mH}) \times 57.90 \times 1.00 \times 1.00$

Maintenance Bay

$249 \mathrm{~m}^{2}(8 \mathrm{mH}) \times 57.90 \times 1.20 \times 1.00$

$82 \mathrm{~m}^{2}(10 \mathrm{mH}) \times 57.90 \times 1.40 \times 1.00$

$217 \mathrm{~m}^{2}(5 \mathrm{mH}) \times \quad 57.90 \times 1.00 \times 1.00$

$$
1,088 \mathrm{~m}^{2} \quad(5 \mathrm{mH}) \times \quad 57.90 \times 1.00 \times 1.00
$$

9. Accelerator Assembly Maintenance

10. Control Room

11. Shipping Bay

12. Health Physics Station

13. Uncontaminated Shop

14. Storage
$350 \mathrm{~m}^{2}(5 \mathrm{mH}) \times 57.90 \times 1.00 \times 1.00$

$165 \mathrm{~m}^{2}(7 \mathrm{mH}) \times \quad 57.90 \times 1.10 \times 1.00$

$249 \mathrm{~m}^{2}(8 \mathrm{mH}) \times 57.90 \times 1.20 \times 1.00$

$70 \mathrm{~m}^{2}(5 \mathrm{mH}) \times 57.90 \times 1.00 \times 1.00$

$70 \mathrm{~m}^{2}(5 \mathrm{mH}) \times \quad 57.90 \times 1.00 \times 1.00$

$318 \mathrm{~m}^{2} \quad(5 \mathrm{mH}) \times \quad 57.90 \times 1.00 \times 1.00$
Cost

795.888

22,292

266,120

24,318

13,433

17,301

6,647

12,564

62,995

20,265

10,509

17,301

4,053

4,053

18,412 
15. Shipping Bay

16. Passage Hali

17. Passage Hali

18. Staircase Hall

19. Passage Hall

20. Passage Hall

21. High Hall

22. Administration Building
$173 \mathrm{~m}^{2}(10 \mathrm{MH}) \mathrm{x}$

$113 \mathrm{~m}^{2}(5 \mathrm{mH}) \mathrm{x}$

$79 \mathrm{~m}^{2}(5 \mathrm{mH}) \mathrm{x}$

$50 \mathrm{~m}^{2}(5 \mathrm{mH}) \mathrm{x}$

$113 \mathrm{~m}^{2}(5 \mathrm{mH}) \mathrm{x}$

$113 \mathrm{~m}^{2}(5 \mathrm{mH}) \mathrm{x}$

$2,288 \mathrm{~m}^{2} \quad(9 \mathrm{mH}) \mathrm{x}$

$1,650 \mathrm{~m}^{2}(5 \mathrm{mH}) \mathrm{x}$
$57.90 \times 1.40 \times 1.00$

$57.90 \times 1.00 \times 1.00$

$57.90 \times 1.00 \times 1.00$

$57.90 \times 1.00 \times 1.00$

$57.90 \times 1.00 \times 1.00$

$57.90 \times 1.00 \times 1.00$

$57.90 \times 1.20 \times 1.00$

$57.90 \times 1.00 \times 1.00$
14,023

6,543

4,574

2,895

6,543

6.543

158.970

95,535
1.2.0 Type-1 Controlled Area

1. Li Cooler Room

2. N/A

3. Li Purification Room

4. Li Surge Tank Room

5 . Access Maintenance Roon

6. Target Interface Roon

7. Beam Calibration Station

8. Test Cell Technology Room

9. Test Cell

10. Beam Calibration Station

11. Test Call

12. Test Cell Technology Room

13. Operating Area

14. Red Waste Processing

15. Red Waste Shipping

16. Hot Cell Utility Area

17. PIE Laboratory Area

18. Tritum Laboratory

19. Manipulator Repair

20. Hot Shop

1.3.0 Type-2 Controlled Area

1. Li Dump Tank Room

2. Spare Room

3. Beam Tutning Room

4. Accelerator Hîll

5. Accelerator Hasl

\section{$4182 \mathrm{~m}^{2}$}

$188 \mathrm{~m}^{2}(6 \mathrm{mH}) \mathrm{x}$ $211 \mathrm{~m}^{2}(20 \mathrm{mH}) \mathrm{x}$

$161 \mathrm{~m}^{2}(6 \mathrm{mH}) \mathrm{x}$

$177 \mathrm{~m}^{2}(6 \mathrm{mH}) x$

$161 \mathrm{~m}^{2}(14 \mathrm{mH}) x$

$102 \mathrm{~m}^{2}(10 \mathrm{mH}) \mathrm{x}$

$139 \mathrm{~m}^{2}(7 \mathrm{mH}) \mathrm{x}$

$23 \mathrm{~m}^{2}$ (3 mH) $x$

$13 \mathrm{~m}^{2}(6 \mathrm{mH}) \mathrm{x}$

$13 \mathrm{~m}^{2}(4 \mathrm{mH}) \mathrm{x}$

$13 \mathrm{~m}^{2}(6 \mathrm{mH}) \mathrm{x}$

$23 \mathrm{~m}^{2}(3 \mathrm{mH}) \mathrm{x}$

$560 \mathrm{~m}^{2}(12 \mathrm{mH}) \mathrm{x}$

$150 \mathrm{~m}^{2}(5 \mathrm{mH}) \mathrm{x}$

$150 \mathrm{~m}^{2}(5 \mathrm{mH}) \mathrm{x}$

$821 \mathrm{~m}^{2}(5 \mathrm{mH}) \mathrm{x}$

$605 \mathrm{~m}^{2}(5 \mathrm{mH}) \mathrm{x}$

$518 \mathrm{~m}^{2}(5 \mathrm{mH}) \mathrm{x}$

$77 \mathrm{~m}^{2}$ (5 $\left.\mathrm{mH}\right) \mathrm{x}$

$77 \mathrm{~m}^{2}(5 \mathrm{mH}) x$
$57.90 \times 1.10 \times 2.00$

$57.90 \times 1.80 \times 2.00$

$57.90 \times 1.10 \times 2.00$

$57.90 \times 1.00 \times 2.00$

$57.90 \times 1.40 \times 2.00$

$57.90 \times 1.40 \times 2.00$

$57.90 \times 1.20 \times 2.00$

$57.90 \times 1.00 \times 2.00$

$57.90 \times 1.10 \times 2.00$

$57.90 \times 1.10 \times 2.00$

$57.90 \times 1.10 \times 2.00$

$57.90 \times 1.10 \times 2.00$

$57.90 \times 1.40 \times 2.00$

$57.90 \times 1.00 \times 2.00$

$57.90 \times 1.00 \times 2.00$

$57.90 \times 1.10 \times 2.00$

$57.90 \times 1.00 \times 2.00$

$57.90 \times 1.00 \times 2.00$

$57.90 \times 1.00 \times 2.00$

$57.90 \times 1.00 \times 2.00$

551.555

23,947

43,981

20,508

22,546

26,101

16,536

19,315

2,663

1,656

1,505

1,656

2,663

90,787

17,370

17,370

95,072

70,059

59,984

8,917

8,917

173,324

$246 \mathrm{~m}^{2}$

28,852

10,190

80,655

26,813

26,813 
WORKSHEET

WBS 5.3.2 Service Water System (JA)

\section{A. Summary Cost Estimate:}

\begin{tabular}{|c|c|c|c|c|c|c|c|}
\hline \multicolumn{4}{|c|}{ Off-IFMIF Site } & \multicolumn{4}{|c|}{ On-Site At IFMFF } \\
\hline Industry & Instif' & & & Const. Cl & tractor & Instital & \\
\hline Mat'/Lab Engin & Engin & AFI & Total & Mat'l/Lab & Engin & Engin & AFI \\
\hline nc & $\mathbf{n c}$ & $\mathbf{n c}$ & $n c$ & 578,162 & $\mathrm{ne}$ & $\mathbf{n c}$ & $115,632693,794$ \\
\hline
\end{tabular}

Currency Units: kilo Yen

\section{B. Description:}

The total price is not included management (1.5\%) and tax (5\%).

\section{Detailed WBS Listing:}

2. 0. 0. Service Water Systen

1. 0. Cols Area

2. 0. Type-i Controlled Area

3. 0. Type-2 Controlled Area

\section{Costing Rational;}

Type of Estimate :

bottom-lip

Allowance for Indeterminates : $\quad 20 \%$ based on technical risk

\section{E Detaled Costing: (Unit : k-yen)}

\subsubsection{Cold Area}

1. AAMB

2. RF PowerBay

3. Staircase Hall

4. Data Acquisition

5. HEBT Assembly

6. Staircase Hall

7. Ventilation Room

8. Auxiliary Equipment Room 1,088 $\mathrm{m}^{2}$

9. Accelerator Assembly Maintenance

10. Control Roorn

11. Shipping Bay

12. Health Physics Station

13. Uncontaminated Shop

14. Storage

15. Shipping Bay

Bay

\subsection{7 $\mathrm{m}^{2}$}

$350 \mathrm{~m}^{2}(7 \mathrm{mH}) \times 26.00 \times 1.00 \times 1.00$

$3,283 \mathrm{~m}^{2}(12 \mathrm{mH}) \times 26.00 \times 1.00 \times 1.00$

$105 \mathrm{~m}^{2}(40 \mathrm{mH}) \times 26.00 \times 1.00 \times 1.00$

$232 \mathrm{~m}^{2}(5 \mathrm{mH}) \times 26.00 \times 1.00 \times 1.00$

$249 \mathrm{~m}^{2}(6 \mathrm{mH}) \times 26.00 \times 1.00 \times 1.00$

$82 \mathrm{~m}^{2}(10 \mathrm{mH}) \times 26.00 \times 1.00 \times 1.00$

$217 \mathrm{~m}^{2}(5 \mathrm{mH}) \times 26.00 \times 1.00 \times 1.00$

$350 \mathrm{~m}^{2}(5 \mathrm{mH}) \times 26.00 \times 1.00 \times 1.00$

$165 \mathrm{~m}^{2}(7 \mathrm{mH}) \times 26.00 \times 1.00 \times 1.00$

$249 \mathrm{~m}^{2}(6 \mathrm{mH}) \times 26.00 \times 1.00 \times 1.00$

$70 \mathrm{~m}^{2}(5 \mathrm{mH}) \times 26.00 \times 1.00 \times 1.00$

$70 \mathrm{~m}^{2}(5 \mathrm{mH}) \times 26.00 \times 1.00 \times 1.00$

$318 \mathrm{~m}^{2}(5 \mathrm{mH}) \times 26.00 \times 1.00 \times 1.00$

$173 \mathrm{~m}^{2}(10 \mathrm{mH}) \pi 26.00 \times 1.00 \times 1.00$
Cost

296, 582

9,100

85,358

2,730

6,032

6,474

2,132

5,642

28,288

9,100

4,290

6,474

1,820

1,820

8,268

4,498 
16. Passage Hall

17. Passage Hall

18. Staircase Hall

19. Passage Hall

20. Passage Hall

2I. High Hiall

22. Administration Building
$113 \mathrm{~m}^{2}(5 \mathrm{mH}) \mathrm{x}$

$79 \mathrm{~m}^{2}(5 \mathrm{mH}) \mathrm{x}$

$50 \mathrm{~m}^{2}(5 \mathrm{mH}) \mathrm{x}$

$113 \mathrm{~m}^{2}(5 \mathrm{mH}) \mathrm{x}$

$113 \mathrm{~m}^{2}(5 \mathrm{mH}) \mathrm{x}$

$2,288 \mathrm{~m}^{2}(9 \mathrm{mH}) \mathrm{x}$

$1,650 \mathrm{~m}^{2}(5 \mathrm{mH}) \mathrm{x}$
$26.00 \times 1.00 \times 1.00$

$26.00 \times 1.00 \times 1.00$

$26.00 \times 1.00 \times 1.00$

$26.00 \times 1.00 \times 1.00$

$26.00 \times 1.00 \times 1.00$

$26.00 \times 1.00 \times 1.00$

$26.00 \times 1.00 \times 1.00$
2,938

2,054

1,300

2,938

2,938

59,488

42,900
1.2.0 Type-1 Controlled Area

1. Li Cooler Room

2. N/Aq

3. Li Purification Room

4. Li Surge Tank Room

5. Access Maintenance Room

6. Target Interface Room

7. Beam Calibration Station

8. Test Cell Technology Room

9. Test Cell

10. Beam Calibration Station

11. Test Call

12. Test Cell Technology Room

13. Operating Area

14. Red Waste Processing

15. Red Waste Shipping

16. Hot Cell Utility Area

17. PIE Laboratory Area

18. Tritium Laboratory

19. Manipulator Repair

20. Hot Shop

1.3.0 Type-2 Controlled Area

1. Li Dump Tank Room

2. Spare Room

3. Bearn Tuming Room

4. Accelerator Hall

5. Accelerator $\mathrm{Hall}$

\section{$4182 \mathrm{~m}^{2}$}

$188 \mathrm{~m}^{2}(6 \mathrm{mH}) \times 26.00 \times 1.00 \times 2.00$

$211 \mathrm{~m}^{2}(20 \mathrm{MH}) \times 26.00 \times 1.00 \times 2.00$

$161 \mathrm{~m}^{2}(6 \mathrm{mH}) \times 26.00 \times 1.00 \times 2.00$

$177 \mathrm{~m}^{2}(6 \mathrm{mH}) \times 26.00 \times 1.00 \times 2.00$

$161 \mathrm{~m}^{2}(14 \mathrm{mH}) \times 26.00 \times 1.00 \times 2.00$

$102 \mathrm{~m}^{2}(10 \mathrm{~m}+\mathrm{H}) \times 26.00 \times 1.00 \times 2.00$

$139 \mathrm{~m}^{2}(9 \mathrm{mH}) \times 26.00 \times 1.00 \times 2.00$

$23 \mathrm{~m}^{2}(3 \mathrm{mH}) \times 26.00 \times 1.00 \times 2.00$

$13 \mathrm{~m}^{2}(6 \mathrm{mH}) \times 26.00 \times 1.00 \times 2.00$

$13 \mathrm{~m}^{2}(4 \mathrm{mH}) \times 26.00 \times 1.00 \times 2.00$

$13 \mathrm{~m}^{2}(6 \mathrm{mH}) \times 26.00 \times 1.00 \times 2.00$

$23 \mathrm{~m}^{2}(3 \mathrm{mH}) \times 26.00 \times 1.00 \times 2.00$

$560 \mathrm{~m}^{2}(12 \mathrm{mH}) \times 26.00 \times 1.00 \times 2.00$

$150 \mathrm{~m}^{2}(5 \mathrm{mH}) \times 26.00 \times 1.00 \times 2.00$

$150 \mathrm{~m}^{2}(5 \mathrm{mH}) \times 26.00 \times 1.00 \times 2.00$

$821 \mathrm{~m}^{2}(5 \mathrm{mH}) \times 26.00 \times 1.00 \times 2.00$

$605 \mathrm{~m}^{2}(5 \mathrm{mH}) \times 26.00 \times 1.00 \times 2.00$

$518 \mathrm{~m}^{2}(5 \mathrm{mH}) \times 26.00 \times 1.00 \times 2.00$

$77 \mathrm{~m}^{2} \quad(5 \mathrm{mH}) \times 26.00 \times 1.00 \times 2.00$

$77 \mathrm{~m}^{2} \quad(5 \mathrm{mH}) \times 26.00 \times 1.00 \times 2.00$

\section{$2466 \mathrm{~m}^{2}$}

$453 \mathrm{~m}^{2}(7 \mathrm{mH}) \times 26.00 \times 1.00 \times 1.00$

$176 \mathrm{~m}^{2}(5 \mathrm{mH}) \times 26.00 \times 1.00 \times 1.00$

$995 \mathrm{~m}^{2}(11 \mathrm{mH}) \times 26.00 \times 1.00 \times 1.00$

$421 \mathrm{~m}^{2}(6 \mathrm{mH}) \times 26.00 \times 1.00 \times 1.00$

$421 \mathrm{~m}^{2}(6 \mathrm{mH}) \times 26.00 \times 1.00 \times 1.00$
217.464

9,776

10,972

8,372

9,204

8,372

5,304

7,228

1,196

676

676

676

1,196

29,120

7,800

7,800

42,692

31,460

26,936

4,004

4,004

64.116

11,778

4,576

25,870

10,946

10,946 
WORKSEEET

WBS 5.3.3 Cooling Water Utlltites (JA)

\section{A. Summary Cost Estimate:}

\begin{tabular}{|c|c|c|c|c|c|c|c|}
\hline \multicolumn{4}{|c|}{ Off-IFMIF Site } & \multicolumn{4}{|c|}{ Oa-Site At IFMIF } \\
\hline Industry & Instit' & & & Const. Contractor & Instit'al & & \\
\hline Mar'l/Lab Engin & Engin & AFI & Total & Mat'1/Lab Engin & Engin & AFI & Total \\
\hline nc & $\mathbf{n c}$ & nc & $\mathbf{n c}$ & $1,117,500$ & $\mathbf{n c}$ & 223,500 & $1,341,000$ \\
\hline
\end{tabular}

Currency Units: kilo Yen

\section{B. Description:}

The Cooling Water Utilities consist of cooling system for type-1 area, type-2 \&ccold area and accelerator \& target. The total price is mot included management $(1.5 \%$ and tax (5\%).

\section{Detailed WBS Listing:}

3. 0. 0. Cooling Water Utilities

1. 0. Cooling system for Type-1 Area

2. 0 . Cooling systern for Type-2 Area \& Cold Area

3. 0. Cooling system for Accelerator \& Target

\section{Costing Rational:}

Type of Estimate :

bottom-up

Allowance for Indeterninates : $\quad 20 \%$ based on technical risk

E. Detalled Costing: (Unit : k-yen)

3.1 Type-1 Area

3.2 Type-2 \& Cold Area

3.3 Accelerator \& Target $1,380-\operatorname{ton} x @ 150$

850 -ton $x @ 150$

$40 \mathrm{MW}$ (Open type) cost

207,000

127,500

783,000

Total $\quad 1,117,500$ 
WORKSHEET

WBS 5.3.4 Special Equipment (JA)

\section{A. Summary Cost Estimate;}

\begin{tabular}{|c|c|c|c|c|c|c|}
\hline \multicolumn{4}{|c|}{ Off-IFMiF Site } & \multicolumn{3}{|c|}{ On-Site At IFMIF } \\
\hline Industry & Instit' & & & Const. Contractor & Instital & \\
\hline Mat'"'Lab Engin & Engin & AF & Total & Mat'ULab Engin & Engin & Total \\
\hline nc $\quad$ nc & $\mathrm{nc}$ & nc & $\mathrm{nc}$ & 905,879 & $\mathrm{nc}$ & $181,176 \quad 1,087,055$ \\
\hline
\end{tabular}

Curency Units: kilo Yen

\section{B. Description:}

The total price is not included management $(1.5 \%)$ and tax $(5 \%)$.

\section{Detailed WBS Litting}

4. 0. 0. Special Equipment

1. 0 . Filiter and etc.

2. 0. Control System

D. Costing Rational:

Type of Estimate :

bottom-up

Allowance for Indeterninates: $\quad 20 \%$ based on technical risk

E. Detalled Costing: (Unit : k-yen)

4.1 Filter, etc.

1. Ventilation Filter

2. Automatic valve

3. High density Dumper

4. Monitor tube

5. Root Blower

6. Pressure Control System

7. Flow Meter

8. Central Control Plate

9. Factory Waste Pool

10. Factory Waste Path

11. Factory Waste Meter

12. Drain Pump

4.2 Control System 1,380-ton $\times 150$

(16,600)5

(11) $9,883 \times 10$

(9.) $4,612 \times 16$

(1i) $3,878 \times 4$

(9) $2,560 \times 12$

(9) 5.3

$\left(6,182 \mathrm{~m}^{3} \mathrm{x}\right.$ (500A)

(1200A)

(19) 2,610x 6

(1) $2,830 \times 6$

$16,405 \mathrm{~m}^{2} \mathrm{x}$

$20 \mathrm{~m}^{3} \mathrm{x}$

(a) 8.3

] set

$@ 16,730 \times 2$

(9) $3,590 \times 2$

850-ton $x$ (a) $3,140 \times 4$

(1) 3,140 cost

614.891

133,000

98,830

73,792

15,512

30,720

22,165

16,570

15,660

16,980

136,162

33,460

2,300

7,180

12,560

290.988

\section{Ground Total $\quad 905,879$}


WORKSHEET

WBS 5.4 Conventional Facilities ; Electric Utilities (JA)

\section{A. Summary Cost Estinater}

\begin{tabular}{|c|c|c|c|c|c|c|c|c|}
\hline \multicolumn{4}{|c|}{ Off-IFMIF Site } & \multicolumn{5}{|c|}{ On-Site At IFMIF } \\
\hline Industry & Instit' & & & Const. Co & iractor & Inștital & & \\
\hline Mat'ULab Engin & Engin & AFI & Total & Mat'T/Lab & Engin & Engin & $\mathrm{AFI}$ & Total \\
\hline$\overline{m c}$ & $\overline{\mathrm{nc}}$ & $\overline{\mathrm{nc}}$ & $\overline{\mathrm{nc}}$ & $3,100,760$ & $\mathbf{n c}$ & nc & 620,152 & $3,720,912$ \\
\hline
\end{tabular}

Currency Units: kilo Yen

\section{B. Descriotion:}

The electric service for IFMIF consists of electric service, electric system, special equipment and outside electric utilities. The total orice is not included management (1.5\%) gnd tax (5\%).

\section{Detailed WBS Listing:}

4. 0. 0. 0. Electric Utilities

1. 0. 0. Electric Service

1. 0. Cold Area

2. 0. Type-1 Controlled Area

3. 0. Type-2 Controlled Area

2. 0. 0. Ekectric System

1. 0. System for Utilities

2. 0. System for Accelerator \& Target

3. 0. On/Off Station

4. 0 . Transformer

5. 0 . UPS

6. 0. Emergency Power Supply

3. 0. 0. Electric Special Equipment

1. 0. Power System

2. 0. Ground System

4. 0. 0. Outside Electric Ualitites

\section{Costing Rational:}

Type of Estimate : bottoml-up

Allowance for Indeterminates: $\quad 20 \%$ based on technical risk

E Detailed Costing: (Unit ; k-yen)

Item

Electric Service

Electric System

Special Equipment

Outside Electric Utilities
Cost

548.144

2.433 .640

100760

18.216

Total $3,100,760$
(k-ICF)

5,221

23,178

959

173

29,531 
WORKSHEET

WBS 5.4.1 Electric Service (JA)

\section{A. Summary Cost Estimate:}

\begin{tabular}{|c|c|c|c|c|c|c|c|}
\hline \multicolumn{4}{|c|}{ Off-IFMIF Site } & \multicolumn{4}{|c|}{ On-Site At IFMIF } \\
\hline Industry & Instit' & & & Const. C & tractor & Instit'a & \\
\hline Mat'/Lab Engin & Engin & $\overline{\text { AFI }}$ & Tota & MatVLLab & Engin & Engin & AFI \\
\hline $\mathbf{D C}$ & $\mathbf{n c}$ & $\mathbf{n c}$ & $\mathrm{nc}$ & 348,144 & $\mathrm{nC}$ & ne & $109,629657,7 / 3$ \\
\hline
\end{tabular}

Currency Units: kilo Yen

\section{B. Deseription;}

The total price is not included mangagment $(1,5 \%)$ and tax $(5 \%)$.

\section{Detailed WaS Listing;}

1. 0. 0. Electric Sersice

1. 0. Cold Area

2. 0. Type-1 Controlled Area

3. 0. Type-2 Controlled Area

\section{Costing Rational:}

Type of Estimate :

Allowance for Indeterminates : $20 \%$ based on technical risk

E. Detailed Costing: (Unit : k-yen)

\subsubsection{Cold Area}

1. AAMB

2. RF PowerBay

3. Staircase Hall

4. Data Acquisition

5. HEBT Assembly Maintenance Bay

6. Staircase Hall

7. Ventilation Room

8. Auxiliary Equipment Room $1088 \mathrm{~m}^{2}$

9. Accelerator Assembly Maintenance

10. Control Room

11. Shipping Bay

12. Health Physics Station

13. Uncontaminated Shop

14. Storage

15. Shipping Bay

\section{$11,407 \underline{m}^{2}$}

$350 \mathrm{~m}^{2}(7 \mathrm{mH}) \times 25.30 \times 1.10 \times 1.00$

$3,283 \mathrm{~m}^{2}(12 \mathrm{mH}) \times 25.30 \times 1.40 \times 1.00$

$105 \mathrm{~m}^{2}(40 \mathrm{mH}) \times 25.30 \times 4.00 \times 1.00$

$232 \mathrm{~m}^{2}(5 \mathrm{mH}) \times 25.30 \times 1.00 \times 1.00$

$249 \mathrm{~m}^{2}(8 \mathrm{mH}) \times 25.30 \times 1.20 \times 1.00$

$82 \mathrm{~m}^{2}(10 \mathrm{mH}) \times 25.30 \times 1.40 \times 1.00$

$217 \mathrm{~m}^{2}(5 \mathrm{mH}) \times 25.30 \times 1.00 \times 1.00$

$350 \mathrm{~m}^{2}(5 \mathrm{mH}) \times 25.30 \times 1.00 \times 1.00$

$165 \mathrm{~m}^{2}(7 \mathrm{mH}) \times 25.30 \times 1.10 \times 1.00$

$249 \mathrm{~m}^{2}(8 \mathrm{mH}) \times 25.30 \times 1.20 \times 1.00$

$70 \mathrm{~m}^{2}(5 \mathrm{mH}) \times 25.30 \times 1.00 \times 1.00$

$70 \mathrm{~m}^{2}(5 \mathrm{mH}) \times 25.30 \times 1.00 \times 1.00$

$318 \mathrm{~m}^{2}(5 \mathrm{mH}) \times 25.30 \times 1.00 \times 1.00$

$173 \mathrm{~m}^{2}(10 \mathrm{mH}) \times 25.30 \times 1.40 \times 1.00$
Cost

351.918

9,740

116,283

10,626

5,869

7,559

2,904

5,490

27,526

8,855

8,748

7,559

1,771

1,771

8,045

6,127 
16. Passage Hall

17. Passage Hall

18. Staircase Hall

19. Passage Hall

20. Passage Hall

21. High Hall

22. Administration Building
$113 \mathrm{~m}^{2}(5 \mathrm{mH}) \times 25.30 \times 1.00 \times 1.00$

$79 \mathrm{~m}^{2}(5 \mathrm{mH}) \times 25.30 \times 1.00 \times 1.00$

$50 \mathrm{~m}^{2}(5 \mathrm{mH}) \times 25.30 \times 1.00 \times 1.00$

$113 \mathrm{~m}^{2}(5 \mathrm{mH}) \times 25.30 \times 1.00 \times 1.00$

$113 \mathrm{~m}^{2}(5 \mathrm{mH}) \times 25.30 \times 1.00 \times 1.00$

$2,288 \mathrm{~m}^{2}(9 \mathrm{mH}) \times 25.30 \times 1.20 \times 1.00$

$1,650 \mathrm{~m}^{2}(5 \mathrm{mH}) \times 25.30 \times 1.00 \times 1.00$
2,858

1,998

1,265

2,858

2,858

69,463

41,745
1.2.0 Type-1 Controlled Area

1. Li Cooler Room

2. N/A

3. Li Purification Room

4. Li Surge Tank Room

5. Access Maintenance Room

6. Target Interface Room

7. Beam Calibration Station

8. Test Cell Technology Room

9. Test Cell

10. Beam Calibration Station

11. Test Call

12. Test Cell Technology Room

13. Operating Area

14. Red Waste Processing

15. Red Waste Shipping

16. Hot Cell Utility Area

17. PIE Laboratory Area

18. Tritium Laboratory

19. Manipulator Repair

20. Hot \$hop

1.3.0 Type-2 Controlled Area

1. Li Dump Tank Room

2. Spare Room

3. Beam Tuming Room

4. Accelerator Hall

5. Accelerator Hall

\section{$4182 \mathrm{~m}^{2}$}

$188 \mathrm{~m}^{2}(6 \mathrm{mH}) \mathrm{x}$

$211 \mathrm{~m}^{2}(20 \mathrm{mH}) \mathrm{x}$

$161 \mathrm{~m}^{2}(6 \mathrm{mH}) \mathrm{x}$

$177 \mathrm{~m}^{2} \quad(6 \mathrm{mH}) \mathrm{x}$

$161 \mathrm{~m}^{2}(14 \mathrm{mH}) x$

$102 \mathrm{~m}^{2}(10 \mathrm{mH}) \mathrm{x}$

$139 \mathrm{~m}^{2}(9 \mathrm{mH}) \mathrm{x}$

$23 \mathrm{~m}^{2}(3 \mathrm{mH}) \mathrm{x}$

$13 \mathrm{~m}^{2}(6 \mathrm{mH}) x$

$13 \mathrm{~m}^{2} \quad(4 \mathrm{mH}) \mathrm{x}$

$13 \mathrm{~m}^{2} \quad(6 \mathrm{mH}) x$

$23 \mathrm{~m}^{2}$ ( $\left.3 \mathrm{mH}\right) \mathrm{x}$

$560 \mathrm{~m}^{2}(12 \mathrm{mH}) \mathrm{x}$

$150 \mathrm{~m}^{2}(5 \mathrm{mH}) \mathrm{x}$

$150 \mathrm{~m}^{2}(5 \mathrm{mH}) \mathrm{x}$

$821 \mathrm{~m}^{2}(5 \mathrm{mH}) \mathrm{x}$

$605 \mathrm{~m}^{2} \quad(5 \mathrm{mH}) \mathrm{x}$

$518 \mathrm{~m}^{2}(5 \mathrm{mH}) \mathrm{x}$

$77 \mathrm{~m}^{2}(5 \mathrm{mH}) \mathrm{x}$

$.77 \mathrm{~m}^{2}(5 \mathrm{mH}) \mathrm{x}$

$25.30 \times 1.10 \times 2.00$

$25.30 \times 1.80 \times 2.00$

$25.30 \times 1.10 \times 2.00$

$25.30 \times 1.00 \times 2.00$

$25.30 \times 1.40 \times 2.00$

$25.30 \times 1.40 \times 2.00$

$25.30 \times 1.20 \times 2.00$

$25.30 \times 1.00 \times 2.00$

$25.30 \times 1.10 \times 2.00$

$25.30 \times 1.10 \times 2.00$

$25.30 \times 1.10 \times 2.00$

$25.30 \times 1.10 \times 2.00$

$25.30 \times 1.40 \times 2.00$

$25.30 \times 1.00 \times 2.00$

$25.30 \times 1.00 \times 2.00$

$25.30 \times 1.10 \times 2.00$

$25.30 \times 1.00 \times 2.00$

$25.30 \times 1.00 \times 2.00$

$25.30 \times 1.00 \times 2.00$

$25.30 \times 1.00 \times 2.00$

$2466 \mathrm{~m}^{2}$

$453 \mathrm{~m}^{2}(7 \mathrm{mH}) \mathrm{x}$

$176 \mathrm{~m}^{2}(5 \mathrm{mH}) \mathrm{x}$

$995 \mathrm{~m}^{2}$ (11 MH) $\mathrm{x}$

$421 \mathrm{~m}^{2}(6 \mathrm{mH}) \mathrm{x}$

$421 \mathrm{~m}^{2}(6 \mathrm{mH}) x$
$25.30 \times 1.10 \times 1.00$

$25.30 \times 1.00 \times 1.00$

$25.30 \times 1.40 \times 1.40$

$25.30 \times 1.10 \times 1.00$

$25.30 \times 1.10 \times 1.00$
120,494

5,232

9,608

4,480

4,925

5,702

3,612

4,220

581

361

328

361

581

19,835

3,795

3,795

20,771

15,306

13,105

1,948

1,948

75.732

12,606

4,452

35,242

11,716

11,716 
WORKSHEET

WBS 5.4.2 Electric System (JA)

\section{A. Sungmary Cost Estimate:}

\begin{tabular}{|c|c|c|c|c|c|c|}
\hline \multicolumn{4}{|c|}{ Off-IFMir Site } & \multicolumn{3}{|c|}{ On-Site At IFMEF } \\
\hline Industry & Instit' & & & Const. Contractor & Instit'al & \\
\hline Mat'/Lab Engir & Engin & AFI & Total & Mat3/Lab Engin & Engin & Total \\
\hline $\mathbf{n} \bar{c}$ & ne & nc & $n$ & $2,433,640$ & $\mathrm{nc}$ & $2,920,368$ \\
\hline
\end{tabular}

\section{Currency Units: kilo Yen}

\section{B. Description:}

The total price is not included management $(15 \%)$ and tax $(5 \%)$.

\section{Detalled WBS Lisfing:}

2. 0, 0. Electric System

1. 0. Systern for Utilities

2. 0. Systern for Accelerator \& Target

3. 0. On/Off Station

4. 0. Transfonter

5. 0. UPS

6. 0. Emergency Power Supply

\section{Costing Rational:}

Type of Estimate :

Allowance for Indeterminates : $\quad 20 \%$ based on technical risk

E. Detailed Costing: (Unit : k-yen)

2.1.0 System for Utilities

1. 22 kV System

2. Master Line Board

3. Primary Board

4. Transformer $1000 \mathrm{kAV} 22 \mathrm{kV} / 420 \mathrm{~V}$

5. High Voltage Swiching boazd $6 \mathrm{kV}$ VCB

6. Low Voltage Swiching board

7. System watching Board

8. Power Supply 250 AH

9. Ground E1, ES3, E2

2.2.0 Accelerator \& Target

2.3.0 On/Off Station

2.4.0 Transformer

2.5.0 UPS

2.6.0 Emergency Power Supply
1 set

2 sets $x$ (1) 5,500

6 sets $x @ 10,000$

(a) $15,000 \times 7$

2 sets $x @ 14,000$

20 sets $x @ 7,500$

1 set

1 set

1 set
Cast

427,150

25,000

11,000

60,000

105,000

28,000

150,000

17,500

29,551

1,099
60 MVA

$100 \mathrm{kVA}$

$200 \mathrm{kVA}$
500,000

7010,000

620.000

80,030

106,490

Total $\quad \overline{2,433,640}$ 
WBS 5.4.3 (JA)

WORKSHEET

WBS 5.4,3 Electric Special Equipment (JA)

A. Summary Cost Estimate:

\begin{tabular}{|c|c|c|c|c|c|c|c|}
\hline \multicolumn{4}{|c|}{ Off-IFMIF Site } & \multicolumn{4}{|c|}{ On-Site At IFMIF } \\
\hline Industry & Instit' & & & Const. C & tractor & Instit'a & \\
\hline Mat'1/Lab Engin & Engin & AFI & Total & Mat'VLab & Engin & Engin & Total \\
\hline$\overline{\mathrm{nc}}$ & nc & ne & nc & $100,760^{\circ}$ & $\overline{n c}$ & nc & $20,152 \quad 120,912$ \\
\hline
\end{tabular}

Currency Ujoits: kilo Yen

B. Description:

The Cooling Water Utilities consist of cooling system for type-1 area, type-2 \& cold area and accelerator \& target. The tofal price is not included management $(1.5 \%)$ and tax $(5 \%)$

C. Detailed WBS Listing:

3. 0. 0. Special Equipment

1. 0. Fower System

2. 0 . Ground System

D. Costing Rational:

Type of Estimate :

Allowance for Indeterninates : $\quad 20 \%$ based on technical risk

E. Detailed Casting: (Unit : k-yen)

cost

3.1 Power System

97,600

3.2 Ground System

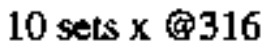

3,160

Total 100,760 
WORKSEEET

WBS 5.4.4 Outside Electric Utilities (JA)

\section{A. Summary Cost Estimate:}

\begin{tabular}{|c|c|c|c|c|c|c|c|c|}
\hline \multicolumn{4}{|c|}{ Off-IFMifF Site } & \multicolumn{5}{|c|}{ On-Site At IFMIF } \\
\hline Industry & Instit' & & & Const. C & itractor & Instit'al & & \\
\hline Mat'LLab Engin & Engin & AFI & Total & Mat'1/ab & Engin & Engin & AFI & Total \\
\hline$\overline{\mathrm{MC}} \quad \mathrm{nc}$ & $\overline{\mathrm{nc}}$ & nc & $\mathrm{nc}$ & 18,216 & $\mathrm{nc}$ & $\mathfrak{n c}$ & 3,644 & 21,860 \\
\hline
\end{tabular}

Currency Units: kilo Yen

\section{B. Description:}

The distance from substation to this building is $100 \mathrm{~m}$. The total price is not included management $(1.5 \%)$ and tax $(5 \%)$.

C. Detailed WBS Listing:

4. 0. 0. Ontside Electric Utilities

\section{Costing Rationat:}

Type of Estimate :

Allowance for Indeterminates: $20 \%$ based on tecthical risk

E. Detailed Costing: (Unit : k-yen)

1. $22 \mathrm{kV}$ CVT 150

2. CVVS $2-10 \mathrm{C}$

3. CPEVS $0.9 \times 30 P$

4. Outside Path GL-1200, $150 \times 2$

5. Outside Path GL-600, 100x3

6. Manhole for $22 \mathrm{kV}$

7. Manhole bottom-up 
WBS 5.5.0(JA)

\section{WORKSHEET \\ WBS 5.5.0 Radioactive Waste Treatment Systems (JA)}

\section{A. Summary Cost Bstimate:}

\begin{tabular}{|c|c|c|c|c|c|c|}
\hline \multicolumn{3}{|c|}{ Off-IFMLF Site } & \multicolumn{4}{|c|}{ On-Site At IFMIF } \\
\hline Industay & Instit & & Const. Co & itractor & Instit'al & \\
\hline Mat'l/Lab Engin & Engin & AFI Total & Matl'Lab & Engin & Engin & AF் Total \\
\hline $2,859 \quad 2,114$ & 787 & $2,4688,228$ & $\overline{\mathbf{n c}}$ & 2,493 & 2,493 & $2,138 \quad 7,124$ \\
\hline
\end{tabular}

Currency Units: kilo.ICF

\section{B. Description:}

The Waste Treatment Systerns will manage the gaseous, liquid and solid wastes generated from IFMIF components. They consist of Exhaust Gas Detritiation System, Temporary Exhaust Detritjation System, Liquid Waste Treatment System and Solid Waste Treatment System. Exhaust gas that contains tritium is cleaned in the processing systems described here and sent to the Nuclear HVAC for disposal from stack. Solid and Licuid wastes are processed and packaged for shipment to the final processing / disposal facility of the hosting site.

\section{Detailed WBS Listing}

\subsubsection{Exhaust Gas Detritiation System}

5.5.2 Temporary Exhaust Gas Detritiation System

5.5 .3 Liquid Waste Treatment System

5.5.4 Solid Waste Treatment System

\section{Casting Rational:}

Most of the cost estimated are obtained by scaling and factoring from the experience of the existing facilities that handles irradiated and/or contaminated materials. Equipment to be installed in the system are assumed to be purchased from the industry including design, assembly and testing. Industry and institutional engineering costs are estimated for the total of the each subsystems. AFIs are estimated to be $30 \%$, because of the uncertainty of the detailed requirements and source terms, while major part of the system can be assembied with existing technology. Personnel costs are estimated as follows;

Industry: $10 \%$ manager, $50 \%$ experts and $40 \%$ labor, averaged to be 19 Myen/year. Institutional : 15M yen/year. 
WBS 5.5.1(JA)

WORKSHEET

WBS 5.5.1 Exhanst Detritiation System (JA)

\section{A. Summerry Cost Estimate:}

\begin{tabular}{|c|c|c|c|c|c|c|c|}
\hline \multicolumn{4}{|c|}{ Off-IFMIF Site } & \multicolumn{4}{|c|}{ On-Site At IFMIF } \\
\hline Ind & & Instit' & & Const. Co & ntractor & Instit'al & \\
\hline Mat'/Lab & Engin & Engin & Total & Mat'L/Lab & Eñgin & Engin & AFI Total \\
\hline 899 & 453 & 215 & 2,238 & nc & 950 & 950 & $814 \quad 2,714$ \\
\hline
\end{tabular}

Currency Units: kilo.ICF

\section{B. Description:}

Exhaust Gas Detritiation System is operated for management of the exhaust gas from vacuum systems, the tritium cell, GB exhaust system and some other process effluent. The exhaust gas from the vacuum system is assumed to consist of about $1 \mathrm{~m}^{\mathrm{s}} / \mathrm{h}$ of Ar with $1 \times 10^{\mathrm{s}}$ $\mathrm{Bq} / \mathrm{cc}$ tritium gas and about $19 \mathrm{~m}^{3} / \mathrm{h}$ of atr with $0-5 \mathrm{~Bq} / \mathrm{cc}$ liquid tritiated water equivalent vapor. The amount of the exhaust gas from other sources such as tritium cell and GB exhausting system is considered to be total of $200 \mathrm{~m}^{3} / \mathrm{h}$ with a small amount of tritiated water. Process is based on permeation membrane technology and no materials are consumed by the operation.

\section{C.WBS.Listing;}

\subsubsection{Exhazst Detritiation System}

\section{Costing Rational:}

Cost estimate on this system is based on the industrial dry air production equipment, and a detritiation system being developed in Japanese facility. 
WBS 5.5.2(JA)

WORKSHEET

WBS 5.5.2 Temporary Exhaust Detritiation System (JA)

\section{A. Summary Cost Estimate:}

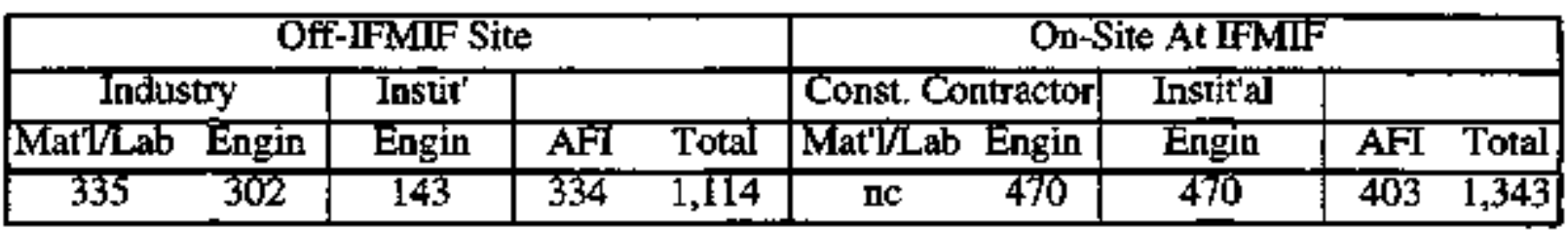

Currency Units:_kilo.ICF

\section{B. Description:}

Temporary Exhaust Gas Detritiation System is operated for management of the gas, mostly anticipated to be air with low level tritiated water vapor which is exhausted in operation for mainfenance. The amount of temporary exhaust gas is considered to be $100 \mathrm{~m}^{3} / \mathrm{h}$ with a small amount of tritiated water, fed through the flexible ventilation ducts from various areas of the facility where the maintenance operation with radioactive contamination is anticipated.

\section{WBS Listing}

\subsubsection{Temporary Exhaust Detritiation System}

\section{Cosfing Rational:}

Cost is estimate from a dry air production unit based on hollow fiber permeation membrane commercially available in Japan. 
WORKSHEET

WBS 5.5.3 Liquid Waste Treatment System (JA)

\section{A. Summary Cost Estimate:}

\begin{tabular}{|c|c|c|c|c|c|c|c|c|c|}
\hline \multicolumn{5}{|c|}{ Off-IFMIF Site } & \multicolumn{5}{|c|}{ On-Site At IFMIF } \\
\hline Indu & & Instit' & & & Const. & ntractor & Instit'a & & \\
\hline Mat'/Lab & Engin & Engin & AFI & Total & Mat'VLab & Engin & Engin & $\widehat{\mathrm{AFI}}$ & Total \\
\hline 414 & 453 & 143 & 433 & 1,443 & nc & 640 & 640 & 349 & 1,829 \\
\hline
\end{tabular}

\section{Currency Units: kilo ICF}

\section{B. Description:}

Liquid Waste Treatment System is operated for management of liquid wastes. Liquid wastes are considered to be generated mainly from cooling system of accelerator facility and decontamination facility for the components removed for maintenance purpose. Backwall and target assemble from the target system, and irradiated VTA and sample capsule parts are anticipated to be the major source of the solid waste to be cleaned. The amount of the liquid wastes is considered to be about $10 \mathrm{~m}^{3} / y e a r$ of alkaline water with lithium bydroxide and about $5 \mathrm{~m}^{3} /$ year of neutral water. A small amount of tritiated water and radioactive metals generated by collision are considered to be included in the liquid wastes.

Waste water is recycled after the treatment by neutralization, evaporation and ion exchange for purification. Concentrated liquid waste is solidified for disposal. Tritium removal is not attempted.

\section{WRS Listinat:}

\subsubsection{Liquid Waste Treatment System}

\section{Costing Rational:}

Cost is based on a small liquid waste bandling equipment recently installed in a irradiation facility in Japan. 
WORKSHEET

WBS 5.5.4 Solid Waste Treatment System (JA)

\section{A._Summary Cost Fstimate:}

\begin{tabular}{|c|c|c|c|c|c|c|c|c|}
\hline \multicolumn{5}{|c|}{ Off-IFIMIFSife } & \multicolumn{4}{|c|}{ On-Site At LFMIF } \\
\hline Indu & & Instit' & & & Const. C & atractor & Instit'a & \\
\hline Mat'//Lab & Engin & Engin & $\overline{\mathrm{AFT}}$ & Total & Mat'1/Lab & Engin & Engin & AFI Total \\
\hline $1,2 \mathrm{II}$ & 906 & 286 & 1,030 & 3,433 & nc & $\overline{433}$ & $4 \overline{33}$ & 1,238 \\
\hline
\end{tabular}

\section{Cumency Units: kilo ICF}

\section{B. Description:}

Solid Waste Treatment System is operated for management of solid wastes. The main solid wastes are considered to be irradiated articles of consumption from the target room. About $30 \mathrm{~kg} /$ year of solid wastes are considered to be generated from the target room in normal operation, and about $200 \mathrm{~kg} / \mathrm{batch}$ of solid wastes are also considered to be generated irregularly at maximum. The amount of other solid wastes such as irradiated specimens and holders, etc., is considered to be about 10 containers/year.

The system is installed in the tritium hot cell in the Post Iradiation Examination facility that has a capability to handle activated and tritium-contaminated materials.

\section{WBS Listing:}

\subsubsection{Solid Waste Treatment System}

\section{Costing Rational:}

Cost is based on a small solid waste handling equipment recently installed in a iradiation facility in Japan. 
Cost Estimating

Worksheets

\section{for \\ WBS 6.0}

Central Instrumentation and Control Systems 


\section{WORKSHEET}

\section{WBS 6.0 Common Instrumentation and Central Control Systems \\ WBS 6.1 System Management \\ WBS 6.1.1 Project Management and Administration}

A. Summary Cost Estimate:

\begin{tabular}{|c|c|c|c|c|c|}
\hline \multicolumn{3}{|c|}{ Off-IPMIF Site } & \multicolumn{3}{|c|}{ On-Site At IFMIF } \\
\hline Industry & 'Instit' & & $\begin{array}{l}\text { Const. } \\
\text { Contractor }\end{array}$ & Instit'al & \\
\hline $\begin{array}{l}\text { Matl/ Engin } \\
\text { Lab }\end{array}$ & Engin & AFI Total & $\begin{array}{l}\text { Mat'l/ Engin } \\
\text { Lab }\end{array}$ & Engin & AFI Total \\
\hline & 38 & 40 & 0 & 76 & 80 \\
\hline
\end{tabular}

Currency Units: kilo_ICF

B. Description:

This project management and administration are included in works : a) Outline system design, b) Time schedule management, c) Process management, d) Cost management, e) Regulation with the Accelerator, Test Cell Facilities, Target System, Conventional Facility, etc., f) Documentation.

\section{Detailed WBS Listing:}

1. 0.0 . 0 . Project Management and Administration

1. 0 . 0 . Administration

3. 0 . 0. Schedule

4. 0. 0. Documentation

D._Costing Rationale:

(1) Cost of Labor : $6 \mathrm{My}$

Type of Estimate: Bottoms-up

E. Detailed Costing:

(1) 114,000 ICF (2 My for off-site $+4 \mathrm{My}$ for on-site)

(2) AFI : about $5 \%$ 6,000 ICF 


\section{WORKSHEET \\ WBS 6.2.1 Beam Instrumentation}

\section{A. Summary Cost Estimate:}

\begin{tabular}{|c|c|c|c|c|c|c|}
\hline \multicolumn{3}{|c|}{ Off-IFMīF Site } & \multicolumn{4}{|c|}{ On-Site At IFMIF } \\
\hline Industry & Instit' & & Const. C & ntractor & Instital & \\
\hline $\begin{array}{l}\text { Mat'l/ Engin } \\
\text { Lab }\end{array}$ & Engin & AFI Total & $\begin{array}{l}\text { Mat'I/ } \\
\mathrm{Lab}\end{array}$ & Engin & Engin & AFI \\
\hline 92,000 & $\overline{\mathrm{IC}}$ & $27,600 \quad 119,600$ & 0 & 18,000 & $\mathbf{n c}$ & 5,400 \\
\hline
\end{tabular}

\section{Currency Units: kilo Yen}

\section{B. Description:}

Two types of on-target beam profile monitors are considered bere. One is a set of IR thermal tmage camera, telescope lens, mirror and sapphive window. The other is a set of collimators and small neutron detectors.

\section{Detailed WBS Listing:}

1. 0. 0. 0. Beam Instrumentation

1. 0. D. On-Target Profile Monitor

1. 0. Optical/RR Viewing

2. 0. Neutron Imaging

\section{Costing Rationale;}

The cost estimation is based on the information of IR themal image camera makers micro-channel plate/image intensifjer maker and JAERI's experience.

Type of Estimate : nearly bottom-up and scaling

Allowance for Indeterminates: $\quad 30 \%$ based on technical risk

\section{E. Detailed Costing:}

\subsection{Optical $\mathbb{R}$ Viewing}

(1) Research and Development Cost : $\quad 40,000 \mathrm{k}$-yen for two years

(2) Manufacturing

(3) Instaltation and test $32,000 \mathrm{k}-\mathrm{yen}$ for two sets $6,000 \mathrm{k}$-yen

\subsection{Neutron Imaging}

(1) Research and Development Cost :

(2) Manufacturing

(3) Installation and test 


\section{WORKSHEET}

\section{WBS 6.2.2 Radiation Monitaring}

A. Surmary Cost Estimate:

\begin{tabular}{|c|c|c|c|c|c|c|}
\hline \multicolumn{3}{|c|}{ Off-IFMIF Site } & \multicolumn{4}{|c|}{ On-Site At IFMIF } \\
\hline Industry & Instit' & & Const. Contractor & Instit'g! & & \\
\hline$\underset{\mathrm{b}}{\text { Mat'Va Engin }}$ & Engin & Total & $\underset{b}{M a t V l a}$ Engin & Engin & AFI & Total \\
\hline $274,630 \quad 7,200$ & ne & 287,296 & $14,700 \quad 44,340$ & ne & $6 \overline{14}$ & 59,654 \\
\hline
\end{tabular}

Currency Units: kilo Yen

B. Description:

The radiation monitoring system for IFMIF consists of existing ordinary equipment, devices, detectors and electronic modules. They are summarized in attached table. No R\&D is nteded.

C. Detailed WBS Listing:

2. 0. 0. 0. Radiation Monftoring

1. 0. 0. Radiation Monitor

2. 0. 0. Device Controller

D. Costing Rationale:

The cost estimation is based on manufacturer quotes.

Type of Estimate bottom-up

Allowance for Indeterminates: usually low

Additional two gamma and one neutron monitors are assumed as AFI.

E. Detailed Costing: (Unit : k-yen)

1. Radiation Monitor

Item

Hand \& Foot Monitor

GM Survey Meter

Dose Meter $(\mathrm{g} \& \mathrm{~b})$

Neutron REM Counter

Surface Tritium Survey Meter

\begin{tabular}{rcrl} 
Price & Number & \multicolumn{1}{c}{ Cost } & Rernarks \\
$8,500$. & 3 & $\underline{25.500}$ & MBR-49 \\
390. & 6 & $\underline{2.340 .}$ & TGS-133 \\
350, & 6 & $\underline{\mathbf{2 . 1 0 0}}$ & ICS-311 \\
1,200, & 3 & $\underline{3.600}$ & TPS-4S1BS \\
1,200, & 3 & $\underline{3.600}$ & TPS-303 \\
5,500, & 2 & $\underline{11.000}$ & MGR-121 \\
50, & 25 & $\underline{1,250 .}$ & ADM-102 \\
& 1 & $\underline{16.800}$ & LSC-LB III
\end{tabular}

Potable Tritium/Gas Monitor

Pocket Dosimeter

Liquid Scintillation Counter 
Item

Personnel Glass Dosimeter

Glass Dosimeters with holder Continuous Reader

Stack Gas Monitor

Detector Module

Measuring Modules

Stack Dust Monitor

Detector Module

Measuring Modules

Integral Tritium Monitor

Tritium Catcher

Liquid Scintillation Counter

Room Gas Monitor

Detector Module

Detector Modules

Neutron Area Monitor

Detector Module

Measuring Modules

Gamma-Ray Area Monitor

Detector Module

Measuring Modules

Outdoor Monitoring Post

Monitoring Post

Measuring Modules

Leak Detector for Organic Loop

Detextor Module

Measuring Modules

Indication Panel

Air Sarmpling System

Installation (on-site)

Total \$ystem Design

Total Test and Adjustment

Test at Factory

Price

Number

9, $\begin{array}{rr}\text { Subtotal } & 11,900 \\ 100 & 900 \\ 1 & 11,000\end{array}$

Remarks

\begin{tabular}{cr} 
Subtotal & 12,000 \\
\hline 1 & 9,000, \\
1 & 3,000
\end{tabular}

\begin{tabular}{|c|c|c|c|}
\hline & $\begin{array}{r}\text { Subtotal } \\
1 \\
1\end{array}$ & $\begin{array}{l}6,910 \\
4,350 \\
2,560\end{array}$ & DSH-451R, \\
\hline & See Above & 1.700 & S-1878TND \\
\hline 9,000 & 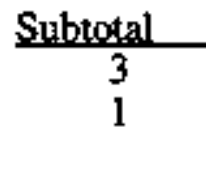 & $\begin{array}{c}34,000 \\
27,000 \\
7,000\end{array}$ & $\begin{array}{l}\text { RIC-512BU } \\
\text { MGR-R74, } \\
\text { etc. }\end{array}$ \\
\hline 1,440 , & $\begin{array}{c}\text { Subtotai: } \\
5 \\
1\end{array}$ & $\begin{array}{r}15,400 \\
7,200 \\
8,200\end{array}$ & NDB-52152, \\
\hline 870 , & 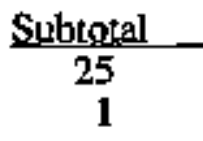 & $\begin{array}{l}59,640 \\
21,750 \\
37,890\end{array}$ & \\
\hline 9,000 & $\frac{\text { Subtotal }}{2}$ & $\begin{array}{l}30,000 \\
18,000 \\
12,000\end{array}$ & DPM-201 \\
\hline & $\begin{array}{c}\text { Subtotal } \\
1 \\
1\end{array}$ & $\begin{array}{r}2.360 \\
870 \\
1,490\end{array}$ & \\
\hline & Subtotal & 21750 & \\
\hline & & 5,400 & \\
\hline & & 14.100. & \\
\hline & & $6,000$. & \\
\hline & & 6.800 & \\
\hline \multicolumn{4}{|c|}{1.200} \\
\hline
\end{tabular}

DSH-451R,

RIC-512BU

AM-23MR74, etc.

GD-402

FGD-603

RIC-512BU

MGR-R74, 
Item

Transportation/Shipping

Inspection/Test (On-site)

Documents

Total Charge

AFI for Materials

AFI for Construction
Price Number Cost

600.

2.200

4.800.

28.340

5.466.

614.

Total of Rediation Monitor

344,370, k-Yen

\section{Device Controller}

Item

CPU

ADC

Data Input

Data Output

Chassis

Software (OS)

$\begin{array}{cccl}\text { Price } & \text { Number } & \text { Cost } & \text { Remarks } \\ & 1 & \underline{700,} & \text { DVE-AT486, 32MB } \\ 300, & 3 & \underline{900,} & \text { MVNE-512,16ch } \\ 160, & 2 & \underline{320} & \text { DVE-528, 49ch } \\ & 1 & \underline{160} & \text { DVE-529,16ch } \\ & 1 & \underline{400} & \\ & 1 & \underline{100} & \text { Windows-NT } \\ \text { rooller } & & 2580, k-Y e n\end{array}$

Remarks

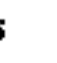




\section{IFMIF Site and Building Health Physics Monitors}

Tye

Hand \& Foot Monitor

GM Survey Meter

Dose Meter (g b)

Neutron REM Counter

Sufface Tritium Survey Meter

Potable Tritiurd/Gas Moritor

Pocket Dosimeter

\section{E}

Reader for Glass Dosimeter

Liquid Scintillation Counter

Stack Gas Monitor

Stack Dust Monitor

Integral Tritium Monitor

Room Gas Monitor

Newtrọn Area Monitor

Gamma Arta Monitor

Monitoring Post ( $\mathbf{0} \& \mathbf{g}$ )

Leak Detector (g \& b)
Outșide

Entrance of Controlled Area

Rad Waste Processing

Entrance of Controlled Area

Entrance of Contuolied Area

Entrance of Controlled Area

Entrance of Controlled Area

Entrance of Controllod Area

utrance of Coutrolled Area

Entrance of Controlled Area

Entrance of Controlled Area

Entrance of Controlled Area

Ventitation Stack

Vertilation Stack

Ventilation Stack

PIE Laboratory Areas

Li Process Area

Target Access Rooms

Control Room

Beam Turning Areas

Test Cell Techlnołogy Rooms

Accelerator Rooms

Beam Turving Area

RF Power Bay

Test Cell Technology Rooms

Control Room

PIE Laboratory Artas

Hot Shop

Manipulator Repair

Rad Waste Processing

Rad Waste Shipping

Organic Loop
Ninmber

Distance

$15 \mathrm{~m}$

$130 \mathrm{~m}$

6

3

3

2

25

100

1

l

with alarm

g. X, nth

$>100$

t]ra-Low Level

$30^{* *}+40$ Iㅁ

$30^{* *}+40 \mathrm{~m}$

L.S.C. is needed.

1

$60^{* *}+40 m$

$30^{* * *}+40 \mathrm{~m}$

$30^{m *}+40 \mathrm{~m}$

2

$20 \mathrm{~m}$

$60 \mathrm{~m}$

$30 \mathrm{~m}$

$120 \mathrm{~m}$

$60 \mathrm{~m}$

$120 \mathrm{~m}$

$30 \mathrm{~m}$

$20 \mathrm{~m}$

$40 \mathrm{~m}$

$80 \mathrm{~m}$

$80 \mathrm{~m}$

$50 \mathrm{~m}$

$60 \mathrm{~m}$

$150 \mathrm{mt}$

for Skyshine

$30 \mathrm{~m}$

* Distance between detector bead and controllerfrecorder

** Distance between sampler head and detector, and between detector and contrallerfrecorder 
WORKSHEET

WBS 6.2.3 Video Monitoring

\section{A. Summary Cost Estimate:}

\begin{tabular}{|c|c|c|c|c|c|}
\hline \multicolumn{3}{|c|}{ Off-IFMif Site } & \multicolumn{3}{|c|}{ On-Site At IFMiF } \\
\hline Industry & Instit' & & Const. Contractor & Instit'al & \\
\hline $\begin{array}{l}\text { Mat'/ Engin } \\
\text { Lab }\end{array}$ & Engin & Total & $\begin{array}{c}\text { Mat'y Engin } \\
\text { Lab }\end{array}$ & Engin & AFI \\
\hline 24,000 & 0 & $11,415 \quad 113,56$ & 21,000 & 0 & 21.000 \\
\hline
\end{tabular}

\section{Currency Units: kilo Yen}

\section{B. Description:}

Video monitoring system considered here are used for visually monitoring all over the IFMIF facility. This system includes 24 zoom cameras with panheads, 6 video displays and 1 local area network. Because this system send both image data and camera control signals through its own local area network, it is very easy to expand.

\section{Detailed WBS Listing:}

3. 0 . 0. t. Video Monitoring

1. D. D. ITV Camera

2. 0. 0. Display

3. 0. 0. Device Controller

\section{Costing Rationale:}

The cost estimation is based on manufacturer quotes.

Type of Estimate : bottom-up

Allowance for Indeterminates: 10\% AFI is applied to account for change in material and laboring cost, and $15 \%$ AFI is applied to account for ambiguity of development of application software in engineering cost.

E. Detailed Costing: See detailed estimate 
WORKSHEET

5WBS 6.2.4 Aceess Control

\section{A. Summary Cost Estimate:}

\begin{tabular}{|c|c|c|c|c|c|}
\hline \multicolumn{3}{|c|}{ Off-IFMIF Site } & \multicolumn{3}{|c|}{ On-Site At IFMIF } \\
\hline Industry & Tnstit' & & Const. Contractor & Instit'al & \\
\hline $\begin{array}{l}\text { Mat'l/ Engin } \\
\text { Lab }\end{array}$ & Engin & Total & $\begin{array}{c}\text { Mat'l/ Engin } \\
\text { Lab }\end{array}$ & Engin & AFI \\
\hline 24,000 & 0 & 59,341 & 14,000 & 0 & 14,000 \\
\hline
\end{tabular}

Currency Units: kilo Yen

B. Description:

Access control system js provided for the protection of personal from the hazards of radiation generated by the machine. This system limits personal access by door limit switches and keybank cormbination, and notify the operation mode by warning lights. This system also includes emergency stop switches.

\section{Detailed WBS Listing:}

4. 0. 0. 0. Access Control

t. 0. 0. Door Lturit Switch

2. 0. 0. Keybank

3. 0. D. Warning Light

4. 0. 0. Emergency Stop Switch

D. Costing Rationale:

The cost estimation is based on manufacturer quotes.

Type of Estimate : bottom-up

Allowance for Indeterminates: $10 \% \mathrm{AFI}$ is applied to account for change in material and laboring cost, and 15\% AFI is applied to account for ambiguity of development of application software in engineering cost.

E. Detailed Costing: See detailed estimate 
WORKSHEET

WBS 6.2.5 Annunciator

A. Summary Cost Estimate:

\begin{tabular}{|c|c|c|c|c|c|c|}
\hline \multicolumn{3}{|c|}{ Off-IFMif Site } & \multicolumn{4}{|c|}{ On-Site At IFMiF } \\
\hline Industry & Instrt ${ }^{\prime}$ & & Const. Contractor & Instit'al & & \\
\hline $\begin{array}{l}\text { Mat'li Engin } \\
\text { Lab }\end{array}$ & Engin & Total & $\begin{array}{c}\text { Mat'V Engin } \\
\text { Lab }\end{array}$ & Engin & $\mathrm{AFI}$ & Total \\
\hline $22,500 \quad 24,000$ & 0 & 52,350 & 8,400 & 0 & 0 & 8,400 \\
\hline
\end{tabular}

Currency Units: kilo Yen

\section{B. Description:}

Annunciator system is used for alerting and notifying about system condition. This system is also usable as paging and broadcasting system over this facility.

C. Detailed WBS Listing:

5. 0. 0. 0. Annunctotor

I. 0. 0. Speaker

2. 0. 0. Device Coniroller

D. Costing Rationale:

The cost estimation is based on manufacturer quotes.

Type of Estimate : bottom-up

Alowance for Indeterminates: $10 \%$ AFl is applied to account for change in material and laboring cost, and $15 \%$ AFI is applied to account for ambiguity of development of application software in engineering cost.

E. Detailed Costing: See detailed estirnate 
WORKSHEEY

WBS 6.2.6 Information Display Stations

A. Summary Cost Estimate:

\begin{tabular}{|c|c|c|c|c|c|c|}
\hline \multicolumn{3}{|c|}{ Off-IFMIF Site } & \multicolumn{4}{|c|}{ On-Site At IFM } \\
\hline Industry & Instit' & & Const. Contracto & Instit'a & & \\
\hline $\begin{array}{l}\text { Mat'l Engin } \\
\text { Lab }\end{array}$ & Engin & Total & $\begin{array}{c}\text { Mat'l/ } \\
\text { Labs }\end{array}$ & Engin & $\overline{\mathrm{AFI}}$ & \\
\hline 24,000 & 0 & 88,779 & 16,800 & 0 & 0 & 16,800 \\
\hline
\end{tabular}

Cumency Units: kilo Yen

B. Description:

Information display stations considered here is used for broadcasting system condition, operation schedules, shift tables, and so on. On each terminal, any information is available by selecting channel on this CCTV network.

\section{Detailed WBS Listing:}

6. 0. 0. 0. Informatlon Depplay Stations

1. 0. 0. CCTV Network

2. 0. D. Controller

3. 0. 0. Display Terminals

\section{Costing Rationale:}

The cost estimation is based on manufacturer quotes.

Type of Estimate : bottom-lop

Allowance for lndeterminates: $10 \%$ AFI is applied to account for change in material and laboring cost, and $15 \%$ AFI is applied to account for ambigutity of development of application software in engineering cost.

E. Detailed Costing: See detailed estimate 
WORKSHEET

WBS 6.2.7 Safety and Emergency Equipment

\section{A. Summary Cost Estimate:}

\begin{tabular}{|c|c|c|c|c|c|c|c|}
\hline \multicolumn{4}{|c|}{ Off-1FVur Site } & \multicolumn{4}{|c|}{ On-Site At Ir MiF } \\
\hline Industry & Instif' & & & Const. Co & intracto & Instit'al & \\
\hline $\begin{array}{l}\text { Mat17 Engin } \\
\text { Lab }\end{array}$ & Engin & $\overline{\mathrm{AF} 1}$ & Total & $\begin{array}{c}\text { Mat'l' } \\
\text { Lab }\end{array}$ & Engin & Engin & Total \\
\hline 9,730 & $\mathrm{nc}$ & $\mathbf{n c}$ & 9,730 & 0 & 500 & nc & 500 \\
\hline
\end{tabular}

\section{Dumency Units:_kilo Yen}

B. Descriotion:

Equipment considered here are used for fire, oxygen deficit, Li leak, radioactive gas leak accidents and so on. All of them are commercially available.

\section{Detgiled WBS Listing:}

7. 0. 0. 0. Safety and Emergency Equipurent

1. 0. 0. Oxygen Deficit

2. 0. 0. Fire

3. 0. 0. Radio Active Gas Leak

\section{Costing Rationale:}

The cost estimation is based on manufacturer quotes.

Type of Estimate : bottom-up

Allowance for Indeterminates : low

E. Detailed Costing: (Unit : k-yen)

Item

Oxygen Monitor

Sensor

Indicator/Controller

Recorder

Installation/Test

Fire-proof Protective Clothing

Self-Contained Breathing Apparatus

Mask with cylinder

Storage Case

Escape Mask for Oxygen Deficit

Oxygen Reseue
Price Number Cost

$\begin{array}{rcr} & \text { Subtotal } & 2760 \\ 80, & 8 & 640 \\ 920, & 1 & 920, \\ 350, & 2 & 700, \\ 500, & 1 & 500\end{array}$

$289, \quad 10 \quad 2,890$,

$\begin{array}{lcr}282 & \text { Sultotal } & -3,670 \\ 170, & 5 & 2,820 \\ 5 & 850,\end{array}$

25. 10

250.

330
2 660
Remarks

Riken-Kagaku

OH-D4

$\mathrm{KU}-7 / \mathrm{G}$

$\mathrm{mR} 1800$

FC-30PM

L30-815FG

Life Rescue mini-2

Total 
WaS 6.2 .7

Safety and Emergency Equipment at IFMIF Site and Building

Type

Oxygen Monitor

Fireproof Protective Clothing

Seff-Contained Breathing Apparatus

Escape Mask for Oxygen Deficit

Oxygen Rescue
Location

Accelerator Rooms

Li Process Area

Target Access Rooms

Entrance of Controlled Area

Entrance of Controlled Area

Each Room to be expected

Entrance of Controlled Area
Number Distance* Remarks

$\begin{array}{rr}4 & 120 \mathrm{~m} \\ 2 & 40 \mathrm{~m} \\ 2 & 40 \mathrm{~m}\end{array}$

10

10

10

2 fire accident

radioactive gas

Li accident

for evacuation

oxygen accident 
WORKSHEET

WBS 6.3.1 Central Control

\section{A. Summary Cost Estimate:}

\begin{tabular}{|c|c|c|c|c|c|c|}
\hline \multicolumn{3}{|c|}{ Off-IFMIIF Site } & \multicolumn{4}{|c|}{ On-Site At IFMIF } \\
\hline İndustry & Instit' & & Const. Coneracto & Instit'al & & \\
\hline $\begin{array}{c}\text { Mat'ly } \\
\text { Lab }\end{array}$ & Engin & Total & $\begin{array}{c}\text { Mat'l/ Engin } \\
\text { Lab }\end{array}$ & Engin & AFI & Total \\
\hline $88,830 \quad 192,000$ & 0 & $37,683 \quad 318,513$ & 7,000 & 0 & 0 & 7,000 \\
\hline
\end{tabular}

\section{Currency Units: kilo Yen}

\section{B. Description:}

Central Control (CC) concerned here supervisory controls operations, manages data and fault, and monitors conditions of all facilities. The main computer that works as a data server provides acquisition, formatting, storage, and concurrent archiving of time-tagged diagnostics data, status data, and values of plant perfornance parameters. This control system also has two equivalent workstations named as support computer provide all supervisory functions that the main computer does not provide, operation and configuration control, acquiring, processing and displaying of IFMIF system status, data analysis, software development, and so on. This computer system should bave redundancy. The main computer bas 4 CPU's and has auto. disconnection function of troubled CPU's. The two workstations share their functions, and one of them execute important functions (such as operation control, system monitoring, etc.) when the other workstation can not works well. The $8 \mathrm{X}$-window terminals with touch panels are provided as operator interfaces. Operator interfaces are connected to computers viat the HUB for CC terminals.

\section{Detailed WBS Listing:}

1. 0. 0, 0. Central Control

1. 0. 0. Computer System

2. 0. 0. Computer Racks, Furniture

3. 0. 0. Data Storage

4. 0. 0. Uninterruptable Power Supply

5. 0. 0. Operator Interface

\section{Costine Rationale:}

The cost estimation is based on manufacturer quotes.

Type of Estimate : bottorn-up

Allowance for Indeterminates: 10\% AFI is applied to account for change in material and laboring cost, and $15 \% \mathrm{AFI}$ is applied to account for ambiguity of development of application software in engineering cost.

E. Detailed Costing: See detailed estimate 


\section{WORKSHEET}

WBS 6.3.2 Local Area Network

A. Summary Cost Estimate:

\begin{tabular}{|c|c|c|c|c|c|}
\hline \multicolumn{3}{|c|}{ Off-IFMIIF Site } & \multicolumn{3}{|c|}{ On-Site At IFMIF } \\
\hline Industry & 'Instit' & & Const. Contracto & Instit'al & \\
\hline$\underset{\text { Lab }}{\text { Mat' }}$ & Engin & AFI & $\underset{\mathrm{Lab}}{\text { Mat'V Engin }}$ & Engin & Tota \\
\hline 24,000 & $\overline{0}$ & 83,779 & 16,800 & 0 & 16,800 \\
\hline
\end{tabular}

\section{Cumency Units: kilo Yen}

\section{B. Description}

Through the Local Area Network the cestral control controls all substations, sends information and gathering data and status of all systems. This LAN is a star-like connection of a FDDI switch and connects the central control to X-terminals, network printers, 4 substations of other subfacilities and so on.

C. Detailed WBS Listing:

2. 0. 0. 0. Local Area Network

1. 0. 0. Network

2. 0. 0. Substation Interface

3. 0. 0. Network Printer

\section{Costing Rationale:}

The cost estimation is based on manufacturer quotes.

Type of Estimate : bottom-up

Allowance for Indeterminates: $10 \%$ AFI is applied to account for change in material and laboring cost, and $15 \%$ AFI is applied to account for ambiguity of development of application software in engineering cost.

E._Detailex_Costing: See detailed estimate 
WORKSHEET

WBS 6.3.3 Interlock Logic

A. Summary Cost Estimate:

\begin{tabular}{|c|c|c|c|c|c|c|}
\hline \multicolumn{3}{|c|}{ Off-IFMIIF Site } & \multicolumn{4}{|c|}{ On-Site At IFMIF } \\
\hline Industry & Instit' & & Const. Contracto & Instit'a] & & \\
\hline $\begin{array}{c}\text { Mat't } \\
\text { Lab }\end{array}$ & Engin & Total & $\begin{array}{c}\text { Maty/ } \\
\text { Lab }\end{array}$ & Engin & $\overrightarrow{\mathrm{AFI}}$ & Total \\
\hline $43,05596,000$ & 0 & $18,706 \quad 157,761$ & 21,000 & $\mathbf{0}$ & 0 & 21,000 \\
\hline
\end{tabular}

\section{Cumency Units: kilo Yen}

\section{B. Description:}

Interlock Logic is composed from programmable logic units and provide equipment safety, plant safety and personnel access interlock according to interlock signals sent from all other systems. Status of interlock are monitored by the central control and displayed on a logic status display panel.

\section{Detailed WBS Listing:}

3. a. 0. 0. Interlock Logic

1. 0. 0. Hardwired Logic

2. 0. 0. Logic and Starus Display

3. o. D. Interface for Computer Control

\section{Costing Rationale:}

The cost estimation is based on manufacturer quotes.

Type of Estimate : bottom-up

Allowance for Indeterminates: $10 \%$ AFI is applied to account for change in material and laboring cost, and $15 \%$ AFI is applied to account for ambiguity of developunent of application software in engineering cost.

E. Detailed Costing: See detailed estimate 
WORKSHEET

WBS 6.3.4 Central Display Panel

A. Summary Cost Essimate:

\begin{tabular}{|c|c|c|c|c|c|c|}
\hline \multicolumn{3}{|c|}{ Off-IFMIF Site } & \multicolumn{4}{|c|}{ On-Site At IFMIF } \\
\hline Indüstry & Instit $^{1}$ & & Const. Contracto & Instit'al & & \\
\hline $\begin{array}{l}\text { Mat'l Engin } \\
\text { Lab }\end{array}$ & Engin & Total & $\begin{array}{l}\text { Mar'y Engin } \\
\text { Lab }\end{array}$ & Engin & AFI & Total \\
\hline $166,676 \quad 12,000$ & 0 & 197,14 & 14,000 & $\overline{0}$ & 0 & 4,000 \\
\hline
\end{tabular}

Curency Units: kilo Yen

B. Dessription:

There are two $150^{\text {"n }}$ screen color display are used as the Central Display Panels. One of these panels displays subsystem status and the other displays radiation monitoring and area access status.

C. Detailed WBS Listing:

4. 0. *. 0. Central Display Panel

1. 0. 0. Subsystem Status

2. 0. 0. Radiation and Area Aceess \$tatus

\section{Costing Rationale:}

The cost estimation is based on manufacturer quotes.

Type of Estimate : bottom-up

Allowance for Indeterminates: $10 \% \mathrm{AFI}$ is applied to account for change in material and laboring cost, and $15 \%$ AFl is applied to account for ambiguity of development of application software in engintering cost.

E. Detailed Costing; See detailed estimate 
WORKSHEET

WBS 6.3 .5 Sequence Symchronizer

A. Summary Cost Estimate:

\begin{tabular}{|c|c|c|c|c|c|}
\hline \multicolumn{3}{|c|}{ Offifimif Site } & \multicolumn{3}{|c|}{ On-Site At IriMli- } \\
\hline Industry & Instit' & & Const. Contracto & Instit'al & \\
\hline$\underset{\mathrm{Lab}}{\prod_{\text {Mat'V }} \text { Engin }}$ & Engin & Total & $\underset{\text { Lab }}{\text { Mat'y Engin }}$ & Engin & Total \\
\hline $124,628 \quad 24,000$ & $\overline{0}$ & $16,063 \quad 164,69$ & 14,000 & 0 & 14,000 \\
\hline
\end{tabular}

Currency Units: kilo Yen

B. Descriotion:

Sequence Synchronizer generates timing pulses and event triggered pulses tor synchronous operation of IFMIF facility. Modes and patterns of pulses are controlled by the central computer.

C. Detailed WBS Listing:

5. 6. 0. 0. Sequence Synchronizer

1. 0. 0. Timing Data Generator

2. 0. 0. Interface for Computer Control

D. Costing Rationale:

The cost estimation is based on manufacturer quotes.

Type of Estimate : bottom-up

Allowance for Indeterminates: 10\% AFI is applied to account for change in marerial and laboring cost, and $15 \%$ AFI is applied to account for ambiguity of development of application software in engineering cost.

E. Detailed Costing: See detailed estimate 
WORKSBEET

WBS 6.3.6 Dummy Substation

\section{A. Summary Cost Estimate:}

\begin{tabular}{|c|c|c|c|c|c|}
\hline \multicolumn{3}{|c|}{ Off-IFMIF Site } & \multicolumn{3}{|c|}{ On-Site At IFMAF } \\
\hline Industry & Instit' & & Const. Contractor & Instit'al & \\
\hline $\begin{array}{c}\text { Mat'V Engin } \\
\text { Lab }\end{array}$ & Engin & Total & $\begin{array}{c}\text { Mat'l] Engin } \\
\text { Lab }\end{array}$ & Engin & Total \\
\hline 96,000 & 0 & 148,657 & 7,000 & 0 & 7,000 \\
\hline
\end{tabular}

Currency Units: kilo Yen

\section{B. Description:}

Dumny Substation simulates the responses of substations. By using this substation, we can test performance of control system without the other substations and develop software with no interrupt to other substations.

\section{Detailed WBS Listing:}

6. 0. 0. 0. Dummy Sabstation

1. 0. D. Computer

2. 0. 0. Operator listerface

3. 0. 0. Interface for Computer Control

\section{Costing Rationale:}

The cost estimation is based on manufacturer quotes.

Type of Estimate : bottom-up

Allowance for Indeterminates: $10 \%$ AFI is applied to account for change in material and laboring cost, and 15\% AFI is appjed to account for ambiguity of development of application software in engineering cost.

E_Detailed Costing: See detailed estimate 
WORKSHEET

\section{WBS 63.7 Operation and Configuration Control}

\section{A. Summary Cost Estimate:}

\begin{tabular}{|c|c|c|c|c|c|}
\hline \multicolumn{3}{|c|}{ Off-IFMIF Site } & \multicolumn{3}{|c|}{ On-Site At IFiMiF } \\
\hline Industry & 'Instit' & & Const. Contractor & Instift'al & \\
\hline $\begin{array}{l}\text { Mat'l/ Engin } \\
\text { Lab }\end{array}$ & Engin & Total & $\begin{array}{c}\text { Mat'l' Engin } \\
\text { Lab }\end{array}$ & Engin & Total \\
\hline 240,000 & 0 & $36,000 \quad 276,000$ & 0 & 0 & 0 \\
\hline
\end{tabular}

\section{Currency Units: kilo Yen}

\section{B. Description:}

Operation and Conffguration Software provides functions to control operations, manage data and fault, and monitor conditions of all facilities. We assigned 10 man-year to basic and detailed designing and coding of these software.

\section{C.Detailed WBS Listing:}

7. 0. 0. 0. Operation and Configuration Control

1. 0. 0. Operation and Configuration Software

\section{Costing Rationale:}

The cost estimation is based on manufacturer quotes.

Type of Estimate : bottom-up

Allowance for Indeterminates: $15 \%$ AFI is applied to account for ambiguity of development of application software in engineering cost.

E. Detailed Costing; See detailed estimate 


\section{WORKSHEET \\ WBS 6.4.1 Installation and Test}

\section{A. Summary Cost Estimate:}

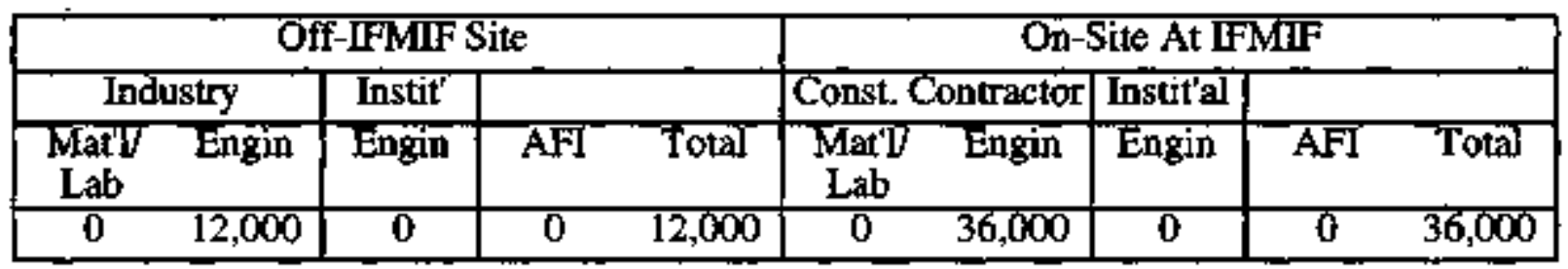

Cuntency Units: kilo Yen

\section{B. Description:}

Installation and test mentioned here is for operating system, applications and device driver software. The costs for installation of hardware are included in costing in each elements. We assigned 2 man-year totally to engineering cost of factory off- and on-IFMIF site. This cost also includes AFI.

\section{c. Detailed WBS Listing:}

1. 0. 0. 0. Installation and Test

\section{Costing Rationale;}

The cost estimation is based on manufacturer quotes.

\section{E. Detailed Costing:}
1. Planning
0.5 man-year
$12,000 \mathrm{k}$ Yen
2. Installation and Testing
1.0 man-year
$24,000 \mathrm{k}$ Yen
3. Documentation
0.5 Man-year
$12,000 \mathrm{k}$ Yen 
WORKSHEET

WBS 6.4.2 System Verification Testing

A. Summary Cost Estimate:

\begin{tabular}{|c|c|c|c|c|c|c|c|c|c|}
\hline \multicolumn{5}{|c|}{ Off-IFMIF Site } & \multicolumn{5}{|c|}{ On-Site At IFMIF } \\
\hline Ind: & stry & Instit' & & & Const. C & ontractor & Instit'al & & \\
\hline $\begin{array}{l}\text { Mat'l] } \\
\mathrm{Lab}\end{array}$ & Engin & Engin & AFI & Total & $\begin{array}{c}\text { Mat'l/ } \\
\text { Lab }\end{array}$ & Engin & Engin & AFI & Total \\
\hline 0 & 12,000 & 0 & 0 & 12,000 & 0 & 36,000 & 0 & 0 & 36,000 \\
\hline
\end{tabular}

Cursency Units: kilo Yen

B. Description:

System Verification Testing is verification of overall $\mathrm{CC}$ and $\mathrm{CI}$ systems. We assigned 2 Man-year totally to engineering cost of factory off- and on-IFMIF site. This cost aiso includes AFI.

C. Detailed WBS Listing:

1. 0. 0. 0. System Verrification Testing

D. Costing Rationale:

The cost estimation is based on manufacturer quotes.

E. Detailed Costing:

1. Planning

0.5 Man-year $\quad 12,000 \mathrm{k}$ Yen

2. System Verification

1.0 Man-year $\quad 24,000 \mathrm{k}$ Yen

3. Documentation

0.5 Man-year $\quad 12,000 \mathrm{k}$ Yen 


\section{Cost Estimating}

Worksheets

\section{for}

WBS 7.0

Startup and Commissioning 
WORKSHEET

WBS 7.1 Startup \& Commissioning Personnel

\section{A. Summary Cost Estimate:}

\begin{tabular}{|c|c|c|c|c|c|}
\hline \multicolumn{3}{|c|}{ Off-IFMIF Site } & \multicolumn{3}{|c|}{ On-Site At IFMTF } \\
\hline Industry & Insitit $^{t}$ & & $\begin{array}{c}\text { Const. } \\
\text { Contractor }\end{array}$ & Instit'al & \\
\hline $\begin{array}{l}\text { Mat'l' Engin } \\
\text { Lab }\end{array}$ & Engin & AFI Total & $\begin{array}{l}\text { Mat'l/ Engin } \\
\text { Lab }\end{array}$ & Engin & Total \\
\hline $\mathrm{nc} \quad \mathrm{nc}$ & nc & IC & 00 & 32918 & $3292 \quad 36210$ \\
\hline
\end{tabular}

Currency Units: kilo ICF

B. Descriofion:

This element includes the technical support staff on-site to operate the Facilities during startup and commissioning, and the operations personnel hired during the Startup and Commissioning phase of the construction project to be trained by the technical support staff.

This element covers activites in calendar years 2005 and 2006 per the current IFMIF construction schedule.

Not included are costs associated with the installation and check-out of equipment prior to the Facility startup. Those costs are included in the individual Facility construction costs.

\section{Detailed WBS Listing:}

See listing in Table 7.1.2 below.

\section{Costing Rationale:}

The personnel costs were determined in a two step process; first, the unit cost for each type of personel (i.e. technicians, managers, engineers and shop labor) including all burdens and overtead in each of the prospective countries was determined. The summary of the rates is included in attached Table 7.1.1. The US figures are based on rates at Oak Ridge National Laboratory and those used by Northrop Grumman in similar estimates The EU rates were provided by Frascati and FZK, and the Japanese rate by JAERI. Since the rates for all the countries are comparable within the accuracy of the overall estimate a single average rate was agreed on as sbown in the Table.

In the second step of the estimating process, the number of personnel required to operate the facilities during startup of both the total IFMIF facility and the individual technical facilities was estimated by the approptiate groups. In addition, the core of the operations staff expected to be hired during the startup and commissioning period was determined. This group will include key supervisory and technical leaders who will ultimately train the operators. An annual summary for the two years (caleadar years 2005 and 2005) of the startup is attached as Table 7.1.2.

The Allowance For Indeterminates is established at $10 \%$ to account for probabje but unpredictable difficulties which will result in overtime and extended operating times. 
A detailed explanation of the subelements in this WBS is as follows:

\subsubsection{Administration}

The plant management team will begin to assemble in second year and increase each year throughout the startup phase

\subsubsection{Operations}

The operations staff is buitt for each Facility group in accordance with the construction schedule.

\subsubsection{Maintenance}

This staff is generally hired late in the startup phase to avoid conflict with the onsite construction crews which are responsible for the maintenance and tuning of the uncomanissioned systems.

\subsubsection{Experimental Operations}

This staff will be start being assembled in the tinal year of the startup phase.

\section{1 .5 Startup Staffs}

The technical teams brought on-site to perform the startup operations. The teams will be supplemented by installation and construction personnel costed to the individual facilities. The startup staff will be responsible for training the permanent operations team.

ESTIMATE TYPE: BOTTOMS UP; each element and unit cost was determined individually based on a detailed analysis of the requirements of IFMIF. 


\section{E. Detailed Costing:}

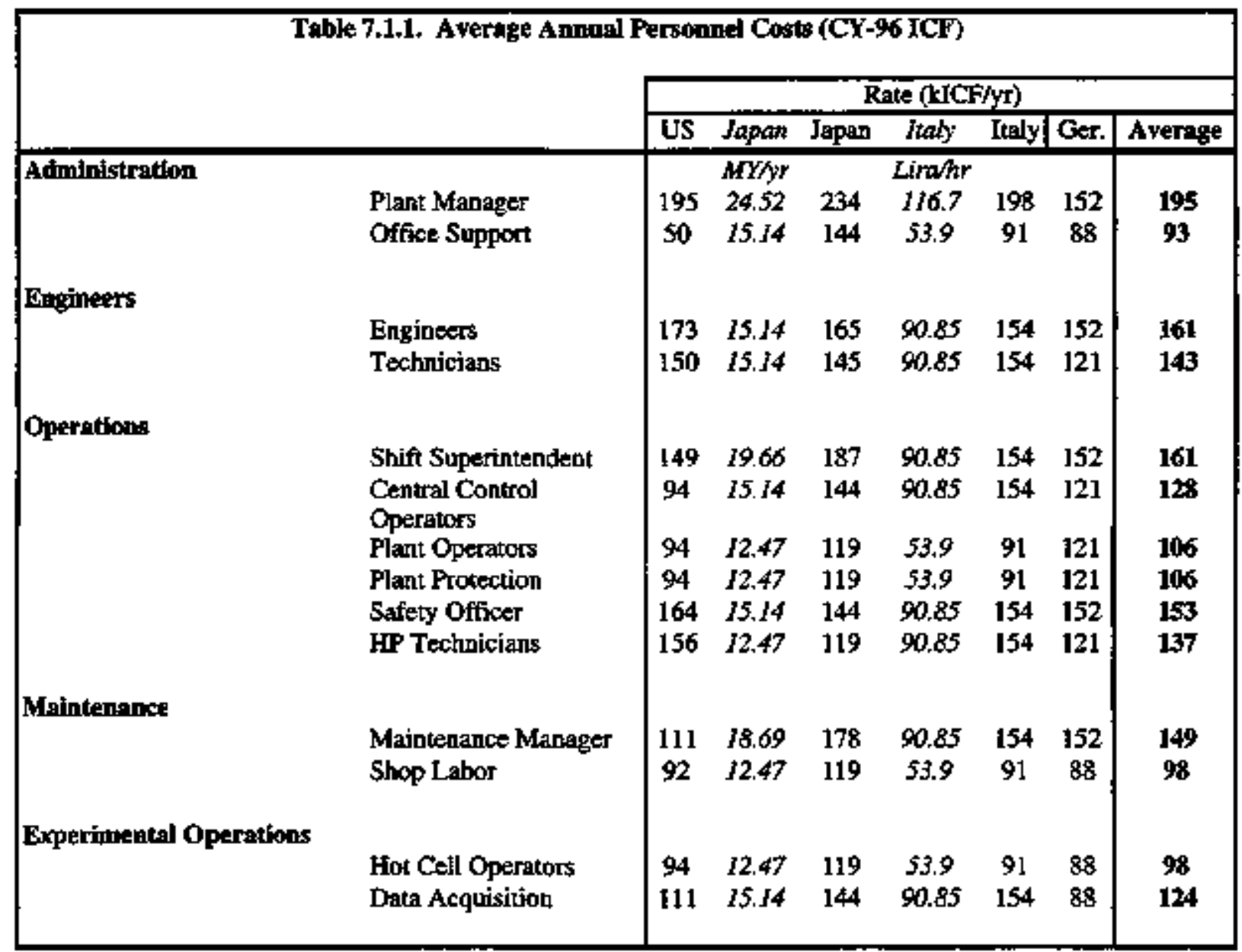


Table 7.1.2. IFMIT Startop Pensonnel Costs

\begin{tabular}{|c|c|c|c|c|c|}
\hline & \multicolumn{3}{|c|}{ Year 2005 } & \multirow{2}{*}{$\frac{\text { Yeaj2006 }}{\text { Cost }}$} & Total \\
\hline & Total & $\begin{array}{c}\operatorname{Cos} t \\
\mathrm{kICF} / \mathrm{yr}\end{array}$ & Total & & Cost \\
\hline Adiministration & $\mathbf{3}$ & 381 & 4 & 475 & 856 \\
\hline Plant Manager & $\mathbf{I}$ & 195 & 1 & 195 & 389 \\
\hline Office Support & 1 & 93 & 2 & 187 & 280 \\
\hline Vistitcr Control & 1 & 93 & 1 & 93 & 187 \\
\hline Plant Operations & 15 & 1690 & 26 & 3184 & 4880 \\
\hline Shift Superiatendent & I & 161 & 4 & 642 & 803 \\
\hline Plant Operators & 4 & 425 & 7 & 744 & 1170 \\
\hline Plant Protection & 9 & 957 & 9 & 957 & 1914 \\
\hline Safexy Officer & 1 & 153 & 1 & 153 & 307 \\
\hline HP Technicians & 0 & d & 5 & 687 & 687 \\
\hline Test Operstions & $\mathbf{0}$ & 0 & 2 & 392 & $30 \%$ \\
\hline Experiment Control & 0 & q & 1 & 161 & 161 \\
\hline Operations Labor & 0 & 0 & 1 & 149 & 149 \\
\hline Target Operations & 1 & 161 & 4 & 642 & 803 \\
\hline Supervision & 1 & 161 & 4 & 642 & 803 \\
\hline Accelerntor Operations & 91 & 11974 & $\mathbf{9 3}$ & 11744 & 23718 \\
\hline Supervision & 30 & 1605 & 15 & 2408 & 4013 \\
\hline Operations Labor & 13 & t382 & 22 & 2339 & 3722 \\
\hline Engineering \& Toch Support & 46 & 6840 & 30 & 4461 & 11301 \\
\hline Accellerator Shop Lobor & 22 & 2146 & 26 & 2536 & 4683 \\
\hline Mainfenance & $\mathbf{1}$ & 149 & 10 & 1180 & 1329 \\
\hline Maintenatkce Manager & 1 & 149 & 4 & 595 & 744 \\
\hline Shop Labor & 0 & 0 & 6 & 585 & 585 \\
\hline Central Contral & 1 & 128 & 7 & 894 & 1023 \\
\hline Central Control Operators & 1 & 128 & 6 & 770 & 898 \\
\hline Data Acquisition & 0 & q & 1 & 124 & 124 \\
\hline Startap Stafi & 112 & 1448s & 146 & 18429 & $32 \% 18$ \\
\hline
\end{tabular}

Notes:

1. Pers"I costs include all benefits and overhead 
WBS 7.2 Startup \& Commissioning-Electric Power

\section{A. Summary Cost Estimate:}

\begin{tabular}{|c|c|c|c|c|c|}
\hline \multicolumn{3}{|c|}{ Off-IFMIF Site } & \multicolumn{3}{|c|}{ On-Site At IFMIF } \\
\hline Industry & Instit' & & $\begin{array}{l}\text { Const. } \\
\text { Contractor }\end{array}$ & Instit'al & \\
\hline $\begin{array}{c}\text { Matll/ Engin } \\
\text { Lab }\end{array}$ & Engin & AFI Total & $\begin{array}{l}\text { Mat'// Engin } \\
\text { Lab }\end{array}$ & Engin & AFi Total \\
\hline $\mathrm{nc}$ & пc & nc & 22,509 & 0 & $225 ! \quad 24,759$ \\
\hline
\end{tabular}

Given the substantial differences between the different potential sites the range of power costs is:

Maximum: 37,000

Minimum: 14,000

Currency Units: kijo ICF

B. Description:

Electric power required during the Startup and Commissioning phase of the project will be used primarily for two purposes; the accelerator and a wide range of smaller users grouped under the heading of "Balance of Plant".

Note: All power used during the Startup and Commissioning phase, calendar years 2005 and 2006 , of the project will be charged to this WBS since it will not be possible to segregate costs to individual Facilities.

\section{Detailed WBS Listing:}

See Section $\mathbf{E}$ for listing.

\section{Costing Rationale:}

Because the cost of electricity varies substantially between potential site countries both an average cost and site specific costs are computed. The estimated power costs computed for a $40 \mathrm{MW}$ facility are shown in Table 7.2.1:

Table 7.2.1. Average power costs for potential site countries

\begin{tabular}{|lcc|}
\hline Costs (40 MW cap'ty) & Capacity & Use Rate \\
kICF/yr & ICF/kWhr \\
\hline Ialy & & 0.131 \\
Germany & & 0.0934 \\
Japan & 5,146 & 0.12 \\
United States & & 0.066 \\
\hline Average & 1,286 & 0.103 \\
\hline
\end{tabular}


Table 7.2.2 shows the power reguirements estimated for IFMIF during the startup and commissioning process. The accelerator requirements are assumed to be roughly half of the maximum operating capacity or; $25 \%$ of capacity in 2005 and $50 \%$ of capacity in 2006. The balance of plant requirements were estimated based on the startup dates for the remaining facilities.

The Allowance For Indeterminares is established at $25 \%$ to account fot probable but unpredictable difficulties which will result in extended operating tines.

ESTTMATE TYPE: BOTTOMS UP; each element and unit cost was determined individeally based on an antlysis of the requirements of IFMIF operations.

\section{E. Detailed Costing:}

Table 7.2.2. Electric Power

\begin{tabular}{|c|c|c|c|c|c|c|c|}
\hline$\frac{\text { Hours N Year }}{8766}$ & $\begin{array}{l}\text { Full } \\
\text { Power } \\
\text { Usage } \\
\text { Mw }\end{array}$ & $\begin{array}{l}\text { Full } \\
\text { Power } \\
\text { On- } \\
\text { time } \\
\text { ô }\end{array}$ & $\begin{array}{c}\text { Half } \\
\text { Power } \\
\text { On- } \\
\text { time } \\
\text { 若 }\end{array}$ & $\begin{array}{l}\text { Power } \\
\text { Off } \\
\text { Time } \\
\%\end{array}$ & $\begin{array}{l}\text { Annital } \\
\text { Power } \\
\text { Usage } \\
\text { Mwhr }\end{array}$ & $\begin{array}{c}\text { Power } \\
\text { Rate } \\
\text { Rate } \\
\text { ICF/kWhr }\end{array}$ & $\begin{array}{l}\text { Total } \\
\text { kICF }\end{array}$ \\
\hline $\begin{array}{l}\text { Year 2005 } \\
\text { 1. 0. "Casics" Accel \& HEBT } \\
\text { 2. 0. "Pollux" Accel \& HEBT } \\
\text { 3. 0. Balance of Plant } \\
\text { 1. Test Frcilities } \\
\text { 2. Target Facilities } \\
\text { 3. Acceleracor Facility } \\
\text { 4. Conventional Fac's } \\
\text { 5. Cengral Control }\end{array}$ & $\begin{array}{c}19.2 \\
19.2 \\
5.0\end{array}$ & $\begin{array}{l}20 \% \\
0 \% \\
0 \%\end{array}$ & $\begin{array}{l}30 \% \\
0 \% \\
50 \%\end{array}$ & $\begin{array}{l}50 \% \\
100 \% \\
50 \%\end{array}$ & $\begin{array}{l}6.99 \mathrm{E}+07 \\
5.90 \mathrm{E}+07 \\
0.00 \mathrm{E}+00 \\
1.10 \mathrm{E}+07\end{array}$ & 0.103 & $7, \sqrt[174]{ }$ \\
\hline $\begin{array}{l}\text { Year 2016 } \\
\text { 1. 0. "Castor" Accel \& HEBT } \\
\text { 2. 0. "Poilux" Accel \& HEBT } \\
\text { 3. 0. Balance of Plant } \\
\text { 1. Test Facilities } \\
\text { 2. Target Facilities } \\
\text { 3. Accelerator Facility } \\
\text { 4. Conventional Fac's } \\
\text { 5. Central Control }\end{array}$ & $\begin{array}{l}19.2 \\
19.2 \\
5.0\end{array}$ & $\begin{array}{l}33 \% \\
20 \% \\
40 \%\end{array}$ & $\begin{array}{l}18 \% \\
30 \% \\
10 \%\end{array}$ & $\begin{array}{l}49 \% \\
50 \% \\
50 \%\end{array}$ & $\begin{array}{l}1.49 \mathrm{E}+08 \\
7.08 \mathrm{E}+07 \\
5.90 \mathrm{E}+07 \\
1.97 \mathrm{E}+07\end{array}$ & 0.103 & 15,334 \\
\hline Total & - & - & - & - & $2,19 \mathrm{E}+08$ & 0.103 & 22509 \\
\hline
\end{tabular}


WORKSHEET

WBS 7.3 Startup \& Commissioning-Utilities

A. Summary Cost Esstimate:

\begin{tabular}{|c|c|c|c|c|c|c|}
\hline \multicolumn{4}{|c|}{ Off-IFMiF Site } & \multicolumn{3}{|c|}{ On-Site At IFIMiF } \\
\hline Industry & Instit' & & & $\begin{array}{c}\text { Const. } \\
\text { Contractor }\end{array}$ & Instit'a! & \\
\hline $\begin{array}{c}\text { Mat'l/f Engin } \\
\text { Lab }\end{array}$ & Engin & AFI & Total & $\begin{array}{c}\text { Mat1/f Engin } \\
\text { Lab }\end{array}$ & Engin & Total \\
\hline ac & $\mathbf{n c}$ & AC & $\mathrm{bc}$ & 578 & 0 & 636 \\
\hline
\end{tabular}

Currency Units: kilo ICF

B. Description:

Conventional Utilities will be purchased from commercial vendors and pubiic utilities to support IFMIF operations. These include, sanitary water, sewer, natural gas for heating and inert gases.

The inert gases are assumed to be provided in over-the-road tank trucks or in bottles delivered by a commercial vendor. The gases will be transferred to on-site storage facilities. The quality of the gases required are important in the cost determination; for this estimate the gases are assumed to be pure at the $10^{-4}$ level.

It is assumed that there will be a water dionization unit on-site at IFMIF, thus all provided water is potable quality. The water and sewer charges vary by a factor of about eight between the three potential sites; however, an average number is applied because the impact on the total cost is relativejy small.

It is assumed that all water effluent will not be contaminated with chemicals or radionuclides.

C. Detailed WBS Listing:

See detailed listing in Table 7.3.1

D. Costing Rationale:

Table 7.3.1 shows the utility requirements estimated for IFMIF during the startup and commissioning process. The estimated usages were provided by each Facility group. Note that the sewer charge assumes that all water is cycled to the sewer system.

The Allowance For Indeterminates is established at $10 \%$ to account for probable but unpredictable difficulties which will result in extended operating times and increased utility ușage.

ESTIMATE TYPE: BOTTOMS UP (Estimate) each utility requirement is estimated; unit costs were determined individually. 


\section{E. Detailed Costing:}

Table 73.I IFMIf Startup Costs-Utilities

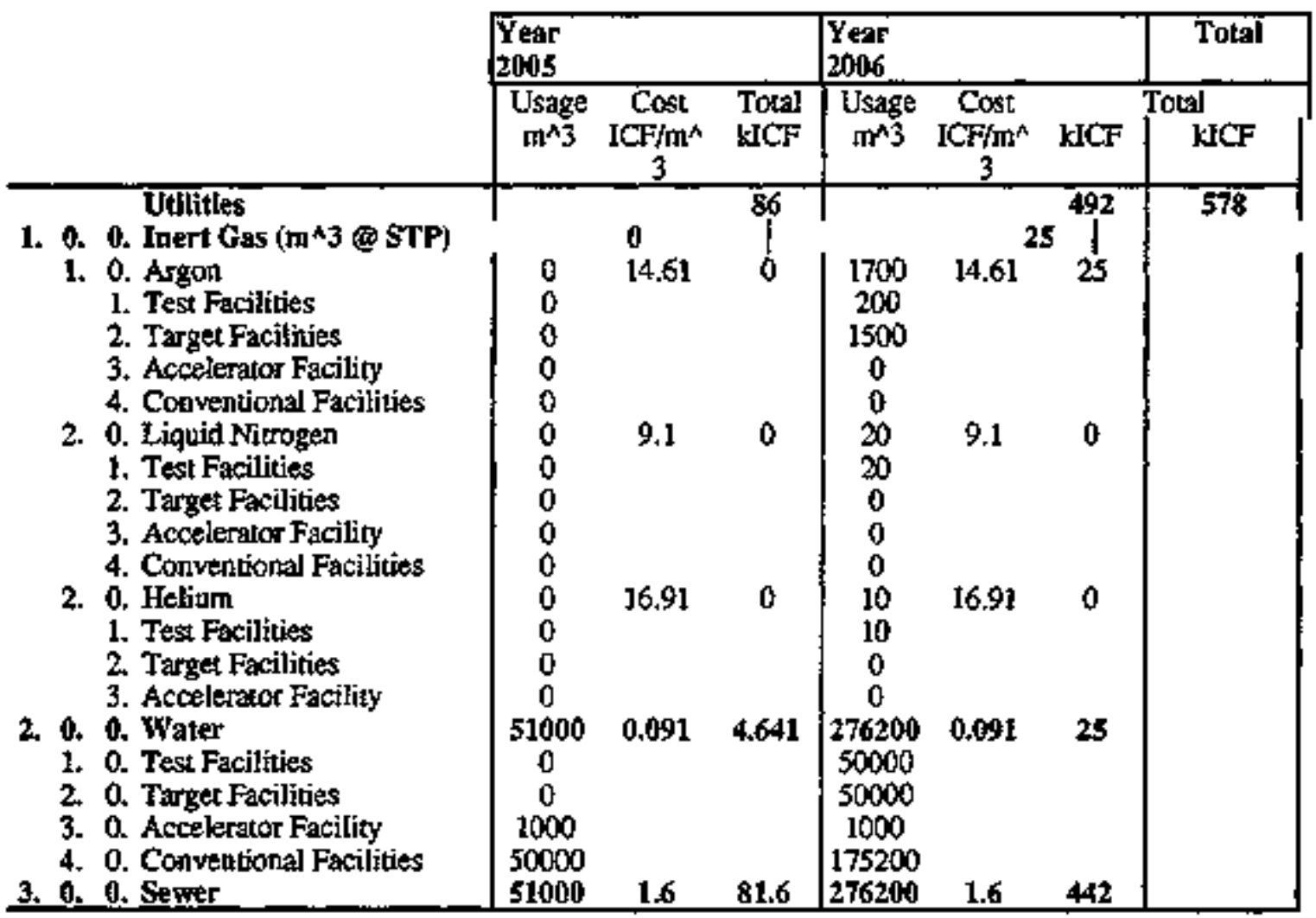




\section{WORKSHEET}

WBS 7.4 Startup \& Commissionimg-Maintenance

\section{A. Summary Cost Estimate:}

\begin{tabular}{|c|c|c|c|c|c|}
\hline \multicolumn{3}{|c|}{ Off-IFMilF Site } & \multicolumn{3}{|c|}{ On-Site At IFMIF } \\
\hline Industry & Instit' & & $\begin{array}{c}\text { Const. } \\
\text { Contractor }\end{array}$ & Instit'al & \\
\hline $\begin{array}{c}\text { Mat'"f Engin } \\
\text { Lab }\end{array}$ & Engin & AFI Total & $\begin{array}{c}\text { Mat'l/f } \\
\text { Lab }\end{array}$ & Engin & Total \\
\hline nc $\quad$ ac & nc & $\mathrm{nc}$ & 1000 & 0 & 1100 \\
\hline
\end{tabular}

Currency Units: kile\$

\section{B. Description:}

Maintenance operations during the Startup and Commissioning Phase will be negligible since the Facility construction groups will be responsible for the upkeep and condition of the buildings and equipment. Consequently most maintenance costs are assumed to be included in the Facility estimates. An arbitrary cost of $1000 \mathrm{kICF}$ with an AFI of $10 \%$ has been estimated to account for miscellaneous maintenance items not covered by the construction contracts.

\section{Detailed WBS Listing:}

\subsection{0. Maintenance}

D. Costing Rationale:

Engineering Judgement

E. Detailed Costing:

None 
WORKSHEET

WRS 7.5 Startup \& Commissioning-Waste Disposal

\section{A. Summary Cost Estimate:}

\begin{tabular}{|c|c|c|c|c|c|}
\hline \multicolumn{3}{|c|}{ Off-IFinilifsite } & \multicolumn{3}{|c|}{ On-Site At IFMIF } \\
\hline Industry & Instit' & & $\begin{array}{c}\text { Const. } \\
\text { Contractor }\end{array}$ & Instit'a] & \\
\hline $\begin{array}{l}\text { Mar'y Engin } \\
\text { Lab }\end{array}$ & Engin & AFi Total & $\begin{array}{l}\text { Mat'V Engin } \\
\text { Lab }\end{array}$ & Engin & AFI Totä \\
\hline $\mathrm{nh} \quad \mathrm{nc}$ & $\overline{n c}$ & ac & 298 & 0 & 327 \\
\hline
\end{tabular}

\section{Currency Units: kilo $\$$}

\section{B._Description:}

Waste Disposal Services will be purchased from commercial vendors or public services to support IFMF operations. Uncontaminated waste will be handied and removed via conventional transport. Low level contaminated waste will be handled in accordance with local requirements. High level waste is not included in this estimate; the volume will be relatively small and it is considered the responsibility of the Host country.

Note; it is exteremly difficult to estinate both the type and quantity of waste generated by IFMIF. It is aiso difficult to obtain costs for disposal at most facilities. As a result approximate numbers based on engineering judgement are used in this preliminary estimate.

All waste generated on the IFMIF site during the Startup and Commissioning period, calendar years $\mathbf{2 0 0 5}$ and 2006 is included in this element.

It is important to note that waste resulting from constniction activities concurrent with the startup and commissioning work will be costed in the Facility estimates.

\section{Detailed WBS Listing:}

\subsection{0. Waste Disposal \\ 1. 0. Uncontaminated \\ 2. 0. Low Level Contaminated}

\section{Costing Rationale:}

The estimated costs for waste disposal costs in the US are based on costs at ORNL; costs for Europe and Japan are guesses.

Table 7.5.1 shows the disposal requirements estimated for IFMIF during the startup and commissioning process. The estimated rates were estimaled by consensus of the IFMIF design integration group based on engineering judgment.

The Allowance For Indeterminates is established at $10 \%$ to account for probable but unpredictable difficulties which will result in extended operations and additional waste. 
E. Detailed Costing:

Table 7.5.1, IFMIF Startup Costs-Waste Disposal

\begin{tabular}{|c|c|c|c|}
\hline & \multicolumn{3}{|c|}{ Annual } \\
\hline & $\begin{array}{c}\text { Usage } \\
\mathbf{m}^{\wedge} 3\end{array}$ & $\begin{array}{c}\text { Rate } \\
\text { ICF } / \mathrm{m}^{\wedge} 3\end{array}$ & $\begin{array}{l}\text { Total } \\
\text { kiCF }\end{array}$ \\
\hline $\begin{array}{l}\text { Year 20155 } \\
\text { 1. Uncontaminated } \\
\text { 2. Contaminated }\end{array}$ & $\begin{array}{c}500 \\
0\end{array}$ & $\begin{array}{c}75 \\
7400\end{array}$ & $\begin{array}{c}38 \\
38 \\
0\end{array}$ \\
\hline $\begin{array}{l}\text { Yeas } 2006 \\
\text { 1. Uncontaminated } \\
\text { 2. Contaminated }\end{array}$ & $\begin{array}{c}1000 \\
25\end{array}$ & $\begin{array}{c}75 \\
7400\end{array}$ & $\begin{array}{l}260 \\
75 \\
185\end{array}$ \\
\hline Waste Disposal & & & 298 \\
\hline
\end{tabular}

